\title{
Plants and Their Environments: Proceedings of the First Biennial Scientific Conference on the Greater Yellowstone Ecosystem
}

Technical Report NPS/NRYELL/NRTR

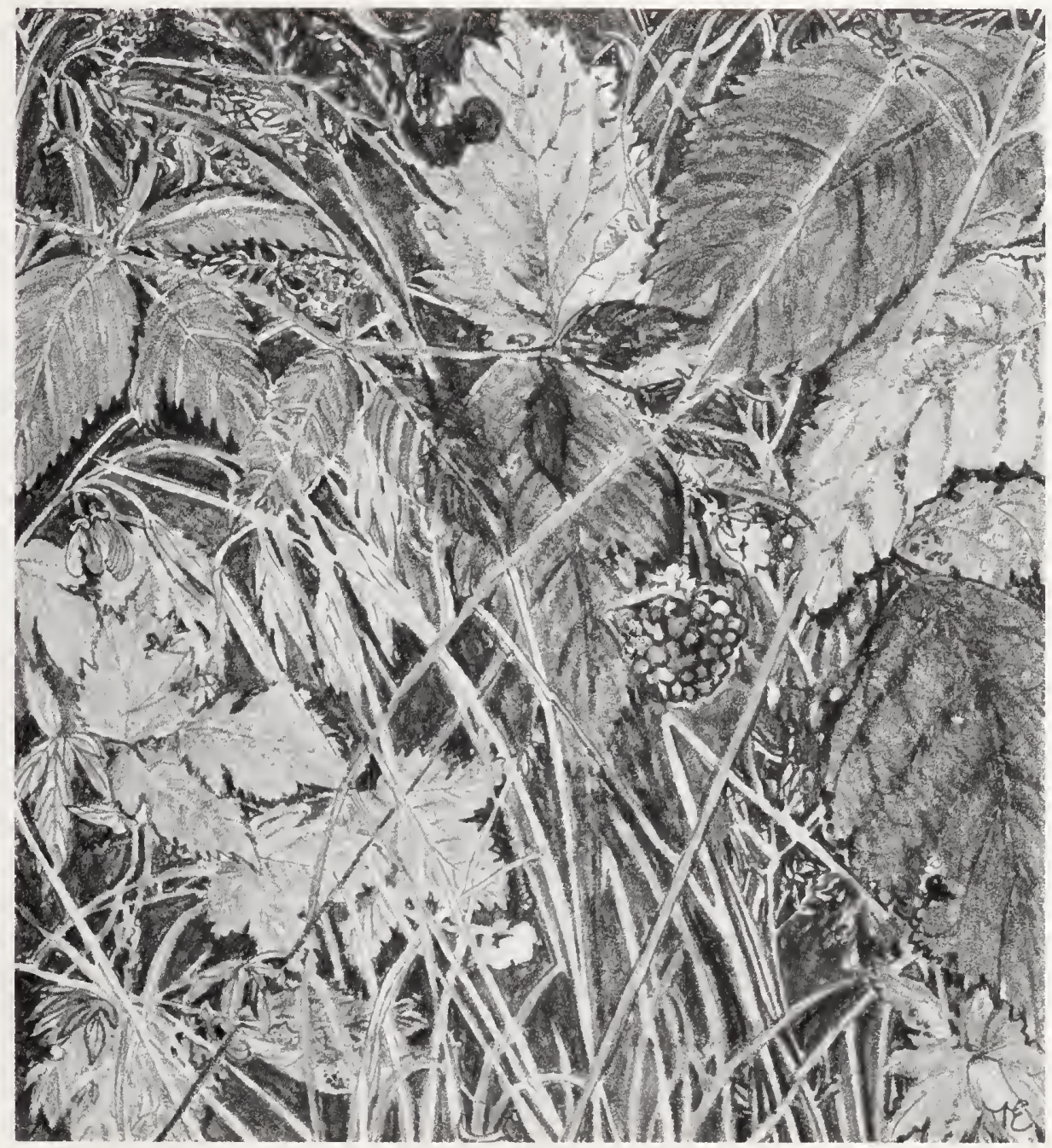


The National Park Service disseminates the results of biological, physical, and social science research through the Natural Resources Technical Report Series. Natural resources inventories and monitoring activities, scientific literature reviews, bibliographies, and proceedings of technical workshops and conferences are also disseminated through this series. Documents in this series usually contain information of a preliminary nature and are prepared primarily for internal use within the National Park Service. This information is not intended for use in open literature.

Mention of trade names or commercial products does not constitute endorsement or recommendation for use by the National Park Service.

Copies of this report are available from the following:

Publications Coordinator

National Park Service

Natural Resources Publication Office (WASO-NRPO)

P.O. Box 25287

Denver, CO 80225-0287 
Plants and their Environments:

Proceedings of the First

Biennial Scientific Conference

on the Greater Yellowstone Ecosystem

\author{
September 16-17, 1991 \\ Mammoth Hot Springs Hotel \\ Yellowstone National Park, Wyoming \\ Technical Report NPS/NRYELL/NRTR-93/XX
}

April 1994

\author{
Editor \\ Don G. Despain \\ Technical Assistance and Logistics \\ Sarah Broadbent \\ Renee Evanoff
}

United States Department of the Interior

National Park Service

Natural Resources Publication Office

Denver, Colorado 


\section{Digitized by the Internet Archive in 2013}




\section{Conference Committee Members}

Chairman: John D. Varley

Program

Committee: Don Despain, National Park Service, Co-Chair Glenn Plumb, University of Wyoming, Co-Chair Jeanne Chambers, Society for Range Management Kathy Hansen, Montana State University Richard D. Laven, Society for Conservation Biology Ward McCaughey, USDA Forest Service Duncan Patten, Ecological Society of America Harold Picton, The Wildlife Society

Planning

Committee: Ron Jones, U.S. Fish and Wildlife Service Richard Krebill, USDA Forest Service Richard Mackie, The Wildlife Society Duncan Patten, Ecological Society of America Glen Plumb, University of Wyoming Jim Schmidt, Montana State University Paul Schullery, National Park Service Stan Temple, Society for Conservation Biology Stan Tixier, Society for Range Management

Cosponsors: Ecological Society of America National Park Service (host agency) Society for Range Management U.S. Fish and Wildlife Service Society for Conservation Biology USDA Forest Service The Yellowstone Association The Wildlife Society Montana State University-University of Wyoming-Yellowstone National Park Cooperative Park Studies Unit 
HAROLD B LEE LIBRAPI BRIGHAM YOUNG UNIVERSITY PROVO. UTAH 


\section{Preface}

Yellowstone National Park is internationally recognized as a unique and beautiful place. Its status as a World Heritage Site and a Biosphere Reserve testify to the world's affection and concern for it. Since its establishment, the park has largely been protected from spoliation through the energetic efforts of generation after generation of its friends.

Researchers and managers here deal with what we might call the "Yellowstone concept," a complex set of hypotheses that are continually reshaped by social constraints, political exigencies, and biological surprises. This concept exists within the confines of an ecosystem--a wonderfully complex and often awe-inspiring group of interacting biotic and abiotic entities. Proper management of such an area requires several things, including political savvy, a good sense of our own history, and a strong measure of patience, but most of all it requires the best information available regarding the state of the natural systems that operate without regard to human-imposed boundaries or value systems.

Proper management, however, is both a goal and a problem, because there is no reliable set of principles to guide us; wilderness does not come with an instruction book. Thus it is that management of a place as complex and culturally challenging as Yellowstone seems always to be controversial. Controversy arises largely because the workings of the ecosystem are not fully understood. The effects and extent of historical events are not clear to modern observers, and the science of ecosystems is still young. Our ability to understand ecological processes, just like our ability to manage Yellowstone, is constantly growing and maturing.

This volume represents a process that is intended to make science more serviceable in the management of Yellowstone National Park, and more accessible to those in need of scientific information. It is hoped that this is only the first in a long series of biennial meetings and their proceedings that will bring together the results of continuing scientific investigations in the Greater Yellowstone Area.

The foundation of all ecosystems is plants. Plants are the procurers of energy and nutrients, the flow and cycles of which define and operate the ecosystem. It is fitting that plant research is the focus of this first scientific conference devoted entirely to Yellowstone National Park and its surroundings. Much research has been conducted on this ecosystem component, especially within the past twenty years; that blossoming of scientific interest holds great promise for our future understanding of Yellowstone, its natural systems, and its role in our society.

Many people and organizations have been involved in searching for answers about the workings of the Yellowstone ecosystem and exploring its state of health. The following papers and abstracts represent many investigators from numerous agencies and institutions. We were fortunate to attract the support 
and participation of ecologists with national and international reputations. The keynote address by Dwight Billings places the Yellowstone ecosystem in context with the mountain ecosystems of the world and its impending climatic changes. Norm Christensen gives us a good overview of recent changes in the direction and emphasis of ecological research and thought. The whole conference is ably summarized by Dennis Knight.

Papers with data and discussion are presented in the first section. Abstracts are included in section 2 to document ideas presented at the conference and give contacts to those who would like to follow up on those ideas.

It is hoped that this volume will be a foundation for further research and understanding of the Yellowstone ecosystem and a source of information for those responsible for the management of this singular place. 


\section{Contents}

\section{SECTION I: CONFERENCE PAPERS}

The Effects of Global and Regional Environmental Changes on Mountain Ecosystems . . . . 1 W.D. Billings

Figure 1. Relative values of six principal environmental factors in arctic and alpine ecosystems along a latitudinal gradient from the Arctic to the

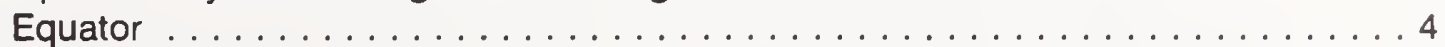

Figure 2. Diagram of a typical alpine mesotopographic environmental gradient . . . . . 4

Figure 3. Diagram through a solifluction terrace in the Beartooth Mountains,

Carbon County, Montana ...........................6

Figure 4. Relative distribution and floristic richness along an elevational gradient on the east escarpment of the Sierra Nevada near Bishop Creek, California ...................................6 6

Figure 5. The decreasing number of plant species with increasing elevation in the European Alps, compared with the mountain ranges in Central

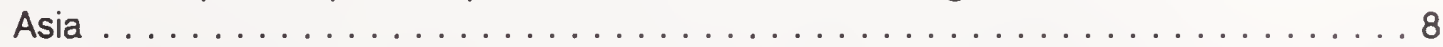

Figure 6. The mountain village of Obergurgl in the Austrian Tirol as it appeared in 1964 with its surrounding hay fields $\ldots \ldots \ldots \ldots \ldots \ldots \ldots \ldots \ldots \ldots \ldots$

Figure 7. The Obergurgl Model, with its four main components and subcomponents ................................ 11

Figure 8. Rate controller model of the impact of treading on photosynthesis and carbohydrate storage in subalpine and alpine meadow vegetation in Glacier National Park, Montana

\section{The Submersed Plant Community in Jackson Lake, Wyoming: Dynamics}

of a Disturbed System . . . . . . . . . . . . . . . . . . . . . . . . . . . . . . . . .

Carol A. Brewer and Thomas G. Thompson

Figure 1. The vertical gradient in a reservoir with a fluctuating water level consists of both the lake bed and adjacent shoreline . . . . . . . . . . . 32

Figure 2. Location of Jackson Lake within Grand Teton National Park . . . . . . . . . . 33

Figure 3. Distribution of major habitat types along the shoreline of Jackson Lake . . . . . 36

Figure 4. Depth distributions of macrophyte species in Jackson Lake relative to the median water level .......................... 40 
Table 1. Morphological features of Jackson Lake . . . . . . . . . . . . . . . 34

Table 2. Characteristic water chemistry data as mean values for the summers

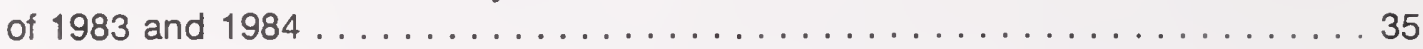

Table 3. Names of families and species collected from Jackson Lake . . . . . . . 38

\section{Factors Affecting Plant Establishment in an Alpine Ecosystem on the Beartooth}

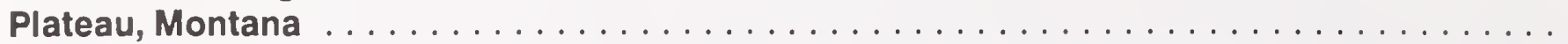

Jeanne C. Chambers, Ray W. Brown, and James A. MacMahon

Figure 1. Seed viability of alpine species collected during four consecutive years

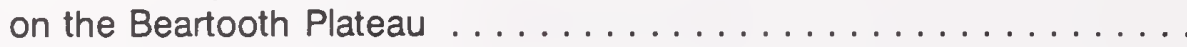

Figure 2. Generalized models of how small, medium-sized, large, and adhesive diaspores are trapped in soils over a range of increasing particle sizes in the entire soil column and at the depth at which germination

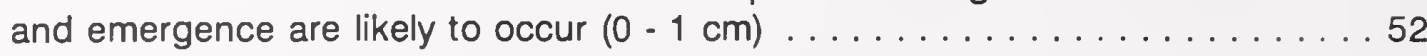

Figure 3. Numbers of Geum rossii and Deschampsia cespitosa plants that emerged in $1985,1986,1987$, and 1988 and the numbers of individuals alive in the years following emergence in borrow area plots on the Beartooth Plateau that were mulched or not mulched, but not fertilized . . . . . . . . . 56

Table 1. Total seed rain (seeds $\mathrm{m}^{-2}$ ) by life form on the Beartooth Plateau borrow and Geum turf sites during the active diaspore dispersal periods of 1988 ,

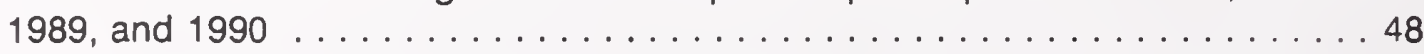

Table 2. Spearman's correlation coefficients comparing numbers of diaspores of each species caught in pitfall traps with cover indices for the same

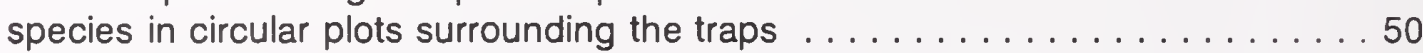

Table 3. Germination response of alpine species to wet or dry cold storage . . . . . . 53

Table 4. Seed mass and length and number of seedlings $\mathrm{m}^{-2}$ that emerged in mulched vs. unmulched plots on the Beartooth Plateau borrow area

\section{Plants in Dynamic Environments: Is "Wilderness Management" an Oxymoron?}

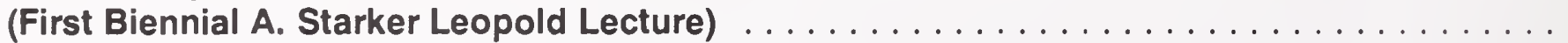

Norman L. Christensen, Jr.

The Parker Transects Revisited: Long-Term Herbaceous Vegetation Trends on Yellowstone's Northern Winter Range Michael B. Coughenour, Francis J. Singer, and James Reardon

Figure 1a. Total plant frequency on upper and lower winter range, inside and outside exclosures . . . . . . . . . . . . . . . . . . . . . . . 77

Figure 1b. Elk numbers on Yellowstone's northern winter range . . . . . . . . . . . . . 77

Figure 2. Proportions of plant groups and major species in the Parker transect data from the upper winter range $\ldots \ldots \ldots \ldots \ldots \ldots \ldots \ldots$. . . . . 80

Figure 3. Proportions of plant groups and major species in the Parker transect data from the lower winter range $\ldots \ldots \ldots \ldots \ldots \ldots \ldots \ldots . \ldots 2$

Figure 4. Seasonal precipitation over the period in comparison to total plant

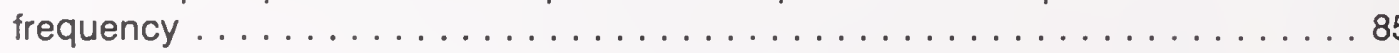

Table 1. Significance testing using repeated measures ANOVA (univariate approach), for effects of year and exclosure $\ldots \ldots \ldots \ldots \ldots \ldots \ldots \ldots$ 
Table 2. Total grass, forb, and dwarf shrub frequencies; mean (standard

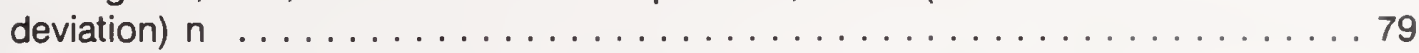

Table 3. Major grass species frequencies; mean (standard deviation) $n \ldots \ldots . \ldots .81$

Table 4. Significant correlations with seasonal and total precipitation in the current year, the previous year, and the period between the previous sample date and the current sample date $(3-8$ years $) \ldots \ldots \ldots \ldots \ldots$

\section{Elk Carrying Capacity on Yellowstone's Northern Elk Winter Range: Preliminary}

Modeling to Integrate Climate, Landscape, and Nutritional Requirements

Michael B. Coughenour

Figure 1. Fluctuations in forage biomass density, showing the amounts of forage that can meet daily energy and nitrogen requirements of elk during the winter . . . . . . . . . . . . . . . . . . . . . . . . . . . . . . . . . . . . 104

Figure 2. Variations in $\mathrm{K}$ over time, where $\mathrm{K}$ is calculated as the product of elk-days/ha and available foraging area . . . . . . . . . . . . . 105

Figure 3. Calculated levels of defoliation over the winter range $\ldots \ldots \ldots \ldots \ldots \ldots$

Figure 4. Comparison of summer-calf survivorship in year $t+1$ to fluctuations in mean available foraging area and forage $\ldots \ldots \ldots \ldots \ldots \ldots . \ldots \ldots$

Northern Rocky Mountain Paleoecology in Archeological, Paleobotanical, and

Paleoethnobotanical Perspective ...

Leslie B. Davis, Stephen A. Aaberg, and Linda Scott Cummings

Figure 1. Location of major archeological sites in southwestern and west-central Montana featured in the text

Figure 2. An east wall excavation profile of Unit 4 of the Indian Creek site section

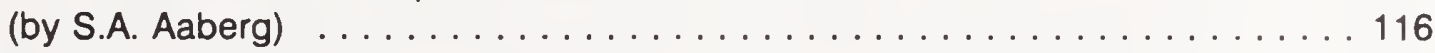

Figure 3. Southeast-northwest vegetational transect across Indian Creek (by S.A. Aaberg) . . . . . . . . . . . . . . . . . . . . . . 117

Figure 4. The Indian Creek site pollen diagram (after Fredlund and Bozarth 1987) . . . 117

Figure 5. A north wall excavation profile of the MacHaffie site section (by S.A. Aaberg) . . . . . . . . . . . . . . . . . . . . . . 118

Figure 6. The MacHaffie site pollen diagram (after Cummings 1990a) . . . . . . . . 119

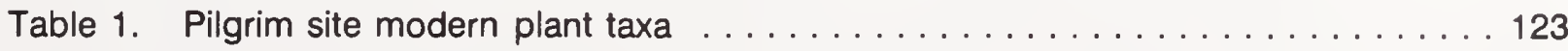

Table 2. Alder complex plant macrofossil taxa . . . . . . . . . . . . . . . . . . 124

\section{Bioenvironmental Representativeness of Nature Preserves: Assessment}

Using a Combination of a GIS and a Rule-based Model . . . . . . . . . . . . . . . . . . . . . . . 131

Robert L. DeVelice, Gerald J. Daumiller, Patrick S. Bourgeron, and John O. Jarvie

Figure 1. Graphic representations of elevation and slope

Table 1. Partial listing of model rules

Table 2. Area occupied by each of the 18 bioenvironmental classes in both the total study area and within preserves 


\section{Some Important Factors Affecting Density of Lodgepole Pine Seedlings Following}

the 1988 Yellowstone Fires

Marshall Ellis, Carol D. von Dohlen, Jay E. Anderson, and William H. Romme

Figure 1. Mean densities of lodgepole pine seedlings in moderate, canopy, and remote canopy burn transects at 12 study sites in Yellowstone

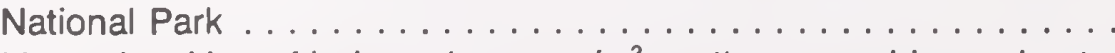

Figure 2. Mean densities of lodgepole cones $/ \mathrm{m}^{2}$ on the ground in moderate and canopy burn transects at 12 study sites in Yellowstone National

Park

Figure 3. Mean densities of lodgepole cones in the crowns of 10 dominant trees in moderate and canopy burn transects at 12 study sites

in Yellowstone National Park

Table 1. The 12 sites used to study density of lodgepole pine seedlings, and

their elevation and serotiny

Table 2. Ratios of postfire seedling density to prefire stand density

in 12 study sites

Historical Condition of Woody Vegetation on Yellowstone's Northern Range: A Critical

Evaluation of the "Natural Regulation" Paradigm . . . . . . . . . . . . . . . . . . . . . 15

Charles E. Kay and Frederic H. Wagner

Figure 1. Highlined conifers on Yellowstone's northern range . . . . . . . . . . 154

Figure 2. Repeat photoset of conifers at Mammoth Hot Springs on Yellowstone's northern range . . . . . . . . . . . . . . . . . . 156

Figure 3. Early photograph of Rainy Lake on Yellowstone's northern range southeast of Tower Junction . . . . . . . . . . . . . . . . . . . . . . . . 157

Figure 4. Douglas-fir trees growing on the north side of a glacial erratic boulder in the lower Lamar Valley on Yellowstone's northern range c. 1890

Figure 5. Conifers in William H. Jackson's c. 1883 photograph of Crested Hot Spring with Old Faithful erupting in the distance . . . . . . . . . . . 161

Figure 6. A typical aspen stand on Yellowstone's northern range today . . . . . . . . 162

Figure 7. Company D, Minnesota National Guard camp at Little Blacktail

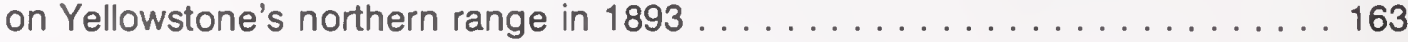

Figure 8. Closeup of aspen felled by beaver on Yellowstone's northern range in $1899 \ldots 164$

Figure 9. Early photo of aspen on Yellowstone's northern range . . . . . . . . . 165

Figure 10. Early photographs of tall willows on Yellowstone's northern range . . . . . . 167

\section{Short- and Long-Term Changes in Riparian Zone Vegetation and Stream}

Macroinvertebrate Community Structure

Deron E. Lawrence and G. Wayne Minshall

Figure 1. Photographs of short-term changes in the riparian zone of a firstorder tributary of Cache Creek

Figure 2. Artist's representation of long-term changes in central Idaho riparian areas following fire, based on actual photographs taken using spacefor-time substitutions

Figure 3. Scatter plots of (a) Simpson's Index against RBI.i. (b) $H^{\prime}$ diversity against RBI.i 
Figure 4. Scatter plots of (a) Simpson's Index against RBI.ii. (b) $H^{\prime}$ diversity

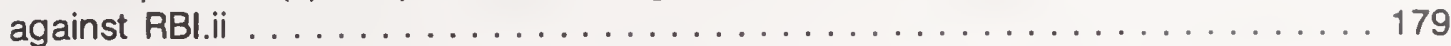

Figure 5. Line plots of correlations between Simpson's Index and RBI.i (circles), and $H^{\prime}$ diversity against RBI.i (squares) over the four sampling seasons . . . . 180

Table 1. Weighting scores for each Riparian Burn Intensity (RBI) index . . . . . . . . 174

Table 2. Correlations between community indices and percent of area burned . . . . 180

Demographic and Genetic Analyses of Sapphire Rockcress, a Rare Endemic 185 Donna Leeper, Diane Pavek, Roberta Walsh, and Thomas Mitchell-Olds

Figure 1. Geographic locations of the 13 populations of Sapphire rockcress

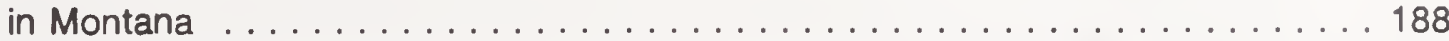

Figure 2. Geographic relationships of the populations of Sapphire rockcress . . . . . . 189

Figure 3. Net gain of individuals in the five populations used in the multiyear demography study . . . . . . . . . . . . . . . . . . . . . 192

Table 1. Estimates of demographic parameters within three classes of individuals . . . . 190

Table 2. Allelic mobility relative to the most common allele (100) . . . . . . . . . . . . . . 193

Native Plant Die-offs

Gary S. Maskarinec

Variation in Production and Bear Use of Whitebark Pine Seeds in the Yellowstone Area

David J. Mattson, Daniel P. Reinhart, and Bonnie M. Blanchard

Figure 1. Relationship for the years 1980 through 1989 between percent frequency of pine seed remains in September and October grizzly bear feces and mean number of cones produced per tree on nine transects established in 1980

Figure 2. Proportional distribution of grizzly bear feeding on whitebark pine seeds, by four aspect and three elevation categories, for use of the 1985, 1987, and 1989 seed crops . . . . . . . . . . . . . . . . . . . . . . . . . 210

Figure 3. Percent frequency of whitebark pine seeds in Yellowstone grizzly bear feces and number of pine seed feeding sites per sampled telemetry location, by year and month . . . . . . . . . . . . . . . . 212

Figure 4. Relative percentage of different feeding activities encountered on bear sign transects in the Cooke City area during 1989 and 1990, by month and pooled for fall of 1989

Table 1. Mean number and standard deviation (SD) of whitebark pine cones produced per tree, averaged across transects and by year and elevational

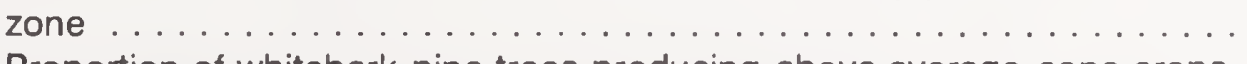

Table 2. Proportion of whitebark pine trees producing above-average cone crops, considering production relative to the contemporaneous mean during the previous two moderate to large crops, and statistics for analysis of independence 

Ward W. McCaughey

Figure 1. Percent germination of whitebark pine seed as related to lengths of embryo, endosperm, and total seed for seven collection dates

Table 1. Mean cone length, width, specific gravity, and percent germination of whitebark pine by collection date . . . . . . . . . . . . . . . . . . . . 224

Table 2. Mean ratios for embryo and endosperm (total cavity filled) to total seed length, and embryo to endosperm length of whitebark pine

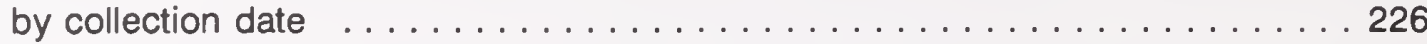

Responses of Nematodes to Ungulate Herbivory on Bluebunch Wheatgrass and Idaho Fescue in Yellowstone National Park

Evelyn Merrill, Jon Hak, and Nancy Stanton

Table 1. Biomass (matter/plant core) of standing dead, green, and crown and root biomass of Agropyron spicatum and Festuca idahoensis plants inside and outside a permanent exclosure on Crystal Bench winter

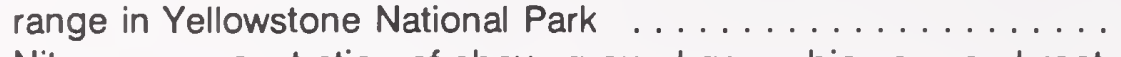

Table 2. Nitrogen concentration of above-ground green biomass and roots of Agropyron spicatum and Festuca idahoensis plants inside and outside a permanent exclosure on Crystal Bench winter range in Yellowstone

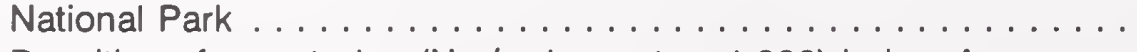

Table 3. Densities of nematodes (No./g dry roots $\times 1,000$ ) below Agropyron spicatum and Festuca idahoensis plants from inside and outside a permanent exclosure on Crystal Bench winter range in Yellowstone National Park

The Genus Cortinarius (Agaricales) in the Greater Yellowstone Area; Mycorrhizal Host Associations and Taxonomic Considerations

Meinhard Moser, Kent H. McKnight, and Martin Sigl

Table 1. Cortinarius species common to Europe and the GYA . . . . . . . . . 243

Table 2. New species of Cortinarius described from the GYA . . . . . . . . . . . . . . 244

Table 3. Spore measurements in $\mu \mathrm{m}$ for several American and European collections of $C$. fulvoochrascens $R$. Henry respecting $C$. pseudoarquatus $\mathrm{A}$. H. Smith

The Effects of the 1988 Wildfires on Diatom Assemblages in Streams of Yellowstone National Park

Christopher T. Robinson, G. Wayne Minshall, and Samuel R. Rushforth

Figure 1. Principal components analysis scattergram for the 14 study streams, and scattergram of percent catchment burned against amount of channel change

Figure 2. Bar graph summarizing temporal patterns in diatom species richness, Simpson's Index, and Shannon's Diversity for small and large streams and grouped as being either high- or low-disturbance systems 
Figure 3. Principal components analysis scattergram for study streams using the top 20 diatom taxa . . . . . . . . . . . . . . . . . . . . 253

Figure 4. Separate regression scatterplots of amount of channel change against change in diatom species composition for small streams and large streams

Table 1. List of physical measures to characterize study sites $\ldots \ldots \ldots \ldots \ldots \ldots$

Interactions Between Fire-injured Trees and Insects in the Greater Yellowstone Area . 259 Kevin C. Ryan and Gene D. Amman

Figure 1. Percent mortality by species and year for trees burned in the 1988 Greater Yellowstone Area fires

Table 1. Location of plots and number of trees by species in the fire-injury and insect interaction survey of the 1988 Yellowstone fires . . . . . . . . . . 262

Table 2. Bark beetles and wood borers infesting trees in the Greater Yellowstone Area following the 1988 fires . . . . . . . . . . . . . . . . . . . . 263

Table 3. Average tree diameter, percentage crown scorch, and percentage basal girdling, and predicted probability of mortality $\left(\boldsymbol{P}_{\text {mort }}\right)$, by species and status . . . . . . . . . . . . . . . . . . . . . . . . 264

Table 4. Number of trees, percentage mortality, and number of trees infested by insects by species and fire injury . . . . . . . . . . . . . . 265

Table 5. Cumulative distribution of insect infestation through 1991 , by species . . . . 266

Table 6. Cumulative insect infestation and observed mortality through July 1991 and expected mortality by location . . . . . . . . . . . . . . . . 267

Table 7. Observed vs. expected mortality for four species $\ldots \ldots \ldots \ldots \ldots \ldots$

Landscapes of Northwestern Yellowstone National Park: Soils, Landforms, and Vegetation Characteristics with Interpretations for Erosion Potential

Henry F. Shovic

Figure 1. Location of the study area with respect to Yellowstone National Park . . . . . 274

Figure 2. Schematic soil/landscape map of the study area $\ldots \ldots \ldots \ldots \ldots \ldots$

Table 1. Areal extent of map units in the survey area . . . . . . . . . . . . . 276

Table 2. Management interpretations and pertinent soil conditions for each

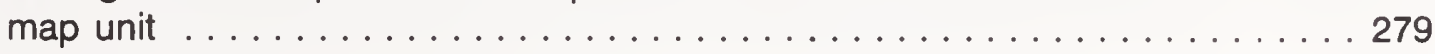

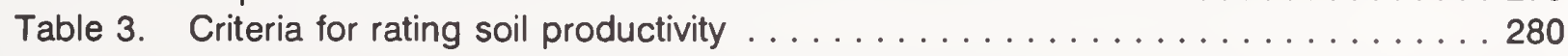

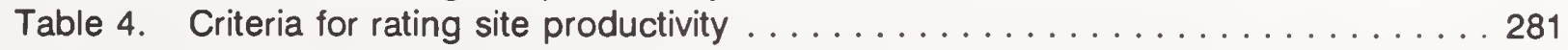

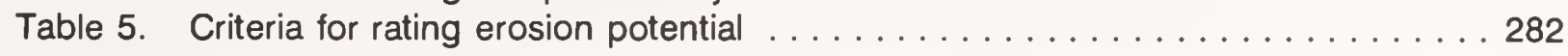

Vegetation Characteristics of Elk Summer Range in South-Central Montana . . . . . . . . . . . 285 Fred G. Van Dyke, Brenda L. Probert, and Jennifer J. Rozema

Figure 1. Plant coverage (percent) of shrubs, forbs, and graminoids on wet and dry alpine sites on the Line Creek and Silver Run study areas, south-central Montana, 1989 - 91 
Figure 2. Species diversity (Shannon-Weiner) indices of wet and dry alpine sites from June - August on the Line Creek and Silver Run study areas, south-central Montana, $1989-91$. . . . . . . . . . . . . . . . . . . . . 291

Figure 3. Succession of community similarity from June - August on the Line Creek and on the Silver Run study areas, south-central Montana, $1989-91 \ldots . . .293$

Figure 4. Use of habitat types in July and August by elk on the Line Creek and Silver Run study areas, south-central Montana, 1988 - 91 . . . . . . . . . . . 297

Figure 5. Grass, sedge, shrub, and forb proportions in July and August diets of elk on the Line Creek and Silver Run study areas, south-central Montana, 1988 - 89 . . . . . . . . . . . . . . . . . . . . . . . . . . . . . . . . . 298

Table 1. Summer plant production ( $\mathrm{kg} / \mathrm{ha}$, dry weight) of graminoids and forbs on Line Creek (LC) and Silver Run (SR) study areas at wet and dry alpine sites, south-central Montana, 1989 - 1991 . . . . . . . . . . . . . . . 290

Table 2. Average community similarity of wet and dry alpine sites on the Line Creek (LC) and on the Silver Run (SR) study areas in June - August, south-central Montana, 1989 - 1991

Table 3. Plant nutritional values (\%) of shrubs, forbs, and graminoids on wet and dry alpine sites on the Line Creek and Silver Run study areas in June and July, south-central Montana, 1989 - 1991 . . . . . . . . . . . . . . . . . . 294

Table 4. Plant nutritional values (\%) of shrubs, forbs, and graminoids on the Line Creek and Silver Run study areas in June and July, south-central Montana, 1989 - 1991 . . . . . . . . . . . . . . . . . . . . . . . . . . . . . . . 295

Table 5. Plant nutritional values (\%) of shrubs, forbs, and graminoids on the Line Creek and Silver Run elk summer ranges in June and July, south-central Montana, $1989-1991 \ldots \ldots \ldots$. . . . . . . . . . . . . . . . . . 296

Long-term Vegetational Response to Climatic Change and Edaphic Conditions in Yellowstone National Park

Cathy Whitlock

Yellowstone Plants and Their Environments: A Conference Review 305 Dennis H. Knight

\section{SECTION II: CONFERENCE ABSTRACTS}

GIS Documentation of the 1988 Greater Yellowstone Area Fire Growth . . . . . . . . . . . . . 313

C.H. Chase, R.A. Hartford, and R.C. Rothermel

Seedbanks under Climax Rocky Mountain Vegetation and the Effects of Fire on Them 315 D.L. Clark, T.W. Weaver, and D.G. Despain

Plant-Ungulate Ecology of Grasslands on the Northern Range of Yellowstone National Park

Douglas A. Frank and Samuel J. McNaughton 
Packhorse Grazing Impacts in a Wilderness Area

Katherine Hansen, Kathrin Olson-Rutz, Clayton Marlow, and Leonard Gagnon

Relationships among Breeding Songbirds, Willows, and Browsing by Elk and Moose in and Around Northern Yellowstone National Park

Sally Graves Jackson and John A. Kadlec

Short-Term (Five-Year) Effects of Air Pollution on Lodgepole Pine

J. Jacobs, T. Weaver, and M. Cole

Comparison of Soils Inside and Outside of Grazing Exclosures on Yellowstone

National Park's Northern Winter Range . . . . . . . . . . . . . . . . . . . . . . . . . . . . 329

John R. Lane and Cliff Montagne

Records of Fire Preserved in Lake Sediments from the Central Plateau

of Yellowstone National Park . . . . . . . . . . . . . . . . . . . . . . . . 331

Sarah H. Millspaugh

Aspen Seedlings Following the 1988 Yellowstone Fires

Roy Renkin, Don Despain, and Dave Clark

Forest Type, Fuel Moisture, and Lightning-Caused Fires

Roy Renkin and Don Despain

Suckering in Burned Aspen as Related to Above-Ground and Below-Ground

Biomass

Roy Renkin and Don Despain

Relationships Between Spatial Heterogeneity and Large-Scale Fires

on Subalpine Plateaus in Yellowstone National Park . .

Monica G. Turner, William H. Romme, and Robert H. Gardner 

Section I

Conference Papers 



\title{
The Effects of Global and Regional Environmental Changes on Mountain Ecosystems
}

\author{
W.D. Billings \\ Department of Botany \\ Duke University, Box 90338 \\ Durham, NC 27708-0338
}

\section{Introduction}

The key word in this essay is "change." To paraphrase the distinguished ecologist William S. Cooper (1926): Change in vegetation is like a braided glacial river flowing through time. The complexities of the separations and rejoinings and the new combinations of species are almost limitless and filled with surprises.

One cannot view the biosphere provincially either in space or in time; this is true of any regional ecosystem, including mountain ecosystems or other component biospheric systems. Crosswall barriers to environmental change do not exist in the biosphere nor within its component ecosystems. However, limiting factors to the successful growth and reproduction of biotic populations do exist and are unique to specific populations. And, within ecosystems and the biosphere itself, trigger factors may initiate farreaching changes and readjustments within the system. Such trigger factors are exemplified by increases in atmospheric carbon dioxide concentrations and by the destruction of stratospheric ozone by chlorofluorocarbons.

There is an eventual carrying capacity for populations at trophic levels above the primary level; this encompasses all levels of consumer biota, including people - locally, regionally, and globally. Also, through time, "surprises" can occur episodically, cumulatively, and evolutionarily in the biosphere, such as fire, volcanic activity, atmospheric carbon dioxide increase, glaciation, accelerated erosion, climatic change, release of toxic substances, and genetic change in populations of microorganisms, plants, and animals.

The lithosphere, atmosphere, hydrosphere, and biosphere have changed both continuously and episodically during the past in both space and time, and they will continue to do so in the future. Many of these changes have been unpredictable; this is true at present, and very likely such "surprises" will be common in the future. But some changes have been repeated many times in the past. Similar repetitive changes occur at present and some can be predicted. An example of past repetitive changes in the present mountainous Yellowstone ecosystem is the case of a number of petrified forests, one above the other, at Fossil Forest in the mountains above the Lamar River Valley. Dorf (1960) estimated 
that burial of these forests by pyroclastic debris occurred over c. 20,000 years by repeated episodic volcanic events during the Middle Eocene. The estimated elevation at the site at that time was c. $915 \mathrm{~m}$ in relatively low mountains. The present elevation there is near 2,135 m. More recently, however, Fritz (1980) has shown that mud flows and braided streams from nearby Eocene volcanic peaks transported plant parts, including logs, stumps, and roots of Picea and Abies, from the cooler high mountains. These plant parts were deposited among petrified remnants of tropical and temperate region trees in the lowlands. Vegetational changes occurred, also during the Cenozoic, in the mountains of western Nevada (Axelrod 1962, 1976, 1991) and in other western mountain ranges. In recent centuries, much global change has resulted from an increasing series of natural and industrial "surprises" that have led to a new and different earth, ecologically, economically, and politically. Some of this change had been predicted or planned for, but much had not.

Can one predict ecosystemic futures by using the past as analogue? The answer is only partially, and only qualitatively. The biosphere appears to be changing faster now than at most times in the past. The fossil record generally shows slower and steadier migration rates than those sudden adventive jumps, so common today, that are exemplified by the spread of cheatgrass (Bromus tectorum L.) and starlings (Sturnus vulgaris) across North America in this century. In these two instances, the introductory vectors were human beings. People are now primarily responsible for many such "invasions" that have resulted in large changes in widespread native ecosystems. An example is the destruction of great areas of Artemisia tridentata Nutt. (sagebrush steppe) in the Great Basin of western North America, caused both by the growth of cheatgrass and by fire (Billings 1990).

Even so, existing species of plants probably will not be able to continue their migrations because of future climatic changes. Also, their latitudinal migration rates may not prevent population decreases or even extinctions. Moreover, climates can change more rapidly than suitable soils can develop northward or up-mountain on glaciated rock, scree, or rocky fellfield.

In general, we have only relatively crude methods in our attempts to predict the possible effects of climatic and weather changes on evolutionary rates and extinctions and changes in plant populations and vegetational structure. These methods include experimentation with single plants, clones, local populations, and ecosystemic natural microcosms under simulated future environments in phytotrons or in the field (Billings et al. 1982). Measurements of growth, reproduction, survival, photosynthesis, nutrient uptake, and respiration can be made on these models under an array of postulated environments of the next few centuries. In using such experimental approaches, one must be aware that carbon-nutrient interactions act as major constraints on the success of the population under new and future environments (Shaver et al. 1992). Also, all of the above experimental procedures must be accompanied and aided by continuous monitoring of plant growth, reproduction, and population structure in the field. Such work is time consuming and tedious. But such "ground truth" is absolutely necessary if useful predictions are to be obtained. Such information can then be incorporated into mathematical models.

But all of this is far from perfect, even at the levels of populations, communities, and biomes, and is even more so at biospheric levels. There are strong possibilities that climatic changes and surprising episodes may come before we have answers for montane and alpine populations and ecosystems, including timberlines. For high latitudes, where alpine ecosystems merge with arctic tundras, this is a particularly urgent issue. It is in these ecotonal regions that climatic warming is predicted to occur more rapidly than elsewhere and with disastrous results to soils and vegetation underlain with permafrost (Billings 1992; Billings and Peterson 1992; Oechel and Billings 1992). At the same time, it would be very surprising if 
plant migrations could keep pace with climatic warming before natural loss of the tundra soils occurred, caused by melting permafrost (Billings and Peterson 1992).

The result, in both alpine and arctic ecosystems, may be local and general extinctions of plants and animals. In a warming climate, what will happen to Brown's $(1971,1978)$ "alpine islands" of mammals in the western North American mountains and their already partially depleted alpine biota? These questions are also applicable to the vegetational and floristic "alpine islands" from the Sierra Nevada to the Rocky Mountains, including the Beartooth Plateau, the Absarokas, the Big Horns, the Wind Rivers, and the Medicine Bow as described by Billings (1978, 1979), Bliss (1956), Chabot and Billings (1972), Despain (1973), Johnson and Billings (1962).

Analogous situations have occurred in postglacial times in the high Southern Appalachians and to some extent in the alpine zones of Mt. Katahdin and Mt. Washington in the Northern Appalachians (Bliss 1963). The loss of an alpine zone to forests in the Great Smoky Mountains and on Mt. Mitchell in the Black Mountains of North Carolina has already occurred in recent millennia, with some arctic-alpine relictual plant taxa disappearing there within the last century. And now, the spruce-fir forests that cap the Southern Appalachian high peaks are dying due to a combination of biologic adventives and atmospheric pollution. Similar "Waldsterben" are also occurring in the Northern Appalachians and in the Adirondack Mountains (see Eagar and Adams 1992).

\section{Western North American Mountain Gradients Now}

\section{Environmental}

There are three main environmental gradients that interact to govern biological and physical systems on the earth's mountain ranges: latitudinal, elevational, and topographic. Each of these environmental gradients consists of many interacting factors that vary quantitatively along the gradient. Figure 1 (from Billings 1979) diagrams qualitatively the relative values of a few of the important factors that govern arctic-alpine environments along mountains from the Arctic to the equatorial Andes. Only daily mean air temperature is relatively uniform along this gradient of 70 degrees of latitude. At a given degree of latitude, the interacting factors create a unique mountain environment. This condition is further complicated by the effects of the elevational gradient and altitudinal atmospheric gradient. Superimposed on these complications are the effects of topography.

The topographic gradient, in turn, consists of two main subdivisions differing in scale, the larger being termed mesotopographic and the smaller microtopographic (Billings 1973). Figure 2 diagrams a typical alpine mesotopographic gradient and its effects on water, snow, and vegetation in the Beartooth Mountains near the Yellowstone Plateau. A diagram of one kind of common alpine microtopographic feature, a solifluction terrace, common in the Beartooth, appears in figure 3 (Johnson and Billings 1962). Almost identical solifluction terraces occur in the alpine zones of New Zealand mountains (Billings and Mark 1961) arid in the mountains of central Alaska.

\section{Ecosystemic}

The actual gradients of ecosystems on the sides of mountain ranges reflect the interactions of latitudinal, elevational, and topographic gradients with the available floristic and faunistic populations. Such populations have migrated somewhat independently along all three major gradients for millennia and, 


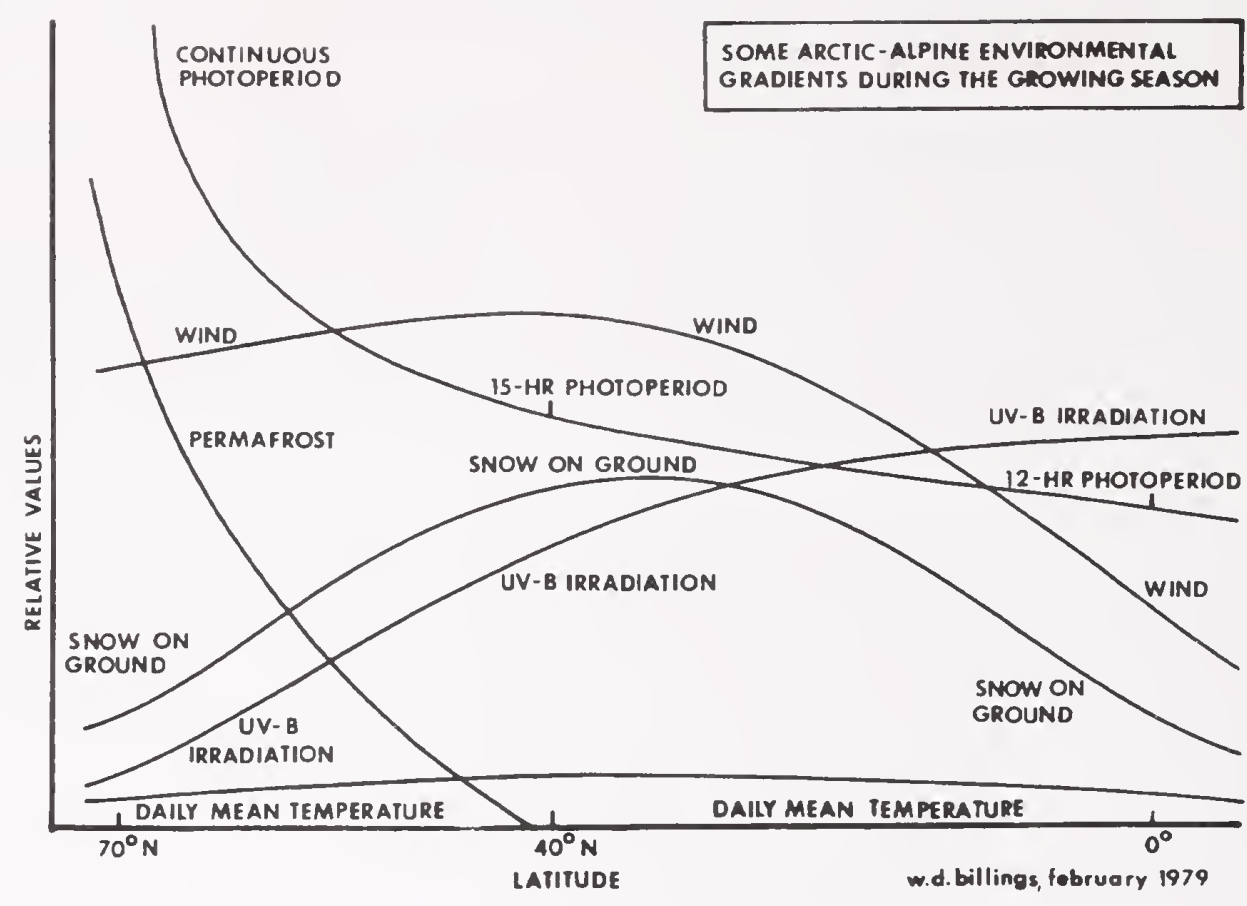

Figure 1. Relative values of six principal environmental factors in arctic and alpine ecosystems along a latitudinal gradient from the Arctic to the Equator. At any given latitude, the combinational effect of the factors is unique to that latitude. From Billings (1979).

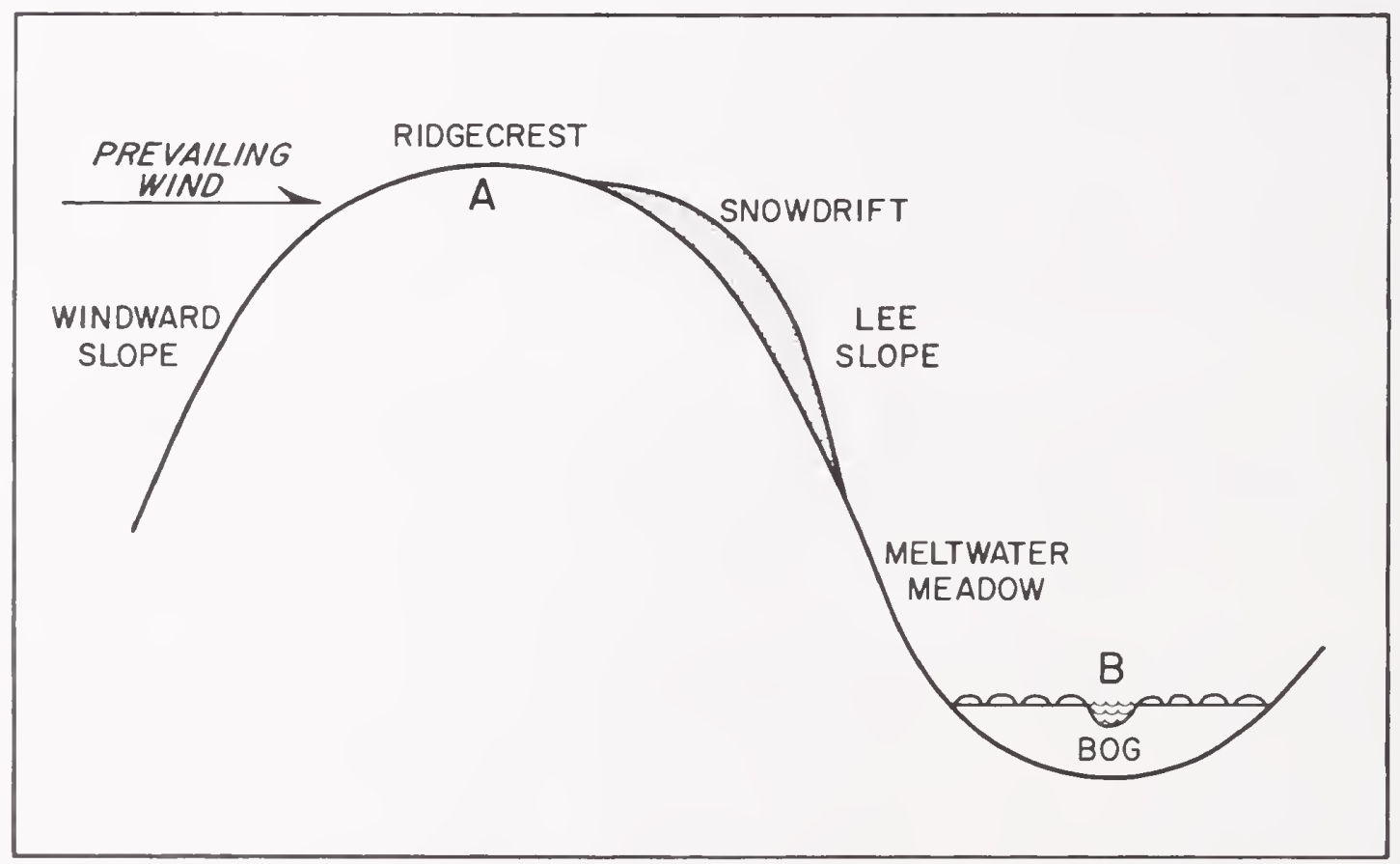

Figure 2. Diagram of a typical alpine mesotopographic environmental gradient. The scale can vary from c. $50 \mathrm{~m}$ from A to B up to c. $800 \mathrm{~m}$. From Billings (1973). 
in some cases, for millions of years through the Cenozoic as climates have changed and the mountains have risen.

In addition to climatic change, geologic uplift, and weather gradients, geologic substratum plays an important role in determining ecosystemic composition and process in mountains. The greatest impacts on biologic structure and physiology of the community are made by parent rocks of unusual chemical composition. Some examples are limestone and dolomite (Billings and Thompson 1957; Despain 1973; Marchand 1973), serpentines (Kruckeberg 1969, 1985), and the very acid and nutrient-poor hydrothermally altered rocks (Billings 1950; Schlesinger, DeLucia, and Billings 1989). Ecotones between these chemically extreme rocks and adjacent rocks of mixed mineralogical composition are usually rather sharp and narrow compared with ecotones and continua that are due to differences in weather and climate accompanying increased elevation.

\section{Evolutionary and Migrational}

The source regions for montane and alpine plant taxa through the Cenozoic have been most often the neighboring lowlands or foothills, either wet or dry. As the mountains rise, new elevational gradients are created, ranging from warm temperatures in the foothills to cold temperatures on the ridges and peaks. Snow and winds dominate the environments of the higher elevations, except in most tropical mountains. Atmospheric pressure and the partial pressures of metabolic gases also decrease with altitudinal elevation.

The Great American Cordilleran Pathway. By far the longest and oldest (Cretaceous and Paleocene) latitudinal mountain gradient in North America is the greater Rocky Mountain complex, which extends from tropical Central America to Alaska, where it reaches its arctic limit in the Brooks Range near 68 degrees north latitude. In western and coastal British Columbia, this system is joined from the south by the Sierran-Cascadian chain. In southeastern Alaska, the St. Elias-Alaska Range diverges to the northwest and west into a snowy, cold, maritime climate. Far to the south, beyond the Panamanian lowlands, the northern Andes of Colombia and Venezuela stretch southward along the west edge of South America to the subantarctic mountains of Cape Horn near 56 degrees south latitude. The addition of the very long Andean system to the Rocky Mountains forms the longest mountain migrational biotic pathway on earth. The approximate total length of the Rocky Mountain-Andean Cordillera is c. 17,000 $\mathrm{km}$. (10,500 mi). Its latitudinal span is almost 125 degrees. Its alpine and timberline ecosystems show similar plant life forms along most of this distance (Billings 1973, 1974).

During the entire Cenozoic, alpine and timberline floras have evolved by migrations upward from the lowlands into the western North American and South American high mountains (Axelrod 1990; Axelrod and Raven 1985; Billings 1974; Chabot and Billings 1972; Vuilleumier 1971). Figure 3 represents a quantitative example of upslope migration and evolution of taxa on the east slope of the Sierra Nevada of California (Chabot and Billings 1972).

Once the heights are achieved, migration north and south is possible a few steps at a time or by longdistance dispersal. The latter type of dispersion is often aided by mammal and/or bird vectors. This is particularly true along the old tried and true Rocky Mountain pathway to and from the Arctic and the Tropics - and even from Colorado to the far southern Andes (Simpson and Todzia 1990). Figure 4 (Johnson and Billings 1962) illustrates migratory pathways as affected by several principal stresses: low temperatures, drought, predation, and solar radiation. The pathway is a two-way road for migrating taxa. 


\section{Top Soil}

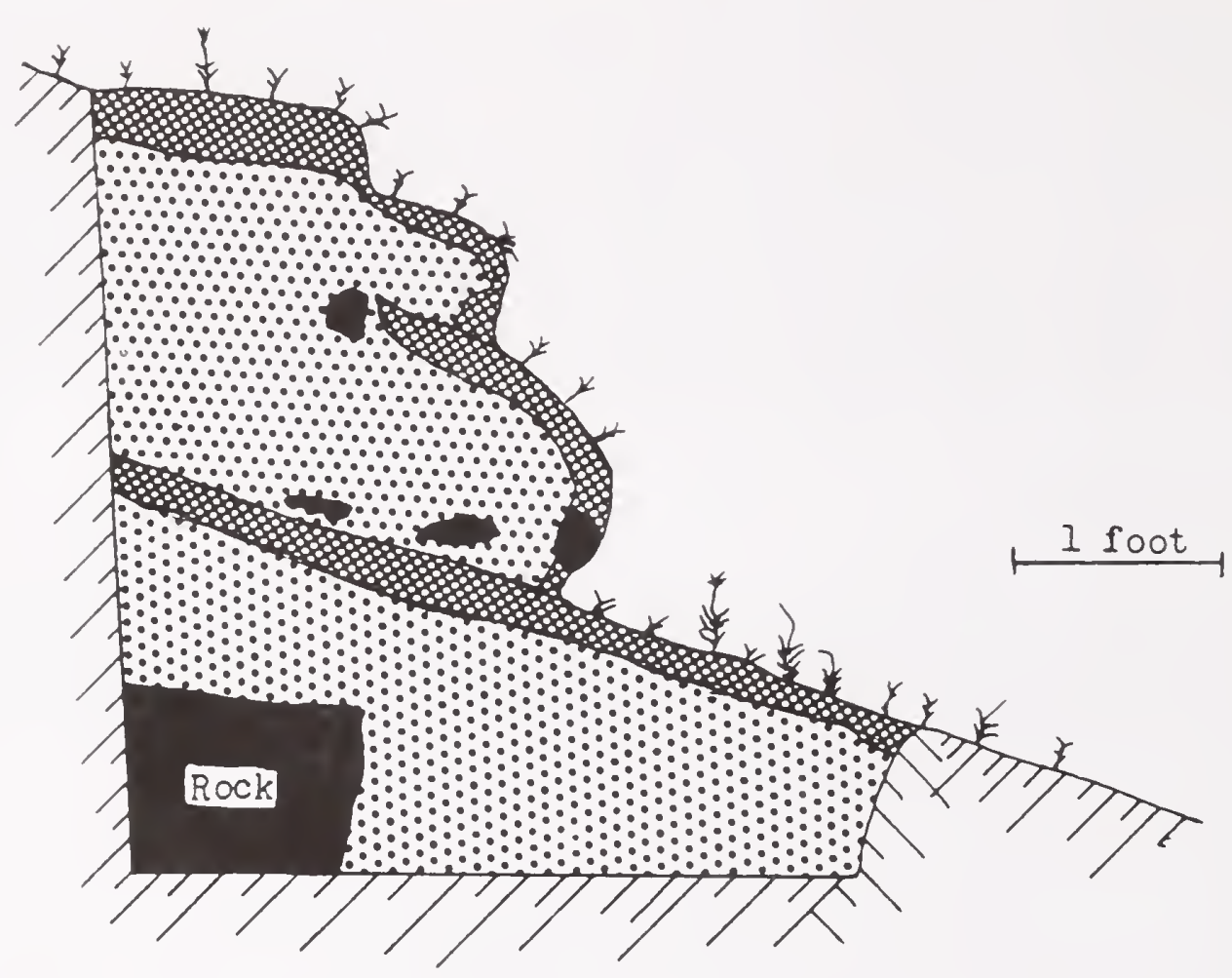

Figure 3. Diagram through a solifluction terrace in the Beartooth Mountains, Carbon County, Montana. The buried organic horizons and several organic involutions show that amorphous solifluction has been active. From Johnson and Billings (1962).

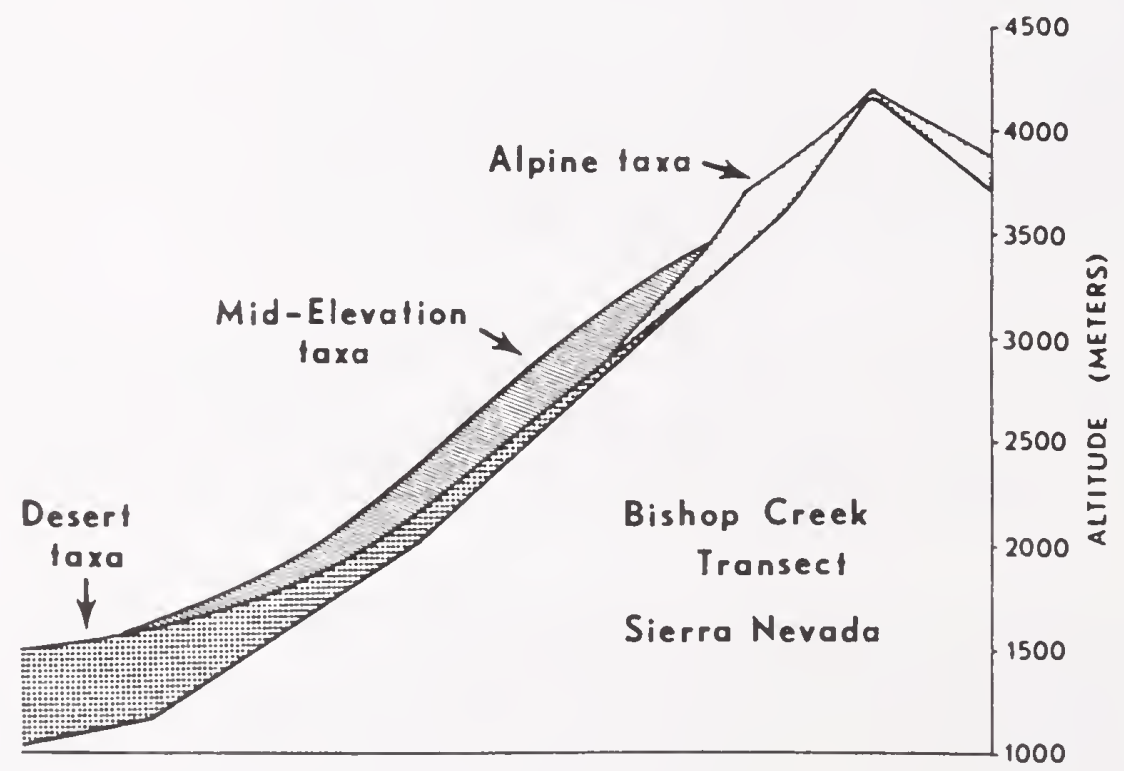

Figure 4. Relative distribution and floristic richness along an elevational gradient on the east escarpment of the Sierra Nevada near Bishop Creek, California. The relative numbers of taxa in each of three major floristic groups are indicated by the thickness of the shaded sections. From Chabot and Billings (1972). 
Latitudinal and Elevational Floristic Gradients. Floristic richness decreases with both increasing elevation and increasing latitude toward the Arctic (Billings 1973, 1987, 1992). The causes of such decreases in number of species are decreases in mean annual and growing season temperatures (Billings 1973; Cailleux 1961; Rannie 1986), drought stress in polar deserts (Bliss, Svoboda, and Bliss 1984), and drought stress at very high elevations in tropical mountains (Smith 1981, 1987). Ultraviolet-B irradiation is also a severe environmental stress on mountain plants. Ultraviolet-B reaches its highest levels on tropical mountains at high elevations such as Haleakala on Maui and on the high Andes of Venezuela, Colombia, Ecuador, and Peru (Caldwell, Robberecht, and Billings 1980).

Environmental gradients up the sides of mountains are steeper than latitudinal environmental gradients. In general, floristic diversity and richness decrease as mountain elevations increase. This is especially true when elevation is combined with increasing latitude (Billings 1987; Breckle 1974); see figure 5. However, the geologically new Sierra Nevada of California, which extends for c. $650 \mathrm{~km}$ between the latitudes of 36 and 40 degrees north, is floristically very rich in its subalpine and alpine elevations (Raven and Axelrod 1978; Stebbins and Major 1965). Raven and Axelrod propose that the subalpine and alpine endemics evolved in situ from the subalpine forests as the Sierra rose during the Pliocene and Pleistocene. Added to these endemics are some arctic-alpine species derived from the north (Billings 1978). These arctic derivatives are generally taxa that are rather widespread in the western high mountains. A number of archetypical arctic-alpine plant species such as Silene acaulis, Saxifraga oppositifolia, and Koenigia is/andica are conspicuous by their absence in the Sierra. Still, the alpine flora of the Sierra is the largest, and uniquely the richest, on the North American continent (Billings 1988). Only 19 percent of the alpine plant species growing at 3,700 $\mathrm{m}$ on the glacially scoured granites near Piute Pass (lat. $37^{\circ} \mathrm{N}$ ) in the Sierra Nevada also occur in the Arctic (Billings 1978). In a similar alpine region near Olancha Peak (lat. $36^{\circ} \mathrm{N}$ ), c. $115 \mathrm{~km}$ southeast of Piute Pass in the Sierra, there are c. 102 alpine vascular plant species (Howell 1951). Only 13 percent of these species also occur in the Arctic. These figures contrast sharply with the geographic relationships of the alpine flora of the Beartooth Mountains, Wyoming-Montana, (lat. $45^{\circ} \mathrm{N}$ ) on the main Cordilleran pathway, where 47 percent of the vascular species also occur in the Arctic (Billings 1978, 1988).

If one examines widespread arctic-alpine plant species at the level of the ecotype, it becomes apparent that ecogenetic populations within species determine much of the tolerance to latitudinal and elevational climatic gradients (Clausen, Keck, and Hiesey 1948; Turesson 1925). One of the most widely distributed arctic-alpine plant species is Oxyria digyna (L.) Hill, or mountain sorrel. Its physiological ecology and flowering were first studied in detail by Mooney and Billings (1961), who found that arctic and alpine populations differed in their breaking of dormancy, flowering, and return to dormancy as determined by day length in combination with temperature. Alpine populations broke dormancy at shorter day lengths than those from the Arctic and produced preformed flower buds at shorter day lengths (12 to 13 hours) than the 18 to 20 hours that triggered such dormancy mechanisms in arctic ecotypes.

Some years later, Billings et al. (1971) measured photosynthesis, dark respiration, and other biochemical metabolic processes in 17 populations of Oxyria grown from seed in the Duke Phytotron. These seeds were collected in the field from North American and European alpine and arctic populations along a latitudinal gradient extending from 35 degrees north to 82 degrees north. The North American populations were obtained from San Francisco Peaks, Arizona, and at sites along the Rocky Mountain Cordillera through Colorado, Wyoming, and Montana to the Alaskan Arctic and Ellesmere Island. Other mountain populations in western North America included those from the Sierra Nevada and the Olympic Mountains. European populations ranged from the Pyrenees to the Scottish Highlands, the Tatra Mountains of Poland, and Finnish Lappland. 


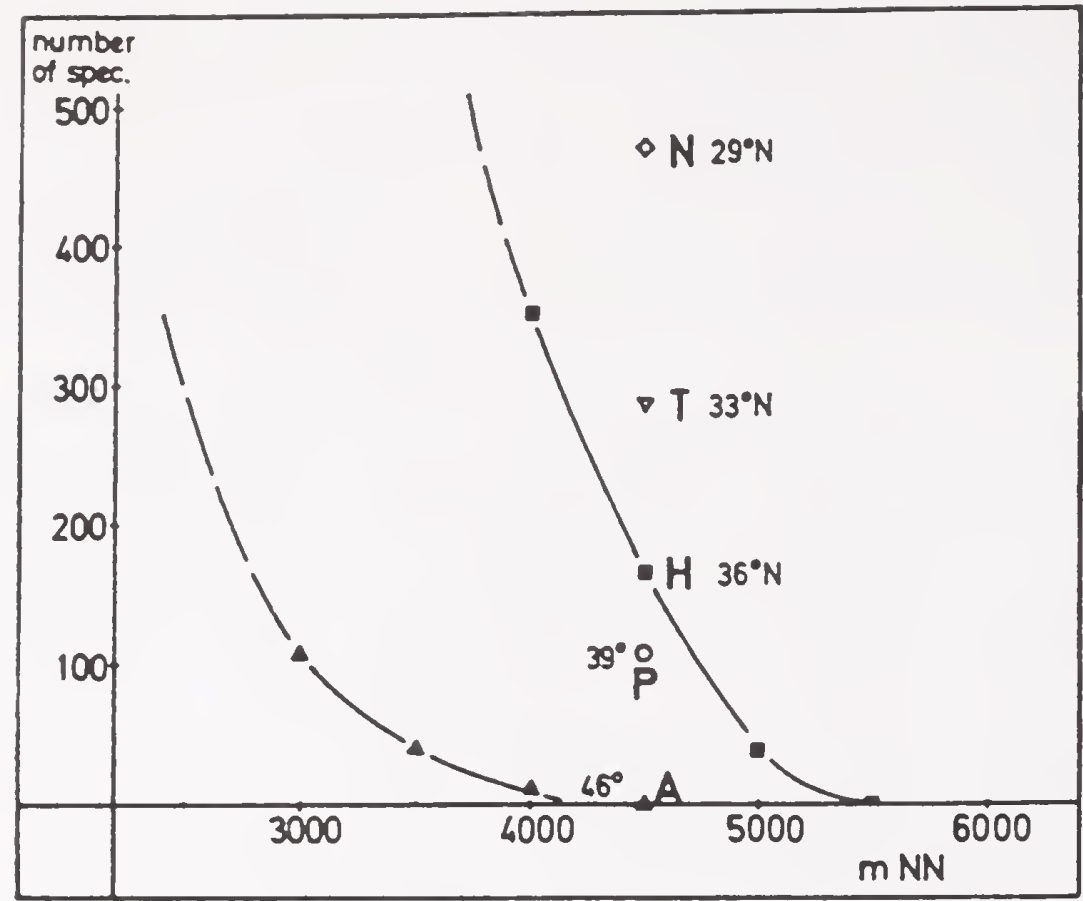

Figure 5. The decreasing number of plant species with increasing elevation in the European Alps, compared with the mountain ranges in Central Asia. The letters show the increasing number of species with decreasing latitude: $\mathrm{A}=$ Alps, $\mathrm{P}=$ Pamir, $\mathrm{H}=$ Hindu Kush, $\mathrm{T}=$ Tibet, $\mathrm{N}=$ Nepal Himalaya. From Breckle (1974).

The principal question asked in that research was, "What is the relative effect of phenotypic temperature acclimation on metabolic rates compared to the effect conferred by the genetic ecotype?"

Some of the results obtained are as follows: Dark respiration rates were increased by cold acclimation in all 17 ecotypes. Maximum net photosynthesis rates in this C3 species (in which ribulose bisphosphate is the $\mathrm{CO}_{2}$ receptor) were lowered in all arctic populations but in only a few alpine populations after warm acclimation. The temperature of maximum net photosynthesis was increased by warm acclimation. Maximum net photosynthesis rates were higher in arctic populations than in alpine populations; this difference was increased by cold acclimation. The upper temperature compensation point in both arctic and alpine ecotypes was increased by warm acclimation. Alpine populations showed ideal homeostasis in net photosynthesis, while arctic ecotypes showed only a low degree of partial homeostatic adjustment in net photosynthesis. On the other hand, dark respiration homeostasis was almost ideal in all populations and showed no ecotypic difference. Efficiency of chlorophyll was higher in alpine ecotypes and at high temperature in all ecotypes, particularly after warm acclimation. Mitochondrial oxidative activity was increased by cold acclimation; the rates from arctic populations were higher after cold acclimation than those from alpine populations. We conclude that, in Oxyria, acclimation is under genetic control and that "acclimation ecotypes" exist. The most plastic phenotypes in regard to acclimation occur in alpine ecotypes.

In view of the above results, climatic changes are quite likely to change metabolism, growth, reproduction, and survival of mountain plant populations. Those ecotypes that have the genetic ability to acclimate will be favored. In Oxyria, alpine populations and ecotypes probably would survive climatic 
warming better than their arctic counterparts because of their more plastic acclimation potentials. Populations that cannot acclimate or survive extreme temperatures or drought stress during climatic warming are likely to die out.

Gradients of People and Their Effects in Mountains. Now, finally, we come to relatively recent mountain gradients: those of people and their effects. These effects are almost entirely products of the Holocene, and primarily of the last century or two. The impacts on vegetation are relatively great and intensively localized compared with those of long-term climatic changes.

Mankind has been living in the high mountains of the Northern Hemisphere for thousands of years, probably for most of the Holocene and at least as soon as the continental ice melted in Europe. There is good evidence at a relatively low elevation $(300-400 \mathrm{~m})$ in the mountains of South Wales near Paviland of early man very close to the continental ice front. This is an elaborate cave burial of a 25-yearold male with much ivory jewelry and a worked mammoth skull in the same cave (Dennell 1983). The man's skeleton has been radiocarbon dated by Oakley (1980) at 18,460 years before the present (B.P.). At that time, the burial site was only c. $6 \mathrm{~km}$ from the front of the ice sheet.

However, there are relatively few concrete details in time and space on true alpine populations of human beings. Therefore, the discovery of a frozen mummified man, complete with gear, exposed in September 1991, at an elevation of $3,200 \mathrm{~m}$, by the peripheral melting of the Similaun Glacier, was of great significance. This is not far below the 3,525 m summit of the Finailspitze near the head of the Otztal (thus the nickname "Ötzi" applied to the body) in the Austrian Tirol. The discovery is solid evidence of the kind of people who lived and hunted in those high mountains more than 5,000 years B.P. (Harrigan 1992; Jaroff 1992).

In the Himalayas and Andes, there are people living now whose ancestors cut the original timber for fuel and housing. The Andean Quechua also grew crops (maize, potatoes, and quinoa) on the steep slopes, and still do. The large human population increases in the Andes, much of it caused by up-mountain migration in the last century or two, has led to severe accelerated gully erosion, which is destroying the very cropland so necessary to the survival of these peoples.

In the western North American high mountains, the climates were too severe for the native Americans to live throughout the year and to cultivate crops. These people were hunter-gatherers crossing and recrossing the Rocky Mountains or Sierra Nevada, hunting as they went. But the greater parts of their lives were spent in the bordering foothills and valleys on either side, where the majority of the large game animals grazed.

In Europe, particularly in the Swiss Alps and the high mountains of the Austrian Tirol, people have lived for a long time in small village populations as high as timberline. Primary production of grasses and forbs in the alpine meadows is good enough to allow milk cows to graze during the summer. The farmers harvest the meadow hay to feed the animals in shelters during the long snowy winters. All of this is done very carefully by these people who live in the mountains and know them very well - as did their ancestors.

In this century, the development of skiing as a sport has brought great changes to the mountains in Austria and Switzerland, and to all the western and northern mountains in Europe and North America. Skiing has brought tourists by the many thousands into the villages and resorts in Europe and North America, and also into similar mountain environments in the Southern Andes, Japan, New Zealand, and Australia. 
The economic and ecologic impact of ski tourism on a European alpine farming village has been studied by Moser and Moser (1986) and others in the Austrian Tirol. The village is Obergurgl near timberline at the head of the Ötztal at an elevation of c. $1,950 \mathrm{~m}$. The village is surrounded by glaciers and snowcovered sharp peaks not far north of the Italian border, which lies on the crests of the highest mountains on the southern horizon. This village and its surroundings were also studied by Bunnell et al. ("Bubu Himamowa") in 1974. This research group produced the famous Obergurgl Model using the village as a microcosm of economic and sociologic growth in relation to a mountain environment of limited ecological resources.

Obergurgl village has a permanent population of c. $300-500$ persons. It has been settled since the 12 th century largely by subsistence farmers. Until the 20th century, the subalpine meadows and alpine grasslands supported c. 15 farm families totaling c. 120 persons (Moser and Moser 1986). The villagers' careful agriculture allowed sustainable yield of cattle, milk, and cheese using the native herbaceous vegetation. Close to the village, hay was harvested, and on the rougher mountainsides, the cattle grazed during the summer. The vegetation was carefully protected and so were the soils. The higher peaks around $3,700 \mathrm{~m}$ in elevation were not exploited by the farming families. In the years before World War II, people interested in mountaineering arrived in relatively small numbers from the countries of western and central Europe, giving summer business to the village inn.

The real increase in alpine tourism throughout the upper Ötztal came after World War II. The number of small hotels increased in the village and by the 1970s, there were c. 2,000 guest house and hotel beds for tourists winter and summer. This resulted in a tremendous influx of tourists (c. 40,000 per year), as well as perhaps 800 seasonal migrant workers from Yugoslavia, Turkey, and other countries in southeastern Europe. The number of permanent Obergurgl families grew to almost 80 (Moser and Moser 1986). Only a few families continued to farm, while many families entered the hotel and restaurant business or worked on the ski lifts. The influx of money into Obergurgl naturally has made quite an economic impact on the community and has changed dramatically the way of life in this alpine farming community. The ski lifts and ski slopes have changed much of the mountainous land east of the village. And, a great deal of the formerly productive agricultural land in the canyon bottom east of the Gurgler Ache (a small river from the Gurgler Gletscher) is now occupied by small Tyrolean-type hotels and restaurants. West of the Gurgler Ache, the trail network is expanding over the flowery meadows, creating a trampling problem with some erosion.

The native attractiveness of the village and its mountain setting (figure 6) were being endangered by the overwhelming impact of the total winter and summer tourist trade. By the early 1970s, the village and environs were beginning to lose some of their charm. But even in 1974, the economic and ecologic threats to Obergurgl's future had not been integrated so that forecasts could be made. A Man and the Biosphere-6 project was set up in that year through the International Institute for Applied Systems Analysis in Vienna and brought together villagers, scientists, economists, and other specialists.

This team approach defined the total Obergurgl problem. The result was the preliminary version of the Obergurgl Model of a mountain tourist village as a microcosm. Such a model can be useful worldwide for similar people-mountain problems. The model consists of four main groups of factors: (1) recreational demand, (2) population and economic development, (3) farming and ecological change, and (4) land use and control of development (see figure 7). Major problems seen by the modelers were (1) sociology of villagers, (2) perception of environmental quality by villagers and tourists, (3) mapping of ecological conditions in the area, (4) determination of primary production of vegetation in relation to grazing by domestic stock and native animals, (5) projection of potential recreational demands, (6) continued policy analysis of alternative development schemes, (7) ecological studies of human and animals impacts on 


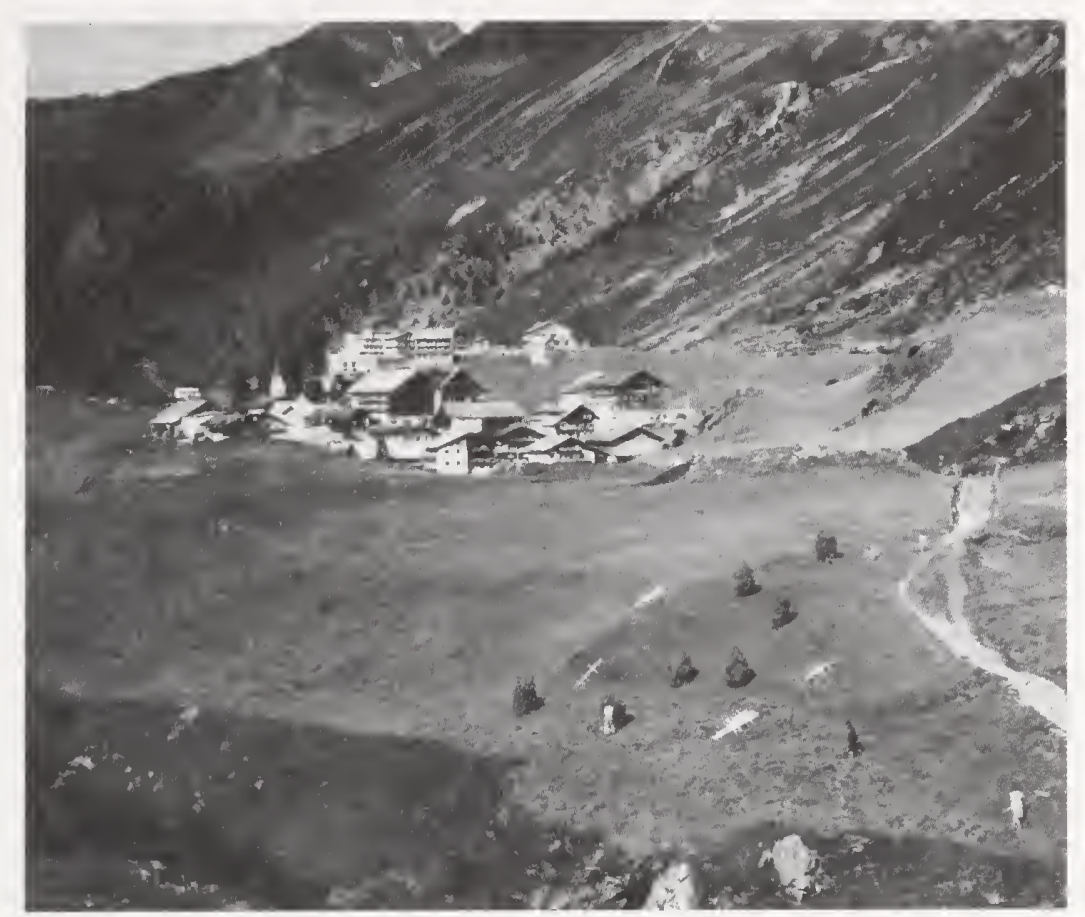

Figure 6. The mountain village of Obergurgl in the Austrian Tirol as it appeared in 1964 with its surrounding hay fields. Photograph by W.D. Billings.

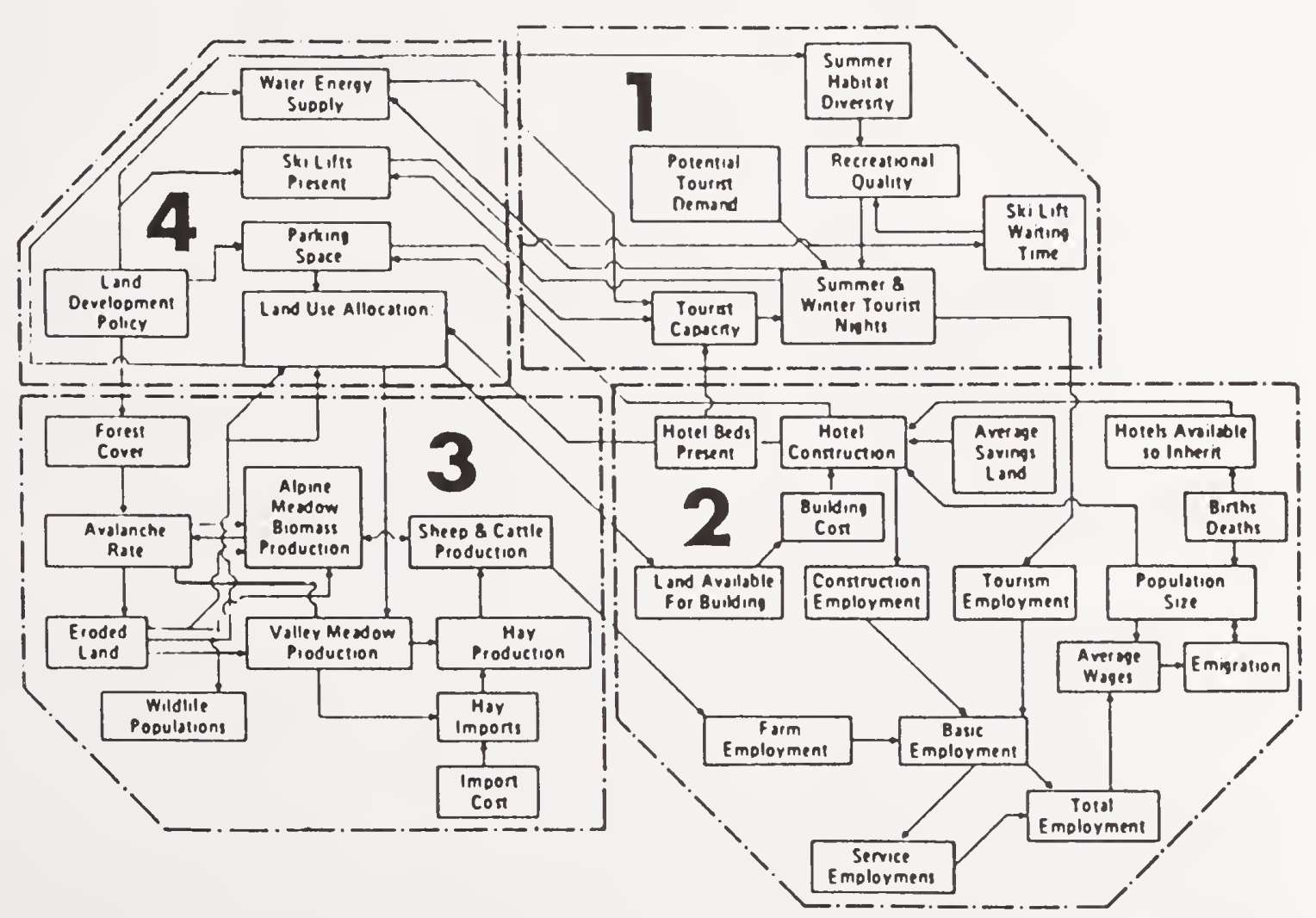

Figure 7. The Obergurgl Model, with its four main components and subcomponents. From Moser and Moser (1986). 
meadows, and (8) economic analysis of the village and its population. While the model is far from perfect at this time, and many of the data are lacking or not yet complete, it is an example of what can be done in an interdisciplinary and interpopulational way to begin forecasting and, possibly, to solve, at least partially, some of the modern problems of how aggregations of people might live, work, and play in high mountain environments without destroying them.

Problems similar to those faced in the greater Obergurgl ecosystem occur widely throughout these high mountain regions of the earth that are affected by tourism and livestock grazing. Within the United States, these regions are exemplified by the National Parks and certain National Forest areas, as well as by many state parks and recreational areas.

Alpine vegetation above timberline is very susceptible to trampling by people and hooved animals, both domestic stock and native ungulates. These effects lead to trail proliferation and, eventually, to erosion, especially in snowdrift areas and some kinds of wet meadows. Pioneer research on these effects on alpine vegetation in National Parks of the United States include those of Willard and Marr (1970) in Rocky Mountain National Park, Colorado; Bell and Bliss (1973) in Olympic National Park, Washington; and Hartley $(1976,1980)$ in Glacier National Park, Montana, which still continues. In addition, Grabherr's (1982) pertinent paper describes quantitative results on trampling on Hohe Mut, a mountain ridge at an elevation of 2,550 to 2,650 $\mathrm{m}$ accessible by cable car from Obergurgl in the Tirolean Alps. Grabherr found that the most sensitive species on Hohe Mut were fruticose lichens. The dominant angiosperms, Carex curvula and Ligusticum mutellina, did not disappear completely even at a tourist frequency of 150 per meter of trail per day.

The most thorough field research on trampling effects on alpine vegetation and trail formation by people is that of Hartley (1976) in the meadows east of Logan Pass in Glacier National Park. His work was started in 1967 and still continues, with the latest measurements on damage and recovery being taken in July 1992. It is truly long-term ecological research.

Hartley's main conclusions as of 1976 and 1980 are as follows:

1. The local landscape at Logan Pass has changed conspicuously owing to the building of amenities, educational facilities, and water supplies for tourists.

2. Animal life has been affected in various ways by the continued closeness of people. This is true of grizzly bears, mountain goats, and mountain sheep. Smaller mammals, including Columbian ground squirrels and hoary marmots, have adjusted to the presence of people, as have a number of bird populations, including the white-tailed ptarmigan.

3. The herbaceous plant cover near Logan Pass has been reduced by human activity, and the floristic composition has been changed by such activity through the years. Aside from permanent structures, paved roads, parking lots, and constructed trails, much of the remaining vegetation has been trampled to some extent. Such damage is particularly severe along trails and close to them. The degree of vegetational damage depends on foot traffic interacting with the kind of vegetation, slope, and wetness of the soil. Wet meadows are often damaged severely but may recover more rapidly also. Only a few people walking single file can create a new trail. If other groups follow the trail, the damage is started. Some plant species are very sensitive and can disappear very soon even under light use. 
4. Hartley constructed a useful model of the effects of trampling on the physiological status of alpine vegetation under the stress of trampling. Billings (1983) modified Hartley's model slightly; it appears here as figure 8. Primarily, the effect starts through physical damage to the plants and the loss of photosynthetic tissue. Secondarily, energy capture by leaves and thence by translocation to carbohydrate storage in roots, rhizomes, and bulbs is severely hampered or stopped. Since these are the perennating organs of these herbaceous plants, lack of regrowth and reproduction can cause the local extinction of susceptible species. These species include Phyllodoce empetriformis, Senecio resedifolius, and, to some extent, the bulbiferous Erythronium grandiflorum.

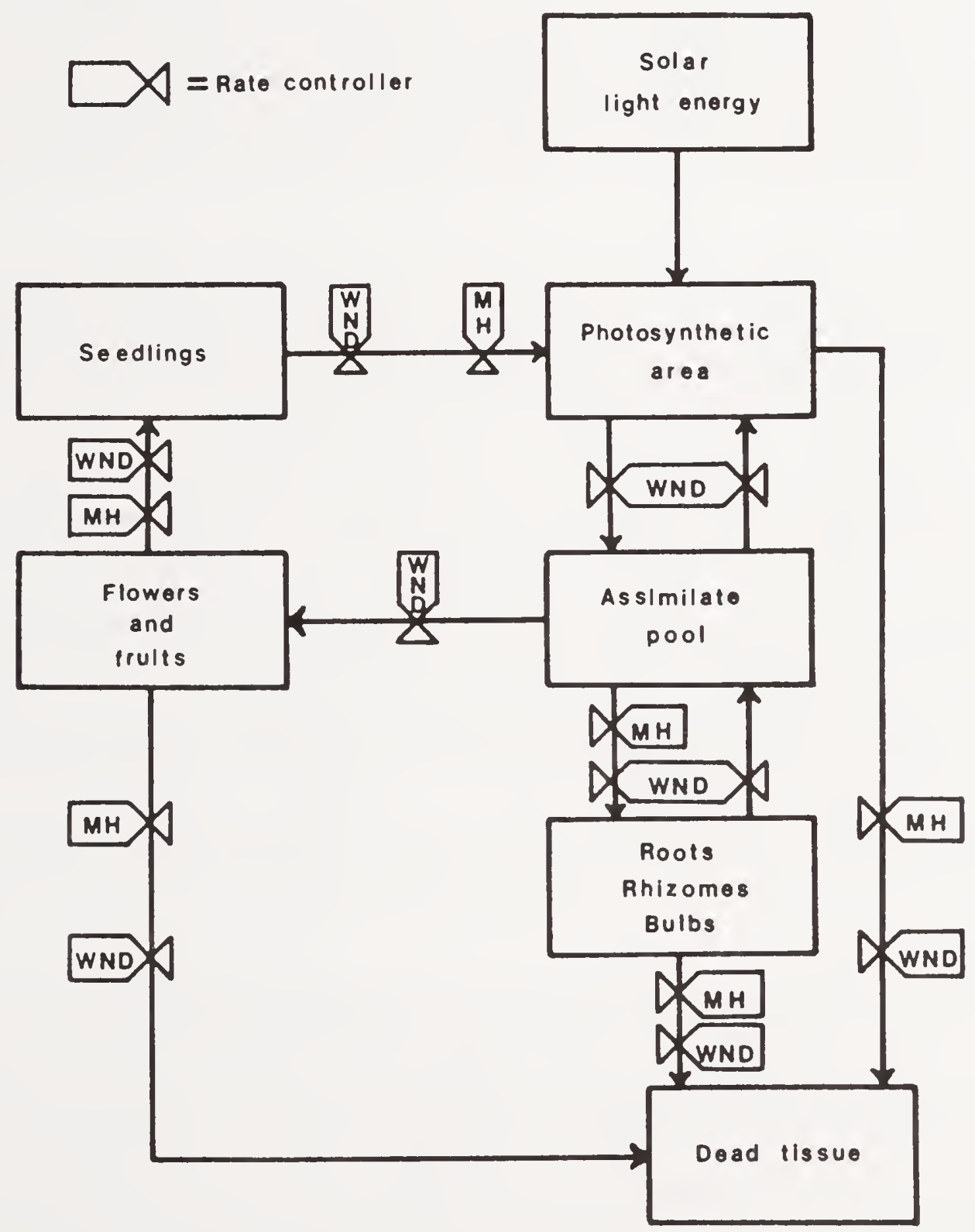

Figure 8. Rate controller model of the impact of treading on photosynthesis and carbohydrate storage in subalpine and alpine meadow vegetation in Glacier National Park, Montana. Slightly modified and redrawn by Billings (1983) from Hartley (1976). $W=$ water status, $N=$ nutrient status, $D=$ disease, $H=$ herbivores, $M=$ man. 
5. The soils of the research area were damaged by trail traffic by compaction and subsequent erosion. Such soil destruction makes vegetational reestablishment very difficult and slow. Depending on the degree of soil damage and loss of plant reproduction potential, revegetation and soil development may take centuries or even tens of thousands of years in alpine ecosystems of the type near Logan Pass.

\section{What Will Mountain Ecosystems Be Like in the Next Century?}

And, what are the problems likely to be? What environmental "surprises" await for these ecosystems either globally or locally? As Rosenberg (1986) entitled his paper, "A Good Crystal Ball Is Hard to Find!" Will the global climate in the mid-21st century be warmer than it is now as the carbon dioxide, methane, and other greenhouse gases increase in atmospheric concentration? Or are there uncertainties in this regard? Local mountain environments will certainly vary, plus or minus, in temperature trends from global means. Some mountain regions possibly will be cloudier than they are now; others may be less cloudy and perhaps drier.

It is difficult enough to predict what the climates of the lowlands will be in the next century with their thousands of first-class and long-term weather observing stations. But as Barry (1992) reminds us, few mountain weather stations are relatively and usually far between, and with records mostly spanning only the last century or less. In the western North American mountains, there are very few observing stations at all and only two or three equipped with first rate instruments and personnel. Switzerland has many more and has had them for a longer time. In the United States, the better mountain weather stations are those on Mt. Washington, New Hampshire, which was established in 1932, and the Institue of Arctic and Alpine Research (INSTAAR) station on Niwot Ridge, Colorado, established by Dr. John Marr in 1952.

Good past records of weather observations at a given site are the foundations upon which climatic predictions for that site can be made from the best predictive models. Therefore, we face a handicap in trying to predict what the montane weather and climate will be like in the middle of the next century. However, estimates can and should be made now based on available regional and global data and their possible impacts on mountain vegetation and the rest of the biota, including people.

In this concluding section, I shall discuss only a few of the interacting factors that can affect plant growth and vegetation in the western North American high mountains:

greenhouse gases and possible climatic change loss of stratospheric ozone and the increase in ultraviolet- $B$ irradiation possible changes in snowfall, glaciers, and runoff climatic change and wildland fires in mountains migrations and possible extinctions of plant taxa

\section{Greenhouse Gases and Possible Climatic Change}

Within this century, it is apparent that the global mean air temperature is increasing. But global warming, in spite of much research and modeling efforts, is still rather unpredictable (Jones and Wigley 1990). True, atmospheric $\mathrm{CO}_{2}$ levels have increased in the past two centuries from c. $280 \mathrm{ppm}$ by volume to almost 360 ppm. However, the longest consistent and detailed record in one place (Mauna Loa, Hawaii) 
only began in 1958 (Keeling, Bacastow, and Whorf 1982), when the $\mathrm{CO}_{2}$ concentration there was 315 ppm. There are now a number of other global stations continuously monitoring atmospheric $\mathrm{CO}_{2}$ but with far shorter records.

Even though $\mathrm{CO}_{2}$ is the main and most abundant "greenhouse" gas, there are several others of importance. Notable among these are methane $\left(\mathrm{CH}_{4}\right)$, which has more than doubled in the past several decades to over 1,700 ppb; nitrous oxide to $310 \mathrm{ppb}$; and the man-made chlorofluorocarbons (CFCs) that did not even exist in the first half of this century and now are c. 1 ppb. The CFCs, of course, are also the primary causes of the breakdown of the stratospheric ozone layer and of the ultraviolet-B (UV-B) problem (Rowland 1989).

Jones and Wigley (1990) calculate that the present global air temperature is $\mathrm{C} .0 .75^{\circ} \mathrm{C}$ warmer than it was in the early part of this century. However, the yearly means are rather erratic. All models predict that warming will accelerate logarithmically in the first half of the 21 st century. But there is considerable uncertainty between low and high temperature increase. By the year 2050, global air temperatures could be somewhere between 2.0 to more than $4.0^{\circ}$ warmer than now on a global basis.

What does this warming mean for the high mountains of the earth? As Barry (1992) emphasizes, it is difficult to predict the effects of global warming on mountain climates for several reasons. One reason is the considerable difference in areal scale between mountains and the globe. Other reasons are concerned with primary climatic effects on so many environmental factors for which we have so few data both spatially and temporally. These include especially those concerned with water: snowfall, snowpack, snowdrifts, glaciers, meltwater, and runoff.

Soil temperatures in permafrost in the arctic tundra of Alaska from Cape Thompson to Barrow to Prudhoe Bay have been reported by Lachenbruch and Marshall (1986). These temperatures show widespread secular warming trends of the permafrost surface ranging from $2^{\circ}$ to $4^{\circ} \mathrm{C}$ during the past few decades. The loss of permafrost by melting is often accompanied by severe thermokarst erosion and loss of vegetation that literally holds the tundra ecosystems together (Billings and Peterson 1992). Since permafrost has been reported from a number of places in the high Rocky Mountains, the loss of these cold soils could cause considerable change in the kinds of alpine plant communities above timberline in these mountains. In the Yellowstone region, permafrost and other cryopedogenic features are known from the Beartooth Plateau (Johnson and Billings 1962). Farther south in the Cordillera, permafrost is known from the Medicine Bow Mountains of Wyoming (Billings and Mooney 1959) and from the Front Range of Colorado (Greenstein 1983; Ives and Fahey 1971).

Aside from the peripheral effects of global warming in the earth's high mountains, there are the direct effects of increasing $\mathrm{CO}_{2}$ levels on photosynthesis and growth of mountain plants. Almost all plants at high elevations in the mountains of the middle latitudes have the C3 photosynthetic pathway. Plants with the $\mathrm{C} 4$ mode of photosynthesis do not operate well in these cold summer temperatures. Also, the direct effects of increasing atmospheric $\mathrm{CO}_{2}$ on photosynthesis and growth favor $\mathrm{C} 3$ plants over those with $\mathrm{C} 4$ metabolism (Strain 1987). Strain also reports that water-use efficiency increases as atmospheric $\mathrm{CO}_{2}$ concentration increases. This leads to stomatal closure, causing transpiration to decrease at the same time that photosynthesis is increasing. This improved plant water balance is estimated to be sufficient to increase water yield in some mountain watersheds.

At the ecosystem level, Bazzaz (1990) concludes that the intricate interactions between $\mathrm{CO}_{2}$ levels and other environmental factors make it rather difficult to extrapolate advantages or disadvantages from the level of the individual plant to the community and the ecosystem. 
Körner (1992) has studied the effects of climatic warming on alpine vegetation in the Tirolean Alps with special attention to the interactions between rising $\mathrm{CO}_{2}$ and temperature. He concludes that the extent to which rising $\mathrm{CO}_{2}$ levels will result in increased primary production and consequent changes in alpine vegetational patterns will depend on trends in atmospheric and soil temperatures. Growth and changes in alpine vegetation appear to have a high priority as indicators of climatic warming effects on ecosystemic processes.

One way of attempting to study arctic (or alpine) tundra is to use natural vegetation-soil microcosms extracted whole in frozen condition during the arctic winter and then measure carbon exchange as thaw proceeds under controlled and simulated conditions of the 21 st century in a phytotron (Billings et al. 1982, 1983, 1984). We got the following results using cores from Barrow, Alaska, at $71^{\circ} \mathrm{N}$ latitude: (1) increasing the summer temperatures from $4^{\circ}$ to $8^{\circ} \mathrm{C}$ reduced net ecosystem carbon uptake by half;

(2) lowering the water table by $5 \mathrm{~cm}$ and increasing temperature greatly lowered ecosystem carbon storage; (3) doubling ambient atmospheric $\mathrm{CO}_{2}$ concentration alone had little effect on the total ecosystem carbon balance; (4) adding nitrogen (the present limiting factor in most arctic tundras) had far more effect on ecosystemic net carbon gain than simultaneously increasing atmospheric $\mathrm{CO}_{2}$ concentration; and (5) the most probable effects of higher atmospheric $\mathrm{CO}_{2}$ levels on the Alaskan tundra will be through indirect effects on temperature, water levels, decomposition, and availability of soil nutrients.

\section{Loss of Stratospheric Ozone and the Increase in Ultraviolet-B (UV-B) Irradiation}

The high mountains of the middle latitudes and the tropics have always had an environment with strong fluxes of incoming solar ultraviolet radiation. This downward flux is in spite of the screening of such radiation, especially UV-B, by the stratospheric ozone layer. A key environmental danger is, therefore, severe sunburn or skin cancer of most people who inhabit these mountains or climb in them in the clear, transparent air. Snow cover and ice, by reflection, increase the irradiation of ultraviolet $A$ and $B$ as received on the skin. Plants also receive this irradiation; some leaves reflect it, while others screen it out.

While this ultraviolet hazard has been present as long as mountains have been raised, the UV-B gradient between the polar mountains and those in the tropics curvilinearly increases toward the tropics: the Andes, the Himalayas, the Hawaiian volcanoes, and the equatorial mountains of east Africa (see figure 1). This increase toward the equator is due to a combination of increased mountain elevation, a thinner ozone layer over the tropics than over the polar regions, and the steeper angle of incidence of solar radiation received at the earth's surface in the tropics.

The 20th century has seen drastic increases in UV-B irradiation, not only in the mountains but also at sea level. It is now known, of course, that the stratospheric ozone screen is breaking down, not just over the tropics, but in the polar regions over Antarctica and the Arctic. The cause is the continued accidental release of a product of the mid-20th century, the man-made chlorofluorocarbon gases (CFCs or "freons"). As Rowland (1974) and his colleagues discovered c. 20 years ago, these chlorine compounds, escaping from aerosol cans, refrigerators, and air conditioners into the atmosphere, rise to high altitudes where they break down the stratospheric ozone molecules. This effect is summarized in Rowland (1989).

We still know relatively little of the effects of solar and sky UV-B radiation on the growth and physiological processes of plants. It has been only in the past 30 years or so that precise measurements of UV-B have been made with improved instrumentation. Even so, such modern measurements preceded our knowledge of the breakdown of stratospheric ozone. It was suspected even earlier that UV-B irradiance 
was greater on high mountains in spite of its absorption by stratospheric ozone. This assumption led to speculation concerning the effects of such irradiance on the growth, structure, and physiology of alpine plants. It was not until the work of Caldwell (1968) that ecologists began to use the new measurement techniques and to understand plant reactions and adaptations to increased UV-B dosages. Caldwell's results gave impetus to research on effects of UV-B not only on high mountain plants but also on crop plants.

The field location of Caldwell's pioneer (1968) work was on Niwot Ridge in the Colorado Front Range at an elevation of $3,750 \mathrm{~m}$ in alpine tundra. His laboratory measurements were under controlled conditions in our laboratory at Duke University. In the field, Caldwell measured the responses of alpine plants (Kobresia myosuroides, Carex rupestris, Geum rossii, Trifolium dasyphllum, and Oreoxis alpina) to the exclusion of natural solar and sky UV-B radiation. Caldwell's principal results showed the following:

Under high-intensity monochromatic UV irradiation in the laboratory, there was an inverse relationship between UV filtration capacity of alpine plant epidermis and leaf sensitivity to UV-B damage.

When grown under controlled laboratory conditions, plants of Oxyria digyna from the Arctic, where solar UV is attenuated, had significantly higher epidermal UV transmission than did Oxyria plants from western North American alpine locations. In this species, red leaves with higher anthocyanin contents were consistently less susceptible than green leaves to tissue destruction by $296.7 \mathrm{~nm}$ at $1.4 \times 10$ quanta $\mathrm{cm}^{-1} \mathrm{sec}^{-1}$. Other snowbank species that turn bright red after emergence, such as the high Sierran Polygonum davisii, probably are also less susceptible to UV damage.

The UV filtration capacity of plants of the Colorado alpine Ranunculus adoneus, a snowbank emergent, was suppressed by covering the snow (before plant emergence) with UV-absorbing plastic filters. After emergence of control plants of this species on the open tundra, UV-absorbing filters of the same type also decreased UV filtration capacity. If the filters were suddenly removed from either set of these Ranunculus plants, no apparent damage occurred. Removal of filters was accompanied by rapid reddening of the leaves as anthocyanins were synthesized and screened out UV-B.

Photoreactivation (PR) by visible light of leaf damage caused by UV-B wavelengths within the alpine solar spectrum was shown by several species of high mountain plants.

Tissue destruction by UV-B under controlled laboratory conditions was evident in some individuals. In nature, on Niwot Ridge, where high-intensity visible and UV-A radiation are both available for PR, such severe tissue destruction by UV-B does not normally occur.

Beginning in the 1970s, Caldwell and several colleagues began additional UV-B and plant measurements on a much larger geographical stage. This research was done on the high mountains of North and South America and Hawaii. The first of these projects was a quantification of solar UV-B radiation along the high alpine Cordillera from Atkasook at $70^{\circ} 28^{\prime} \mathrm{N}$ latitude in the Alaskan Arctic to the mountains above Snowbird, Utah $\left(40^{\circ} 32^{\prime} \mathrm{N}\right)$, to the Andean páramo in Venezuela $\left(8^{\circ} 50^{\prime} \mathrm{N}\right)$, to the Andean puna above

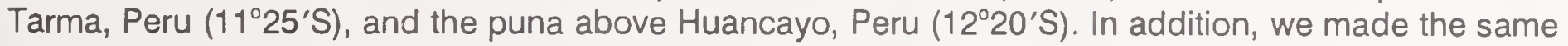
measurements on the summit of Haleakala, Maui, at $20^{\circ} 42^{\prime} \mathrm{N}$ latitude in the Pacific Ocean. 
The first paper (Caldwell, Robberecht, and Billings 1980) concerned the actual field measurements of solar UV-B radiation in the arctic-alpine zone along a latitudinal gradient of almost 90 degrees. All of the measurements were made at the season of highest noon altitude of the sun above the horizon at each site. Along this entire alpine gradient, maximum daily total shortwave irradiance varied only by a factor of 1.6 and total daily shortwave radiation by less than 15 percent for cloudless conditions. In contrast, maximum integrated effective UV-B irradiance varied by a full order of magnitude along the transect from the Arctic to the Andean puna in the southern latitudes in Peru, and the total daily effective radiation by as much as 7 times. The far steeper UV-B gradient is the result of the natural latitudinal gradient in stratospheric ozone column thickness, solar angles, elevation above sea level, and optical amplification. Much of the solar UV-B flux (40 - 70 percent) is in the form of scattered radiation that still strongly affects even pendant foliage. And, snow cover can add considerably to the UV-B radiation load on alpine plant leaves.

Simultaneously with measurements of incoming UV-B radiation at the various sites on this long latitudinal mountain gradient, we also measured leaf ultraviolet optical properties on several plant species in each of the rather different vegetation types representative of the different latitudes (Robberecht, Caldwell, and Billings 1980). Epidermal transmittance of solar UV-B $(295-320 \mathrm{~nm})$ was measured on a number of plant species at each site. In the equatorial and tropical mountains, mean leaf epidermal transmittance was less than 2 percent. At the higher latitudes, such transmittance exceeded 5 percent. Even though incoming solar UV-B dose along the latitudinal gradient varied sevenfold in daily integrated UV-B irradiance, the mean effective UV-B irradiance at the top of the mesophyll of equatorial and tropical highmountain plant leaves was not essentially different from those of plants at high latitudes. Mountain plants in high UV-B radiation environments seem to attenuate this radiation more effectively than do those in the lower UV-B environments of the subarctic mountains. This seems to be due to the absorption of UV-B wavelengths in the epidermis.

Reflectance of UV-B is generally less than 10 percent from glabrous leaves. However, some species with glaucous or pubescent leaves reflected a considerable fraction of the UV-B irradiance. In the very high UV-B environment on the summit of Haleakala (elevation 3,024 m) on Maui, the light-colored pubescent leaves of the shrubby Geranium tridens reflected c. 20 percent of the irradiance across the UV spectrum from 290 to $400 \mathrm{~nm}$. Its neighboring species in that barren, open landscape, Argyroxiphium sandwicense (silversword or "ahinahina"), reflected about 40 percent of the UV across the same spectral gradient, from silvery appressed pubescence. Modification of epidermal transmittance either by reflectance or absorbance resulting in lower UV-B irradiance at the mesophyll may represent one mechanism toward acclimation by plants to UV-B radiation. This acclimation possibly could help high mountain plants survive and adapt if the UV-B flux downward increases with breakdown of the stratospheric ozone layer.

Recently, Ziska, Teramura, and Sullivan (1992) have studied the physiological sensitivity of four plant pairs, from sea level on Maui to the summit of Haleakala, to UV-B radiation. In a controlled greenhouse experiment, these plants were grown under UV-B radiation levels that could be expected by a 20 percent and a 40 percent stratospheric ozone depletion at the latitude of Maui. Increases in UV-B radiation on plants from higher elevations on Haleakala, where natural UV-B radiation is already high, caused earlier reproductive effort, maintenance of relative water content, increased dark respiration, increased photosynthesis, and increased apparent quantum efficiency. Plants from low elevations in the same experiment showed a significant decrease in average plant and floral biomass, a decline in apparent quantum efficiency and also in relative water content, and a reduction in light-saturated photosynthetic capacity. As with our results, the authors found that UV-B - absorbing compounds (e.g., flavonoids, including anthocyanins) increased under UV-B irradiance in the low elevation plants. But the plants from high elevations on Haleakala consistently produced larger amounts of these flavonoids even in the 
absence of UV-B radiation. It appears that plants growing in a naturally high UV-B environment have developed mechanisms that maintain reproductive phenology and carbon uptake in spite of increased UV-B irradiance.

Caldwell et al. (1982) earlier had found, experimentally, with several ecotypic or species pairs from the arctic-alpine zone along the Cordillera that UV-B radiation inhibited photosynthesis. These taxa included arctic and alpine ecotypes of Oxyria digyna, the arctic Taraxacum lateritium and a Taraxacum sect. Mexicanum from 4,000 m elevation in the Peruvian Andes, and Lupirus arcticus from northern Alaska vs. $L$. meridanus from the Venezuelan Andes at 3,000 $\mathrm{m}$ elevation. The authors found that ecotypes of Oxyria, the arctic Lupinus, and the arctic Taraxacum were consistently and significantly more sensitive to UV-B radiation than their southern Rocky Mountains or Sierran ecotypes (Oxyria) or Andean counterpart species (Taraxacum, Lupinus) in regard to inhibition of photosynthesis. The arctic taxa exhibited short-term fluorescence transients indicating damage to the oxidizing side of Photosystem II in the photosynthetic light reaction. There was no indication of this in the alpine taxa.

\section{Possible Changes in Snowfall, Glaciers, and Runoff}

Wind, snowdrift patterns, and meltwater runoff govern the local distribution and community structure of most alpine-subalpine herbaceous and woody plants, since all can metabolize, grow, and reproduce at low temperatures after thaw. Referring back to figure 2 on the effects of topography and wind force on snow, one can deduce that the mountain mesotopographic snow-moisture gradient controls alpine community structure and vegetational pattern (Billings 1973). Meltwater meadows lying below relatively early-melting snowdrifts are the most productive alpine and subalpine ecosystems (Billings and Bliss 1959; Billings and Billings in preparation).

Precipitation types and regimes of the next century are more difficult to predict than atmospheric $\mathrm{CO}_{2}$ concentrations or changes in temperature. Such predictions are even more difficult in mountains than elsewhere because of the complexity of topographic, geographic, and atmospheric factors involved. Certainly, whether or not precipitation, particularly snowfall, increases or decreases in the western North American mountains, there will be considerable impact on runoff as it affects urban water supplies and agricultural irrigation water in these arid and semiarid lowland regions. In all such dry regions in the middle latitudes, water supply is largely dependent on mountain snowpacks, and especially so now that subterranean aquifers are being depleted.

A warming of climate could also result in the shrinking or loss of mountain glaciers. Such retreats or even gains have occurred at times during the Holocene. But as Ladurie (1971) chronicles, extensive retreat of European alpine glaciers in the recent past, 1860 to the present, due to "amelioration" of the global climate, is a fact. This shrinkage of montane ice is of relatively long duration and essentially is worldwide, including North America, New Zealand, Greenland, Scandinavia, and other continents, as well as the Alps. However, some mountain glaciers have retreated extensively and then advanced again, for example, the Nisqually Glacier on Mt. Rainier (Harrison 1952 - 1956 cited in Ladurie 1971). Glacier National Park in Montana was established in 1910, in part because of its many small alpine glaciers. Today, few of them remain. Within the Greater Yellowstone Ecosystem itself, Grasshopper Glacier in the Beartooth Mountains has receded to only 38 percent of its 1956 area (Lockwood et al. 1992). In the lowest glacial remnants of this glacier, they found numerous parts of the extinct Rocky Mountain grasshopper, Melanopus spretus (Walsh), which is last known from swarms between 1873 and 1876. The grasshopper parts found in the ice are not younger than the later date but may be much older. Climatic warming has reduced this glacier by 89 percent since 1940 (Lockwood et al. 1990). In this case, 
glacier melting, climatic warming, and loss of ecosystem diversity have gone hand in hand to reveal change in the upper elevations of the Yellowstone Ecosystem.

\section{Climatic Change and Wildland Fires in Mountains}

To speak of forest and wildland fires in the Yellowstone is like carrying coals to Newcastle, to use an overworked phrase. Such fires have always been a controling element of the forested parts of the Yellowstone ecosystem, as they are in all forested regions in the western North American mountains. However, 1988 was an unusually severe fire year even in these forests. It was interpreted very early afterward by Christensen et al. (1989). Additionally, there are a number of pertinent papers in this volume as well as others of importance (Despain 1990; Romme 1982; Romme and Despain 1989, for example). In this section, I shall cite just a few other examples of mountain ecosystems changed by wildfires. In most cases, these fires are followed by relatively typical secondary succession of shrubs and trees, unless the burned areas are too large to have nearby seed sources. In cases where the burned areas are indeed too large for natural reseeding, whole native ecosystems may be replaced by weedy systems of exotic invaders unless they are replanted with native species. Replanting can be very expensive.

In some mountains, the loss of subalpine forest by fire just below timberline may open the site to strong winds, drifting snow, and lack of tree reproduction (Billings 1969; Stahelin, 1943). In essence, under such a change to a severely stressful environment, subalpine forest often is replaced by an alpine tundra ecosystem, as on Libby Flats at an elevation of 3,300 m in the Medicine Bow Mountains of southeastern Wyoming. Billings (1969) has described this situation in some detail. Repeated fires there during the 18 th and 19th centuries in the subalpine spruce-fir forests have been succeeded by secondary lodgepole pine forests. When the fires burned to timberline, lodgepole forests did not establish and alpine tundra has taken over and persisted for centuries. When this happens, blowing snow carried by the western winds moves leeward and is deposited in deep drifts in the stillness of the unburned subalpine forests below. These forest drifts melt so late during the following summer that many of the trees (Engelmann spruce, subalpine fir, lodgepole pine) die and are replaced by wet boggy areas. In drier, protected areas near the old timberline, spruce and fir often become reestablished in the form of "ribbon forests" perpendicular to the prevailing winds (Billings 1969). These ribbon forests act as living snow-fences, allowing the deposit of deep and long-lasting snowdrifts in their lee and thus preventing tree reproduction. Such lee sites in ribbon forests are now occupied by very wet alpine meadows or "snow glades" like that on the east side of Cinnebar Park in the Medicine Bow. This deep drift, behind a long ribbon forest, at an elevation of c. $2,950 \mathrm{~m}$, is almost $2 \mathrm{~km}$ long (Billings 1969). So, forest fire in places just below timberline can result in completely new ecosystems.

It is difficult to predict how global warming may affect frequency and intensity of fires in the mountains. One way, of course, is to use past environments, vegetation, and events as possible prologues to the future. Since our future will have higher atmospheric $\mathrm{CO}_{2}$ concentrations, higher incoming UV-B fluxes, and more people in the mountains, it is difficult to find close analogues in the past 1,000 years to likely environmental situations in the mountains of a century from now. Romme and Despain (1989) show clearly that the Yellowstone fires of 1988, severe as they were, are not abnormal if one examines the fire history of this plateau for the past 350 years. Such fires did occur in the decades from 1690 to 1739. Balling, Meyer, and Wells (1992), in attempting to predict future wildfire risk in Yellowstone by using past fire records, show that temperatures during the fire season are increasing while precipitation is decreasing in the preceding year, with some early drought in the year of the fire or fires. This trend toward increasing aridity may presage more fires in the next century. 
In addition to the possibility of increasing aridity in western North American mountains, there is the problem of the invasion of fire-susceptible Mediterranean annual grasses in the semiarid mountains of the western third of the United States. These grasses include Bromus tectorum (cheatgrass), B. rubens, $B$. rigidus, and Taeniatherum asper (medusahead), among the important ones, particularly on the mountains of the Intermountain West. Mack (1981) has documented the invasion of Bromus tectorum, the most important and widespread of these invaders into the western United States, c. a century ago. More recently, Mack (1986) has reviewed the annual grass invasion problem in some depth by comparing the different species of many genera, some flammable, some not.

Bromus tectorum was first reported in the Reno region in 1906 by Kennedy (1907). It spread rapidly into the nearby mountains. Billings (1948) reported on the fire hazard caused by the invasive Bromus tectorum in the native Artemisia tridentata - bunchgrass steppe, which is the matrix of the middle elevation vegetation in the mountains and plateaus of the Great Basin east of the Sierra Nevada. All other Great Basin woody vegetation is superimposed on this sagebrush-grass vegetation. Prehistoric fires were rare because of the scattered and open nature of the perennial grasses and shrubs (Billings 1990; Young and Evans 1985). I set up permanent plots in this unburned sagebrush ecosystem (with Bromus tectorum already present as an understory) as early as 1941. These were sampled before fires occurred and also afterward. Also, plots were photographed and rephotographed from standard points through a period of 50 years. Much of the sagebrush ecosystem on the lower slopes (up to elevations of c. 1,800 m) has now been burned at least once. A number of sites have burned several times, with the fires starting from dry lightning storms or from the activities of people and spreading through an understory of dry Bromus tectorum during the typically dry summers. Those sites burned several times have become annual grasslands of little biological diversity. Even in areas burned only once, succession of native shrubs and trees back into the burned areas is very slow, and some species do not return at all; this is particularly true of the perennial dicot herbaceous species and the grasses. But cheatgrass does return and the fire danger remains.

Cheatgrass now has spread up the mountains through the pinyon-juniper woodland zone and above. This conifer woodland is now being destroyed, as is the shrubland at the lower elevations. Billings (1990) has described the destruction by fire of great areas of both the sagebrush and pinyon-juniper ecosystems. The long-term ecological effects of this destruction triggered by wildfires originating in dry expanses of Bromus tectorum are not easy to predict. This invasion has resulted in an ecological "surprise" of some magnitude. Annual-grass-caused fires have continued in many western states during the long period of drought of the past several years, and especially in the drought-stricken summer of 1992. Is it a portent of the next century, or will we see a moister surprise?

\section{Migrations and Possible Extinctions of Plant Taxa}

As mountain climates warm, and perhaps get drier in the lower and middle elevations, plant populations should migrate vertically up-mountain or latitudinally along the Cordillera - or possibly become extinct. In this regard, interglacial refugia are fully as important as glacial refugia, especially under present climates. Also, alpine floras and populations, while their vegetation occupies relatively small space, are evolving and consolidating their genetic adaptations after catastrophic selection during the present interglacial. Examples of such interglacial refugia are mountain peaks, certain rock types, glacial moraines, bogs, moist canyons, and cloudy and foggy cliffs with suitable crevices.

If the climate warms in the western North American mountains, timberline vegetation and its associated species will move up the mountains, but rather slowly. For example, Carrara, Trimble, and Rubin (1991) 
have quantified Holocene timberline fluctuations in the San Juan Mountains of southwestern Colorado. Between 9,600 and 5,400 years B.P., treeline in the northern San Juans was at an elevation at least 80 $\mathrm{m}$ higher than at present. A large fragment of spruce wood with complacent annual-rings and a radiocarbon date of C. 8,000 years B.P. suggests that timberline may have been at least $140 \mathrm{~m}$ higher in elevation than at present. During the early and mid-Holocene, mean July temperatures in the higher San Juans probably were at least 0.5 to $0.9^{\circ}$ higher than at present.

The upward movement of timberlines in the western North American Cordillera could eventually result in smaller and less continuous "islands" that would decrease the opportunities for migrations of the alpine biota either north or south. In colder climates of the past, these Cordilleran routes were open and available to many cold-tolerant species of plants, a situation that has already been reduced in the past two or three centuries. Some species will become extinct, locally at least, but others migrating up from below may take their places.

Hofer (1992) has tabulated lists of vascular plant species on 14 peaks in the Bernina region of the Swiss Alps between 1905 and 1985. On 12 of the 14 peaks, in the subnival and nival zones, significant immigration of species from below has occurred in that period. All the adventive species now present at the end of those 80 years are typically alpine or arctic taxa with seeds mostly distributed by wind. The average number of species per peak has increased from 16 to 28 . Hofer attributes this increase to the rise in temperature on these mountains in this century and the retreat of glacial and firn ice. The rise in temperatures between 1911 and 1990 in the higher zones of the Alps is C. $0.6^{\circ}$ to $0.8^{\circ} \mathrm{C}$. Rübel (1912), reporting on his 1905 survey that is the initial basis of Hofer's comparison, listed 70 species of vascular plants above timberline on 20 Bernina peaks. Hofer, using only 14 of these 20 peaks, now has found 108 species. Only one peak, Piz Languard at 3,261 m, has fewer species now (36) than found by Rübel in his 1905 census. Apparently, in the Bernina Alps, immigration from below has dominated considerably over extinction during this century. As Billings (1992) has suggested, however, global and mountain warming may proceed much faster latitudinally than various vectors (birds, mammals, wind) can carry seeds and other plant propagules to these new and distant habitats.

Through time, "surprises" occur episodically, cumulatively, and evolutionarily, in both the physical and biological parts of the mountain ecosystem, and at any ecosystemic level. Examples of such surprises are fire, volcanic activity, carbon dioxide increase, drought, and glaciation. In view of such surprises and the rapid changes in environments during the past two or three centuries in global atmospheric components and carbon balance of the whole earth, is it possible to predict what the earth and its mountains and polar regions will be like a century from now? Unfortunately, there are no easy answers to these environmental, ecologic, and economic problems.

\section{Acknowledgments}

I thank Patricia James, Susan Gerbeth-Jones, Karen Bowen, and Gela Duke for going beyond the call of duty in helping me with the word processing of this manuscript. I appreciate it very much. 


\section{Literature Cited}

Axelrod, D.I. 1962. A Pliocene Sequoiadendron Forest from Western Nevada. University of California Publications in Geological Sciences Vol. 39, No. 3:195-268, including plates.

Axelrod, D.I. 1976. History of the Coniferous Forests, California and Nevada. University of California Publications in Botany Vol. 70:1-62.

Axelrod, D.I. 1990. Age and origin of subalpine forest zone. Paleobiology 16:360-369.

Axelrod, D.I. 1991. The Early Miocene Buffalo Canyon Flora of Western Nevada. University of California Publications in Geological Sciences, Berkeley, CA. Vol. 135:1-76, plus 22 plates.

Axelrod, D.I. and P.H. Raven. 1985. Origins of the Cordilleran flora. Journal of Biogeography 12:21-47.

Balling, Jr., R.C., G.A. Meyer, and S.G. Wells. 1992. Climate change in Yellowstone National Park: is the drought-related risk of wildfires increasing? Climatic Change 22:35-45.

Barry, R.G. 1992. Climate change in the mountains. Pages 359-380. in P.B. Stone, editor, The State of the World's Mountains. Zed Books, London.

Bazzaz, F.A. 1990. The response of natural ecosystems to the rising global $\mathrm{CO}_{2}$ levels. Annual Review of Ecology and Systematics 21:167-196.

Bell, K.L. and L.C. Bliss. 1973. Alpine disturbance studies: Olympic National Park, U.S.A. Biological Conservation 5:25-32.

Billings, W.D. 1948. Preliminary notes on fire succession in the sagebrush zone of western Nevada. Bulletin of the Ecological Society of America. 29(2):30 (abstract).

Billings, W.D. 1950. Vegetation and plant growth as affected by chemically altered rocks in the western Great Basin. Ecology 31:62-74.

Billings, W.D. 1969. Vegetation pattern near alpine timberline as affected by fire-snowdrift interactions. Vegetation 19:192-207.

Billings, W.D. 1973. Arctic and alpine vegetations: Similarities, differences, and susceptibility to disturbance. BioScience 23(12):697-704.

Billings, W.D. 1974. Adaptations and origins of alpine plants. Arctic and Alpine Research 6:129-142.

Billings, W.D. 1978. Alpine phytogeography across the Great Basin. Pages 105-117 in K.T. Harper and J.L. Reveal, editors, Intermountain Biogeography: A Symposium. Great Basin Naturalist Memoirs, No. 2. Brigham Young University Press, Provo. 268pp.

Billings, W.D. 1979. Alpine ecosystems of western North America. Pages 6-21 in D.A. Johnson, editor, Special Management Needs of Alpine Tundra Ecosystems. Range Management Society, Denver. 100pp. 
Billings, W.D. 1983. Man's influence on ecosystem structure, operation, and ecophysiological processes. Chapter 16, pages 527-548 in O.L. Lange, P.S. Nobel, C.B. Osmond, and H. Ziegler, editors, Ecosystem Processes: Mineral Cycling, Productivity, and Man's Influence. Physiological Plant Ecology IV. Springer-Verlag, Berlin. 644pp.

Billings, W.D. 1987. Constraints to plant growth reproduction, and establishment in arctic environments. Arctic and Alpine Research 19:357-365.

Billings, W.D. 1988. Alpine vegetation. Chapter 13, pages 391-420 in M.G. Barbour and W.D. Billings, editors, North American Terrestrial Vegetation. Cambridge University Press, New York. 434pp.

Billings, W.D. 1990. Bromus tectorum, a biotic cause of ecosystem impoverishment in the Great Basin. Chapter 15, pages 301-322 in G.M. Woodwell, editor, The Earth in Transition: Patterns and Processes of Biotic Impoverishment. Cambridge University Press, New York. 530pp.

Billings, W.D. 1992. The phytogeographic and evolutions potential of the arctic flora and vegetation in a changing climate. Chapter 5, pages 91-109 in F.S. Chapin et al., editors, Arctic Ecosystem in a Changing Climate: An Ecophysiological Perspective. Academic Press, San Diego. 469pp.

Billings, W.D. and J.H. Thompson. 1957. Composition of a stand of old bristlecone pines in the White Mountains of California. Ecology 38:158-160.

Billings, W.D. and A.F. Mark. 1961. Interactions between alpine tundra vegetation and patterned ground in the mountains of southern New Zealand. Ecology 42:18-31.

Billings, W.D. and H.A. Mooney. 1959. An apparent frost hummock-sorted polygon cycle in the alpine tundra of Wyoming. Ecology 40:16-20.

Billings, W.D. and K.M. Peterson. 1992. Some possible effects of climatic warming on arctic tundra ecosystems of the Alaskan North Slope. Chapter 18, pages 233-243 in R.L. Peters and T.E. Lovejoy, editors, Global Warming and Biological Diversity. Yale University Press, New Haven. 386pp.

Billings, W.D. and L.C. Bliss. 1959. An alpine snowbank environment and its effects on vegetation, plant development and productivity. Ecology 40:388-397.

Billings, W.D. and Shirley M. Billings. 1992. Phytomass and plant productivity in wet and dry subalpine meadows in the Medicine Bow Mountains, Wyoming. In preparation.

Billings, W.D., J.O. Luken, D.A. Mortensen, and K.M. Peterson. 1982. Arctic tundra: a source or sink for atmospheric carbon dioxide in a changing environment? Oecologia 53:7-11.

Billings, W.D., J.O. Luken, D.A. Mortensen, and K.M. Peterson. 1983. Increasing atmospheric carbon dioxide: possible effects on arctic tundra. Oecologia 58:286-289.

Billings, W.D., J.O. Luken, D.A. Mortensen, and K.M. Peterson. 1984. Interaction of increasing atmospheric carbon dioxide and soil nitrogen on the carbon balance of tundra microcosms. Oecologia 65:26-29. 
Billings, W.D., P.J. Godfrey, B.F. Chabot, and D.P. Bourque. 1971. Metabolic acclimation to temperature in arctic and alpine ecotypes of Oxyria digyna. Arctic and Alpine Research 3:277-289.

Bliss, L.C. 1956. A comparison of plant development in microenvironments of arctic and alpine tundras. Ecological Monographs 26:303-337.

Bliss, L.C. 1963. Alpine plant communities of the Presidential Range, New Hampshire. Ecology 44: 678-697.

Bliss, L.C., J. Svoboda, and D.I. Bliss. 1984. Polar deserts, their plant cover, and plant production in the Canadian High Arctic. Holarctic Ecology 7:305-324.

Breckle, Sigmar-W. 1974. Notes on alpine and nival flora of the Hindu Kush, East Afghanistan Botaniska Notises 127:280-284.

Brown, J.H. 1971. Mammals on mountaintops: nonequilibrium insular biogeography. American Naturalist 105:467-478.

Brown, J.H. 1978. The theory of insular biogeography and the distribution of boreal birds and mammals. Pages 209-227 in K.T. Harper and J.L. Reveal, editors, Intermountain Biogeography: A Symposium. Great Basin Naturalist Memoirs, No. 2. Brigham Young University Press, Provo. 268pp.

Bunnell, F., P. Bunnell, S. Buckingham, R. Hilborn, G. Margreiter, W. Moser, and C. Walters ("Bubu Himamowa"). 1974. The Obergurgl Model: a microcosm of economic growth in relation to limited ecological resources. IIASA Conference Proceedings CP-74-2. Schloss Laxenburg, Austria. 80pp.

Cailleux, A. 1961. Biogeographic Mondiale, 4th ed. Presses Universitaire de France, Paris. 127pp.

Caldwell, M.M. 1967. Solar ultraviolet radiation and plant processes on the alpine tundra. Doctoral dissertation, Duke University. 222pp.

Caldwell, M.M. 1968. Solar ultraviolet radiation as an ecological factor for alpine plants. Ecological Monographs 38:243-268.

Caldwell, M.M., R. Robberecht, R.S. Nowak, and W.D. Billings. 1982. Differential photosynthetic inhibition by ultraviolet radiation in species from the arctic-alpine life zone. Arctic and Alpine Research 14: 195-202.

Caldwell, M.M., R. Robberecht, and W.D. Billings. 1980. A steep latitudinal gradient of solar ultraviolet-B radiating in the arctic-alpine life zone. Ecology 61:600-611.

Carrara, P.E., D.A. Trimble, and M. Rubin. 1991. Holocene treeline fluctuations in the northern San Juan Mountains, Colorado, U.S.A., as indicated by radiocarbon-dated conifer wood. Arctic and Alpine Research 23:233-246.

Chabot, B.F. and W.D. Billings. 1972. Origins and ecology of the Sierran alpine flora and vegetation. Ecological Monographs 42:163-199. 
Christensen, N.L., J.K. Agee, P.F. Brussard, J. Hughes, D.H. Knight, G.W. Minshall, J.M. Peek, S.J. Pyne, F.J. Swanson, J.W. Thomas, S. Wells, S.E. Williams, and H.A. Wright. 1989. Interpreting the Yellowstone fires of 1988: ecosystem responses and management implications. BioScience 39:678-685.

Clausen, J., D.D. Keck, and W.M. Hiesey. 1948. Experimental studies on the nature of species. III. Environmental responses of climatic races of Achillea. Publication 581, Carnegie Institution of Washington, Washington, DC. 129pp.

Cooper, W.S. 1926. The fundamentals of vegetational change. Ecology 7:391-413.

Dennell, R. 1983. European Economic Prehistory: A New Approach. Academic Press, London. 217pp.

Despain, D.G. 1973. Vegetation of the Big Horn Mountains, Wyoming, in relation to substrate and climate. Ecological Monographs 43:329-355.

Despain, D.G. 1990. Yellowstone Vegetation: Consequences of Environment and History in a Natural Setting. Roberts Rinehart Publishers, Boulder, Colorado. 239pp.

Dorf, E. 1960. Tertiary fossil forests of Yellowstone National Park, Wyoming. Pages 253-260 in Billings Geological Society, 11th Annual Field Conference.

Eagar, C. and Mary Beth Adams (editors). 1992. Ecology and Decline of Red Spruce in the Eastern United States. Ecological Studies 96. Springer-Verlag, New York. 417pp.

Fritz, W.J. 1980. Reinterpretation of the depositional environment of the Yellowstone "fossil forests." Geology 8:309-313.

Grabherr, G. 1982. The impact of trampling by tourists on high attitudinal grassland in the Tyrolean Alps, Austria. Vegetatio 48:209-217.

Greenstein, L.A. 1983. Alpine permafrost on Niwot Ridge, Colorado. Pages 380-383 in 4th International Conference Proceedings. National Academy Press, Washington, DC.

Harrigan, S. 1992. The long-lost hunter. Audubon 94(5):92-96.

Harrison, A.E. 1952-1956. Glacial activity (Nisqually Glacier) in the western United States. Journal of Glaciology 2:666-668 + 675. (cited in Ladurie, 1971)

Hartley, E.A. 1976. Man's Effects on the Stability of Alpine and Subalpine Vegetation in Glacier National Park, Montana. Doctoral dissertation, Duke University, Durham, North Carolina. 258pp.

Hartley, E.A. 1980. Visitor impact on subalpine meadow vegetation in Glacier National Park. Going-to-theSun Magazine 1(2):23-26.

Hofer, H.R. 1992. Veränderugen in der Vegetation von 14 Gipfeln des Berninagebietes Zwischen 1905 und 1985. Berichte des Geobotanischen Institutes der ETH, Stiftung Rübel 58:39-54. 
Howell, J.T. 1951. The arctic-alpine flora of three peaks in the Sierra Nevada. Leaflets of Western Botany 6:141-156.

Ives, J.D. and B.D. Fahey. 1971. Permafrost occurrence in the Front Range, Colorado Rocky Mountains, U.S.A. Journal of Glaciology 10:105-111.

Jaroff, L. 1992. Iceman: The discovery of a frozen 5,300-year-old wanderer. Time Vol. 140 (No. 17) October 26, 1992:62-69.

Johnson, P.L., and W.D. Billings. 1962. The alpine vegetation of the Beartooth Plateau in relation to cryopedogenic processes and patterns. Ecological Monographs 32:105-135.

Jones, P.D. and T.M.L. Wigley. 1990. Global warming trends. Scientific American 263(2):84-91.

Keeling, C.D., R.B. Bacastow, and T.P. Whorf. 1982. Measurements of the concentration of carbon dioxide at Mauna Loa Observatory, Hawaii. Pages 377-385 in W.C. Clark, editor, Carbon Dioxide Review: 1982. Oxford University Press, New York.

Kennedy, P.B. 1907. Botanical features around Reno. Muhlenbergia 3(2):17-32.

Körner, Ch. 1992. Response of alpine vegetation to global climatic change. Pages 85-96 in M.M. Boer and E.A. Koster, editors, Greenhouse Impact. Catena Supplement 22, Catena Verlag, Cremlingen, Germany.

Kruckeberg, A.R. 1969. Plant life on serpentinite and other ferromagnesian rocks in northwestern North America. Syesis 2:15-114.

Kruckeberg, A.R. 1985. California Serpentines: Flora, Vegetation, Geology, Soils, and Management Problems. University of California Press, Berkeley. XIV + 180pp.

Lachenbruch, A.H. and B.V. Marshall. 1986. Changing climate: Geothermal evidence from permafrost in the Alaskan Arctic. Science 234: 689-696.

Ladurie, E.L.R. 1971. Times of Feast, Times of Famine: A History of Climate Since the Year 1000, trans. Barbara Bray. Doubleday, Garden City, New York. 426pp.

Lockwood, J.A., R.A. Nunamaker, R.E. Pfadt, and L.D. DeBrey. 1990. Grasshopper Glacier: characterization of a vanishing biological resource. American Entomologist 36:18-27.

Lockwood, J.A., S.P. Schell, J.K. Wangberg, L.D. DeBrey, and C.R. Bomar. 1992. Preserved insects and physical condition of Grasshopper Glacier, Carbon County, Montana, U.S.A. Arctic and Alpine Research 24(3):229-232.

Mack, R.N. 1981. Invasion of Bromus tectorum L. into western North America: an ecological chronicle. Agro-Ecosystems 7:145-165.

Mack, R.N. 1986. Alien plant invasion into the Intermountain West: a case history. Chapter 12, pages 191-213 in H.A. Mooney and J.A. Drake, editors, Ecology of Biological Invasions of North America and Hawaii. Ecological Studies 58, Springer-Verlag, New York. 321pp. 
Marchand, D.E. 1973. Edaphic control of plant distributions in the White Mountains, eastern California. Ecology 54:233-250.

Mooney, H.A. and W.D. Billings. 1961. Comparative physiological ecology of arctic and alpine populations of Oxyria digyna. Ecological Monographs 31:1-29.

Moser, P. and W. Moser. 1986. Reflections on the MAB-6 Obergurgi project and tourism in an alpine environment. Mountain Research and Development 6:101-118.

Oakley, K.P. 1980. Relative dating of the fossil hominids of Europe. Bulletin of the British Museum: Natural History (Geology) 34(1):1-63.

Oechel, W.C. and W.D. Billings. 1992. Effects of global change on the carbon balance of arctic plants and ecosystems. Chapter 7, pages 139-168 in F.S. Chapin et al., editors, Arctic Ecosystems in a Changing Climate: An Ecophysiological Perspective. Academic Press, San Diego. 469pp.

Rannie, W.F. 1986. Summer air temperature and number of vascular species in arctic Canada. Arctic 39:133-137.

Raven, P.H. and D.I. Axelrod. 1978. Origin and relationships of the California flora. University of California Publications in Botany 72:1-134. University of California Press, Berkeley.

Robberecht, R., M.M. Caldwell, and W.D. Billings. 1980. Leaf ultraviolet optical properties along a latitudinal gradient in the arctic-alpine life zone. Ecology 61:612-619.

Romme, W.H. 1982. Fire and landscape diversity in subalpine forests of Yellowstone National Park. Ecological Monographs 52:199-221.

Romme, W.H. and D.G. Despain. 1989. Historical perspective on the Yellowstone fires of 1988. BioScience 39:695-699.

Rosenberg, N. 1986. A good crystal ball is hard to find. American Heritage of Invention and Technology $1(3): 44-50$.

Rowland, F.S. 1974. Aerosol sprays and the ozone shield. New Scientist 64:717-720.

Rowland, F.S. 1989. Chlorofluorocarbons and the depletion of stratospheric ozone. American Scientist 77:36-45.

Rübel, E. 1912. Pflanzengeographische monographic des Berninagebietes. Engelmann, Leifezig. 615pp.

Schlesinger, W.H., E.H. DeLucia, and W.D. Billings. 1989. Nutrient-use efficiency of woody plants on contrasting soils in the western Great Basin, Nevada. Ecology 70:105-113.

Shaver, G.R., W.D. Billings, F. Stuart Chapin III, Anne E. Giblin, K.J. Nadelhoffer, W.C. Oechel, and E.B. Rastetter. 1992. Global change and the carbon balance of arctic ecosystems. BioScience 42:433-441.

Simpson, Beryl B. and Carol A. Todzia. 1990. Patterns and processes in the development of the high Andean flora. American Journal of Botany 77:1419-1432. 
Smith, A.P. 1981. Growth and population dynamics of Espeletia (Compositae) in the Venezuelan Andes. Smithsonian Contributions to Botany No. 48:1-45.

Smith, A.P. 1987. Tropical alpine plant ecology. Annual Review of Ecology and Systematics 18:137-158.

Stahelin, R. 1943. Factors influencing the natural restocking of high altitude burns by coniferous trees in the central Rocky Mountains. Ecology 24:19-30.

Stebbins, G.L., and J. Major. 1965. Endemism and speciation in the California flora. Ecological Monographs 35:1-35.

Strain, B.R. 1987. Direct effects of increasing atmospheric $\mathrm{CO}_{2}$ on plants and ecosystems. Trends in Ecology and Evolution 2:18-21.

Turesson, G. 1925. The plant species in relation to habitat and climate. Hereditas 15:81-101.

Vuilleumier, B.S. 1971. Pleistocene changes in the fauna and flora of South America. Science 173: $771-780$.

Willard, Beatrice E. and J.W. Marr. 1970. Effects of human activities on alpine tundra ecosystems in Rocky Mountain National Park, Colorado. Biological Conservation 2:257-265.

Young J.A. and R.A. Evans. 1985. Demography of Bromus tectorum in Artemisia communities. Pages 489-502 in J. White, editor, The Population Structure of Vegetation. Dr. W. Junk Publishers, Dortrecht, Netherlands.

Ziska, L.H., A.H. Teramura, and J.H. Sullivan. 1992. Physiological sensitivity of plants along an elevational gradient to UVB radiation. American Journal of Botany 79(8):863-871. 



\title{
The Submersed Plant Community in Jackson Lake, Wyoming: Dynamics of a Disturbed System
}

\author{
Carol A. Brewer \\ Department of Botany, University of Wyoming \\ Laramie, WY 82071 \\ Thomas G. Thompson ${ }^{1}$ \\ Wyoming Game and Fish Department \\ Cheyenne, WY 82006
}

\section{Introduction}

Submergent macrophyte distribution in lakes is usually related to depth. At lower depths - downslope on the littoral lake bed (figure 1) - macrophyte distribution and growth have been related to light (Spence 1982), substrate texture (Pearsall 1920), nutrient status (Carpenter and Adams 1977), and lake morphometry (Duarte and Kalff 1986). Factors limiting distribution and growth at shallower depths upslope on the littoral shore - are not as well understood.

Meaningful descriptions of plant distributions in reservoirs are problematic because water levels vary throughout the course of a year (Brewer and Rørslett 1987). Water level fluctuations are a challenge to plant growth (figure 1). A plant that begins the growing season at a depth of $3 \mathrm{~m}$ may be under $6 \mathrm{~m}$ of water after spring runoff fills the reservoir. Later in the summer the same plant may be left at a depth of only $1 \mathrm{~m}$ as water is removed from the reservoir during summer drawdown. In reservoirs, where lake levels fluctuate substantially during the growing season, the physical environment is characterized by increased spatial and temporal heterogeneity. Disturbances associated with changing water levels include ice scour during winter drawdown, abrasion caused by increased erosion along the lake shore and wave action. Recent work suggests that the magnitude and timing of water level fluctuations may be the most important factor regulating macrophyte community processes at shallower depths in reservoirs (Brewer and Parker 1990; Gasith and Gafny 1990; Rørslett 1984, 1985, 1988, 1989).

The status of the aquatic plant community in Jackson Lake was evaluated from 1983 through 1985. During this time, we compiled a species list, mapped the distribution of macrophyte species, and evaluated the effect of changing water levels on the macrophyte community. Later, because of impacts

\footnotetext{
${ }^{1}$ Present address: Department of Botany, University of Wyoming, Laramie, WY 82071.
} 


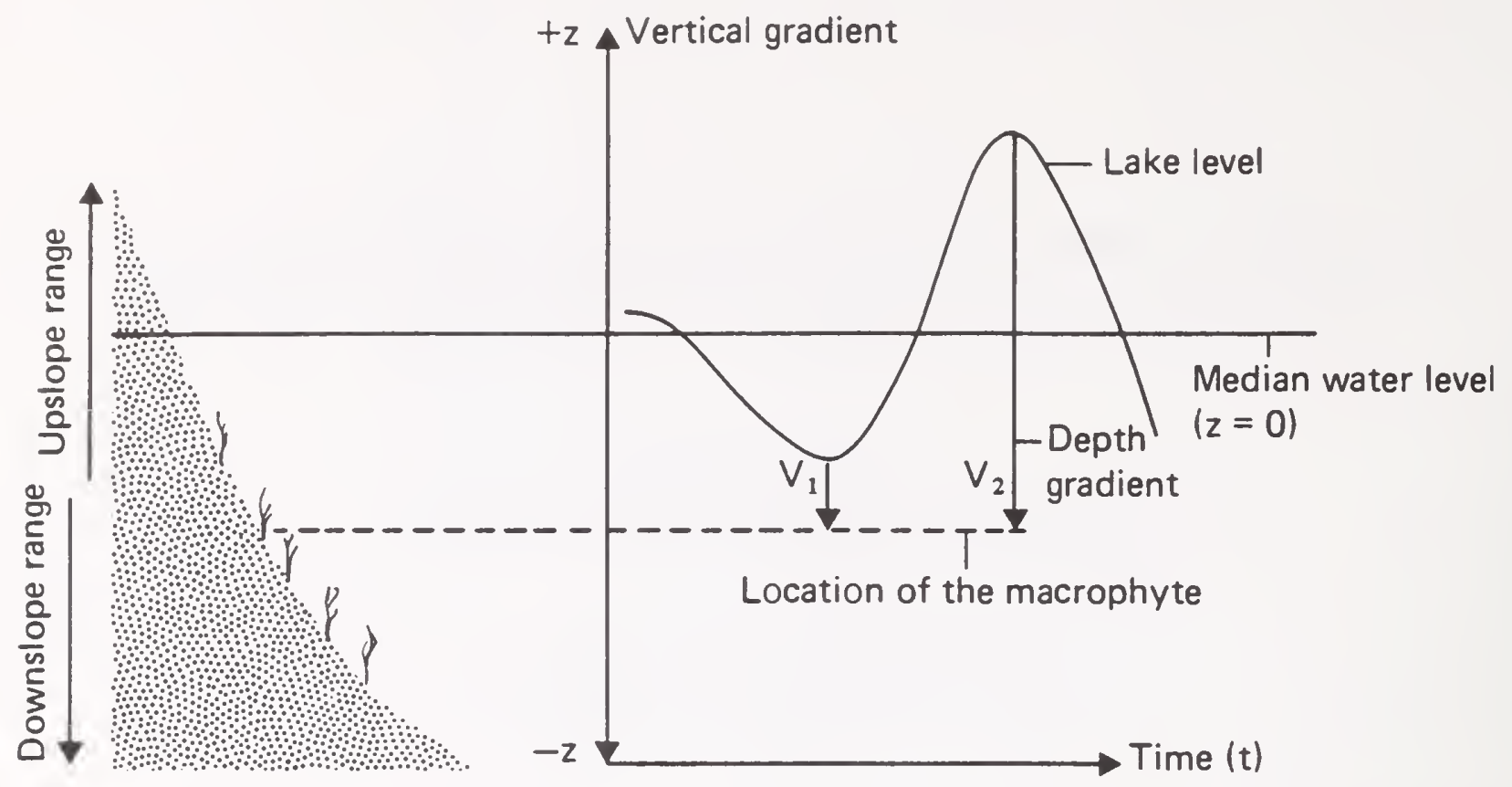

Figure 1. The vertical gradient in a reservoir with a fluctuating water level consists of both the lake bed and adjacent shoreline. The depth gradient is only the portion of the vertical gradient below the water surface. Instantaneous depths are designated as " $v$ "; positions along the vertical gradient are designated as "z." As the surface elevation (lake level) varies through time, the position of a macrophyte along the vertical gradient changes (redrawn after Rørslett 1984, Brewer and Rørslett 1987).

on the littoral plant community caused by restoration of a dam at the Snake River outlet from 1986 to 1988, the status of the aquatic plant community was reevaluated from 1989 to 1991.

\section{Study Area}

\section{Physical and Chemical Features}

Jackson Lake, located at roughly lat. $44^{\circ} \mathrm{N} /$ long. $110^{\circ} 42^{\prime} \mathrm{W}$, is contained within the boundaries of Grand Teton National Park, Wyoming (figure 2). At maximum capacity the surface of the lake is at an elevation of 2,065 m. Lake morphometry data are summarized in table 1. Immediately west of the lake is the Teton Mountain Range; the Jackson Hole valley is located to the east and southeast of the lake. Overturn the period of water mixing and circulation before thermal stratification occurs - is in June and again in late October or early November. By July the lake is thermally stratified to a depth of $8-9 \mathrm{~m}$.

During the Pinedale glaciation (between 6,000 and 9,000 years before the present), the south and north basins of what is now Jackson Lake were carved by the Pinedale ice sheet (Clark 1981). In 1916 an earthen dam was constructed at the Snake River outflow to provide irrigation water and to control runoff. Impoundment increased the depth of the lake by $12 \mathrm{~m}$ and the length of the shoreline by about $60 \mathrm{~km}$. 


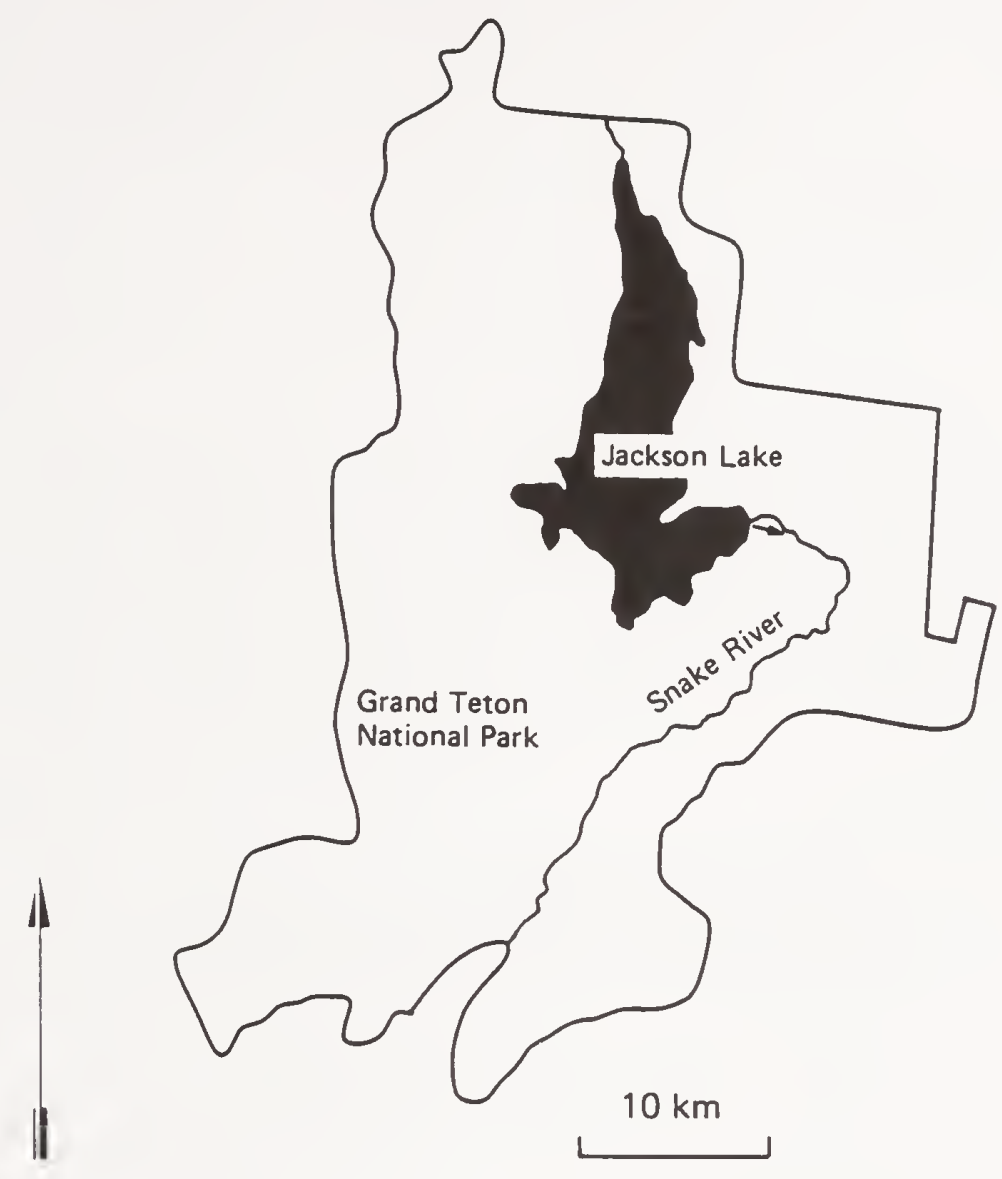

Figure 2. Location of Jackson Lake within Grand Teton National Park.

Inflow to the lake now comes from the Snake River to the north as well as from many small streams flowing out of the Teton Mountain Range. Outflow into the Snake River occurs through the dam at the southeast shore of the lake.

\section{Lake Level Regulation Scheme}

Prior to 1975 water levels in Jackson Lake were controlled to be lowest in April or May $(2,060 \mathrm{~m})$ before runoff began. By July the maximum surface elevation of 2,065 $\mathrm{m}$ was usually reached. Toward the end of the growing season for aquatic plants in late September, subsequent drawdown reduced the surface elevation by as much as $5 \mathrm{~m}$.

Beginning in 1976 the water level of Jackson Lake was lowered from 2,065 $\mathrm{m}$ to about 2,061 $\mathrm{m}$, and then in 1985 to $2,054 \mathrm{~m}$. These drawdowns were to facilitate repair and modification of the Jackson Lake dam. In 1989, after four years of low water levels, repair was completed and the reservoir was allowed to fill back to $2,065 \mathrm{~m}$. From 1989 to August 1991 the lake surface elevation varied $2-3 \mathrm{~m}$ annually from about 2,061-2,064 m. 
Table 1. Morphological features of Jackson Lake

\begin{tabular}{|l|c|}
\hline \multicolumn{1}{|c|}{ Morphometry } & \\
\hline Surface elevation & $2,065 \mathrm{~m}$ \\
\hline Surface area & $10,366 \mathrm{ha}$ \\
\hline Volume & $4 \times 10^{6} \mathrm{~m}^{3}$ \\
\hline Maximum length & $26 \mathrm{~km}$ \\
\hline Maximum width & $13 \mathrm{~km}$ \\
\hline Shoreline length & $140 \mathrm{~km}$ \\
\hline Maximum depth & $136 \mathrm{~m}$ \\
\hline Average depth & $38 \mathrm{~m}$ \\
\hline Ice-covered period & $150 \mathrm{days}$ \\
\hline Average vertical extent of regulation & $4 \mathrm{~m}$ \\
\hline Position of thermocline in midsummer & $8-9 \mathrm{~m}$ \\
\hline
\end{tabular}

\section{Methods}

\section{Physical Environment}

To characterize the physical environment in Jackson Lake, water samples were collected from various sites in the lake in the summers of 1983 and 1984. Sites were chosen to represent the different habitat types in Jackson Lake (figure 3). Results for each parameter were averaged over the two summers. Conductivity and $\mathrm{pH}$ were measured electrometrically. Total alkalinity, dissolved oxygen, calcium, and total hardness were determined by titration (Lund 1979). Light penetration was measured with a Secchi disc. The bottom of the photic zone was calculated according to Cole (1979) as approximately three times the Secchi Depth.

The lake shore was divided into habitat types using several kinds of data. Maximum fetch was measured using U.S. Geological Survey (USGS) topographic maps. Littoral slope was calculated by measuring the perpendicular distance from the shore to a depth of $10 \mathrm{~m}$. These data, along with field observations (e.g., visual classification of substrate texture as boulders, rock, gravel, silt), were used to assign habitat categories.

\section{Plant Community Composition and Distribution}

Macrophyte community composition and plant distribution data were gathered from 1983 to 1985 and again from 1989 to 1991. At various times during the growing seasons (June through September) macrophytes were collected from around the periphery of the lake by either wading, scuba diving, dredging, or using a plant hook. The use of several plant collection methods increased the likelihood 
of collecting all the species in Jackson Lake regardless of growth form. Depth ranges were standardized to the median water level according to Rørslett (1984). Plants were identified using standard taxonomic keys (Correll and Correll 1975; Shaw 1976). Voucher specimens were deposited in the Grand Teton National Park Herbarium in Moose, Wyoming.

\section{Results}

\section{Physical Environment}

Water chemistry parameters for Jackson Lake (table 2) are typical for oligotrophic water bodies. The 1991 values for these parameters are nearly the same as in 1983 and 1984 (John Boutwell, Bureau of Reclamation, Denver, Colorado, personal communication). Usually a heavy silt load enters Jackson Lake during spring runoff; consequently, water transparency and light penetration are much lower in the spring and early summer than later in the summer. During spring runoff the limit of the photic zone may be only $1.5 \mathrm{~m}$, but by late August the limit may extend deeper than $10 \mathrm{~m}$ (Secchi depth $>4 \mathrm{~m}$ ) along some shores.

Table 2. Characteristic water chemistry data as mean values for the summers of 1983 and 1984

\begin{tabular}{|l|c|}
\hline \multicolumn{1}{|c|}{ Parameter } & \\
\hline $\begin{array}{l}\text { Secchi depth range } \\
\text { late spring } \\
\text { late summer }\end{array}$ & $\begin{array}{l}0.5 \text { to } 1.8 \mathrm{~m} \\
1.8 \text { to } 7.0 \mathrm{~m}\end{array}$ \\
\hline $\mathrm{pH}$ & 7.8 \\
\hline Conductivity & $128.0 \mathrm{umhos} / \mathrm{cm}$ \\
\hline Alkalinity (total) & $48.0 \mathrm{mg} / \mathrm{l}$ \\
\hline Dissolved oxygen & $9.2 \mathrm{mg} / \mathrm{l}$ \\
\hline Ca ${ }^{2+}$ & $11.4 \mathrm{mg} / \mathrm{l}$ \\
\hline Total hardness & $47.0 \mathrm{mg} / \mathrm{l}$ \\
\hline
\end{tabular}

Jackson Lake has three habitat types suitable for submersed plant growth - sheltered bays, shallow zones, and steep, exposed zones (figure 3). Sheltered bays occupied the least amount of shoreline. Typically, the littoral slope was less than $9^{\circ}$ in these areas. Substrates were usually fine textured, and silts were common. Shallow zones predominated along the north and southeast shores of the lake. These shores were also characterized by silt and sand substrates and gradual slopes $\left(<7^{\circ}\right)$. The remaining shores were steep $\left(10^{\circ}-17^{\circ}\right)$, exposed to frequent wave action, and had large, coarse sediments such as cobble and rocks. 


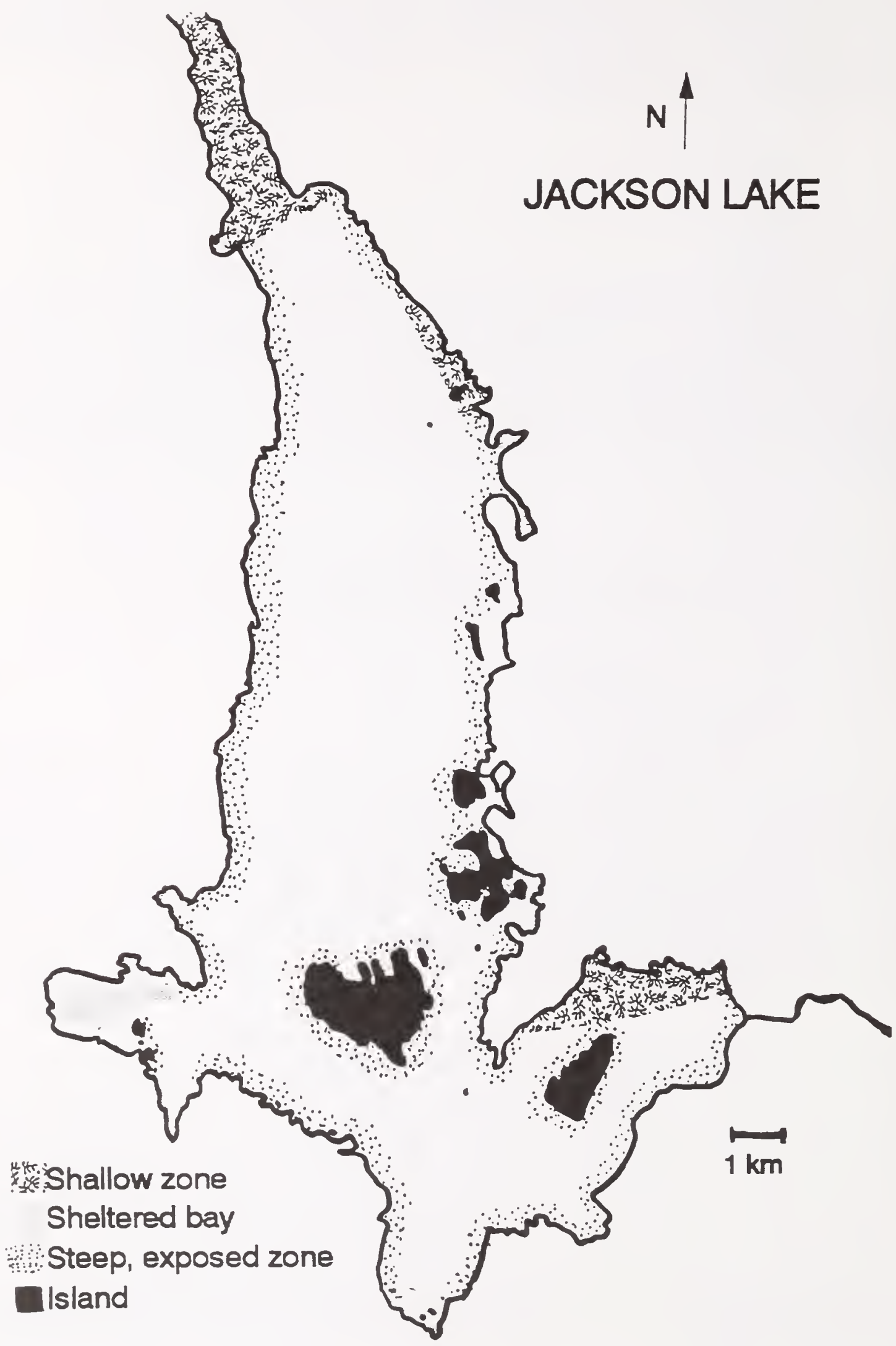

Figure 3. Distribution of major habitat types along the shoreline of Jackson Lake. 


\section{Plant Community Composition}

We collected 19 submersed plant species of 13 families in Jackson Lake (table 3). Vegetation was predominately submergent. Potamogetonaceae was represented by the greatest number of species that were most abundant in shallow zones. Elodea canadensis was the dominant species in Jackson Lake. E. canadensis was found in all habitat types and in all but the deepest water (figure 4). Other macrophyte species were locally abundant, and some were rarely collected. For example, Ranunculus aquatilis, Chara sp., and Nitella sp. were locally abundant, especially in bays. However, Hippuris vulgaris and Zannichellia palustris were very restricted in distribution and abundance to a few locations in shallow zones. Ten species were restricted to shallow water (figure 4), while four species were common throughout the vertical gradient. Macrophytic green algae had the deepest distributions.

Before the lake was lowered for reconstruction of the dam in 1984, plant cover was highest below the summertime median water level. In general, highest cover occurred in a band at depths between 3 and $7 \mathrm{~m}$. Along exposed shorelines, cover peaked about $5 \mathrm{~m}$ below the median water level and then declined rapidly both upslope and downslope along the lake bed. In shallow water, cover was higher in sheltered than in exposed habitats.

Incidence of rooted macrophytes was appreciably reduced in the summer of 1985 after the water level was lowered by as much as $10 \mathrm{~m}$ for reconstruction of the dam. Much of the previously colonized slope was left exposed for nearly four years. Few individuals of any species were found in Jackson Lake in 1985. From 1986 through 1988 the macrophyte community shifted downslope, and Elodea canadensis, Ranunculus species, Myriophyllum sibiricum, Chara sp., and Nitella sp. were common and widely distributed. Potamogeton species were still present but at much lower densities than before.

After repair of the Jackson Lake Dam was completed in 1989, the lake surface was returned to prerepair levels within one year. This left the macrophyte community in $10.20 \mathrm{~m}$ of water, far deeper than most species except macrophytic green algae can survive (figure 4). The shallow littoral zone $(0-10 \mathrm{~m})$ was essentially devoid of submerged vegetation. Recovery of the macrophyte community was slow during 1989 for several reasons. During the 1989 growing season the change in water level was $10 \mathrm{~m}$. Furthermore, light penetration was extremely low (Secchi depth $<2 \mathrm{~m}$ ) due to suspended sediments and particulates that remained in the water column all summer. These fine sediments and particulates entered the water column because of erosion from unvegetated shores after the lake was filled. Finally, natural processes of plant recruitment (e.g., clonal duplication) were not occurring (Brewer and Parker 1990).

During the growing seasons of 1990 and 1991 when water levels were mostly stable (change in elevation $<3 \mathrm{~m}$ ) and water clarity markedly improved (Secchi depth up to $7 \mathrm{~m}$ ), the macrophyte community experienced localized recovery (see table 3 for species list) because of both natural recruitment and a planting program implemented by the Bureau of Reclamation. Potamogeton pectinatus and Elodea canadensis were extensively planted in bays and along the southeast shore. In August 1991 dense macrophyte beds were found in many shallow bays. Elodea canadensis, Chara sp., and Nitella sp. were especially abundant along the shores of bays. Potamogeton pectinatus was abundant in shallow habitats along the southeast shores of the lake. The distribution of Potamogeton richardsonii, P. pusillus, and Myriophyllum sibiricum was patchy in both habitat types. Polygonum amphibium was locally abundant along the far northwest shore of the lake, especially near dead and dying willows. Elsewhere in the lake the distribution of this species was also patchy. Exposed, steep shores remained mostly unvegetated in 1991. 
Table 3. Names of families and species collected from Jackson Lake

\begin{tabular}{|c|c|c|}
\hline \multirow[b]{2}{*}{ Species } & \multicolumn{2}{|c|}{ Years Collected } \\
\hline & 1983-1985 & 1989-1991 \\
\hline $\begin{array}{l}\text { Alismatacea } \\
\text { Sagittaria cuneata Shel. }\end{array}$ & $t^{a}$ & + \\
\hline $\begin{array}{l}\text { Callitrichaceae } \\
\text { Callitriche sp. }\end{array}$ & + & + \\
\hline $\begin{array}{l}\text { Characeae } \\
\text { Chara sp. } \\
\text { Nitella sp. }\end{array}$ & $\begin{array}{l}+ \\
+\end{array}$ & $\begin{array}{l}+ \\
+\end{array}$ \\
\hline $\begin{array}{l}\text { Cyperaceae } \\
\text { Eleocharis acicularis (L.)R.\&S. }\end{array}$ & + & + \\
\hline $\begin{array}{l}\text { Haloragaceae } \\
\text { Myriophyllum sibiricum Kom. }\end{array}$ & + & + \\
\hline $\begin{array}{l}\text { Hippuridaceae } \\
\text { Hippuris vulgaris L. }\end{array}$ & + & $-^{b}$ \\
\hline $\begin{array}{l}\text { Hydrocharitaceae } \\
\text { Elodea canadensis Michx. }\end{array}$ & + & + \\
\hline $\begin{array}{l}\text { Polygonaceae } \\
\text { Polygonum amphibium var. stipulaceum Coleman }\end{array}$ & + & + \\
\hline $\begin{array}{l}\text { Potamogetonaceae } \\
\text { Potamogeton alpinus Balb. } \\
\text { Potamogeton filiformis Pers. } \\
\text { Potamogeton gramineus L. } \\
\text { Potamogeton pectinatus L. } \\
\text { Potamogeton pusillus L. } \\
\text { Potamogeton richardsonii (A. Benn) Rydberg }\end{array}$ & $\begin{array}{l}+ \\
+ \\
+ \\
+ \\
+ \\
+\end{array}$ & $\begin{array}{l}+ \\
?^{c} \\
+ \\
+ \\
+ \\
+\end{array}$ \\
\hline $\begin{array}{l}\text { Ranunculaceae } \\
\text { Ranunculus aquatilis var. capillaceus (Thuill.)DC } \\
\text { Ranunculus flamula L. }\end{array}$ & $\begin{array}{l}+ \\
+\end{array}$ & $\begin{array}{l}+ \\
+\end{array}$ \\
\hline $\begin{array}{l}\text { Scrophulariaceae } \\
\text { Limosella aquatica L. }\end{array}$ & - & + \\
\hline $\begin{array}{l}\text { Sparganiaceae } \\
\text { Sparganium sp. }\end{array}$ & + & + \\
\hline
\end{tabular}


Table 3. Names of families and species collected from Jackson Lake (cont.)

\begin{tabular}{|c|c|c|}
\hline \multirow{2}{*}{ Species } & \multicolumn{2}{|c|}{ Years Collected } \\
\cline { 2 - 3 } & $1983-1985$ & $1989-1991$ \\
\hline $\begin{array}{l}\text { Zannichelliaceae } \\
\text { Zannichellia palustris L. }\end{array}$ & + & + \\
\hline \multicolumn{1}{|c|}{ Total species reported } & 19 & 18 \\
\hline
\end{tabular}

aSpecies was collected.

'Species was not collected.

'Species may have been collected, but positive identification could not be made.

\section{Discussion}

Fluctuating water levels have the greatest effect in shallow, gently sloping habitats because more extensive areas are flooded and exposed with changes in the regulation scheme. Also along convoluted shorelines, changing water levels can substantially alter the size of bays (Gasith and Gafny 1990). Such changes ultimately affect availability of habitat suitable for macrophyte growth.

Since 1983 the macrophyte community in Jackson Lake has been dominated by one species, Elodea canadensis. Other species are commonly found but usually at lower densities (e.g., Nitella sp., Chara sp., and Ranunculus aquatilis). Most species in Jackson Lake have patchy, disjunct distributions (e.g., Polygonum amphibium). Generally, plant cover on the lake bottom was low, and species interference did not seem to be an important factor organizing this community. A similar conclusion has been drawn for plant communities in other regulated lakes characterized by low plant densities and patchy plant cover (Rørslett 1987).

Our data and observations suggest that the plant community in Jackson Lake is organized by physical processes acting along the vertical gradient (Brewer and Parker 1990). The upslope limits of macrophyte growth and persistence in Jackson Lake most likely are set by disturbances associated with changing water levels. Ice scour during winter drawdowns and spring breakup severely impacts overwintering tissues and may be responsible for damaging or removing plants on near-shore lake margins (Rørslett 1984, 1988). Winter drawdowns in Jackson Lake are as much as $1 \mathrm{~m}$. In addition to stranding plants out of water, lowered water levels increase both erosion and suspension of sediments (decreasing light penetration and suitable seedbed) and increase physical abrasion to plants from storm waves and boat wakes.

Rørslett (1984) and Kirk and Henriques (1986) have also observed that community diversity was reduced and patchiness was increased in regulated lakes. As in Jackson Lake, they found that peak cover by macrophytes was shifted into deeper water. Furthermore, the shallow water community was lost completely from some reservoirs. Gasith and Gafny (1990) attribute the much lower diversity and production in the littoral zone of reservoirs to low predictability of the frequency and magnitude of 


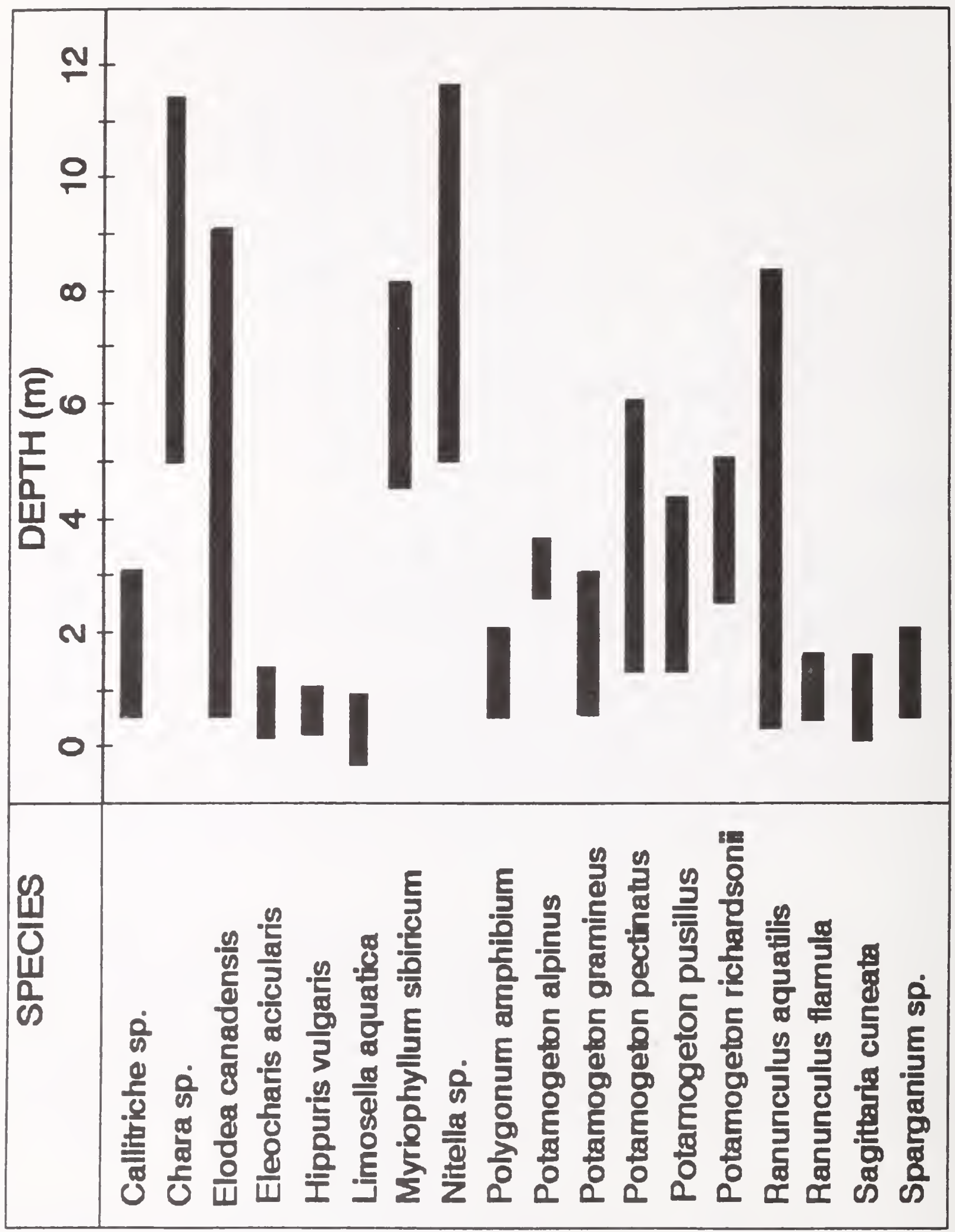

Figure 4. Depth distributions of macrophyte species in Jackson Lake relative to the median water level. Data for Potamogeton filiformis and Zannichellia palustris were not sufficient to plot a depth range. 
changing water levels (versus, for example, the high "pulse stability" of more diverse marine intertidal shores).

Brewer and Parker (1990) related the distribution of macrophytes along the littoral slope in Jackson Lake to mechanical properties of stems. Disturbance associated with moving water (e.g., surging waves along shores, increased abrasion) led to increased plant breakage, especially among species having long, fragile stems with low tensile strength and elasticity. Elodea canadensis, Myriophyllum sibiricum, and Ranunculus aquatilis were particularly susceptible to breaking as they were stranded in progressively more shallow and exposed habitats during summer drawdown. Because these species propagate readily by stem fragmentation (unlike Potamogeton richardsonii and $P$. pectinatus, for example), the disturbance regime at Jackson Lake driven by changing water levels is selecting for clonal, opportunistic species. This disturbance regime is especially important when maximum drawdown corresponds to the time of peak standing crop late in the summer. A high degree of patchiness along the shore of Jackson Lake furnished open space for colonization by Elodea canadensis, which readily propagates by fragmentation. Furthermore, the submergent community is shifted into deeper water as species intolerant of high water movement are removed from shallow shores.

Downslope, it is possible that the bottom limit of macrophytes in Jackson Lake depends on light penetration and even temperature. Both temperature and light vary along the vertical gradient in Jackson Lake, and neither factor was singled out in our analyses. Impoundment of natural lakes generally decreases light penetration (Rørslett 1987). Light penetration eventually increases once small particles are eroded from shorelines. Reduced light penetration caused by the suspension of fine particulates certainly may have limited the reestablishment of macrophytes in 1989, the first summer following the refilling of Jackson Lake. Moreover, Rørslett $(1987,1988)$ found that the water level regulation scheme may exacerbate macrophyte mortality by increasing the probability of low light conditions throughout the vertical gradient. This phenomenon remains important long after fine particulates are no longer present in the water column. Others have reported that the lower limit of macrophyte growth along the vertical gradient coincides with the summer thermocline position (Dale 1986; Sheldon and Boylen 1977). Only macrophytic green algae were present below the thermocline in Jackson Lake (table 1 and figure 4).

\section{Management Implications}

The extent of littoral habitat suitable for macrophyte growth in Jackson Lake depends on the nature of seasonal and long-term drawdowns. Drawdown schedules and resulting fluctuation in water levels may be selecting for a plant community characterized by low diversity and patchy distribution in Jackson Lake. High annual variations above and below the median water level (see figure 1) select for clonal species (e.g., Elodea canadensis, Ranunculus aquatilis, and Myriophyllum sibiricum). Species propagating clonally have enhanced opportunities for dispersal under such a disturbance regime and are favored when drawdown occurs during the period of peak standing crop. Also, as the plant community is shifted into deeper water, it is less accessible to many types of wildlife. Low annual variations around the median water are most favorable for plants that produce seeds annually and prefer shallower waters (e.g., Potamogeton species) as well as for wildlife species that feed in shallow water habitats. 


\section{Acknowledgments}

This study was funded by the University of Wyoming - National Park Service Research Center (1983 1985 ) and by the U.S. Bureau of Reclamation with coordination through the Wyoming Game and Fish Department and the U.S. Fish and Wildlife Service (1989 - 1991). Discussions with Michael Parker and Bjørn Rørslett helped to clarify some of the concepts presented in this paper.

\section{Literature Cited}

Brewer, C.A. and M. Parker. 1990. Adaptations of macrophytes to life in moving water: upslope limits and mechanical properties of stems. Hydrobiology 194:133-142.

Brewer, C.A. and B. Rørslett. 1987. Norwegian macrophyte models applied to an American reservoir. Pages 7-17 in B. Bretten and O.I. Ronning, editors, Symposium in vegetation ecology at Kongsvold Biological Station in March 1987. Universitetet I Trondheim, Vitenskapsmuseet Rapport Botanisk Serie 1987 Vol. 1.

Carpenter, S.R. and M.S. Adams. 1977. The macrophyte tissue nutrient pool of a hardwater eutrophic lake: implications for macrophyte harvesting. Aquatic Botany 3:239-255.

Clark, T.W. 1981. Ecology of Jackson Hole: A Primer. Paragon Press, Salt Lake City, Utah.

Cole, G.A. 1979. Textbook of Limnology. C.V. Mosby, Saint Louis, Missouri.

Correll, D.S. and H.B. Correll. 1975. Aquatic Plants of the South Western United States. Vols. I and II. Stanford University Press, Stanford, California.

Dale, H.M. 1986. Temperature and light: the determining factors in maximum depth distribution of aquatic macrophytes in Ontario, Canada. Hydrobiology 133:73-77.

Duarte, C.M. and J. Kalff. 1986. Littoral slope as a predictor of maximum biomass of submerged macrophyte communities. Limnology and Oceanography 30:1171-1187.

Gasith, A. and S. Gafny. 1990. Effect of water level fluctuation on the structure and function of the littoral zone. Pages 156-171 in M.M. Tilzer and C. Serruya, editors, Large Lakes: Ecological Structure and Function. Springer-Verlag, Berlin.

Kirk, R.M. and P.R. Henriques. 1986. Physical and biological aspects of shoreline change: Lake Ohau, South Island, New Zealand. Journal of Shoreline Management 2:305-326.

Lund, O.T. 1979. Handbook of Common Methods in Limnology. C.V. Mosby, Saint Louis, Missouri.

Pearsall, W.H. 1920. The aquatic vegetation of the English lakes. Journal of Ecology 8:163-201.

Rørslett, B. 1984. Environmental factors and aquatic macrophyte response in regulated lakes - a statistical approach. Aquatic Botany 19:199-220. 
Rørslett, B. 1985. Regulation impact on submerged macrophytes in the oligotrophic lakes of Setesdal, South Norway. Verhandlunge Internationer Vereinigungfuer Limnologie 22:2927-2936.

Rørslett, B. 1987. Niche statistics of submerged macrophytes in Tyrifjord, a large oligotrophic Norwegian lake. Archives of Hydrobiology 111:283-308.

Rørslett, B. 1988. An integrated approach to hydropower impact assessment. I. Environmental features of some Norwegian hydro-electric lakes. Hydrobiology 164:39-66.

Rørslett, B. 1989. An integrated approach to hydropower impact assessment. II. Submerged macrophytes in some Norwegian hydro-electric lakes. Hydrobiology 175:65-82.

Shaw, R.J. 1976. Field Guide to the Vascular Plants of Grand Teton National Park and Teton County, Wyoming. Utah State University Press, Logan, Utah.

Sheldon, R.B. and C.W. Boylen. 1977. Maximum depths inhabited by aquatic vascular plants. American Midland Naturalist 97:248-254.

Spence, D.H.N. 1982. The zonation of plants in freshwater lakes. Advances in Ecological Research 12:37-135. 



\title{
Factors Affecting Plant Establishment in an Alpine Ecosystem on the Beartooth Plateau, Montana ${ }^{1}$
}

\author{
Jeanne C. Chambers \\ Intermountain Research Station \\ Forest Service, U.S. Department of Agriculture \\ Reno, NV 89512 \\ Ray W. Brown \\ Intermountain Research Station \\ Forest Service, U.S. Department of Agriculture \\ Logan, UT 84321 \\ James A. MacMahon \\ College of Science, Utah State University \\ Logan, UT 84322
}

\begin{abstract}
Knowledge of the factors that affect plant establishment processes in alpine ecosystems is essential for restoring disturbed areas, conserving rare or endangered species, and understanding changes in species distributions caused by global change. This paper reviews available literature on plant establishment in tundra environments and synthesizes eight years of research on plant establishment processes in an alpine ecosystem on the Beartooth Plateau, Montana. In alpine ecosystems, constraints on the production of viable seeds and the acquisition of favorable microsites may be at least as important as the ability of seedlings to survive different environmental conditions. High variability exists in the viable seed rain both among years and within species. Individual species vary in seed longevity and seed germination characteristics, and the numbers of seeds that carry over from one year to the next is species specific. Seed entrapment in desirable microsites is highly dependent upon soil surface characteristics. On exposed soils relationships among seed morphological attributes and soil particle size can determine both the horizontal and vertical movement of seeds. The physical and chemical properties of disturbed soils determine nutrient and temperature regimes and thus have a substantial effect on seedling growth and survival. In our studies species differed in growth and survival, but survival of most species exceeded 50 percent after five years on
\end{abstract}

${ }^{1} T$ The use of trade or firm names in this paper is for reader information and does not imply endorsement by the U.S. Department of Agriculture of any product or service. 
both organic and mineral soils. This finding indicated that alpine species often have high physiological tolerances to different environmental conditions caused by different types of disturbance. For species conservation and restoration efforts in alpine ecosystems to be successful, it is necessary to recognize the linkages between processes that affect both seeds and seedlings and the ultimate establishment of plants.

The establishment of plants from seeds depends upon complex processes that begin with the production of viable diaspores by mature plants (Harper 1977). Seeds must be successfully dispersed to microsites that at some time during the lifespans of the seeds provide the necessary conditions for germination. The same microsites must also provide environments that facilitate the growth and survival of seedlings. The cycle can be considered complete when seedlings mature and produce their own viable diaspores. Much of the research on plant establishment has treated seeds and vegetative plants as distinct entities, focusing on processes that are either specific to the seed (e.g., dispersal, dormancy, and germination) or to the plant (e.g., seedling emergence and plant survival). More recent research has acknowledged the implicit connection between the fates of seeds, the establishment of plants, and, ultimately, the manner in which plant populations and communities are structured.

In alpine tundra ecosystems the physical environment has had a strong evolutionary influence on the life history and physiological traits of species and places numerous constraints on the establishment of plants from seeds (Billings 1974; Billings and Mooney 1968; Bliss 1962, 1971, 1985; Callaghan 1988). Tundra vegetation has a characteristic physiognomy and is dominated by low-growing perennial shrubs, forbs, and graminoids. Although annual species are extremely rare, clonal species are abundant. Plant establishment from seed is frequently episodic because it depends upon the proper set of environmental conditions for both seeds and seedlings (Bliss 1985). These factors have caused researchers to generalize that sexual reproduction is less important than vegetative propagation (e.g., Billings and Mooney 1968; Bliss 1971). Despite this, successful seedling establishment has been observed under natural conditions (Bliss 1971; Bonde 1968; Brink 1964; Jolls and Bock 1983) and following seeding or transplanting experiments (Brown, Johnston, and Van Cleve 1978; Chambers, MacMahon, and Brown 1990; Harrington 1946; Roach and Marchand 1984). For many tundra ecosystems, seedling recruitment may be the most common means of colonizing disturbed sites (Gartner, Chapin, and Shaver 1983).

Knowledge of the factors that affect plant establishment processes in tundra ecosystems is essential for restoring disturbed areas, conserving rare or endangered species, and understanding changes in species distributions caused by global change. This paper attempts to review the available literature on plant establishment in tundra environments and to synthesize research that we and our coworkers have conducted on plant establishment processes in an alpine ecosystem on the Beartooth Plateau, Montana, over the past eight years. Because this work has focused primarily on restoration of severely disturbed ecosystems and development of those ecosystems over time, we compare processes on an undisturbed late seral area with those on a previously disturbed early seral area. We emphasize the effects of abiotic factors and disturbance severity and we examine processes that affect both seeds and seedlings. 


\section{Study Area}

The study areas on the Beartooth Plateau in south-central Montana $\left(45^{\circ} 00^{\prime} \mathrm{N} / 109^{\circ} 30^{\prime} \mathrm{W}\right.$, elevation $3,200 \mathrm{~m}$ ) include a severely disturbed 35-year-old gravel borrow area where topsoil and gravel had been removed and an undisturbed area within the Geum turf vegetation type (sensu Johnson and Billings 1962) about $150 \mathrm{~m}$ from the borrow area. The borrow area has loamy sand soils and has been sparsely colonized by plants (<25 percent vegetation cover). Dominant species include Deschampsia cespitosa, Festuca ovina, and Trisetum spicatum. The Geum turf area has organic soils (about 20 percent organic matter) and $>90$ percent vegetation cover. The dominant species are Geum rossii and Lupinus argenteus. Both areas face east and are situated on slopes of $<5$ percent.

Weather of the area was monitored from late June to mid-September from 1985 through 1990. Instruments were placed at or near ground level to sample the plant environment more accurately. The values obtained are similar to those for other North American alpine areas (see Bliss 1985). Mean wind velocity ranged from $2.8 \mathrm{~m} \mathrm{~s}^{-1}$ to $3.9 \mathrm{~m} \mathrm{~s}^{-1}$ with maximum gusts of $23 \mathrm{~m} \mathrm{~s}^{-1}$. Cumulative precipitation averaged $131 \mathrm{~mm}$ with a range of $102 \mathrm{~mm}$ to $170 \mathrm{~mm}$. Temperature was determined only during 1985 and 1986. Mean maximum and minimum daily temperatures differed between the two years $-14.7^{\circ} \mathrm{C}$ and $2.9^{\circ}$, respectively, in 1985 , and $13.7^{\circ} \mathrm{C}$ and $1.0^{\circ}$ in 1986 .

More detailed information about the study area can be found in Chambers, MacMahon, and Brown (1990) and Johnson and Billings (1962).

\section{Seed Rain}

The quality and quantity of seeds produced by tundra species are highly dependent upon environmental conditions. Seed production depends upon the previous and current year's growing seasons. In many tundra species, growth of the inflorescence is initiated one or even two seasons prior to flowering (Billings 1974; Billings and Mooney 1968; Spomer 1964). In dwarf braya (Braya humilis), fruits do not mature the year of flowering, but become dormant during the winter and mature the following summer (Sorenson 1941).

The high variability in seed production can be observed at several different scales. Temporal variation can be observed in the seed rain at the community level and in seed quality at the individual species level. During the active diaspore dispersal periods of 1988, 1989, and 1990 (mid-July to late September), we estimated total seed rain on the borrow and Geum turf areas from 30 pitfall diaspore traps randomly located within $50 \times 50$ m grids on $5 \mathrm{~m}$ centers (i.e., 30 of 100 locations) (Chambers in press). Between 1988 and 1989 there was almost a twofold difference in seed number in the seed rain on both the borrow and Geum turf areas (table 1). If only the forb species are considered, the difference was fiveto sixfold. Similar differences among years have been observed in the seed rain of grassland, herbfield, snowbank, and fellfield communities in the New Zealand alpine (Spence 1990). The seed rain on both the borrow and Geum turf areas was higher than on most of the New Zealand alpine communities, except that the seed rain on the Geum turf area was similar to that of the snowbank community.

The total seed rain is seldom indicative of the viable seed rain in alpine ecosystems (Chambers 1989; Spence 1990). An earlier four-year study revealed significant differences in the percent of seeds filled for grass species and in the seed viability and longevity of both grass and forb species among years 


\begin{abstract}
Table 1. Total seed rain (seeds $\mathrm{m}^{-2}$ ) by life form on the Beartooth Plateau borrow and Geum turf sites during the active diaspore dispersal periods of 1988,1989 , and 1990
\end{abstract}

\begin{tabular}{|l|r|r|r|r|r|r|}
\hline \multirow{2}{*}{\multicolumn{1}{|c|}{ Life forms }} & \multicolumn{3}{|c|}{ Geum turf area } & \multicolumn{3}{c|}{ Borrow area } \\
\cline { 2 - 7 } & 1988 & 1989 & 1990 & 1988 & 1989 & 1990 \\
\hline Graminoids & 2,714 & 2,733 & 1,485 & 6,853 & 8,683 & 5,903 \\
\hline Forbs & 661 & 3,361 & 4,507 & 877 & 5,322 & 4,533 \\
\hline Shrubs & 0 & 0 & 166 & 0 & 0 & 0 \\
\hline & & & & & & \\
Total & 3,375 & 6,095 & 6,158 & 7,730 & 14,005 & 10,436 \\
\hline
\end{tabular}

From Chambers (in press).

(Chambers 1989). Seed viability differed among species within most years (figure 1) and was generally lower and more variable among years for grasses than for forbs. Low seed viability years for the grass species coincided with low seed fill years, indicating poor seed development. Slower phenological development of grasses than of forbs growing within the same community has been observed at alpine sites on Mount Washington, New Hampshire, and Niwot Ridge, Colorado (Bliss 1956, 1966; Fareed and Caldwell 1975). During years with short, cool growing seasons, this condition may result in lower seed fill and viability of grass species.

Viable seed production of alpine species is spatially variable, decreasing with increasing latitude and altitude (Billings and Mooney 1968) and with increasing environmental severity. Species that produce large numbers of seeds in meadows may produce few or no seeds on wind-exposed or late-melting snowbank sites (Bliss 1956). On the Beartooth Plateau the seed rain was routinely higher on the recently disturbed borrow area than on the undisturbed Geum turf area (table 1). This occurrence can be attributed to differences in species composition and in seed production of individual species between the two areas.

The borrow area is dominated by grass species, Deschampsia cespitosa, Trisetum spicatum, Deschampsia atropurpurea, and Festuca ovina, with high growth rates and diaspore production. In contrast, the Geum turf area is dominated by forbs, Geum rossii and Lupinus argenteus, with low growth rates and diaspore production. Shrubs are almost nonexistent on both sites. Because the Geum turf area is characterized by high vegetation cover, resource allocation to growth and reproduction is probably constrained by the effects of other plants on resource availability. On the Beartooth Plateau, individual G. rossii clones growing on the Geum turf area had ramets with low leaf numbers and mass and with low reproductive effort (Chambers 1991). Clones of similar area on the borrow area were characterized by ramets with higher leaf number, mass, and reproductive effort. 


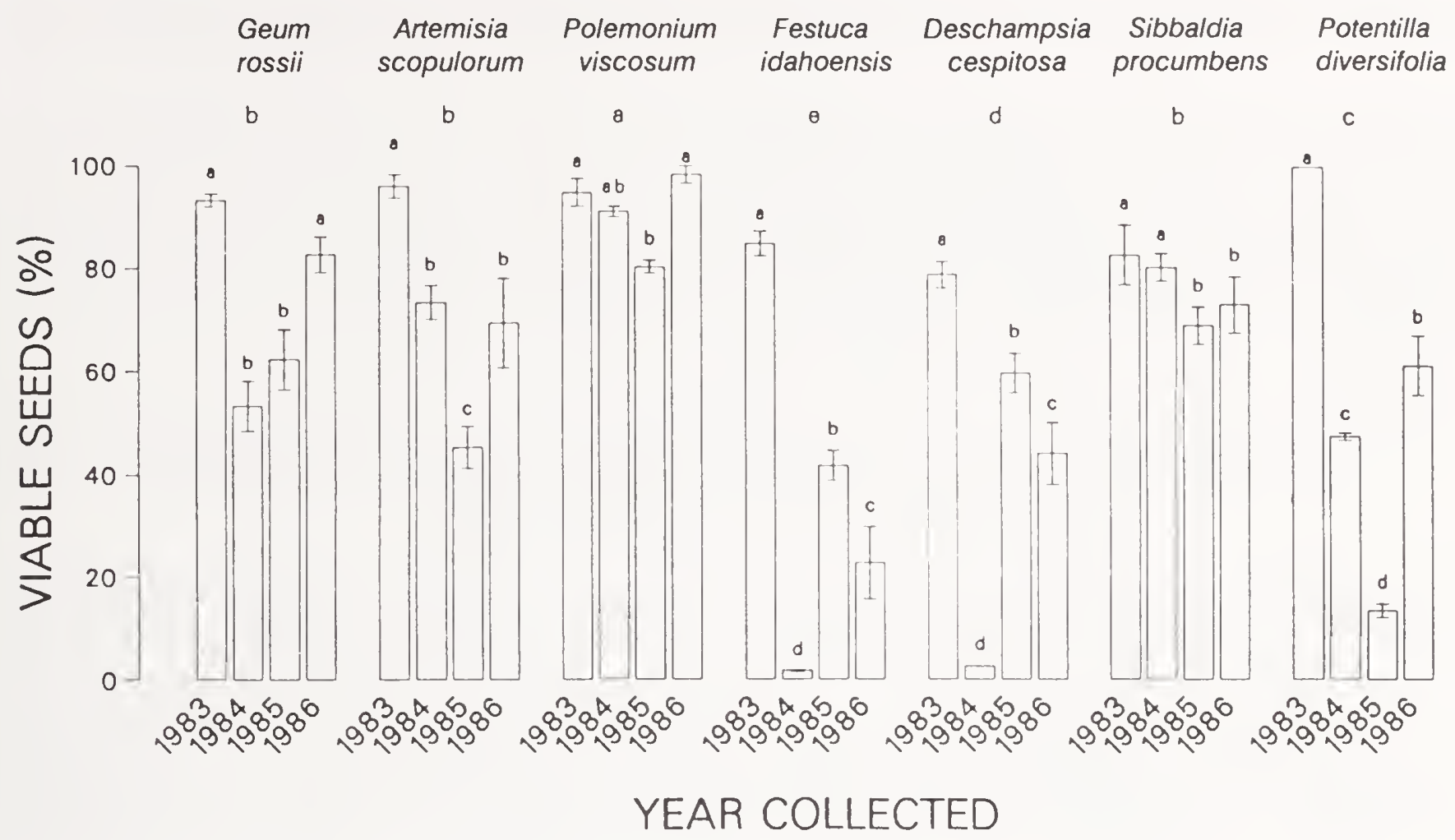

Figure 1. Seed viability of alpine species collected during four consecutive years on the Beartooth Plateau. Values are mean and error bars represent \pm 1 SE (standard error). Unlike letters indicate significant differences in seed viability among species for the first row of letters and among years within species for the second row of letters (Fisher's Protected mean comparisons; $p<0.05$ ). (From Chambers 1989).

\section{Seed Safe Site Acquisition}

Few studies have been conducted on either primary or secondary seed dispersal in tundra ecosystems (Marchand and Roach 1980; Ryvarden 1971; Spence 1990; Spence and Shaw 1983). Seeds of many species lack obvious morphological adaptations for efficient wind or animal dispersal. We have observed birds (horned larks) and seed-eating beetles feeding on seeds on the Beartooth Plateau, but there are few data from this or other alpine sites quantifying the effects of seed predators. On exposed soils wind is an extremely important dispersal vector. It influences the direction of primary dispersal from the parent plant to the soil surface and the secondary dispersal of diaspores on the soil surface.

We examined the effects of prevailing wind direction on distribution of dispersed diaspores on the Geum turf and borrow areas (Chambers unpublished data). Canopy cover of the species surrounding pitfall diaspore traps (described above) was estimated in nested circular plots $\left(0.1,1.0\right.$, and $\left.5.0 \mathrm{~m}^{2}\right)$ that were divided into four wedges, each oriented toward one of the four cardinal directions. Cover indices for 
individual species were obtained for entire plots and for each of the four wedges within each circular plot.

Relationships between seed number and species vegetation cover in the different-sized plots and wedges were evaluated with Spearman's rank correlation coefficients $\left(R_{s}\right)$, nonparametric tests of significance. No relationships between the seed rain and vegetation composition were detected for the Geum turf area (table 2). In contrast, on the borrow area the seed rain and vegetation composition were positively correlated. The strength of the correlation was highest for small plots $\left(0.1>1.0>5.0 \mathrm{~m}^{2}\right)$ and for plots in the direction of the prevailing wind (south and west $>$ east $>$ north).

\section{Table 2. Spearman's correlation coefficients comparing numbers of diaspores of each species caught in pitfall traps with cover indices for the same species in circular plots surrounding the traps}

\begin{tabular}{|l|c|c|c|c|c|c|}
\hline \multirow{2}{*}{ Direction } & \multicolumn{3}{|c|}{ Borrow area } & \multicolumn{3}{c|}{ Geum turf area } \\
\cline { 2 - 7 } & $0.1 \mathrm{~m}^{2}$ & $1.0 \mathrm{~m}^{2}$ & $5.0 \mathrm{~m}^{2}$ & $0.1 \mathrm{~m}^{2}$ & $1.0 \mathrm{~m}^{2}$ & $5.0 \mathrm{~m}^{2}$ \\
\hline North $^{\mathrm{a}}$ & $0.56^{* \mathrm{~b}}$ & $0.38^{\mathrm{ns}}$ & $0.34^{\mathrm{ns}}$ & $-0.01^{\mathrm{ns}}$ & $0.22^{\mathrm{ns}}$ & $0.14^{\mathrm{ns}}$ \\
\hline East & $0.52^{*}$ & $0.50^{*}$ & $0.54^{*}$ & $0.12^{\mathrm{ns}}$ & $0.18^{\mathrm{ns}}$ & $0.17^{\mathrm{ns}}$ \\
\hline South & $0.77^{* *}$ & $0.63^{* *}$ & $0.51^{*}$ & $-0.01^{\mathrm{ns}}$ & $0.16^{\mathrm{ns}}$ & $0.16^{\mathrm{ns}}$ \\
\hline West & $0.75^{* * *}$ & $0.61^{* *}$ & $0.55^{*}$ & $-0.10^{\mathrm{ns}}$ & $-0.09^{\mathrm{ns}}$ & $0.08^{\mathrm{ns}}$ \\
\hline
\end{tabular}

\footnotetext{
aplots were three different sizes and were divided into four wedges based on the cardinal directions; $n=21$ for the borrow area; $n=27$ for the Geum turf area.

$b^{* * *} p<0.001 ;{ }^{* *} p<0.01 ; " p<0.05 ;{ }^{n s}=$ not significant. Probability values were not corrected for multiple tests.

From Chambers (unpublished data).
}

The distance and direction that diaspores move from the parent plant are often correlated with wind speed and direction (Augspurger and Franson 1987). Despite this fact, diaspores are seldom dispersed far from the parent plant (see Cook 1979), even in tundra ecosystems (Marchand and Roach 1980; Spence 1990). This dispersal pattern is evidenced on disturbed tundra sites, as colonizing species often advance as a moving front opposite the direction of the prevailing wind. The degree of vegetation development or cover within vegetation communities can affect diaspore movement (McEvoy and Cox 1987; Verkaar et al. 1983), and the high vegetation cover on the Geum turf area may have impeded diaspore movement.

After diaspores are deposited on exposed soils in windy environments (tundra and desert), they are often transported over the soil surface until they encounter a barrier or depression that traps them in that location (Chambers, MacMahon, and Haefner 1991). Several soil surface properties - including roughness, soil particle size (Harper 1977; Stamp 1984), and the presence or absence of vegetation or organic matter (Stamp 1989) - affect the entrapment of diaspores in soil. In the northern Japanese alps, particle-size distribution is one of the major habitat factors affecting both species composition and vegetation cover (Mizuno 1989). Our studies of seedling emergence and survival indicate that physical 
relationships between soil surface characteristics and diaspore morphological attributes determine the sites of diaspore entrapment and the depth of diaspore movement in the soil column (Chambers, MacMahon, and Brown 1990).

To determine how diaspore morphology and soil particle size affect diaspore incorporation into soils, diaspores with varying morphology of eight alpine species were sown over soils of five different particle sizes (0.5 - 1.0, 1.0 - 2.0, 2.0 - 4.0, 4.0 - 8.0, and 8.0 - 16.0) (Chambers, MacMahon, and Haefner 1991). After four or eight weeks soils were collected from $0-1,1-5$, and $5+\mathrm{cm}$ depth intervals, and diaspores were extracted with a high density salt solution. Models based on the Weibull distribution adequately describe the fraction of diaspores remaining in the soil at all depths and the fraction at the depth in which seed germination occurs $(0-1 \mathrm{~cm}$ ) (figure 2). We chose the Weibull distribution because it is commonly used as a survival function, the equations produced significant agreement with the data, and it has predictive value (see Chambers, MacMahon, and Haefner 1991).

For all diaspore types, increases in soil particle size resulted in increases in the total number of diaspores trapped. At small particle sizes $(0.5-1.0$ and $1.0-2.0 \mathrm{~mm})$ small diaspores and diaspores with adhesive seed coats were trapped, but most large diaspores moved horizontally across the surface and were not trapped. Most diaspores trapped were at the $0-1 \mathrm{~cm}$ depth at small particle sizes. At large particle sizes (2.0 - $4.0 \mathrm{~mm}$ and larger) high numbers of large diaspores were trapped, and more diaspores moved vertically through the soil column. These results show that on exposed soils in windy environments soil particle size and diaspore morphology greatly affect the spatial distribution of dispersed diaspores and, consequently, species colonization patterns.

Abiotic factors other than wind can also influence the horizontal or vertical movement of diaspores at the soil surface (Sheldon 1974; Simpson, Leck, and Parker 1989; van Tooren 1988; Watkinson 1978). Cryoturbation and precipitation can alter the horizontal and vertical distribution of diaspores in soil (Sheldon 1974; van Tooren 1988) and may be especially important in alpine ecosystems. Depending upon the intensity and duration of individual precipitation events, small particle size soils may have more surface runoff containing both soil fines and diaspores, whereas large particle size soils may have higher infiltration and greater downward movement of soil fines and diaspores (Chambers, MacMahon, and Haefner 1991). Both precipitation and cryoturbation can alter the structure of surface soils (Sheldon 1974; Young, Evans, and Palmquist 1990) and, thus, the likelihood of later movement of surface soils and diaspores by wind or water.

\section{Seed Germination and Seedling Emergence}

Seedling emergence in the field is dependent upon the seed germination characteristics of the study species. Seed germination in alpine environments appears to be mediated by several environmental factors, and reports that seed dormancy is characteristic of only a small percentage of alpine and arctic species (e.g., Amen 1966; Bliss 1985) are probably inaccurate. In much of the early work in this area proper experimental controls were not exercised and conclusions were based largely on final germination percentages. Available data indicate that germination percentages are usually highest at alternating temperatures and often peak between $10^{\circ} \mathrm{C}-20^{\circ} \mathrm{C}$ and $10^{\circ} \mathrm{C}-30^{\circ} \mathrm{C}$ or $15^{\circ} \mathrm{C}-20^{\circ} \mathrm{C}$ and $15^{\circ} \mathrm{C}$ $25^{\circ} \mathrm{C}$ (Sayers and Ward 1966).

We examined seed germination of eight alpine species following 90 days of wet or dry cold storage at $1^{\circ} \mathrm{C}-2^{\circ} \mathrm{C}$ in light or dark conditions with daytime temperatures of $18 \pm 1^{\circ} \mathrm{C}$ and nighttime temperatures 


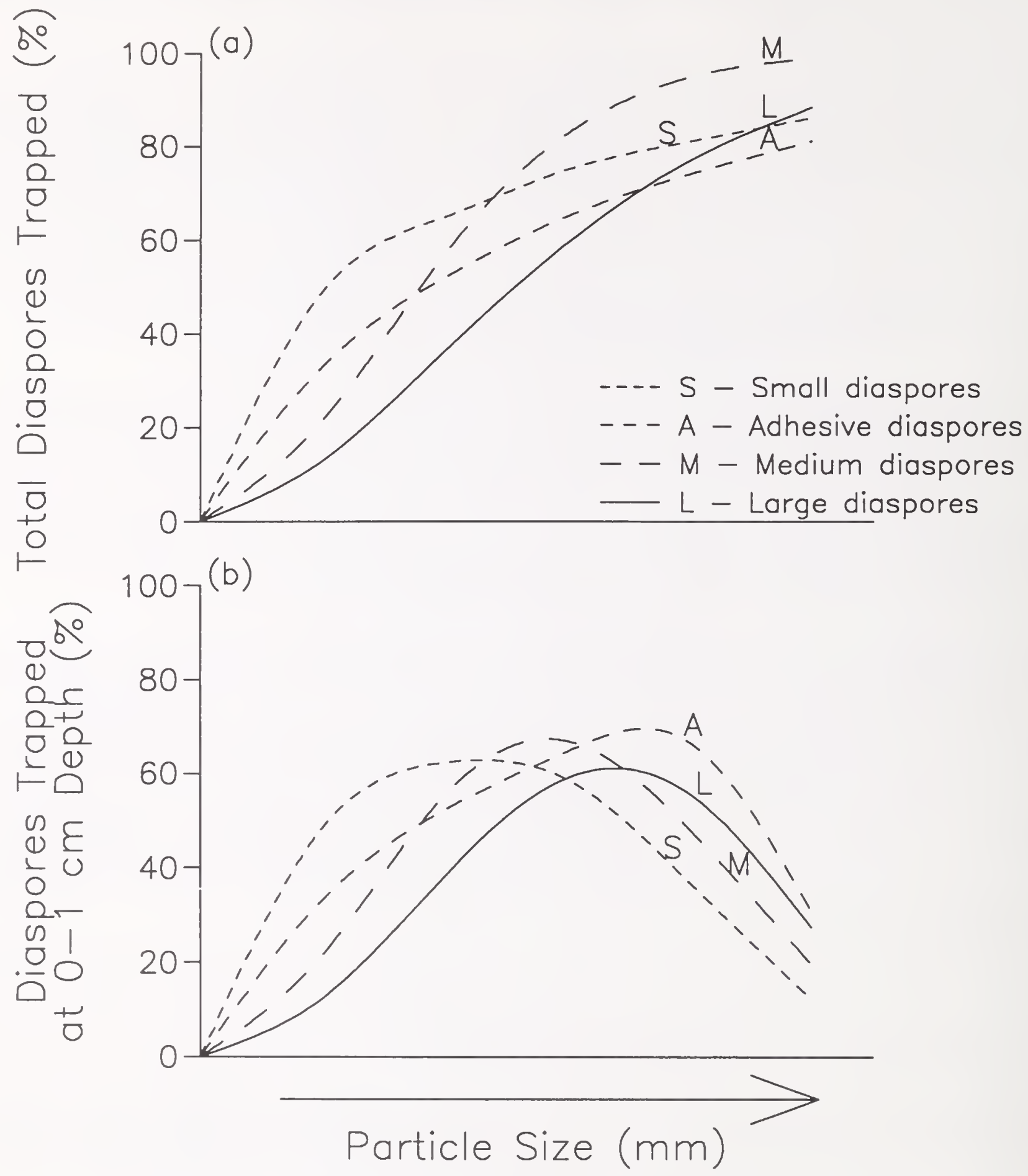

Figure 2. Generalized models of how small (S), medium-sized (M), large (L), and adhesive (A) diaspores are trapped in soils over a range of increasing particle sizes in th eentire soil column (a) and at the depth at which germination and emergence are likely to occur $(0-1 \mathrm{~cm})(\mathrm{b})$. Diaspores shown in column (a) do not leave the soil surface by horizontal processes; those in column (b) do not leave the soil surface by horizontal processes nor the $0-1 \mathrm{~cm}$ depth by vertical processes. Curves were derived from modified Weibull probability distributions. (From Chambers, MacMahon, and Haefner 1991). 
of $4 \pm 1^{\circ} \mathrm{C}$ (Chambers, MacMahon, and Brown 1987). The temperature regime simulated mean ambient temperatures during the growing season on the Beartooth Plateau. After 10-day germination, percentages ranged from 52 percent to 98 percent in one or more treatments for all but one species (table 3). Light frequently increases germination, especially of forbs and some Carex species (Amen and Bonde 1964; Haggas, Brown, and Johnston 1987; Reynolds 1984), and it resulted in higher germination in our study. Wet cold storage (stratification) is required for certain species (Reynolds 1984) and increased the germination of the majority of our species. For several species of legumes, Carex, and Luzula, scarification of the seed coat is necessary to promote germination (Amen and Bonde 1964; Bell and Amen 1970).

Table 3. Germination response of alpine species to wet or dry cold storage

\begin{tabular}{|l|r|r|r|r|}
\hline \multirow{2}{*}{ Species } & \multicolumn{2}{c|}{ Dry cold storage } & \multicolumn{2}{c|}{ Wet cold storage } \\
\cline { 2 - 5 } & Light & Dark & Light & Dark \\
\hline Forbs & & & & \\
Geum rossii & 100.0 & 30.0 & 99.0 & 90.0 \\
Artemisia scopulorum & 67.0 & 0.6 & 88.0 & 46.0 \\
Sibbaldia procumbens & 64.0 & 6.0 & 61.0 & 34.0 \\
Potentilla diversifolia & 71.0 & 10.0 & 90.0 & 63.0 \\
Polemonium viscosum & 3.0 & 0.1 & 17.0 & 11.0 \\
\hline Grasses & & & & \\
Festuca idahoensis & 93.0 & 91.0 & 86.0 & 88.0 \\
Calamagrostis purpurascens & 77.0 & 83.0 & 93.0 & 99.0 \\
Deschampsia cespitosa & 95.0 & 64.0 & 63.0 & 46.0 \\
\hline
\end{tabular}

From Chambers, MacMahon, and Brown 1987.

Note: Seeds were stored for 90 days under wet or dry conditions at $1^{\circ} \mathrm{C}-2^{\circ} \mathrm{C}$ and germinated under light (14-h day, 10-h night) or dark conditions with daytime temperatures of $18^{\circ} \mathrm{C}$ and nighttime temperatures of $4^{\circ} \mathrm{C}$. Values are total mean germination of viable seeds (percent) after 30 days for three replicates of 100 seeds.

The effects of various field environmental conditions on the emergence, growth, and survival of seedlings must be determined to critically evaluate constraints on plant establishment. We compared the soil environment and seedling emergence, growth, and survival of six seeded and five naturally colonizing alpine species on the mineral soils of the borrow area and on sites cleared or not cleared of vegetation on the organic soils of the Geum turf area (Chambers, MacMahon, and Brown 1990). On the borrow site, we also examined the effects of nutrient addition $\left(8.2\right.$ and $15.6 \mathrm{~g} \mathrm{~m}^{2}$ of nitrogen $(N)$ and phosphorus $(P)$, respectively) and mulching $\left(224 \mathrm{~g} \mathrm{~m}^{2}\right)$ on the seedling environment and plant establishment.

Patterns of seedling emergence observed in the field study reflected species differences in the germination experiment (Chambers, MacMahon, and Brown 1990). Species that had high germination percentages under most of the laboratory treatments exhibited little delayed emergence in the field, whereas those that showed a significant response to the germination treatments had delayed emergence 
of a high percentage of the seed population. These studies indicate that some form of dormancy exists in a significant portion of the seed population of most tundra species, and that seed germination often depends upon more than one environmental factor.

The importance of soil surface characteristics on seed entrapment and retention was observed in patterns of seedling emergence. On the cleared Geum turf area both the surface soil and seeds were removed by wind, and few seedlings emerged during the first growing season. The site was reseeded that fall, and two layers of Conwed netting were used to hold the soil and seed in place. On the borrow area, wind removed a significant amount of the mulch during the first winter, but seedling emergence was still $2-16$ times higher on mulched plots than on unmulched plots (Chambers, MacMahon, and Brown 1990) (table 4). Emergence of large seeded species was less than that of small seeded species, illustrating that movement of seeds is often highly dependent on diaspore morphology.

Table 4. Seed mass and length and number of seedlings $\mathrm{m}^{-2}$ that emerged in mulched vs. unmulched plots on the Beartooth Plateau borrow area.

\begin{tabular}{|l|c|c|c|c|}
\hline & \multirow{2}{*}{$\begin{array}{c}\text { Seed } \\
\text { mass }\end{array}$} & \multirow{2}{*}{$\begin{array}{c}\text { Seed } \\
\text { length }\end{array}$} & \multicolumn{2}{c|}{ Seedlings m $^{2}$} \\
\cline { 4 - 5 } & $(\mathrm{mg})$ & $(\mathrm{mm})$ & Mulch & No mulch \\
\hline Artemisia scopulorum & 0.035 & 1.9 & 523 & 1.03 \\
\hline Deschampsia cespitosa & 0.034 & 3.7 & 298 & 80 \\
\hline Sibbaldia procumbens & 0.052 & 1.7 & 450 & 193 \\
\hline Potentilla diversifolia & 0.067 & 1.7 & 442 & 95 \\
\hline Festuca idahoensis & 0.087 & 8.3 & 115 & 18 \\
\hline Geum rossii & 0.159 & 7.5 & 238 & 15 \\
\hline
\end{tabular}

Note: Individual seed masses were obtained from a composite sample of $n=100$; individual lengths are means, $n=20$. Seedlings $\mathrm{m}^{-2}$ are means of three replicates. Compiled from Chambers, MacMahon, and Brown 1990 and Chambers, MacMahon, and Haefner 1991.

\section{Seedling Growth and Survival}

The seedling environment on different types of disturbances is highly dependent upon soil physical and chemical characteristics. In our comparison of the borrow and Geum turf areas, soil temperatures and plant available nutrients were higher on the Geum turf area than on the borrow area. Furthermore, Geum turf cleared of vegetation had higher soil temperatures and plant nutrients than noncleared turf. Well-developed organic soils, like those on the Geum turf area, have higher cation exchange capacities and greater nutrient pools and cycling capacities than mineral soils (Chapin 1983). In addition, organic soils are characterized by lower thermal conductivities, heat capacities, thermal diffusivities, and contact coefficients than mineral soils (Cochran 1969). These characteristics often result in higher diurnal 
fluctuations in soil surface temperatures and generally higher soil temperatures at shallow depths during periods of moderate to high solar radiation in organic soils.

Higher soil temperatures following the removal of insulating vegetation from organic soils can increase rates of mineralization and decomposition (Chapin and Bloom 1976; Matson and Vitousek 1981) and probably contributed to higher nutrient availability on cleared plots than on vegetated Geum turf plots. On the borrow area, fertilization resulted in an artificial short-duration nutrient pulse, probably caused by the low nutrient retention capacities of the mineral soils. Two years after fertilization only about half of the amount of $\mathrm{P}$ and less than one-tenth of the amount of $\mathrm{N}$ applied remained in the soil in the original forms.

Growth and survival of tundra species is often highly correlated with air and soil temperatures and soil nutrients (Bell and Bliss 1980; Bliss 1966; Scott and Billings 1964; Wager 1938; Warren-Wilson 1966). High seedling mortality has been related to slow seedling growth (Wager 1938; Bell and Bliss 1980), needle ice activity (Bliss 1971; Brink et al. 1967; Roach and Marchand 1984), and soil drought (Bliss, 1971; Bell and Bliss 1980; Bonde 1968). On the Beartooth Plateau, ambient temperatures influenced seedling growth and survival. First-year growth of seedlings was lower during a short, cool growing season (1986) than during a longer, warmer growing season (1985). Also, seedling mortality was higher during 1986 than 1985. Overall seedling growth was low regardless of growing season conditions and varied among species and treatments: $0.005 \mathrm{~g}-0.004 \mathrm{~g}$ and $0.02 \mathrm{~g}-0.20 \mathrm{~g}$ total mass after the first and second growing seasons, respectively (Chambers, MacMahon, and Brown 1990).

Differences in soil temperatures and nutrients on the borrow and Geum turf areas were reflected in seedling growth and survival. Higher soil temperatures, combined with higher plant available nutrients, resulted in larger seedlings and lower mortality on cleared Geum turf. On the borrow area, fertilization resulted in higher biomass of all species, but it had little effect on survival of longer lived seeded species and increased mortality of short-lived unseeded species during the first two years. Since higher biomass usually results in lower mortality (Cook 1979), and slow growth has been cited as a cause of increased mortality for tundra species (Bell and Bliss 1980; Wager 1938), these results were unexpected. The higher mortality may have resulted from the initial pulse of $N$ and $P$, followed by a rapid decline in $N$. Decreased nutrient absorption, photosynthesis, and growth can result from declines in fertility following a nutrient pulse and cause greater susceptibility to other stresses (Chapin 1980). For longer lived species, a beneficial effect of fertilization was apparent after the fifth year. Both the age of first reproduction and the number of individuals reproducing were higher on fertilized than on nonfertilized plots. This situation may have resulted from the fact that there were larger first- and second-year seedlings on fertilized than on nonfertilized plots.

On the borrow area, mulch increased seedling survival of most species despite few effects on soil nutrients, water potential, or temperature. The importance of microsites for seedling survival has been observed in alpine (Jolls and Bock 1983) and arctic tundra (Bell and Bliss 1980). A patchy distribution of the mulch after the first winter may have resulted in microsites that favored seedling survival by improving the physiological status of the plants and lessening the physical effects of the wind.

Many plant species have concave survivorship curves, indicating a period of high risk early in the life of the plant (Cook 1979). Previous studies in alpine tundra ecosystems have shown that seedling survival is seldom >50\% after the first growing season (Bonde 1968; Jolls and Bock 1983; Roach and Marchand 1984). In our comparison of the borrow and Geum turf areas, seedling survival varied among species and treatments, but was seldom <50 percent, even after five growing seasons (figure 3). This 


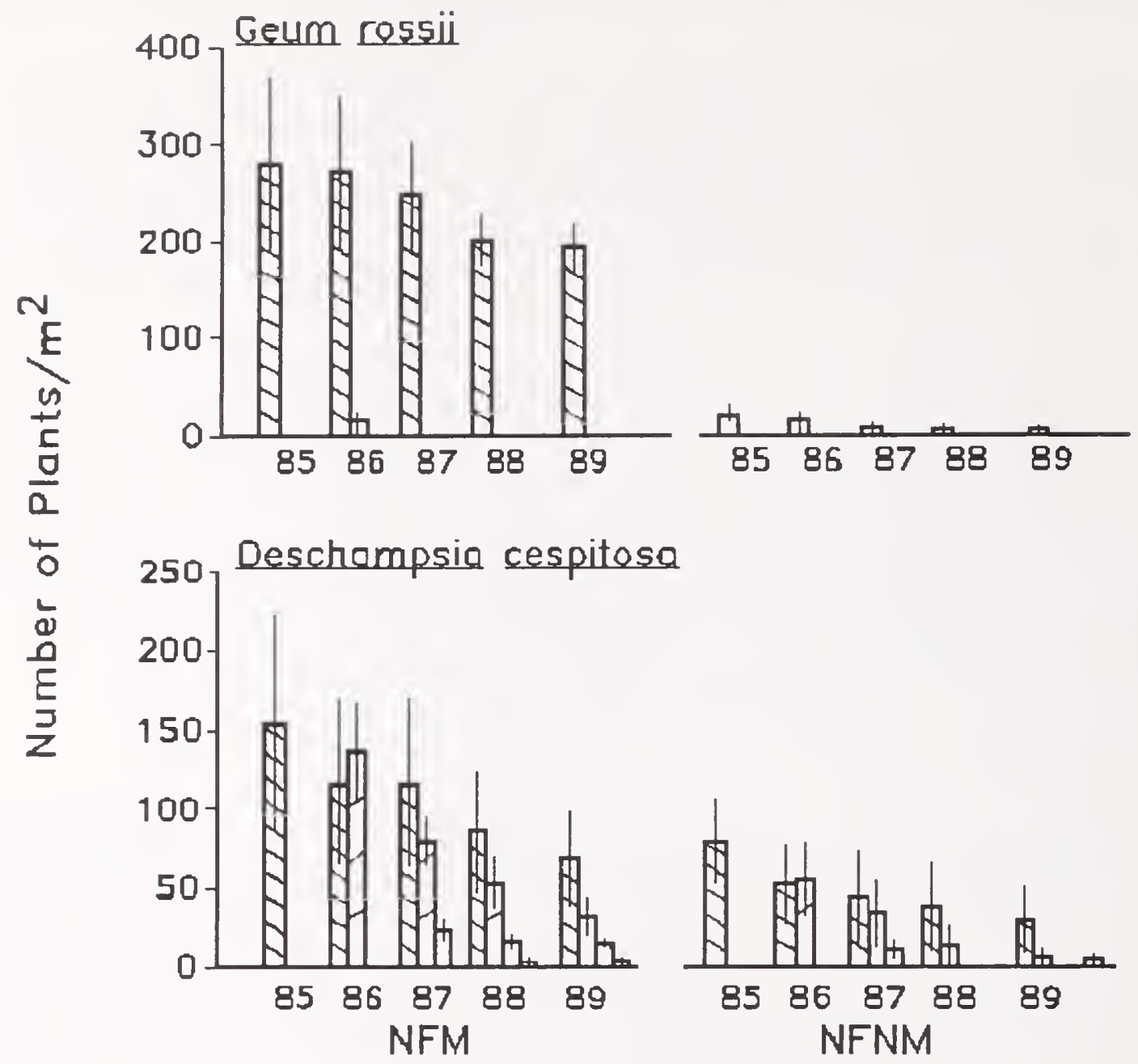

Figure 3. Numbers of Geum rossii and Deschampsia cespitosa plants that emerged in 1985, 1986, 1987, and 1988 and the numbers of individuals alive in the years following emergence in borrow area plots on the Beartooth Plateau that were mulched or not mulched, but not fertilized. Different bar patterns indicate different emergence years (cohorts). Values are mean $\pm \mathrm{SE} ; n=3$. (From Chambers, MacMahon, and Brown 1990 and Chambers and Turner in prep.)

phenomenon indicated that the species studied had a high physiological tolerance to the different environmental conditions on both the borrow and Geum turf areas.

\section{Conclusions}

Plant establishment in this alpine ecosystem is clearly dependent upon processes that affect both seeds and seedlings. High variability exists in the viable seed rain both among years and within species. Species vary in both seed longevity and in the type and degree of seed dormancy. The quantity of seeds 
that carry over from one year to the next is species specific. Seed entrapment in desirable microsites depends upon soil surface characteristics. In our studies, soil surface stabilization was essential for holding both soil and seed in place. Relationships among seed morphological attributes and soil particle size influence not only the horizontal movement of seeds over the soil surface, but also the vertical movement of seeds in the soil column. The germination of most alpine species is mediated by environmental conditions, with many species responding to more than one factor. Various species have been shown to respond to some combination of soil temperature, light, stratification, or scarification.

The chemical and physical properties of disturbed soils determine the nutrient and temperature regimes and have a substantial effect on seedling growth and survival. Following disturbance, soils with organic topsoils have higher soil temperatures, greater rates of decomposition, and higher levels of plant available nutrients, resulting in higher seedling biomass and survival. Mineral soils have inherently low nutrient holding capacities, and fertilization almost always results in a short-term nutrient pulse. Added nutrients increased the mortality of short-lived species, presumably by creating plant nutrient demands in excess of availability. However, the nutrient pulse had positive effects on longer lived species, decreasing the age of first reproduction and increasing the number of reproducing individuals. Despite differences among species in growth and survival, survival of all species exceeded 50 percent, even after five years, indicating high physiological tolerances to the different environmental conditions on both the borrow and Geum turf areas.

Species conservation and restoration efforts in alpine ecosystems must focus on processes that affect both seeds and seedlings. To understand species colonization patterns, it is necessary to recognize the linkages between processes that affect seeds and the subsequent establishment of plants. Constraints on the production of viable seeds and the acquisition of favorable microsites may be at least as important as the ability of seedlings to survive varying environmental conditions.

\section{Acknowledgments}

Several individuals have made substantial contributions to the Beartooth Plateau work. We thank James $\mathrm{H}$. Haefner for his modeling contributions to the seed entrapment studies. Technical expertise was shared by Bob Bayn, Jim Richards, Keith Owens, Dave Pyke, Don Sisson, Rex Hurst, and Dave Turner. John Binder, Kate Dwire, Michael Kelrick, Krista Maguire, Nolan Preece, John Mull, and Ann Mull helped with data collection or analysis. Dave Pyke provided useful comments on the manuscript.

\section{Literature Cited}

Amen, R.D. 1966. The extent and role of seed dormancy in alpine plants. Quarterly Review of Biology 41:271-282.

Amen, R.D. and E.K. Bonde. 1964. Dormancy and germination in alpine Carex from the Colorado Front Range. Ecology 45:881-884.

Augspurger, C.K. and S.E. Franson. 1987. Wind dispersal of artificial fruits varying in mass, area, and morphology. Journal of Ecology 68:27-42. 
Bell, K.L. and R.D. Amen. 1970. Seed dormancy in Luzula spicata and L. parviflora. Ecology 51:492-496.

Bell, K.L. and L.C. Bliss. 1980. Plant reproduction in a high arctic environment. Arctic and Alpine Research 12:1-10.

Billings, W.D. 1974. Arctic and alpine vegetation: plant adaptations to cold summer climates. Pages 403-444 in J.D. Ives and R.G. Barry, editors, Arctic and Alpine Environments. Muthuen, London, England.

Billings, W.D. and H.A. Mooney. 1968. The ecology of arctic and alpine plants. Biological Review 43:481-529.

Bliss, L.C. 1956. A comparison of plant development in microenvironments of arctic and alpine tundras. Ecological Monographs 26:303-337.

Bliss, L.C. 1962. Adaptations of arctic and alpine plants to environmental conditions. Arctic 15:117-144.

Bliss, L.C. 1966. Plant productivity in alpine microenvironments on Mount Washington, New Hampshire. Ecology Monographs 36:125-155.

Bliss, L.C. 1971. Arctic and alpine plant life cycles. Annual Review of Ecology and Systematics 2:405-438.

Bliss, L.C. 1985. Alpine. Pages 41-65 in B.F. Chabot and H.A. Mooney, editors, Physiological Ecology of North American Plant Communities. Chapman and Hall, New York, New York.

Bonde, E.K. 1968. Survival of seedlings of an alpine clover (Trifolium nanum Torr.). Ecology 49:1193-1195.

Brink, V.C. 1964. Plant establishment in the high snowfall alpine and subalpine regions of British Columbia. Ecology 45:431-438.

Brink, V.C., J. MacKay, S. Freyman, and D.G. Pearce. 1967. Needle ice and seedling establishment in southwestern British Columbia. Canadian Journal of Plant Science 47:135-139.

Brown, R.W., R.S. Johnston, and K. Van Cleve. 1978. Rehabilitation problems of arctic and alpine regions. Pages 23-44 in F.W. Schaller and P. Sutton, editors, Reclamation of Drastically Disturbed Lands. American Society for Agronomy, Madison, Wisconsin.

Callaghan, T.V. 1988. Physiological and demographic implications of modular construction in cold environments. Pages 111-135 in A.J. Davy, M.J. Hutchings, and A.R. Watkinson, editors, Plant Population Ecology. Blackwell Scientific Publications, Boston, Massachusetts.

Chambers, J.C. 1989. Seed viability of alpine species: variability within and among years. Journal of Range Management 42:304-308.

Chambers, J.C. 1991. Patterns of growth and reproduction in a perennial tundra forb (Geum rossii): effects of clone area and neighborhood. Canadian Journal of Botany, 1977-1983. 
Chambers, J.C. Seed and vegetation dynamics in an alpine herb field: effects of disturbance type. Canadian Journal of Botany, in press.

Chambers, J.C., J.A. MacMahon, and R.W. Brown. 1987. Germination characteristics of alpine grasses and forbs: a comparison of early and late seral dominants with reclamation potential. Reclamation and Revegetation Research 6:235-249.

Chambers, J.C., J.A. MacMahon, and R.W. Brown. 1990. Alpine seedling establishment: the influence of disturbance type. Ecology 71:1323-1341.

Chambers, J.C., J.A. MacMahon, and J.A. Haefner. 1991. Seed entrapment in disturbed alpine ecosystems: effects of soil particle size and diaspores morphology. Ecology 72:1668-1677.

Chapin, F.S. III. 1980. The mineral nutrition of wild plants. Annual Review of Ecology and Systematics 11:233-260.

Chapin, F.S. III. 1983. Patterns of nutrient absorption and use by plants from natural and man-modified environments. Pages 175-187 in H.A. Mooney and M. Godron, editors, Disturbance and Ecosystems. Ecological Studies 44. Springer-Verlag, New York, New York.

Chapin, F.S. III and A. Bloom. 1976. Phosphate absorption: adaptations of tundra graminoids to a low temperature, low phosphorus environment. Oikos 26:111-121.

Cochran, P.H. 1969. Thermal properties and surface temperatures of seedbeds. U. S. Department of Agriculture, Forest Service, Pacific Northwest Forest and Range Experiment Station, Corvallis, Oregon.

Cook, R.E. 1979. Patterns of juvenile mortality and recruitment in plants. Pages 207-223 in D.T. Solbrig, S. Jain, G.B. Johnson, and P.H. Raven, editors, Topics in Plant Population Biology. Columbia University Press, New York, New York.

Fareed, M. and M.M. Caldwell. 1975. Phenological patterns of two alpine tundra plant populations on Niwot Ridge, Colorado. Northwest Science 49:17-23.

Gartner, B.L., S.F. Chapin, and G.R. Shaver. 1983. Demographic patterns of seedling establishment and growth of native graminoids in an Alaskan tundra disturbance. Journal of Applied Ecology 20:965-980.

Haggas, L., R.W. Brown, and R.S. Johnston. 1987. Light requirements for seed germination of Payson sedge and its application to alpine revegetation. Journal of Range Management 40:180-184.

Harper, J.L. 1977. Population Biology of Plants. Academic Press, New York, New York.

Harrington, H.D. 1946. Results of a seeding experiment at high altitudes in Rocky Mountain National Park. Ecology 27:375-377.

Johnson, P.L. and W.D. Billings. 1962. The alpine vegetation of the Beartooth Plateau in relation to cryopedogenic processes and patterns. Ecological Monographs 32:102-135.

Jolls, C.L. and J.H. Bock. 1983. Seedling density and mortality patterns among elevations in Sedum lanceolatum. Arctic and Alpine Research 15:119-126. 
Marchand, P.J. and D.A. Roach. 1980. Reproductive strategies of pioneering alpine species: seed production, dispersal, and germination. Arctic and Alpine Research 12:137-146.

Matson, P.A. and P.M. Vitousek, 1981. Nitrification potentials following clearcutting in the Hoosier National Forest, Indiana. Forest Science 27:781-791.

McEvoy, P.B. and C.S. Cox. 1987. Wind dispersal distances in dimorphic achenes of ragwort, Senecio jacobaea. Ecology 68:2006-2015.

Mizuno, K. 1989. Distribution of alpine plant communities in relation to surface materials on wind-blown slopes around Mt. Mitsu, the Northern Japan Alps. Japanese Journal of Ecology 39:97-105.

Reynolds, D.A. 1984. Alpine annual plants: phenology, germination, photosynthesis, and growth of three Rocky Mountain species. Ecology 65:759-766.

Roach, D.A. and P.J. Marchand. 1984. Recovery of alpine disturbances: early growth and survival in populations Arenaria groenlandica, Juncus trifidus, and Potentilla tridentata. Arctic and Alpine Research 16:37-43.

Ryvarden, L. 1971. Studies in seed dispersal I. Trapping of diaspores in the alpine zone at Finse, Norway. Norwegian Journal of Botany 18:215-226.

Sayers, R.L. and R.T. Ward. 1966. Germination responses in alpine species. Botanical Gazette 127:11-16.

Scott, D. and W.D. Billings. 1964. Standing crop and productivity of an alpine tundra. Ecological Monographs 34:243-270.

Sheldon, J.C. 1974. The behavior of seeds in soil. III. The influence of seed morphology and the behavior of seedlings on the establishment of plants from surface-lying seeds. Journal of Ecology 62:47-66.

Simpson, R.L., M.A. Leck, and V.T. Parker. 1989. Seed banks: general concepts and methodological issues. Pages 3-8 in M.A. Leck, V.T. Parker, and R.L. Simpson, editors, Ecology of Soil Seed Banks. Academic Press, New York, New York.

Sorenson, T. 1941. Temperature relations and phenology of the northeast Greenland flowering plants. Meddelelser on Gronland 125:1-305.

Spence, J.R. 1990. Seed rain in grassland, herbfield, snowbank, and fellfield in the alpine zone, Craigieburn Range, South Island, New Zealand. New Zealand Journal of Botany 28:439-450.

Spence, J.R. and R.J. Shaw. 1983. Observations on alpine vegetation near the Schoolroom Glacier, Teton Range, Wyoming. Great Basin Naturalist 43:483-491.

Spomer, G.G. 1964. Physiological ecology studies of alpine cushion plants. Physiologia Plantarum 17:717-724.

Stamp, N.E. 1984. Self-burial behavior in Erodium cicutarium seeds. Journal of Ecology 72:611-620. 
Stamp, N.E. 1989. Efficacy of explosive vs. hygroscopic seed dispersal by an annual grassland species. American Journal of Botany 76:555-561.

van Tooren, B.F. 1988. The fate of seeds after dispersal in chalk grassland: the role of the bryophyte layer. Oikos 53:41-48.

Verkaar, H.J., A.J. Schenkeveld, and M.P. van de Klashorst. 1983. The ecology of short-lived forbs in chalk grasslands: dispersal of seeds. New Phytologist 95:335-344.

Wager, H.G. 1938. Growth and survival of plants in the arctic. Journal of Ecology 26:390-410.

Warren-Wilson, J. 1966. An analysis of plant growth and its control in arctic environments. Annals of Botany 30:383-402.

Watkinson, A.R. 1978. The demography of a sand dune annual: Vulpia fasciculata. Journal of Ecology 66:483-498.

Young, J.A., R.A. Evans, and D. Palmquist. 1990. Soil surface characteristics and emergence of big sagebrush seedlings. Journal of Range Management 43:358-366. 



\title{
Plants in Dynamic Environments: Is "Wilderness Management" an Oxymoron? (First Biennial A. Starker Leopold Lecture)
}

\author{
Norman L. Christensen, Jr. \\ School of the Environment, Duke University \\ Durham NC 27706
}

Human beings have always been ambivalent in their attitudes toward wilderness. The wilderness in which Jesus fasted for 40 days and the Israelites wandered aimlessly for 40 years hardly seems congruent with the wilderness portrayed by such luminaries as Henry David Thoreau, John Muir, and David Brower. If there is a unifying thread in most visions of wilderness, it is simply the absence of, even hostility toward, human intervention.

Thus, the phrase "wilderness management" seems blatantly oxymoronic. Almost by definition, wilderness not only does not require human intervention, in many ways it defies it!

I would like to assert that many of the most daunting dilemmas posed by our attempts to preserve wilderness arise in part because of the simple fact that we recognized the need to set aside and preserve wilderness areas long before we understood its true nature.

In 1872, nearly 30 years before Henry Chandler Cowles would publish the first systematic study describing patterns of ecosystem change following disturbance, more than 2 million acres of northwestern Wyoming was, in the words of the Congressional mandate, "withdrawn from settlement, occupancy, or sale ... and set apart as a public park or pleasuring ground for the benefit and enjoyment of the people." Its stewards were instructed to "provide for the preservation of all timber, mineral deposits, and natural curiosities, or wonders ... in their natural condition." Our view of the nature of the management of the newly created Yellowstone is perhaps belied by the fact that its stewardship was for a while entrusted to the U.S. Army.

In 1916, the Organic Act established the National Park Service with the entreaty to "conserve the scenery and the natural and historic objects and the wildlife therein and to provide for the enjoyment of the same means as will leave them unimpaired for the enjoyment of future generations."

In this and other charges to park stewards, the precise mission with respect to wilderness is ambiguous to say the least. Arguments rage over the meanings of words like "scenery" and "natural." Clearly such parks were to be set aside for human enjoyment, a process that hardly remains static from one generation to the next. 


\section{Succession: A Paradigm for Management}

By sheer coincidence, 1916 was the year that Frederick E. Clements published his classic monograph, "Plant Succession: An Analysis of the Development of Vegetation." Recovery from disturbance was the unifying theme in this general theory of the structure and distribution of plant communities. Succession following disturbance was seen as a stepwise and directional process of change driven by plant competition and the effects of dominant plants on their environment. The ultimate endpoint of this autogenic process, the climax, was argued to be that assemblage of plant species that alters its environment in such a manner as to perpetuate itself indefinitely. The nature of this assemblage was thought to be determined by regional patterns of climate (Clements 1936).

Regardless of initial starting conditions, Clements and others argued that succession would ultimately lead to convergence on the same climax community within a given climatic region. The notion of succession toward climax seemed to many to be an ecological homologue to the evolutionary scala naturae, the classical view of evolution toward perfection. Almost by tautology, climax communities were judged to be the most stable imaginable assemblages of plants and animals possible under the prevailing conditions of climate.

Once established, climax communities were considered to be maintained by small-scale disturbances (e.g., individual tree deaths). Disturbances such as fire, pathogen epidemics, or hurricane blowdowns were viewed as infrequent and even unnatural. In his paper entitled, "Ecology in the Public Service," Clements (1935) argued that the ". . great climaxes of North America must have remained essentially intact, since fires from natural causes were undoubtedly both relatively infrequent and localized." My assessment of the prevailing view as park policy evolved during the early years of the Park Service was that the pristine wilderness was composed of climax ecosystems that were generally free of large-scale disturbance.

In the decades following its formulation, considerable additional baggage was added to this theory. Reasoning that stability was inextricably linked to such properties as diversity, fertility, and nutrient cycling efficiency, ecologists reckoned that climax ecosystems, being most stable, also possess these other properties in greatest abundance (cf. Odum 1969). I should add that this reckoning was based on an embarrassingly modest data base.

In its simplest form, wilderness preservation involves answering three basic questions to which this view of natural communities provided relatively easy answers: (1) What should we preserve? Climax ecosystems. (2) How should preserves be designed? Since the processes that maintained climax systems seemed to operate on relatively small spatial scales, the size of preserves and the location of their boundaries seemed not to be compelling ecological questions. Indeed, a quick glance at any map will verify that preserve boundaries were in reality determined by economic and political considerations. For the most part they are ecologically arbitrary. (3) How should management be done? Because dominant organisms structure communities, management should focus on them and large-scale disturbance should be prevented wherever possible. 


\section{Paradigm Lost}

In the time since the boundaries of our major wilderness preserves were set and their management policies first promulgated, ecologists have proceeded to question virtually every tenet of this classical model of succession. A few of these challenges relevant to wilderness management are discussed below.

\section{Pattern and Process}

It has become clear that disturbances occurring at a variety of spatial and temporal scales are ubiquitous and inevitable on most landscapes, even in the absence of human intervention. Furthermore, such spatial and temporal variation contributes mightily to the landscape and biotic diversity that is so often the focus of wilderness preservation.

Even during Clements' time ecologists had become aware that disturbances of various sorts were not only natural, but an integral cause of pattern and diversity on most landscapes (e.g., Harper 1911). In a classic 1947 paper on pattern and process, Alex Watt proposed that successional changes repeat themselves over a wide range of spatial scales. Large-scale disturbance initiates changes that are repeated in smaller-scale disturbances later in succession. Processes or patterns that repeat themselves independent of spatial scale are said to be self-similar.

It has become clear that disturbance processes such as fire, as well as the successional processes that follow them, are self-similar only over limited spatial scales. Fire behavior varies considerably depending on spatial pattern. That fire effects are dependent on spatial scale is wonderfully demonstrated in the startling pictures of the postfire mosaic. The details are poorly understood, but it is likely that patterns of species invasion and recruitment into small disturbances are quite different from those of larger areas.

\section{Directional Change}

Ecosystem change is often not linear or even directional. As a graduate student studying succession following fire in chaparral, I was charmed by the notion of fire cycles. Succession following fire was initiated by diverse, highly productive ecosystems that were subsequently replaced by somewhat more monotonous, less productive, and more flammable communities of shrubs. The longer the time since the last fire, the greater the flammability. Successional change was actually leading to diminished stability in the sense that it seemed to encourage disturbance. Similar patterns of change have been documented for a variety of ecosystems, including the lodgepole pine forests of the Yellowstone Plateau.

In their eternal quest for the silver bullet with which to slay the vampire of ecological complexity, ecologists replaced "time's arrow" with "time's cycle" (cf. Gould 1985). In the 1960s and 1970s, it was fashionable to see ecosystems as "pulse-stable" (Loucks 1970) cybernetic systems tightly regulated by negative feedbacks, and fire cycles seemed to provide a perfect example of such systems.

This cyclic view of nature had the important effect of broadening the focus of wilderness management from climax ecosystems to entire temporal sequences. Successful management seemed most dependent on understanding the period or return time for such cycles.

Over the past two decades, the complexity vampire has again reared its ugly head; patterns of change are far more complex than a series of endless cycles of equal period. On many landscapes particular ecosystem types are stable only so long as disturbance regimes remain within certain boundary 
conditions. When those boundaries of intensity or frequency are crossed, ecosystems may undergo change to other "metastable" states.

A classic example of such a situation involves the distribution of longleaf pine-wiregrass sandhill, sand pine scrub, and xeric hardwood hammock ecosystems in central Florida. Until recently the distribution of such ecosystems was thought to be determined by soil variation (Christensen 1981). However, recent work by Kalisz and Stone (1984) and Myers (1985) indicates that the mosaic distribution of these ecosystem types is determined in large part by fire history. The savanna-like structure of sandhill vegetation favors frequent low-intensity fires, and climatic conditions that diminish ignition probabilities, such as a series of wetter-than-normal years, may favor invasion of sand pine scrub species. Such an invasion may diminish flammability even if cliılate returns to "normal." Consequently, fires in scrub are less frequent (every 30 to 50 years) and much more intense. Repeated fires, such as those during very dry periods, can reestablish sandhill, whereas prolonged fire-free intervals favor succession to comparatively nonflammable xeric hardwood communities. Fuels in each of these ecosystem types tend to favor the fire cycle that maintains that type; however, when boundary conditions are crossed, a new pattern is favored. Similar patterns have been described for chaparral (Keeley and Keeley 1988) and southeastern wetlands (Hamilton 1984).

\section{Spatial and Temporal Dependency}

Ever searching for the silver bullet, we might envision a world of multidirectional change as a matrix of probabilities that expressed the likelihood of a landscape patch of a particular type being transformed by disturbance or succession into some other type. On large landscapes, such a projection matrix might provide us with a model (or at least a mental construct) for predicting the likely frequency distribution of patch types. In their simplest form, such models assume that transition probabilities are determined largely by the character of the particular patch and that they are fixed or stationary through time. What a pity! The truth of Thomas Huxley's aphorism about the unfortunate impact of data on great ideas is once again verified.

The diversity of disturbance and disturbance recovery processes is increased considerably by the fact that what happens in any particular landscape patch is affected, often dramatically, by the character of the adjacent landscape. The role of whole landscape pattern in determining the fire regime at any specific location is a fact recognized in most fire spread models (e.g., Kessell 1976; Rothermel 1972). A patch of flammable old-growth forest is much less likely to burn if surrounded by nonflammable early successional vegetation. The structure and composition of adjacent patches also affects successional changes within a patch. For example, Myers (1985) found that fire exclusion resulted in succession of sandhill to sand pine scrub only if scrub vegetation was nearby to provide seed.

Furthermore, transition probabilities are anything but stationary. All ecosystem change occurs against a backdrop of change. For example, recent dendrochronological studies in the sequoia-mixed conifer forests of the western Sierra Nevada indicate that fire frequency (and likely intensity) have varied over the past two millennia in close correlation with climatic variation on the scale of centuries. During the warm medieval optimum (1000 - 1400 A.D.) fires were frequent, and during the moist and cool Little lce Age (1500 - 1750 A.D.) fire return intervals and regional fire frequency diminished significantly (Swetnam 1993). Clearly, the structure of that wilderness must have changed dramatically from 1000 to 1750 A.D. Similar kinds of change have been documented for other landscapes (e.g., Clark 1990; Grimm 1983). The importance of this backdrop of change is wonderfully captured in the words of Henry Chandler Cowles (1901): "Succession is a variable converging on a variable." 


\section{Predictability}

It seems like the height of understatement to assert at this point that ecosystem change is often unpredictable. There is a tendency for most of us to think that the source of this unpredictability is ignorance; if we knew more, we could make better predictions. Admitting the partial truth of this assertion, it is equally important to acknowledge that a considerable amount of unpredictability is inherent in the complexity and nonlinear character of the processes underlying change. Studies of the chaotic nature of ecosystem processes have taught us that small, virtually unmeasurable features or events in complex systems may greatly alter future states. There are limits to the precision of predictions about the future (or our understanding of the past) that no amount of enlightenment can expand!

\section{If We Had Only Known?}

I began this exegesis with the assertion that, if we had somehow been in possession of this knowledge in 1871, many of the problems confronting wilderness managers might have been avoided. We would have set aside preserves of sufficient size to maintain the full array of landscape states. We would have designed preserves such that their borders corresponded to the spatial and temporal behavior of ecosystem processes. Had we done all these things properly, one might argue that wilderness management would distill down to three words, "let it be!"

But I was careful in my early assertion to suggest that our ignorance of the natural world's complexity was only part of the difficulty. If we had possessed complete knowledge and understanding, and even more fantastic, we were able to transmit it to legislators and policy makers in a manner so compelling that they would follow its directives, we might be better off, but we would still face the paradox of wilderness management.

Human activities are too ubiquitous and intrusive to permit us to view any wilderness as self-contained. Landscape fragmentation, independent of changes in ignition frequency, greatly alters regional disturbance regimes. Large-scale, even global changes in our atmosphere caused by human activities are affecting ecosystems everywhere. For example, atmospheric pollutants produced in the San Francisco area, along with prolonged drought, have altered the demography of conifers in the remote wilderness areas of Sequoia National Park, 300 miles away. These population changes have altered fuel conditions and will likely result in changes in fire behavior. It is not extreme to say that if we wish to design a wilderness in which the borders are not at all arbitrary ecologically, it would need to include the entire biosphere.

In the "real world" the borders of our wilderness preserves are clearly arbitrary, even capricious, with respect to the ecological processes necessary for their preservation. Furthermore, human intrusion is inevitable; indeed, it is legislatively mandated. If we wish to preserve any vestige of wilderness, then "wilderness management" is not an oxymoron. 


\section{Lessons for Management}

Although the complexity of wilderness landscapes presents formidable challenges, I believe the lessons we have learned since Clements' time do provide us with guidelines for wilderness management. Five areas are particularly important.

\section{Explicit Management Objectives}

It is clear from today's view of the parks that the past focus on preservation of objects such as specific vegetation types and charismatic species in national park management is not supported by current science, although that focus may have been supported by the science that was current at the time.

Quite properly, wilderness management strategies in national parks have shifted from an "object orientation" to a "process orientation," with an emphasis on the proper role of natural disturbance. I completely support this shift in strategies but would also assert that it is still necessary to set clear ecosystem and landscape guidelines and objectives.

In setting objectives, we must differentiate between ends and means. For example, with respect to fire management, we do not preserve parks so that fires can burn them. Rather, we should prescribe, augment, or suppress fires in order to achieve specific management objectives. I should make it very clear that I am not advocating that those objectives should be the preservation of specific scenes or static configurations. Rather, we understand that fire plays a very crucial role in wilderness ecosystems with respect to properties and processes such as carbon cycling, nutrient budgets, biodiversity, hydrology, and geomorphology. Not all fires have the same impact on these processes, and simply allowing areas to burn does not guarantee that the roles of this process are being realized. Wilderness management objectives need to be cast in terms of the important consequences of managed processes. This is a daunting challenge, made all the more difficult by the limits of our understanding. Nevertheless, we must confront it.

\section{All That Is Natural Is Not Necessarily Prudent Wilderness Management}

Naturalness is often defined operationally in terms of past history. If an event happened on landscapes prior to human intervention, it is usually judged as natural. Thus, the fact that very large fires burned over the Yellowstone Plateau in the early 18th century is a reasonable argument that the 1988 complex of fires in Yellowstone National Park were within the range of "natural." The fact that half of those 1988 fires were begun from "unnatural" (i.e., human) sources is, in a sense, irrelevant with respect to their ecological consequences.

Suppose that the 1988 fires could easily have been contained (history clearly indicates that this was not the case) or that we had possessed the prescience in May of that year to know that the little fires that started within the acceptable conditions of the park's natural prescribed fire program would grow naturally to be so large. I would argue that the mere fact that large fires burned in the 18th century would not have been sufficient justification for allowing over a million acres of the Yellowstone ecosystem to burn. This is almost a trivial point. The context in which the 1988 fires burned was much different from that of the 1700 fires. Three hundred years ago, the scale of the wilderness was vastly greater than even these large fires. The importance of context is clearly demonstrated by the fact that over 3 million acres burned in the wilderness of Alaska in 1988 with minimal public attention. 
The central management question here should not focus on historical precedent. Whether or not events of particular scales or intensities should be permitted (if indeed such control is possible) should depend on the compromise to wilderness values (those objectives) if they are not permitted. We can only answer my obviously rhetorical question about the Yellowstone fires by asking, "Would the Yellowstone wilderness have been impoverished in the absence of those fires?" "If so, in what manner?" "Could surrogate strategies (e.g., many small, artificial-ignition, prescribed fires) have accomplished the same effect?" All of this assumes some level of control over such processes.

\section{Recognize Management Limitations}

A poster I stole from the door of John Varley (Chief of Research, Yellowstone) immediately after the Yellowstone fires poked fun at critics of the park's fire management policy by proposing a mythical "let blow" policy for hurricanes that might disturb national parks such as Padre Island. Its underlying point was very clear: we should not propose unrealistic management protocols for processes we cannot control.

Fire management is especially vexing in this regard. At the low-intensity end of the fire regime spectrum, we can predict and manage fire with great precision. At the other extreme, we may as well try to control an earthquake. We may experience the entire continuum within a single event and often cannot tell when thresholds of control are crossed.

Management plans need to accept these kinds of processes and, perhaps, focus on postdisturbance responses. For example, much of the discussion following the Yellowstone fires involved the wisdom of such postfire interventions as supplemental feeding of wildlife, watershed mitigation, and the need for reforestation. These kinds of questions should be part of fire management plans.

\section{Clarify the Past and Future Role of Humans in Wilderness}

Many of the issues regarding the proper role of humans in wilderness areas are value laden and cannot be addressed from a strictly scientific standpoint. Nevertheless, management objectives must be developed with a clear sense of what those roles have been in the past and will be in the future.

The questions of whether and how the activities of Native Americans should be incorporated into fire management policies illustrates some of the difficulties this presents. Few would question whether Native Americans altered fire regimes that shaped vast landscapes over most of North America during the past ten millennia. The Interagency Panel that reviewed the Park Service and National Forest Service responses to the Yellowstone fires reiterated the need to maintain "natural fire regimes" and went on to define as natural those processes and components that "would likely exist today and go on functioning, if technological humankind had not altered them." Putting aside the implication that pre-Columbian cultures lacked technology, this statement seems to imply that the fire management activities of Native Americans should be included in our notion of wilderness fire. Current Park Service management does not necessarily include the activities of Native Americans in the development of fire management plans, and some have argued that the result is diminished fire frequency and significant changes in ecosystem structure in some areas (e.g., Chase 1986).

However, consider for a moment the difficulties inherent in incorporating such activities into a management plan. First, we have only the most rudimentary understanding of the ways Native Americans used fire. But more to the point of the Interagency Panel's remarks, Native American culture and land 
management practices were by no means static. We can only imagine what they might be today in the absence of intervention by "technological humankind."

We do know that past human activities have created particular landscape configurations and perpetuated particular processes. Whether or not those are "natural" and ought to be included in our notions of wilderness is not a question for science. It nevertheless demands a clear answer before appropriate management objectives can be set.

\section{Acknowledge Uncertainty}

Some would argue that we cannot manage what we do not understand. The cold fact is that ignorance will not provide a reprieve from managing. Our knowledge base will always be imperfect, and as I indicated above, even if we chose to do nothing, humans are actively intervening in the future of wilderness.

It was not my intent to portray the patch-mosaic model of ecosystem change as absolute truth any more than Clements' model of linear change to climax should be portrayed as such. Both are very simple maps of very complex territory. The map analogy is a useful one. A variety of flat map projections of our spherical oblate globe has been developed. Each depicts certain of the Earth's properties properly while distorting others. I have great hope that more accurate maps will be developed to guide future management.

However, where the terrain is constantly changing, a compass is often more valuable than a map. If there is a management analogy to the compass in my orienteering metaphor, it is prudence. Aldo Leopold likened wilderness management to intelligent tinkering, the first rule of which is "don't throw away the pieces." I would only add that we must acknowledge that we truly are tinkerers. Our knowledge is woefully imperfect... perhaps necessarily so.

We must acknowledge our ignorance and uncertainty in several ways. Educational and interpretive programs should attempt to convey the limits of our understanding and a sense of the experimental nature of management. As the Gordon Committee (Gordon 1989) so eloquently argued, a greater commitment to research would diminish the level of uncertainty considerably.

Given uncertainties, some would argue that wilderness management is more of an art than a science. Their arguments are based on a notion that science operates on hard and fast laws. I feel that this is a mistaken view of management. Science is constantly working to destroy established hypotheses. Management plans should be taken to be working hypotheses. The objectives upon which they are based should form specific expectations that are constantly tested by monitoring programs. This loop is closed when monitoring data inform management such that objectives and strategies can be adjusted.

\section{A Final Note}

Given the difficulties and challenges listed above, one might wonder whether the enterprise of wilderness management is worth the bother. It is perhaps appropriate in a lecture honoring $\mathrm{A}$. Starker Leopold that I close this essay with a quote from his father. It certainly removes any doubt about the importance of addressing these challenges. 
All history consists of successive excursions from a single starting point, to which man returns again and again to organize yet another search for durable values. That starting point is wilderness ....

Sand County Almanac, 1949

\section{Literature Cited}

Christensen, N.L. 1981. Fire regimes in southeastern ecosystems. Pages 112-136 in H.A. Mooney, T.M. Bonnicksen, N.L. Christensen, J.E. Lotan, and W.A. Reiners, editors, Fire Regimes and Ecosystem Properties. Gen. Tech. Rep. WO-26. U.S. Department of Agriculture, Forest Service.

Clark, J.S. 1990. Fire and climate change during the last 750 years in northwestern Minnesota. Ecological Monographs 60:135-159.

Clements, F.E. 1916. Plant succession: an analysis of the development of vegetation. Carnegie Institute Publication No. 242. Washington, DC.

Clements, F.E. 1935. Ecology in the public service. Ecology 16:342-363.

Clements, F.E. 1936. Nature and structure of climax. Journal of Ecology 24:252-284.

Cowles, H.D. 1901. The physiographic ecology of Chicago and vicinity: a study of the origin, development, and classification of plant societies. Botanical Gazette 31:73-108, 145-182.

Gordon, J.C. 1989. National Parks: From Vignettes to a Global View. National Parks and Conservation Association, Washington, DC.

Gould, S.J. 1985. Time's Arrow, Time's Cycle. Harvard University Press, Cambridge, Massachusetts. $222 \mathrm{pp}$.

Grimm, E.C. 1983. Chronology and dynamics of vegetation change in the prairie-woodland region of southern Minnesota, U.S.A. New Phytologist 93:311-350.

Hamilton, D.B. 1984. Plant succession and the influence of disturbance in the Okefenokee Swamp. Pages 86-111 in A.D. Cohen, D.J. Casagrande, M.J. Andrejko, and G.R. Best, editors, The Okefenokee Swamp. Wetland Surveys, Los Alamos, New Mexico.

Harper, R.M. 1911. The relation of climax vegetation to islands and peninsulas. Bulletin of the Torrey Botanical Club 38:515-525.

Kalisz, P.J. and E.L. Stone. 1984. The longleaf pine islands of Ocala National Forest, Florida: a soil study. Ecology 65:1743-1754.

Keeley, J.E. and S.C. Keeley. 1988. Chaparral. Pages 165-208 in M.G. Barbour and W.D. Billings, editors, North American Terrestrial Vegetation. Cambridge University Press, Cambridge, England. 
Kessell, S.R. 1976. Gradient modeling: A new approach to fire modeling and wilderness resource management. Environmental Management 1:39-48.

Leopold, A.S., S.A. Cain, C.H. Cottam, I.N. Gabrielson, and T.L. Kimball. 1963. The Leopold Committee Report. Wildlife management in the National Parks. American Forests 69:32-35, 61-63.

Loucks, O.L. 1970. Evolution of diversity, efficiency, and community stability. American Zoologist 10:1725.

Myers, R.L. 1985. Fire and the dynamic relationship between Florida sandhill and sand pine scrub vegetation. Bulletin of the Torrey Botanical Club 112:241-252.

Odum, E.P. 1969. The strategy of ecosystem development. Science 164:262-270.

Rothermel, R.C. 1972. A mathematical model for predicting fire spread in wildland fuels. Research Paper INT-115. U.S. Department of Agriculture, Forest Service.

Swetnam, T.W. 1993. Fire history and climate change in giant sequoia groves. Science 262:885-889.

Watt, A.S. 1947. Pattern and process in the plant community. Journal of Ecology 35:1-22. 


\title{
The Parker Transects Revisited: Long-Term Herbaceous Vegetation Trends on Yellowstone's Northern Winter Range
}

\author{
Michael B. Coughenour \\ Natural Resource Ecology Laboratory, Colorado State University \\ Ft. Collins, CO 80523 \\ Francis J. Singer \\ Research Division, Box 168 \\ Yellowstone National Park, WY 82190 \\ James Reardon \\ Research Division, Box 168 \\ Yellowstone National Park, WY 82190
}

\begin{abstract}
A method to rapidly assess range condition and trend from line transect measurements of basal area and species composition (Parker 1954) was first applied in Yellowstone in 1958 in association with 2-ha grazing exclosures established on the northern winter range. Transects in and out of the exclosures were resampled in 1962 , $1967,1974,1981,1986$, and 1989. Total live plant frequencies increased significantly both in and out of exclosures between 1967 and 1981 and decreased from 1981 to 1986. Changes in plant frequencies between 1958 and 1989 were much more significant than changes caused by exclosure from grazing. Precipitation variability was the most probable cause of these temporal changes, as suggested by correlations between precipitation and plant frequencies. Exclosure had no impact on total live plant frequencies. The increase in total plant frequency until 1981 implied a converse decrease in bare ground. The decrease in plant frequency after 1981 was climatically driven, as evidenced by parallel changes outside and within exclosures. Dominant perennial grasses either maintained their relative abundance or increased until 1986. Forbs decreased in relative abundance until 1986 and increased after 1986 in response to drought. On the basis of these trends we could not conclude that elk grazing has degraded the herbaceous component of the Yellowstone northern winter range. However, we recommend that the Parker data be converted to basal areas using a recent algorithm and that the technique be dropped in favor of less problematic methodologies.
\end{abstract}




\section{Introduction}

Yellowstone National Park's (YNP) management of ungulates requires reliable long-term monitoring of trends in vegetation cover and plant species diversity (Beetle 1974; Cayot, Prukop, Smith 1976; Coughenour and Singer 1991; Houston 1982). Rangeland measurements date back to the 1930s on the northern range (Gammill 1939 - 41; Grimm 1935 - 38, 1943 - 47). The park's current range-monitoring program was initiated in 1958 - 1962 (Barmore 1980, Bergstrom 1962, Denton 1958). Eight 2-ha exclosures were constructed in 1958 and 1962 along with a series of permanently marked Parker transects (Francis, Driscoll, and Reppart 1972; Parker 1954). These transects have constituted the principal long-term sampling program of herbaceous vegetation on the Yellowstone northern winter range.

There is concern that the Parker transect methodology is outdated and that it may be inadequate for detecting vegetation change. Parker transect data are obfuscated by differing effects of plant density, shape, size, and size-class distribution of plants. As a result, Parker transects are difficult to interpret (Francis, Driscoll, and Reppart 1972; Houston 1982:383). The data cannot be analyzed in a straightforward, mechanical manner (Francis, Driscoll, and Reppart 1972; Risser 1984). Computer algorithms have only recently been developed to convert Parker frequencies to basal area (Cook, Brady, and Aldon 1992). Parker transect frequencies often overestimate the most common plant species (Cook and Box 1961). A positive bias toward higher frequency in comparison to cover of smaller plants has been reported (Francis, Driscoll, and Reppart 1972). Therefore Parker frequencies should not be expected to be correlated with estimates of plant cover (Risser 1984). Parker frequencies showed poor relationship with plant cover, herbaceous weight, and plant density (Francis, Driscoll, and Reppart 1972). As a result, the northern regions of the U.S. Forest Service dropped Parker transect readings in 1982 (Tyers, 1991, personal correspondence, USDA Forest Service, Gardiner, Montana). Small sample sizes limit the power of statistical tests, particularly for tests of individual species abundances. Species data have necessarily been pooled together to conduct statistical tests (Barmore 1980; Houston 1982). Yet comments on YNP's ungulate management program have expressed concern over possible species increases or decreases due to possible excessive grazing of the range (Beetle 1974; Chase 1986).

The purpose of this investigation is to reexamine the Parker transect results. We report on more recent trends on Parker transects during 1981 - 1989 that have not been reported following Houston's (1982) report. We attempt to correlate the plant frequency to weather and ungulate population trends. We also compare Parker frequencies with measures of plant cover and biomass from the same sites and evaluate the Parker transect method.

\section{Methods}

\section{Study Sites}

The lower winter range study site was located below Mammoth and near the park boundary at Gardiner, Montana. Elevations of the lower winter range are 1,500-2,000 m. The growing conditions are relatively xeric. Precipitation averages $20 \mathrm{~cm} / \mathrm{yr}$. Less snowfall, faster melting, and wind removal of snow from the slopes relative to the upper winter range result in easy access to forage and high use by wintering elk. 
The higher, 2,000 - 2,400 m elevation grassland study sites on the upper winter range were located near Mammoth, Blacktail Creek, Junction Butte, and the Lamar Valley. The upper winter range grasslands tend to be more mesic and more productive than those of the lower winter range; precipitation ranges from $30 \mathrm{~cm} / \mathrm{yr}$ at Mammoth to $55 \mathrm{~cm} / \mathrm{yr}$ at the Lamar Ranger Station.

\section{Weather Data}

Monthly precipitation data were obtained for Mammoth, Tower Ranger Station, Lamar Ranger Station, Gardiner, and Cooke City. Precipitation data were summarized by site and season. Fall included September - October, winter included November - March, spring included April - May, and summer included June - August. Precipitation from September of the preceding year through August of a given year was summed to yield "water year precipitation" because fall and winter precipitation are manifested in plant growth measurements the following summer. Precipitation for Gardiner was used for the lower winter range site; precipitation data for Mammoth, Tower, and Lamar were averaged for correlations with plant growth measurements made on the upper winter range.

\section{Vegetation Sampling}

Parker transects (Parker 1954) were established in 1957 and 1962 in conjunction with 2-ha grazing exclosures on the northern winter range (Barmore 1980; Houston 1982). Six exclosures were established on the four sites of the upper winter range and two exclosures were established on the lower winter range site. Transects were sampled in 1958, 1962, 1967, 1974 (Barmore 1980; Houston 1982) and then in 1981, 1986, and 1989. The original intent of the method was to monitor trends in range condition, primarily by detecting changes in relative species abundances and changes in total vegetated soil surface relative to nonvegetated soil surface. The transects were part of the Parker three-step method: step one - establish transects and record data; step two - analyze the data; step three - establish permanent photopoints on the range. Permanent line transects $32.8 \mathrm{~m}(100 \mathrm{ft})$ in length were established. A $1.9 \mathrm{~cm}(3 / 4 \mathrm{in}$.) loop was lowered to the ground at $30.5-\mathrm{cm}(1-\mathrm{ft})$ intervals, and contacts with plant tissues were recorded. Contacts were classified by species, litter, or type of abiotic material. Thus data were composed of total contact counts for each species and material. Perennial grasses and forbs must have had their root crown within the loop to have been recorded. Transects were organized in paired clusters of one to three, but normally two, with one cluster inside and one cluster outside an exclosure. Thus, there were two to six transects per site, with roughly half inside and half outside exclosures. Each cluster pair was selected to represent similar topography and soil. Fourteen clusters containing 29 transects were established inside and 9 clusters containing 18 transects were established outside exclosures. Transects within each pair were located on similar soils and topography. "Overstory" shrub data were also collected (i.e., shrubs with canopies well above the herbaceous vegetation layer), but these data were not used here. Results from a parallel belt transect survey (a better methodology for measuring large shrub abundance) are reported elsewhere (Houston 1982; Singer N.D.). "Dwarf" shrubs, however, were included in the analyses because their shoots are within the herbaceous stratum. Our conclusions are thus restricted to the responses of the predominantly herbaceous understory.

A repeated-measures, two-way analysis of variance (ANOVA) was performed with year and exclosure from grazing as main effects. Cluster means rather than transects were replications because transects within a cluster are nonindependent by definition and because the low number of transects per cluster (usually two) prohibits accurate assessment of within-cluster variance. Repeated-measures ANOVA was used because the same clusters were read every year. Thus the analysis corrects for possible correlations of frequencies within a given cluster over time. A univariate repeated ANOVA used data from 
all sample years. Multivariate repeated ANOVAs were also calculated, but only the years 1974 - 1989 could be included because of high numbers of missing values for clusters in earlier years. Exclosure effects were also tested with t-tests comparing means inside and outside exclosures in individual years. If variances were unequal, a $t^{\prime}$ statistic was used (Sokal and Rohlf 1981). Proportion data were transformed with the arcsine function before testing. Duncans multiple range test was used to determine differences among yearly means.

The Parker transect data were correlated against seasonal, annual, and multiannual precipitation data. Data from inside and outside exclosures were pooled at each site for correlations on precipitation due to lack of significant exclosure effects (Barmore 1980; Houston 1982, this volume).

\section{Results}

Total live plant frequencies (figure 1a) increased from 1967 to 1981 (Houston 1982) and decreased from 1981 to 1986, both inside and outside exclosures. While the decrease from 1981 to 1986 reduced lower winter range frequencies to pre-1974 levels, upper winter range frequencies were greater in 1986 than in 1958 to 1967. Lower winter range frequencies were consistently less than those on the upper winter range, probably as a result of a warmer, drier climate near Gardiner. Significant temporal changes occurred only between 1967 and 1974 and 1981 and 1986 (figure 1a). In comparison, elk numbers declined from 1956 to 1968, then generally increased from 1968 to 1988 (figure 1b).

ANOVA indicated there was more K. cristata and Poa spp. outside exclosures (table 1); however, there was an interaction between exclosure and year effects on Poa. However, t-tests indicated significant differences between inside versus outside exclosure frequencies for $K$. cristata in 1974 only $(p<.05)$, with marginally significant differences $(.05<p<.01)$ in 1986 and 1989 (table 2). The exclosure effect on Poa spp. was limited to 1989, with a marginally significant effect in 1974 . There were no significant differences in plant frequencies inside versus outside lower winter range exclosures (tables 1,2 ), despite dramatic changes in elk population numbers (figure 1b). Data for means of plant frequencies in each cluster are provided in appendix tables 1 and 2 in this report to facilitate potential uses by others in the future.

Proportions of species and plant functional groups changed over time (figure 2). Grass proportion declined from 1958 to 1962, then increased from 1974 to 1981 and declined again from 1986 to 1989. These changes were mirrored by an increase in the proportion of forbs from 1958 to 1962, a decrease from 1974 to 1986, and an increase again from 1986 to 1989. Dwarf shrub fraction did not change significantly with time. A. spicatum fraction declined from 1958 to 1962 . F. idahoensis fraction increased from 1962 to 1967 and 1981 to 1986, but declined from 1986 to 1989 . K. cristata fraction declined from 1958 to 1967, increased from 1974 to 1981, and decreased from 1986 to 1989. Poa spp. fraction declined from 1974 to 1981 but increased again between 1986 and 1989 (table 3). Proportions changed in similar patterns over time on the lower winter range (figure 3). No significant changes in the proportion of grass over the years were detectable. However, forb proportion declined significantly from 1968 to 1972 and increased from 1986 to 1989. Dwarf shrub fraction increased significantly between 1958 and 1976. The fraction of $A$. spicatum did not change significantly as sample sizes were small relative to variance. K. cristata increased from 1962 to 1976 and from 1976 to 1981, then decreased from 1986 to 1989. Poa spp. decreased from 1976 to 1981 and increased from 1986 to 1989. 


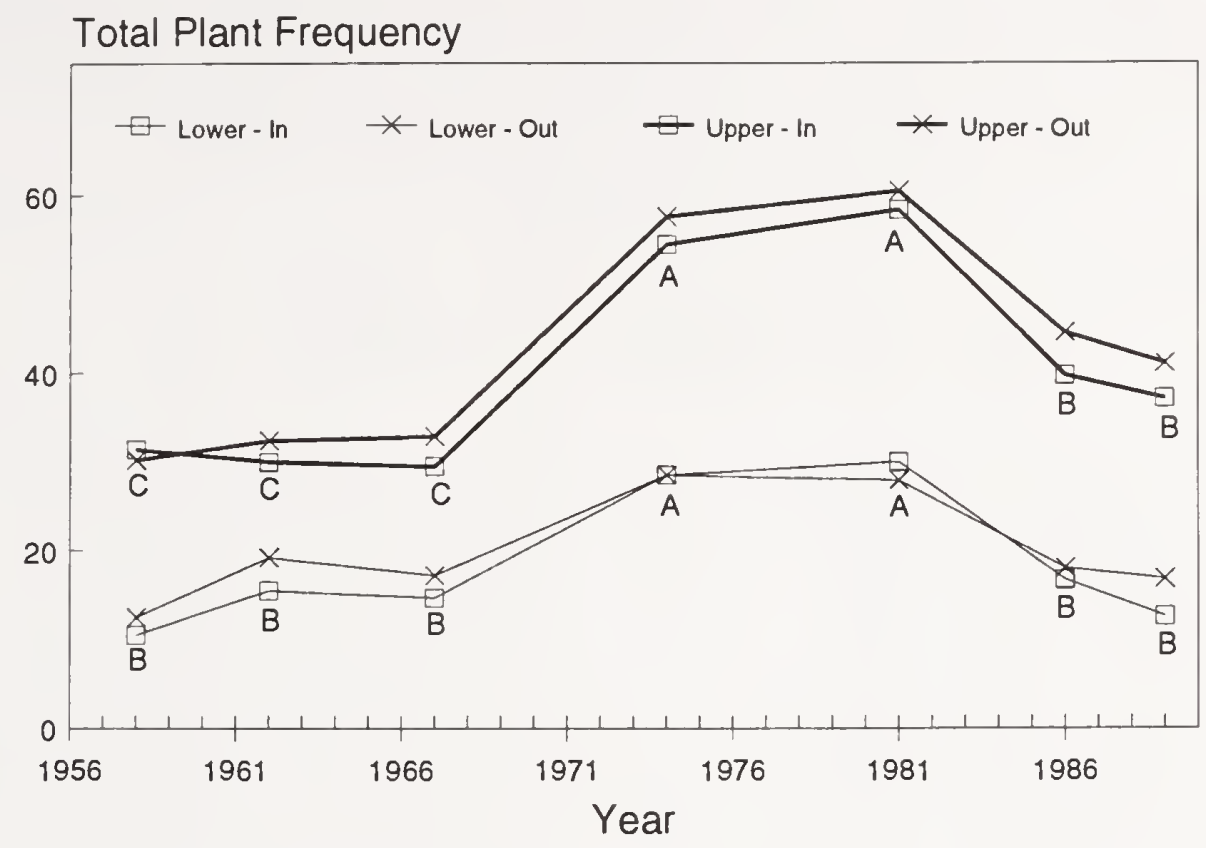

Figure 1a. Total plant frequency on upper and lower winter range, inside and outside exclosures. There were no significant differences between frequencies in and out of exclosures. Means for years (upper or lower winter range) having the same letter are not statistically different $(p \leq 0.05)$.

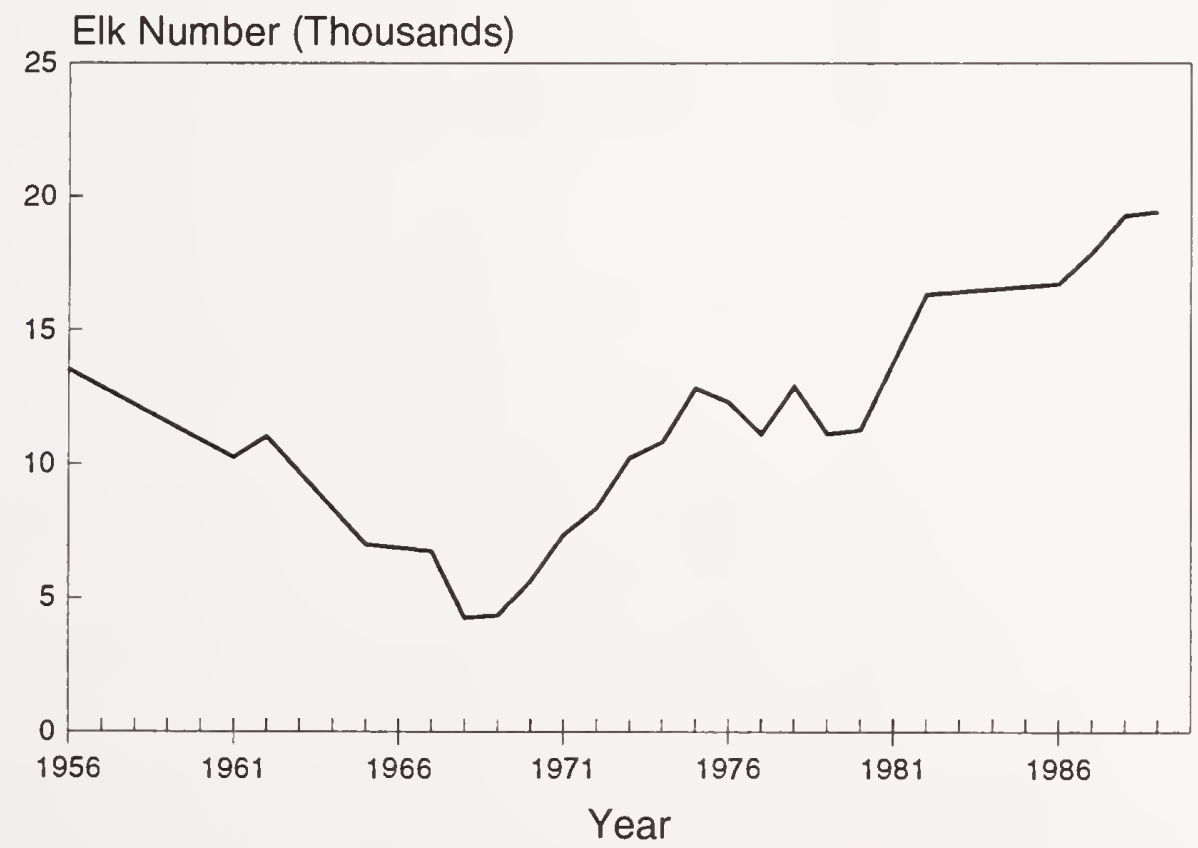

Figure 1b. Elk numbers on Yellowstone's northern winter range. 
Table 1. Significance testing using repeated measures ANOVA (univariate approach), for effects of year and exclosure. There were no significant main effects or year $x$ exclosure interactions on the low elevation winter range.

\begin{tabular}{|c|c|c|c|c|}
\hline \multirow[b]{2}{*}{ Variable } & \multicolumn{3}{|c|}{ Upper Winter Range } & \multirow{2}{*}{$\begin{array}{c}\text { Lower Winter Range } \\
\text { Year }\end{array}$} \\
\hline & Year & Exclosure & $\begin{array}{c}\text { Year } x \\
\text { Exclosure }\end{array}$ & \\
\hline Grass & c & & & a \\
\hline Forb & c & & & d \\
\hline Dwarf Shrub & & & & $b$ \\
\hline A. spicatum & & & & \\
\hline F. idahoensis & c & & & \\
\hline K. cristata & c & a & & c \\
\hline Poa spp. & c & a & a & $b$ \\
\hline Total & c & & & c \\
\hline$\%$ Grass & $b$ & & & \\
\hline$\%$ Forb & $b$ & & & c \\
\hline \% Dwarf Shrub & & & & $d$ \\
\hline$\%$ A. spicatum & d & & & \\
\hline$\%$ F. idahoensis & c & & & \\
\hline$\%$ K. cristata & $b$ & & & $b$ \\
\hline \% Poa spp. & c & a & $b$ & a \\
\hline
\end{tabular}

a $.01<p \leq 0.05$

$.001<p \leq .01$

${ }^{c} p \leq .001$

${ }^{\circ}$ marginal, $.05<p \leq .1$ 
Table 2. Total grass, forb, and dwarf shrub frequencies; mean (standard deviation) $n$. Here, $\mathbf{n}$ is the number of clusters sampled each year. For these aggregate plant groups there were no significant differences between inside and outside exclosures (t-tests, each year). Units are hits/transect.

\begin{tabular}{|c|c|c|c|c|c|c|}
\hline \multirow[b]{2}{*}{ Year } & \multicolumn{2}{|c|}{ Grass } & \multicolumn{2}{|c|}{ Forb } & \multicolumn{2}{|c|}{ Dwarf Shrub } \\
\hline & In & Out & In & Out & In & Out \\
\hline \multicolumn{7}{|l|}{ Upper Winter Range } \\
\hline 1958 & $25.5(15.0) 3$ & $24.2(11.1) 3$ & $5.4(4.4) 2$ & $5.8(3.1) 3$ & $0.6(0.52) 3$ & $0.17(.29) 3$ \\
\hline 1962 & $19.6(5.7) 8$ & $22.4(8.9) 5$ & $9.8(4.5) 8$ & $9.9(4.5) 5$ & $0.69(0.88) 8$ & $0(0) 5$ \\
\hline 1967 & $17.3(5.2) 8$ & $21.6(10.6) 5$ & $11.7(8.6) 8$ & $10.9(7.3) 5$ & $0.48(0.47) 8$ & $0.40(0.55) 5$ \\
\hline 1974 & $34.1(5.9) 10$ & $41.3(10.4) 7$ & $19.4(6.3) 10$ & $16.1(4.4) 7$ & $0.96(1.6) 10$ & $0.21(0.29) 7$ \\
\hline 1981 & $41.5(13.2) 10$ & $46.3(10.0) 7$ & $16.4(7.1) 10$ & $13.2(4.9) 7$ & $0.46(1.0) 10$ & $1.0(1.2) 7$ \\
\hline 1986 & $30.9(9.5) 10$ & $35.0(8.0) 7$ & $8.8(4.0) 10$ & $9.4(3.6) 7$ & $0.02(0.06) 10$ & $0.18(0.24) 7$ \\
\hline 1989 & $23.7(7.8) 10$ & $27.9(6.5) 7$ & $13.2(4.9) 10$ & $12.8(4.5) 7$ & $0.26(0.44) 10$ & $0.41(0.72) 7$ \\
\hline \multicolumn{7}{|l|}{ Lower Winter Range } \\
\hline 1958 & $6.8(3.2) 2$ & $7.7(3.9) 2$ & $2.7(0.35) 2$ & $4.7(3.2) 2$ & $1.0(0.71) 2$ & $0(0) 2$ \\
\hline 1962 & $9.2(4.6) 3$ & $11.2(6.1) 2$ & $3.8(2.7) 3$ & $5.5(0.49) 2$ & $2.6(1.8) 3$ & $2.5(1.9) 2$ \\
\hline 1967 & $5.2(1.5) 3$ & $9.0(4.9) 2$ & $6.2(3.7) 3$ & $6.7(0.35) 2$ & $3.3(2.5) 3$ & $1.5(2.1) 2$ \\
\hline 1974 & $16.8(9.8) 4$ & $13.9(8.3) 2$ & $3.4(2.5) 4$ & $2.3(2.6) 2$ & $8.3(3.5) 4$ & $11.9(15.4) 2$ \\
\hline 1981 & $17.8(6.2) 4$ & $18.5(17.7) 2$ & $3.6(3.6) 4$ & $1.6(1.2) 2$ & $8.5(1.9) 4$ & $7.9(10.4) 2$ \\
\hline 1986 & $11.5(4.8) 4$ & $10.3(2.6) 2$ & $0.70(0.77) 4$ & $1.6(2.3) 2$ & $4.5(2.5) 4$ & $6.1(7.2) 2$ \\
\hline 1989 & $6.0(4.0) 4$ & $5.9(2.9) 2$ & $5.2(5.5) 4$ & $8.5(4.6) 2$ & $1.3(1.1) 4$ & $2.5(1.4) 2$ \\
\hline
\end{tabular}



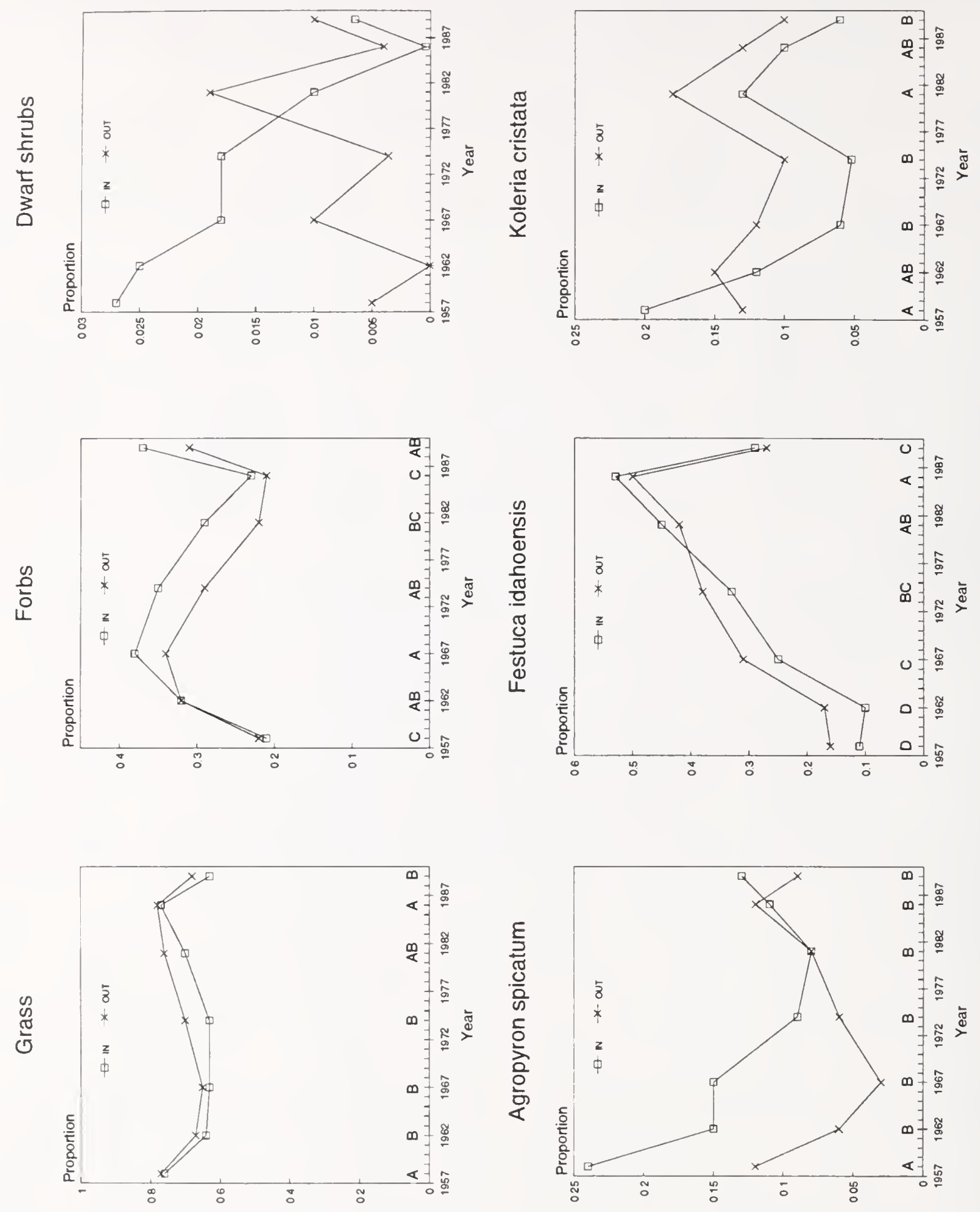

Figure 2. Proportions of plant groups and major species in the Parker transect data from the upper winter range. Means for years with the same letter above the $X$ axis are not significantly different $(p \leq 0.05)$. There was a single significant difference between exclosed and unexclosed proportions in a given year - K. cristata in 1974. 


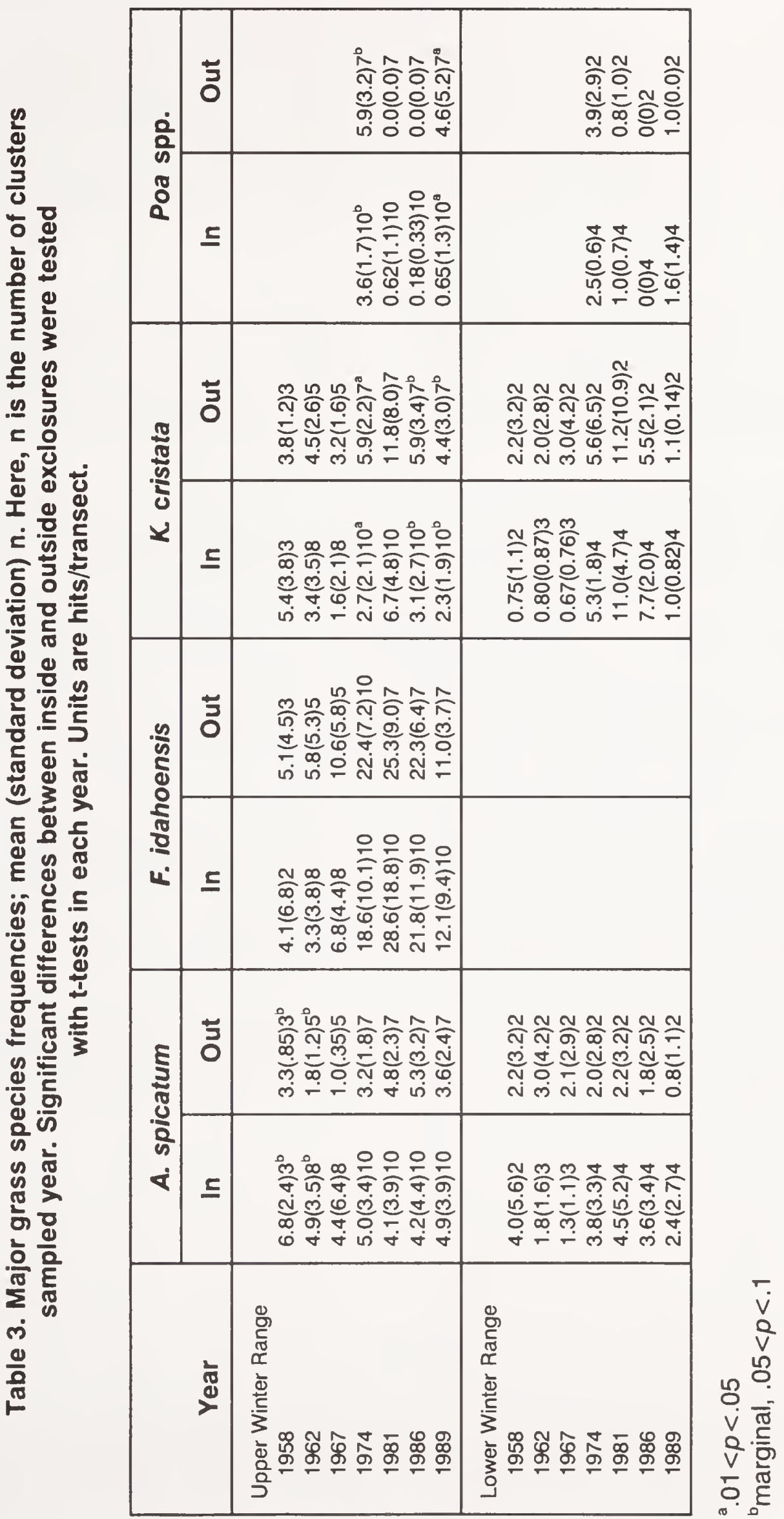



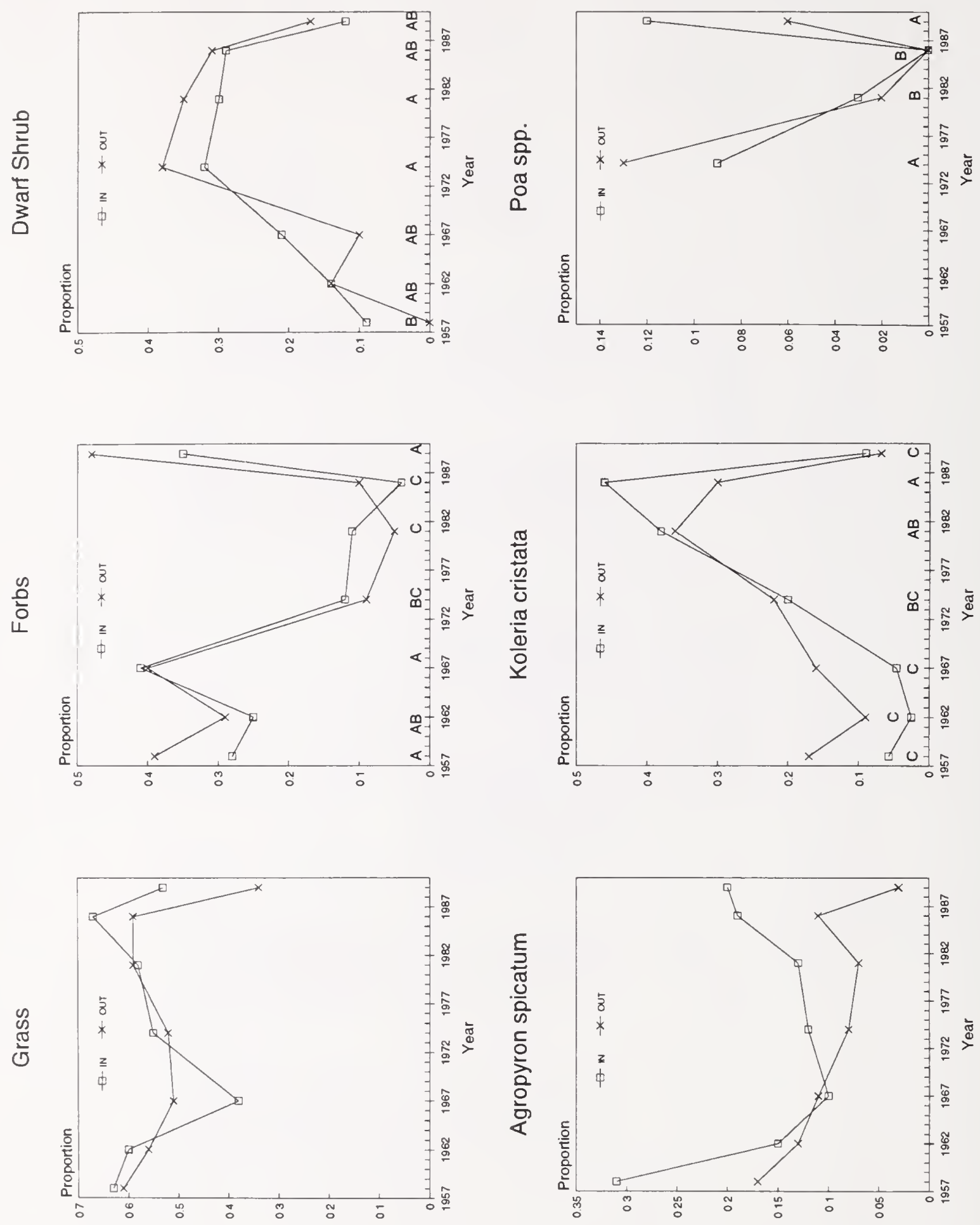

Figure 3. Proportions of plant groups and major species in the Parker transect data from the lower winter range. Means for years with the same letter above the $X$ axis are not significantly different $(p \leq 0.05)$. There were no significant differences between frequencies inside and outside exclosures in any given year. 
On the upper range the fraction of Poa spp. was relatively more abundant outside exclosures in 1989. The fraction of $K$. cristata was significantly greater outside the exclosure in 1974 only (t-test). On the lower range it appeared that $A$. spicatum relative abundance had declined outside exclosures by 1989 ; however, the difference was not significant in any test $(p>.1)$. In 1989 A. spicatum was 0 percent, 12 percent, 24 percent, and 45 percent of total plant hits in the four clusters inside, and 0 percent and 7 percent of the two clusters outside the lower range exclosures (see appendix tables 1 and 2 for individual cluster data).

The repeated-measures multivariate analysis of variance (MANOVA) for 1974 to 1989 yielded only slightly different results from table 1 . On the upper winter range MANOVA indicated significant year $x$ exclosure effects on $A$. spicatum $(.01<p<.05)$ and percent $A$. spicatum $(.05<p<.1)$. The year $x$ exclosure effects on Poa and percent Poa were marginal in MANOVA $(.05<p<.1)$. On the lower range MANOVA indicated no year effects on forb, dwarf shrub, percent forb, or percent dwarf shrub. MANOVA showed a significant year $x$ exclosure effect on percent $K$. cristata $(.01<p<.05)$.

Climatic causes of changes in total plant frequencies among years were explored with correlation (table 4). Correlations were attempted between all vegetation variables and seasonal precipitation in the current year, the previous year, and the mean of all years since the previous Parker sample date. Only correlations which were significant at $p<0.1$ are displayed in table 4 . On the upper winter range $K$. cristata was highly correlated with summer precipitation in the current year. The composition of percent grass versus forb was highly correlated with precipitation in the previous winter; wet winters favored grass over forbs. $F$. idahoensis was highly correlated with summer rainfall over the period since last sampling. Weaker correlations were observed between previous winter precipitation and $A$. spicatum and $K$. cristata, previous summer rainfall and total grass, and period winter precipitation and dwarf shrub.

On the lower winter range a significant correlation was observed between period spring rainfall and forb and dwarf shrub abundances (table 4). Forbs were favored by wet springs, while dwarf shrubs were disfavored. The percentage of forbs tended to be greater in years with wet springs; $A$. spicatum percentage was greater in years with wet winters in the prior year; grass percentage was greater if the prior year's summer was wet, and dwarf shrub was greater if the prior year's fall was wet.

Seasonal precipitation data for each year were examined to seek a finer resolution explanation for the rise in Parker frequencies between 1967 and 1974 (figure 4). There were no runs of unusually wet falls, winters, or springs that would explain the increase. However, there was an exceptionally wet summer in 1968; June and August were both quite wet, and September was moderately wet.

\section{Discussion}

\section{Responses to Climate}

Changes in plant frequencies between 1958 and 1989 were much more significant than changes caused by exclosure (table 1). Climate, specifically precipitation, was the most probable cause of these temporal changes (table 4). The marked increases in $F$. idahoensis on the upper winter range and of dwarf shrubs and $K$. cristata on the lower winter range between 1967 and 1974 (table 3) were most responsible for the large increases in total plant frequency over that period (figure 1). 
Table 4. Significant correlations with seasonal and total precipitation in the current year, the previous year, and the period between the previous sample date and the current sample date ( $3-8 \mathrm{yrs})$. In all cases $n=7$.

\begin{tabular}{|c|c|c|}
\hline \multirow{2}{*}{ Upper Winter Range } & \multicolumn{2}{|c|}{ Correlation Coefficient $(r)$} \\
\hline & & \\
\hline \multirow{3}{*}{$\begin{array}{l}\text { Current Year - Summer } \\
\text { K. cristata } \\
\% \text { K. cristata }\end{array}$} & & \\
\hline & $0.82^{\mathrm{a}}$ & \\
\hline & $0.70^{\mathrm{a}}$ & \\
\hline \multicolumn{3}{|l|}{ Previous Year - Winter } \\
\hline A. spicatum & $0.66^{\mathrm{b}}$ & \\
\hline K. cristata & $0.72^{\mathrm{b}}$ & \\
\hline$\%$ Grass & $0.82^{\mathrm{a}}$ & \\
\hline$\%$ Forb & & $-0.81^{a}$ \\
\hline \multicolumn{3}{|l|}{ Period - Summer } \\
\hline Grass & $0.69^{\mathrm{b}}$ & \\
\hline F. idahoensis & $0.87^{\mathrm{a}}$ & \\
\hline$\%$ F. idahoensis & & $0.95^{\mathrm{a}}$ \\
\hline \multicolumn{3}{|l|}{ Period - Winter } \\
\hline \% Dwarf Shrub & & $0.67^{b}$ \\
\hline \multicolumn{3}{|l|}{ Lower Winter Range } \\
\hline \multirow{2}{*}{\multicolumn{3}{|c|}{$\begin{array}{l}\text { Current Year - Spring } \\
\text { \% Forb }\end{array}$}} \\
\hline & & $0.78^{b}$ \\
\hline \multicolumn{3}{|l|}{ Previous Year - Winter } \\
\hline$\%$ A. spicatum & & $0.79^{\mathrm{b}}$ \\
\hline \multirow{2}{*}{\multicolumn{3}{|c|}{$\begin{array}{l}\text { Previous Year - Summer } \\
\% \text { Grass }\end{array}$}} \\
\hline & $0.65^{\mathrm{b}}$ & \\
\hline \multicolumn{3}{|l|}{ Period - Fall } \\
\hline \% Dwarf Shrub & & $0.67^{\circ}$ \\
\hline \multicolumn{3}{|l|}{ Period - Spring } \\
\hline Forb & $0.84^{\mathrm{a}}$ & \\
\hline Dwart Shrub & $-0.70^{b}$ & \\
\hline K. cristata & $-0.74^{a}$ & \\
\hline $\begin{array}{l}\% \text { Forb } \\
\% \text { Dwarf Shrub }\end{array}$ & & $\begin{array}{r}0.90^{\mathrm{a}} \\
-0.82^{\mathrm{a}}\end{array}$ \\
\hline & & \\
\hline
\end{tabular}

${ }^{\mathrm{a} p} p<0.05$

${ }^{\mathrm{b}} 0.05<p<0.1$ 

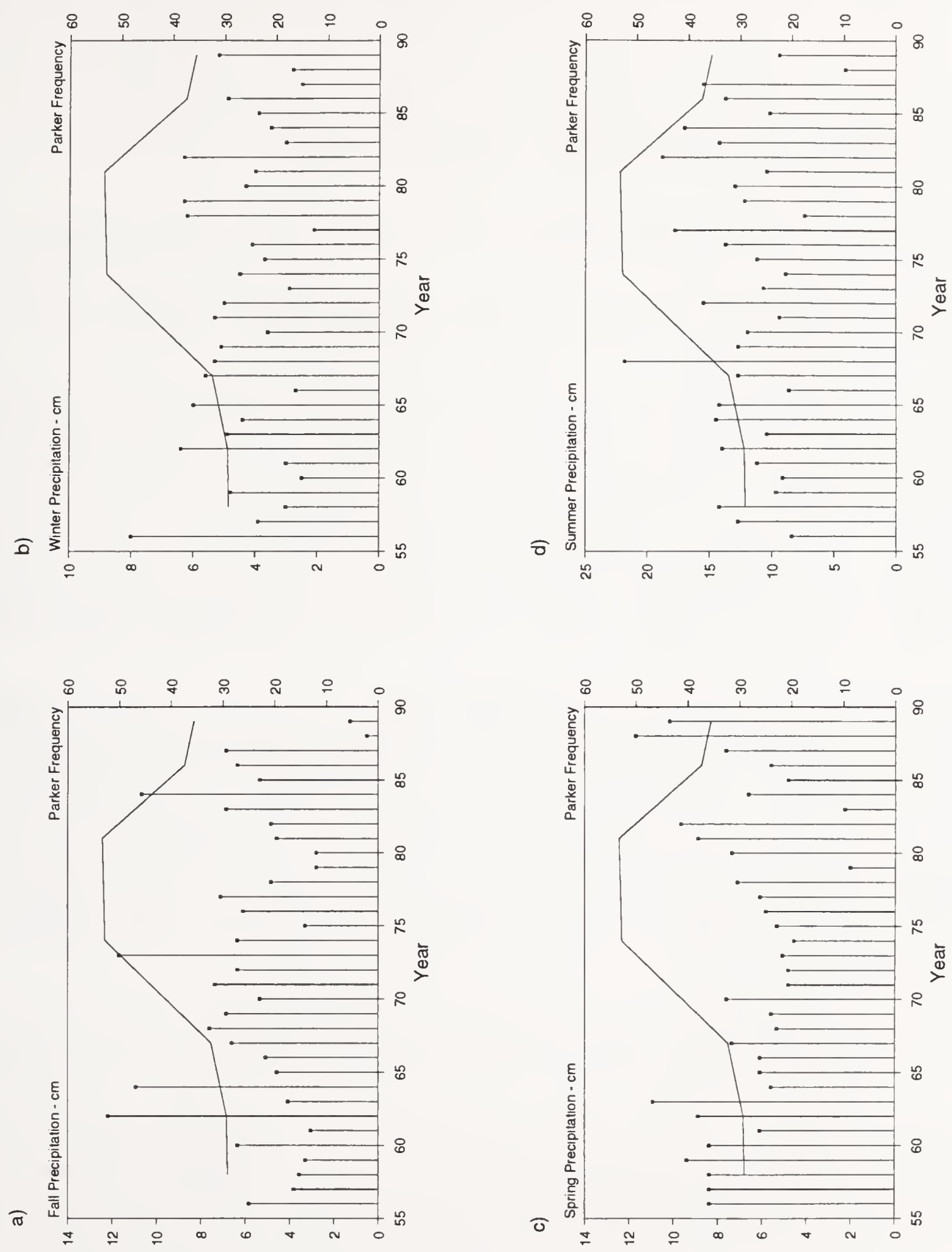

Figure 4. Seasonal precipitation over the period in comparison to total plant frequency. a) fall; b) winter; c) spring; d) summer. Precipitation is displayed as bars; Parker frequency is displayed as a line. 
A plausible explanation for the large increase in total plant frequency on the upper range between 1967 and 1974 was an increase in $F$. idahoensis in response to a favorable year for germination and seedling establishment. This year could have been 1968, when summer rainfall was far above normal (figure 4). A single favorable year for germination and establishment, if not followed by drought, would be followed by a steady increase in plant size. The combination of increased plant number and size could explain the increase in Parker frequency. The increase between 1967 and 1974 on the lower range site was due to an increase in dwarf shrubs and $K$. cristata. According to the correlations, these plants increase during relatively dry springs. Indeed, there were no wet springs during 1967 to 1974.

Total plant frequency decreased between 1982 and 1986. This decrease paralleled a declining trend in precipitation. In particular, the spring of 1983 was very dry and was preceded by a relatively dry winter. A dry spring also occurred in 1979, but it was preceded by a wet winter. The dry winter - dry spring pattern could have increased plant mortality in 1983. The dry years of 1987 and 1988 caused an insignificant decrease in frequencies 1986 to 1989 , but spring was moist in both years.

Plant community composition proved to be dynamic, rather than static, both inside and outside of the exclosures (figures 2,3 ). Changes in relative abundances of species and plant functional groups over time were likely the results of changing weather patterns over the period. Community changes included a decline in the proportion of $A$. spicatum in 1958 to 1962 on upper and lower ranges, along with an increase in proportion of forbs on the upper range and in dwarf shrubs on the lower range. Most of the forbs that were observed here were perennials. As such, their abundances depend on climatic events that affect germination, establishment, and survival. Changes in the abundances of long-lived perennial grasses probably affect the amount of space that is available for forb and dwarf shrub establishment, as suggested by the inverse relationships between forbs or dwarf shrubs and $A$. spicatum.

The increase in the proportion of $F$. idahoensis on the upper winter range over the years 1962 to 1974 was accompanied by decreases in $A$. spicatum and $K$. cristata, suggesting possible competition between dominant perennial grasses. Correlations suggested that competitive interactions between plant groups are altered by precipitation (table 4). The percentage of grass was positively correlated and the percentage forb was negatively correlated with winter precipitation on the upper range, suggesting that wet winters shift the competitive balance toward grass. On the lower winter range, $K$. cristata and dwarf shrubs generally decreased while forbs increased, and their correlations with spring precipitation were also opposite. The latter relationships suggested that forbs may respond favorably to spring rainfall, and when they do, they become increasingly competitive with perennial grasses.

If climatic events are stochastic and plant community composition responds to these fluctuations, then the concept of a singular climax community composition becomes untenable. Rangeland plant community compositions may change in response to weather events and patterns, irrespective of grazing (Coughenour and Singer 1991; Friedel 1991; Laycock 1991; Westoby, Walker, and Noy-Meir 1989). Differences among species in their responses to climatic events inevitably cause changes in plant community composition. Temporal changes in composition may simply arise from secondary competitive interactions among plants. For example, a dry year may cause mortality of one perennial grass species, which provides an opportunity for establishment of another species given another climatic event.

Changes are sometimes dramatic, as environmental thresholds for various plant population events are crossed (Friedel 1991; Laycock 1991; Westoby 1991). Movements across thresholds may or may not be irreversible. There was no evidence for such dramatic shifts here. However, the changes that were observed here point out that the long, prevailing, steady-state climatic climax plant community of Clements should be thought of as dynamic, with responses to short-term climatic fluctuations, as 
Clements (1916) originally discussed. Fortunately, an experimental control for the grazing treatment (inside exclosures) showed that plant community changes that otherwise might have been ascribed to grazing were, instead, due to climate.

\section{Responses to Elk Grazing}

The ANOVA indicated more K. cristata and Poa spp. outside exclosures in certain years. Similarly, the only grazing related differences detected by Barmore (1980) were slightly, but significantly, higher graminoid frequencies outside exclosures, and this was interpreted as spurious. There were no significant exclosure effects on frequencies on the lower winter range (table 1).

The fact that the only significant exclosure effects were increases in K. cristata and Poa spp. caused by grazing, and the consistent parallel changes in frequencies inside and outside exclosures, indicates that elk grazing has not impaired plant growth on the northern winter range in spite of fluctuations in elk numbers (figure 1b). Houston (1982:389) also concluded from his analysis of Parker transect data from 1958 to 1974 that grazing had no significant effect on perennial grasses, forbs, shrubs, total perennial vegetation, bare ground, or litter. Pavement decreased inside exclosures, apparently because of increases in dead plant material. Direct sampling of plant biomass (Coughenour 1991) also revealed no differences in total root biomass inside versus outside exclosures. There were no differences in aboveground plant biomass inside versus outside in 1987. Grass biomass was reduced outside exclosures in 1988, but elk remained on the winter range longer that spring Vales, 1991, personal communication, Department of Fish and Wildlife Resources, University of Idaho). Frank (1991) documented increases in plant growth caused by grazing.

Two differences in species composition were observed between the inside and outside of the upper winter range exclosures. K. cristata and Poa spp. were relatively more abundant outside exclosures, but only in certain years. K. cristata was significantly more abundant (relative and absolute) outside exclosures only in 1974. Poa was more abundant outside exclosures only in 1989. These differences in composition are limited but positive responses to grazing (figures 1,2 ).

On the lower winter range there appeared to be progressively decreasing relative abundance of $A$. spicatum outside exclosures, particularly from 1986 to 1989 (figure 3). However, variances among clusters were high and the number of clusters was small, thus the differences were not significant. The trend of increasing divergence between relative $A$. spicatum abundances in and out of exclosures was most pronounced during the drought year of 1988. Elk used the lower winter range heavily during the severe winter of $1988-89$, when much of the herd suffered winter mortality. The combined impact of drought and increased elk use could have been particularly stressful, but the response was inconsistent among clusters.

A widespread method for assessing rangeland condition is that derived from Dyksterhuis (1949), which evaluates condition with respect to changes in cover of plant species that typically either increase or decrease in response to overgrazing. Most often, overgrazing will cause decreases in dominant perennial grasses, increases in weedy forbs, and under severe degradation, increases in bare ground. On the Yellowstone winter range, total plant frequency increased until at least 1981. By definition, this increase was necessarily accompanied by a converse decrease in bare ground. The decrease in plant frequency after 1981 was climatically driven, as evidenced by parallel changes outside and within exclosures. Dominant perennial grasses either maintained relative abundance or increased. Forbs decreased until 
1986 and increased after 1986 in response to declining grass during drought. On the basis of these trends, we cannot conclude that elk grazing has degraded the Yellowstone northern winter range.

Elk use the winter range during a time of year when most plants are dormant and after seasonal production has already occurred. Thus, elk grazing would not be expected to have large effects on the plant community except through responses to trampling, removal of dead leaves, and increased rates of nutrient recycling (see also Coughenour 1991).

\section{The Method}

Parker transect data primarily reflect, but overestimate, basal cover rather than above-ground standing crop; the protocol requires that plant bases be within the sampling loop. Basal cover is primarily affected by the number of plants and the size of the perenniating root crown of bunch grasses. Frequencies of forbs are more strongly affected by the numbers of plants and their stem diameters. Basal area of perennial bunch grasses changes more slowly than, and is not necessarily correlated with, annual variations in peak above-ground standing crop. For example, a large basal area may have accumulated because of prior wet years, but a subsequent dry year may cause low grass production without reducing basal area. Plant productivity is determined by plant height and leaf length as well as by basal area.

A problem with the technique is that it is influenced by plant size and plant numbers in different ways. The method is biased toward higher frequencies if plants have small basal area (Francis, Driscoll, and Reppart 1972; Hutchings and Holmgren 1959; Smith 1962). Measurements are also affected by the shape of plants and the pattern of their distribution, such that there is positive bias toward plants with noncircular shapes (Hutchings and Holmgren 1959). Even with constant basal area, then, changes in plant size and shape influence Parker frequencies. Thus, any changes in plant form due to grazing or climate could confound interpretation. If plants were larger in an exclosure, for example, the measured grazing impact would be diminished because the method is biased toward smaller plants.

Insufficient sample size may be the most serious limitation of the method. Each half of a cluster pair in YNP is composed of one to three transects or $100-300$ hits on an exclosed/nonexclosed treatment at a site. The number of 100 -foot transects required to measure dominant grasses at 95 percent confidence within 10 percent of the mean can vary from 2 to 68 (Johnston 1957). Smith (1962) concluded that 200 3,400 hits (loops) are required to establish 95 percent confidence intervals within 10 percent of the mean, depending on plant abundance. Everson, Clarke, and Everson (1990) reached a similar conclusion for plant frequency hits. They estimated that 1,200 hits of a Tidmarsh wheel were required to detect changes for plant species comprising 5 percent or more of the community within 90 percent confidence intervals that are \pm 20 percent of the mean. Pooling of species improves accuracy statistically (Smith 1962). Because of limited sample sizes, Barmore (1980) and Houston (1982) were forced to pool plant species frequencies for YNP to conduct statistical tests. Unfortunately, pooling of plant species represents a loss of information.

Plant frequencies measured with the Parker transect method in Yellowstone had high variances. This problem is partly due to small numbers of transects but also to landscape heterogeneity. Stratification of samples on the landscape could reduce variance. The organization of transects into clusters that have similar soils and plant communities is a form of stratification, but statistical tests cannot be conducted with one to two samples per strata. Here we were forced to treat clusters as samples because the transects are nonindependent and the number of transects per cluster was too small to assess withincluster variance. Despite the heterogeneity that was covered by the transects, the transects were 
primarily on upland sites (Beetle 1974; Houston 1982). No transects were in swales or valley bottoms, probably because upland sites appeared to be most intensively grazed (Coughenour and Singer 1991).

Despite these limitations, the method does provide important information. The method was sensitive enough to detect changes that have occurred over the 30-year period, which suggests that it would also be sensitive enough to detect significant changes of comparable magnitude that would be due to grazing. While it is difficult to determine what the Parker transect data are measuring in an absolute sense, the data contain information about relative differences in plant abundance over time and as affected by exclosure from grazing.

A promising set of procedures for converting old Parker data to equivalent basal area has been developed recently (Cook, Brady, and Aldon 1992). This technique accounts for the various effects of plot size, plant size, shape, and density on loop frequency. Once old data are converted, they can be compared with data from future studies that use better sampling methods (although it is unclear how the method might account for changes in plant size and shape within a species over time). We concur with Cook, Brady, and Aldon (1992) in recommending that old Parker data be converted to basal area and that future monitoring programs not include the Parker method.

The Parker transects have provided data over a long period utilizing a consistent methodology. Nevertheless, the value of this longevity is reduced because the data are difficult to interpret, biologically and statistically. We therefore recommend that YNP institute a program that institutes a wider diversity of plant-soil associations. It should be designed to reduce variance through stratification, with adequate random sampling within strata. More frequent sampling, at least annually, is recommended to enable clearer interpretation of responses to annual and seasonal climatic variation. The attribute or attributes to be measured (frequency versus cover versus biomass) need to be carefully considered. Biomass has the most direct effect on ungulate forage abundance and is the most direct and incontestable measure of plant abundance; it measures the amount of energy, carbon, and mineral elements that are incorporated by the plant. Unfortunately it is very laborious and costly to obtain biomass data at the species level. Plant community composition may be best sampled with a quadrat-based cover technique. If the use of Parker transects is continued, we recommend their sample sizes be increased severalfold.

\section{Literature Cited}

Barmore, W.J. 1980. Population characteristics, distribution and habitat relationships of six ungulates in northern Yellowstone Park. Final Report. Yellowstone National Park files.

Beetle, A.A. 1974. The zootic disclimax concept. Journal of Range Management 27:30-32.

Bergstrom, R.C. 1962. A report of changes and trends of vegetation in and near six elk exclosures on the northern Yellowstone winter range. Yellowstone National Park files. 13pp.

Cayot, L.J., J. Prukop, and D.R. Smith. 1976. Zootic climax vegetation and natural regulation. Wildlife Society Bulletin 7:162-169.

Chase, A. 1986. Playing God in Yellowstone: The Destruction of America's First National Park. Atlantic Monthly Press, New York. 
Clements, F.E. 1916. Plant succession: an analysis of the development of vegetation. Pub. 242, Carnegie Institute of Washington, Washington, DC.

Cook, C.W. and T.W. Box. 1961. A comparison of the loop and point methods of analyzing vegetation. Journal of Range Management 14:22-27.

Cook, J.W., W.W. Brady, and E.F. Aldon. 1992. Handbook for converting loop frequency data to basal area. Gen. Tech. Rep. RM-212. U.S. Department of Agriculture, Forest Service.

Coughenour, M.B. 1991. Biomass and nitrogen responses to grazing of upland steppe on Yellowstone's northern winter range. Journal of Applied Ecology 28:71-82 .

Coughenour, M.B. and F.J. Singer. 1991. The concept of overgrazing and its application to Yellowstone's northern range. Pages 209-230 in R.B. Keiter and M.S. Boyce, editors, The Greater Yellowstone Ecosystem: Redefining America's Wilderness Heritage. Yale University Press, New Haven.

Denton, G.B. 1958. Vegetational cover in and near five wildlife exclosures on the northern Yellowstone National Park winter game range. Yellowstone National Park files. 5pp.

Dyksterhuis, E.J. 1949. Condition and management of rangeland based on quantitative ecology. Journal of Range Management 2:104-115.

Everson, T.M., G.P.Y. Clarke, and C.S. Everson. 1990. Precision in monitoring plant species composition in montane grasslands. Vegetatio 88:135-141.

Francis, R.E., R.S. Driscoll, and J.M. Reppart. 1972. Loop frequency as related to plant cover, herbage production and plant density. Research Paper RM-94. U.S. Department of Agriculture, Forest Service. 8pp.

Frank, D. 1991. Interactive ecology of plants, herbivores and climate in Yellowstone's northern range. Doctoral dissertation, Syracuse University, Syracuse, New York. 150pp.

Friedel, M.H. 1991. Range condition assessment and the concept of thresholds: a viewpoint. Journal of Range Management 44:422-426.

Gammill, W.H. 1939-1941. Yellowstone National Park range studies. Yellowstone National Park files.

Grimm, R.L. 1935-1938, 1943-1947. Yellowstone National Park range studies. Yellowstone National Park files.

Houston, D.B. 1982. The Northern Yellowstone Elk: Ecology and Management. Macmillan, New York.

Hutchings, S. and R.C. Holmgren. 1959. Interpretation of loop-frequency data as a measure of plant cover. Ecology 40:668-677.

Johnston, A. 1957. A comparison of the line intercept, vertical point quadrat and loop methods as used in measuring basal area of grassland vegetation. Canadian Journal of Plant Science 37:34-42. 
Laycock, W.A. 1991. Stable states and thresholds of range condition on North American rangelands: a viewpoint. Journal of Range Management 44:427-433.

Parker, K.W. 1954. A method for measuring trend in range condition on National Forest ranges with supplemental instructions for measurement of vigor, composition and browse. U.S. Department of Agriculture, Forest Service Report.

Risser, P.G. 1984. Methods for inventory and monitoring vegetation, litter and soil surface conditions. Pages 647-701 in Developing strategies for rangeland management, National Research Council/National Academy of Sciences. Westview Press, Boulder, Colorado.

Sharp, A. 1954. Evaluation of the loop procedure of the 3-step method in the salt-desert shrub. Journal of Range Management 7:83-88.

Singer, F.J. and J.E. Norland. 1991. Diet and habitat overlaps among increasing populations of ungulates in Yellowstone National Park. In Grazing on Yellowstone's northern range - A report to the U.S. Congress.

Smith, J.G. 1962. An appraisal of the loop transect method for estimating root crown area changes. Journal of Range Management 15:72-78.

Sokal, R.R. and F.J. Rohlf. 1981. Biometry. W.H. Freeman, San Francisco.

Westoby, M., B. Walker, and I. Noy-Meir. 1989. Opportunistic management for rangelands not at equilibrium. Journal of Range Management 42:265-273. 
Appendix Table 1. Frequencies for plants at each cluster of the high winter range sites (J-Junction Butte; B-Blacktail; L-Lamar). There were two transects per cluster except at $\mathrm{J}-62-2$, where $\mathrm{n}=1$, and $\mathrm{B}-57-1$ and $\mathrm{B}-62-1$, where $\mathrm{n}=3$. Each value is mean over the transects in a cluster. Year number in the cluster code refers to the year of establishment. Blanks indicate values not available for this analysis. (Dwsh-dwarf shrub; Agsp-A. spicatum;

Feid-F. idahoensis; Kocr-K. cristata; Posp-Poa spp.;

Posa-Poa sandberghii.) Units are hits per transect.

\begin{tabular}{|c|c|c|c|c|c|c|c|c|c|c|c|c|}
\hline In/Out & Yr & Cluster & Rep & Grass & Forb & Dwsh & Total & Agsp & Feid & Kocr & Posp & Posa \\
\hline Inside & & & & & & & & & & & & \\
\hline 1 & 58 & B-57-1 & 4 & 8.2 & 5.3 & 0.8 & 14.3 & 4.8 & 0.3 & 4.8 & & \\
\hline 1 & 58 & B-57-2 & 5 & 36 & 1 & 1 & 38 & 6 & 12 & 2 & & \\
\hline 1 & 58 & L-57-1 & 8 & 32 & 10 & 0 & 42 & 9.5 & 0 & 9.5 & & \\
\hline 1 & 62 & J-62-1 & 1 & 13.5 & 14.5 & 0 & 28 & 2 & 2 & 1.8 & & \\
\hline 1 & 62 & $J-62-2$ & 2 & 22.5 & 8.5 & 0 & 31 & 4 & 4 & 2 & & \\
\hline 1 & 62 & B-57-1 & 4 & 10.5 & 12.3 & 2.5 & 25.3 & 1.7 & 1.3 & 5.5 & & \\
\hline 1 & 62 & B-57-2 & 5 & 20 & 2 & 1 & 23 & 1 & 7 & 0 & & \\
\hline 1 & 62 & B-62-1 & 6 & 18.7 & 8.7 & 0 & 27.4 & 5.8 & 0 & 11 & & \\
\hline 1 & 62 & B-62-2 & 7 & 29.2 & 7.7 & 1 & 37.9 & 5 & 10.8 & 1 & & \\
\hline 1 & 62 & L-57-1 & 8 & 22.5 & 16.5 & 1 & 40 & 11 & 1 & 2 & & \\
\hline 1 & 62 & $L-62-1$ & 9 & 20 & 8 & 0 & 28 & 8.5 & 0 & 4 & & \\
\hline 1 & 67 & $J-62-1$ & 1 & 15.2 & 26.8 & 0.5 & 42.5 & 0.75 & 8 & 1.5 & & \\
\hline 1 & 67 & J-62-2 & 2 & 14.5 & 16.5 & 0 & 31 & 0 & 8.5 & 0 & & \\
\hline 1 & 67 & B-57-1 & 4 & 8 & 20 & 0.3 & 28.3 & 1.2 & 2 & 3.2 & & \\
\hline 1 & 67 & B-57-2 & 5 & 17 & 1 & 1 & 19 & 0 & 13 & 0 & & \\
\hline 1 & 67 & B-62-1 & 6 & 18 & 8 & 0 & 21 & 3.5 & .5 & 6 & & \\
\hline 1 & 67 & B-62-2 & 7 & 18 & 7 & 1 & 26 & .5 & 11.5 & .5 & & \\
\hline 1 & 67 & L-57-1 & 8 & 25 & 6 & 1 & 32 & 15.5 & 7.5 & 0 & & \\
\hline 1 & 67 & L-62-1 & 9 & 23 & 8 & 0 & 31 & 13.5 & 3.5 & 2 & & \\
\hline 1 & 74 & $J-62-1$ & 1 & 35.5 & 31.8 & 0.5 & 67.8 & 1.5 & 25 & 0.75 & 5 & 0 \\
\hline 1 & 74 & $\mathrm{~J}-62-2$ & 2 & 40.5 & 23 & 0 & 63.5 & 0 & 32.5 & 2 & 1.5 & 0 \\
\hline 1 & 74 & J-62-3 & 3 & 25.8 & 27.7 & 2.2 & 55.7 & 4.5 & 11.2 & 3.5 & 2 & 2 \\
\hline 1 & 74 & B-57-1 & 4 & 29.5 & 19.3 & 0.8 & 49.6 & 6.7 & 9.2 & 5.3 & 5.6 & 2.5 \\
\hline 1 & 74 & B-57-2 & 5 & 37.5 & 15.5 & 0 & 53 & 3.8 & 27.2 & 0.5 & 5 & 0 \\
\hline 1 & 74 & B-62-1 & 6 & 28.8 & 18 & 5.1 & 51.9 & 12.2 & 1.7 & 0.5 & 5.2 & 0 \\
\hline 1 & 74 & B-62-2 & 7 & 43.8 & 17.2 & 0.5 & 61.5 & 3.5 & 27.8 & 3 & 1 & 0 \\
\hline 1 & 74 & L-57-1 & 8 & 36 & 15 & 0 & 51 & 7 & 17 & 6.8 & 2.8 & 0 \\
\hline 1 & 74 & L-62-1 & 9 & 27.5 & 11.5 & 0.5 & 39.5 & 6.5 & 10.2 & 3.5 & 4.2 & 0 \\
\hline 1 & 74 & $M-57-1$ & 10 & 36.2 & 15.2 & 0 & 51.4 & 4.2 & 24 & 1.2 & 4.2 & 0 \\
\hline 1 & 81 & $\mathrm{~J}-62-1$ & 1 & 34 & 28.5 & 0 & 62.5 & 0 & 28.7 & 4.7 & 0 & 0 \\
\hline 1 & 81 & $\mathrm{~J}-62-2$ & 2 & 57.5 & 10.5 & 0 & 68 & 0 & 51 & 4.5 & 0 & 0 \\
\hline 1 & 81 & J-62-3 & 3 & 25.2 & 27.2 & 0.5 & 52.9 & 2.5 & 12.5 & 7.2 & 0 & 0 \\
\hline 1 & 81 & B-57-1 & 4 & 29.7 & 22.2 & 0.3 & 52.2 & 7.7 & 15.2 & 6.3 & 0.5 & 0 \\
\hline 1 & 81 & B-57-2 & 5 & 45.7 & 13.8 & 0 & 59.5 & 3.7 & 38.2 & 3.2 & 0 & 0 \\
\hline 1 & 81 & B-62-1 & 6 & 29.3 & 13.3 & 3.3 & 45.9 & 10 & 1 & 17.7 & 0 & 0 \\
\hline 1 & 81 & B-62-2 & 7 & 61.7 & 13.2 & 0 & 74.9 & 0 & 52 & 1.5 & 0.25 & 0 \\
\hline 1 & 81 & L-57-1 & 8 & 44 & 12 & 0 & 56 & 6.2 & 26.5 & 8.7 & 2.5 & 0 \\
\hline 1 & 81 & L-62-1 & 9 & 32.8 & 8 & 0.5 & 41.3 & 9.2 & 9.8 & 10.5 & 3 & 0 \\
\hline 1 & 81 & M-57-1 & 10 & 55.5 & 15.5 & 0 & 71 & 2.25 & 50.7 & 2.5 & 0 & 0 \\
\hline 1 & 86 & J-62-1 & 1 & 28.8 & 12.8 & 0 & 41.6 & 0.5 & 25.8 & 2.5 & 0 & 0 \\
\hline 1 & 86 & J-62-2 & 2 & 35 & 4 & 0 & 39 & 0 & 34 & 0 & 0 & 0 \\
\hline 1 & 86 & J-62-3 & 3 & 17 & 7 & 0 & 24 & 2.5 & 9.5 & 4.5 & 0 & 0 \\
\hline 1 & 86 & B-57-1 & 4 & 18.8 & 10.5 & 0 & 29.3 & 1.7 & 13.7 & 3.5 & 0 & 0 \\
\hline
\end{tabular}


Appendix Table 1. Frequencies for plants at each cluster of the high winter range sites (J-Junction Butte; B-Blacktail; L-Lamar). There were two transects per cluster except at J-62-2, where $n=1$, and B-57-1 and B-62-1, where $n=3$. Each value is mean over the transects in a cluster. Year number in the cluster code refers to the year of establishment. Blanks indicate values not available for this analysis. (Dwsh-dwarf shrub; Agsp-A. spicatum;

Feid-F. idahoensis; Kocr-K. cristata; Posp-Poa spp.;

Posa-Poa sandberghii.) Units are hits per transect. (Continued)

\begin{tabular}{|c|c|c|c|c|c|c|c|c|c|c|c|c|}
\hline In/Out & $\mathbf{Y r}$ & Cluster & Rep & Grass & Forb & Dwsh & Total & Agsp & Feid & Kocr & Posp & Posa \\
\hline 1 & 86 & B- $57-2$ & 5 & 37.2 & 8.2 & 0 & 45.4 & 2 & 35.2 & 2 & 0 & 0 \\
\hline 1 & 86 & B-62-1 & 6 & 24.6 & 15.3 & 0.2 & 40.1 & 12.8 & 3.5 & 7.5 & 0.3 & 0.3 \\
\hline 1 & 86 & B-62-2 & 7 & 43 & 11.2 & 0 & 54.2 & 3 & 24.5 & 0.25 & 0.5 & 0 \\
\hline 1 & 86 & L-57-1 & 8 & 38.5 & 11.2 & 0 & 49.7 & 11 & 22.5 & 4 & 1 & 0 \\
\hline 1 & 86 & L-62-1 & 9 & 24 & 5 & 0 & 29 & 6 & 11 & 7 & 0 & 0 \\
\hline 1 & 86 & $M-57-1$ & 10 & 42 & 3 & 0 & 45 & 2.5 & 38 & 0 & 0 & 0 \\
\hline 1 & 89 & J-62-1 & 1 & 22.2 & 21.5 & 0 & 43.7 & 1 & 16.7 & 1 & 0 & 0 \\
\hline 1 & 89 & $J-62-2$ & 2 & 32.5 & 13.5 & 1 & 47 & 1.5 & 30 & 1 & 0 & 0 \\
\hline 1 & 89 & J-62-3 & 3 & 22 & 21.5 & 0 & 43.5 & 4.2 & 8.2 & 5 & 0 & 0 \\
\hline 1 & 89 & B-57-1 & 4 & 22 & 11 & 0 & 33 & 8.5 & 8.1 & 2.7 & 0 & 0 \\
\hline 1 & 89 & B-57-2 & 5 & 6 & 10.7 & 0 & 16.7 & 0.5 & 1 & 0 & 1 & 0 \\
\hline 1 & 89 & B-62-1 & 6 & 22.2 & 10.8 & 1.1 & 34.1 & 12.7 & 3.7 & 5.8 & 0 & 0 \\
\hline 1 & 89 & B-62-2 & 7 & 24 & 6 & 0 & 30 & 2.5 & 7.8 & 0.5 & 1.5 & 0 \\
\hline 1 & 89 & L-57-1 & 8 & 29.5 & 13.5 & 0.5 & 43.5 & 4.2 & 12.5 & 2.5 & 4 & 0 \\
\hline 1 & 89 & $L-62-1$ & 9 & 22.5 & 10.5 & 0 & 33 & 8.5 & 7 & 3.5 & 0 & 0 \\
\hline 1 & 89 & $M-57-1$ & 10 & 34.5 & 13 & 0 & 47.5 & 5 & 25.8 & 1.5 & 0 & 0 \\
\hline Outside & & & & & & & & & & & & \\
\hline 2 & 58 & B-57-1 & 4 & 11.8 & 8.8 & 0 & 20.6 & 4.2 & 1 & 4 & & \\
\hline 2 & 58 & B-57-2 & 5 & 28 & 2.5 & 0.5 & 31 & 2.5 & 10 & 2.5 & & \\
\hline 2 & 58 & L-57-1 & 6 & 33.0 & 6 & 0 & 39 & 3.3 & 4.2 & 5 & & \\
\hline 2 & 62 & J-62-1 & 1 & 16.5 & 13 & 0 & 29.5 & 1.5 & 6.5 & 3 & & \\
\hline 2 & 62 & $J-62-2$ & 2 & 18.5 & 15.5 & 0 & 34 & 3 & 4 & 6 & & \\
\hline 2 & 62 & B-57-1 & 4 & 13.5 & 10.5 & 0 & 24 & 2.8 & 0.5 & 8.2 & & \\
\hline 2 & 62 & B-57-2 & 5 & 29.7 & 4.8 & 0 & 34.5 & 0 & 14.5 & 2 & & \\
\hline 2 & 62 & L-57-1 & 6 & 34 & 6 & 0 & 40 & 1.8 & 3.5 & 3.2 & & \\
\hline 2 & 67 & J-57-1 & 1 & 19.2 & 19.7 & 0 & 38.9 & 1.5 & 12 & 3 & & \\
\hline 2 & 67 & J-57-2 & 2 & 17 & 17 & 1 & 35 & 1 & 11 & 2 & & \\
\hline 2 & 67 & B-57-1 & 4 & 9.5 & 7.5 & 0 & 17 & 1 & 1 & 6 & & \\
\hline 2 & 67 & B-57-2 & 5 & 24.5 & 1.8 & 1 & 27.3 & 0.5 & 17 & 2 & & \\
\hline 2 & 67 & $L-57-1$ & 6 & 38 & 8.5 & 0 & 46.5 & 1 & 12 & 3.2 & & \\
\hline 2 & 74 & $J-62-1$ & 1 & 35.7 & 19 & 0.7 & 55.4 & 3 & 19.2 & 5.8 & 3 & 0 \\
\hline 2 & 74 & J-62-2 & 2 & 34 & 21.5 & 0 & 55.5 & 1.5 & 22 & 4 & 5.5 & 0 \\
\hline 2 & 74 & J-62-3 & 3 & 30.7 & 19 & 0 & 49.7 & 1.5 & 16.8 & 6.2 & 5 & 0 \\
\hline 2 & 74 & B-57-1 & 4 & 32.8 & 15.8 & 0.3 & 48.9 & 5 & 13.7 & 9.7 & 3.8 & 0 \\
\hline 2 & 74 & B-57-2 & 5 & 49.5 & 9.2 & 0 & 58.7 & 1.5 & 33 & 3 & 3.5 & 0 \\
\hline 2 & 74 & $L-57-1$ & 6 & 49.7 & 111.2 & 0 & 160.9 & 4.5 & 21 & 5.2 & 10.85 & 0 \\
\hline 2 & 74 & $M-57-1$ & 7 & 56.7 & 17.2 & 0.5 & 74.4 & 5.5 & 31.5 & 7.8 & 10 & 1.5 \\
\hline 2 & 81 & J-62.1 & 1 & 56.7 & 15 & 0.8 & 72.5 & 5 & 28.5 & 18.5 & 0 & 0 \\
\hline 2 & 81 & J-62-2 & 2 & 56.5 & 16.5 & 0.5 & 73.5 & 2 & 29.5 & 24 & 0 & 0 \\
\hline 2 & 81 & $J-62-3$ & 3 & 37.2 & 16.8 & 1 & 55 & 2.5 & 18.5 & 14.5 & 0 & 0 \\
\hline 2 & 81 & $J-57-1$ & 4 & 29.8 & 18.3 & 3.3 & 51.4 & 7.3 & 15.7 & 6.8 & 0 & 0 \\
\hline 2 & 81 & B-57-2 & 5 & 49.8 & 4.2 & 0 & 54 & 3.2 & 38.5 & 1.7 & 0 & 0 \\
\hline
\end{tabular}


Appendix Table 1. Frequencies for plants at each cluster of the high winter range sites (J-Junction Butte; B-Blacktail; L-Lamar). There were two transects per cluster except at J-62-2, where $n=1$, and B-57-1 and B-62-1, where $n=3$. Each value is mean over the transects in a cluster. Year number in the cluster code refers to the year of establishment. Blanks indicate values not available for this analysis. (Dwsh-dwarf shrub; Agsp-A. spicatum;

Feid-F. idahoensis; Kocr-K cristata; Posp-Poa spp.; Posa-Poa sandberghii.) Units are hits per transect. (Continued)

\begin{tabular}{|c|c|l|c|c|c|c|c|c|c|c|c|c|}
\hline In/Out & Yr & Cluster & Rep & Grass & Forb & Dwsh & Total & Agsp & Feld & Kocr & Posp & Posa \\
\hline 2 & 81 & L-57-1 & 6 & 43.8 & 11.2 & 1.8 & 56.8 & 7.7 & 15 & 4.2 & 0 & 0 \\
2 & 81 & M-57-1 & 7 & 50.2 & 10.2 & 0 & 60.4 & 6 & 31.5 & 12.8 & 0 & 0 \\
2 & 86 & J-62-1 & 1 & 38.1 & 9.5 & 0 & 47.6 & 4.8 & 24.5 & 6.8 & 0 & 0 \\
2 & 86 & J-62-2 & 2 & 27.5 & 11.5 & 0 & 39 & 1 & 20.56 & 6 & 0 & 0 \\
2 & 86 & J-62-3 & 3 & 29.5 & 14.5 & 0.5 & 44.5 & 2.5 & 18.5 & 8.5 & 0 & 0 \\
2 & 86 & B-57-1 & 4 & 25.8 & 6.2 & 0.3 & 32.3 & 7.3 & 15.5 & 3 & 0 & 0 \\
2 & 86 & B-57-2 & 5 & 48.8 & 5.2 & 0 & 54 & 10.2 & 33.5 & 0 & 0 & 0 \\
2 & 86 & L-57-1 & 6 & 37.7 & 12.7 & 0.5 & 50.9 & 7.5 & 16.8 & 10.2 & 0 & 0 \\
2 & 86 & M-57-1 & 7 & 38.2 & 6.2 & 0 & 44.4 & 3.8 & 27.2 & 7.2 & 0 & 0 \\
2 & 89 & J-62-1 & 1 & 26.7 & 13.7 & 0 & 40.4 & 4.8 & 9.8 & 4.8 & 2 & 0 \\
2 & 89 & J-62-2 & 2 & 30.5 & 16.5 & 0 & 47 & 2 & 8.5 & 4 & 15 & 0 \\
2 & 89 & J-62-3 & 3 & 20 & 13.5 & 0 & 33.5 & 4.5 & 7 & 3 & 3.2 & 0 \\
2 & 89 & B-57-1 & 4 & 22.5 & 10.8 & 1.7 & 35 & 8.2 & 9.2 & 2.8 & 1.7 & 0 \\
2 & 89 & B-57-2 & 5 & 24.7 & 3.7 & 0 & 28.4 & 1.5 & 12.3 & 2.2 & 0 & 0 \\
2 & 89 & L-57-1 & 6 & 32.2 & 17.5 & 0 & 49.7 & 2 & 12 & 3 & 2.5 & 0 \\
2 & 89 & M-57-1 & 7 & 39 & 14 & 1.2 & 54.2 & 2 & 18.2 & 11 & 7.8 & 0 \\
\hline
\end{tabular}


Appendix Table 2. Frequencies of plants at each cluster at the low elevation site (Gardiner). Mean for each cluster is the mean over two transects. Blanks indicate values not available for this analysis. Units are hits/transect.

\begin{tabular}{|c|c|c|c|c|c|c|c|c|c|c|c|c|}
\hline In/Out & Yr & Cluster & Rep & Grass & Forb & Dwsh & Total & Agsp & Feid & Kocr & Posp & Posa \\
\hline Inside & & & & & & & & & & & & \\
\hline 1 & 58 & G-57-1 & 1 & 4.5 & 3 & 0.5 & 8 & 0 & 0 & 0 & & \\
\hline 1 & 58 & G-57-2 & 2 & 9 & 2.5 & 1.5 & 13 & 8 & 0 & 1.5 & & \\
\hline 1 & 62 & G-57-1 & 1 & 6 & 7 & 4 & 17 & 0 & 0 & 0 & & \\
\hline 1 & 62 & G-57-2 & 2 & 14.5 & 2.5 & 3 & 20 & 2.5 & 0 & 1.5 & & \\
\hline 1 & 62 & G-62-1 & 3 & 7 & 2 & 0.5 & 9.5 & 3 & 0 & 14.5 & & \\
\hline 1 & 67 & G-57-1 & 1 & 3.5 & 10 & 5 & 18.5 & 0 & 0 & 0.5 & & \\
\hline 1 & 67 & G-57-2 & 2 & 6.5 & 2.5 & 4.5 & 13.5 & 2 & 0 & 1.5 & & \\
\hline 1 & 67 & G-62-1 & 3 & 5.5 & 6 & 0.5 & 12 & 2 & 0 & 0 & & \\
\hline 1 & 74 & G-57-1 & 1 & 8 & 2.5 & 13.2 & 23.7 & 2 & 0 & 4.2 & 1.8 & 0 \\
\hline 1 & 74 & G-57-2 & 2 & 29.2 & 6.2 & 5 & 40.4 & 7 & 0 & 3.5 & 3.2 & 0 \\
\hline 1 & 74 & G-62-1 & 3 & 10 & 4.5 & 7.2 & 21.7 & 0 & 0 & 7.3 & 2.7 & 0 \\
\hline 1 & 74 & G-62-2 & 4 & 19.8 & 0.5 & 8 & 28.3 & 6.2 & 0 & 6.2 & 2.2 & 0 \\
\hline 1 & 81 & G-57-1 & 1 & 9 & 2 & 10.5 & 21.5 & 0 & 0 & 7.8 & 0.5 & 0 \\
\hline 1 & 81 & G-57-2 & 2 & 20.8 & 8.8 & 7 & 36.6 & 8.5 & 0 & 8.8 & 2 & 0 \\
\hline 1 & 81 & G-62-1 & 3 & 19 & 0.75 & 9.7 & 29.45 & 0 & 0 & 18 & 0.5 & 0 \\
\hline 1 & 81 & G-62-2 & 4 & 23 & 2.8 & 6.8 & 32.6 & 9.5 & 0 & 9.5 & 1.2 & 0 \\
\hline 1 & 86 & G-57-1 & 1 & 7 & 0 & 8 & 15 & 1.5 & 0 & 5.5 & 0 & 0 \\
\hline 1 & 86 & G-57-2 & 2 & 17 & 1.8 & 3.8 & 22.6 & 6.5 & 0 & 10.5 & 0 & 0 \\
\hline 1 & 86 & G-62-1 & 3 & 8 & 0.5 & 4 & 12.5 & 0 & 0 & 7.5 & 0 & 0 \\
\hline 1 & 86 & G-62-2 & 4 & 14.2 & 0.5 & 2.2 & 16.9 & 6.5 & 0 & 7.2 & 0 & 0 \\
\hline 1 & 89 & G-57-1 & 1 & 5.2 & 1.5 & 1.8 & 8.5 & 1 & 0 & 0 & 1.8 & 0 \\
\hline 1 & 89 & G-57-2 & 2 & 11.8 & 13 & 1 & 25.8 & 6.2 & 0 & 2 & 3.5 & 0 \\
\hline 1 & 89 & G-62-1 & 3 & 2.5 & 5.5 & 2.5 & 10.5 & 0 & 0 & 1 & 0.5 & 0 \\
\hline 1 & 89 & G-62-2 & 4 & 4.5 & 1 & 0 & 5.5 & 2.5 & 0 & 1 & 0.5 & 0 \\
\hline Outside & & & & & & & & & & & & \\
\hline 2 & 58 & G-57-1 & 1 & 10.5 & 2.5 & 0 & 13 & 4.5 & 0 & 4.5 & & \\
\hline 2 & 58 & G-57-2 & 2 & 5 & 7 & 0 & 12 & 0 & 0 & 0 & & \\
\hline 2 & 62 & G-57-1 & 1 & 15.5 & 5.9 & 1.1 & 22.5 & 6 & 0 & 4 & & \\
\hline 2 & 62 & G-57-2 & 2 & 7 & 5.2 & 3.8 & 16 & 0 & 0 & 0 & & \\
\hline 2 & 67 & G-57-1 & 1 & 12.5 & 6.5 & 0 & 19 & 4.2 & 0 & 6 & & \\
\hline 2 & 67 & G-57-2 & 2 & 5.5 & 7 & 3 & 15.5 & 0 & 0 & 0 & & \\
\hline 2 & 74 & G-57-1 & 1 & 8 & 0.5 & 22.8 & 31.3 & 0 & 0 & 1 & 6 & 0 \\
\hline 2 & 74 & G-57-2 & 2 & 19.8 & 4.2 & 1 & 25 & 4 & 0 & 10.2 & 1.8 & 0 \\
\hline 2 & 81 & G-57-1 & 1 & 6 & 0.75 & 15.2 & 21.95 & 0 & 0 & 3.5 & 0 & 0 \\
\hline 2 & 81 & G-57-2 & 2 & 31 & 2.5 & 0.5 & 34 & 4.5 & 0 & 19 & 1.5 & 0 \\
\hline 2 & 86 & G-57-1 & 1 & 8.5 & 0 & 11.2 & 19.7 & 0 & 0 & 7 & 0 & 0 \\
\hline 2 & 86 & G-57-2 & 2 & 12.2 & 3.2 & 1 & 16.4 & 3.5 & 0 & 4 & 0 & 0 \\
\hline 2 & 89 & G-57-1 & 1 & 3.8 & 5.2 & 3.5 & 12.5 & 0 & 0 & 1 & 1 & 0 \\
\hline 2 & 89 & G-57-2 & 2 & 8 & 11.7 & 1.5 & 21.2 & 1.5 & 0 & 1.2 & 1 & 0 \\
\hline
\end{tabular}





\title{
Elk Carrying Capacity on Yellowstone's Northern Elk Winter Range: Preliminary Modeling to Integrate Climate, Landscape, and Nutritional Requirements
}

\author{
Michael B. Coughenour \\ Natural Resource Ecology Laboratory, Colorado State University \\ Ft. Collins, CO 80523
}

\begin{abstract}
A model was developed to use climate and landscape data to calculate available forage for elk on their winter range. The model incorporated data on habitat types and topography from the Yellowstone geographic information system (GIS). Monthly climate data were derived for locations throughout the winter range. Forage estimates were based on observed relationships between precipitation and forage. Snow-depth distributions were simulated and used to constrain available foraging area. Energy and nitrogen requirements of elk were derived from metabolic equations and elk activity budgets. A dietary mixing model was used to assess the amount of forage on the range that would meet elk nitrogen and energy requirements. The model suggested that elk herbivory over the range as a whole has been moderate, ranging from 3 percent forage utilization in 1968 - 69 to 15 to 20 percent in 1983 to 1986 . However, utilization in roughly 5 to 10 percent of locations exceeded 50 percent in some years after 1974. A surplus of forage was calculated relative to recent elk population sizes, despite evidence that the population is nutritionally limited. Additional factors such as snow hardness and forage depletion during the winter must be included in future models. Carrying capacity must ultimately be estimated from forage and foraging rate effects on population growth rate.
\end{abstract}

\section{Introduction}

The extent to which forage limits the northern Yellowstone elk population and the associated levels of herbivory imposed by elk on winter range plants have eluded biologists and managers for several decades. At least since the 1920 s there has been a concern that elk grazing has led to winter range degradation. If herbivory pressure is strong enough to constitute overgrazing, then a large fraction of plant growth must be harvested by elk. However, calculations have suggested that the northern Yellowstone elk population could be supported through winter by only 5 to 10 percent of the forage that is produced on the winter range (Barmore 1972, 1980; Houston 1982). Thus, it is not clear how the elk population could be naturally regulated by food limitation (Cole 1971; Houston 1982). If elk population 
size is nutritionally limited, then either forage productivity has been greatly overestimated or the forage that is produced is not entirely available or suitable.

There are several potential reasons why the elk population could be nutritionally limited in spite of an apparent forage surplus. It is possible that not all of the forage is of sufficient quality to support elk energy or nitrogen requirements. Periodic drought and food shortages could limit the population, even though there is a forage surplus in most years. Possibly, foraging area is limited by snow or topography. Alternatively, the rate of forage intake may become limited long before the forage is completely depleted.

Since the works of Barmore and Houston, additional information on plant production has been obtained, and new techniques for modeling temporal and spatial variation and manipulating spatial data have been developed. Techniques for estimating elk energy and nitrogen requirements and effects of forage quality on forage abundance have been greatly improved (Hobbs 1989; Hobbs and Swift 1985). As the question of elk overabundance has once again been raised (Coughenour and Singer 1991), it is timely to apply new information and techniques to reassess forage quantity and quality on the winter range, how forage may limit the elk population, and how elk herbivory is distributed over forage plants on the winter range.

This report is an overview of an initial effort to (1) develop a dynamic model of elk carrying capacity (K) that is nutritionally based and further constrained by snow, and (2) determine the level and spatial distribution of herbivory that elk populations impose on winter range forage plants. These are first steps to assess limitations on elk population size that may arise from spatial and temporal variations in the quantity and quality of available forage.

\section{Methods}

\section{The Winter Range and Its Habitat Types}

The location and extent of the Yellowstone northern winter range were described by Barmore (1980) and Houston (1982). The winter range covers more than 140,000 ha and is composed of many different forested and nonforested habitat types. The perimeter of the winter range, extending well beyond the northern park boundary, was delimited by circumscribing the outermost locations of elk groups sighted during aerial censuses and radio-collar locations (Coughenour and Singer 1992).

Habitats within the park boundary have been classified and mapped (Despain 1990), as have habitats north of the park boundary (U.S. Forest Service, data set, N.D.). The habitat maps for Yellowstone National Park and adjoining U.S. National Forests were simplified to 10 habitat classes: (1) dry lodgepole pine and spruce forest (24 percent), (2) wet forests (0.8 percent), (3) dry Douglas-fir forest (15.8 percent), (4) moist Douglas-fir forest (1.1 percent), (5) xeric sagebrush/grassland at low elevations (2.3 percent), (6) dry sagebrush/grassland (8.9 percent), (7) moist sagebrush/grassland (22.5 percent), (8) Deschampsia wetland (1.5 percent), (9) other (predominantly sedge) wetlands (0.5 percent), and (10) a mosaic mixture of dry grass types (1.0 percent).

Calculations of forage production, snow depth, elk nutritional requirements, and other variables were performed for each of 5,605 25-ha square grid cells covering the entire elk winter range in and out of the Yellowstone National Park boundary. 


\section{Forage Standing Crops}

Elk consume primarily herbaceous plants, although diets may shift to shrubs and trees (browse) in periods of heavy snowfall (Skovlin 1982). The fraction of browse in the winter diets of the northern Yellowstone elk herd is 11 to 16 percent (Barmore 1980; Singer and Norland 1992). Herbaceous aboveground standing crop on the Yellowstone northern winter range varies greatly among habitats and years. Much of this variation can be attributed to changes in precipitation over time and over the landscape, run-off and run-on.

Herbaceous standing crop has been intensively studied on the lower elevation sagebrush/grasslands (habitats 5, 6, and 7). Data from recent and older Yellowstone sagebrush/grassland plant production studies were collated and used to derive a regression model of herbaceous standing crop versus precipitation (Coughenour and Singer 1992). Data included points from $15-45 \mathrm{~cm} / \mathrm{yr}$ precipitation, producing $30-120 \mathrm{~g} / \mathrm{m}^{2}$ standing crops. The resultant regression model (hereafter referred to as the "base model") was used to provide an estimate of herbaceous standing crop $\left(\mathrm{g} / \mathrm{m}^{2}\right)$ from total water-year precipitation $(\mathrm{cm})$ in each year $1968-1987$, on each 25 -ha grid cell on the winter range. The model was $\mathrm{g} / \mathrm{m}^{2}=25.0+1.0 \mathrm{PPT}\left(\mathrm{r}^{2}=0.2, p<.0001\right)$. Differences between habitats in shrub and tree cover and run-on water subsidies generate responses in forage productivity. To correct for habitat differences I relied on published data that suggested what those differences are.

Studies of unexclosed plots on the dry to xeric grassland sites within habitats 5,6 , and 10 have shown a mean standing crop of $65 \mathrm{~g} / \mathrm{m}^{2}$ based on $67 \mathrm{~g} / \mathrm{m}^{2}$ (Houston 1982), $56-61 \mathrm{~g} / \mathrm{m}^{2}$ (Coughenour 1991; Singer 1992), $65 \mathrm{~g} / \mathrm{m}^{2}$ (Frank 1991), and $74 \mathrm{~g} / \mathrm{m}^{2}$ (Merrill et al. 1988). Since the base model was developed from data from these types of sites, I did not alter the base model estimate except to correct for sagebrush cover, as explained below.

Sites in more mesic sagebrush/grasslands, or studies that have included moist sites within dry sagebrush/grasslands, were studied recently by Singer and Harter (1992) $-112 \mathrm{~g} / \mathrm{m}^{2}$; J. Norland (N.D.) $-128 \mathrm{~g} / \mathrm{m}^{2}$; and Merrill et al. (1988) $-102 \mathrm{~g} / \mathrm{m}^{2}$. These data were combined with an estimate of $168 \mathrm{~g} / \mathrm{m}^{2}$ (Houston 1982) for a mean of $127 \mathrm{~g} / \mathrm{m}^{2}$. Thus, the ratio $127: 65=1.9$ was used as the scalar to correct the base estimate for habitat 7 .

Most or all of the sampling of herbaceous production on sagebrush/grasslands has been conducted by sampling small plots covered by herbaceous plants only. However, some of the total area is actually covered by sagebrush, where herbaceous forage may be reduced by competition. Ten $152-\mathrm{m}^{2}$ belt transects located outside exclosures on the Yellowstone winter range (Houston 1982; Singer N.D.) had only 0.6 to 3.2 percent sagebrush cover. However, herbaceous production estimates collated or taken by Mueggler and Stewart (1980) in comparable sagebrush/grasslands indicated about 60 to 75 percent more herbaceous standing crop in open grasslands than in comparable sagebrush/grasslands. Given that elk diets are only 2.0 percent (Barmore 1980) to 3.8 percent (Singer and Norland 1992) sagebrush, forage production in sagebrush habitats was discounted by 30 percent. In habitats 5,6 , and 7 , approximately 31 percent, 88 percent, and 67 percent area is sagebrush-dominated (based on underlying habitat types), giving rise to base model reduction factors of $0.9,0.84$, and 0.8 , respectively.

Productivity of the herbaceous understory of forested areas has been much less studied. Recently, standing crops in Douglas-fir and nearby sagebrush/grassland were sampled (Norland N.D.). While the grassland produced $128 \mathrm{~g} / \mathrm{m}^{2}$ standing crop, the forest supported only $79 \mathrm{~g} / \mathrm{m}^{2}$. To estimate standing crops over time in habitats 3 and 4 , I scaled base model estimates by the ratio 79:128 $=0.62$. Similarly, 
Houston (1982) communicated that understories in six Douglas-fir stands contained $59 \mathrm{~g} / \mathrm{m}^{2}$ of herbaceous standing crop, while mesic and shrub steppe standing crops were estimated at 168 $250 \mathrm{~g} / \mathrm{m}^{2}$.

The understory vegetation biomasses of habitats 1 and 2 have not been studied in YNP. Prescott et al. (1989) found that in similar types of forests in Alberta there was 0.45 to 0.90 as much biomass in the forest understory as in comparable clearcuts. In Montana lodgepole pine, Basile and Jensen (1971) found 0.50 as much biomass in forest understory as in clearcuts. Similarly, there was 0.62 as much biomass under Idaho grand fir (Jensen 1991) and 0.50 as much under larch/fir (Schmidt 1979). Much (23 percent) of the dry lodgepole forest in YNP has an understory composed primarily of grouse whortleberry (Vaccinium scoparium), which is little used by elk in winter. Thus, the reduction factor I use for habitat 1 is $0.23 \times 0.50=0.36$. For comparison, Houston (1982) estimated there was only $35 \mathrm{~g} / \mathrm{m}^{2}$ in forest understory, compared with $168 \mathrm{~g} / \mathrm{m}^{2}$ in mesic steppe.

Deschampsia and sedge meadows are more productive due to run-on. An estimated mean of $290 \mathrm{~g} / \mathrm{m}^{2}$ for Deschampsia meadow (Mueggler and Stewart 1980) suggests that the base estimate can be scaled by the ratio of 290:65 $=4.5$. Frank (1990) measured sedge meadows and river terraces in the Lamar Valley and found a mean of $505 \mathrm{~g} / \mathrm{m}^{2}$ production. Houston (1982) reported a value of $449 \mathrm{~g} / \mathrm{m}^{2}$. Thus, I used the ratio $477: 65=7.3$ as a scalar for habitat 9 .

\section{Precipitation and Snow Depth Maps}

Spatial and temporal distributions of precipitation are the primary driving variables that affect interannual variations of plant growth and snow depths, and thus elk distributions. Precipitation varies widely over the winter range, primarily in response to elevation (Dirks and Martner 1982).

Monthly maps of precipitation were calculated from weather station data and from empirical monthly relationships between precipitation and elevation. Weather stations included those at Gardiner, Mammoth, Tower, Lamar, Cooke City, and Lake. For each 25-ha cell on the winter range in each month, an estimate was derived by inverse squared distance weighted interpolation to the weather stations. This estimate was then corrected with monthly empirical regression relationships between precipitation and elevation derived from the weather station data.

A simplified snow model was developed to estimate monthly snow depth maps. Snowfall at each point on the map was estimated in the same manner as precipitation - from spatial interpolation on station data corrected for elevation effects. Snowmelt rate was linearly rela!ed to temperature above a critical value, with different melting coefficients above and below freezing (e.g., Martinec and Rango 1986; Tarboton, Al-Adhami, and Bowles 1991). The model was calibrated against 1948 - 1988 data from the Lupine and Crevice Creek SCS snow courses. The Lupine site is on the upper boundary of the winter range on Blacktail Plateau. The Crevice Creek site is well above the winter range and just north of the Park.

\section{Elk Energy and Nitrogen Requirements}

The amounts of energy and nitrogen that are required for an elk to survive winter were calculated from equations presented in Hobbs et al. (1982) and Hobbs (1989). Hobbs (1989) simulated deer energy requirements and activities and foraging over hourly time intervals. I used these equations to estimate daily energy and nitrogen requirements for biweekly periods during the winter. The equations were 
parameterized for elk based on values from the literature (e.g., Gates and Hudson 1970; Parker and Robbins 1984; see also Cassirer and Ables 1990).

Elk enter winter with an energy reserve of body fat. It was assumed that at most 67 percent of the animal's total body fat could be catabolized before death (Hobbs 1989). There may be mortality in the population when even smaller fractions of mean fat reserves are used due to variation about the mean (Hobbs 1989). An energy reserve use that results in 25 percent mortality was used (86 percent). This reserve was subtracted from the energy required from forage during the course of a winter.

Nitrogen requirements were calculated as the sum of nitrogen lost through metabolic fecal nitrogen and endogenous urinary nitrogen (Hobbs et al. 1982). Rate of loss to metabolic fecal nitrogen was a linear function of forage intake rate. Rate of loss to endogenous urinary nitrogen was a power function of elk body weight.

Energy requirements were calculated from elk activity budgets and the energetic costs of each type of activity (Hobbs 1989). Activities included lying, standing, ruminating, moving, and eating. In addition, the energetic cost of digging feeding craters in the snow was calculated from a relationship observed by Fancy and White (1985). Additional energy costs included those of thermoregulation and gestation (Hobbs 1989).

\section{Activity}

Elk activity budgets varied with feeding conditions. Data for elk cratering times are lacking. However, I estimated that the ratio of cratering to feeding time increased gradually from 0 at $0 \mathrm{~cm}$ snow depth to 0.1 at $40 \mathrm{~cm}$ depth (after Collins and Smith 1991) and then to 1.0 at $60 \mathrm{~cm}$ depth. The total amount of time that an elk must spend cratering and biting to meet energy requirements was then calculated. Elk could spend at most $16 \mathrm{hr}$ per day foraging (moving among craters, cratering, and biting). For comparison, Craighead et al. (1972) found an average of $\sim 11 \mathrm{hr}$ were spent feeding. However, the animals Craighead et al. studied fed extensively on thermal areas and snow-free areas near warm streams.

\section{Dietary Mixing by Elk}

Large ruminants such as elk may mix forage of high quality with forage of otherwise insufficient quality to satisfy their total forage requirements. An algorithm (Hobbs and Swift 1985) was employed that calculates the total amount of available forage that meets the nutritional requirements of the elk after dietary mixing. The most nutritious items are summed first, and the sum progressively includes poorer items until the entire mix just satisfies the forage quality required to maintain the elk. Available forage ( $\mathrm{kg} / \mathrm{ha}$ ) of various qualities was calculated by applying the frequency distribution of forage quality to the mean forage standing crop ( $\mathrm{kg} / \mathrm{ha}$ ) of the habitat, where the latter was estimated from precipitation and habitat type as described above. The dietary mixing model calculates the fraction of forage that is suitable from the rate of dry matter intake, the energy and nitrogen requirements of the animal, and the nutrient contents of the forage.

\section{Forage Quality}

In prior applications of the dietary mixing model (Hanley and Rogers 1989; Hobbs and Swift 1985) forage was classified to the species level, and data were obtained on forage quality and quantity of each 
species. Here, however, frequency distributions of forage quality were determined by random sampling of the quality forage tissues on the winter range during winter, irrespective of species.

Forage quality for each of the 10 habitat types was sampled in two winters (1989 - 90, $1990-91)$. In each habitat 20 samples were taken randomly from burned and unburned sites. The samples were analyzed for total nitrogen content and in vitro dry matter digestibility. Dry matter digestibility was converted to forage metabolizable energy content using an equation reported by Hobbs et al. (1982). Frequency distributions of nitrogen content and dry matter digestibility were developed from these data for each habitat type to account for the possibility that much of the forage could be of low quality.

\section{Intake Rates}

Foraging intake rates of elk were studied by Hudson and Watkins (1986). They quantified the functional response of foraging, which describes how intake rate declines when forage standing crop is lowered. I used the functional response to calculate intake rate, based on the forage biomass density present at the start of the winter. Rates of forage intake per minute were multiplied by the minutes spent eating per day to derive intake rates per day. However, the time spent eating could increase within the limits described above to satisfy forage requirements.

\section{Nutritional Carrying Capacity}

The number of elk per hectare that could be sustained for the winter was calculated from the energy and nitrogen requirements per elk for the winter period, the total amount of forage per hectare of sufficient quality that could be mixed to meet those requirements, and the rate of forage intake per elk (see Hobbs et al. 1982; Hobbs and Swift 1985). Both energy- and nitrogen-based estimates of carrying capacity were calculated. The lesser of the two was taken as the nutritional carrying capacity.

\section{Snow and Resultant Areal Constraints on Carrying Capacity}

Foraging is limited to areas where snow does not prohibit forage intake. Elk probably avoid deep snow because foraging in deep snow causes excessive deficits of energy and time. Not only is the daily rate of forage intake reduced by the time spent cratering and moving, but energy expenditure is also elevated. At some range of depth, cratering becomes infeasible. Unfortunately, the mechanistic aspects of elk foraging during winter have been little studied.

There are several different estimates of snow depths that elk avoid, or that seem to induce movements to lower elevations or areas of shallower snow. Leege and Hickey (1977) found snow depths in excess of $30-60 \mathrm{~cm}$ caused elk to emigrate. Houston (1982) found 94 percent of elk fed in depths of $30 \mathrm{~cm}$ or less, and the remaining 6 percent foraged in $30-75 \mathrm{~cm}$ snow depths. Rudd (1982) found that migrations began when snow depth surpassed $20 \mathrm{~cm}$. Sweeny and Sweeny (1984) observed emigration at $40 \mathrm{~cm}$ and very little use of areas where snow depth was greater than $75 \mathrm{~cm}$. Skovlin (1982) summarized literature values that suggested no effects on movement at less than $46 \mathrm{~cm}$, with substantial diet shifts to browse above $61 \mathrm{~cm}$ and critical conditions at $76 \mathrm{~cm}$. I conservatively assumed that areas with greater than $40 \mathrm{~cm}$ of snow were avoided.

The reduction of available forage caused by deep snow was calculated by assuming a zero carrying capacity when snow depth exceeds a critical level. This was done for each 25 -ha grid cell for each twoweek period during winter. Total elk-days that could be supported on the winter range were the product 
of mean total hectares of available range during winter and the number of elk-days per hectare that could be supported by the forage biomass on the available area (stocking rate). Elk-days were converted to total elk numbers by dividing by an average length of stay on the winter range (168 days).

\section{Elk Distribution within Available Area}

The amount of forage removed by elk in a given location on the winter range was calculated by estimating the mean spatial distribution of elk-days and the foraging rate per individual elk. Elk-days were distributed in relation to potential elk-days/ha, total time that an area was open to foraging compared with all other areas, and habitat preferences. Habitat preference factors were derived by calibrating the model to observed values of habitat use:availability ratios (Singer N.D.). The distribution of elk-days was calculated only once for each winter as an estimate of season-long utilization.

\section{Model Output}

Elk energy and nitrogen requirements, amount of nutritionally adequate forage, snow depth, and resultant elk-days/ha were calculated for each 25 -ha grid cell at biweekly intervals during the winters of 1968 - 69 and 1987 - 88. Model outputs included summaries of mean elk-days/ha, available foraging area across the entire winter range, energy and nitrogen requirements, intake rates, and defoliation levels. Monthly maps of snow depth and yearly maps of elk-days/ha, forage, and forage utilization were generated and imported into a GIS (GRASS) for visual interpretation.

\section{Results}

Mapped model outputs revealed considerable spatial heterogeneity of elk-days/ha over the winter range within a given winter owing to the spatial distributions of precipitation and water-subsidized habitats. Dynamic snow-depth distributions were realistic and graphically portrayed the expected variation among elevations on the winter range, among severe and mild winters, and among months over individual winters. Variations in forage utilization over the landscape were apparent, with greatest levels at lower elevations, as would be expected.

Over the period $1968-1987$, the forage density on the winter range fluctuated between 70 and $110 \mathrm{~g} / \mathrm{m}^{2}$ (figure 1). Temporal variation was a consequence of precipitation fluctuation. Variations in forage density were less pronounced than variations in precipitation because of the flatness of the regression model relating the two (Coughenour and Singer 1992). Essentially all of the forage on the available area could be mixed to meet elk energy requirements. However, a fraction of the forage had very low nitrogen contents, so not all of the forage could be used to fulfill elk nitrogen requirements.

Mean elk-days/ha that could be supported by suitable forage on the available winter range fluctuated between 125 and 167 (figure 2). The season-long mean area having $<40 \mathrm{~cm}$ snow depth varied from 50,000 to 130,000 ha (figure 2a). Based on those results, the total number of elk that could be supported varied from 40,000 to 100,000 . The two-week period having the minimum area with $<40 \mathrm{~cm}$ snow depth varied from 20,000 to 90,000 ha (figure $2 \mathrm{~b}$ ). Based on that result, the total number of elk that could be supported varied from 15,000 to 90,000 . 
Forage Density

(with suitable nutritional contents)

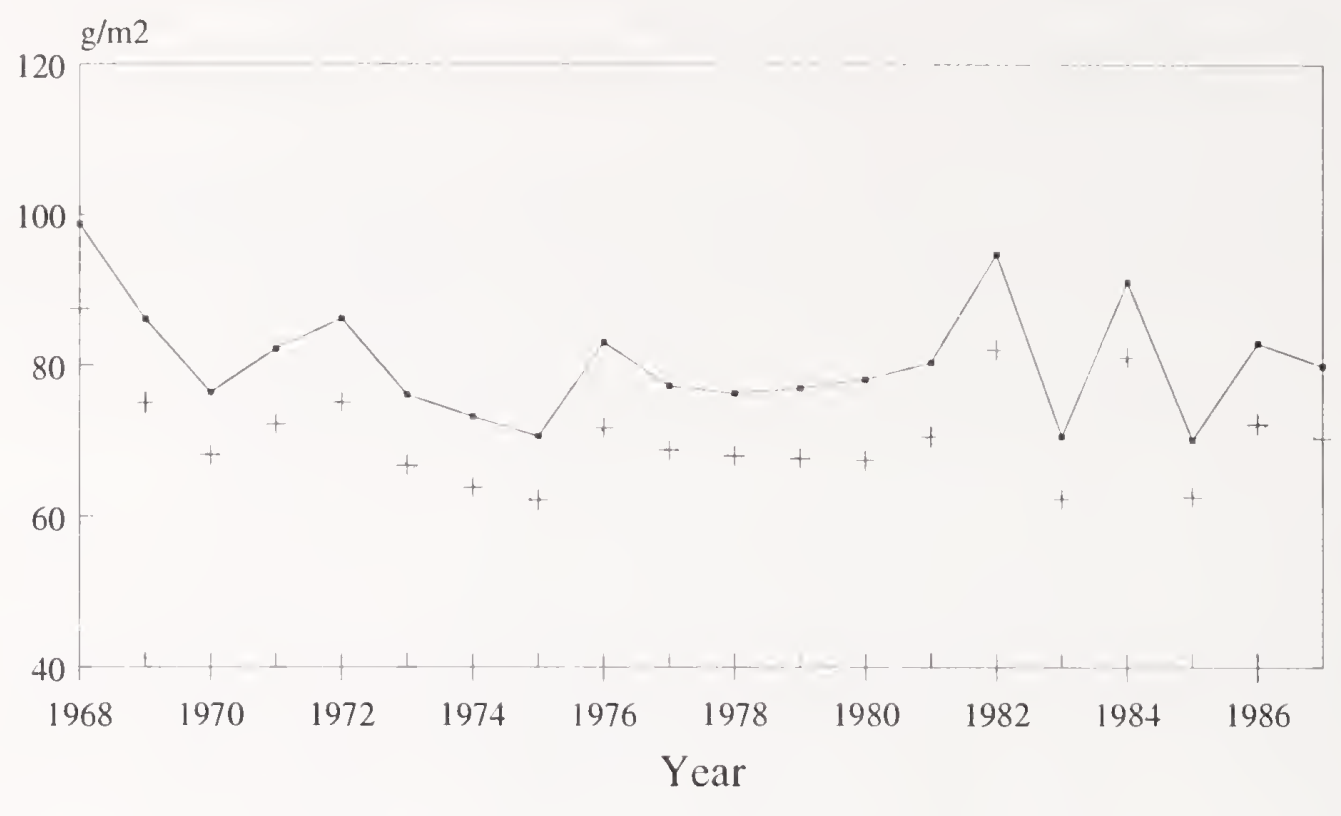

- with suitable energy

with suitable $\mathrm{N}$

Figure 1. Fluctuations in forage biomass density, showing the amounts of forage that can meet daily energy and nitrogen requirements of elk during the winter. Years are numbered so that 1968 represents the winter of $1968-69$.

Averaged over all cells on the winter range, mean forage removal ranged from 3.1 percent in 1968 - 69 to 21.0 percent in 1985 - 86 (figure 3). An upward trend in herbivory pressure, as measured by the percentage of forage mass removed, was due to the increase in elk population size from 4,355 in 1968 to 19,292 in 1987 . Within each year there was considerable variation in herbivory pressure among 25 -ha cells. The percentage of cells with greater than 25 percent forage removal increased from 0 percent in 1969 - 70 to over 32 percent in 1987 - 88. The percentage of cells with greater than 50 percent forage removal increased as well, from $0-5$ percent prior to 1977 to $5-13$ percent after 1977.

\section{Discussion}

The nutritional carrying capacity approach has been employed for many decades, although it has been considerably refined (Hobbs et al. 1982; Hobbs and Swift 1985). Originally it was believed that carrying capacity could be calculated by summing the total forage on the range and dividing it by the forage required per animal. Later it was realized that forage quality must be considered as well. Thus, for example, Hobbs et al. (1982) calculated carrying capacity (K) by summing dietary items having greater than a certain nitrogen content. As a result, estimates of $K$ were reduced. However, on the Yellowstone winter range, forage quality was high, so estimates of $K$ were not significantly reduced (figure 1 ). The disparity between forage abundance and elk forage demands seems unlikely to be explained by low forage quality. 
a)

$\mathrm{K}$ - based on mean area

available during winter

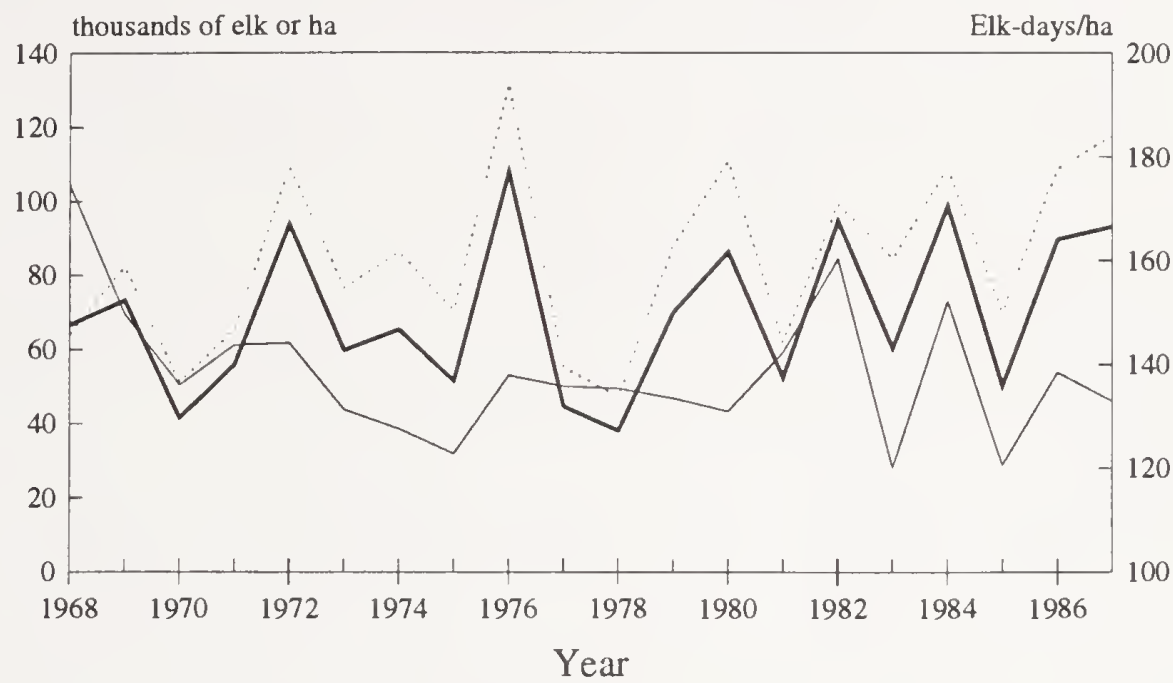

Elk-days/ha Available Area-mean $\quad$ K

b)
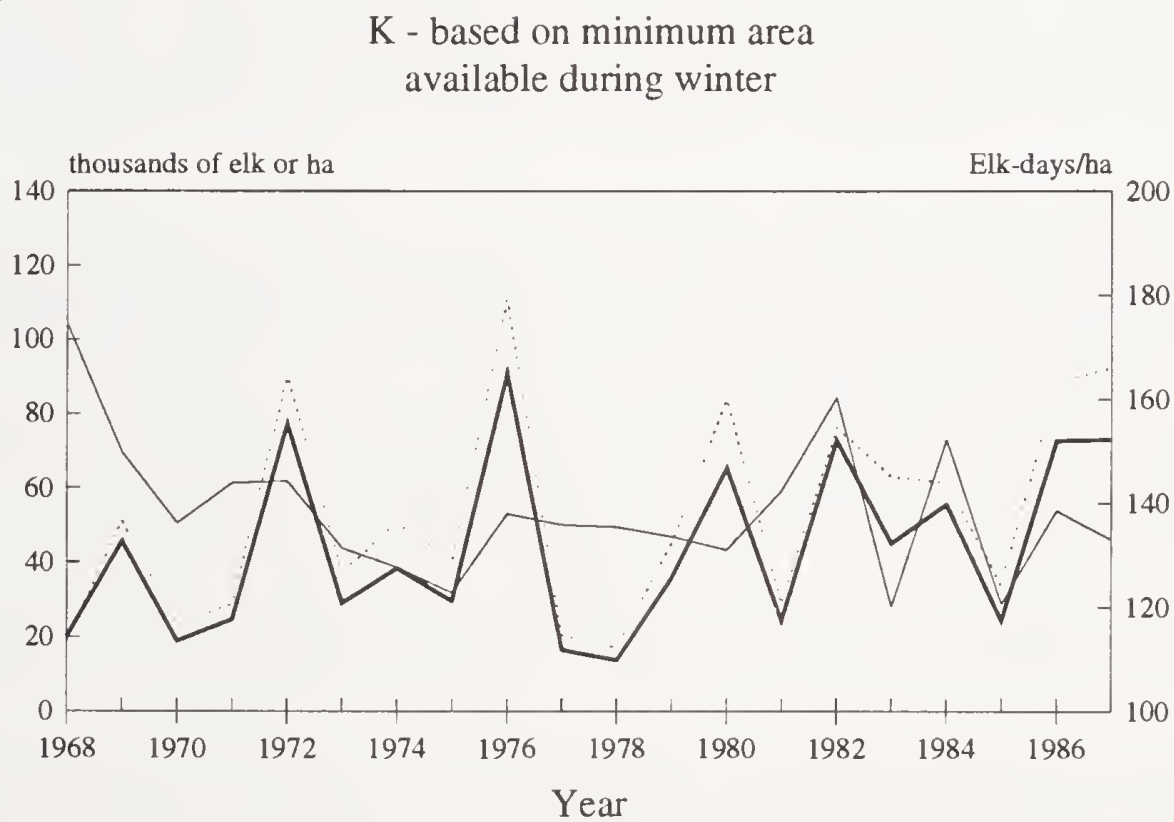

Elk-days/ha

Available Area-min. $\quad-\mathrm{K}$

Figure 2. Variations in $\mathrm{K}$ over time, where $\mathrm{K}$ is calculated as the product of elk-days/ha and available foraging area. In figure $2 a$ the mean area available for foraging ( $<40 \mathrm{~cm}$ snow) was considered, and in figure $2 b$ the minimum area available for foraging during a two-week period during the winter was used. Years numbered as in figure 1. 


\section{Defoliation Levels}

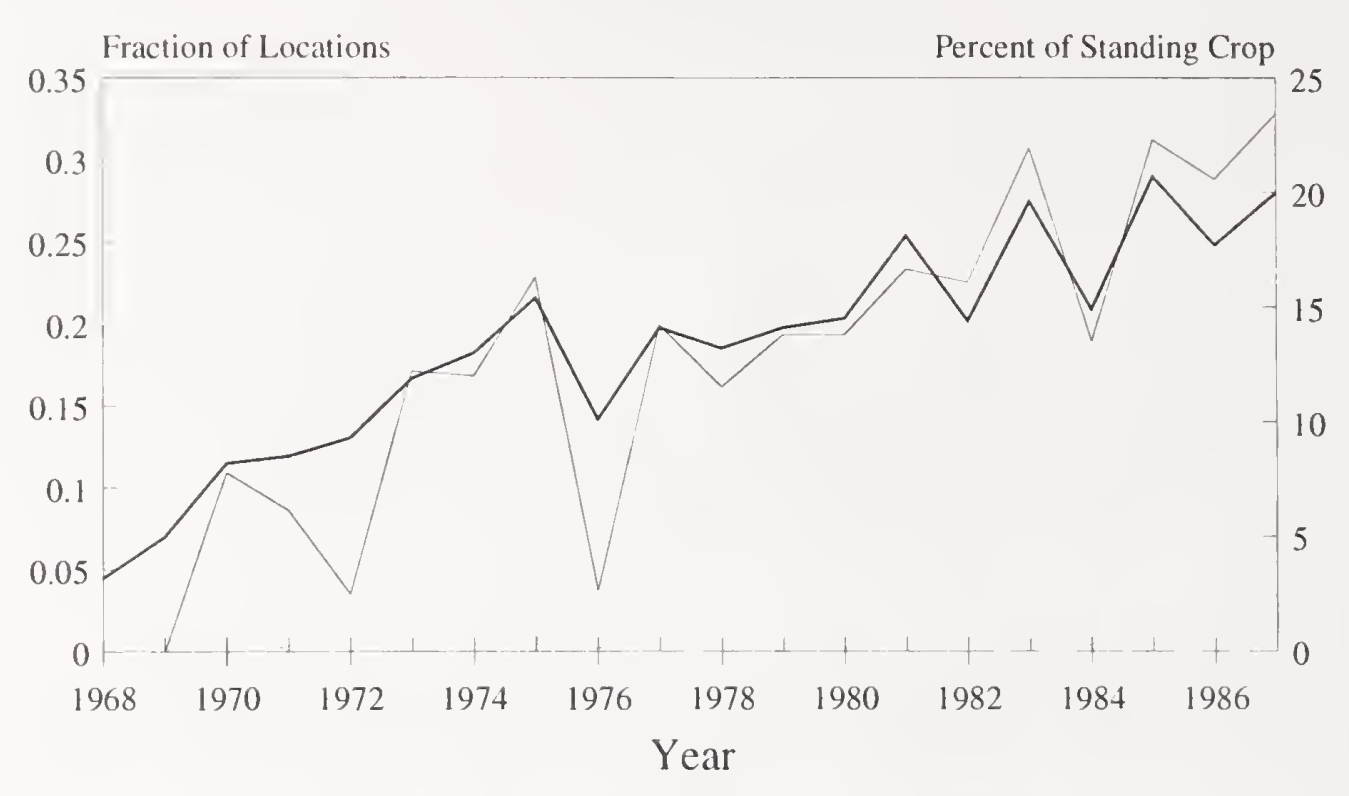

Fraction w. $>25 \%$ Def

Fraction w. $>50 \%$ Def

- Mean Defoliation \%

Figure 3. Calculated levels of defoliation over the winter range. The mean percentage defoliation is the percentage of all forage produced on the range that is consumed. In some locations, however, over 25 percent and over 50 percent defoliation levels were imposed. The fraction of all 5,605 grid cells having $>25$ percent and $>50$ percent defoliation is displayed. Years numbered as in figure 1.

In most attempts to calculate nutritionally limited $\mathrm{K}$, emphasis has been placed on available forage and elk nutritional requirements, while little attention has been paid to the area available for foraging or the spatial distributions of elk. Much of the variation in calculated carrying capacity (figure 2) was due to fluctuations in snow cover. Out of 140,000 ha, the amount of area with $<40 \mathrm{~cm}$ snow was calculated as ranging between 51,000 ha (winter minimum) and 82,000 ha (winter mean) in $1969-70$, for example. Barmore (1980) estimated that $19,000-28,000$ ha were used by elk that winter. For the winter of 1968 69 the model indicated 19,000 - 64,000 ha should have been available, while Barmore (1980) found that $21,000-39,000$ ha were actually used. Barmore's estimates of available area were lower partly because he did not include winter range area north of the park boundary that was rarely used by elk at that time (but is used now).

Delimitation of available foraging area by a sharp $40-\mathrm{cm}$ snow-depth isoline is undoubtedly an oversimplification. Elk occasionally use areas of deeper snow. Beyond the 40-cm snow isoline there may be microhabitats that are usually windblown. On the other hand, within the $40-\mathrm{cm}$ isoline there are microhabitats where snow accumulates. More important, snow hardness and crusting may have significant effects that are independent of snow depth. Barmore (1980) felt that snow hardness was a more important factor when snow depth was less than $61 \mathrm{~cm}$. Good correlations between snow hardness and time spent cratering have been found for reindeer, irrespective of snow depths between $-25-55 \mathrm{~cm}$ (Collins and Smith 1991). If snow hardness affects foraging irrespective of depth, then the significance of a given snow-depth isoline is considerably blurred. Despite the problems of using a threshold snow depth to delimit foraging area, snow depth must be taken into account. Clearly, elk migrate in response 
to deep snow (Skovlin 1982). It has long been known that ungulate populations respond to winters with deep snow (Edwards 1956).

Over the entire winter range and even within areas having less than $40 \mathrm{~cm}$ snow depth, there would seem to be enough forage to support a much larger elk population. Based on the mean area during winter with $<40 \mathrm{~cm}$ snow, $\mathrm{K}$ was two to three times larger than recent elk population sizes. Even $\mathrm{K}$ based on the minimum area during winter with $<40 \mathrm{~cm}$ snow only occasionally dropped down to 20,000 - 30,000 elk. The mean level of herbivory on forage plants would therefore appear to have been moderate. Yet analyses of population rates of increase in recent years suggest that the population was at or near carrying capacity (Boyce 1991; Coughenour and Singer 1992; Houston 1982). Observed decreases in population growth rates at higher densities have clearly shown that there has been intraspecific competition for forage or suitable habitat. Analyses of elk population data suggest that the population also responds to variations in forage supply (Coughenour and Singer 1992). Calf mortality in particular was negatively correlated with precipitation in the prior year, which would be indicative of an effect of forage abundance on pregnant and nursing cows. Analyses of urine from elk during the winter have also shown that elk are under nutritional deprivation (Delguidice, Singer, and Seal 1991).

Several effects could contribute to the discrepancy between the evidence for nutritional limitation and the apparent forage surplus suggested by calculations here. First, it is possible that the regression model used to predict forage supply was not sufficiently responsive to precipitation. The slope of the line was flattened, with a positive $X$ intercept, due to the wide range of variance in the data. Second, forage could be overestimated if it is based on fall standing crop. Forage may fall to the ground during winter or be compressed by snow, making a fraction of it unavailable. Consequently, transfer of plant tissue to the soil surface and burial of forage under snow could reduce the level of herbivory imposed upon the forage plants. Transfer of forage to soil surface could also reduce total standing crop at snow melt, causing overestimation of standing crop.

A third possibility is that there are finer scaled patches of suitable or preferred habitat within the larger area. Just as fire perimeters overestimated the total burned area in Yellowstone in 1988 because of patchiness of burned and unburned areas within perimeters, the area of suitable habitat for elk within the winter range may be overestimated by its perimeter. Certainly, topographic variation within 25-ha cells could produce finer scaled patchiness, as could variation within the topographic contour lines that are generated by cartographers. Furthermore, patches with greater forage density would also be areas of deeper snow (i.e., swales), whereas areas that are windblown would have less forage (i.e., ridgetops).

As forage is depleted, forage intake rate is diminished due to the foraging functional response. The consequences of this for elk energy balance were not considered here, as forage was not depleted during the simulated winter. In order to deplete forage, stocking density must be specified, so elk density distributions must be modeled throughout the winter. Here, elk-day distributions were calculated on a season-long basis. However, a modeling experiment at a single location revealed the importance of forage depletion. The dietary mixing model was used to determine that the area could support $x$ number of elk/ha for the winter. However, that density of elk depleted forage at a rate that led to 100 percent mortality by the 20th week of winter in the dynamic model. The elk depleted the forage to a level that reduced their intake rate below that needed to maintain their energy balance. Responses to forage depletion would increase model sensitivity to variations in forage biomass and may result in significant overestimation of carrying capacity. Elk would also be less likely to impose a high level of herbivory on the forage plants. 
A shortcoming of the dietary mixing model is that it does not consider the possibility that forage intake rates may be reduced by low forage quality, as passage rate through the rumen declines. While lowquality items may be mixed with high-quality items to increase total forage, intake rate may decline, thus increasing the dietary quality needed to fulfill elk nutritional requirements. This would decrease carrying capacity.

Estimates of summer calf survival can be compared with fluctuations in snow cover and forage density to determine population responses to these factors (figure 4). High summer-calf survival rates were observed during 1968 - 1971 because elk densities were very low. Calf mortality did not respond strongly to large fluctuations in areas having $<40 \mathrm{~cm}$ snow depth, such as during $1971-73$ and $1976-77$. Changes in available area may, however, have contributed to variance in survivorship in $1974-76$. Changes from 1984 - 86 in forage and area were parallel, making it difficult to discern which factor may have caused a survivorship response. Indeed, both factors have effects. However, the effects of snow depth were likely overemphasized in the current model while the effects of forage abundance were likely underemphasized.

The current model may be incomplete, but it is an essential step. The exercise pointed out that the effects of spatial and temporal variations in forage quality and quantity, effects of snow depth on available foraging area, and elk nutritional requirements must be synthesized to calculate spatial and temporal patterns of herbivory. It would be logical to extend this approach by dynamically modeling elk spatial distributions, forage depletion, elk energy balance, and resultant population responses. In the final analysis, carrying capacity must be calculated as the population size at which mortality and natality rates are in balance.

\section{Summer Calf Survivorship \\ Compared to Area and Forage}

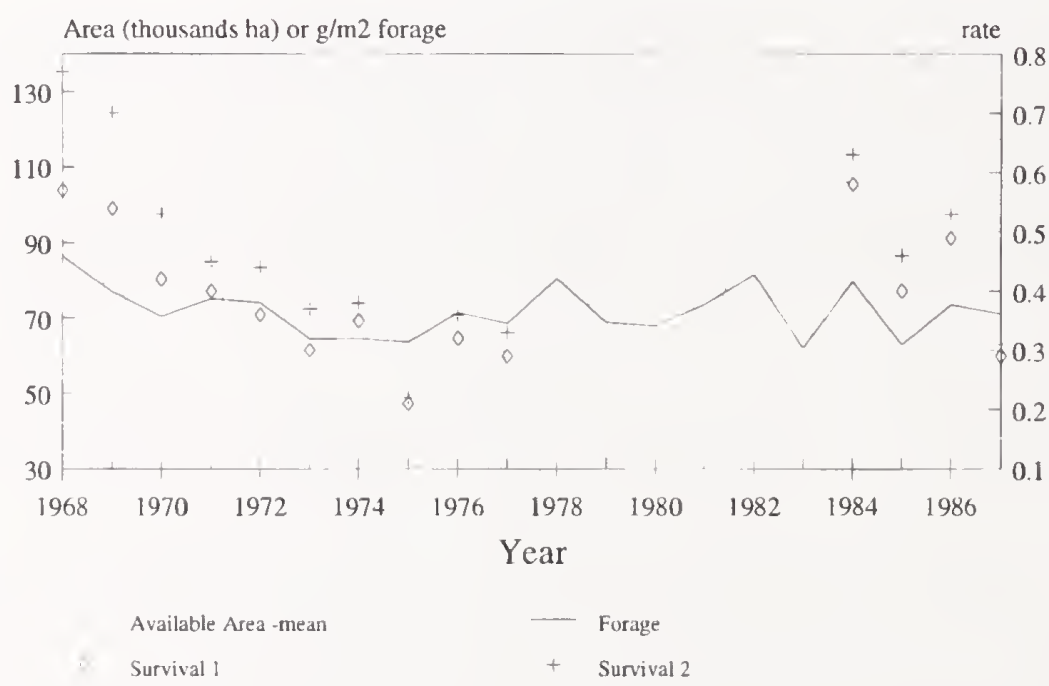

Figure 4. Comparison of summer-calf survivorship in year $t+1$ to fluctuations in mean available foraging area and forage. Calf survivorship was calculated two different ways (Coughenour and Singer 1991). Years are numbered as in figure 1, so calf survival in summer of 1969 would be affected by conditions in winter 1968 - 69 (year 1968). 


\section{Literature Cited}

Barmore, W.J. 1972. A computer simulation model of elk distribution, habitat use, and forage consumption on winter range in Yellowstone National Park. 27pp.

Barmore, W.J. 1980. Population characteristics, distribution and habitat relationships of six ungulates in Yellowstone National Park. Final Report. Yellowstone National Park files.

Basile, J.J. and C.E. Jensen. 1971. Grazing potential on lodgepole pine clearcuts in Montana. Res. Pap. INT-98. U.S. Department of Agriculture, Forest Service.

Cassirer, E.F. and E.D. Ables. 1990. Effects of disturbance by cross country skiers on elk in northern Yellowstone National Park. Final Report. Yellowstone National Park.

Cole, G.F. 1971. An ecological rationale for the natural or artificial regulation of elk native ungulates in parks. Transactions of the North American Wildlife Conference 36:417-425.

Collins, W.B. and T.S. Smith. 1991. Effects of wind-hardened snow on foraging by reindeer (Rangifer tarandus). Arctic 44:217-222.

Coughenour, M.B. 1991. Biomass and nitrogen responses to grazing of upland steppe on Yellowstone's northern winter range. Journal of Applied Economics 28:71-82.

Coughenour, M.B. and F.J. Singer. 1991. The concept of overgrazing on Yellowstone's northern winter range. In R. Keiter and M. Boyce, editors, The Greater Yellowstone Ecosystem - Redefining America's Wilderness Heritage. Yale University Press, New Haven.

Coughenour, M.B. and F.J. Singer. 1992. Evidence for nutritional limitation of elk on Yellowstone's northern winter range. In Grazing on Yellowstone's Northern Winter Range - A Report to the U.S. Congress. Yellowstone National Park.

Craighead, J.J., F.C. Craighead Jr., R.L. Ruff, and B.W. O'Gara. 1972. Home ranges and activity patterns of non-migratory elk of the Madison drainage as determined by bio-telemetry. Wildlife Monograph 33. 50 p.

Delguidice, G.D., F.J. Singer, and U.S. Seal. 1991. Physiological assessment of winter nutritional deprivation in elk of Yellowstone National Park. Journal of Wildlife Management 55:653-664.

Despain, D. 1990. Yellowstone Vegetation: Consequences of Environment and History in a Natural Setting. Roberts Rinehart, Boulder, Colorado.

Dirks, R.A. and B.E. Martner. 1982. The climate of Yellowstone and Grand Teton National Parks. U.S. Department of the Interior. National Park Service. Occasional Paper No. 6.

Edwards, R.Y. 1956. Snow depths and ungulate abundance in the mountains of western Canada. Journal of Wildlife Management 20:159-168. 
Fancy, S.G. and R.G. White. 1985. Incremental cost of activity. Pages 143-159 in R.J. Hudson and R.G. White, editors, Bioenergetics of Wild Herbivores. CRC Press, Boca Raton, Florida.

Frank. D. 1990. Interactive ecology of plants, herbivores and climate in Yellowstone's northern range. Doctoral dissertation, Syracuse University, Syracuse, New York. 150pp.

Garton, E.O., A.L. Crabtree, B.B. Ackerman, and G. Wright. 1990. The potential impact of a reintroduced wolf population on the northern Yellowstone elk herd. Pages 3.61-3.91 in Wolves for Yellowstone: A Report to the U.S. Congress. Vol. II. Yellowstone National Park.

Gates, C.C. and R.J. Hudson. 1979. Effects of posture and activity on metabolic responses of wapiti to cold. Journal of Wildlife Management 43:564-567.

Hanley, T.A. and J.J. Rogers. 1989. Estimating carrying capacity with simultaneous nutritional constraints. Research Note PNW-RN-485. U.S. Department of Agriculture, Forest Service. 29pp.

Hobbs, N.T. 1989. Linking energy balance to survival in mule deer: development and test of a simulation model. Wildlife Monograph 101. 39pp.

Hobbs, N.T., D.L. Baker, J.E. Ellis, D.M. Swift, and R.A. Green. 1982. Energy- and nitrogen-based estimates of elk winter-range carrying capacity. Journal of Wildlife Management 46:12-21.

Hobbs, N.T. and D.M. Swift. 1985. Estimates of habitat carrying capacity incorporating explicit nutritional constraints. Journal of Wildlife Management 49:814-822.

Houston, D.B. 1982. The Northern Yellowstone Elk: Ecology and Management. MacMillan, New York. 474pp.

Hudson, R.J. and W.G. Watkins. 1986. Foraging rates of wapiti on green and cured pastures. Canadian Journal of Zoology 64:1705-1708.

Jensen, M.E. 1991. Ecological classification and cumulative soil effects. Pages 218-223 in Proceedings of the Conference on Management and Productivity of western forest montane soils. Gen. Tech. Rep. INT-280. U.S. Department of Agriculture, Forest Service.

Leege, T.A. and W.O. Hickey. 1977. Elk-snow-habitat relationships in the Pete King Drainage, Idaho. Idaho Department of Fish and Game, Wildlife Bulletin No. 6.

Martinec, J. and A. Rango. 1986. Parameter values for snowmelt runoff modeling. Journal of Hydrology 84:197-219.

Merrill, E., M.S. Boyce, R.W. Marrs, and M.K. Bramble-Brodahl. 1988. Grassland phytomass, climate variation and ungulate population dynamics in Yellowstone National Park. Final Report. Yellowstone National Park.

Mueggler, W.F. and W.L. Stewart. 1980. Grassland and shrubland habitat types of western Montana. Gen. Tech. Rep. INT-66. U.S. Department of Agriculture, Forest Service. 
Parker, K.L. and C.T. Robbins. 1984. Thermoregulation in mule deer and elk. Canadian Journal of Zoology 62:1409-1422.

Prescott, C.E., J.P. Corbin, and D. Parkinson. 1989. Biomass, productivity and nitrogen use efficiency of aboveground vegetation in four Rocky Mountain coniferous forests. Canadian Journal of Forest Research 19:309-317.

Rudd, W.J. 1982. Elk migrations and movements in relation to weather and hunting in the Absaroka Mountains, Wyoming. Master's thesis, University of Wyoming.

Schmidt, W.C. 1979. Environmental consequences of timber harvesting in Rocky Mountain coniferous forests. Gen. Tech. Rep. INT-90. U.S. Department of Agriculture, Forest Service.

Singer, F.J. 1992. Effects of elk and other ungulate grazing on the northern winter range of Yellowstone National Park. In Grazing on Yellowstone's Northern Winter Range - A Report to the U.S. Congress. Yellowstone National Park.

Singer, F.J. and M.K. Harter. 1992. Interactive effects of an autumn wildfire and elk herbivory on an elk winter range. (submitted).

Singer, F.J. and J. Norland. 1992. Diet and spatial overlaps amongst increasing populations of ungulates in Yellowstone National Park. (submitted).

Skovlin, J.M. 1982. Habitat requirements and evaluations. Pages 369-423 in J.W. Thomas and D.E. Toweill, editors, Elk of North America. Stackpole Books, Harrisburg, Pennsylvania.

Sweeny, J.M. and J.R. Sweeny. 1984. Snow depths influencing winter movements of elk. Journal of Mammalogy 65:524-526.

Tarboton, D.G., M.J. Al-Adhami, and D.S. Bowles. 1991. A preliminary comparison of snowmelt models. Pages 79-91 in Models for erosion prediction, Proceedings of the Western Snow Conference, Colorado State University, Fort Collins. 



\title{
Northern Rocky Mountain Paleoecology in Archeological, Paleobotanical, and Paleoethnobotanical Perspective
}

\author{
Leslie B. Davis \\ Museum of the Rockies \\ Montana State University \\ Bozeman, MT 59717 \\ Stephen A. Aaberg \\ Aaberg Cultural Resource Consulting Service \\ 712 South 7th Avenue \\ Bozeman, MT 59715 \\ Linda Scott Cummings \\ PaleoResearch Laboratories \\ 15485 West 44th Avenue, Suite A \\ Golden, CO 80403
}

\begin{abstract}
Multidisciplinary investigations of prehistoric cultural contexts within archeological sites in montane west-central and southwestern Montana (Indian Creek, MacHaffie, Pilgrim, and Barton Gulch) that span Paleoindian to Late Prehistoric times are contributing natural and cultural history data essential for understanding human subsistence behavior. Radiocarbon-dated culture-bearing strata currently provide an 11,000-year, Late Pleistocene through Late Holocene, paleoclimatic, paleoenvironmental, and paleocultural record that can facilitate the understanding of complex, dynamic interactions between and among intercorrelated natural conditions and human responses. Emerging knowledge of the early Native American use of plants for subsistence, industrial, medicinal, and ritual/ceremonial purposes - inferred from pollen, phytolith, and plant macrofossil analyses and augmented by modern vegetational community studies and reference to historic Native American culture traits - is deepening appreciation of early human-land resource interrelationships in the Northern Rockies.
\end{abstract}

\section{Holocene Vegetational History}

Holocene vegetational changes in southwestern and western Montana and northwestern Wyoming have been varied, complex, and responsive to local conditions (Baker 1970, 1983; Barnosky 1989; Mack 1983; 
Mehringer, Arno, and Peterson 1977; Waddingham and Wright 1974; Whitlock 1990). However, the absence of primary paleoecological records for such patterns from Montana east of the Continental Divide is a noteworthy deficiency. That deficit has prevented the testing of regional and larger geographic scale hypotheses regarding paleoecological and paleocultural reconstructions using locally developed primary data. Instead, research findings elsewhere have been imported and used uncritically to interpret paleoecology-human ecology relationships for most of Montana prehistory.

Late Pleistocene through Late Holocene sequences that span 11,000 to 300 years before the present (B.P.) - developed through a series of archeological investigations of prehistoric human lifeways in both montane and plains settings in Montana - provide data baselines that contribute significantly to Holocene vegetational history. Key interrelationships among paleoenvironments, resources, and human interactions can now be examined in some detail. The development of local data-based models that will both predict and guide intensive research into these dynamics is in progress. Two sites presently provide key stratigraphic sequences.

\section{The Indian Creek Site (24BW626)}

This site is located within the south floodplain of Indian Creek (1,350 $\mathrm{m}$ above mean sea level [AMSL]), which flows eastward out of the Elkhorn Mountains and is tributary to the Missouri River that flows $7 \mathrm{~km}$ distant east of Townsend (figure 1). The 7.3-m-deep geological section at this deeply stratified open-air occupation site contains remains that represent 28 buried, superimposed, vertically sequential prehistoric campsites (Davis 1984; Davis, Aaberg, and Fisher 1980; Davis, Greiser, and Greiser 1987; Davis et al. 1991). The respective occupations range from 10,980 to 300 B.P. in age, spanning the Early, Late Middle, and Late Prehistoric periods; 13 occupations have been radiocarbon dated. The base of the section exhibits a radiocarbon-dated Glacier Peak, Layer G, tephra, c. 11,125 B.P. A locally dated Mt. Mazama tephra, C. 6,700 B.P., is present above midsection. A 10,700-year postglacial Holocene stratigraphic record of natural events and associated but intermittent human activities is thus available (figure 2).

Abundant evidence for game hunting and utilization is documented throughout the section, including remains of bison (Bison sp.), deer (Odocoileus sp.), mountain sheep (Ovis canadensis), black bear (Ursus americanus), pronghorn antelope (Antilocapra americana), yellowbellied marmot (Marmota flaviventris), black-tailed prairie dog (Cynomys ludovicianus), and vole (Microtus sp.). Site seasonality, inferred from faunal remains recovered from the respective sampled campsites, ranges from early spring through late summer occupations.

A vegetation inventory conducted along a southeast-northwest traverse Indian Creek at the site location identified numerous potentially exploitable plant resources (figure 3). However, no evidence for plant utilization by prehistoric site occupants was recognized. The detailed pollen (Fredlund and Bozarth 1987) (figure 4) and phytolith (Lewis 1986) records developed at Indian Creek are relevant here for paleoecological reconstructive purposes (see intersite comparative discussion below).

\section{The MacHaffie Site (24JF4)}

The open-air MacHaffie site is located on the northwest flank of the Elkhorn Mountains (1,280 m AMSL) near Montana City, south of Helena (Forbis and Sperry 1952) (figure 1) and in the floodplain of an ephemeral stream tributary to Prickly Pear Creek, $22 \mathrm{~km}$ south of the Missouri River. The site presents a 1.2-m-deep alluvial section overlain by $1.4 \mathrm{~m}$ of colluvium (Davis et al. 1991) (figure 5). The alluvium encases four stratified Paleoindian campsites once occupied by peoples of the Folsom and Scottsbluff 


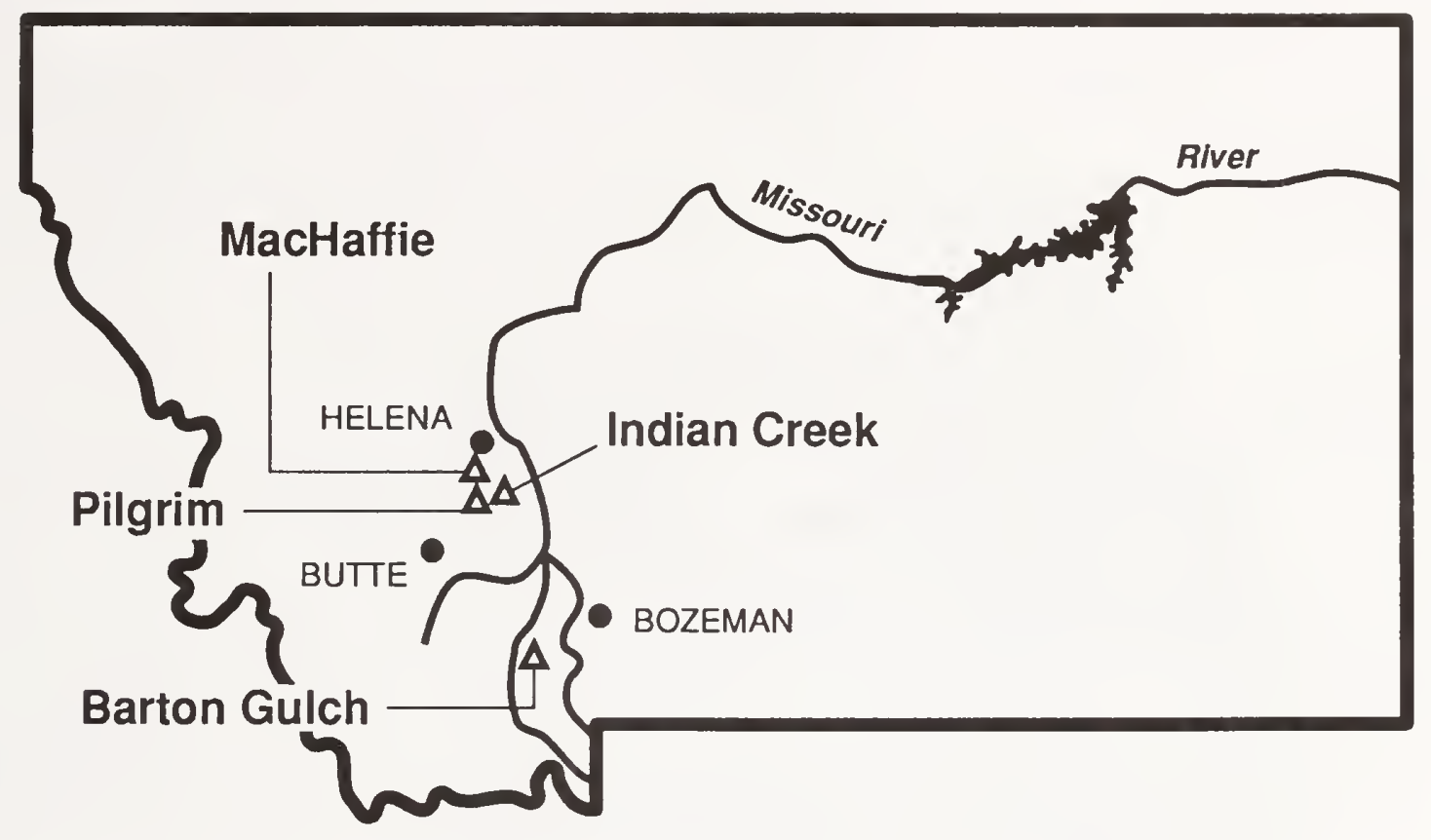

Figure 1. Location of major archeological sites in southwestern and west-central Montana featured in the text.

complexes (c. 9,340 to 8,100 B.P.), who procured bison (Bison sp.), deer (Odocoileus sp.), wolf (Canis lupus), and jackrabbit (Lepus sp.), most likely during nonwinter seasons.

No evidence for the human use of plants has yet been recognized at MacHaffie. The associated pollen (figure 6) and phytolith records (Cummings 1990a) are, however, informative regarding local paleoecological history and aid in understanding conditions faced at intervals by occupying humans. The pollen data indicate the presence of a sagebrush steppe in the valley of the MacHaffie site throughout much of the time span represented. The portion of the valley floor in the area sampled, however, was covered by typical riparian vegetation prior to approximately 8,280 B.P., continuing for an unknown time thereafter following the increase in Artemisia steppe. The riparian vegetation included abundant to scattered birches (Betula sp.) and occasional willows (Salix sp.), as well as large quantities of Liguliflorae-type composites, grasses, a few sedges and lilies, and saxifrages.

There is no evidence in this portion of the record of forested slopes such as those evident in the vicinity today. The lower portion of the phytolith record from the alluvial deposits indicates very wet sediments through the Folsom occupation (9,130 B.P.). After that date, however, soil moisture declines, suggesting a lowering of the water table at some time between the Folsom and Scottsbluff occupations. The pollen and phytolith records do not display as large a change as is indicated by diatoms. From the base of the column to the Folsom occupation, the sediments along the banks of this stream were probably extremely wet and marshy. 


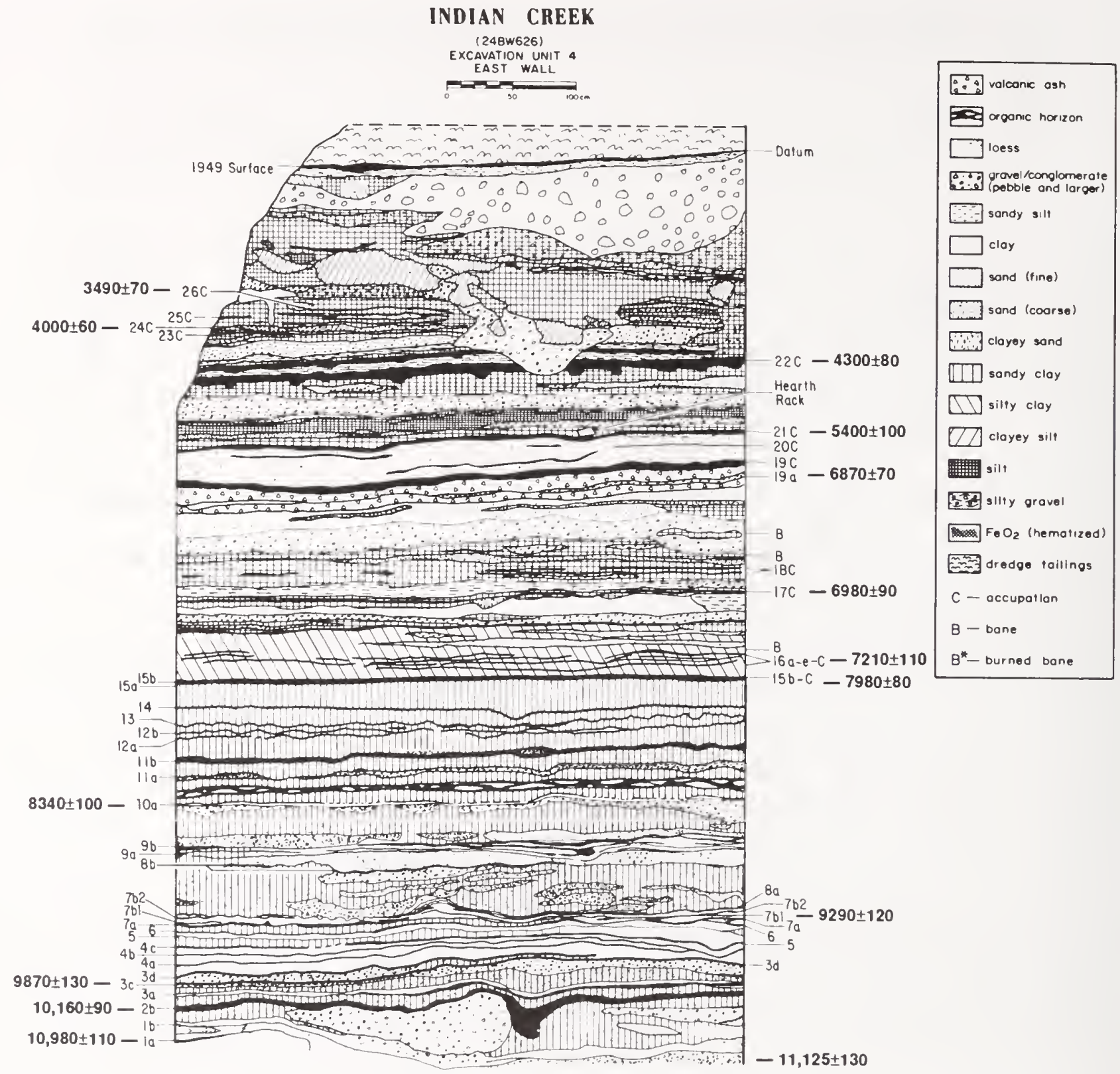

Figure 2. An east wall excavation profile of Unit 4 of the Indian Creek site section (by S.A. Aaberg). 


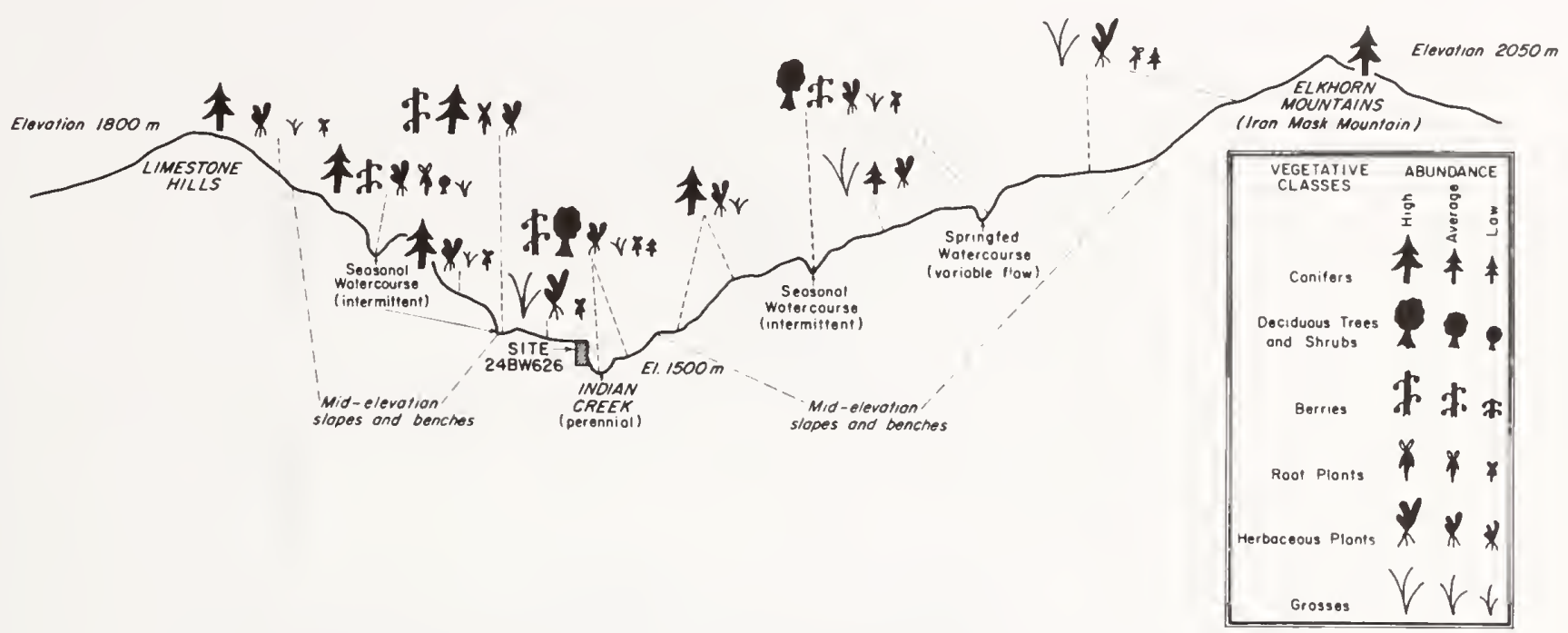

Figure 3. Southeast-northwest vegetational transect across Indian Creek (by S.A. Aaberg).

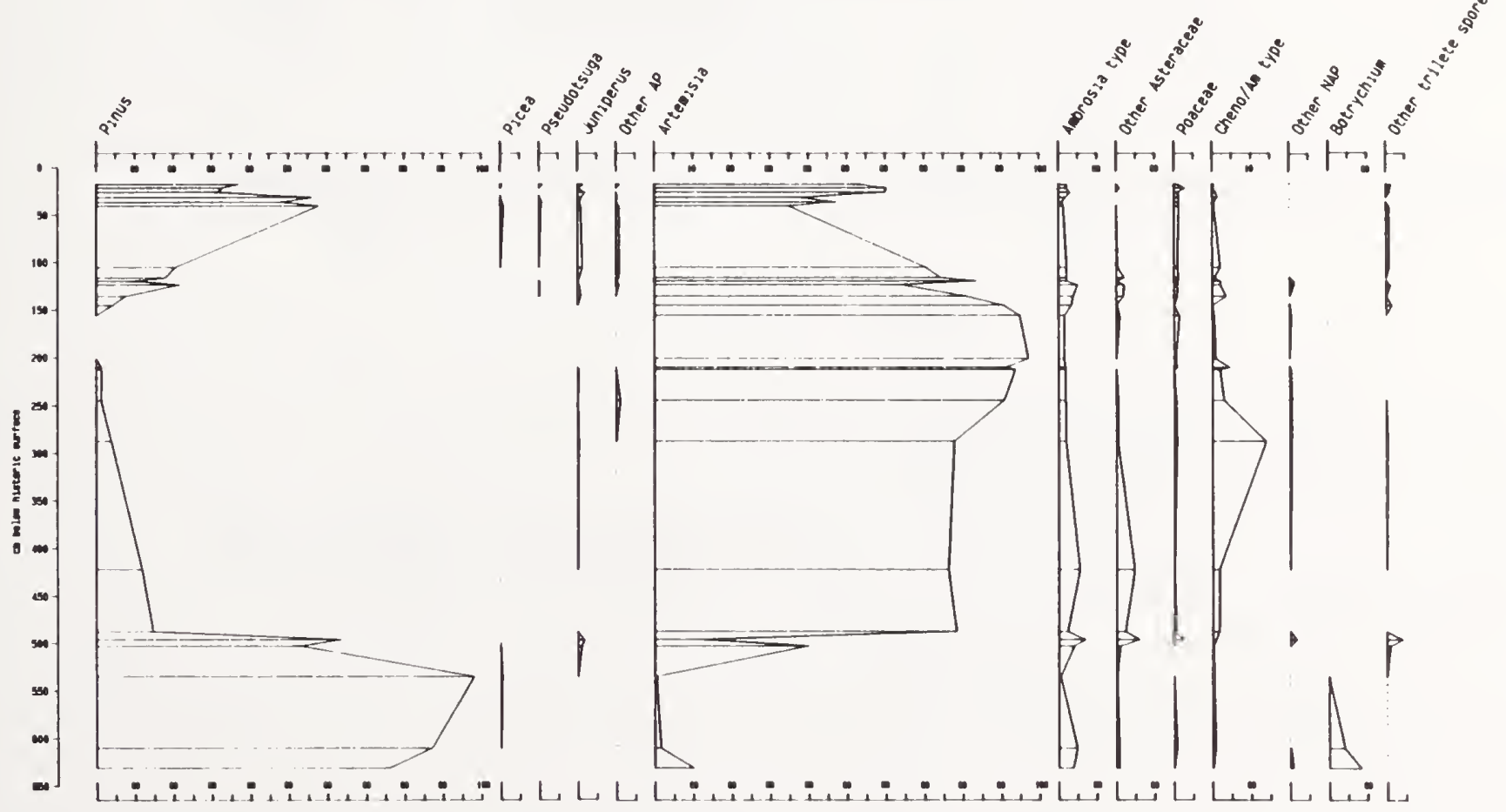

Figure 4. The Indian Creek site pollen diagram (after Fredlund and Bozarth 1987). 


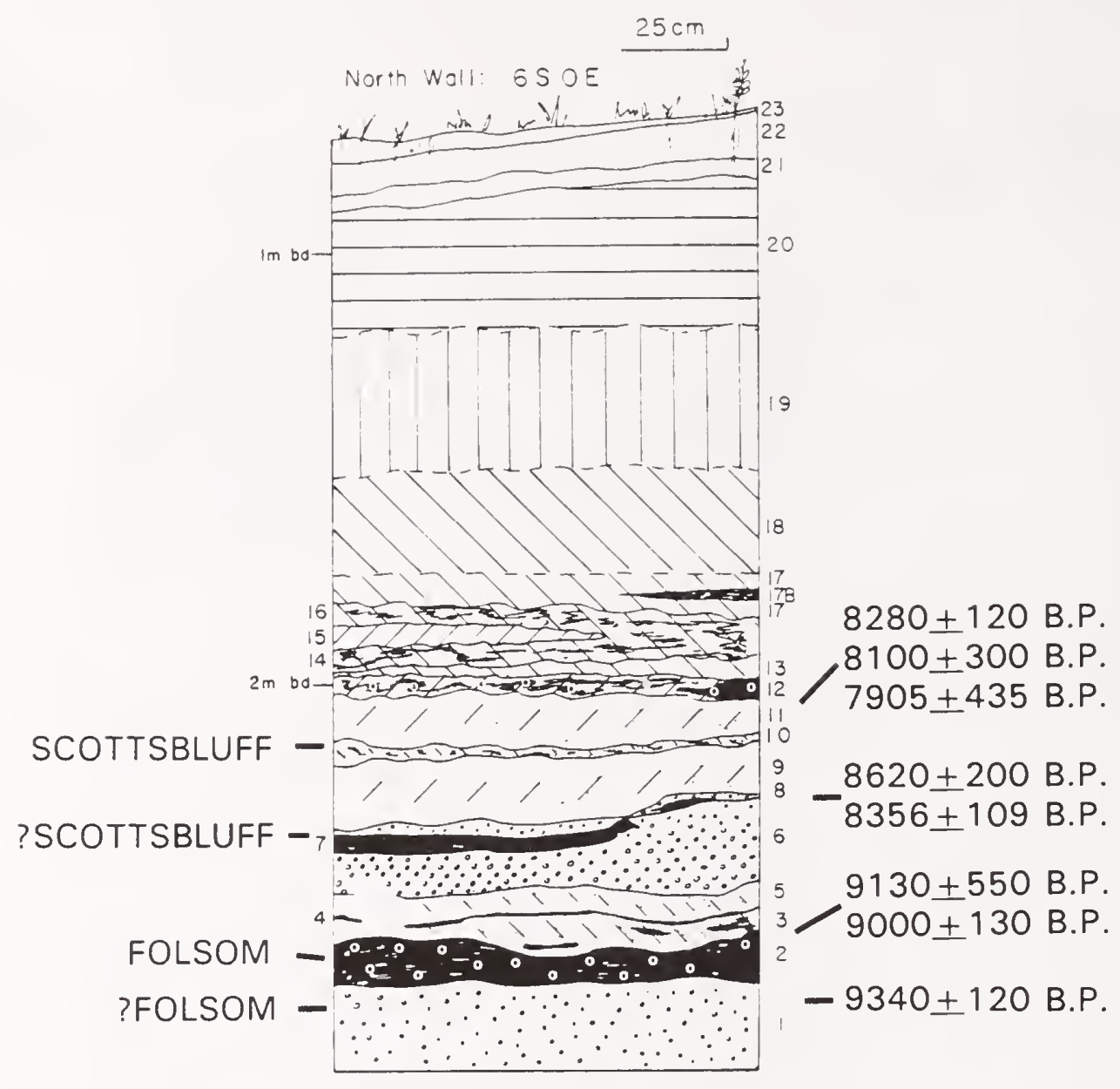

Figure 5. A north wall excavation profile of the MacHaffie site section (by S.A. Aaberg).

In the upper portion of the alluvium, it is clear that the sagebrush-steppe habitat encroached on this portion of the valley floor since Artemisia pollen rises substantially in the upper five samples collected from the alluvium, which suggests at least a lowering of the water table, with a probably associated reduction in stream flow. Occurring immediately after the Scottsbluff occupation, dated at 8,280 B.P., the large increase in sagebrush steppe is consistent with evidence of altithermal conditions and sagebrush-steppe expansion observed elsewhere. The phytolith record indicates the continuation of a well-developed riparian community along the banks of the stream throughout this time period, although the banks do not appear to be as wet then as earlier in the Holocene. The difference noted between the pollen and phytolith records reflects a more regional picture in the pollen record, contrasted with a more local picture in the phytolith record. The riparian community may well have narrowed along the stream, with encroachment of the sagebrush steppe in the valley floor, as represented in the pollen record. There was evidently sufficient moisture in sediments along the stream to continue support of a substantial population of Festucoid-type grasses along the streambanks in the colluvial sediments. 


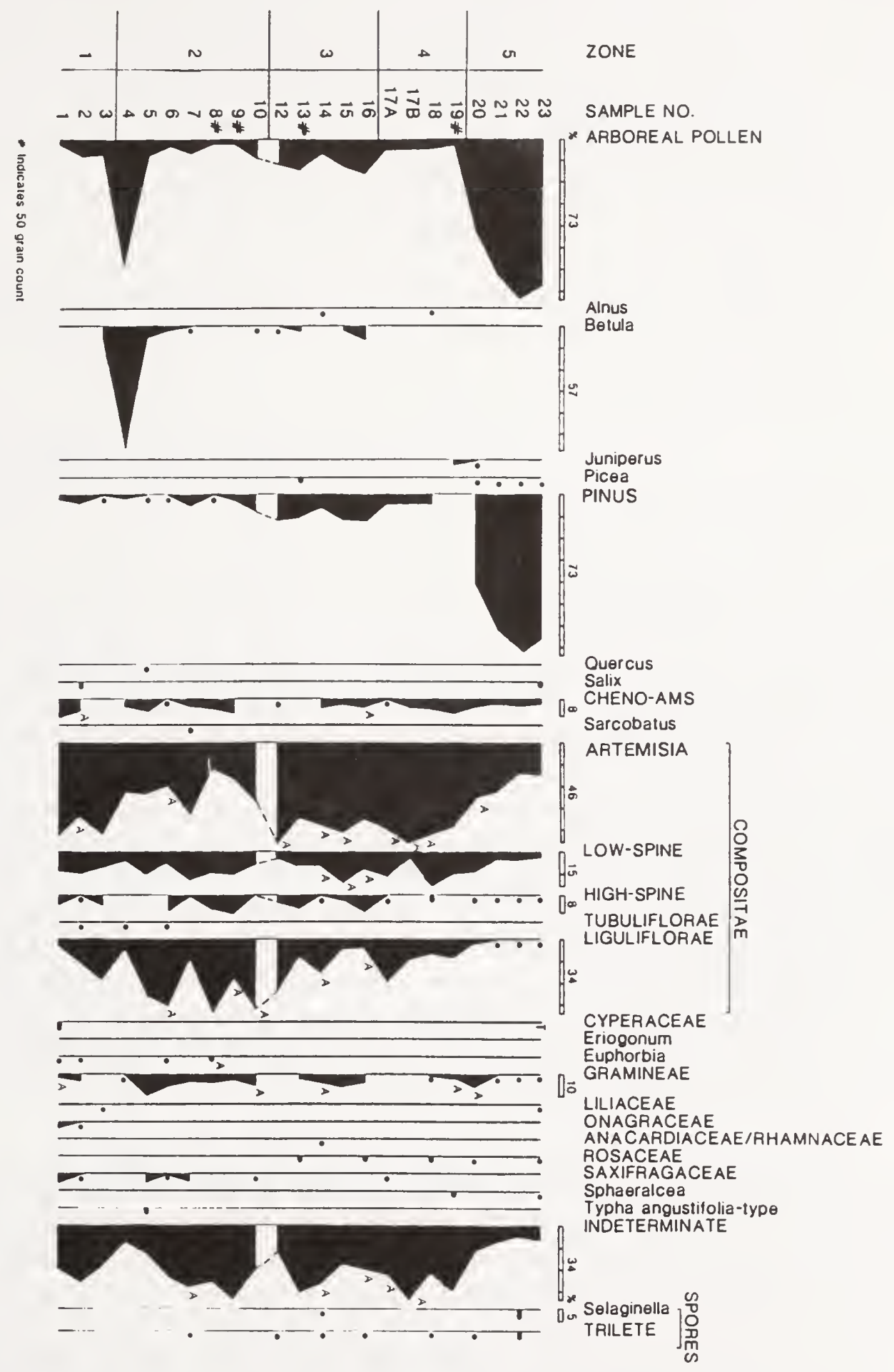

Figure 6. The MacHaffie site pollen diagram (after Cummings 1990a). 
Evidence of continued dry conditions is noted in the colluvial deposits by the retention of the sagebrush-steppe habitat and the decline in both the Liguliflorae-type composites and grass populations in the vicinity of the site. An abrupt change in forested slopes is noted in sample 20, when the sagebrush and all composite pollen decline severely and Pinus pollen increases explosively. These conditions were maintained to the top of the profile, which represents the present. The reduction in diatoms early in the colluvial record, and their absence from the record until nearly the present, suggests drier conditions along the streambank during this period. It is interesting to note, however, that Chloridoid grasses did not establish themselves at this time. Cool-season (Festucoid) grasses dominate the record, with little presence even of the Panicoid grasses that represent warm-season grasses that prefer more moisture.

The pollen and phytolith record reported nearest to the MacHaffie site was developed at the Indian Creek archeological site, approximately $35 \mathrm{~km}$ to the southeast. Exhaustive pollen and phytolith analyses at the Indian Creek site provide a stratigraphic record that extends in time from the Glacier Peak volcanic ashfall (c. 11,125 B.P.) to 300 B.P (Lewis 1986; Fredlund and Bozarth 1987) (figure 2). Two major changes are recorded in the Indian Creek drainage basin vegetation (figure 4). The first occurred around 8,300 B.P., at which time the forest in the site vicinity was apparently replaced by sagebrush steppe. Sagebrush steppe persisted until approximately 4,300 B.P., when open forests gradually replaced the dominant sagebrush steppe of the mid-Holocene (Fredlund and Bozarth 1987).

Fredlund and Bozarth (1987) briefly discuss fire ecology; however, charcoal concentration was not examined at the Indian Creek site because its excessive abundance in the samples prevented a statistically significant optical count. Portions of the charcoal in the Machaffie site samples were routinely removed during the process of extracting pollen and phytoliths from the sediments, thus reducing the utility of optical counts of charcoal for statistical purposes. Two of the samples, however, contained very large quantities of charcoal that could not be removed from the phytolith samples: samples 2 and 4 near the base of the record (figure 6). It is interesting to note that one of these, sample 4, corresponds with the Betula pollen peak. Data reported by Mehringer (1985) indicate that fires were least frequent in western Montana during the Early Holocene (approximately 11,500 to 8,000 B.P.) and more frequent during the altithermal $(8,000$ to 4,800 B.P.). A dramatic increase in fire frequency was recorded during the Late Holocene (1,750 B.P. to Euroamerican settlement). It is possible that the rapid expansion of birch at the MacHaffie site reflects both post-fire succession and increased wet conditions at that time. Local evidence for fire is manifested in the presence of subjectively larger quantities of charcoal in samples 2 and 4 than elsewhere in the site record. In addition, samples 2 through 4 also yielded greater quantities of diatoms, representing the wettest soil conditions during the history of this site.

Identification of a sagebrush steppe representing the altithermal from post-8,300 B.P. to approximately 4,300 B.P. at the Indian Creek site correlates well with the Artemisia maximum recorded at the MacHaffie site. Artemisia increases post-8,200 B.P. and continues until replaced by a large increase in Pinus pollen at the MacHaffie site. This suggests a change in vegetation in both areas around 8,300 B.P., signaling a vegetative response to altithermal conditions.

The pollen records at the MacHaffie and Indian Creek sites compare favorably in their identification of a sagebrush steppe most probably associated with the altithermal between approximately 8,300 B.P. and 4,300 B.P. at the Indian Creek site and between approximately 8,300 B.P. and an as yet unknown recent time period at the MacHaffie site. The rapid increase in Pinus pollen toward the terminus of the record at the MacHaffie site may date to a time period similar to the expansion of forest at the Indian Creek site c. 4,300 B.P. 
Holocene vegetational changes in southwestern Montana - as inferred from the Indian Creek and MacHaffie pollen and phytolith records (Cummings 1990a; Fredlund and Bozarth 1987; Lewis 1986) indicate that, although a response to the mid-Holocene altithermal is usually recognizable, the pattern of response can and does differ from place to place. At higher elevation sites, evidence for moisture stress is usually absent, although signs of climatic warming or lengthening of the growing season are often observed. Changes in vegetation that result from regional altithermal warming and drying are noted somewhat earlier at low elevations than at higher elevations. Early Holocene forest was often replaced by sagebrush steppe around 8,300 B.P., a situation that persisted until C. 4,300 B.P. At that time, steppe forests often gradually replaced the sagebrush steppe. Sagebrush-steppe vegetation representing the altithermal may also displace riparian vegetation. Expansion of the sagebrush steppe appears to have been a common response to changes in paleoenvironmental conditions during the altithermal in southwestern Montana.

\section{Prehistoric Plant Utilization Practices}

For more than three decades, archeologists have assumed that prehistoric Native Americans utilized the rich and varied plant resources of the Northern Rockies. That assumption rests in the scholarly belief that the nearly $\mathbf{3 0 0}$ generations of hunter-gatherers who frequented this region seasonally, as residents or visitors, developed lifeways similar in type to those followed by Native Americans adapted to the region later in historic times. The presumption that plant gathering was a seasonally routine subsistence strategy for prehistoric peoples is amply and persistently demonstrated in the literature (e.g., Bender and Wright 1988; Reeve 1980; Wright 1984; Wright, Bender, and Reeve 1980).

Specification of a typical plant processing tool and feature assemblage, presumptively associated with and/or required for plant processing (i.e., grinding stones and roasting pits or ovens), has led some to infer plant processing from the mere presence of such artifacts and features. In this region, such assumptions are not often supported by the recovery of specifically identifiable utilized plant macrofossils as positive evidence for plant processing and utilization. Often the presence of plants known to have been utilized elsewhere by historic Native Americans, when recognized as available in site localities, has been sufficient for assertion of former plant utilization. Unfortunately, unsupported assertions fail to contribute the substantive data essential for demonstrating plant utilization at archeological sites. A concerted technical effort is inevitably required to develop proof positive evidence for early plant utilization.

Over a period of at least 11,500 years, groups of prehistoric hunter-gatherers did frequent the area and utilize mineral, vegetable, animal, and myriad other natural resources offered by the Northern Rockies ecosystem. The archeological record is replete with evidence for the early selection of minerals for tool production and the remains of game procured for food, bone as toolmaking raw material, and hides for body cover and protection. However, a deficiency of evidence for the patterned utilization of plants for food, industrial, medicinal, and ritual/ceremonial purposes is a consequence of several factors. Limitations are imposed by the variable preservation of utilized plants in the archeological record. The fact that few, if any, durable artifacts or features were necessary for the preparation and consumption of many plant species sets critical limits. Furthermore, the kinds of archeological contexts or catchments that potentially contain essential evidence are rarely found, let alone investigated in detail. Finally, our prevailing inability to adequately predict and recognize trace evidence of early plant selection, collection, and utilization behavior is a basic reality threshold that must be transcended through technical means. 
The notion that prehistoric hunter-gatherers adapted to this region accessed its resources selectively and on a seasonal basis, but did not make significant use of plants is inconceivable in light of the abundant ethnographic and ethnohistoric accounts of plant use by later generations of locally adapted Native Americans. Also, the seasonally scheduled, repetitive selection of a wide spectrum of life-supporting animal and plant resources is inherent in and intrinsic to hunter-gatherer lifeways.

Intensified multidisciplinary field research in the Montana Rockies is beginning to fulfill historically founded logical and intuitive expectations and predictions relative to early plant use by regional hunter-gatherers. This breakthrough of sorts is promising because of the window of research opportunity that has been opened and which can stimulate comparable research. Two prominent and additional examples of the parallel research approaches that have contributed importantly to that development are discussed below.

\section{The Pilgrim Site (24BW675)}

This large-scale open-air occupation site is located in an arid, spring-fed basin within the Limestone Hills (1,510 $\mathrm{m} \mathrm{AMSL})$ on the east flank of the Elkhorn Mountains, west of the Missouri River and $12 \mathrm{~km}$ southwest of Townsend (figure 1). The site was visited and occupied intermittently from 3,400 to 1,400 years B.P. by members of three Late Middle to Late Prehistoric period archeological cultures (Davis 1983; Davis, Aaberg, and Fisher 1980; Davis et al. 1982). Seventy-two stone circles or tipi rings that represent abandoned prehistoric household structures and ephemeral communities survive as evidence of former habitation events. Pilgrim is the most extensive habitation site located during the 24,000 -acre Limestone Hills survey conducted by Montana State University in 1979.

Since only scant remains of bison (Bison bison bison), pronghorn antelope (Antilocapra americana), deer (Odocoileus sp.), and a nestling grouse-sized bird were recovered by excavation, an additional local resource attraction was suspected. A vegetational inventory of the site basin itself identified numerous plant species known to have been utilized by historic Native Americans for various purposes (Aaberg 1983; Davis, Aaberg, and Fisher 1980; Davis et al. 1982). Plant processing features and artifacts are generally believed to be diagnostic for plant utilization. The lack of such features and artifacts, both within and outside stone circles in the encampment, provoked an intensive literature search. The fact that neither specialized tools nor facilities were required for collection or preparation of many utilized plant species soon became obvious.

The recognition of highly productive patches of bitterroot (Lewisia rediviva) and wild parsley (Musineon divaricatum) - in coassociation with numerous other potentially usable plants (table 1) distributionally restricted within the immediate site area (and recognized nowhere else inside the survey area) provoked the advancement of a hypothesis of seasonally selective, multiple species plant food gathering. Such subsistence and settlement behavior would best account for the intermittent but repetitive selection of the Pilgrim site for occupation, most often during spring months (Aaberg 1983, 1991a). Various of the locally represented species were used during one or more seasons for one or more purposes.

The fact that bitterroot is not widespread in the Limestone Hills survey area is consistent with other data that suggest spotty, localized occurrences of bitterroot east of the Continental Divide in Alberta and Montana (Wilson et al. 1988). 
Table 1. Pilgrim site modern plant taxa

\begin{tabular}{|l|}
\hline 78 Species identified \\
45 known subsistence utility \\
32 known medicinal utility \\
23 known ritual and/or industrial utility \\
30 no known human utility \\
\hline Seasonal availability \\
Spring (40) \\
Summer (43) \\
Autumn (35) \\
Winter (11) \\
\hline Principal edible plants (spring harvest) \\
Lewisia rediviva (bitterroot) \\
Musineon divaricatum (wild parsley) \\
\hline
\end{tabular}

\section{The Barton Gulch Site (24MA171)}

The Barton Gulch site, located east of the Ruby River valley at the west base of the Greenhorn Range (1,675 m AMSL) in the upper Missouri River watershed (figure 1), presents an 8-m thick culture-bearing section that contains a 9,400-year-old Late Paleoindian Period Alder Complex occupation. Investigations since 1987 (Davis, Aaberg, and Greiser 1988; Davis et al. 1989) have enabled the detailed study of well-preserved and unequivocal evidence of Paleoindian plant utilization (Aaberg 1991a).

Analysis of pollen from that buried surface and certain subfloor features - intentionally excavated depressions that take several shapes, have varying dimensions, and served multiple functions - suggest that plant cover in the site area differed little 9,400 years ago in structure and appearance from that of modern vegetation (Fredlund 1989): open pine parklands interspersed with patches of sagebrush grassland, the latter dominated by cool-season grasses.

Sixteen systematically spaced, grouped features, or "paleokitchens," made up of 175 individual features organized in varying combinations, were constructed by site occupants to facilitate food preparation and processing. With peripheral superstructures in place, the feature aggregates could also have served a dual function as smokehouses for tanning deerskins and drying meat. In addition to the intensive utilization of deer (Odocoileus sp.), hare (Lepus sp.), and rabbit (Sy/vilagus sp.), several local plant species were collected in the spring to supplement the predominantly high protein and fat diet made possible by consumption of game. Charred-seed grinding slabs and associated handstones and stone anvils and hammerstones associated with bone breakage and marrow extraction were placed and employed within or adjacent to some of the food-processing facilities.

Preliminary analysis of plant macrofossils recovered by flotation, as discarded or wasted residues in abandoned food-preparation features, identified 14 genera or species of utilized and nonutilized plants (Aaberg 1991a) (table 2). The carbonized, often popped seeds of slimleaf goosefoot (Chenopodium leptophyllum) and pricklypear (Opuntia polycantha) represent the predominant plant food species selected, with sunflower (Helianthus sp.), blazing star (Mentzelia sp.), limber pine, and chokecherry 
(Prunus virginiana) represented by fewer charred seeds. Pollen analysis of these sediments identified only sunflower, pricklypear, and sedges (Carex spp.) among those species recognized within the macrofossil suite (Fredlund 1989). Other edible plants identified from pollen - such as huckleberry/blueberry (Vaccinium sp.), wild parsley (Musineon divaricatum), wild onion (Allium canadense), limber pine, a Cheno-am, possibly pigweed (Amaranthus graecizans), and ragweeds (Ambrosia sp.) - are not represented in the macrofossil assemblage. Inherent in the compositional differences noted between these data sets are such factors as differential plant species availability (abundance) in space or seasonality and human needs and preferences regarding plant selection and utilization.

Table 2. Alder complex plant macrofossil taxa

\begin{tabular}{|c|}
\hline $\begin{array}{l}\text { Chenopodium leptophyllum (slimleaf goosefoot) } \\
\text { Opuntia polycantha (pricklypear) } \\
\text { Helianthus sp. (sunflower) }^{\mathrm{b}} \\
\text { Mentzelia sp. (cf. blazing star) }^{\mathrm{b}} \\
\text { Pinus flexilis (limber pine) }^{\mathrm{b}} \\
\text { Prunus virginiana (chokecherry) } \\
\text { Rosa sp. (wild rose) } \\
\text { Sphaeralcea coccinea (scarlet globemallow) } \\
\text { Scirpus americanus (common bullrush) } \\
\text { Carex sp. (sedge) }^{\mathrm{d}} \\
\text { Hypericum sp. (cf. St. John's-wort) } \\
\text { Cuscata sp. (cf. dodder) }^{\mathrm{d}} \\
\text { Stipa viridula (green needlegrass) } \\
\text { Bouteloua gracilis (blue grama) }\end{array}$ \\
\hline
\end{tabular}

\footnotetext{
aPrincipal subsistence plants.

'Secondary subsistence plants.

'Medicinal uses.

Industrial uses associated with food preparation and wood artifact manufacture.

${ }^{\ominus}$ No known human uses. Probably local background species.
}

Still other small-scale glimpses of documented prehistoric plant utilization have been developed recently in montane Montana. Charred seeds from a single partial hearth at the open-air Toston occupation site (24BW182) along the Missouri River upstream from Townsend document the use of juniper (Juniperus sp.), chokecherry, and bedstraw (Galium trifidum) at a Late Prehistoric Period site dated c. 1,400 - 1,800 A.D. (Aaberg 1988; Herbort 1988). Plant processing artifacts, other than the hearth itself, were lacking. The casual exploitation of a variety of plants was also documented at site 24MA557, along the Madison River some $10 \mathrm{~km}$ east of the Barton Gulch site. Charred macrofloral remains of pigweed, wild mustard (cf. Brassica sp.), slimleaf goosefoot, fescue (Festuca sp.), bedstraw, false pennyroyal (Hedeoma sp.), sunflower, lupine (Lupinus sp.), and wild rose (Rosa sp.) were recognized in features at this Late Prehistoric Period occupation site (Aaberg 1991b; Deaver 1991). No plant collection or processing paraphenalia were recovered in association. 
Such small-scale glimpses as these instances of archeologically inspired plant use identification are valuable for elaborating the detailed historical and single-event records resulting from larger scale investigations.

\section{Research Implications}

This paper presents a brief overview of findings developed principally from four archeological investigations conducted in Northern Rockies settings within Montana over the past decade. These projects contribute primary contextual evidence useful for reconstructing local and regional scale vegetational histories and demonstrating intersite variability in that regard and for elucidating the nature, role, and significance of prehistoric human plant use practices. Results from the Pilgrim site research are fully published (Aaberg 1983; Davis 1983), while the Indian Creek and MacHaffie project reports have been published (Davis and Greiser 1991; Davis et al. 1991) or accepted for publication. Barton Gulch field research, only initially published (Davis, Aaberg, and Greiser, 1988; Davis et al. 1989), is scheduled for a sixth season of investigation in 1992. This remarkable site affords a singular opportunity to study human plant utilization in the context of a well-preserved, radiocarbon-dated, and multispecies bioarcheological record at a large-scale Late Paleoindian Period base camp.

Certain of the more salient benefits of these archeological projects are particularly relevant for improving our understanding of the Greater Yellowstone ecosystem as it was exploited by early peoples. The temporally long stratigraphic sequences, punctuated at intervals by evidence of discrete, buried, radiocarbon-dated campsites, enable both historical and single-event studies of local vegetation and, less often, of prehistoric plant utilization. Variation and change in human and plant niche expressions can be examined in historical perspective, following proscriptions such as those of Crites (1987). Such data can serve as the basis for formulating and testing vegetation-related propositions. Vegetation-oriented research in Yellowstone would be enriched by approaches that ask questions regarding the human utilization of and effects on plant communities. Harvested root crops added carbohydrates, fiber, and vitamins; seeds contributed fat and protein; and herbaceous parts supplied vitamins and mineral supplements to the daily fare. Among plant-using hunter-gatherers, what fraction of the diet was provided by gathering and at what labor cost? The subsistence significance of plant gathering relative to the nutritional contribution of hunting is not yet understood.

The long-term, if seasonal, Holocene occupation of the region by hunter-gatherers clearly involved many landscapes and the use of diverse mineral, faunal, floral, and associated resources. Which game species were available and exploited, or not exploited? Did hunting affect game species population numbers? Did early peoples set fires to rejuvenate once-attractive summering/wintering ranges? Did the selective gathering of plants, if it can be documented, affect the distribution, composition, and productivity of affected plant species? These questions should be followed by sustained, on-the-ground inquiry to find satisfactory answers.

Only a few archeological investigations in Yellowstone have addressed the paleoecological and vegetational aspects of excavated culture-bearing deposits by applying palynological and other plant identification techniques, e.g., Marceau and Reeve (1984), Cummings (1991), Cannon (1991), and Cannon and Phillips (1990).

A recent enumeration of the Yellowstone vegetational suite and plant ecology (Despain 1990) demonstrated that Yellowstone is a natural cornucopia of plants desired and selected by Native American 
consumers of both the prehistoric and ethnohistoric pasts. Knowledge and public appreciation of the Greater Yellowstone Region can be enhanced significantly by the co-application of historical approaches to understanding the roles played by plants in human life and, conversely, the effects that such utilization may have had on exploited plant communities.

Identification of local and regional vegetation through combined pollen, phytolith, and macrofloral sampling is recommended for the Greater Yellowstone Region. The interpretation of paleoenvironmental conditions and studies of prehistoric vegetation may be accomplished through analysis of stratigraphic samples drawn from lakebeds and bogs and directly from areas where people lived through analysis of stratigraphic samples taken within and near archeological sites. Identification of specific plants and animals used by peoples of the Greater Yellowstone Region should be addressed through pollen and macrofloral analysis of feature content and tools. Blood residue studies will also contribute to a better understanding of the exploitation of animals and tool utilization. Studies addressing specific tool use within the boundaries of Yellowstone National Park, while few (Cummings 1991; Newman 1991), indicate that groundstone implements were not always used only for grinding plant parts. Pollen and macrofloral evidence for the utilization of features, which is likewise rare (Cummings 1990b), indicates that prickly pear cactus (Opuntia sp.), grass seeds, a member of the Liguliflorae portion of the Asterace family, and possibly a member of the Cheno-am (Chenopodiaceae or Amaranthus sp.) were processed. Charcoal recovered from features documents that local trees, such as pine (Pinus sp.) and birch (Betula sp.), were used for fuel by prehistoric site occupants. Comparison of charcoal recovered with the pollen record provides insight regarding the preferential exploitation of local plant resources. In one instance, pine (Pinus sp.) was selected over locally abundant alder (Alnus sp.) and birch (Betula sp.). Comparison of evidence for utilization with stratigraphic evidence for local vegetation and ecotones will assist in understanding movements of people within and through this region. It will also assist in interpreting prehistoric resource use and site location strategies. The vegetation of the Greater Yellowstone Region is inextricably bound with human use of the area and can be better understood through expanded study of human-plant-animal relationships during the 11,500-year Northern Rockies Prehistoric Period.

\section{Acknowledgments}

The Montana State University-Museum of the Rockies research addressed in this paper was supported variously by Joe and Ruth Cramer (Denver), the Kokopelli Archeological Research Fund, the Montana Department of Military Affairs, the State Historic Preservation Office, the National Science Foundation (BNS-8508068), the Museum of the Rockies, and the MSU offices of the president and the vice president for research and creativity. We are grateful for their support and to our coworkers and collaborators over the past decade for their energetic, enthusiastic, and effective participation. We are indebted to the owners of the properties on which the Indian Creek site, the MacHaffie site, and the Barton Gulch site are located (Nyla Tyrrel and John Wright, Pamela Bompart, and Harold Kelly, respectively) for their generosity and hospitality. Diane Fuhrman typed this manuscript. Anonymous reviewers and John W. Fisher, Jr., provided constructive and useful criticisms that inspired improvements in the readability of this article. We remain, however, responsible for judgments and interpretations conveyed herein. 


\section{Literature Cited}

Aaberg, S.A. 1983. Plant gathering as a settlement determinant at the Pilgrim stone circle site. Pages 279-303 in L.B. Davis, ed., From microcosm to macrocosm: advances in tipi ring investigation and interpretation. Memoir 19, Plains Anthropologist. Lincoln, Nebraska.

Aaberg, S.A. 1988. Flotation analysis and plant macrofossils from the Toston site (24BW182). Contract report to G.C.M. Services, Inc., Butte, Montana.

Aaberg, S.A. 1991a. The archeological record of plant use from Montana. Paper presented at the Thirty-Fourth Annual Meeting of the Montana Archeological Society in Billings, Montana.

Aaberg, S.A. 1991b. Plant remains for 24MA557. Appendix 7 in K. Deaver, ed., Mitigation of sites 24MA225 and 24MA557, Beartrap Canyon, Montana. Report by Ethnoscience of Billings, Montana, to the Montana Department of Highways, Helena, Montana.

Baker, R.G. 1970. Pollen sequence from Late Quaternary sediments in Yellowstone Park. Science 1968:1449-1460.

Baker, R.G. 1983. Holocene vegetational history of the western United States. Pages 109-127 in H.E. Wright, Jr., ed., Late-quaternary Environments of the United States, Vol. II. The Holocene. University of Minnesota Press, Minneapolis, Minnesota.

Barnosky, C.W. 1989. Postglacial vegetation and climate in the northwestern Great Plains of Montana. Quaternary Research 31:57-73.

Bender, S.J. and G.A. Wright. 1988. High-altitude occupations, cultural process, and High Plains prehistory. American Anthropologist 90(3):619-639.

Cannon, K.P. 1991. Site testing along the north shore of Yellowstone Lake, Yellowstone National Park, Wyoming. Ms. on file with the Rocky Mountain Regional Office, National Park Service, Denver, and the Midwest Archeological Center, National Park Service, Lincoln, Nebraska.

Cannon, K.P. and P. Phillips. 1990. Post-fire inventory and survey of archeological sites in Yellowstone National Park, Wyoming. Draft ms. by the Midwest Archeological Center, Lincoln, Nebraska.

Crites, G.D. 1987. Human-plant mutualism and niche expression in the paleoethnobotanical record: a Middle Woodland example. American Antiquity 52:725-740.

Cummings, L.S. 1990a. Pollen and phytolith analysis at the MacHaffie Paleoindian site (24JF4), west-central Montana. Ms. on file with the Museum of the Rockies, Montana State University, Bozeman, Montana.

Cummings, L.S. 1990b. Pollen analysis at 24 YE353 and MWAC 89-22, along the Yellowstone River, Montana. Ms. on file with the Midwest Archeological Center, National Park Service, Lincoln, Nebraska.

Cummings, L.S. 1991. Pollen analysis at 48YE701. Appendix B in Site testing along the north shore of Yellowstone Lake Yellowstone National Park, Wyoming, by K.P. Cannon. Ms. on file with the Rocky 
Mountain Regional Office, Denver, and the Midwest Archeological Center, National Park Service, Lincoln, Nebraska.

Davis, L.B. 1983. Stone circles in the Montana Rockies: relict households and transitory communities. Pages 235-278 in L.B. Davis, ed., From microcosm to macrocosm: advances in tipi ring investigation and interpretation. Memoir 19, Plains Anthropologist. Lincoln, Nebraska.

Davis, L.B. 1984. Late Pleistocene to mid-Holocene adaptations at Indian Creek, west-central Montana Rockies. Current Research in the Pleistocene 1:9-10. Center for the Study of Early Man, University of Maine-Orono.

Davis, L.B., S.A. Aaberg, W.P. Eckerle, J.W. Fisher, Jr., and S.T. Greiser. 1989. Montane Paleoindian occupation of the Barton Gulch site, Ruby Valley, southwestern Montana. Current Research in the Pleistocene 6:5-7. Center for the Study of the First Americans, University of Maine-Orono.

Davis, L.B., S.A. Aaberg, and J.W. Fisher, Jr. 1980. Cultural resources in the Limestone Hills Montana Army National Guard Training Site, Broadwater County, Montana. Report to the Montana Department of Military Affairs, Helena, Montana, by Montana State University, Bozeman, Montana.

Davis, L.B., S.A. Aaberg, and S.T. Greiser. 1988. Paleoindians in transmontane southwestern Montana: the Barton Gulch occupations, Ruby River drainage. Current Research in the Pleistocene 5:9-11. Center for the Study of Early Man, University of Maine-Orono.

Davis, L.B., S.A. Aaberg, M. Wilson, and R. Ottersberg. 1982. Stone circles in the Montana Rockies: systematic recovery and culture-ecological inference. Report to the Montana Department of Military Affairs by Montana State University, Bozeman, Montana.

Davis, L.B., J.P. Albanese, L.S. Cummings, and J.W. Fisher, Jr. 1991. Reappraisal of the MacHaffie Paleoindian occupational sequence. Current Research in the Pleistocene 8:17-20. Center for the Study of the First Americans, Oregon State University.

Davis, L.B. and S.T. Greiser. 1991. Indian Creek Paleoindians: early occupation of the Elkhorn Mountains, southeast flank, west-central Montana. Pages 225-283 in D.J. Stanford and J.S. Day, editors, Ice Age Hunters of the Rockies. Denver Museum of Natural History and University of Colorado Press, Niwot, Colorado.

Davis, L.B., S.T. Greiser, and T.W. Greiser. 1987. Spring cleanup at a Folsom campsite in the Montana Rockies. Current Research in the Pleistocene 4:5-6. Center for the Study of Early Man, University of Maine-Orono.

Deaver, K. 1991. Mitigation of sites 24MA225 and 24MA557, Beartrap Canyon, Montana. Report by Ethnoscience of Billings, Montana, to the Montana Department of Highways, Helena, Montana.

Despain, D.G. 1990. Yellowstone vegetation: consequences of environment and history in a natural setting. Roberts Rinehart, Boulder, Colorado.

Forbis, R.G. and J.D. Sperry. 1952. An early man site in Montana. American Antiquity 18:127-133. 
Fredlund, G.G. 1989. Preliminary analysis of pollen and opal phytoliths from the initial late Paleoindian occupation at the Barton Gulch site (24MA171), Montana. Ms. submitted to the Department of Sociology at Montana State University, Bozeman, Montana.

Fredlund, G.G. and S. Bozarth. 1987. A Holocene alluvial pollen record from the Indian Creek archeological site, Montana. Ms. on file with the Department of Sociology, Montana State University, Bozeman, Montana.

Herbort, D. 1988. Excavation and mitigation of the Toston site, 24BW182, Broadwater County, Montana. Contract report by G.C.M. Services, Inc., Butte, Montana, to the Montana Department of Natural Resources and Conservation, Helena, Montana.

Lewis, R.O. 1986. Phytolith results from the Indian Creek site, Montana. Ms. submitted to the Department of Sociology at Montana State University, Bozeman, Montana.

Mack, R.N., N.W. Rutter, and S. Valastro. 1983. Holocene vegetational history of the Kootenai River valley, Montana. Quaternary Research 20(2):177-193.

Marceau, T.E. and S.A. Reeve. 1984. Data recovery and analysis at Chittenden Bridge (48YE516), Yellowstone National Park, Wyoming. Draft mitigation report to the National Park Service by the State University of New York at Albany.

Mehringer, P.J. 1985. Late-Quaternary pollen records from the interior Pacific Northwest and northern Great Basin of the United States. Pages 167-168 in V.M. Bryant, Jr. and R.G. Holloway, editors, Pollen Records of Late-Quaternary North American Sediments, American Association of Stratigraphic Palynologists Foundation, Dallas, Texas.

Mehringer, P.J., S.F. Arno, and K.L. Peterson. 1977. Postglacial history of Lost Trail Pass Bog, Bitterroot Mountains, Montana. Arctic and Alpine Research 9(4):345-368.

Newman, M.E. 1991. Residue analysis of a grinding stone from Yellowstone Lake, Wyoming. Appendix A in Site testing along the north shore of Yellowstone Lake, Yellowstone National Park, Wyoming, by K.P. Cannon. Ms. on file with the Rocky Mountain Regional Office, National Park Service, Denver, and Midwest Archeological Center, Lincoln, Nebraska.

Reeve, S.A. 1980. Ethnobotany and archaeology in Yellowstone and Grand Teton National Parks. Pages 362-380 in Proceedings of the Conference on Scientific Research in the National Parks, Vol 1. National Technical Information Service, Springfield, Virginia.

Waddington, J.C.B. and H.E. Wright, Jr. 1974. Late Quaternary vegetational changes on the east side of Yellowstone National Park. Quaternary Research 4:175-184.

Whitlock, C. 1990. Late-Quaternary vegetational history of the Yellowstone region. Final report of the University of Wyoming-National Park Service Research Center. Laramie, Wyoming.

Wilson, M.C., L.V. Hills, B.O.K. Reeves, and S.A. Aaberg. 1988. Bitterrott, Lewisia rediviva, in southwestern Alberta: cultural versus natural dispersed. Canadian Field-Naturalist 102(3):515-522. 
Wright, G.A. 1984. People of the high country: Jackson Hole before the settlers. American University Studies, Series 11, Vol. 7. Peter Lang, New York, New York.

Wright, G.A., S. Bender, and S.A. Reeve. 1980. High country adaptations. Plains Anthropologist 25(89):181-197. 


\title{
Bioenvironmental Representativeness of Nature Preserves: Assessment Using a Combination of a GIS and a Rule-based Model
}

\author{
Robert L. DeVelice' \\ Montana Natural Heritage Program \\ 1515 East 6th Avenue \\ Helena, MT 59620 \\ Gerald J. Daumiller \\ Montana Natural Resources Information System \\ 1515 East 6th Avenue \\ Helena, MT 59620 \\ Patrick S. Bourgeron \\ The Nature Conservancy \\ 2060 Broadway, Suite 230 \\ Boulder, CO 80302 \\ John O. Jarvie \\ Montana Natural Resources Information System \\ 1515 East 6th Avenue \\ Helena, MT 59620
}

\begin{abstract}
Identification of ecologically significant types and acquisition of representative sets of preserves are important objectives in nature conservation. A combination of a Geographic Information System (GIS) and a rule-based model were used to evaluate preserves in a 200,000-hectare (ha) $(500,000$-acre) area in western Montana. The climatic and soil attributes hypothesized to have the most direct influence on plant species growth and survival (i.e., moisture regime, temperature regime, and soil fertility) were aggregated in a bioenvironmental classification. A map of the resultant bioenvironmental types was generated. Existing preserve boundaries were overlaid on this map. These preserves cover 32 percent of the study area. Gaps in the representation of bioenvironmental types were identified. Results indicate that 96 percent of the preserve acreage is cold limited and 98 percent of the nonpreserve acreage is water limited. Thus, cold-limited environments (mostly high elevations) are well represented in the existing preserve network, and
\end{abstract}

'Present address: USDA Forest Service, Chugach National Forest, 201 East 9th Avenue, Suite 206, Anchorage, AK 99501. 
water-limited environments (mostly low elevations) are poorly represented. Use of these methods in the Greater Yellowstone ecosystem (GYE) would allow rapid bioenvironmental analysis and representativeness planning of the entire 7.7 million ha (19 million acres).

Primary challenges in nature conservation include identification of ecologically significant types and establishment of nature preserve networks that represent biodiversity in a region. We tested a methodology that provides for both of these needs through use of an explicit and repeatable combination of a GIS and a rule-based environmental model.

The methods used are modified from those effectively used in Australia by Mackey et al. (1988, 1989). Specifically, our study evaluated the adequacy of existing preserves (i.e., wilderness areas and natural areas) in representing the range of bioenvironments within a 200,000-ha $(500,000$-acre) area in western Montana. The same methods could be efficiently and effectively applied to much larger areas, e.g., the 7.7 million-ha (19 million-acre) GYE of Wyoming, Montana, and Idaho.

In addition to applications in representativeness assessment, the procedures used will be useful in locating such ecologically significant sites as those with rare bioenvironmental combinations and potential habitat for threatened, endangered, and sensitive (TES) species.

\section{Methods}

\section{Study Area}

The area studied is located in the upper Blackfoot River region of western Montana. The rectangular area extends from $112^{\circ} 52^{\prime} 30^{\prime \prime} \mathrm{W}$ in the east to $113^{\circ} 30^{\prime} \mathrm{W}$ in the west and from $47^{\circ} \mathrm{N}$ in the south to $47^{\circ} 22^{\prime} 30^{\prime \prime} \mathrm{N}$ in the north. This area ranges in elevation from 1,150 $\mathrm{m}-2,775 \mathrm{~m}(3,800-9,100$ feet $)$ and includes forbland, grassland, shrubland, and forested vegetation types.

Nature preserves in the area include all of the Pyramid Peak Research Natural Area, the southern portion of the Bob Marshall Wilderness Area, and the southwestern portion of the Scapegoat Wilderness Area.

\section{Rule-based Model}

This study required making a bioenvironmental classification of over 15,500 sample points. One method of doing this is through the use of cluster analysis (Mackey et al. 1988). While statistical clustering may be effective, convenient, and objective, such procedures have ecological problems. Primary among these is the fact that the aggregates produced may not be ecologically meaningful since no functional logic is present in the statistical model (Coughlan and Running 1989).

The present study used an alternative strategy that generates bioenvironmental aggregates based on ecological knowledge rather than statistical properties. Our procedure is a modification of the Coughlan and Running (1989) method. General knowledge of factors controlling species survival and growth were coded as rules in a computer model to aggregate environmental data. The goal of this rule-based classification was to preserve ecologically meaningful information in the aggregates while reducing the data to a manageable amount. 
Our model is based on the theory that species survival and growth are primarily a function of moisture, temperature, radiation, and nutrient regimes (Nix 1982) and that biotic patterns are primarily determined by those environmental requirements that are in the least supply (i.e., Law of the Minimum; see Coughlan and Running 1989). Thus, for each of the more than 15,500 sample points, the rule-based model estimated the magnitude of soil water limitations, temperature limitations, and soil fertility limitations and classified each point based on this diagnosis. Adjacent sample points belonging to the same class were ultimately aggregated in a GIS to form bioenvironmentally based landscape units.

Soil water limitations are based on the fact that little effective summer precipitation occurs in the study area and that most effective soil water recharge is the result of snow melt (Nemani and Running 1989; Weaver 1980). Thus, soils with higher available water-holding capacities retain more water for vegetation growth throughout the summer. Temperature limitation estimates are based on the hypothesis that species range limits are strongly influenced by temperature extremes and growing season length (Botkin, Janak, and Wallis 1972). Soil fertility limitations are based on nutrient supply indices for given soil types (Mackey et al. 1988, 1989).

Using Arc/Info GIS software and a 1:250,000 scale digital elevation model, elevation, slope, and aspect values were recorded for the 15,500 points on an approximately $345 \times 345 \mathrm{~m}$ grid $(1,125 \times 1,125$ feet). Similarly, for the same grid points, indices of available soil water-holding capacity (SWHC) and soil fertility were derived from the 1:250,000 scale STATSGO database (STATSGO 1991). For each soil map unit, the SWHC indices are estimates of SWHC in the top $50 \mathrm{~cm}$ (20 inches) of the soil profile and soil fertility indices are estimates of cation exchange capacity in the top $50 \mathrm{~cm}$.

The rule-based model was used to classify soil moisture limitations, temperature limitations, and soil fertility limitations for each grid point based on the elevation, slope, aspect, SWHC, and soil fertility data (Note: solar radiation regime was factored into the model through indirect effects on the soil water and temperature regimes).

Table 1 provides a partial listing of the rules contained in the model. Degree of membership values for each variable are defined using graphs such as those presented in figure 1. For example, a slope of 50 percent has a degree of membership value of 0.2 , indicating low relevancy to the concept of "steep slope" whereas a 100 percent slope has a value of 1.0, indicating an absolutely steep slope. The form of the curves in these graphs was selected to minimize the likelihood of the model indicating a particular factor is limiting when, in fact, it is not (i.e., to minimize Type I error).

Output of the rule-based model is a bioenvironmental classification based on the three values per grid point, i.e., one value each for soil moisture limitations, temperature limitations, and soil fertility limitations, respectively. Since there are 11 levels of each of the three factors and $11^{3}$ equals 1,331 possible combinations, it was desirable to simplify the classification by aggregating factor levels to $3^{3}$ (i.e., 27 possible combinations). The following aggregation was used:

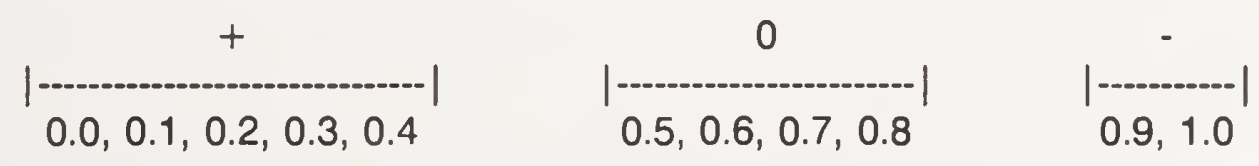

A " +" is used to indicate no limitation, a "0" indicates slight limitation, and a "-" indicates strong limitation. The diagnosis $(.2,9, .1)$ belongs to the diagnostic class $(+-+)$. In this study only 18 of the 27 possible classes were actually represented in the study area (table 2 ). 
Table 1. Partial listing of model rules

\section{Soil Water and Temperature Limitations}

$\underline{\text { Initial rules - temperature }}$

1 if elevation is low $(0.3)^{1}$

then temperature is warm $(0.3)$

2 if elevation is high $(0.7)^{2}$

then minimum temperature is cold $(0.7)$

3 if aspect is north $(0.9)^{3}$ and slope is steep $(0.8)^{4}$

then radiation is low $(0.8)^{5}$

4 if radiation is low $(0.8)$

then temperature is $\mathrm{cool}(0.8)$

5 if temperature is $\mathrm{cool}(0.5)^{6}$

then growing degrees are few (0.5)

6 if growing degrees are few (0.5)

then growing season is short (0.5)

Initial rules - soil water

7 if elevation is low (0.3)

then annual precipitation is low (0.3)

8 if annual precipitation is low (0.3) then snowpack is low (0.3)

9 if snowpack is low (0.3)

then soil water is low (0.3)

10 if radiation is low (0.8) or temperature is cool (0.5) then snowmelt is slow $(0.8)^{7}$

11 if snowmelt is slow (0.8) then soil water is high (0.8)

Terminal rules/final diagnosis - soil water

12 if soil water-holding capacity is low (1.0) ${ }^{8}$ then soil water limitation is supported (1.0)

13 if soil water is high $(0.5)^{9}$

then soil water limitation is unsupported (0.5)

soil water limitation is supported $(0.5)^{10}$ 
Table 1. Partial listing of model rules (cont.)

Terminal rule/final diagnosis - temperature

14 if growing season is short $(0.5)$ or minimum temperature is cold $(0.7)$ then temperature limitation is supported $(0.1)^{11}$

Soil Fertility Limitation (final diagnosis)

15 soil fertility limitation is supported $(0.1)^{12}$

\section{Combined final diagnosis}

$(.5, .7, .1)$ for water limitation, temperature limitation, and fertility limitation, respectively. In this case, soil moisture is indicated as being slightly limiting at the site, temperature is strongly limiting (cold), and soil fertility is not limiting.

1 Value associated with 7,000 feet in figure 1.

${ }^{2}$ Maximum value - value from rule \#1 (i.e., 1 -.3 = .7).

${ }^{3}$ Value from graphic representation of aspect (not shown).

${ }^{4}$ Value associated with $90 \%$ slope in figure 1.

${ }^{5}$ The smaller of .8 and .9 .

${ }^{6}$ Value from rule \#4 - value from rule \#1 (i.e., . 8 - $.3=.5$ ).

7 The larger of .5 and .8.

${ }^{8}$ Value from graphic representation of soil water holding capacity (not shown).

${ }^{9}$ Value from rule \#11 - value from rule \#9 (i.e., . 8 - .3 = .5).

${ }^{10}$ Value from rule \#12 - value from rule \#13 (i.e., 1 - .5 = .5).

11 The larger of .5 and .7.

${ }^{12}$ Value from graphic representation of soil fertility (not shown).

Note: Example degree of membership values for elevation (rules 1,2, and 7), slope (rule 3), aspect (rule 3), soil water-holding capacity (rule 12), and soil fertility (rule 15) are in parentheses. These values are carried forward in the model as new variables are asserted. Loosely based on Coughlan and Running (1989).

\section{Representativeness Assessment}

Arc/Info GIS software was used to generate maps of the bioenvironmental classes at about 12 ha resolution (30 acres). The area occupied by each of the bioenvironmental classes was evaluated for both the total study area and existing preserves. These were compared to judge how well the existing preserves represent the bioenvironmental diversity of the area.

\section{Results and Discussion}

Of the 182,752 ha $(451,664$ acres) in the study area, 32 percent are included in preserves (table 2). Most of the preserved land is in the Bob Marshall and Scapegoat wilderness areas. 


\section{Representation of Low Elevation}

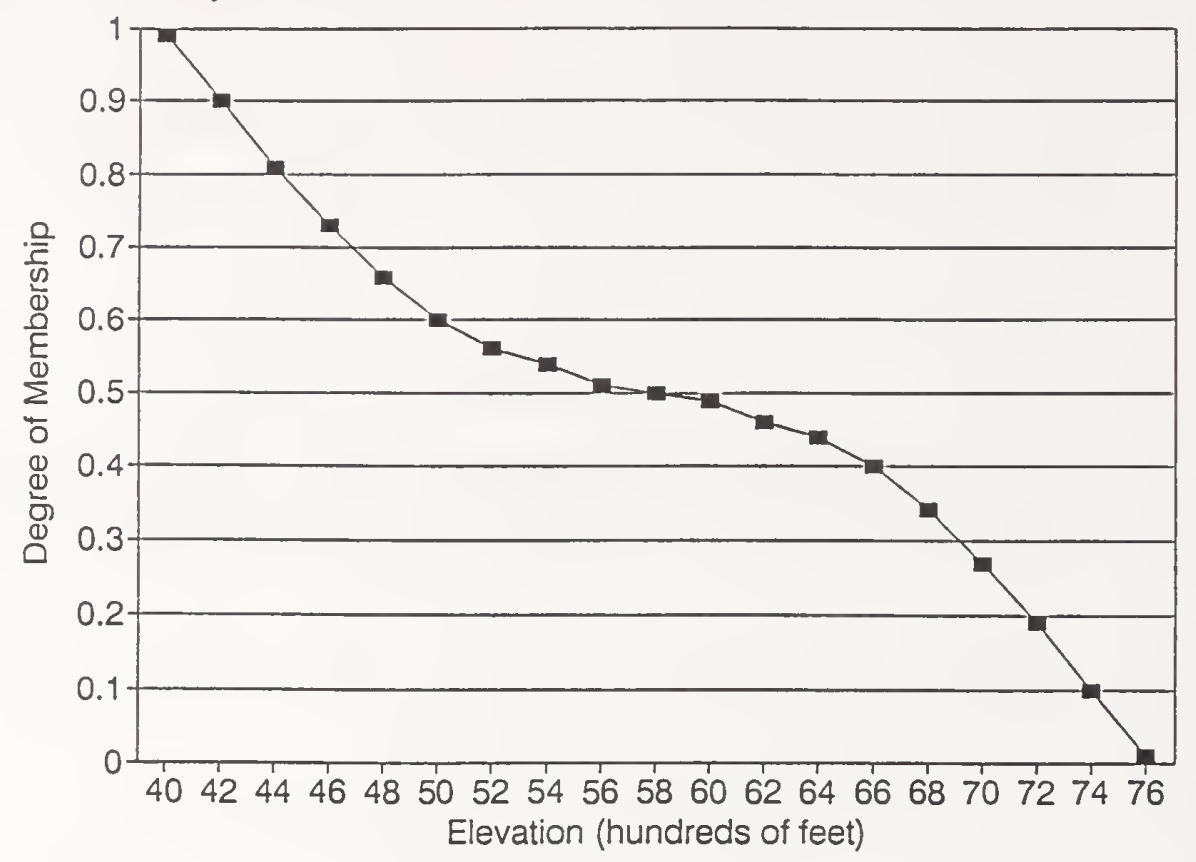

\section{Representation of Steep Slope}

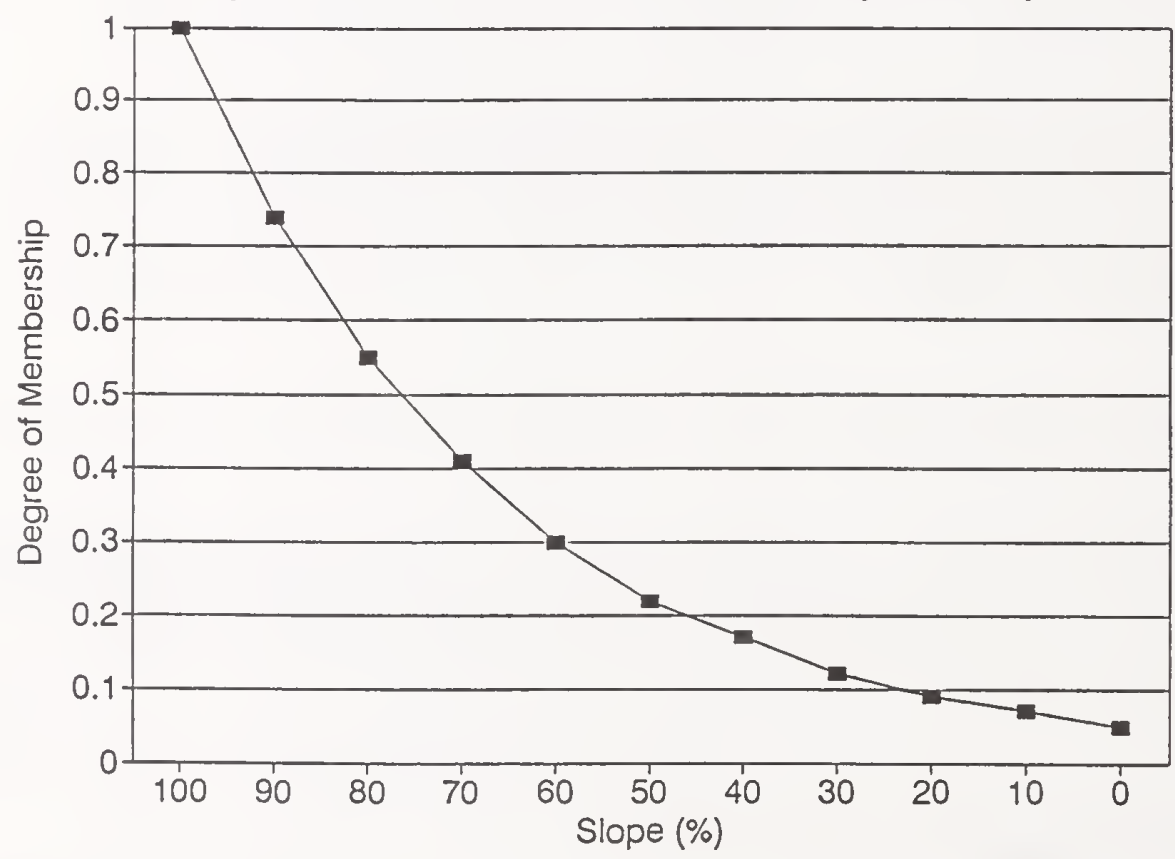

Figure 1. Graphic representations of elevation and slope. Lognormal curves similar to that used for elevation were developed for aspect. Exponential curves similar to that used for slope were developed for available soil water-holding capacity and soil fertility. 
Table 2. Area occupied by each of the 18 bioenvironmental classes in both the total study area and within preserves

\begin{tabular}{|c|c|c|c|c|c|c|c|}
\hline & & \multicolumn{2}{|c|}{ Total Area } & \multirow[b]{2}{*}{$\%$} & \multicolumn{2}{|c|}{ Presenve Area } & \multirow[b]{2}{*}{$\%$} \\
\hline \multicolumn{2}{|c|}{ Class $^{1}$} & hectares & acres & & hectares & acres & \\
\hline 1 & +++ & 10,182 & 25,160 & 5.6 & 1,530 & 3,781 & 2.6 \\
\hline 2 & ++0 & 10,448 & 25,816 & 5.7 & 238 & 589 & 0.4 \\
\hline 3 & $+0+$ & 43,449 & 107,362 & 23.8 & 22,962 & 56,739 & 39.0 \\
\hline 4 & $0++$ & 13,524 & 33,418 & 7.4 & 24 & 60 & 0.0 \\
\hline 5 & ++- & 5,850 & 14,454 & 3.2 & 86 & 212 & 0.1 \\
\hline 6 & +-+ & 11,243 & 27,782 & 6.2 & 6,905 & 17,061 & 11.7 \\
\hline 7 & -++ & 7,260 & 17,938 & 4.0 & 0 & 0 & 0.0 \\
\hline 8 & +00 & 17,514 & 43,277 & 9.6 & 2,982 & 7,368 & 5.1 \\
\hline 9 & $0+0$ & 14,167 & 35,006 & 7.8 & 486 & 1,201 & 0.8 \\
\hline 10 & $00+$ & 2,374 & 5,865 & 1.3 & 2,276 & 5,624 & 3.9 \\
\hline 11 & $+0-$ & 905 & 2,237 & 0.5 & 36 & 90 & 0.1 \\
\hline 12 & +-0 & 5,353 & 13,226 & 2.9 & 3,527 & 8,716 & 6.0 \\
\hline 13 & $0+-$ & 8,189 & 20,235 & 4.5 & 0 & 0 & 0.0 \\
\hline 14 & -+0 & 3,642 & 9,000 & 2.0 & 0 & 0 & 0.0 \\
\hline 15 & 000 & 24,272 & 59,975 & 13.3 & 17,590 & 43,464 & 29.9 \\
\hline 16 & -+- & 158 & 391 & 0.1 & 0 & 0 & 0.0 \\
\hline 17 & $0-0$ & 303 & 749 & 0.2 & 196 & 485 & 0.3 \\
\hline 18 & -00 & 3,919 & 9,683 & 2.1 & 0 & 0 & 0.0 \\
\hline \multicolumn{2}{|c|}{ Totals } & 182,752 & 451,664 & 100.2 & 58,838 & 145,450 & 99.9 \\
\hline
\end{tabular}

${ }^{1}$ Class symbols indicate limitation by moisture (first), temperature (second), and soil fertility (third). - indicates strong limitation, 0 indicates slight limitation, and + indicates no limitation.

Despite this high coverage, five of the bioenvironmental classes are not found in preserves, and two are represented by less than 40 ha (100 acres). These seven bioenvironments total 21 percent of the study area.

Six of these seven bioenvironments are water limited (totaling 98 percent of the nonpreserve acreage). Of the 11 bioenvironments that are represented by more than 40 ha ( $100 \mathrm{acres})$ within preserves, 7 are temperature limited, i.e., cold (totaling 96 percent of the preserve acreage).

In summary, 96 percent of the preserve acreage is indicated as cold limited, and 98 percent of the nonpreserve acreage is indicated as water limited. Thus, the existing preserve network in the study area appears to represent cold environments (mostly high elevations) very well but represents water-limited environments (mostly low elevations) very poorly.

If the preserve network is to be representative of the bioenvironments present, new preserves need to be established on water-limited sites. 


\section{Implications for the GYE}

Like the upper Blackfoot River area, the GYE contains an extensive nature preserve network. However, the bioenvironmental representativeness of this network has never been evaluated. The same digital data used in this study are available for the GYE. The methods we have described and implemented provide a means to quickly and quantitatively evaluate representativeness across the GYE.

The analysis of the upper Blackfoot River area required approximately 100 person hours to complete. We developed and tested the rule-based model in about 75 hours and could possibly adjust it to the GYE within 15 hours. Data inputs and processing for the Blackfoot area (200,000 ha; 500,000 acres) required about 25 hours. If analysis time increased linearly, completing the same type of study for the GYE (7.7 million ha; 19 million acres) would require about six months.

\section{Literature Cited}

Botkin, D.B., J.F. Janak, and J.R. Wallis. 1972. Some ecological consequences of a computer model of forest growth. Journal of Ecology 60:849-872.

Coughlan, J.C. and S.W. Running. 1989. An expert system to aggregate biophysical attributes of a forested landscape within a geographic information system. Al Applications 3(4):35-43.

Mackey, B.G., H.A. Nix, M.F. Hutchinson, J.P. MacMahon, and P.M. Fleming. 1988. Assessing representativeness of places for conservation reservation and heritage listing. Environmental Management 12:501-514.

Mackey, B.G., H.A. Nix, J.A. Stein, S.E. Cork, and F.T. Bullen. 1989. Assessing the representativeness of the wet tropics of Queensland world heritage property. Biological Conservation 50:279-303.

Nemani, R.R. and S.W. Running. 1989. Testing a theoretical climate-soil-leaf area hydrologic equilibrium of forests using satellite data and ecosystem simulation. Agricultural and Forest Meteorology 44:245-260.

Nix, H.A. 1982. Environmental determinants of biogeography and evolution in Terra Australis. Pages 47-65 in W.R. Barker and P.J.M. Greenslade, editors, Evolution of the Flora and Fauna of Arid Australia. Peacock Press, Adelaide, Australia.

STATSGO. 1991. State soil geographic data base. Montana data base. U.S. Department of Agriculture, Soil Conservation Service, National Soil Survey Center, Lincoln, Nebraska. 86pp.

Weaver, T. 1980. Climates of vegetation types of the northern Rocky Mountains and adjacent plains. American Midland Naturalist 103:392-398. 


\title{
Some Important Factors Affecting Density of Lodgepole Pine Seedlings Following the 1988 Yellowstone Fires
}

\author{
Marshall Ellis \\ Department of Biological Sciences \\ Idaho State University \\ Pocatello, ID 83209 \\ Carol D. von Dohlen \\ Department of Biological Sciences \\ Idaho State University \\ Pocatello, ID 83209 \\ Jay E. Anderson \\ Department of Biological Sciences \\ Idaho State University \\ Pocatello, ID 83209 \\ William H. Romme \\ Department of Biology \\ Fort Lewis College \\ Durango, CO 81301
}

\begin{abstract}
The 1988 fires in the Greater Yellowstone Area affected 45 percent of Yellowstone National Park, burning approximately 240,000 hectares of the park's forests and producing a mosaic of unburned, moderately burned, and severely burned lodgepole pine stands at spatial scales ranging from a few meters to several kilometers. We hypothesized that fire severity would strongly influence the initial postfire density of lodgepole pine seedlings. In 1989 we inventoried lodgepole pine seedling densities in paired transects at 4 burned sites in northwestern Yellowstone National Park, and in 1990 we expanded the study to 12 sites spanning the range of lodgepole pine throughout the park. One transect in each site was in an area of moderate, or surface, fire severity. A paired transect was in an adjacent stand that had been subjected to severe, or canopy, fire. In 1990 seedling densities ranged from $0.06 \mathrm{~m}^{-2}$ to $184 \mathrm{~m}^{-2}$ and were consistently higher in the moderately burned transects. Seedling densities were highest at elevations from 2,000 to $2,300 \mathrm{~m}$. We observed little seedling mortality between the first and second postfire years. Across sites, the proportion of trees bearing serotinous cones in unburned stands near the burned transects ranged from 0 to 48 percent and was significantly correlated with lodgepole seedling densities. Also, the number of cones on the ground
\end{abstract}


was positively correlated with seedling density in moderately burned transects. Our data suggest that lodgepole pine seedling numbers in severely burned transects were inversely related to distance from the nearest seed source (unburned or moderately burned area). Densities in severely burned transects adjacent to a moderately burned transect were two to seven times greater than those in more distant severely burned transects. Almost without exception seedling densities at all sites, regardless of burn severity, far exceeded the density of the prefire forest. We conclude that broad differences in lodgepole pine seedling densities within sites resulted from differential mortality of seeds caused by varying fire severity. Across sites, differences in seedling densities appear to reflect seed availability at the time of the fire.

\section{Introduction}

The fires that swept the Yellowstone Plateau in the summer and fall of 1988 burned approximately 570,000 ha in the Greater Yellowstone ecosystem (GYE) and constituted the region's most extensive fires since the establishment of Yellowstone National Park in 1872 (Romme and Despain 1989a,b). The fires affected 45 percent of the park's area, and over half of the 400,000 ha that burned within park boundaries were on forested lands (Schullery 1989).

Fires of the scale and severity seen in 1988 arise and persist as the result of complex interactions. The fires of 1988 were primarily a consequence of unprecedented postsettlement drought, multiple points of ignition, and persistent high winds. These factors acted in concert over an extensive cover of highly flammable old-growth lodgepole pine (Pinus contorta) forests that had developed on the Yellowstone Plateau since the last major fires there in the first decade of the 18th century (Romme and Despain 1989b; Turner and Romme 1991). Although vast, the fires of 1988 were not unprecedented in the ecological history of the region and appear to have been comparable in behavior and extent to fires that burned over the same area 250 to 300 years ago (Romme and Despain 1989b). Fire has played a significant role in shaping most Northern Rocky Mountain ecosystems (Arno 1980; Habeck and Mutch 1973; Loope and Gruell 1973), and fire history studies suggest that the forested ecosystems of the Yellowstone Plateau are characterized by long-term, widespread changes in landscape composition and diversity that may be initiated by cyclical fire regimes under which large areas burn every 300 to 400 years (Romme 1982; Turner and Romme 1991).

Lodgepole pine (Pinus contorta), which typically forms vast stands throughout the western United States, figures prominently in the fire cycle and is the only northern Rocky Mountain conifer to produce serotinous, or fire-opened, cones. Serotinous cones may be retained by lodgepoles indefinitely, and although not all individuals possess the serotinous habit, those that do are uniquely adapted for recolonizing burned areas (Fahey and Knight 1986; Muir and Lotan 1985a). Although fuel loads capable of supporting widespread stand-reducing fires are generally slow to form in these forests, infrequent holocaustic fires are endemic to western U.S. subalpine forest ecosystems (Stickney 1990), and the dependence of these forests on widespread stand-replacing fires as a rejuvenative force is well documented (Brown 1975; Loope and Gruell 1973; Lotan, Brown, and Neuenschwander 1985; Romme 1982; Romme and Despain 1989a,b). Hence, these and other northern Rocky Mountain forests are often referred to as "crown fire ecosystems" (Turner and Romme 1991).

However, even under conditions as extreme as those in the summer of 1988 , widespread holocaustic crown fires rarely consume entire landscapes. Such was the case in Yellowstone, where even the worst 
fires were influenced by local winds, fuel availability, and topography. Consequently, large pulsating fire complexes of uneven intensities produced a mosaic of burn severities over spatial scales ranging from a few meters to several kilometers. Aside from the sheer extent of the Yellowstone fires, it is this widespread heterogeneity in burn severity that is their most striking feature. The scale of heterogeneity offers an unparalleled opportunity to initiate long-term landscape-scale studies addressing forest regeneration and dynamics in relation to a variety of factors (Christensen et al. 1989; Knight and Wallace 1989).

Although the influence of burn severity on postfire plant reestablishment is well documented (see Lyon and Stickney 1976; Turner and Romme 1991), the site-specific processes controlling the postfire density of lodgepole pine seedlings remain poorly understood (Brown 1975; Lyon and Stickney 1976). Using data from a 1989 pilot study, we began investigating the specific ways in which fire severity and prefire stand composition interact to control the postfire regeneration of lodgepole pine. These data suggested that fire severity exerted a strong influence on lodgepole seed survival and initial seedling densities. We postulated that within sites, seedling densities would be higher in areas subjected to fire of moderate intensity than in adjacent areas subjected to severe canopy fire. We also postulated that an inverse relationship would exist between seedling density in severe canopy fire areas and distance to the nearest moderately burned or unburned stand serving as a seed source. Across sites, we hypothesized that a stand's prefire level of cone serotiny would determine seed availability, resulting in a positive correlation between prefire stand levels of cone serotiny and postfire seedling density. Because these sites are within park boundaries, we will be able to study their long-term development without the interference of such manipulations as seeding with exotic species, stand thinning, and cattle grazing, which have plagued postfire research in similar northern Rocky Mountain ecosystems (see Lyon 1976, 1984).

\section{Study Area}

Yellowstone National Park covers $9,000 \mathrm{~km}^{2}$ within the nearly $50,000 \mathrm{~km}^{2}$ GYE and is located in the extreme northwestern corner of Wyoming. Elevations range from 1,800 $\mathrm{m}$ to $>3,000 \mathrm{~m}$, and although vegetation patterns are quite diverse, approximately 80 percent of the park is characterized by higher altitude subalpine plateaus supporting extensive lodgepole pine forests.

Our study was conducted in the subalpine lodgepole pine forests that burned throughout the Yellowstone Plateau in 1988. Landscape mosaics produced by the 1988 fires are typified by widespread networks of severely burned, moderately burned, and unburned stands. In severely burned areas the entire forest canopy and most of the litter and duff on the forest floor were consumed. These areas are surrounded by halos of moderately burned forest, in which surface fire killed the trees but failed to consume fine fuels in the canopy or on the ground. Both categories of fire represent stand-replacing burns (see photos in Christensen et al. 1989:682).

\section{Methods}

In August 1989 we established permanent 50-m straight-line transects at 4 sites in northern Yellowstone National Park where lodgepole pine forests burned during September 1988; in 1990 we expanded the study to 12 sites. The sites range in elevation from 2,040 $\mathrm{m}$ to $2,560 \mathrm{~m}$ and spanned the range of environmental conditions supporting lodgepole pine forests on the Yellowstone Plateau (table 1). All 
study sites were subjectively selected to ensure widespread replication of the burn mosaic. At the time of the fires, each site supported mature, nearly monospecific stands of lodgepole pine.

Table 1. The 12 sites used to study density of lodgepole pine seedlings, and their elevation and serotiny

\begin{tabular}{|c|c|c|c|c|c|}
\hline Site/Location & Elev (m) & Substrate & $M / F^{a}$ & Stage $^{b}$ & Serotiny (\%) \\
\hline 1 Solfatara & 2,490 & rhyolite & xeric & LP $3 / 2$ & 0 \\
\hline 2 Mt. Washburn & 2,560 & andesite & mesic & LP 4 & 11 \\
\hline 3 Lewis River & 2,500 & rhyolite & mesic & LP 2/3 & 0 \\
\hline 4 Lewis Lake & 2,350 & rhyolite & mesic & LP 2/3 & 0 \\
\hline 5 Norris Jct. East & 2,270 & alluvium & mesic & LP 2 & 0 \\
\hline 6 Indian Creek & 2,260 & basalt & xeric & LP 2 & 48 \\
\hline 7 Swan Lake Flat & 2,270 & basalt & mesic & LP 2 & 13 \\
\hline 8 Whiskey Flat & 2,290 & rhyolite & both & $\operatorname{LP} 1 / 2$ & 48 \\
\hline 9 Norris Jct. South & 2,320 & rhyolite & xeric & LP 2 & 4 \\
\hline 10 West Yellowstone & 2,040 & alluvium & xeric & LP 2 & 15 \\
\hline 11 Madison R. Bridge & 2,100 & tuff & mesic & LP 1 & 45 \\
\hline 12 Madison Junction & 2,120 & rhyolite & both & LP 1 & 44 \\
\hline
\end{tabular}

${ }^{a} \mathrm{M} / \mathrm{F}$ is a relative moisture/fertility rating.

'Stage is successional stage as described by Romme and Despain 1989a. When two stages are shown (e.g., 3/2), the site was intermediate but tended toward first stage listed.

Each of the 12 sites contained the following paired transects: the first was in an area subjected to moderate (or surface) fire; the second was in an adjacent area that had experienced severe canopy fire. In addition to these paired transects, a third transect was established as a control in the nearest unburned stand at each site and served as an estimator of prefire stand serotiny and vegetation. To investigate limitations of seed dispersal, we also established at 10 of the study sites an additional or "remote" severely burned transect that was at least $100 \mathrm{~m}$ from the nearest potential seed source. Each site's transects were subjectively located so that slope, aspect, and substrate were as similar as possible. With the exception of the remote canopy fire plots, transects were situated so that there was at least $20 \mathrm{~m}$ (but not more than $60 \mathrm{~m}$ ) along either side to a discernible change in fire intensity.

Each site's prefire stand structure was reconstructed by estimating the age, density, and size distribution at all transects. Age was estimated by coring the nearest canopy-dominant tree at 5-m intervals along each transect (10 trees total). Annual rings were counted using a dissecting microscope. Binoculars were used to count the number of cones remaining in the crown of each stand-dominant tree that was cored. Size distribution of the prefire community was estimated by recording the diameter at breast height $(\mathrm{DBH})$ of all trees with a $\mathrm{DBH}>2.5 \mathrm{~cm}$ within a $50-\mathrm{m} \times 20-\mathrm{m}(0.1 \mathrm{ha})$ quadrat defined by the transect; density was estimated by counting these same trees. Stand structure homogeneity within each site was assessed using DBH data to construct size-distribution histograms for each transect. An estimate of 
prefire serotiny was made by using binoculars to note the presence or absence of serotinous cones in a minimum of 100 live trees at the unburned transect in each study site.

Lodgepole pine seedlings and cones were counted in 50 contiguous $1-\mathrm{m}^{2}$ quadrats along each transect; seedlings of other species were noted when encountered but were not included in the seedling density analyses. Correlation between lodgepole seedling density and lodgepole cones on the ground or remaining in stand-dominant trees was assessed for each burned transect using simple linear regression. Correlation between prefire serotiny and postfire seedling density for each burned transect was assessed using the Spearman rank correlation test. An alpha level of 0.05 indicated significance for all tests.

\section{Results}

Lodgepole seedling densities in 1990 exhibited tremendous variation and were generally highest at lowelevation and mid-elevation sites $(2,000-2,300 \mathrm{~m})$. Densities ranged from $.008 \mathrm{~m}^{2}$ in the remote canopy burn transect at site 1 to $184 \mathrm{~m}^{2}$ in the moderately burned transect at site 11 . Seedling density was consistently higher in the moderately burned transects, ranging from 4 to 24 times greater than those in the severely burned transects. Data from the remote canopy burn transects suggest that seedling density is inversely related to distance from the nearest seed source. Seedling densities in remote canopy transects $>100 \mathrm{~m}$ from the nearest moderately burned or unburned transect were two- to sevenfold less than in canopy burn transects adjacent to or within $60 \mathrm{~m}$ of a moderate or unburned transect (figure 1). However, with the exception of only four transects, 1990 lodgepole seedling densities were more than sufficient to replace the prefire stands, regardless of fire severity. Ratios of postfire seedling density to prefire stand density ranged from 0.05 to 402 (table 2). Seedlings of other conifer species were so infrequent at any of the transects in 1990 that they appear to be of virtually no consequence in the early postfire community. Interestingly, aspen (Populus tremuloides) seedlings were present in each of our study sites in moderate and canopy burn areas.

The number of lodgepole cones on the ground in 1990 was consistently higher in the moderately burned transects (figure 2) and was positively correlated with seedling density across the 12 sites $(r=0.92, p<$ 0.001). While statistically weaker, the correlation between cones remaining on the ground and seedling density across severely burned transects was probably still biologically significant $(r=0.53, p=0.07)$. With the exception of a single site, canopy cone counts, like seedlings and cones on the ground, were consistently higher in moderately burned transects (figure 3). However, regardless of burn severity, lodgepole seedling density was poorly correlated with cones remaining in the crowns of stand-dominant trees $(r=0.26, p=0.41$ for moderately burned transects; $r=0.32, p=0.34$ for severely burned transects).

Prefire stand densities and ages were markedly similar among transects within any given site. Sizedistribution histograms demonstrated that the burned plots at any one site exhibited strikingly parallel structure profiles, suggesting that transects within a site shared similar stand histories.

The proportion of trees bearing serotinous cones was highest at low-elevation and mid-elevation sites, but was quite variable, ranging from 0 to 47.8 percent (table 1). Regardless of burn severity, prefire stand serotiny and postfire lodgepole seedling densities were strongly correlated $\left(r_{s}=0.71, p=0.0031\right.$ for moderately burned transects; $r_{s}=0.75, p=0.0023$ for severely burned transects). 

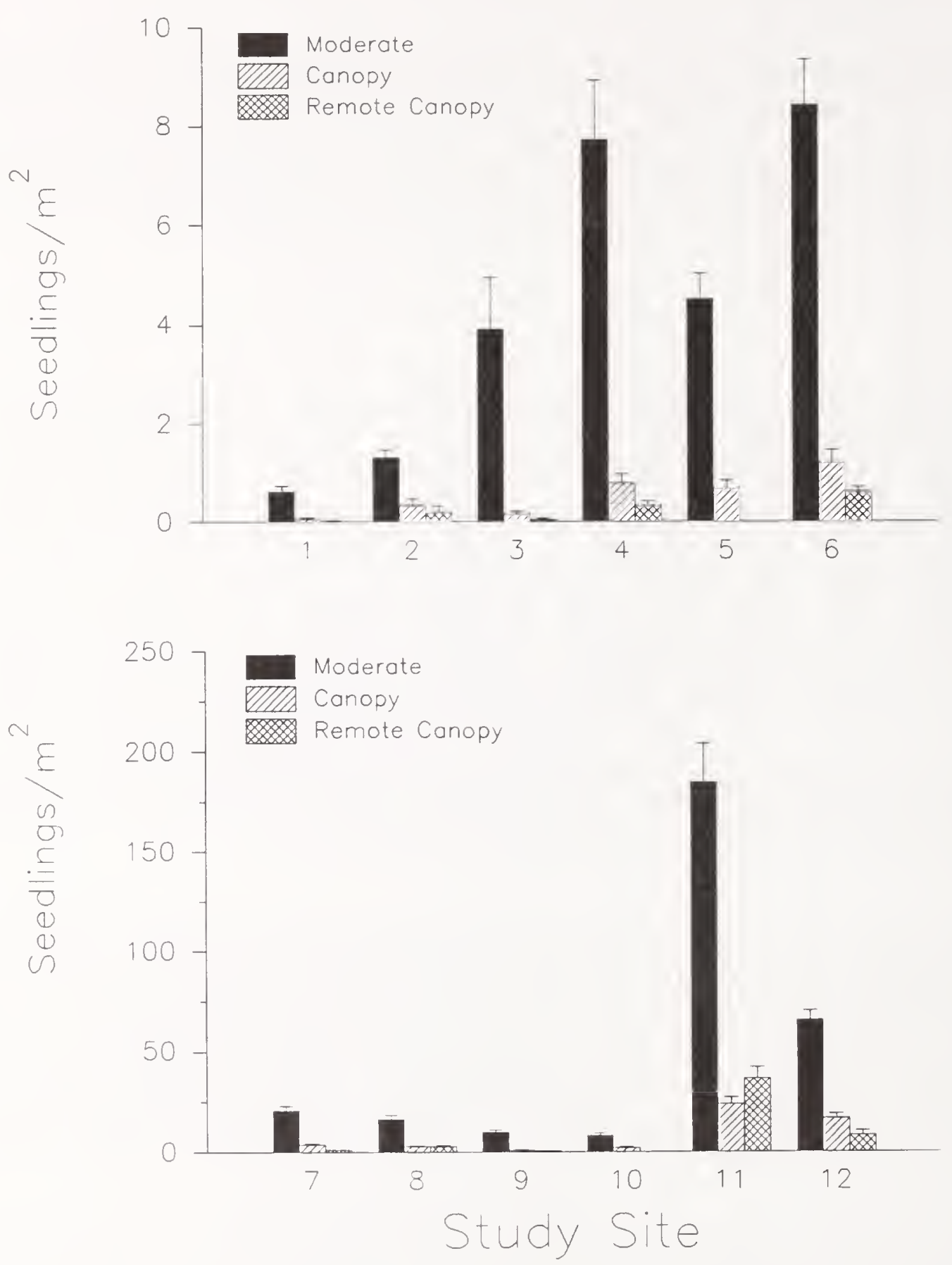

Figure 1. Mean densities of lodgepole pine seedlings in moderate, canopy, and remote canopy burn transects at 12 study sites in Yellowstone National Park. All data from 1990. 


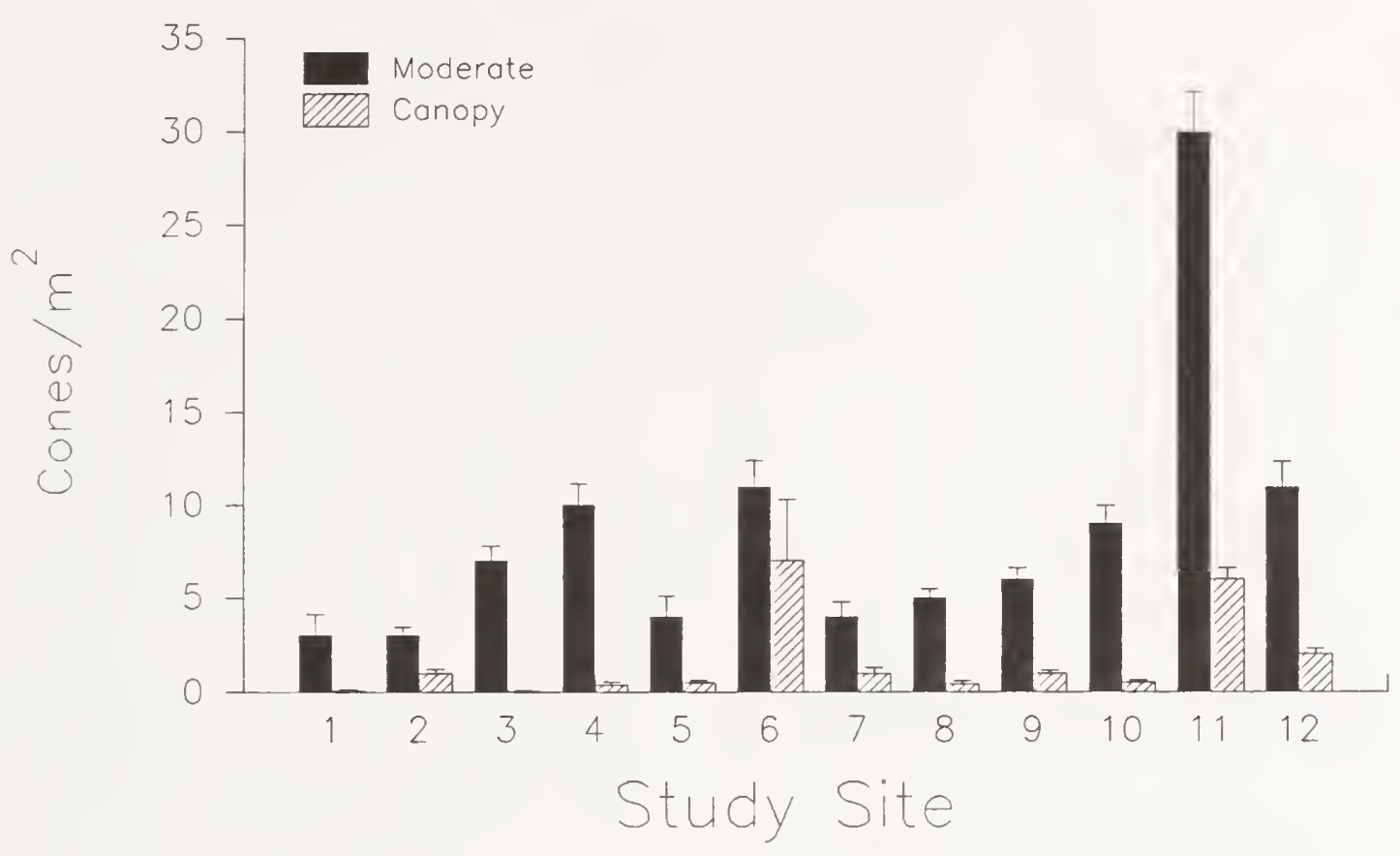

Figure 2. Mean densities of lodgepole cones $/ \mathrm{m}^{2}$ on the ground in moderate and canopy burn transects at 12 study sites in Yellowstone National Park. All data from 1990.

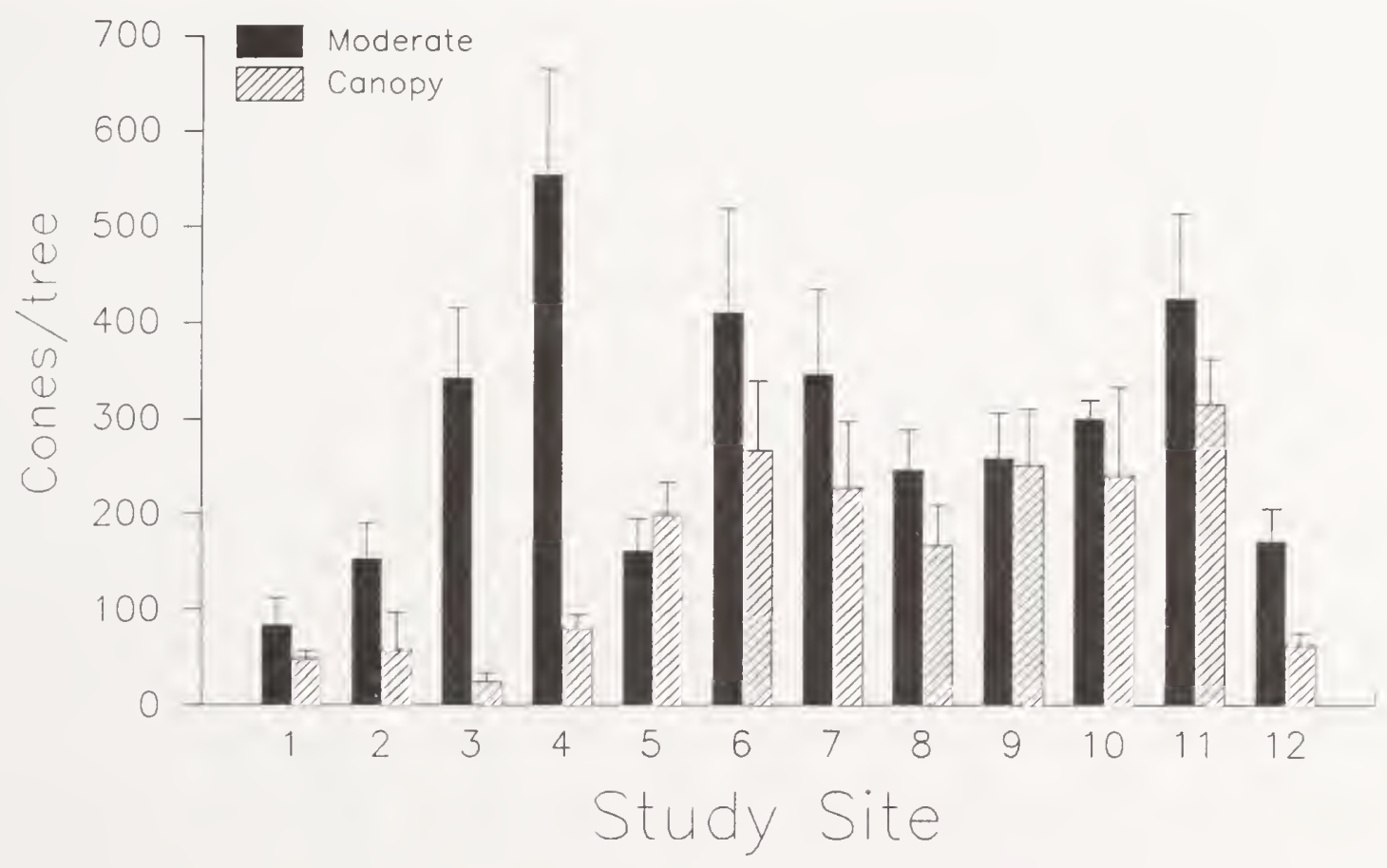

Figure 3. Mean densities of lodgepole cones in the crowns of 10 dominant trees in moderate and canopy burn transects at 12 study sites in Yellowstone National Park. All data from 1990. 
Table 2. Ratios of postfire seedling density to prefire stand density in 12 sites

\begin{tabular}{|l|c|c|c|}
\hline Site/Location & Moderate & Canopy & Remote Canopy \\
\hline 1 Solfatara & 7.7 & $0.4^{\star}$ & $0.1^{\star}$ \\
2 Mt. Washburn & 9.3 & 2.4 & 1.1 \\
3 Lewis River & 33.6 & $0.7^{\star}$ & $0.3^{\star}$ \\
4 Lewis Lake & 65.8 & 7.2 & 3.3 \\
5 Norris Jct. East & 45.4 & 5.9 & $\mathrm{NA}$ \\
6 Indian Creek & 56.7 & 8.7 & 3.4 \\
7 Swan Lake Flat & 214.0 & 37.4 & 9.5 \\
8 Whiskey Flat & 31.9 & 5.1 & 6.2 \\
9 Norris Jct. South & 45.8 & 4.1 & 2.2 \\
10 W. Yellowstone & 35.2 & 17.1 & $\mathrm{NA}$ \\
11 Madison R. Bridge & 402.2 & 76.3 & 141.0 \\
12 Madison Jct. & 38.8 & 13.4 & 9.3 \\
\hline
\end{tabular}

$\mathrm{NA}=$ No remote canopy transect on that site.

* $=$ Transects with insufficient seedlings to replace the prefire stand.

\section{Discussion}

We believe that the widespread and consistent relationship between burn severity and postfire densities of lodgepole pine seedlings demonstrated by our data suggests that local differences in burn severity can interact to produce large-scale patterns that may persist over the landscape until the next standreducing fires occur (Huston, DeAngelis, and Post 1988; Turner and Romme 1991). This relationship prompts two questions: (1) Were the differences in burn severity and seedling density a consequence of site characteristics, or did they arise as a consequence of stochastic fire behavior? (2) What implications do these differences hold for long-term forest dynamics?

Because prefire stand homogeneity was so consistent within sites, we suggest that local differences in burn severity resulted from stochastic factors (most likely abrupt changes in wind direction) rather than local differences in stand structure. Assuming that seed availability was similar for the burned transects at any given site, differences in seedling densities between moderately and severely burned transects probably resulted from differential seed mortality caused by local fire intensity. The decreased abundance of seedlings, cones on the ground, and cones in the crowns of dominant trees at severely burned transects suggests that holocaustic fires may in fact consume the bulk of a stand's seed supply, resulting in low postfire seedling densities (Beaufait 1960; Brown 1975; Knapp and Anderson 1980).

In severely burned stands, distance to a seed source may play an important role in postfire seedling densities and may affect the rapidity of stand regeneration. Seedling densities in remote, severely burned transects were greatly reduced compared with canopy-burned transects adjacent to a seed source, suggesting that distant, severely burned areas were located outside the limits of normal seed dispersal. These results are consistent with previous findings that parent lodgepole pines seldom cast their seeds past $60 \mathrm{~m}$ (Fowells 1965) and that the density of dispersing seeds is expected to fall logarithmically with 
distance from the parent (Harper 1977). The Yellowstone fires, however, are not likely to create vast meadows where forests stood in 1988. Although initial postfire seedling densities were comparatively low in the remote canopy burn transects, they are at present sufficient to replace the prefire stands in 80 percent of our remote, severely burned transects. Even so, it is apparent that the reforestation of some large, severely burned areas will be a very slow process.

Severely burned areas with extremely low initial seedling densities will probably develop into open, grown stands containing relatively few dominant individuals that will slowly fill in the gaps and produce an unevenly aged stand. However, it is also likely that sparsely populated sites with uneven age distributions will be limited to the relatively few large areas that suffered unusually intense and extensive canopy fires. Because 1990 seedling densities at most transects were more than sufficient to replace the prefire stands, we suspect that the majority of the park's burned areas will be characterized by extensive stands of evenly aged (but unevenly dense) forests, much like the pattern in evidence after the fires of the early 1800s (Romme 1982; Romme and Despain 1989b).

Although the majority of Yellowstone's burned lodgepole forests should regenerate in the next decades, large differences in initial postfire seedling establishment will almost certainly exert a lasting influence on postfire stand structure and dynamics (Anderson and Romme 1991). It is well known that lodgepole pine often establishes at very high densities after fire (Fowells 1965), and densities in Yellowstone are comparable to those reported by Lyon (1984) following the 1961 Sleeping Child fire in Montana. The extremely dense stands that have established in some of our sites may form stagnated "dog hair" stands (Fowells 1965). Although the specific conditions favoring the development of such stands are not well understood (Lyon 1984), our data suggest that such stands are more likely to occur in areas subjected to fire of moderate severity.

Previous studies investigating the fire-initiated population dynamics of western U.S. coniferous forests have shown that selective, density-dependent seedling mortality in crowded seedling cohorts is initially high but then decreases over the first 10 postfire years (Johnson and Fryer 1989). Although we noted virtually no lodgepole seedling mortality on the original pilot study transects from 1989 to 1990 , we suspect that local crowding will play an increasingly important role in determining individual seedling performance, particularly as canopies begin to close and the competition for light becomes one with fatal consequences. Although both intra- and interspecific competition will almost certainly influence seedling survival in subsequent years, aside from Lyon's (1984) study, little long-term demographic information on seedling dynamics is available. We hope that our studies will lead to long-term information on seedling mortality.

Prefire stand serotiny across sites was generally low, but such low serotiny is common in the Greater Yellowstone Area; Lotan (1975) reported less than 30 percent stand serotiny in lodgepole stands on National Forest lands adjacent to Yellowstone National Park. Lotan (1975) and Muir and Lotan (1985 a,b) have suggested that such wide variability in prefire serotiny may provide an index of local seed availability and could, therefore, have a role in explaining differences in postfire seedling densities across sites. Because our data indicated widespread correlation between prefire serotiny levels and postfire seedling densities, we believe that our results are consistent with that argument, and we conclude that postfire lodgepole seedling density is a function of prefire stand serotiny.

Although prefire stand serotiny and postfire seedling densities were positively correlated, the incidence of serotiny was quite variable, even over short distances; this trend was also demonstrated by Lotan (1975), who reported that serotinous trees frequently occurred in dense, variably sized pockets with abrupt boundaries. Muir and Lotan (1985a) observed marked differences in the frequency of cone type 
in lodgepole stands separated by $<1 \mathrm{~km}$ in the Bitterroot watershed of western Montana, and we have observed similar swings in serotiny throughout Yellowstone National Park. We suspect that the serotiny mosaic is related to burn severity in much the same way as seedling densities. Because holocaustic canopy fire may consume the bulk of the seed rain, the production of a widespread serotinous cohort in severely burned areas becomes unlikely. This phenomenon may be particularly true in Yellowstone's lodgepole pine forests above $2,300 \mathrm{~m}$, where serotiny is frequently very low. Consequently, the forests arising from the 1988 fires will likely favor their predecessors and exhibit a very mixed and patchy regeneration of cone types.

We agree with Huston, DeAngelis, and Post (1988) and Turner and Romme (1991) that small-scale mechanisms and local interactions can combine to produce complex patterns at landscape scales, and the Yellowstone fires of 1988 provide a unique opportunity to investigate this phenomenon. The type and severity of disturbance, rather than autogenic succession, may play a predominant role in prescribing the course of vegetation development on a site (Henry and Swan 1974; Veblen 1989), and variations in initial conditions can interact to have significant consequences for patterns at larger scales. Understanding how these small- and large-scale factors interact should provide insight into the dynamics of lodgepole pine communities throughout the northern Rocky Mountains.

\section{Acknowledgments}

We thank Pamela Goodman, Donna Blakely, Deborah Jones, and Natalie Kelly for assistance in data collection. The assistance of the Ranger and Research Divisions, National Park Service, Yellowstone National Park, is much appreciated. This research was supported in part by the United States Forest Service under agreement no. INT-90491-RJVA.

\section{Literature Cited}

Anderson, J.E., and W.H. Romme. 1991. Initial floristics in lodgepole pine (Pinus contorta) forests following the 1988 Yellowstone fires. International Journal of Wildland Fire 1:127-132.

Arno, S.F. 1980. Forest fire history in the northern rockies. Journal of Forestry 78:460-465.

Beaufait, W.R. 1960. Some effects of high temperatures on the cones and seeds of jack pine. Forest Science 6:194-199.

Brown, J.K. 1975. Fire cycles and community dynamics in lodgepole forests. Pages 429-456 in D.M. Baumgartner, editor, Management of Lodgepole Pine Ecosystems. Washington State University Cooperative Extension Service, Pullman, Washington.

Christensen, N.L., J.K. Agee, P.F. Brussard, J. Hughes, D.H. Knight, G.W. Minshall, S.E. Williams, and H.A. Wright. 1989. Interpreting the Yellowstone fires of 1988. BioScience 39:678-685.

Fahey, T.J., and D.H. Knight. 1986. Lodgepole pine ecosystems. BioScience 36:610-617. 
Fowells, H.A. 1965. Silvics of forest trees of the United States. Agriculture Handbook No. 271. U. S. Department of Agriculture, Washington, DC.

Habeck, J.R., and R.W. Mutch. 1973. Fire dependent forests in the northern rockies. Quaternary Research 3:408-424.

Harper, J.L. 1977. Population Biology of Plants. Academic Press, London.

Henry, J.D., and J.M.A. Swan. 1974. Reconstructing fire history from live and dead plant material - an approach to the study of forest succession in southwest New Hampshire. Ecology 55:772-783.

Huston, M., D. DeAngelis, and W. Post. 1988. New computer models unify ecological theory. BioScience 38:682-691.

Johnson, E.A., and G.I. Fryer. 1989. Population dynamics in lodgepole pine-Engeimann spruce forests. Ecology 70:1335-1345.

Knapp, A.K., and J.E. Anderson. 1980. Effect of heat on germination of seeds from serotinous lodgepole pine cones. American Midland Naturalist 104:370-372.

Knight, D.H., and L.L. Wallace. 1989. The Yellowstone fires: issues in landscape ecology. BioScience 39:700-706.

Loope, L.L., and G.E. Gruell. 1973. The ecological role of fire in the Jackson Hole area, northwestern Wyoming. Quaternary Research 3:425-443.

Lotan, J.E. 1975. The role of cone serotiny in lodgepole pine forests. Pages 471-495 in D.M. Baumgartner, editor, Management of Lodgepole Pine Ecosystems. Washington State University Cooperative Extension Service, Pullman, Washington.

Lotan, J.E., J.K. Brown, and L.F. Neuenschwander. 1985. Role of fire in lodgepole pine forests. Pages 133-152 in D.M. Baumgartner, R.G. Krebill, J.T. Arnott, and G.F. Westman, editors, Lodgepole Pine: The Species and Its Management. Washington State University Cooperative Extension Agency, Pullman, Washington.

Lyon, L.J. 1976. Vegetal development on the Sleeping Child Burn in western Montana, 1961 to 1973. Research Paper INT-184. U.S. Department of Agriculture, Forest Service, Intermountain Forest and Range Experiment Station, Ogden, Utah. 24pp.

Lyon, L.J. 1984. The Sleeping Child Burn -21 years of postfire change. Research Paper INT-330. U.S. Department of Agriculture, Forest Service, Intermountain Forest and Range Experiment Station, Ogden, Utah. 17pp.

Lyon, L.J. and P.F. Stickney. 1976. Early vegetal succession following large northern Rocky Mountain wildfires. Proceedings of the Montana Tall Timbers Fire Ecology Conference and Fire and Land Symposium 14:355-375.

Muir, P.S., and J.E. Lotan. 1985a. Disturbance history and serotiny in Pinus contorta in Western Montana. Ecology 66:1658-1668. 
Muir, P.S. and J.E. Lotan. 1985b. Serotiny and life history of Pinus contorta var. latifolia. Canadian Journal of Botany 63:938-945.

Romme, W.H. 1982. Fire and landscape diversity in subalpine forests of Yellowstone National Park. Ecological Monographs 52:199-221.

Romme, W.H. and D.G. Despain. 1989a. Historical perspective on the Yellowstone Fires of 1988. BioScience 39:695-699.

Romme, W.H. and D.G. Despain. 1989b. The long history of fire in the Greater Yellowstone Ecosystem. Western Wildlands 15:10-17.

Schullery, P. 1989. The fires and fire policy. BioScience 39:686-694.

Stickney, P.F. 1990. Early development of vegetation following holocaustic fire in northern Rocky Mountain forests. Northwest Science 64:243-246.

Turner, M.G., and W.H. Romme. 1991. Landscape dynamics in crown fire ecosystems. In R.D. Laven and P.N. Omi, editors, Pattern and Process in Crown Fire Ecosystems. Princeton University Press, Princeton, New Jersey.

Veblen, T.T. 1989. Tree regeneration responses to gaps along a transandean gradient. Ecology $70:$ 541-543. 


\title{
Historical Condition of Woody Vegetation on Yellowstone's Northern Range: A Critical Evaluation of the "Natural Regulation" Paradigm"
}

\author{
Charles E. Kay ${ }^{2}$ \\ Department of Fisheries and Wildlife \\ Utah State University \\ Logan, UT 84322-5210 \\ Frederic $\mathrm{H}$. Wagner \\ Ecology Center and Department of Fisheries and Wildlife \\ Utah State University \\ Logan, UT 84322-5210
}

\begin{abstract}
The Park Service's "natural regulation experiment" is predicated on the assumption that large numbers of elk $(12,000-15,000)$ have wintered on Yellowstone's northern range for the last several thousand years. Agency biologists believe that the park's vegetation coevolved with these herbivores and reached equilibrium conditions, which they term "ecological carrying capacity." According to this model, elk influences on the vegetation are "natural" and represent the "pristine" condition of the park. If this paradigm is correct, early historic photographs of woody vegetation should show that aspen, willows, and conifers were as heavily browsed or highlined by ungulates in the early years of the park's existence as they are today, and aspen stem damage by elk was the norm then as it is now.

To evaluate these predictions and to test the "natural regulation" paradigm, we reviewed approximately 50,000 early images taken in the park. Photos of aspen stands on the park's northern range taken during the 1880 s and 1890 s do not show any evidence of elk-induced bark damage. Photos of aspen, willows, and conifers taken from 1872 to the 1890 s do not show evidence of ungulate browsing or highlining. Some early photos do show occasional conifers that lacked their lower branches, but evidence indicates that this was caused by light groundfires burning or killing the lower branches and by human removal of branches. Previous authors apparently confused fire and human highlining with that caused by ungulates.
\end{abstract}

'The study was funded by the Rob and Bessie Welder Wildlife Foundation (Contribution No. 384) and Utah State University's Ecology Center.

${ }^{2}$ Present address: Institute of Political Economy, Utah State University, Logan, UT 84322-0725. 
Conifers and other woody vegetation in these 1870 - 1890 images were approximately 70-100 years old or older when they were photographed. Since they show no evidence of ungulate use, this suggests that few, if any, elk wintered in Yellowstone from the late 1700 s through the 1870 s. Thus, ungulate highlining of conifers and repeated browsing of other woody vegetation are not "natural" and represent a departure from conditions that existed before the establishment of Yellowstone National Park. These photographs do not support the Park Service's contention that Yellowstone was always a major elk wintering area and that the northern herd did not increase and alter the vegetation. Since these data do not support one of the key assumptions upon which "natural regulation" is based, that paradigm must be rejected.

\section{Introduction}

The relationship between vegetation and ungulates in Yellowstone National Park has long been a subject of conflicting opinions and intense debate (Chase 1986; Despain et al. 1986; Houston 1982; Kay 1990). Before 1968, Park Service officials contended that an "unnaturally" large elk (Cervus elaphus) population, which had built up in Yellowstone during the late 1800 s and early 1900s, had severely "damaged" ${ }^{\text {"3 }}$ the park's northern winter range, including aspen (Populus tremuloides) and willow (Salix spp.) communities (Tyers 1981). However, agency biologists now hypothesize that elk and other animals in Yellowstone are "naturally regulated," being resource (food) limited (Despain et al. 1936; Houston 1982), and that the condition of the ecosystem today is much as it was at park formation.

Under "natural regulation" (Kay 1990, 1-31) the following assumptions are made: First, predation is an assisting but nonessential adjunct to the regulation of ungulate populations. If wolves (Canis lupus) were reintroduced into the ecosystem, they would take only the ungulates slated to die from other causes, such as starvation, and hence predation would not lower ungulate numbers. Second, if ungulates and vegetation have coevolved for a long period of time and occupy an ecologically complete habitat, the ungulates cannot cause retrogressive plant succession or "range damage." The ungulates and vegetation will reach an equilibrium, called "ecological carrying capacity," in which continued grazing will not change plant species composition or the physical appearance of the plant communities. And finally, at equilibrium, competitive exclusion of sympatric herbivores caused by interspecific competition will not occur. In Yellowstone this means that competition by elk has not reduced the numbers of other ungulates or beaver (Castor canadensis) since park formation.

The Park Service's "natural regulation experiment" (cf. Despain et al. 1986) is predicated on the assumption that large numbers of elk $(12,000-15,000)$ have wintered on Yellowstone's northern range for the last several thousand years. Park Service biologists now hypothesize that elk, vegetation, and other herbivores in Yellowstone have been in equilibrium for that period of time (Despain et al. 1986). The agency also holds that any changes in plant species composition since the park was established in 1872 have been primarily caused by suppression of lightning fires, normal plant succession, or climatic change, not by ungulate grazing. According to "natural regulation," elk influences on Yellowstone's vegetation are "natural" and represent the "pristine" condition of the park.

\footnotetext{
${ }^{3}$ Terms such as "overgrazing," "range damage," and "unnatural" elk populations are common in nearly all early government reports on the elk herds in the Greater Yellowstone ecosystem. Since these terms are value laden, they are used throughout this paper only in their historical context.
} 
If this paradigm is correct, historical photographs of woody vegetation in the park should show that aspen, willows, and conifers were as heavily browsed or highlined by ungulates in the early years of the park's existence as they are today and that aspen stem damage by elk was the norm then as it is now. To evaluate these predictions and to test the "natural regulation" paradigm, we reviewed photographs taken in the park since 1870.

\section{Study Area}

The work was conducted primarily on the winter range of Yellowstone's northern elk herd, though other parts of the park also were visited. Houston (1982) provides a description of the climate, physiography, and vegetation of Yellowstone's northern range.

\section{Methods}

We searched archival photographic collections at Yellowstone National Park, the Montana Historical Society, the University of Montana, Montana State University, the Museum of the Rockies, the University of Wyoming, the Colorado Historical Society, the Library of Congress, the National Archives, and the U.S. Geological Survey's Denver Photographic Library for historical photos of the northern range. We reviewed approximately 50,000 images taken in the park and throughout the Yellowstone area. Only a small portion of these photographs were taken on the northern range and a still smaller number contained views of aspen, willows, or conifers of interest. From 1986 through 1989 we rephotographed the locations in the historical pictures to form sets of comparative photos, a process called repeat photography (Rogers, Malde, and Turner 1984). We evaluated the photosets under magnification to determine whether the plants pictured in the early photos showed evidence of ungulate browsing and then compared those data with our photos and notes on the condition of the vegetation in those same areas today. Houston $(1976,1982)$, Gruell $(1980 a, b)$, Cole (1983), and Despain et al. (1986) also used comparative photography to study vegetation changes on the northern winter range and other areas within the Greater Yellowstone ecosystem.

\section{Results and Discussion}

\section{Conifers}

One of the conspicuous characteristics of today's northern range, and indeed other parts of the park as well, is the browsing highline on conifers. Evident to the most casual traveler, the configuration is widely cut into all of the park's coniferous species (figure 1). Of the woody species in the park, conifers are among the least palatable to ungulates (Nelson and Leege 1982). If other foods are available, elk and other herbivores will take them in preference to conifers. When deep snows cover most vegetation and elk are facing starvation, however, they will turn to conifers in an attempt to satisfy their hunger. Thus, throughout most of western North America, ungulate highlining of conifers is usually viewed as a sign of overgrazing and range deterioration. According to Park Service biologist Houston (1982, 129), "High-lining of conifers (heavy browsing of lower branches) has [also] been interpreted as evidence of range deterioration" on Yellowstone's northern range. 


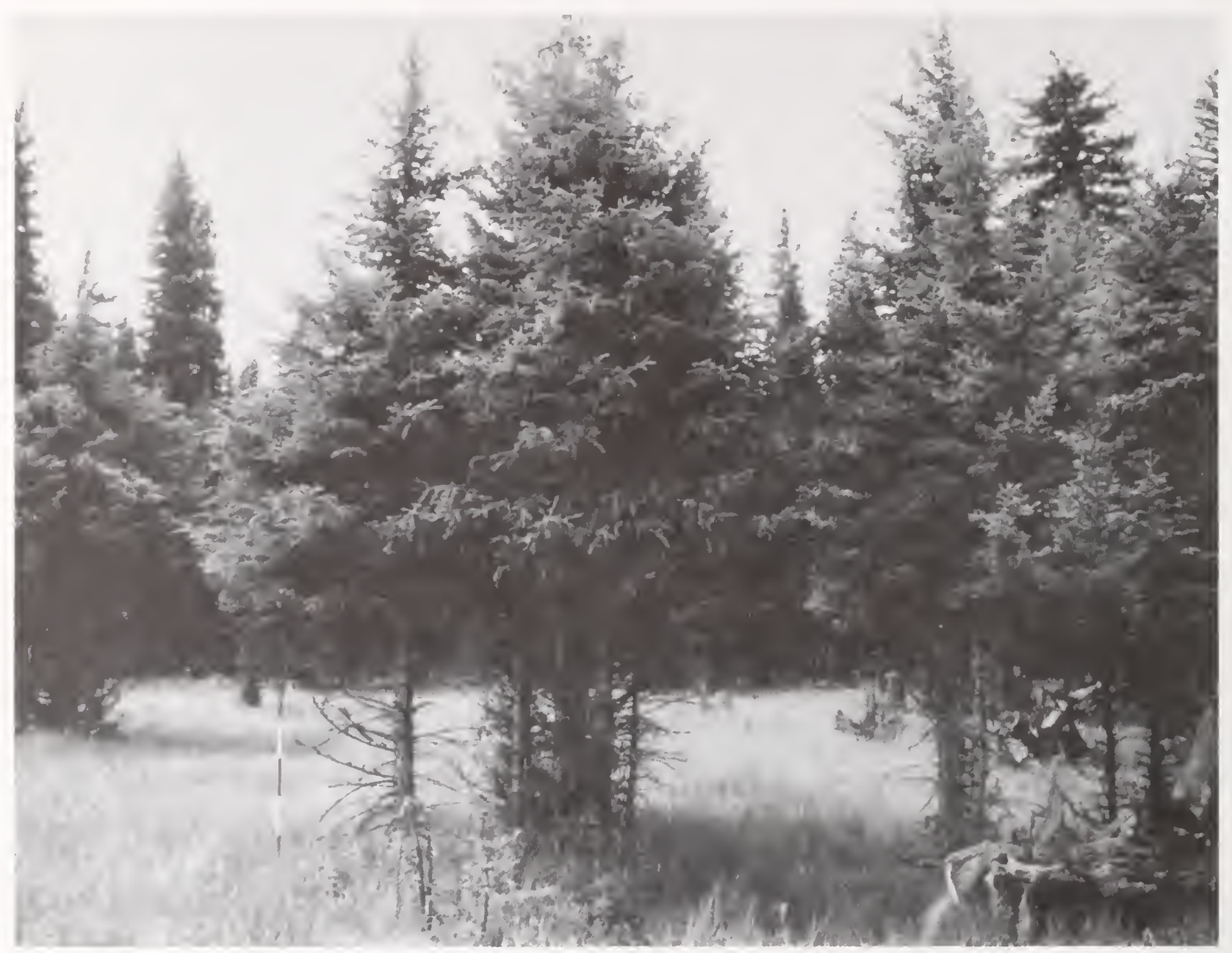

Figure 1. Highlined conifers on Yellowstone's northern range. The lower branches on these Englemann spruce have been browsed off as high as the elk can reach. Of all the conifers in the park, Englemann spruce are the least palatable. For scale, the survey pole (lower left center) is 6 feet tall and is marked in one-foot segments. Photo by Charles E. Kay, August 15, 1986. 
Park Service biologists who examined early photographs, however, observed what they interpreted to be ungulate-induced highlines on conifers. After reviewing 319 repeat photosets of the park and adjacent areas, 244 of which were taken on the seasonal ranges of the northern elk herd, Houston $(1982,129)$ concluded that "Early photos showed high-lined trees [conifers] on the northern range and adjacent areas." In his study of Yellowstone's Firehole elk herd, Park Service biologist Cole (1983) used "57 paired photographs taken at 58 and 104 year intervals" to evaluate vegetation changes. He also concluded that highlined conifers were common in early park photographs. Cole and Houston both implied that highlined conifers were natural and did not signify range overuse. The Park Service has taken these opinions as one line of evidence supporting its contention that elk have always been abundant in the park and that vegetative conditions today are similar to pre-Columbian conditions (cf. Despain et al. 1986).

We have carefully reviewed under magnification all photographs published by Houston $(1976,1982)$, Despain et al. (1986), and Gruell (1980a) as well as other archival photographs. In our judgment, there is no evidence that conifers or any other woody species had been highlined by ungulates in the earliest (1871 - 1890) photos. Instead, there is considerable evidence that few ungulates wintered in the area prior to park establishment. We base this conclusion on three grounds. First, even in those few photos in which Houston $(1976,1982)$ inferred ungulate highlining, we do not see convincing evidence. A few trees in those photographs apparently lack lower branches, yet other conifers in the same pictures have branches that extend down to the ground.

For example, in plate 72 of Houston (1976) and plate 38 of Houston (1982), he infers evidence of ungulate highlining in the c. 1885 Iddings photograph. Two trees in the upper right corner of the photo might support this inference, but the stronger contrary indication are the trees in the upper left corner with branches to the ground. Similarly, Houston (1976, plate 73) infers ungulate highlining in a c. 1871 Jackson photo. There, a single tree on the skyline in the upper center of the photo apparently lacks its lower branches, but the small trees on the skyline in the upper right all have a full complement of branches. We also do not see evidence of highlining in the c. 1885 Iddings photo in Houston's (1982) plate 1 . On the contrary, there are numerous young trees with branches to the ground in the lower right corner and center right of the photo.

Our second line of evidence is the clear absence of highlining on photos we found in our search. Most significant are the conifers in William H. Jackson's c. 1872 photograph of Mammoth Hot Springs on Yellowstone's northern range, which show no evidence of ungulate browsing or highlining (figure 2a). The conifers in that picture are mostly limber pine (Pinus flexilis), juniper (Juniperus scopulorum), and a few Douglas-fir (Pseudotsuga menziesii). Limber pine is one of the most palatable conifers in the park, yet it shows no evidence of ungulate browsing in this photograph. The photo does not support Houston's $(1976,212)$ claim that conifers show "heavy ungulate utilization" in early $(1870$ s) W.H. Jackson photos taken around Mammoth Hot Springs. Today those same trees have had all of their lower branches removed as high as the elk can reach (figure 2b). The conifers in Jackson's photo appear to be approximately 70 to 100 years old or older and show no evidence of ungulate use, which suggests that few if any elk wintered in that area as far back as 1800.

Regenerating conifers in Idding's c. 1890 photo of Rainy Lake (figure 3) and F. Jay Haynes' 1893 photo of Yancy's Hole (figure 10a) also show no evidence of ungulate browsing. Collectively, these photos, the early Mammoth Hot Springs images, and Houston's photos of unbrowsed conifers give no indication of the ubiquity of ungulate highlining that one sees on the northern range today. 

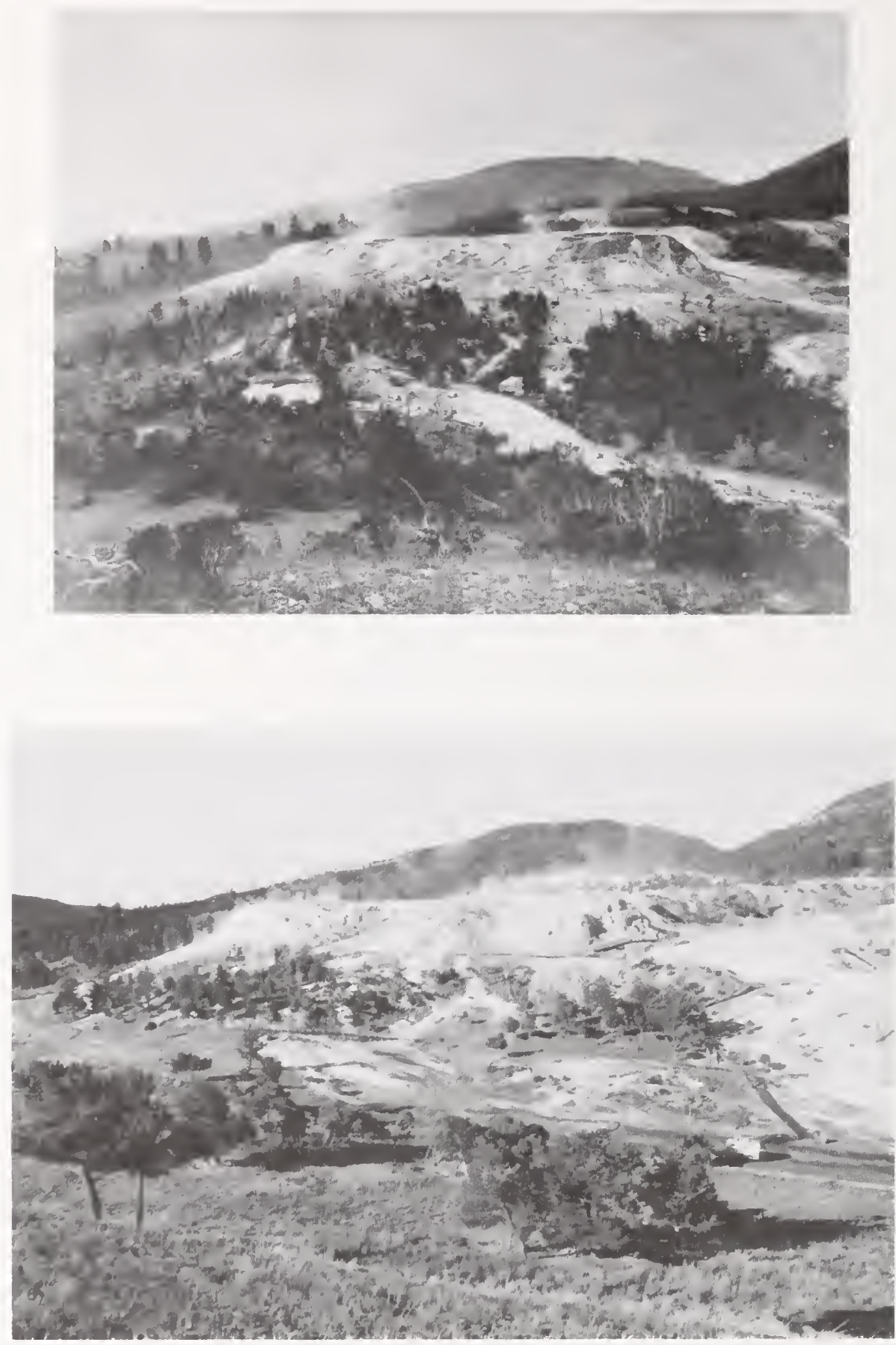

Figure 2. Repeat photoset of conifers at Mammoth Hot Springs on Yellowstone's northern range. (a) Conifers in this William H. Jackson c. 1872 photograph show no evidence of ungulate browsing or highlining. The conifers between the camera and the hot springs are mostly limber pine and juniper. A few Douglas-fir in the left center background show evidence of fire-pruned lower branches. The hot springs apparently kept those fires from burning the conifers in the foreground. Dead trees around the hot springs were most likely killed by changing thermal water runoff patterns, as is often the case today. Regenerating conifers in left center background also do not show any evidence of ungulate highlining. W.H. Jackson photo No. 1,195 (F-28,835), Colorado Historical Society, Denver. (b) That same area in 1989. The conifers are now all highlined as high as the elk can reach. Charles E. Kay photo, No. 3,255-14, August 26, 1989. 


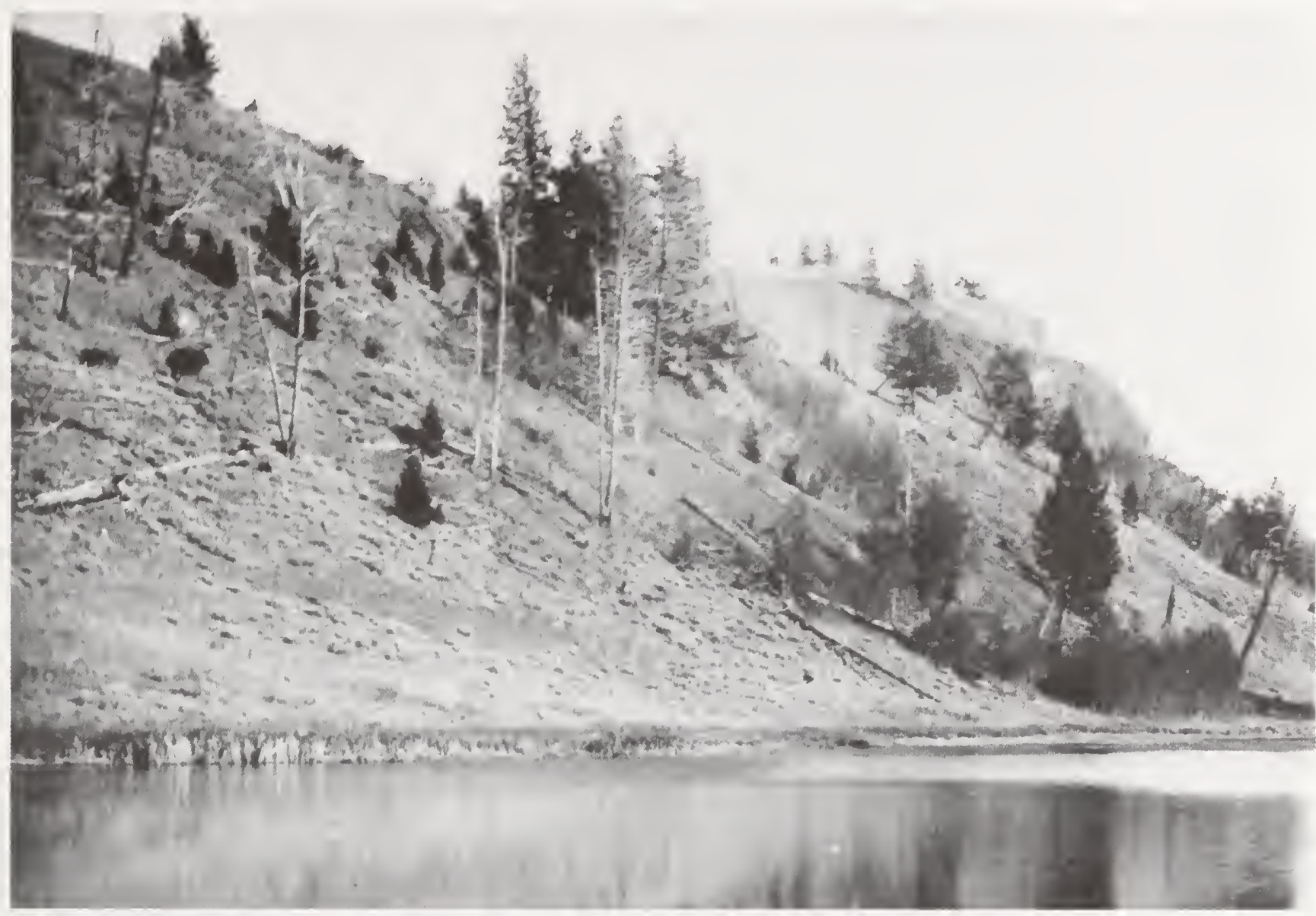

Figure 3. Early photograph of Rainy Lake on Yellowstone's northern range southeast of Tower Junction. Based on the standing snags and height of the regenerating aspen in this c. 1890 photo, it appears that this site burned 10 to 15 years before the photo was taken. The aspen and regenerating conifers, mostly Douglas-fir, show no signs of highlining nor any evidence of ungulate browsing. The lower branches of older conifers have been killed by fire, as the highline height is variable, and the lower branches of some conifers have been removed higher than elk can browse. According to Houston (1976, p. 264), "A fire-scarred tree cut within 40 yards of the camera point showed fire dates of 1876, $\pm 1840 \pm, 1810 \pm$ and several earlier fires." Closeup from a photograph by J.P. Iddings, No. 148, U.S. Geological Survey, Denver. 
The third basis for our conclusions is that other factors besides ungulate highlining may explain the absence of lower branches on conifers. These factors evidently account for most, if not all, of the infrequent cases of what appears to be highlining in the early photos. One factor is pruning by light groundfires that burn and kill lower branches. Fire pruning of the lower branches of conifers can be distinguished from ungulate highlining because fire- pruning height varies, producing an uneven highline instead of the near-constant height that results from ungulate browsing. Second, unless they are standing on packed snow, elk can typically browse to a height of only $3 \mathrm{~m}$ or less, while fires often kill conifer branches to a greater height.

An excellent example is shown in figure 4, a photograph taken by J.P. Iddings on Yellowstone's northern range c. 1890. Iddings, who worked for the U.S. Geological Survey, apparently took this photograph to illustrate glacial erratic boulders, which are common in the lower Lamar Valley where this picture was taken. To the right of the boulder are one large and at least three smaller Douglas-fir trees. The lower branches on the large tree are all dead. If ungulates had highlined this tree, these branches would have been eaten or broken off. Instead, even the small, dead branch tips remain. Since this Douglas-fir grew by itself in the open, its lower branches did not self-prune as a result of lack of sunlight, as commonly occurs in dense forests. Based on the 20- to 25-year fire interval that Houston $(1973,1982)$ obtained for this area and the lack of sagebrush in this photo, we conclude that frequent light groundfires killed the lower branches on this large Douglas-fir.

The young Douglas-firs in figure 4 apparently grew after the last fire at the site and show no evidence of ungulate browsing or highlining. Today all the conifers on this site have been highlined by elk to a height of $3 \mathrm{~m}$, including Englemann spruce (Picea engelmannii), which is the least palatable conifer (Bergerud and Manuel 1968; Miquelle and Van Ballenberghe 1989; Nelson and Leege 1982).

Other early photos also show fire pruning of the lower branches of conifers, including the conifers in the right center of figure 3 and in the upper center and upper left of figure 9 . In both cases, the dead tree snags and clumps of young aspen shoots attest to the fire history of these sites. Fire-pruned conifers can also be seen in the upper right corner of figure 10a, again accompanied by dead snags.

A second explanation for the absence of lower coniferous branches is human pruning. Several historic photos, some as early as the 1880s, show conifers without their lower branches. Most of that highlining, however, was caused by human (European) use. Humans commonly removed lower branches for several purposes. During Yellowstone Park's early years, there were no designated camping areas and no regulations against cutting live trees (Haines 1977). Draft animals, primarily horses, were the main mode of transportation. Riders often removed a tree's lower branches so they could tie their animals directly to the main trunk, which was more secure than tying them to small branches.

Early park visitors also cut conifer branches to sleep on, since they did not carry the foam pads or air mattresses used by today's tourists. For example, William H. Jackson's early (1870s) photos of camp life in Yellowstone show pine boughs cut for bedding. Hamp (Brayer 1942, 284) refers to the "splendid bed of bows" he slept upon while camping in Yellowstone during the summer of 1872. Moreover, early tourists were no different from campers today, who remove lower branches from trees near their campsites to burn as fuel or for other camp activities.

In earlier times, people tended to camp near scenic attractions and hence tended to remove the lower branches from trees at those locations. Those same areas were also commonly photographed by early park visitors. Photography was much more difficult then than it is now, and people did not "waste" time and effort taking pictures that did not include major attractions, such as hot springs. The vast majority 


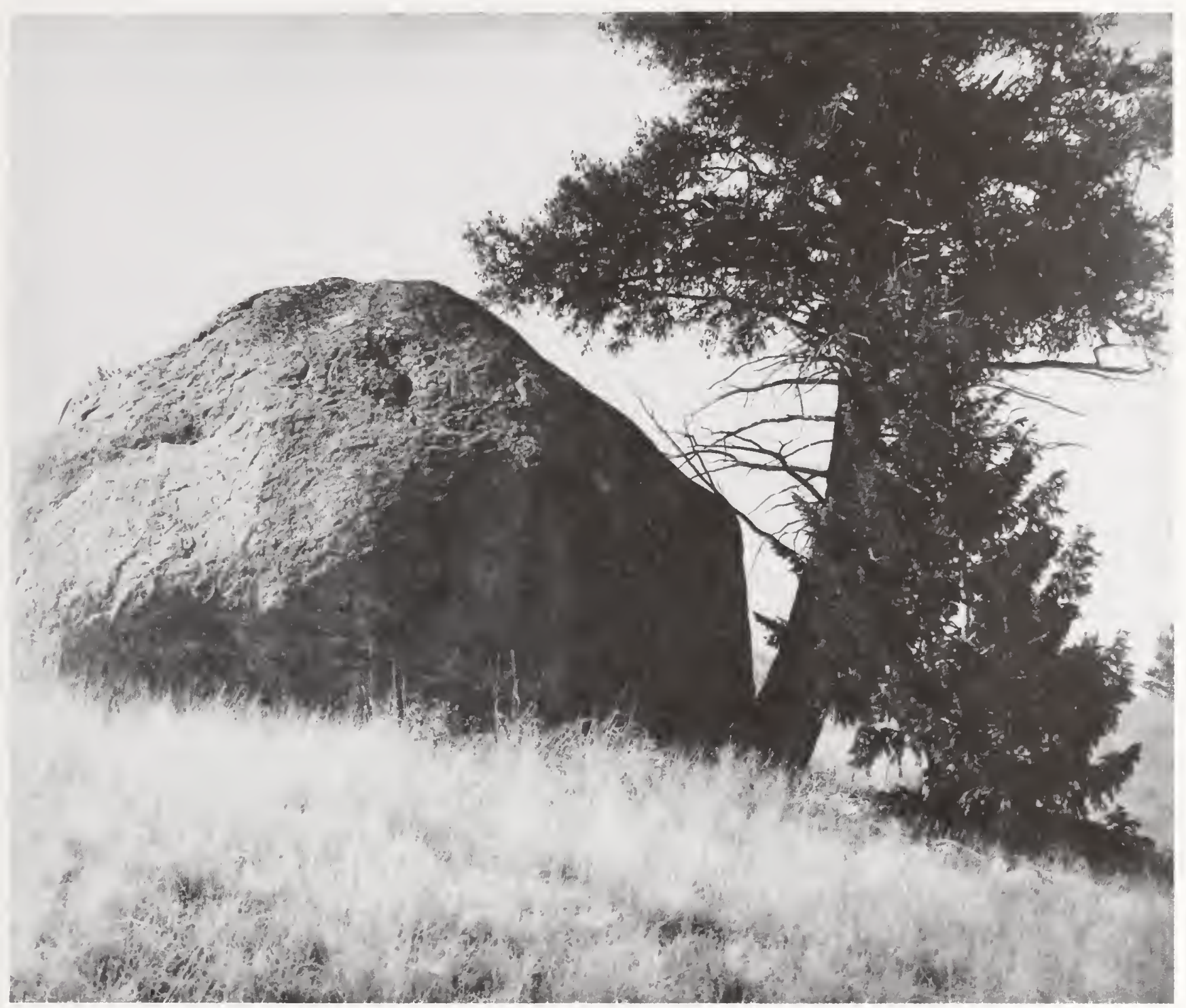

Figure 4. Douglas-fir trees growing on the north side of a glacial erratic boulder in the lower Lamar Valley on Yellowstone's northern range c. 1890. Based on the 20-to 25-year fire interval determined by Houston $(1973,1982)$ for this area and the lack of sagebrush in this photo, the older Douglas-fir's lower branches were probably killed by low-intensity groundfires. The dead branches retain their fine tips, which would not be the case if elk had removed the foliage. Moreover, the branches have been killed to a height beyond the reach of elk or other ungulates. Three young Douglas-firs that have grown since the last fire at this site show no evidence of ungulate browsing or highlining. Photo by J.P. Iddings, No. 149, U.S. Geological Survey, Denver. 
of the approximately 50,000 historic images we reviewed for this study were of major park features. Fewer than 1 percent contained vegetation subjects of interest, and most of those were taken for other purposes. For example, the only reason Haynes took photos in 1893 of aspen and willows on the northern range (figures 7 and 10a) was because his subjects happened to be standing in front of them.

William H. Jackson's c. 1883 photograph of Crested Hot Spring with Old Faithful erupting in the distance (figure 5) illustrates the effect of human highlining on conifers. The conifers in the right center and behind the cabin (left center) do not show evidence of highlining, but the conifers in front of the cabin, along the walkway, and in front of the tent camp on the bench above the Firehole River are all highlined. Apparently people removed the lower branches from these conifers to improve the view.

In total, we see no substantial evidence of ungulate-induced conifer highlining in photos depicting scenes in the first two decades of the park's existence. On the contrary, we see considerable evidence of its absence. The situation is clearly different today: the vast majority of conifers exposed to wintering ungulates on the northern range have had their lower branches removed by browsing animals (figure 1).

\section{Aspen}

Aspen are more palatable to ungulates than conifers and are readily eaten by elk during winter as well as during other times of the year (Nelson and Leege 1982). The animals affect aspen stands in four ways. First, they eat the soft bark, digging their lower front teeth into the bark and then moving their heads upwards, applying pressure to the tree. This enables the animals to gnaw or strip off large pieces of bark, often down to the sapwood (DeByle 1985, 118-119; Krebill 1972). In response to this injury, the trees develop black scar tissue. When the bark damage is extensive, as is characteristic in Yellowstone, the lower $3 \mathrm{~m}$ or so of aspen trunks are black instead of the normal white (figure 6).

Second, in areas of heavy elk use, the animals perennially browse off any young shoots that grow from the clone's root mass. Thus, any trees tend to be uniformly older ones that somehow escaped browsing. There are no young regenerating sprouts greater than $2 \mathrm{~m}$ tall. These characteristics can be seen in figure 6 .

Third, those aspen stems that have managed to escape elk browsing and grow into trees characteristically have no lower branches, i.e., they are highlined. Branches within the animals' reach are browsed off (figure 6).

And finally, in areas of heavy elk use, the understories of aspen stands have a parklike appearance, the vegetation made up largely of grasses (often exotic) and low forbs (Kay 1990; figure 6). Stands not subjected to heavy use, like those outside Yellowstone Park and in enclosures on the park's northern range, have a diverse understory of shrubs and tall forbs (Kay 1990).

Park biologists agree on the above characteristics of contemporary aspen stands on the northern range. But according to the "natural regulation" hypothesis, they contend that aspen in Yellowstone have always exhibited these characteristics (Despain 1991, 94-101; Despain et al. 1986). If this is true, ungulate use should be apparent in early photos of aspen stands on the northern range.

Figures 7 and 8 are 1893 and 1899 photos of aspen on the park's northern range. They show white, unscarred trunks down to ground level; branches or branch scars on their lower $2 \mathrm{~m}$; multisized (aged) stems; and understories that appear to be dominated by tall forbs and shrubs, not grasses. By 1910, however, photos show that elk had started to highline aspen and inflict bark damage. 

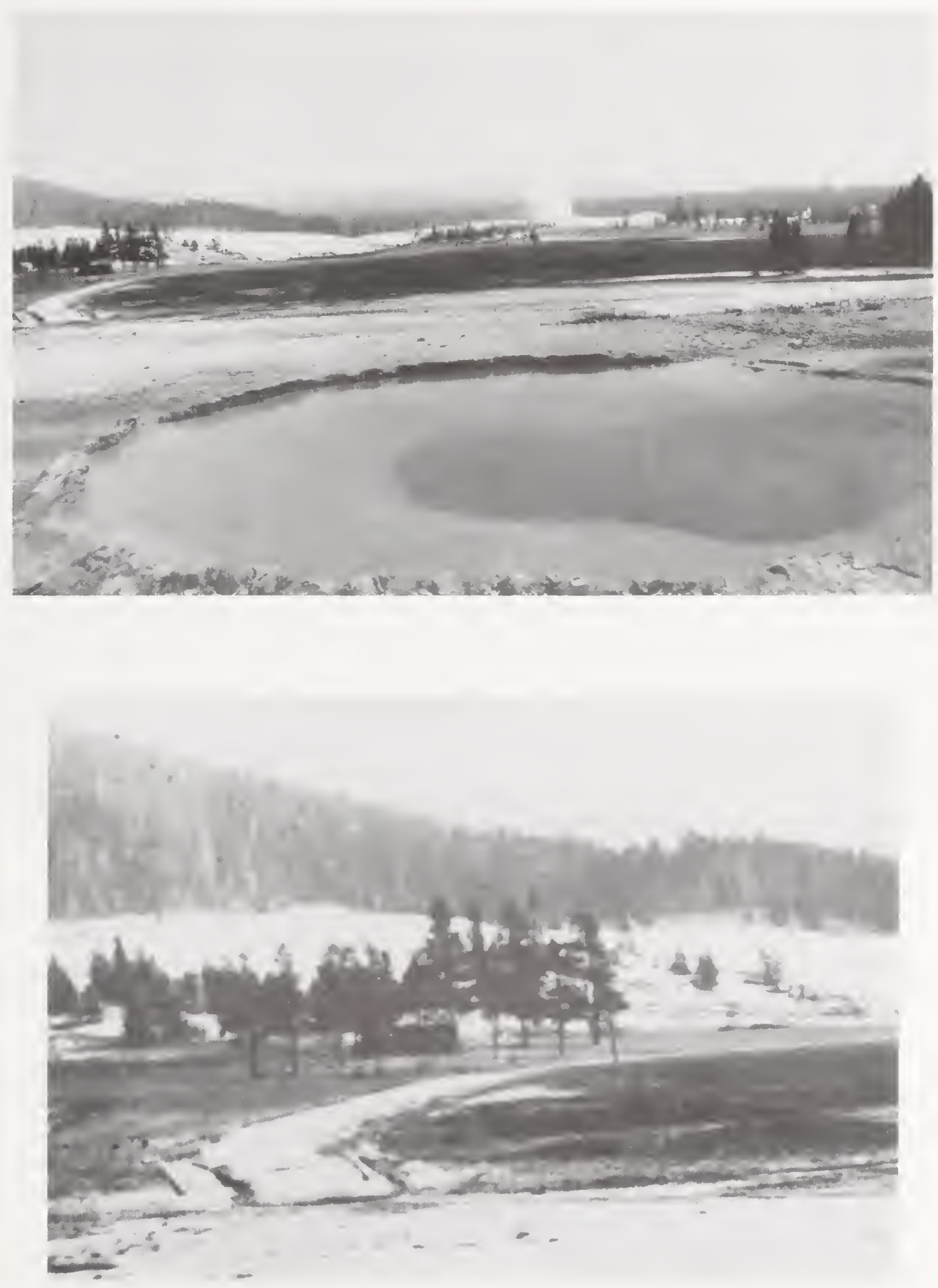

Figure 5. Conifers in William H. Jackson's c. 1883 photograph of Crested Hot Spring with Old Faithful erupting in the distance show evidence of human highlining. (a) Trees in the right center and behind the cabin (left center) do not show any evidence of highlining, whereas conifers in front of the cabin, along the walkway, and in front of the tent camp above the Firehole River have all been highlined. People apparently removed the lower branches from these conifers to improve the view or to facilitate camp activities. (b) Closeup of the area around the cabin. W.H. Jackson photo, No. 235 (F-33,110), Colorado Historical Society, Denver. 


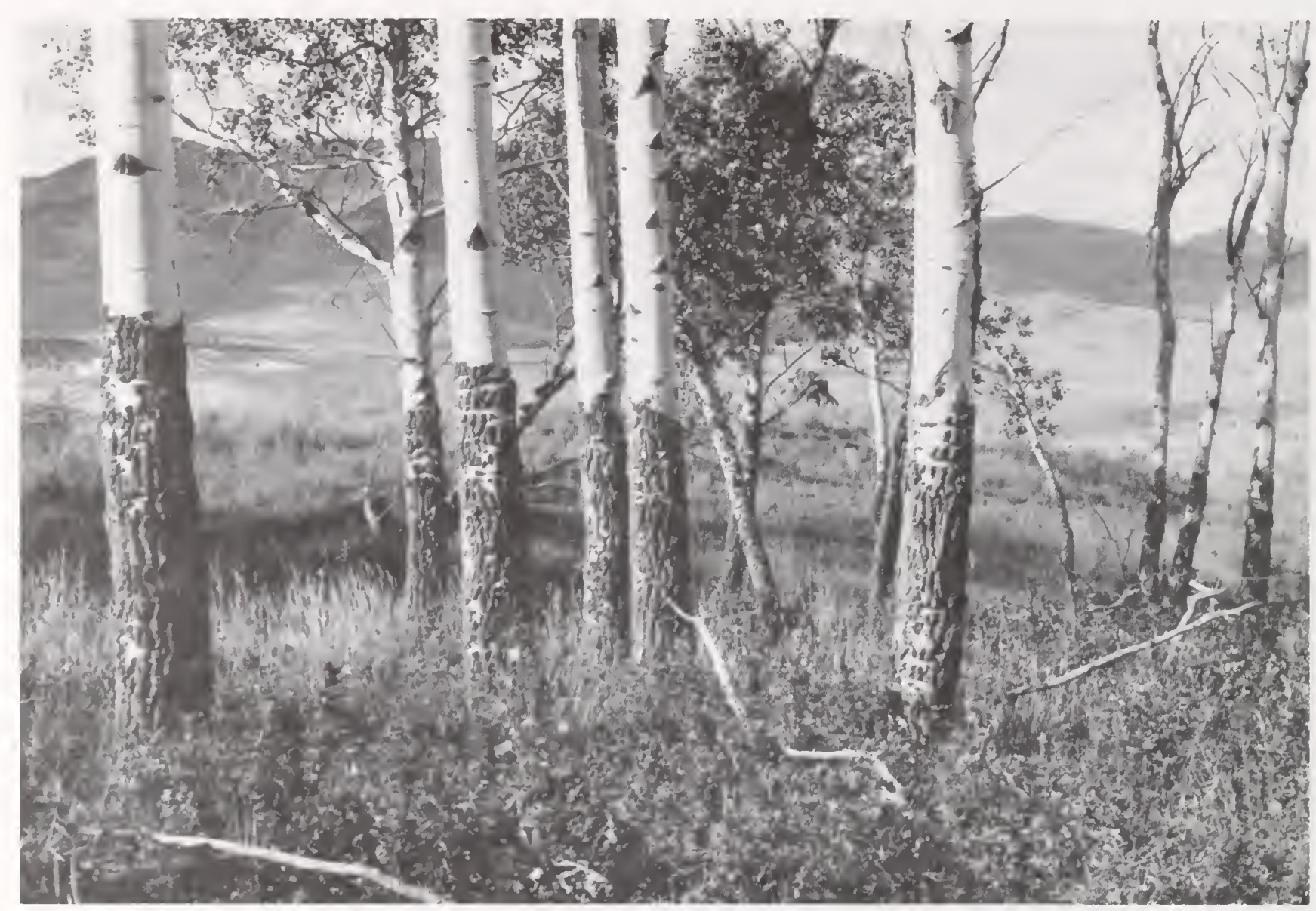

Figure 6. A typical aspen stand on Yellowstone's northern range today, showing extensive black scar tissue induced by elk bark wounding on the lower $3 \mathrm{~m}$ of trunks. Almost all aspen on the northern range have been similarly affected and identical bark coloration patterns are clearly visible in any photograph. Compare this with figures 7 and 8. Charles E. Kay photo, No. 3,272-24, August 28, 1989.

Early photos of other aspen stands on Yellowstone's northern range, such as those depicted in figures 3 and 9 , show dense, relatively short-statured aspen that apparently regenerated after fire. None of these trees show any sign of ungulate browsing. Kay (1990) evaluated more than 460 recently burned aspen stands in the Greater Yellowstone ecosystem. In photographs of those stands several years after they were burned, the only ones that had the same physical appearance as stands on the northern range, c. 1870 to 1890 , were those that experienced little or no ungulate use. Aspen stands on the northern range that were burned by the 1988 wildfires have not been able to grow new stems greater than $2 \mathrm{~m}$ tall because of repeated elk browsing (Kay, unpublished data).

In sum, none of the aspen in early photos show any signs of ungulate browsing or highlining. Instead, stands photographed on Yellowstone's northern range during the late 1800s resemble contemporary stands found within ungulate-proof enclosures and outside the boundaries of the park (Kay 1990). 

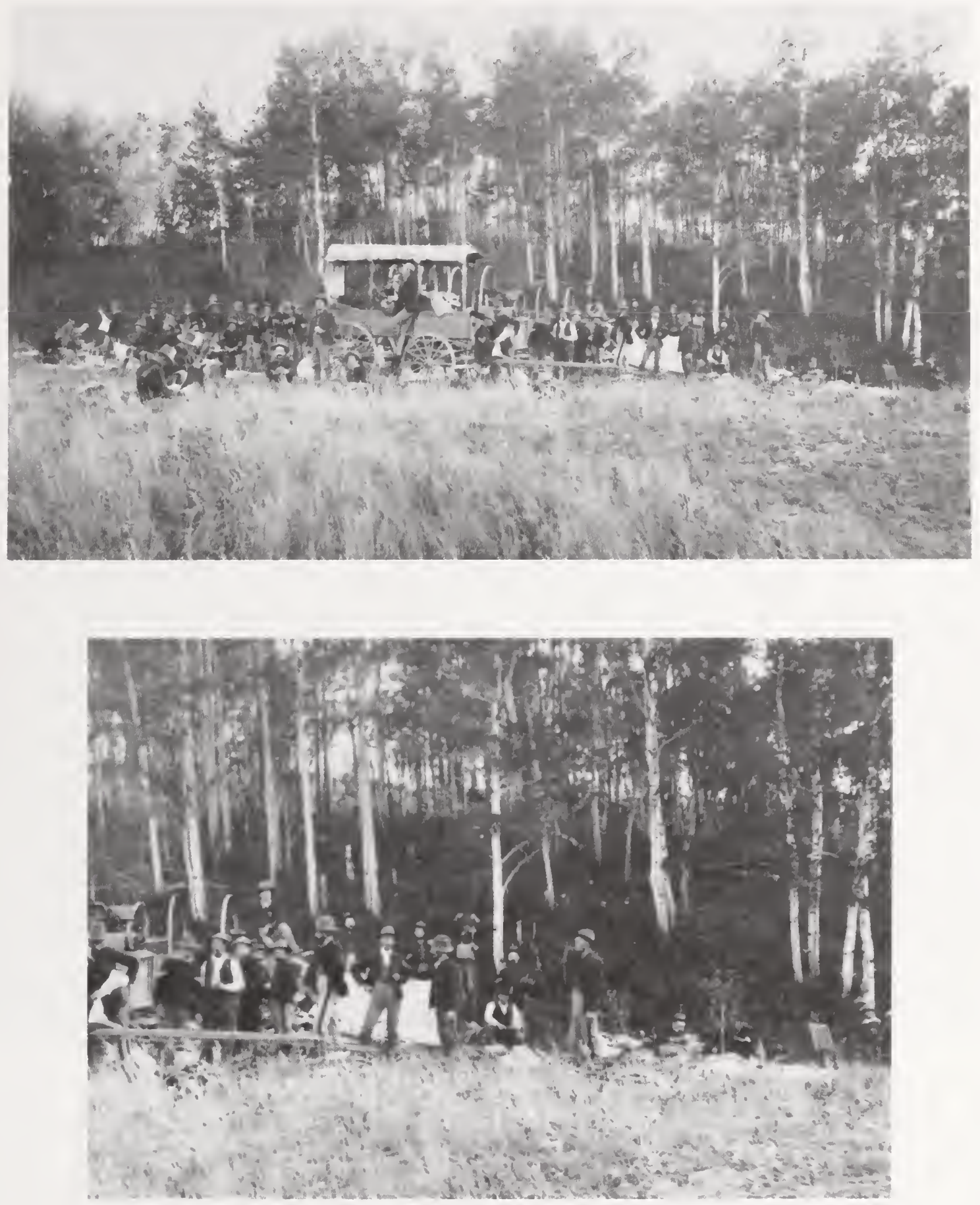

Figure 7. Company D, Minnesota National Guard camp at Little Blacktail on Yellowstone's northern range in 1893. (a) Aspen stands in background show no elk-induced bark injury; multisized (aged) aspen; tall-forb-dominated understory; and little or no use by elk or other ungulates. Stumps in stand indicate some aspen have been cut, probably related to camp activities. In all likelihood, those woodcutting activities injured surrounding aspen and produced the few black scars evident in this photo, as any bark injury will produce black scar tissue. Other black marks are branch scars that aspen normally produce when lower branches die as the trees grow. (b) Closeup of aspen. These aspen clearly do not look like today's heavily scarred trees; compare this photo with figure 6. Photo by F. Jay Haynes, H-3070, courtesy Haynes Foundation Collection, Montana Historical Society, Helena. 


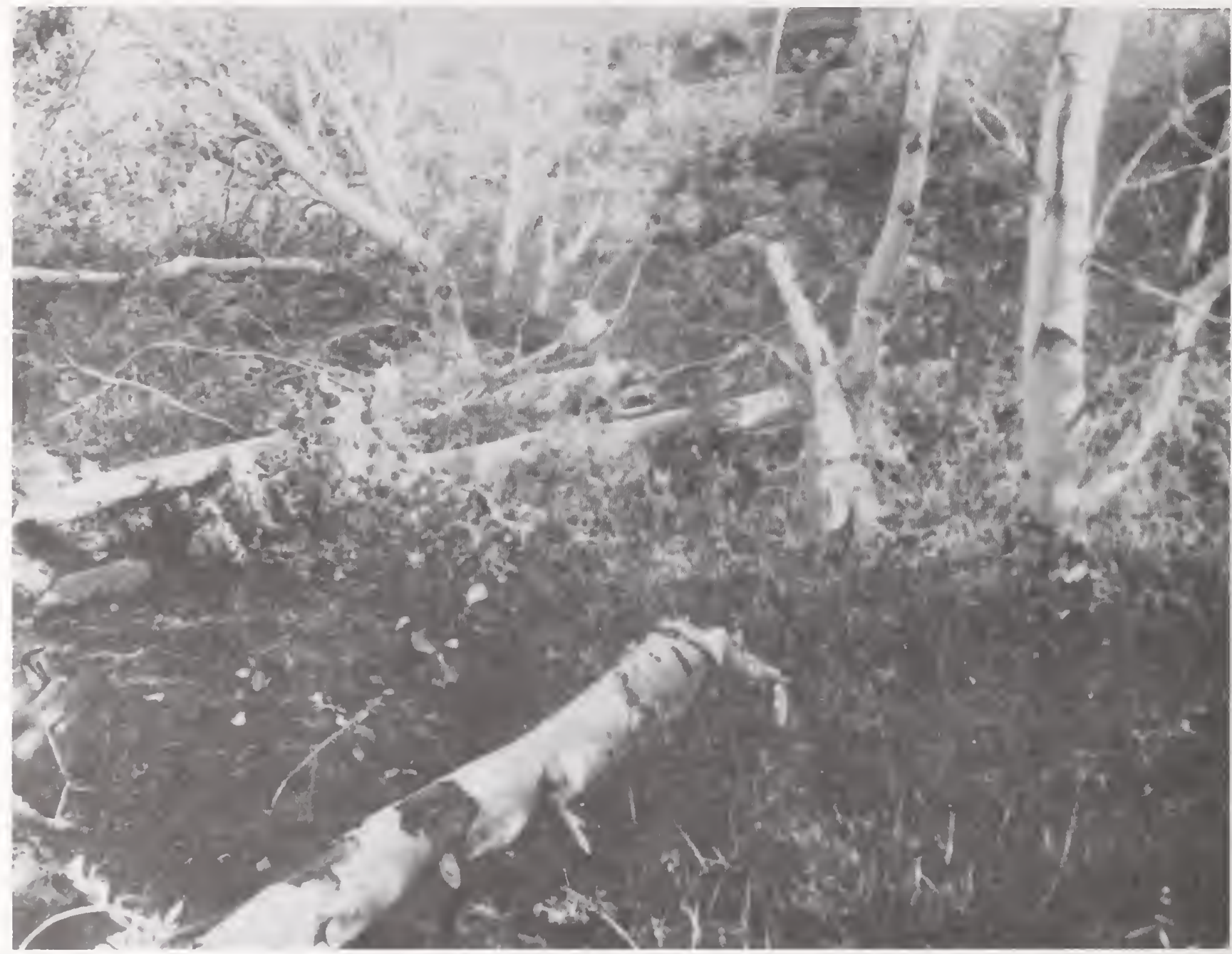

Figure 8. Closeup of aspen felled by beaver on Yellowstone's northern range in 1899. Aspen show no elk-induced bark injury, branch scars or branches on lower $2 \mathrm{~m}$ of trees, multisized (aged) aspen, shrub-tall-forb-dominated understory, and little or no use by elk or other ungulates. Compare this photo with figure 6. Photo by Aven Nelson, N213p-y-nc, courtesy American Heritage Center, University of Wyoming, Laramie. 


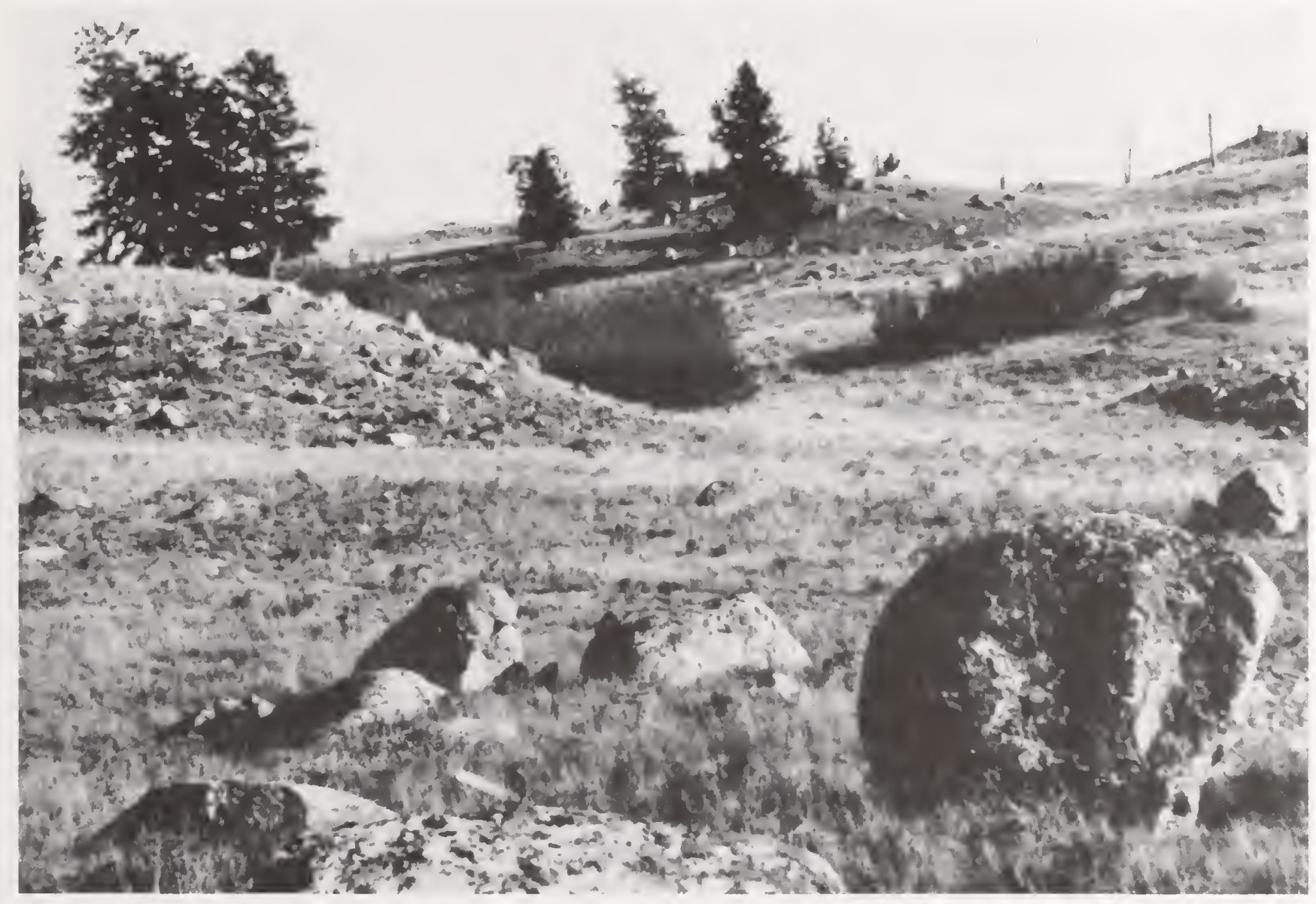

Figure 9. Early photo of aspen on Yellowstone's northern range. The dense aspen regeneration in this c. 1890 photo taken northeast of Tower Junction is not highlined and does not show any evidence of ungulate browsing. Based on the height of the aspen and lack of sagebrush, it appears this site burned 10 to 15 years before the photo was taken. The lower branches of older conifers, mainly Douglas-fir, have been removed or killed by fire. According to Houston (1976, p. 252), "Fire scarred trees cut in this area suggest a historic fire frequency of one fire every 20 - 25 years for the past 300 - 400 years." Closeup from a photograph by J.P. Iddings, No. 152, U.S. Geological Survey, Denver. 


\section{Willows}

Willows, like aspen, are highly palatable to elk. Willows today seldom exist as tall shrubs in the riparian zones of the park's northern range. Instead, most willows are hedged snags $1 \mathrm{~m}$ or less in height that seldom exceed the depth of the previous winter's snow. If the premises of the "natural regulation" paradigm are valid, willow vegetation along streams should have exhibited these characteristics in pre-Columbian times and in the late 1800s, at and following park formation (Despain et al. 1986; Dodd 1991).

Early photos of tall willow communities on the park's northern range, such as those in figure 10, however, show no evidence of ungulate browsing or highlining. Willows photographed on Yellowstone's northern range during the late 1800 s resemble those found today within ungulate-proof enclosures and in riparian zones outside the park (Chadde and Kay 1991; Kay 1990). Thus, conditions inside the enclosures more closely approximate the level of ungulate use that existed when Yellowstone Park was established than do current park conditions. This evidence also implies that, historically, few elk or other ungulates wintered in what is now Yellowstone National Park.

\section{Conclusions}

Photos of conifers, aspen, and willows on Yellowstone's northern winter range show little or no impact of elk browsing when the park was established in 1872. From 1900 to 1920, those same woody species showed increasing evidence of heavy elk use - conifer highlining, aspen bark stripping and highlining, and hedging of willows - became common. Thus, we conclude that the northern range vegetation is not "natural" - if that term is defined as the condition that prevailed at European contact - and represents a departure from the conditions that existed before the creation of Yellowstone Park.

The condition of the woody vegetation in early photographs and in repeat photosets supports the view that Yellowstone was not historical winter range and that the northern herd increased to unprecedented numbers and profoundly altered the park's vegetation. These photographs do not support Houston's (1982) conclusion that Yellowstone was always a major elk wintering area and that the northern herd did not increase or alter the system. Instead, the evidence points to a significant increase in elk that altered the northern range ecosystem. Since these data also disprove one of the key assumptions upon which "natural regulation" is based - i.e., that thousands of elk always wintered in the park - that paradigm must be rejected as well. 

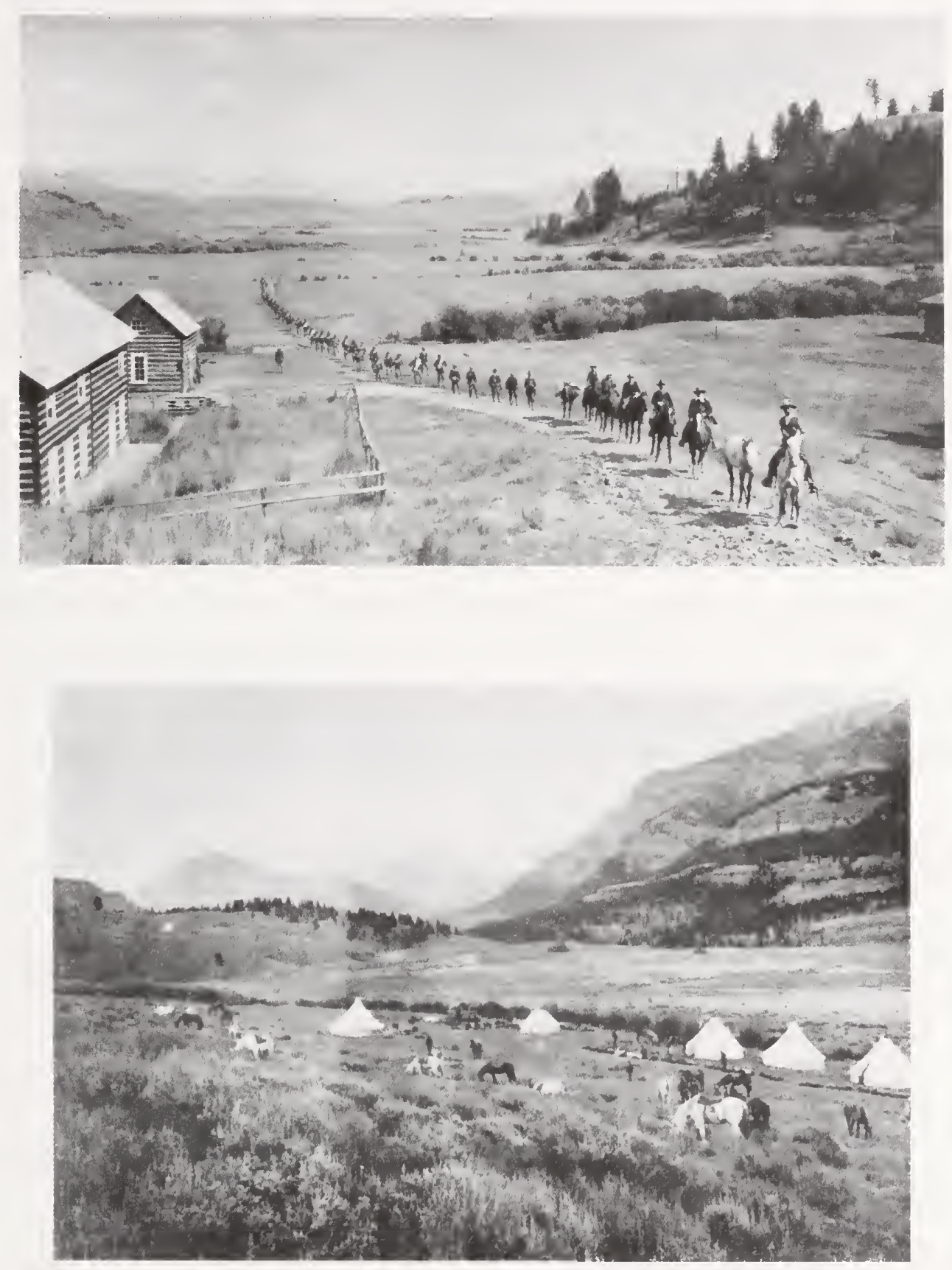

Figure 10. Early photographs of tall willows on Yellowstone's northern range. (a) None of the tall willows in this 1893 photo of Yancy's Hole near Tower Junction shows any evidence of ungulate browsing or highlining. Today, no tall willows exist at this site because of repeated elk browsing (Chadde and Kay 1991 , p. 237). Conifers in right center-top show the results of frequent low-intensity groundfires. The lower branches of older trees have been fire pruned, as the highline height is variable, and the lower branches of some conifers have been removed higher than elk can browse. Young conifers show no evidence of ungulate browsing or highlining. Photo by F. Jay Haynes, H-3080. Courtesy Haynes Foundation Collection, Montana Historical Society, Helena. (b) Willows in this c. 1896 photo of the lower Soda Butte Valley show no evidence of ungulate browsing or highlining. Today, no tall willows exist at this site because of repeated elk browsing (Chadde and Kay 1991, p. 240). Photo by A.E. Bradley, courtesy A.E. Bradley Collection (72-158), Mansfield Library, University of Montana, Missoula. 


\section{Literature Cited}

Bergerud, A.T. and F. Manuel. 1968. Moose damage to balsam fir-white birch forests in central Newfoundland. Journal of Wildlife Management 32:729-746.

Brayer, H.O., ed. 1942. Exploring the Yellowstone with Hayden, 1872: Diary of Sidford Hamp. Annals of Wyoming 14:253-298.

Caughley, G. 1976. Wildlife management and the dynamics of ungulate populations. Applied Biology 1:183-246.

Chadde, S. and C.E. Kay. 1991. Tall willow communities on Yellowstone's northern range: a test of the "natural regulation" paradigm. Pages 231-262 in R.R. Keiter and M.S. Boyce, editors, The Greater Yellowstone Ecosystem: Redefining America's Wilderness Heritage. Yale University Press, New Haven, Connecticut. 428pp.

Chase, A. 1986. Playing God in Yellowstone: The Destruction of America's First National Park. Atlantic Monthly Press, Boston, Massachusetts. 446pp.

Cole, G.F. 1974. Population regulation in relation to K. Paper presented at the annual meeting of the Montana Chapter of the Wildlife Society. Bozeman, Montana. February 22. 17pp.

Cole, G.F. 1983. A naturally regulated elk population. Pages 62-92 in F.L. Bunnell, D.S. Eastman, and J.M. Peek, editors, Symposium on natural regulation of wildlife populations. University of Idaho Forest, Wildlife, and Range Experimental Station Proceedings 14. 225pp.

Debyle, N.V. 1985. Animal impacts. Pages 115-123 in N.V. Debyle and R.P. Winokur, editors, Aspen: Ecology and Management in the Western United States. Gen. Tech. Rep. RM-119. U.S. Department of Agriculture, Forest Service. 283pp.

Despain, D. 1991. Yellowstone Vegetation. Roberts Rinehart, Boulder, Colorado. 239pp.

Despain, D., D. Houston, M. Meagher, and P. Schullery. 1986. Wildlife in Transition: Man and Nature on Yellowstone's Northern Range. Roberts Rinehart, Boulder, Colorado. 142pp.

Dodd, J. 1991. U.S.F.S. Standards for riparian zones: are they based on real world or fantasy world models? Soc. Range Manage., Wyoming Section Newsletter. April. pp. 9-10.

Gruell, G.E. 1980a. Fire's influence on wildlife habitat on the Bridger-Teton National Forest, Wyoming. Vol. 1 - Photographic record and analysis. Res. Paper INT-235. U.S. Department of Agriculture, Forest Service. 207pp.

Gruell, G.E. 1980b. Fire's influence on wildlife habitat on the Bridger-Teton National Forest, Wyoming. Vol. 2 - Changes and causes, management implications. Res. Paper INT-252. U.S. Department of Agriculture, Forest Service. 35pp.

Haines, A.L. 1977. The Yellowstone Story. Vol. I. Yellowstone Library and Museum Association in cooperation with Colorado Association University Press, Yellowstone National Park, Wyoming. 385pp. 
Houston, D.B. 1973. Wild fires in northern Yellowstone National Park. Ecology 54:1111-1117.

Houston, D.B. 1976. The northern Yellowstone elk - parts III and IV: Vegetation and habitat relations. Yellowstone National Park, Wyoming. May. 444pp.

Houston, D.B. 1982. The Northern Yellowstone Elk: Ecology and Management. Macmillan Publishing, New York, New York. 474pp.

Kay, C.E. 1990. Yellowstone's northern elk herd: A critical evaluation of the "natural regulation" paradigm. Ph.D. diss., Utah State University, Logan, Utah. 490pp.

Krebill, R.G. 1972. Mortality of aspen on the Gros Ventre elk winter range. Res. Paper INT-129. U.S. Department of Agriculture, Forest Service. 16pp.

Miquelle, D.G. and V. Van Ballenberghe. 1989. Impact of bark stripping by moose on aspen-spruce communities. Journal of Wildlife Management 53:577-586.

Nelson, J.R. and T.A. Leege. 1982. Nutritional requirements and food habits. Pages 323-367 in J.W. Thomas and D.E. Toweill, editors, Elk of North America: Ecology and Management. Stackpole Books, Harrisburg, Pennsylvania. 698pp.

Rogers, G.F., H.E. Malde, and R.M. Turner. 1984. Bibliography of Repeat Photography for Evaluating Landscape Change. University of Utah Press, Salt Lake City, Utah. 179pp.

Tyers, D.B. 1981. The condition of the northern Yellowstone winter range in Yellowstone National Park a discussion of the controversy. M.S. thesis. Montana State University, Bozeman, Montana. 170pp. 



\title{
Short- and Long-Term Changes in Riparian Zone Vegetation and Stream Macroinvertebrate Community Structure
}

\author{
Deron E. Lawrence \\ Stream Ecology Center, Department of Biology \\ Idaho State University \\ Pocatello, ID 83209 \\ G. Wayne Minshall \\ Stream Ecology Center, Department of Biology \\ Idaho State University \\ Pocatello, ID 83209
}

\begin{abstract}
During and following the 1988 fires, riparian zone vegetation was photographed at five locations along 18 "burn" and 4 reference streams in Yellowstone National Park. Regrowth at each station was dependent both on burn intensity and vegetation present prior to the fires, and many colonizing species were present among the various microhabitats. Reference stream photographs showed a broad array of possible "endpoints" to which each of the burn streams may recover after $200-300$ years. An 11 . year study following canopy fire in central Idaho added insight into plausible changes that will occur in Yellowstone over the next decade. Processes in the riparian zone affected stream structure and benthic macroinvertebrate community diversity, and a method of global information system (GIS) assessment was developed to index fire impact on stream channels. This index was directly correlated with Simpson's Dominance Index and Shannon-Wiener Diversity $\left(\mathrm{H}^{\prime}\right)$, indicating a predictable relationship between riparian zone disturbance and stream biotic structure.
\end{abstract}

\section{Introduction}

Processes within stream systems are strongly driven by conditions within the surrounding watershed (Hynes 1975; Minshall et al. 1985; Ross 1963). Within a watershed, vegetation serves an important purpose in relation to the physical nature of the stream - namely, that peak flows and sediment loads are determined by the degree of surficial runoff that occurs from rainfall or snowmelt events (Dyrness 1963; Helvey 1972; Pase and Ingebo 1965; Tiedemann et al. 1979). While peak flows will move woody debris and cobble in headwater streams during most years, increased peak flows following watershed fire have the capacity to carve new channels, move boulders, and deposit large volumes of gravel and 
cobble (Minshall, Brock, and Varley 1989). This disturbance immediately decreases the diversity of the macroinvertebrate community, although over longer time periods such disturbance may enhance stream community structure (Poff and Ward 1990). In Yellowstone Park, Albin (1979) showed that benthic macroinvertebrate diversity was higher in a stream 40 years following watershed fire, compared with streams in recently burned watersheds.

While flow regimes are in large part controlled by watershed-scale processes, the effects of fire on aquatic biota may be more accurately assessed at the level of the riparian zone (Frissel et al. 1986; Poff and Ward 1990). Vegetal growth in the riparian zone following fire depends on both the species present prior to the fire and the intensity of burning. Many community assemblages can occur after disturbance because of these and other environmental factors (Romme 1982). At both short- and long-term time scales, changes in riparian vegetation composition may lead to differences in benthic macroinvertebrate community structure.

In 1988, fires burned over 200,000 ha throughout Yellowstone National Park, creating an opportunity to study the numerous effects of watershed burning on forested systems. Research occurred with renewed vigor throughout the park, as seen by the many papers in this conference, and much of the focus has been on how to manage fire and the effects of watershed fire. The purpose of this study was twofold: (1) to identify different riparian zone vegetation changes following fire, and (2) to quantify the relationship between fires and aquatic macroinvertebrate community diversity.

\section{Study Area}

Two locations were identified for this study. First, short-term changes have been monitored at 22 stations in Yellowstone Park since the 1988 wildfires. Information about the macroinvertebrate community is available in a report to the Park Service (Minshall, Robinson, and Lawrence 1991). Second, 10 stations in central Idaho's Frank Church "River of No Return" Wilderness area were sampled annually since a stand-replacing wildfire in 1979. Two additional stations in Idaho include sites 50 and an estimated 300 years after watershed fires. Portions of the macroinvertebrate information from these stations has been published in other reports (see Minshall, Robinson, and Lawrence 1989). While station elevations are lower in Idaho $(1,310-1,400 \mathrm{~m})$ than in the park $(2,135-2,440 \mathrm{~m})$, lodgepole pine (Pinus contorta), Douglas-fir (Pseudotsuga menziesii), and subalpine fir (Abies lasiocarpa) are the common old-growth tree species in all of the watersheds studied. Riparian zones were vegetated with these conifers, as well as willows (Salix spp.), aspen (Populus tremuloides), and numerous grasses and other deciduous shrubs. Our ability to work with GIS data was limited to stations within the park.

\section{Methods}

\section{Objective 1}

Following both the 1988 fires in Yellowstone National Park and the 1979 Mortar Creek fire in central Idaho, streamside photographs were taken each year from established locations to monitor vegetal recovery of riparian zones. Photographs were taken with a $35-\mathrm{mm}$ camera of a cross-section of the stream including vegetation on both banks. In Idaho, two additional watersheds ( $~ 50$ and $\sim 300$ years following fire) were located and photographed. A sequence of photos displaying short-term ( 0 to 3 yrs) 
changes has been arranged for Yellowstone National Park, while long-term changes following fire $(5$ to $-300 \mathrm{yrs}$ ) are shown with the Idaho study. A space-for-time substitution was used to illustrate long-term changes in Idaho by using the 50- and - 300-years (since burn) watersheds. With these stations a complete succession from watershed burning to 300 years following fire can be seen. The photographs taken as part of the Idaho study are from several sites and different angles, so an artist's rendition, showing conditions as they would appear from a single perspective at one site, has been substituted for the photographs.

\section{Objective 2}

Through use of the National Park Services GIS Laboratory, assessment of watershed burn percent and riparian zone burn analyses were conducted. All analyses were run using GRASS (version 3.1), and the following databases were either available or were generated from GRASS routines: (1) fire map of areas burned in 1988, (2) watershed boundaries for each stream studied, (3) riparian zone templates for each stream studied (250 $\mathrm{m}$ total width), and (4) a slope map for the park. The percentage of the total area that was burned was determined for both watersheds and riparian zones by calculating the burned areas within each defined area.

Two indices of riparian zone burn impact on streams were calculated by combining watershed burned area, riparian zone distance to stream (in three categories; see table 1), and slope maps; these indices were named Riparian Burn Intensity Index (RBI) i and ii. These indices were generated by using the "weight" command in GRASS, which allows the user to identify different values of, in this case, disturbance, for each map category. Canopy burns were expected to have more effect on streams than mixed burns, which, in turn, were likely to cause greater disturbance than nonforested burns. By weighting each category, the effect of fire could be scaled. In a similar manner three riparian zones were delineated, with the greatest weighting attributed to the zone closest to the stream channel (table 1). RBI.i was produced by (1) multiplying the burn intensity weighting by the weightings given for cells in each of the three riparian zones (producing intensity products of $1,2,3,4,6,9$, and 12); (2) then calculating the percent area for each intensity product; (3) multiplying the intensity product by the percent area each intensity product covered; (4) summing these values; and (5) scaling the resulting range of values to be between 0 and 100. RBI.i included burn information and distance to stream, while slope information was added to RBI.ii. Greater slopes were expected to create more intense peak flows, so greater slopes were weighted with higher values. The steps used to calculate the index were the same as for RBI.i, except (1) there were more intensity product values, possible because of the addition of slope weightings; and (2) the resultant range of values was not scaled. The lack of scaling did not change the statistical results.

At each stream station five samples of benthic macroinvertebrates were collected, using a Surber sampler. Samples were preserved in the field, and sorting and identification took place in our laboratory (also see Merritt and Cummins 1984). Taxa richness, Simpson's Dominance Index, and Shannon-Weiner Diversity ( $\left.H^{\prime}\right)$ were calculated for each sample. Means of the five samples were correlated with the percent watershed burned, percent riparian zone burned, and the two RBI indices. Using Statview SE + Graphics (Abacus Concepts, version 1.03, run on a Macintosh), least-squares regression methods determined the correlation coefficients $(r)$ for each plot. Correlations between samples taken in fall 1988 (after the fires), spring and summer 1989, and summer 1990 and the RBI indices were plotted to reveal temporal responses of the invertebrate communities in relation to conditions in the riparian zone. 
Table 1. Weighting scores for each Riparian Burn Intensity (RBI) index

\begin{tabular}{|l|c|c|}
\hline \multicolumn{1}{|c|}{ Variable and Category } & RBI.i & RBI.ii \\
\hline Burn intensity & & \\
Canopy burn & 4 & 5 \\
Mixed burn & 2 & 3 \\
Undifferentiated burn & 2 & 3 \\
Nonforested burn & 1 & 2 \\
Unburned & 0 & 1 \\
\hline Riparian zone & & \\
$0-25 m$ & 3 & 3 \\
$25-75 m$ & 3 & 3 \\
$75-125 m$ & 1 & 1 \\
\hline Slope & & \\
$0-1^{\circ}$ & & 1 \\
$2-3^{\circ}$ & & 3 \\
$4-5^{\circ}$ & & 4 \\
$6-9^{\circ}$ & & 5 \\
$10-15^{\circ}$ & & 6 \\
$16-20^{\circ}$ & & 7 \\
$21-30^{\circ}$ & & \\
\hline
\end{tabular}

\section{Results}

\section{Vegetative Changes}

Photographs showing short-term ( 0 to $3 \mathrm{yrs}$ ) development of the riparian zone vegetation following fire demonstrate the initial recovery of grasses and forbs. Immediately following fire, riparian vegetation was completely burned - yet many stems and tree boles were still intact (figure 1, 1988). The topsoils were charred and for the most part organic matter was vaporized, leaving only mineralized products. After one year, grasses and forbs were present, although of low stature and incomplete soil coverage (figure 1 , 1989). These plants intercept rainfall and protect soil from minor erosion but do not afford protection from intense rainstorms or snowmelt, which still move large amounts of sediments to the stream channel (Minshall et al. 1989; Tiedemann et al. 1979).

During the second year of recovery, height and coverage of the grasses and forbs increased, stabilizing the soils further (figure 1, 1990). In the third year of the study, a heavy snowpack combined with spring rains caused increased peak flows and sediment loading, which led to widespread debris deposition and channel cutting (figure 1, 1991). Vegetation in this photograph was suppressed because of the overland flows. These high flows acted as a reset mechanism that returned the recovery of the vegetation to an earlier time, in which new plants will colonize areas of sediment deposition. In areas of overland flow but little erosion or deposition, vegetal regrowth should be vigorous during the fourth year. 


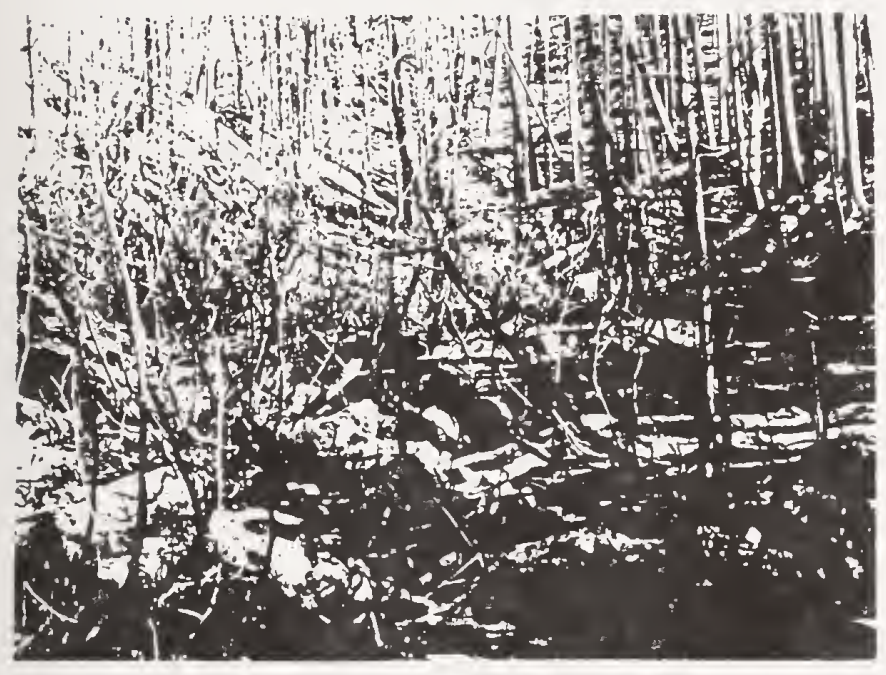

1988

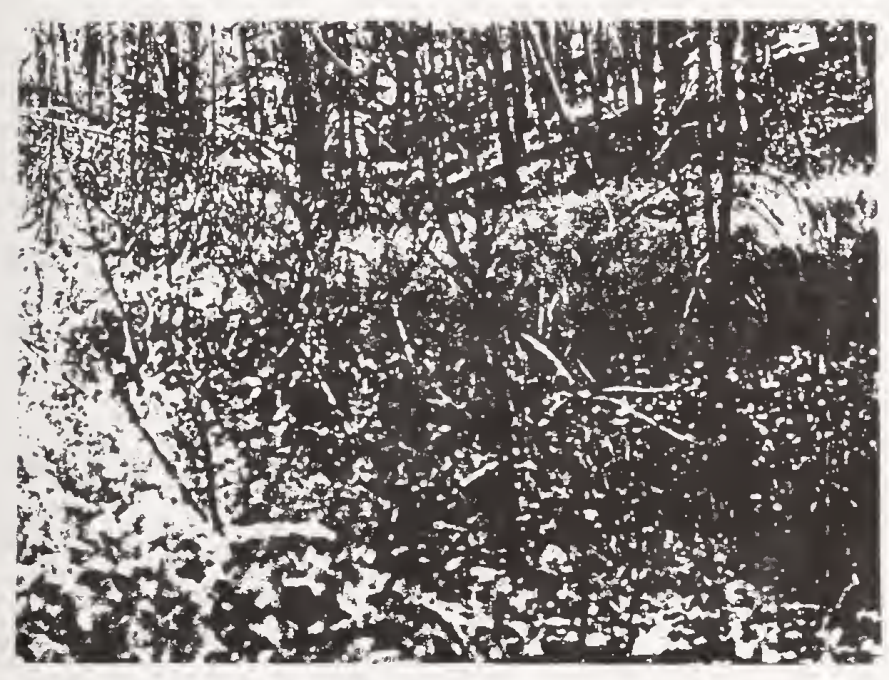

1990

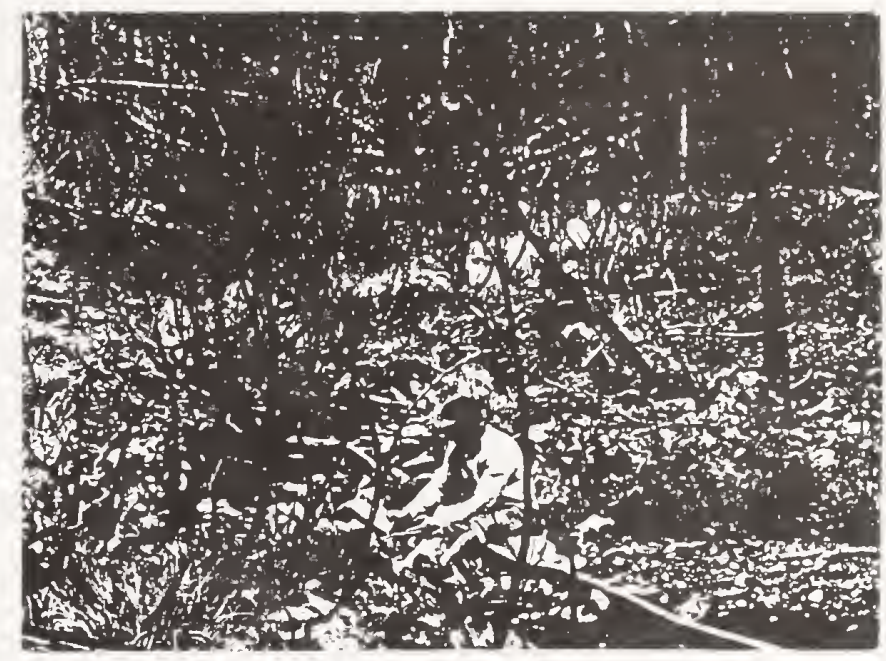

1989

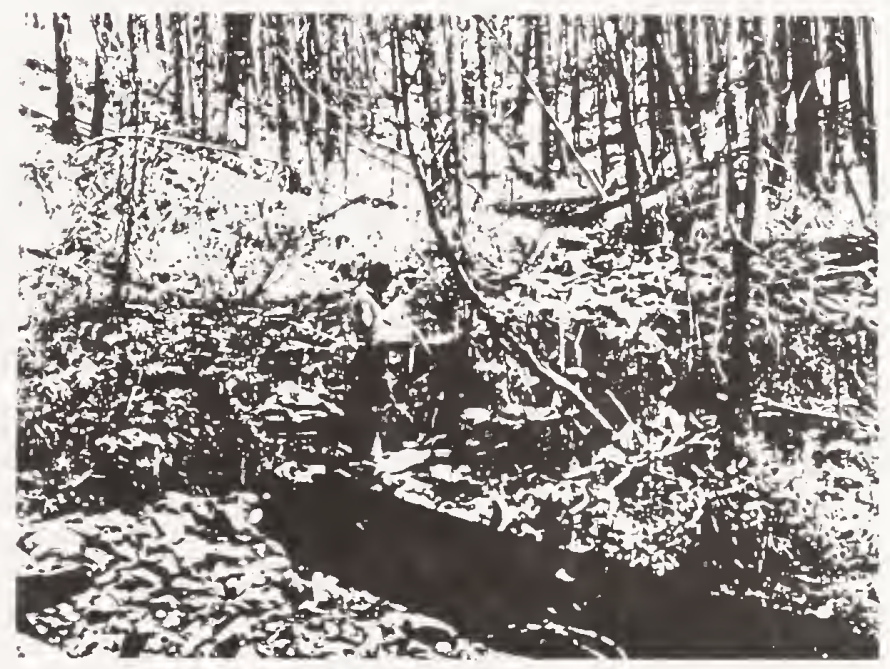

1991

Figure 1. Photographs of short-term changes in the riparian zone of a first-order tributary of Cache Creek. Photographs were taken immediately following the fire in 1988, summer 1989, summer 1990, and summer 1991. 
Long-term changes $(5-300$ yrs) in riparian zone vegetation show the transition from a deciduous community to a coniferous forest. Snags, which are still abundant five years following fire, have been shown to be reduced by about 30 percent from year 0 (Lyon 1984; figure 2, five years). Vegetation offers substantial protection for the soil, which by this time was seen to erode only in the steeper, barren locations. Some locations along the stream channel showed active lateral channel cutting, where additional meandering served to adjust the stream to reduced sediment loading. Surticial soils in the riparian zone appeared to have developed such that only very intense overland flow could cause high amounts of channel scouring as seen in early years. Eleven years following fire, riparian zones had larger willows and alders, which gave nearly complete ground coverage (figure 2, 10 years). Snag density decreased greatly, leaving mainly the larger trees.

Fifty years after watershed burning, mature alders were the dominant riparian vegetation type, although many deciduous shrubs and small- to medium-sized conifer trees were present in the understory (figure 2, 50 years). Only a few broken snags are present, the rest having fallen. Slopes appeared stable, and the steep, actively eroding channel banks were not present as in earlier years. Upland development was seen to be slower than in riparian areas, which we attribute to the more xeric conditions.

Finally, about 300 years following watershed fire, old-growth coniferous trees dominated the riparian zone (figure 2, 300 years). Suppressed willows and alders also were visible, but their abundance was substantially reduced relative to earlier seres. In the riparian zone, grasses were visible in the open patches of more xeric sites or open patches created by treefall, while forbs grew throughout much of the understory.

\section{GIS Analysis}

Percent area of each watershed burned was correlated with taxa richness, Simpson's Dominance Index, and Shannon-Weiner Diversity $\left(H^{\prime}\right)$ from samples taken immediately after the fires in fall 1988 (table 2). No correlation ( $r=-.08$; $P=.74)$ was apparent for taxa richness, while a weak direct correlation $(r=$ $.33 ; P=.18)$ was apparent with Simpson's Index and an inverse relationship $(r=-.57 ; P=.01)$ existed for $\mathrm{H}^{\prime}$ diversity (table 2). The analysis was repeated using burned area within the riparian zone $(0-25 \mathrm{~m}$ from the center of the stream channel), and higher correlations were found for all estimators (table 2). Taxa richness was inversely related to burned area $(r=-.32 ; p=.20)$, while Simpson's Index showed a strong direct relationship $(r=.52 ; p=.03)$, and the correlation with $H^{\prime}$ diversity also was higher $(r=$ $-.61 ; p=.01 ;$ table 2$)$.

RBls were correlated with the benthic community diversity estimators from samples taken in fall 1988 , but not with taxa richness because these values were consistently low. RBI.i correlated more strongly with Simpson's Index $(r=.46 ; p=.05)$, but the $H^{\prime}$ index correlation increased only slightly $(r=-.58$; $p=.01$; figure 3). RBI.ii showed the highest correlations with Simpson's Index ( $r=.62 ; p=.02)$, but again $\mathrm{H}^{\prime}$ index did not change appreciably $(r=.57 ; p=.04$; figure 4).

Correlations between RBI.i and the two community indices were run for samples taken during fall 1988, spring 1989, summer 1989, and summer 1990. These correlations were plotted for each index (figure 5) and show that community diversity changes from an inverse correlation to a direct relationship for $\mathrm{H}^{\prime}$ diversity between fall 1988 and summer 1990 . This indicates that while initially streams experiencing more intense disturbance conditions had lowered community diversity, after two years the more affected streams had higher macroinvertebrate community diversity. Simpson's Index revealed a similar trend, 

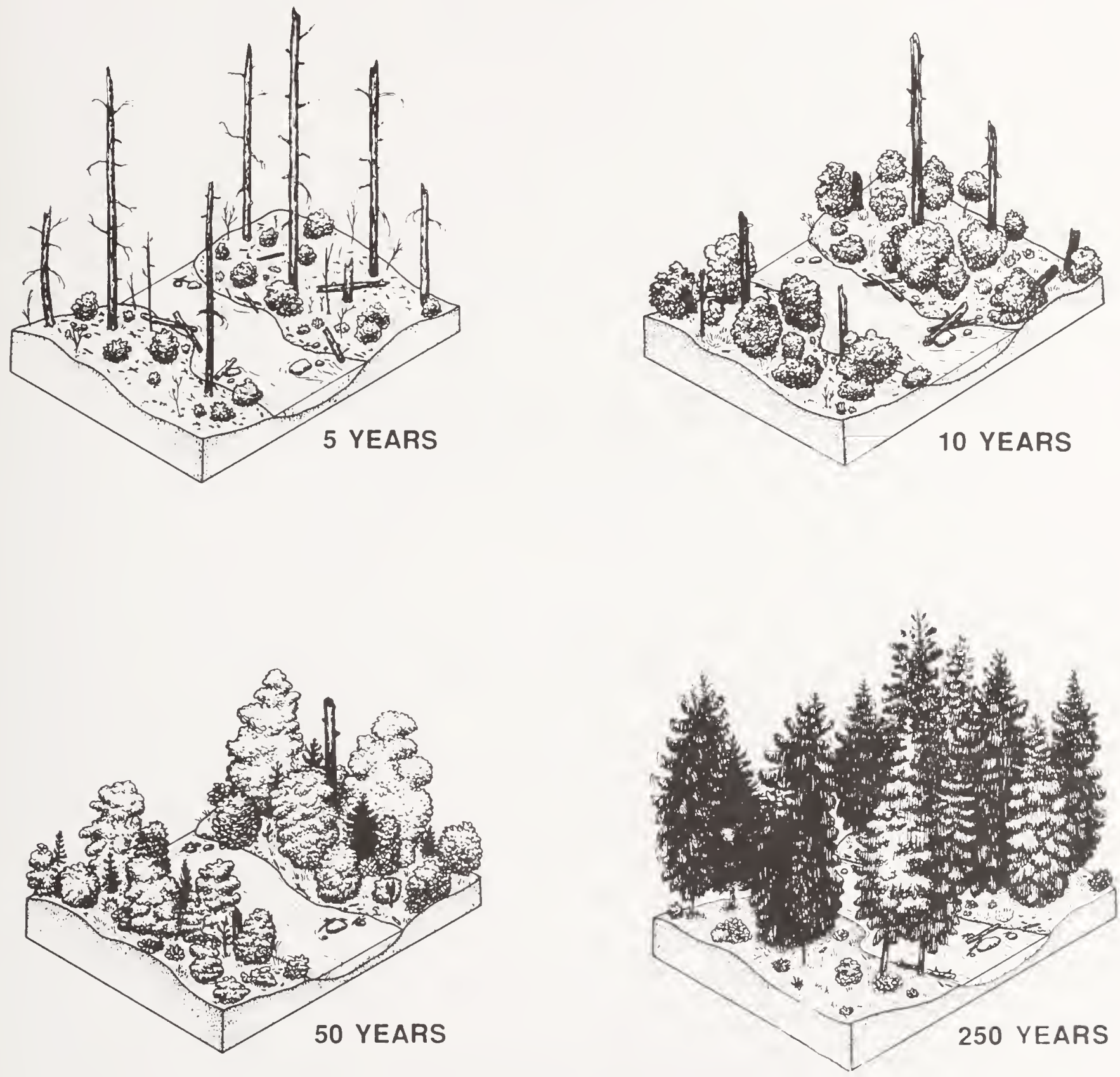

Figure 2. Artist's representation of long-term changes in central Idaho riparian areas following fire, based on actual photographs taken using space-for-time substitutions: Upper Little Loon Creek 5 years following fire, East Fork Little Loon Creek 10 years following fire, Doe Creek 50 years following fire, and a composite of several locations 300 years following fire. 
a)

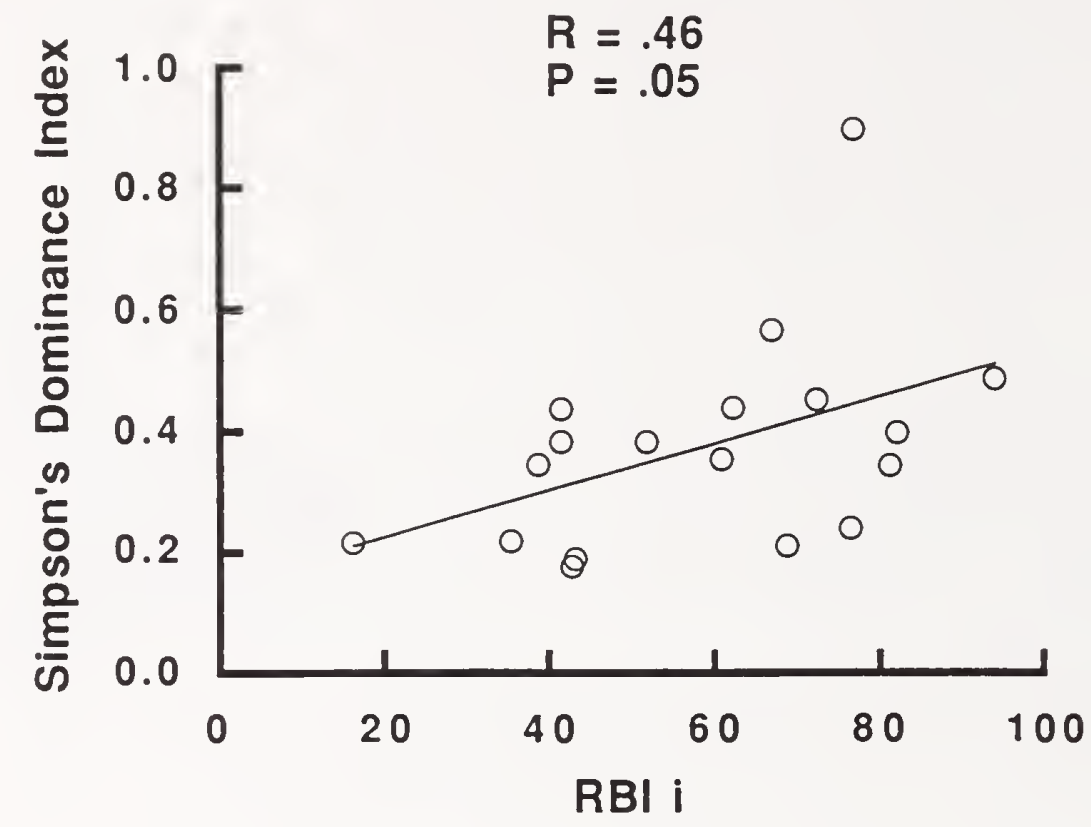

b)

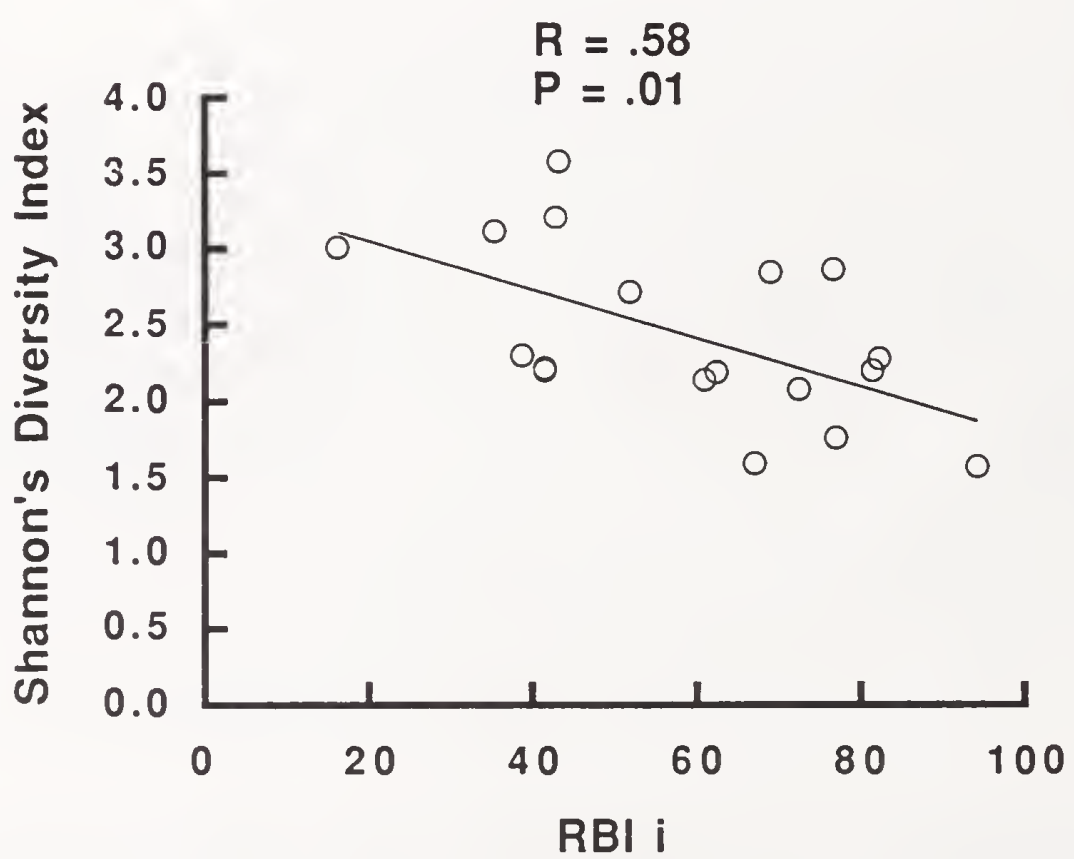

Figure 3. Scatter plots of (a) Simpson's Index against RBI.i. (b) $\mathrm{H}^{\prime}$ diversity against RBI.i. 
a)

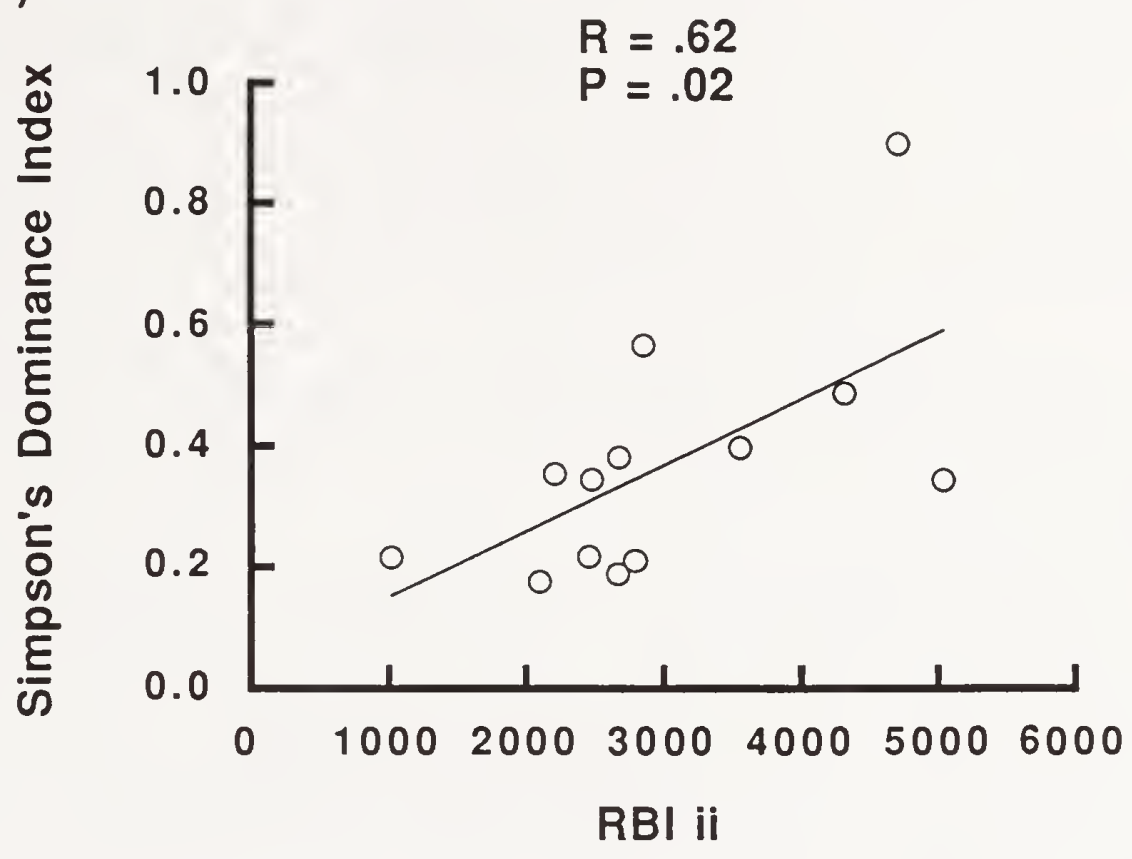

b)

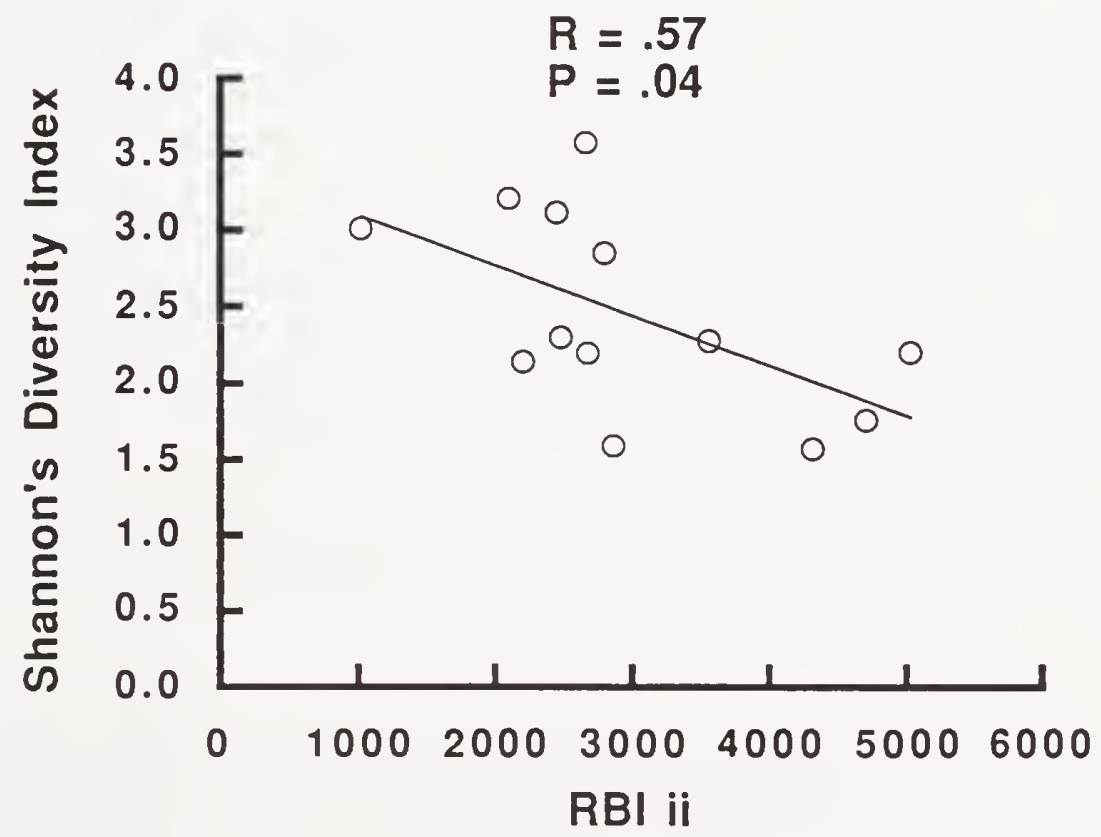

Figure 4. Scatter plots of (a) Simpson's Index against RBI.ii. (b) $H^{\prime}$ diversity against RBI.ii. 
Table 2. Correlations between community indices and percent of area burned

$$
\left({ }^{\star}=p<.05 ;{ }^{* \star}=p<.01\right)
$$

\begin{tabular}{|l|c|c|}
\hline \multicolumn{1}{|c|}{ Index } & Watershed Burn & Riparian Zone Burn \\
\hline Taxa richness & 0.08 & 0.32 \\
Simpson's Index & 0.33 & $0.52^{\star}$ \\
Shannon Diversity & $0.57^{\star \star}$ & $0.61^{\star \star}$ \\
\hline
\end{tabular}

namely that heavily affected streams were dominated by few insect taxa in early years, but after two years they had a more even community structure (figure 5). RBI.ii showed a similar trend.

\section{Correlation between RBI.i and Indices}

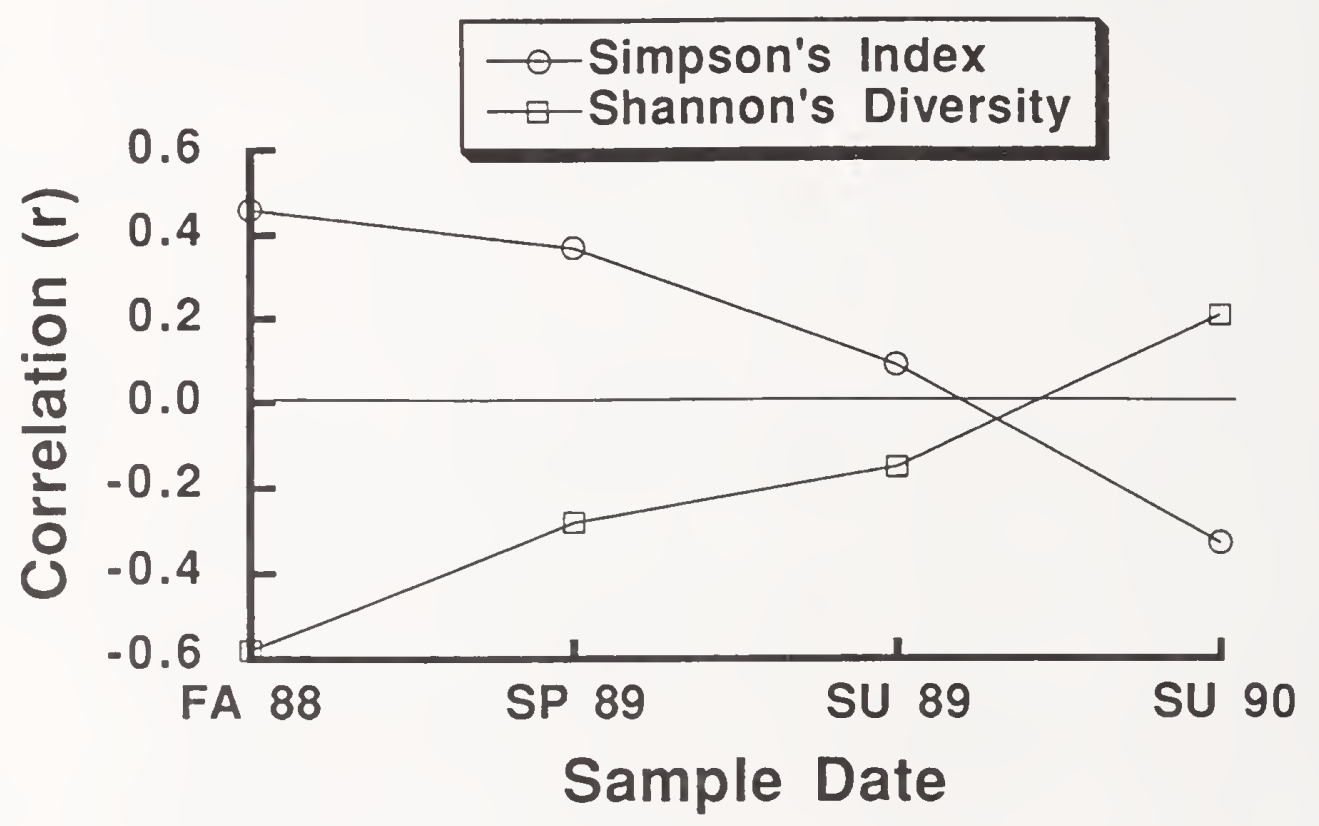

Figure 5. Line plots of correlations between Simpson's Index and RBI.i (circles), and $\mathrm{H}^{\prime}$ diversity against RBI.i (squares) over the four sampling seasons.

\section{Discussion}

Photographs of riparian zones in mature watersheds (>200 yrs since a fire) show a mix of woody and nonwoody vegetation growing on banks that have generally not been created or eroded substantially in the recent (within 50 years) past. Channels are well established, and channel cutting and eroding is gradual. Woody debris in the stream channels is generally more stable, with algae and moss growing 
on submerged and emergent surfaces, respectively. Although these watersheds experience similar snowmelt, rainfall, and peak flow events, the disturbance to the channel is not nearly as evident. Long-term changes in community structure are gradual, as are changes in the physical habitat of the stream (Minshall and Lawrence, manuscript in preparation).

Benthic macroinvertebrates respond to conditions in their aquatic environment, which is in turn affected by the characteristics of the surrounding watershed. Until recently, only simple estimates of a watershed or riparian zone's characteristics were available for use in relation to a stream's aquatic biota. With the advent of GIS, analyses involving entire watersheds and multiple variables simultaneously became possible. While our results are still preliminary, we attempt to use a method of creating a fire disturbance index at the landscape scale that is associated with benthic invertebrate community structure.

We found both burn types and the distance of a burn from the stream channel were correlated with insect community indices, and when both variables were combined the resultant indices' correlation with Simpson's index was increased. Ecological processes are known to be complex and interactive, and by combining these two variables a stronger association between the physical disturbance and the biotic response was found. Water chemistry, watershed geology, peak flow magnitude and frequency, temperature regime, prefire watershed and riparian vegetation, and in-stream physical heterogeneity also affect insect diversity; with a GIS model quantitatively including each of these variables, accurate predictions of benthic community structure change may be possible. A weakness of the approach used here is that scaling values for each variable were chosen based primarily on visual estimates of the impact of each burn type, not on quantitative models predicting the specific contribution of each category within a variable to the community index.

While benthic community indices have not yet been calculated for the summer 1991 field season, we expect the temporal change in correlation values (figure 5) to be reversed. Heavy precipitation during April created above-average snowpack levels, and spring runoff peak flows were higher than average. In addition, a summer storm caused flows to fill the original channel with debris in many of our study sites, and rew channels were cut. This intense disturbance is expected to reduce community diversity, returning the correlations between $\mathrm{RBI}$ and community indices to their original postfire (fall 1988) levels. Following fire, such extreme disturbance in streams may not be infrequent in the Greater Yellowstone Area (GYA). With the high amount of inorganic material available on watershed surfaces, rainstorms and spring snowmelt move higher sediment loads than usual and cause more channel cutting than is possible with an equal flow - but with a fully vegetated watershed and a well-developed soil profile. Such short-term impacts may be as prevalent as once or twice per stream within the first 10 years following fire, rather than a rare event. The amount of scouring and channel cutting from peak flows is expected to decrease over time with the development of perennial vegetation and an organic soil interface.

Further refinement of the $\mathrm{RBI}$ indices is necessary for stronger correlations with benthic macroinvertebrates, but we hope this paper demonstrates the utility in continuing such research. Not only is this approach useful to aquatic ecologists, but terrestrial scientists may also be able to develop models of vegetal and soil change based on pre- and post-disturbance conditions and use of similar methods of analysis. In order to accurately assess disturbances such as the 1988 Yellowstone fires, an integrative approach that combines many factors and has predictive value is necessary: without associated field data, such an approach is not helpful. While only a few years of data have been collected in GYA to date, it is apparent that ecological processes such as fire occur in longer cycles (>200 yrs), and further research is needed in order to characterize longer term trends. 


\section{Acknowledgments}

We thank the U.S. Fish and Wildlife Service for tremendous help in both logistical coordination and field collections, the National Park Service for financial support, and the park's GIS Laboratory in Mammoth for the generous use of their computer system and databases. In addition, George Mckay was instrumental in guiding usage of the GIS system. Many persons were involved in benthic invertebrate sorting and keying, and we thank the people in the Stream Ecology Center at Idaho State University for their contributions. Finally, we thank two anonymous reviewers for their helpful comments on the manuscript.

\section{Literature Cited}

Albin, D.P. 1979. Fire and stream ecology in some Yellowstone Lake tributaries. California Fish and Game 65:216-238.

Dyrness, C.T. 1963. Effects of burning on soil. Pages 291-304 in Symposium of Forest Watershed Management. Oregon State University, Corvallis, Oregon.

Frissell, C.A., W.J. Liss, C.E. Warren, and M.D. Hurley. 1986. A hierarchical framework for stream habitat classification: viewing streams in a watershed context. Environmental Management 10:199-214.

Helvey, J.D. 1972. First-year effects of wildfire on water yield and stream temperature in North Central Washington. Pages 308-312 in National Symposium on Watersheds in Transition. Proceedings American Water Resources Association, Colorado State University, Fort Collins.

Hynes, H.B.N. 1975. The Ecology of Running Waters. University of Toronto Press, Toronto.

Lyon, L.J. 1984. The Sleeping Child Burn - 21 Years of Postfire Change. USFS Research Paper INT330. U.S. Department of Agriculture, Forest Service.

Merritt, R.W. and K.W. Cummins (editors). 1984. An introduction to the aquatic insects, 2 nd ed. Kendall/Hunt, Dubuque, lowa. 722pp.

Minshall, G.W. and J.T. Brock. 1991. Observed and anticipated effects of forest fire on Yellowstone stream ecosystems. Pages 123-135, in R.B. Keiter and M.S. Boyce, editors, The Greater Yellowstone Ecosystem: Redefining America's Wilderness Heritage. Yale University Press, New Haven.

Minshall, G.W., K.W. Cummins, R.C. Petersen, C.E. Cushing, D.A. Bruns, J.R. Sedell, and R.L. Vannote. 1985. Developments in stream ecosystem theory. Canadian Journal of Fisheries and Aquatic Sciences 42:1045-1055.

Minshall, G.W., J.T. Brock, and J.D. Varley. 1989. Wildfires and Yellowstone's stream ecosystems. Bioscience 39:707-715. 
Minshall, G.W., D.A. Andrews, J.T. Brock, C.T. Robinson, and D.E. Lawrence. 1989. Changes in wild trout habitat following forest fire. Pages 111-19 in Wild Trout IV. Proceedings of the Symposium, Yellowstone National Park, Sept. 18-19, 1989.

Minshall, G.W., C.T. Robinson, and D.E. Lawrence. 1989. Final report to the Payette National Forest on research on stream ecology performed during 1988-1989. U.S. Department of Agriculture, Forest Service, Challis, Idaho. 81pp.

Minshall, G.W., C.T. Robinson, and D.E. Lawrence. 1991. Effects of 1988 fires on aquatic systems of Yellowstone National Park - 1990. U.S. Fish and Wildlife Service, Mammoth, Wyoming. 92pp.

Minshall, G.W. and D.E. Lawrence. (In preparation.) Ten years of change: benthic macroinvertebrate community structure change following watershed fire.

Pase, C.P. and P.A. Ingebo. 1965. Burned chaparral to grass: early effects on water and sediment yields from two granitic soil watersheds in Arizona. Arizona Watershed Symposium, September 22, 1965, Tempe, Arizona. U.S. Department of Agriculture, Forest Service.

Poff, N.L. and J.V. Ward. 1990. Physical habitat template of lotic systems: recovery in the context of historical pattern of spatiotemporal heterogeneity. Environmental Management 14:629-645.

Romme, W.H. 1982. Fire and landscape diversity in subalpine forests of Yellowstone National Park. Ecological Monographs 52:199-221.

Ross, H.H. 1963. Stream communities and terrestrial biomes. Archives fur Hydrobiologie 59:235-242.

Tiedemann, A.R., C.E. Conrad, J.H. Dieterich, J.W. Hornbeck, W.F. Megahan, L.A. Viereck, and D.D. Wade. 1979. Effects of fire on water: a state-of-knowledge review. Gen. Tech. Rep. WO-10. U.S. Department of Agriculture, Forest Service, Washington DC.

\section{Questions from the Audience}

1. Q: Is erosion caused by fire good or bad for 1 - 3 order streams in the Greater Yellowstone Area? Specifically, for fisheries?

A: Many of the short-term effects of erosion on headwater streams decrease aquatic macroinvertebrate and fish community diversity. The severe scouring of channels by high sediment loads during spring runoff have caused channel cutting by as much as 2 meters and channel widening of up to 4 meters. In some cases entire channels were filled with cobble and new channels were cut out of the existing floodplain. These physical disturbances caused immediate decreases in aquatic animal life presence. After the channels stabilized and the majority of the fine sediment was flushed from the system, macroinvertebrate community diversity increased. We predict that over the long term community diversity should increase above that seen prior to the fires (see Minshall et al. 1989).

2. Q: Considering streams as dynamic ecosystems, what do you mean by "recovery"? 
A: Recovery used in this presentation refers to the return to a quasi steady-state (prefire) condition from some sort of disturbance. Two types of disturbances were discussed here: wildfires in a watershed, and severe channel scouring following wildfire and induced by heavy sediment loading. Streams are very dynamic systems, whereby steady-state or equilibrium conditions actually have a very high amplitude around their median condition. Conditions in streams also are directly related to their surrounding riparian zones, in terms of allochthonous inputs of food (leaves and fine organics) and woody debris. The changes in riparian zones follow a linear "succession" of events following catastrophic wildfire, beginning with an herbaceous stage, then a seedling, sapling, pole timber, ... through to an oldgrowth forest if another disturbance doesn't interrupt this process.

3. Q: The summer 1991 disturbance was a normal process; was it truly a reset process or an offset process? Reset implies retrogression, is this the case?

A: Reset is retrogressive, in the sense of returning to an earlier condition, because the recovery process continues along a similar "succession" of events following every disturbance (as relevant to the two disturbances discussed here). Severe channel cutting, or abandonment for a new channel, returned the riparian plant growth and aquatic community life to the earliest (or simplest) conditions possible. The recovery will still occur along a generally defined timeline and sequence of species replacements. "Offset" implies a change to a different "succession" of events following disturbance. Climate change is one example of offset. Over the past 10,000 years or so, the GYA has experienced increasingly arid conditions and the reduction of glaciers, which has in turn caused the plant communities to be shifted (north). If the fires or channel cutting cause the plant and aquatic community development to shift to a whole new structure not experienced prior to the 1988 fires, then we would agree that an offset has occurred. Such a contingency is allowed for in our conceptualization of stream ecosystem response to fire in forested catchments (Minshall and Brock 1991; Minshall, Robinson, and Lawrence 1989). 


\title{
Demographic and Genetic Analyses of Sapphire Rockcress, a Rare Endemic
}

\author{
Donna Leeper \\ Division of Biological Sciences, University of Montana \\ Missoula, MT 59812 \\ Diane Pavek \\ Division of Biological Sciences, University of Montana \\ Missoula, MT 59812 \\ Roberta Walsh \\ Division of Biological Sciences, University of Montana \\ Missoula, MT 59812 \\ Thomas Mitchell-Olds ${ }^{1}$ \\ Division of Biological Sciences, University of Montana \\ Missoula, MT 59812
}

\begin{abstract}
Conservation biologists have been concerned for many years about reductions in genetic diversity of populations, especially for sensitive or endangered species of plants and animals. Previously, loss of genetic variability was considered to be the most critical factor, and management plans proposed minimum viable population sizes based on genetic factors. However, recent evidence suggests that demographic stochasticity may be a more important factor to consider. We are currently collecting demographic and genetic data to determine the relative importance of these factors in rare species survival. Sapphire rockcress, Arabis fecunda Rollins (Brassicaceae), is a threatened endemic that occurs only in the Sapphire and East Pioneer mountain ranges of western Montana. It has been the subject of several years of combined demographic and genetic studies.
\end{abstract}

Demographic projections based on computer simulations suggest serious population declines are likely. Mean population size is predicted to decrease 40 percent in the next 10 years, and all simulated populations that have been studied became extinct in less than 80 years. Mean time to extinction in the simulated populations was 41 years. However, preliminary analysis on three years of field data from five

'Address correspondence to this author. 
different populations indicate that population increase or decrease may fluctuate on a yearly basis, with no clear trend yet apparent.

Electrophoretic analysis of the six populations indicated very low levels of genetic polymorphism. Of the 12 enzyme systems analyzed, all were monomorphic except for phosphoglucose isomerase. Estimates of Wright's $F$ statistics, based on one polymorphic locus $\left(F_{I S}=0.57, F_{S T}=0.44\right.$, and $\left.F_{1 T}=0.76\right)$, were as expected for a species with some inbreeding and genetic differentiation between populations.

Population biologists have suggested numbers for minimum viable population sizes based on genetic models because developing a multifactor model of extinction has proved intractable. An effective population size of 500 individuals is commonly proposed for wild populations (Lande 1988). This figure of 500 is based on levels of genetic variation, which balances loss by drift and replacement by mutation (Franklin 1980).

Application of single factor models as a foundation for species management is not supported by theory (Varvio, Chakraborty, and Nei 1986). Projecting species or population sizes requires knowledge of both genetic and ecological factors that affect the species (Lande 1988). Over the past decade, concern about maintenance of genetic diversity and the minimization of inbreeding depression has led to development of conservation plans based solely on population genetics, with a deemphasis of basic demographic considerations (Lande 1988). Most recently, the primacy of demographic variability as a cause of species extinction has gained widespread acceptance among conservation biologists and land managers. Some land managers have argued that inbreeding depression should no longer be considered a severe problem and that genetic variation is generally unimportant for management of biodiversity.

Long-term demographic and genetic data from several populations and species are essential to begin to understand patterns and interactions influencing survival and extinction. Although there are numerous separate studies of demography and the genetics within small populations, conservation biologists do not have sufficient data from combined studies of natural populations to quantify possible deleterious effects of the interaction between demographic stochasticity and genetic factors, or how these factors might change within small populations. Clearly, demographic fluctuations may be a major cause of species extinction. Loss of viability and fecundity due to inbreeding depression and/or loss of genetic variation by genetic drift is a problem with decreasing population size.

Lande (1988) has argued that extinction of endangered species is more likely to arise from demographic fluctuation than from deleterious genetic effects of small population size. Few studies have analyzed demographic variation in endangered plant species (Meagher, Antonovics, and Primack 1978; Menges 1986, 1990). Empirical analysis of demography is straightforward, involving careful measurements of survival and fecundity of many individuals in different age or stage categories. Size of the plant is often a better predictor of survival and reproduction than is age (Caswell 1989). Consequently, size-classified demographic models are practical and useful.

Sensitivity or elasticity analysis indicates aspects of the life cycle in which small changes may have large effects on population fitness and survival, which are important to population management (Silvertown 1982). Using a size-structured matrix approach (Caswell 1989; Leslie 1945), let $N_{1+1}=A_{t}{ }^{\star} N_{1}$, where $p$ is the number of categories, $N_{t}$ is a $p \times 1$ vector indicating the number of individuals in each category at time $t$, and $A_{t}$ is a $p \times p$ transition matrix governing reproduction and transitions among categories during the time interval t to $t+1$ (Law 1983; Leslie 1945). Extensive deterministic theory applies when the transition matrix remains constant, $A_{t}=A_{t+1}=A$ for all $t$ (Caswell 1989). The asymptotic growth rate, denoted by $\lambda$, is given by the leading eigenvalue of $A$. The right eigenvector gives the stable stage 
distribution ( $w$, with elements $w_{\mathrm{j}}$ ). The left eigenvector gives the vector of reproductive values $(v$, with elements $\left.v_{j}\right)$. Letting $A_{\mathrm{ij}}$ represent the $\mathrm{ij}$ th element of $A, \mathrm{~d}(\lambda) / \mathrm{d} A_{\mathrm{ij}}=v_{\mathrm{i}} w_{\mathrm{j}} / w^{\top} v$ is a "matrix sensitivity" that gives the effect of changes in transition parameters on population mean fitness. This matrix sensitivity may be standardized to a "matrix elasticity" $e_{\mathrm{ij}}=\left(A_{\mathrm{ij}} / \lambda\right)\left(\mathrm{d}[\lambda] / d A_{\mathrm{ij}}\right)$ that indicates changes in fitness arising from a percentage change in each element of $A$ (de Kroon et al. 1986). Maximum likelihood inference (Dennis, Munholland, and Scott in press) or Monte Carlo simulation may also be used to extend deterministic sensitivity analyses to stochastic models of population growth when information is available on demographic parameters $\left(A_{1}\right)$ for a number of locations and years.

The best method for determining the level of genetic variation for characters that influence survival of rare species in the wild is identification of important characters affecting fitness (i.e., reproduction and survival), and measurement of the variation in those characters in the field. Measurement of traits influenced by many genes allows selection gradients to be calculated for wild populations and evolutionary change to be predicted using quantitative genetics theory (Bulmer 1980). However, measurement of large numbers of individuals in the field is often costly.

Previous genetic studies have surveyed enzyme variation of rare or geographically restricted species, which may provide an indication of overall patterns of genetic variation (Karron 1987; Ledig 1986; Ritland 1989). Several studies have found that allozymes are poor predictors of the genetic variation quantitative traits (e.g., Clay and Levin 1989; Walters 1988; but see Felsenstein 1986 and Lewontin 1986), or of inbreeding depression (Mitchell-Olds and Guries 1986). Allozyme data may be of little predictive value if there are few polymorphic loci (Karron 1987). Currently a paucity of data is available for evaluating the suitability of allozyme data for quantifying genetic variation in the management of natural populations of rare species. However, allozymes are fast and cost-effective for management surveys as a general indicator of genetic variation in water-soluble enzyme systems, which supposedly are not subjected to the forces of natural selection.

Sapphire rockcress is a recently described endemic species restricted to western Montana (Rollins 1984). It is listed as a threatened species in Montana (Lesica 1985, Lesica and Shelly 1991). All known populations are in the Sapphire and East Pioneer mountains of western Montana (figure 1). There are an estimated 50,000 individuals of this species scattered over eight locations with 13 populations. Population size ranges from 75 - 100 individuals to more than 10,000 (Schassberger 1988).

Sapphire rockcress is an erect, self-compatible, perennial forb (Rollins 1984). It is a small plant with one to many clusters of basal leaves and flower stalks $9.0 \mathrm{~cm}$ high. Basal leaves generally have a smooth margin and are 1.0 to $2.5 \mathrm{~cm}$ long and about $0.3 \mathrm{~cm}$ wide (Lesica 1985). Leaves are hairy and grayish white. Most plants do not flower until the third growing season. Flower stalks are unbranched. Fruits are 2.0 to $5.0 \mathrm{~cm}$ long $\times 0.1 \mathrm{~cm}$ wide and contain a single row of circular, flat seeds. Plants readily selffertilize, although Sapphire rockcress is also fully fertile with outcrossing. Plants bloom April through June. Large numbers of bees may be present in the spring along with ants traveling from flower to flower, probably pollinating plants (Leeper, personal observation).

There is no evidence of apomixis, i.e., no asexual seed set in emasculated, unpollinated flowers (Walsh 1992). In bolting plants, the flowering stalk arises from the meristem at the center of the rosette; after this, the rosette usually dies (Walsh 1992). In nonbolting plants, axial flowering stems grow horizontally outward and upward (Walsh 1992). Although both bolting rosettes and nonbolting rosettes can be found together on the same individual, nonbolting rosettes may not survive (Leeper, personal observation). 


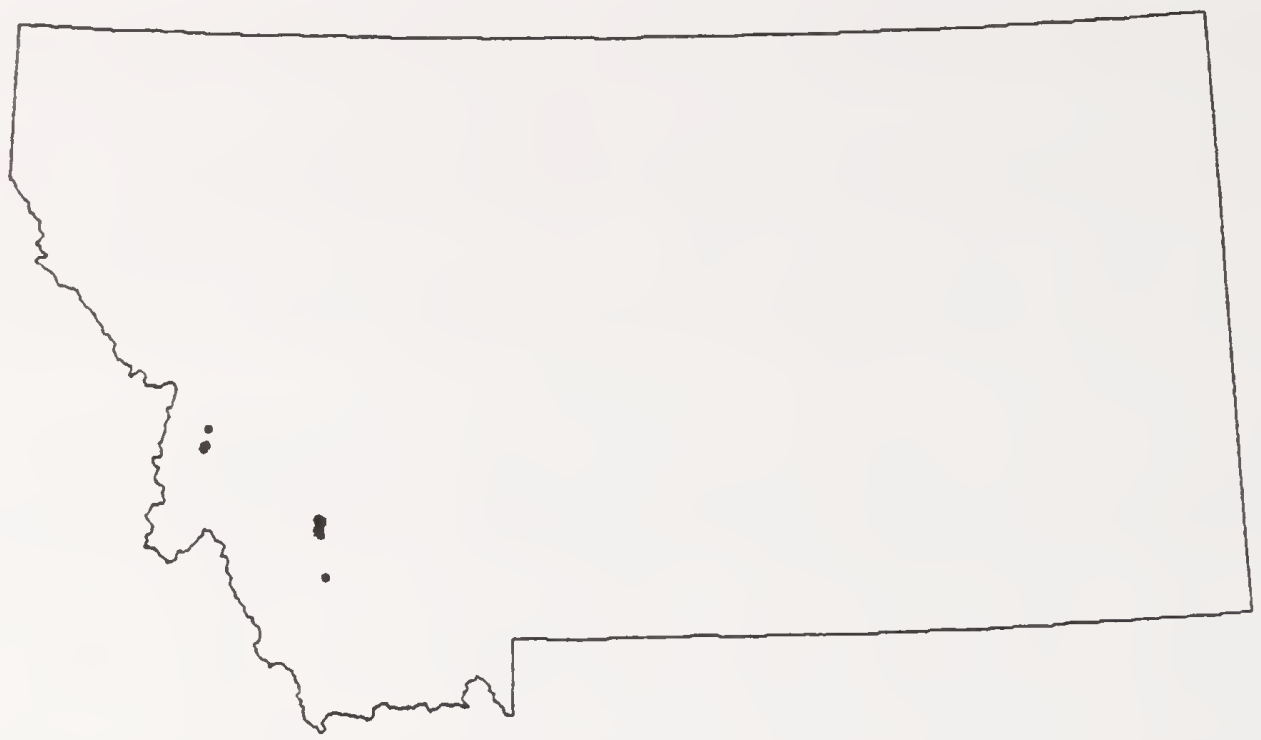

Figure 1. Geographic locations of the 13 populations of Sapphire rockcress in Montana. All known populations are located in the East Pioneer and Sapphire mountains of western Montana.

Sapphire rockcress occurs on metamorphosed calc-silicate outcrops, which are highly erodible. These soils have a calcium to magnesium content of 300:1 (Lesica 1985), while most arid region soils have a calcium to magnesium ratio of 1.7:1 (Boyd 1974).

All known sites occur between 1,220 and 2,590 m in elevation (Schassberger 1988). In most populations, only a small portion of the apparently suitable habitat is occupied by Sapphire rockcress.

The number of individuals ranged from 5,000 to more than 10,000 in our study populations: (1) Charleys Gulch [CG], (2) Jerry Creek [JC], (3) Dewey Cemetery [DC], (4) Vipond Park [VP], (5) Lime Gulch [LG], (6) Birch Creek [BC]; (figure 2). No special management regulations affect Sapphire rockcress at this time.

\section{Methods}

\section{Sensitivity Analysis: Birch Creek}

Demographic analyses were done on data collected from the Birch Creek population in the Sapphire Mountains, Ravalli County, MT (data courtesy of Lesica and Shelly 1989). All plants within $121-\mathrm{m}^{2}$ quadrants were mapped and measured in June 1987 through 1989. Persistent pedicels, withered flowers and infrequent herbivory permit quantification of the flowering that occurred earlier in the spring. Lesica and Shelly (1989) classified all plants into three categories: (1) nonflowering rosettes $<1.3 \mathrm{~cm}$ diameter, (2) nonflowering rosettes $\geq 1.3 \mathrm{~cm}$ diameter, and (3) flowering individuals. Those individuals classified as seedlings were not used in the model because they were not counted in all years. 


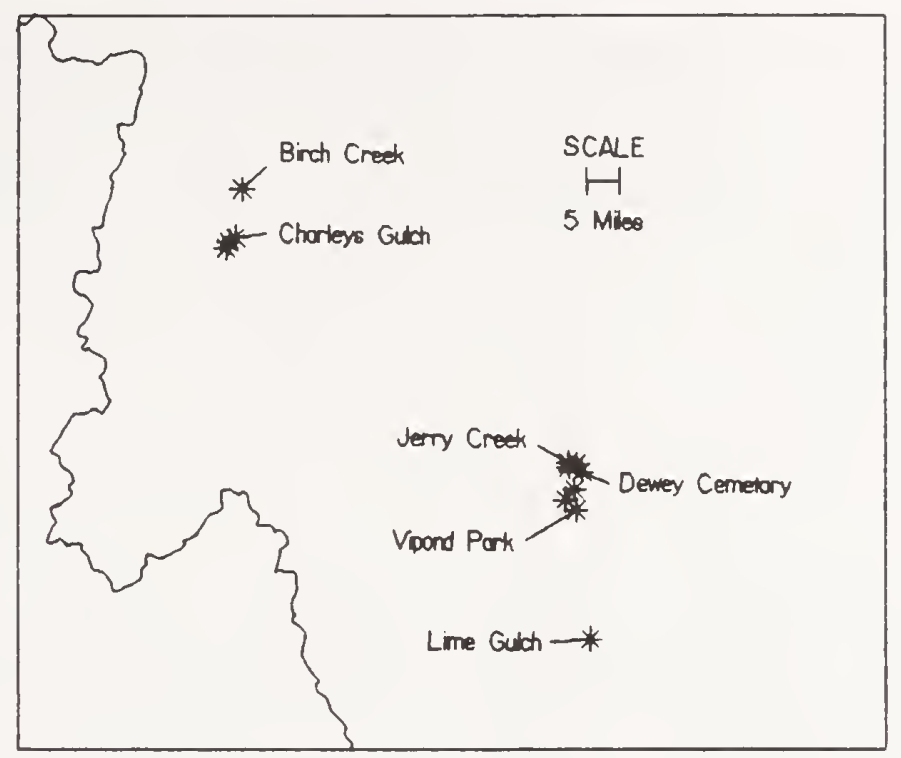

Figure 2. Geographic relationships of the populations of Sapphire rockcress. The six populations used in the demographic and genetic studies are labeled.

\section{Monte Carlo Simulations: Birch Creek}

Estimates of demographic parameters, population growth rate $(\lambda)$, stable stage distribution $(w)$, and reproductive values ( $v$ ) were calculated following Anton (1977). Monte Carlo computer simulations were used to extend the sensitivity analyses to stochastic models of population growth (Mitchell-Olds, original programs). Transition matrices $A_{1}\left(1987\right.$ - 1988) and $A_{2}(1988$ - 1989) were assumed to occur in random order with equal frequency. Assumed computer-simulated populations started with 100 individuals with the same stage distribution as observed in the Birch Creek population. Models were generated from 100 initial individuals to facilitate model operation. Although a population of 100 individuals is not as large as some populations of Sapphire rockcress, the simulations reflect general trends present in all populations with similar transition probabilities (table 1).

\section{Permanent Plots}

A series of permanent $1-\mathrm{m}^{2}$ quadrats along transects of varying length were established during fall of 1989 and spring of 1990 at five populations of Sapphire rockcress (CG, JC, DC, VP, and LG). Of the 13 known populations, these five populations included the most populous and accessible. The Birch Creek population was not included in this portion of the analysis due to restrictions on access.

In 1990 within each of five study populations, approximately 500 individuals were marked and their coordinates recorded (note: JC included only 350 individuals because of the low population number). Morphological measurements on each plant were basal rosette number, height and diameter of largest (or only) rosette, inflorescence number, height of tallest inflorescence, fruit number, and bolting behavior. In spring of 1991 and 1992, data were taken on marked plants and on any new plants that had germinated within the quadrat. Plants that could not be relocated were considered dead. 
Table 1. Estimates of demographic parameters within three classes of individuals*

\begin{tabular}{|l|c|c|c|c|c|c|}
\hline & \multicolumn{3}{|c|}{$1987-\mathbf{1 9 8 8}\left(\mathbf{A}^{1}\right)$} & \multicolumn{3}{c|}{$1988-1989\left(\mathbf{A}^{2}\right)$} \\
\cline { 2 - 7 } & NFS & NFL & FR & NFS & NFL & FR \\
\hline \multirow{2}{*}{ Transition matrix } & 0.10 & 0.00 & 0.73 & 0.00 & 0.00 & 1.18 \\
& 0.43 & 0.85 & 0.52 & 0.17 & 0.35 & 0.36 \\
& 0.05 & 0.08 & 0.36 & 0.00 & 0.41 & 0.36 \\
\hline Lambda & & 0.97 & & & 0.85 & \\
\hline Stage distribution & 0.0067 & 0.577 & 0.356 & 0.388 & 0.333 & 0.279 \\
\hline Reproductive value & 0.186 & 0.494 & 0.083 & 0.504 & 0.414 & 0.320 \\
\hline Elasticities & 0.005 & 0.048 &.- & 0.103 &.- &.- \\
& 0.040 & 0.058 & 0.103 & 0.158 & 0.183 & 0.681 \\
& 0.007 & 0.062 &.- & 0.192 & 0.261 & 0.099 \\
\hline
\end{tabular}

*Data courtesy of Lesica and Shelly 1989.

- indicates zero

$\mathrm{NFS}=$ nonflowering rosettes less than $1.3 \mathrm{~cm}$ in diameter

$\mathrm{NFL}=$ nonflowering rosettes more than $1.3 \mathrm{~cm}$ in diameter

$\mathrm{FR}=$ flowering rosettes

Size stages were from population characteristics based on data collected for each site. Small rosettes were those less than the greatest size attained by any first-year rosette (1 $-7 \mathrm{~mm}$ in all populations). Medium rosettes were those that were greater in size than the small rosettes but smaller than the largest rosette of any blooming individual ( $8-13 \mathrm{~mm}$ in CG, JC, VP; $8-14 \mathrm{~mm}$ in LG; $8-17 \mathrm{~mm}$ in DC). Nonreproductive adults were large enough to flower but had not. Reproductive adults included only plants that had bloomed that spring and had not bolted. Bolting adults included only individuals that had converted the central rosette meristem to an inflorescence.

Sensitivity Analysis: Permanent Plots. Estimates of demographic parameters, population growth rate $(\lambda)$, stable stage distribution $(W)$, and reproductive values $(v)$ were calculated on the $1990-1991$ data.

\section{Electrophoresis}

We included all six populations of Sapphire rockcress in an electrophoretic study (CG, BC, JC, DC, VP, and LG). Young leaves from 40 plants from each population were randomly placed into one of four grinding buffers (Soltis et al. 1983): (1) phosphate-PVP, pH 7.5; (2) Tris-maleate-PVP, pH 7.5; (3) Trishydrochloric acid-PVP, $\mathrm{pH} 7.5$; and (4) distilled water, $\mathrm{pH}$ 6.2. Samples were stored on ice immediately after collection. Plants in each grinding buffer were divided randomly into two grinding methods: (1) tissue ground before freezing at $-80^{\circ} \mathrm{C}$, or (2) tissue ground after freezing at $-20^{\circ} \mathrm{C}$. Tissue was ground in about $0.5 \mathrm{ml}$ grinding buffer. The ratio of tissue to buffer was approximately 1:5. 
We ran a total of 180 plants on 12 percent starch gel, using eight gel and electrode buffers from Clayton and Tretiak (1972); Ridgeway, Sherburne, and Lewis (1970); Rieseberg and Soltis (1987); and Soltis et al. (1983). Twenty enzyme systems were screened. Enzyme abbreviations and locus scoring follow Gottlieb (1977) and Soltis et al. (1983). Data were analyzed using BIOSYS-1 (Swofford and Selander 1981).

\section{Results}

\section{Birch Creek: Simulations}

Stochastic analyses based on the data from Birch Creek predicted that populations will decline drastically. The growth rate was below 1 for the $1987-1988$ period $(\lambda=0.97)$ and for the $1988-1989$ period $(\lambda=0.85)$. This indicates a decline in numbers of individuals for both periods. Projected population size after 10 years will decrease by 40 percent. Mean time to extinction for the modeled populations was 40.5 years. All simulated populations became extinct in less than 78 years.

\section{Permanent Plots: Field Data}

The growth rates for all five populations were below 1 for $1990-1991$ (CG, $\lambda=0.82 ; J C, \lambda=0.65$; DC, $\lambda=0.63$; VP, $\lambda=0.66$; LG, $\lambda=0.79$ ). This indicates that all five populations are declining in size. Mortality exceeded recruitment in all five populations for 1990 - 1991. In 1991 - 1992, three of the five populations had a net loss of individuals (CG, VP, and LG), and two populations had a net gain of individuals (JC and DC; figure 3).

\section{Electrophoresis}

Twelve enzyme systems coded by eighteen putative loci were resolved (table 2). Eight additional enzyme systems were not used because of poor resolution or difficulty of interpretation of banding patterns. All loci were monomorphic except for phosphoglucose isomerase, locus 2 (Pgi-2). Sapphire rockcress expressed two alleles (slow $=100$, fast $=167)$ at Pgi-2. JC and LG were fixed for the slow allele $(100)$. All other populations were polymorphic with some plants possessing either one or both alleles.

The mean number of alleles per locus for the six Sapphire rockcress populations is 1.06 alleles, and mean heterozygosity is 0.006 . The percentage of polymorphic loci is 3.7 percent. Genetic distances were not calculated, since estimates based on a single polymorphic locus have no biological meaning. Wright's $F$ statistics were estimated for the polymorphic locus, Pgi-2 $\left(F_{1 S}=0.57, F_{S T}=0.44\right.$, and $F_{I T}=$ 0.76). The four polymorphic populations showed a significant deficit of heterozygotes at the Pgi-2 locus $\left(F_{1 S}=0.57, X^{2}=12.009, \mathrm{df}=4, P=0.0173\right)$.

\section{Discussion}

Results of the computer-simulated models based on the Lesica and Shelly (1989) data from Birch Creek suggest that although the population is $10,000+$ individuals, it is decreasing rapidly. This conclusion was supported by the data collected from the multisite demography study for 1990 - 1991. All five sites 


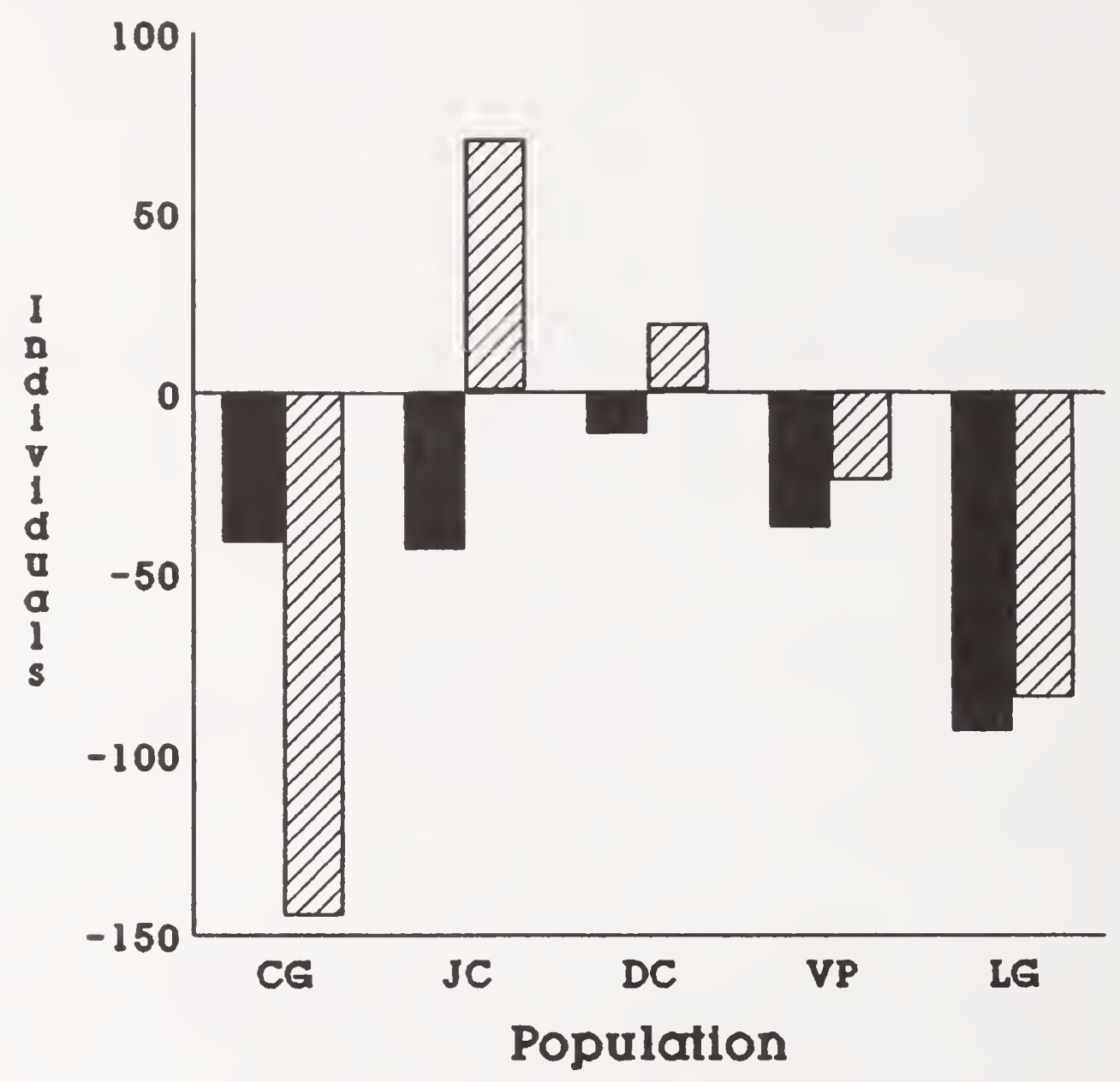

Years

1990-1991 DZय 1991-1992

Figure 3. Net gain of individuals in the five populations used in the multiyear demography study. The populations are Charleys Gulch (CG), Jerry Creek (JC), Dewey Cemetery (DC), Vipond Park (VP), and Lime Gulch (LG). 
Table 2. Allelic mobility relative to the most common allele (100)

\begin{tabular}{|l|l|l|c|}
\hline \multicolumn{1}{|c|}{ Locus } & Mobility & \multicolumn{1}{|c|}{ System $^{1}$} & Sample \# \\
\hline AAT-1 & 100 & RW & 17 \\
ALD-1 & 100 & S1,AC,S7 & 41 \\
APH-2 & 100 & S6 & 34 \\
APH-2 anodal & 100 & S6 & 15 \\
EST-FE-1 & 100 & S7 & 36 \\
EST-FE-2 & 100 & S7 & 36 \\
EST-COLOR-1 & 100 & S6 & 34 \\
IDH-1 & 100 & RW & 44 \\
MDH-1 & 100 & S1,AC,S4 & 90 \\
MDH-2 & 100 & S7,AC,S4 & 89 \\
ME-1 & 100 & S7,AC,S4 & 30 \\
6PGD-1 & 100 & S1,AC & 19 \\
6PGD-2 & 100 & S11,S2,S4 & 19 \\
6PGD-3 & 100 & S2,S4 & 19 \\
PGI-2 & 100 & S2,S4 & 37 \\
SKDH-1 & 100 & S8 & 44 \\
TPI-1 & 100 & S1,AC,S4 & 73 \\
TPI-2 & 100 & S2,S4 & 36 \\
\hline
\end{tabular}

'Systems preceded by $S$ are from Soltis et al. 1983; AC is from Clayton and Tretiak 1972; RW is from Ridgeway, Sherburne, and Lewis 1970.

exhibited greater mortality than recruitment, indicating population decline (figure 3). However, preliminary analysis of 1991 - 1992 data suggests that two of the five populations (DC and JC) increased in size, while three (CG, VP, and LG) decreased. The two populations that grew in size increased to the greatest number of individuals counted in the three years of observation. These results indicate that while some Sapphire rockcress populations may be declining, others may be either increasing or decreasing. Longterm monitoring of the populations must be done to discern general trends.

Sapphire rockcress is predominantly self-pollinating (Walsh, personal communication). Electrophoretic analyses support the theory that Sapphire rockcress is partially inbred (not totally self-fertilizing) because it has very low levels of genetic variation. The level of genetic differentiation at the Pgi-2 locus $\left(F_{\mathrm{ST}}=\right.$ 0.44 ) is typical of geographically isolated populations of partially inbred plant species. Self-compatible plants with self-pollination or local mating commonly have reduced levels of heterozygosity, as was observed here (Loveless and Hamrick 1984). However, identification of populations with unusually high or low susceptibility to deleterious genetic effects of small population size, such as inbreeding depression resulting from lack of genetic variation, is not possible with allozyme data alone. Because of the high level of inbreeding that may be present in these populations, allozyme variation may be misleading in terms of inbreeding depression. Species that primarily self-pollinate or populations that have slowly decreased in size may exhibit much lower levels of inbreeding depression compared with species that primarily outcross, due to gradual reduction of deleterious alleles (Charlesworth and Charlesworth 1987). 
Theory predicts several consequences for populations of limited size, including (1) increased susceptibility to demographic fluctuations, and (2) loss of genetic variation because of population bottlenecks, inbreeding, and genetic drift. These consequences may lead to general loss of vigor and/or viability. The ability of species to adapt to changing conditions depends on the presence of genetic variation. The relative importance of demography and genetics to Sapphire rockcress is not known at this time. If the reduced amount of genetic variation that was detectable through the allozyme analysis is due to inbreeding, further analysis is necessary to determine the amount of inbreeding depression present.

The first year of the multiyear demographic study and the Birch Creek demographic simulation indicate that the populations are in danger of extinction. Both analyses indicate a serious loss of individuals in each of the studied populations within the years included. However, preliminary analysis of the second segment of the multiyear demographic study indicates that the gains and losses of large numbers of individuals may be cyclic or stochastic phenomena, based on unknown factors. Climatic conditions may differ radically among the populations owing to the different geographic locations of the populations. These conditions may result in seed establishment and recruitment in some populations and increased mortality in other populations. Certainly environmental heterogeneity may have a large effect on the persistence of the species.

Currently, there are limited data quantifying the level of genetic variation in this species. We do not know whether populations that are in numerical decline have the smallest amount of genetic variation within the species. Nor do we know whether the populations with fewer than 100 individuals have less genetic variation than the populations with 10,000 individuals. Despite limitations, integrated studies such as ours allow managers a chance to extend results to other species that exhibit comparable life-history traits, especially to isolated populations of plants capable of self-fertilization and restricted by specialized habitats and ecology.

\section{Current Research}

We are currently continuing this multiyear demographic study and the genetic analysis. We are evaluating the relative importance of demographic and genetic factors influencing population viability in two species of rare plants, Sapphire rockcress and keeled bladderpod (Lesquerella carinata Rollins). Due to the limited genetic variation revealed by the allozyme analysis of Sapphire rockcress, we are currently analyzing DNA sequence data to better quantify the level of genetic variation. We will gain a better understanding of the complicated interactions of genetic and environmental factors affecting these species by collecting long-term, integrated, multipopulation data on demographic fluctuation, genetic variation (molecular and quantitative traits), and inbreeding depression.

\section{Acknowledgments}

Access to populations for research has been permitted by the Beaverhead National Forest, Bureau of Land Management, Montana Department of State Lands, and several private landowners. Peter Lesica and Steve Shelly graciously allowed use of their data for the Monte Carlo simulations. Funding for this study has been provided by NSF Conservation Biology Grant \#BSR-9100397 and Montana Natural Heritage Contract No. 051690 to Thomas Mitchell-Olds. 


\section{Literature Cited}

Anton, H. 1977. Elementary Linear Algebra. Wiley, New York. 315pp.

Boyd, N.C. 1974. The demography of jack-in-the-pulpit, a forest perennial that changes sex. Ecological Monographs 52:335-351.

Bulmer, M.G. 1980. The Mathematical Theory of Quantitative Genetics. Oxford University Press, Oxford, United Kingdom. 254pp.

Caswell, H. 1989. Matrix population models. Sinauer Associates, Sunderland, Massachusetts. 328pp.

Charlesworth, D. and B. Charlesworth. 1987. Inbreeding depression and its evolutionary consequences. Annual Review of Ecology and Systematics 18:237-268.

Clay, K. and D.A. Levin. 1989. Quantitative variation in Phlox. Comparison of selfing and outcrossing species. American Journal of Botany 76:577-588.

Clayton, J.W. and D.N. Tretiak. 1972. Amine-citrate buffers for pH control in starch gel electrophoresis. Journal of the Fishing Resources Board of Canada 29:1169-1172.

de Kroon, H., A. Plaiser, J. van Groenendael, and H. Caswell. 1986. Elasticity, the relative contribution of demographic parameters to population growth rate. Ecology 67:1427-1431.

Dennis, B., P.L. Munholland, and J.M. Scott. Estimation of growth and extinction parameters for endangered species. Ecological Monographs. In press.

Felsenstein, J. 1986. Population differences in quantitative characters and gene frequencies: a comment on papers by Lewontin and Rogers. American Naturalist 127:731-731.

Franklin, I.R. 1980. Evolutionary changes in small populations. Pages 135-149 in M.E. Soule and B.A. Wilcox, editors, Conservation Biology. An Evolutionary-Ecological Perspective. Sinauer Associates, Sunderland, Massachusetts.

Gottlieb, L.D. 1977. Evidence for duplication and divergence of the structural gene for phosphoglucoisomerase in diploid species of Clarkia. Genetics 86:289-307.

Karron, J.D. 1987. A comparison of levels of genetic polymorphism and self-incompatibility in geographically restricted and widespread plant congeners. Evolution and Ecology 1:47-58.

Lande, R. 1988. Genetics and demography in biological conservation. Science 241:1455-1460.

Law, R. 1983. A model for the dynamics of a plant population containing individuals classified by age and size. Ecology 66:224-230.

Ledig, F.T. 1986. Heterozygosity, heterosis and fitness in outbreeding plants. Pages 77-104 in M.E. Soule, editor, Conservation biology: The science of scarcity and diversity. Sinauer Associates, Sunderland, Massachusetts. 
Lesica, P. 1985. Report on the conservation status of Arabis fecunda, a potential candidate species. Report to the U.S. Fish and Wildlife Service, Office of Endangered Species, Denver, Colorado. Unpublished.

Lesica, P., and J.S. Shelly. 1989. The ecology of Arabis fecunda: Long-term monitoring and knapweed removal studies. Report to the Montana Natural Heritage Program. Unpublished.

Lesica, P., and J.S. Shelly. 1991. Sensitive, threatened and endangered vascular plants of Montana. Montana Natural Heritage Program, Occasional Publication No. 1. Helena, Montana. 88pp.

Leslie, P. H. 1945. On the use of matrices in certain population mathematics. Biometry 33:183-212.

Lewontin, R.C. 1986. A comment on the comments of Rogers and Felsenstein. American Naturalist 127:733-734.

Loveless, M.D. and J.L. Hamrick. 1984. Ecological determinants of genetic structure in plant populations. Annual Review of Ecology and Systematics 15:65-95.

Meagher, T.R., J. Antonovics, and R. Primack. 1978. Experimental ecological genetics in Plantago. III. Genetic variation and demography in relation to survival of Plantago cordata, a rare species. Biological Conservation 14:243-257.

Menges, E.S. 1986. Predicting the future of rare plant populations: demographic monitoring and modeling. Natural Areas Journal 6:13-25.

1990. Population viability analysis for an endangered plant. Conservation Biology 4:52-62.

Mitchell-Olds, T. and R.P. Guries. 1986. Genetic load and heterozygosity in the Pinaceae. Journal of Genetic Cytology 28:942-946.

Ridgeway, G., S. Sherburne, and R. Lewis. 1970. Polymorphisms in the esterases of Atlantic herring. Transaction of American Fishery Society 99:147-151.

Rieseberg, L.H. and D.E. Soltis. 1987. Allozymic differentiation between Tolmiea menziesii and Tellima grandiflora (Saxifagaceae). Systematic Botany 12:154-161.

Ritland, K. 1989. Genetic differentiation diversity, and inbreeding in the mountain monkeyflower (Mimulus caespitosus) of the Washington Cascades. Canadian Journal of Botany 67:2017-2024.

Rollins, R.C. 1984. Studies in the Cruciferae of western North America II. Contributions to the Gray Herbarium 214:1-18.

Schassberger, L.A. 1988. An update of the report on the conservation status of Arabis fecunda, a candidate threatened species. Report to the U.S. Fish and Wildlife Service, Office of Endangered Species, Denver, Colorado. Unpublished.

Silvertown, J.W. 1982. Introduction to plant population ecology. Longman, New York. 209pp. 
Soltis, D., C. Haufler, D. Darrow, and G. Gastony. 1983. Starch gel electrophoresis of ferns. A compilation of grinding buffers, gel and electrode buffers, and staining schedules. American Fern Journal 73:9-27.

Swofford, D.L. and R.K. Selander. 1981. BIOSYS-1: A FORTRAN program for the comprehensive analysis of electrophoretic data in population genetics and systematics. Journal of Heredity 72:281-283.

U.S. Forest Service. 1990. Biodiversity Symposium, Region I, September 1990.

Varvio, S., R. Chakraborty, and M. Nei. 1986. Genetic variation in subdivided populations and conservation genetics. Heredity 57:189-198.

Walsh, R. 1992. Demography of Sapphire rockcress (Arabis fecunda Rollins: Brassicaceae), a rare endemic Montana species. Master's thesis, University of Montana, Missoula. 95pp.

Walters, T. 1988. Relationship between isozymic and morphologic variation in the diploids Chenopodium fremontii, C. neomexicanum, C. palmeri, and C. watsonii. American Journal of Botany 75:97-105. 



\title{
Native Plant Die-offs
}

\author{
Gary S. Maskarinec \\ Wildlands Restoration \\ Tucson, AZ 85705
}

\section{Introduction}

The native flora of the western United States underwent significant population die-offs during the period 1985 - 1989. The scope of this paper is to describe some of these die-offs in a broad way, rather than to describe the causes in detail.

In the course of collecting seed from native plant species throughout the $1980 \mathrm{~s}$, I observed extensive die-offs of native plant populations. The evidence presented here includes my own observations, observations gathered from conversations with land management professionals and biologists who have noted die-offs in the course of their work in range and timber management, and observations of plant scientists relative to various causes of plant mortality.

Current perspectives present indications of mortality patterns or a partial extent of mortality in a limited part of the range of a species or a type of habitat. Some observations encompass die-offs of entire plant communities, while other observations concentrate on mortalities of populations of individual species. Many observations pertain to arbitrary limits that are relative to stewardship boundaries.

The states of Idaho and Utah are the focus of this paper.

\section{Quantification}

I use four terms to describe the extent of mortalities. "Light" mortality describes death of approximately 10 percent of a population; "significant" equals approximately 20 to 30 percent; "heavy" equals approximately 40 to 60 percent; "severe" equals approximately 70 to 100 percent. 


\section{Die-offs}

I use the term "die-off" to describe situations where mortalities have occurred throughout large portions $(100,000$ acres or more) of a species' range. "Mortality" refers to a more localized phenomenon.

The following description begins with a desert community, then proceeds to contiguous communities at increasing elevations, which are dominated by conifers. From there, the description concerns areas of decreasing altitude and latitude extending to the southern extremes of the Great Basin.

The Snake River Plain traverses southern Idaho, from below the Island Park Caldera near the border of Idaho and Wyoming across the entire state to the border of Idaho and Oregon. The dominant shrubs of this area are big sagebrush (Artemesia tridentata), winterfat (Ceratoides lanata), shadscale (Atriplex confertifolia), horsebrush (Tetradymia spinosa), and snakeweed (Gutierrezia sp.). Owing to drought conditions from 1985 to 1987, populations of these shrubs produced very little seed (Gooch 1988). Continued dryness and extreme heat during the summers of 1988 and 1989 caused a severe die-off of these shrubs over half of the Snake River Plain and a significant die-off over the other half. Other floral members of this habitat, including Calorchortus sp., Castilleia sp., Eriogonum sp., Linum sp., and Penstemon sp., appear to have suffered even more extensive die-off.

Mountain shrub habitat throughout rising elevations contiguous with the Snake River Plain by the summer of 1990 showed die-offs of serviceberry (Amelanchier allnifolia), skunkbrush (Rhus trilobata), currant (Ribes sp.), and snowberry (Symphoricarpus sp.). Local populations of these plants, which I observed both north and south of the Snake River Plain, showed light to severe die-off.

Populations of these species in northern Utah have shown light to heavy die-off. In similar habitat, a heavy mortality of snowberry has been observed in the vicinity of Lowman, Idaho (Rimbey 1991). Narrowleaf cottonwood (Populus angustifolia), along the outer margins of its population, i.e., furthest from river and stream bottoms, showed light to severe die-off.

Throughout Idaho and Utah, Douglas-fir (Pseudotsuga menziesii) has undergone extensive mortality. In the Salmon National Forest, approximately 50 percent of the forest is affected by heavy die-off (Schneider 1991). Limited aerial observations of Forest Service lands revealed significant to heavy die-off of Douglas-fir on 165,000 acres in Utah and southern Idaho (Knapp 1990). Reports from other areas of Douglas fir-habitat suggest a significant die-off over the entire range of this species within the two states (Bartlett, Boyer, Davis, Monson, Winward, separate communications 1991).

Extensive die-offs of other conifer species occurred throughout forested areas of Idaho and Utah. White fir (Abies concolor) underwent an "immense" die-off across all of northern Utah (Harper 1991), where it is the dominant coniferous species. Heavy to severe mortality of this species is reported throughout Idaho and Utah (Anonymous - Boise National Forest, Bartlett, Winward, separate communications, 1991). Alpine fir (Abies lasiocarpa) is similarly affected (Anonymous - Boise National Forest; Bartlett, Winward, separate communications, 1991). Partial aerial surveys show at least 158,000 acres in Utah and southern Idaho affected to a significant or heavy extent (Knapp et al. 1990). A die-off of Engleman spruce (Picea Englemanii) occurred throughout Utah and southern Idaho, with 158,000 acres (acreage in areas separate from the same number of acres cited of alpine fir die-off) affected to a significant extent according to the same incomplete aerial survey cited twice above. Whitebark pine (Pinus albicaulis), limber pine (Pinus flexilis), ponderosa pine (Pinus ponderosa), and lodgepole pine (Pinus contorta) throughout the area under consideration are all affected to some degree, ranging from light to severe. 
A characteristic understory shrub associated with the mountain habitat is mountain lilac (Ceanothus velutina). This species has been "devastated" throughout its range (Monson 1991). Curl-leaf mahogany (Cercocarpus ledifolius) is showing a less severe but similarly range-extensive die-off (Davis 1991). Open meadows consistently show a depletion of forbs that have greater water requirements along with an increase in drought-tolerant species. Willow species associated with riparian areas in mountain habitat underwent extensive declines during the 1980s.

Between the higher conifer habitats and the lower desert habitats throughout Utah and southern Idaho, bigtooth maple (Acer grandidentatum), canyon maple (Acer glabrum), and Gambel oak (Ouercus gambelii) have undergone extensive die-back and die-off, with significant to severe die-off of the maples throughout their habitat. The oak has proved more resilient than the maples, and as of late spring 1991, plants that had defoliated during the summer of 1990 produced vigorous basal sprouts in response to heavy rains. The effect on the oak resembles fire damage (Nelson 1991).

Pinyon pine (Pinus edulis and P. monophylla) and Utah juniper (Juniperus osteosperma) throughout pinyon/juniper habitat in Utah show a light to severe die-off, primarily of pinyon (Boyer, Davis, Harper, Meinrod, separate communications 1991). The most severely affected populations of pinyon are consistently found in the lower thousand feet of their elevational range, to the extent that the habitat range of pinyon pine in the Great Basin has significantly decreased since 1987. Generally, the die-off of juniper throughout this habitat is light. Significant to severe declines and losses of big sagebrush (Artemesia tridentata) and cliffrose (Cowania sp.) have been observed concurrent with the pinyon/juniper die-off (Davis 1991).

A die-off on 734,000 acres in Utah during 1984 - 1985 affected primarily shadscale (Atriplex confertifolia), but also fourwing saltbush (Atriplex canescens), big sage (Artemesia tridentata ssp. tridentata) and Wyoming sage (Artemesia tridentata ssp. wyomingensis), budsage (Artemesia spinescens), black sagebrush (Artemesia nova), winterfat (Ceratoides lanata), greasewood (Sarcobatus vermiculitus), horsebrush (Tetradymia spinosa), spiny hopsage (Grayia spinosa), bitterbrush (Purshia tridentata), and narrowleaf low rabbitbrush (Chrysothamnus viscidiflorus ssp. viscidiflorus var. stenophyllus) (Nelson et al. 1989).

\section{Causes}

Possible causes for the 1985 die-off in Utah that have been considered include grazing impact, winter impact, drought, soil salinity, anaerobiosis, insect epidemics, plant disease, fungal pathogens, mycorrhizal relations, and nematode relations. This die-off, unlike the others described, followed a period of unusually high precipitation. The causes are not conclusively explained.

Insect pests and plant diseases are identified in association with most of the current conifer die-offs (Nelson 1991). More than 300 pests associated with the 1985 Utah die-off were catalogued by Dr. Haws (1990). Haws noted that these pests were in endemic (nonoutbreak) stages.

Drought is apparently a factor in all but the 1985 Utah die-off, either predominantly or as a weakening factor. Wallace (1989), discussing sequentially additive interaction of stresses, notes that "Ordinarily, adapted plants can tolerate degrees of the stresses, but are limited with increasing levels of stresses." And, "The addition of man-induced stresses can be devastating if sequential additivity is operating because the effects of stresses are then multiplied." As Pechanec (1937) noted in his study of the effects 
of the 1934 drought on the sage/grass community of the upper eastern Snake River Plain, "Drought alone and in combination with overgrazing causes depletion in the plant cover and allows wind and water erosion to be accelerated."

\section{Implications}

Pechanec (1937) recorded drastic reductions in overall plant cover during the 1934 drought. Shrub cover had decreased by 46.8 percent. By 1935 shrubs had recovered to 76.9 percent of their 1932 density. Perennial herbs, which had decreased during 1934 to 25 percent of their 1932 density, rebounded in 1935 to surpass their 1932 density by 28 percent. Pechanec did not record plant mortalities. Many of the species that he observed, including Balsamorhiza sagittata, Astragalus salinus, Agoseris sp., Crepis acuminata, Poa nevadensis, Poa secunda, and Agropyron spicatum, no longer constitute a significant component of the plant community on much of the Snake River Plain. They have been largely replaced by crested wheatgrass (Agropyron cristatum), an exotic perennial species widely promoted by the Soil Conservation Service throughout much of the western United States since 1930, and by numerous exotic annual species. The dynamics of the floral community that now inhabits the Snake River Plain have been profoundly altered since the time of Pechanec's study. Introduced exotic species have caused significant displacement of the perennial shrubs of the native plant community. In the case of the Utah and Idaho desert die-offs, extensive populations of both crested wheatgrass and cheatgrass died during 1988 and 1989 , leaving bare soil. While the ecological impacts of this situation are not clearly understood, plainly the intentional and accidental promotion of exotic species creates additional stresses on the native plant community.

A review by Wulff (1943) of articles dealing with introduced species indicated that there was little or no evidence that an alien plant community can survive in a native vegetation except with man's intervention. Piemeisel (1951) noted that "There is no known instance where these alien participants in the earlier stages of successions supersede any native perennials except by man's direct or indirect influence." Further, "In areas of modified sagebrush/grass climax protected against rabbits as well as livestock but adjacent to areas of annual there was eventually no penetration of annuals into the stand of perennials even with the opportunity of heavy influx of seed and during years favorable to the growth of annuals."

A trend in both the Utah shadscale/salbush and the Snake River Plain sage/grass communities has been for exotic annual species to replace large amounts of the territory from which the perennial cover has largely or entirely died. By the late 1980s, areas of this kind of succession typically would terminate in a cheatgrass climax that is perpetuated to some extent by range wildlife (Nelson et al. 1989). Regarding shadscale communities in Utah, Ken Boyer (1991) noted that "In the past you couldn't burn the stuff. Now fire is a regular part of the ecology." "Because few of the major shrubs of the shadscale zone sprout following fire, widespread wildfire could have the potential for converting cold desert shrublands to annual herb communities. This would also increase the danger of fires spreading to adjacent sagebrushgrass and pinyon-juniper zones." (Nelson et al. 1989). Because of the die-offs taking place throughout pinyon-juniper, mountain shrub, and higher mountain conifer habitat, continuous fire fuel is increasing at all elevations, creating a threat of massive wildfire.

Many factors and results involved are not clearly understood. "As things are, the current descriptions of plant communities provide information of some, but not critical, value to an understanding of them" (Watt 1947). "We're losing systems that we haven't even begun to understand." (Nelson 1990). 
Ultimately, the implications include a rapid trend toward an environment that supports little of the biological community that is dependent on the wellness of these systems. While this trend has recently been a focus of much public discussion, most evidence cited is based on losses caused directly by human activities. The changes in the ecological balances and processes of shadscale and sagebrush/grass communities are made dramatically evident by rangeland fires, which expanding populations of exotic annual species perpetuate, and by the accompanying spread of exotic annual communities, which further displace native plant communities. The process signals a profound environmental disruption which, although initiated by human activities and cumulatively exacerbated for over a century, has recently resulted in the presence of biological forces that effect extensive disturbance of the native vegetation regardless of further human influence.

Several professionals in biological fields with whom I have discussed this problem have concluded that the problems responsible for these die-offs are problems with society at large. While clarifying such connections is beyond the scope of this paper, it is easy to conclude that the environmental disruptions taking place threaten not only native plant communities but economic and social systems as well.

\section{Acknowledgments}

I want to thank everyone who has helped me with this project, particularly Ken Boyer, David Nelson, Austin Haws, Kimball Harper, and Richard Felger. They have been generous with their time, help, and encouragement.

\section{Literature Cited}

Bartlett, Floyd. 1991. (Personal communication). Ashley National Forest, Utah.

Boyer, Ken. 1990, 1991. (Personal communication). Bureau of Land Management State Office, Salt Lake City, Utah.

Davis, Jim. 1991. (Personal communication). U.S. Department of Agriculture, Forest Service Shrub Lab, Provo, Utah.

Gooch, Tom. 1988. (Personal communication). Bureau of Land Management Office, Idaho Falls, Idaho.

Harper, Kimball. 1991. (Personal communication). Brigham Young University, Provo, Utah.

Haws, B. Austin. 1990. (Personal communication). Utah State University, Logan, Utah.

Knapp, Andy. 1990. Forest Insect and Disease Conditions in the Intermountain Region. U.S. Department of Agriculture, Forest Service Publication.

Meinrod, Bob. 1991. (Personal communication). Dixie National Forest, Utah.

Monson, Steve. 1991. (Personal communication). Boise National Forest, Idaho. 
Nelson, David. 1990, 1991. (Personal communication). U.S. Forest Service Shrub Lab, Provo, Utah.

Nelson, D., Harper, K.T., Boyer, K.C., Weber, D.J., Haws, B.A., and Marble, J.R. 1989. Wildland Shrub Die-offs in Utah: An Approach to Understanding the Cause. Proceedings - Symposium on Shrub Ecophysiology and Biotechnology. U.S. Department of Agriculture, Forest Service Gen. Tech. Rep. INT-256, pp. 119-135.

Pechanec, J.F., Pickford, G.D., and Stewart, G. 1937. Effects of the drought on native vegetation of the upper Snake River Plains, Idaho. Ecology 18:490-505.

Piemeisel, Robert L. 1951. Causes affecting change and rate of change in a vegetation of annuals in Idaho. Ecology 32:53-72.

Rimbey, Neil. 1991. (Personal communication). Idaho State University Extension, Caldwell, Idaho.

Schneider, Ernie. 1991. (Personal communication). Salmon National Forest, Idaho.

Wallace, A. 1989. Interaction of stresses in the behavior of native shrub populations. Proceedings Symposium on Shrub Ecophysiology and Biotechnology. U.S. Department of Agriculture, Forest Service Gen. Tech. Rep. INT-256, pp. 144-146.

Watt, A.S. 1947. Pattern and process in the plant community. Journal of Ecology 35:1-22.

Winward, A.I. 1991. (Personal communication). Region \#4, U.S. Department of Agriculture, Forest Service, Ogden, Utah.

Wulff, E.V. 1943. An introduction to historical plant geography. Chronica Botanica Co., Waltham, Massachusetts. 


\title{
Variation in Production and Bear Use of Whitebark Pine Seeds in the Yellowstone Area
}

\author{
David J. Mattson \\ Interagency Grizly Bear Study Team \\ Forestry Sciences Lab \\ Montana State University \\ Bozeman, MT 59717 \\ Daniel P. Reinhart' \\ Interagency Grizzly Bear Study Team \\ Forestry Sciences Lab \\ Montana State University \\ Bozeman, MT 59717 \\ Bonnie M. Blanchard \\ Interagency Grizzly Bear Study Team \\ Forestry Sciences Lab \\ Montana State University \\ Bozeman, MT 59717
}

\begin{abstract}
We analyzed variation in counts of whitebark pine (Pinus albicaulis) cones from permanent transects and grizzly bear (Ursus arctos horribilis) use of whitebark pine seeds from radio-telemetry and line-transect samples. Cone production varied among years and sites during the 11 years of study, with typically 4- to 9-year intervals between the two largest crops on individual trees. Bears made widespread use of pine seeds only when $>21$ cones were produced per tree, averaged over all transects. Use of overwintered seeds by bears was common and known to be substantial two out of six years. Sites used by bears to feed on pine seeds varied between successive large crops, with no duplication in aspect and elevation of the most intensive use over three crops. Techniques by which bears acquired seeds also varied, dependent on the presence of red squirrels. Our results suggest that Yellowstone grizzly bears will potentially make intensive use of the entire elevational and site range of whitebark pine, that no part of this range can be discounted as relatively unimportant to the grizzly bear population; and that habitats where bears use pine seeds need to be secure not only during the fall, but also during the summer and
\end{abstract}

'Present address: U.S. National Park Service, Resource Management, Yellowstone National Park, WY 82190. 
late spring. Our results also suggest the importance of long-term studies documenting variation in bear habitat use, in this case associated with foraging on a single important food.

\section{Introduction}

Whitebark pine seeds are an important food of bears in the Yellowstone area. Among other things, variation in seed crops has affected grizzly bear survival (Mattson, Blanchard, and Knight 1992). During poor seed crop years, grizzly bear conflicts with humans escalate, and more adult female and subadult male bears are killed, primarily because bears move to lower elevations nearer humans (Blanchard 1990; Mattson, Blanchard, and Knight 1992). During good seed crop years, most bears feed on seeds in whitebark pine's high-elevation range, farther from human facilities. When pine seeds are available, grizzly bears apparently feed almost exclusively on them, and seek out habitats where these seeds are available (Mattson and Jonkel 1990; Mattson, Blanchard, and Knight 1991).

Because of whitebark pine's importance to the threatened Yellowstone grizzly bear population, predicting seed crops and protecting productive whitebark pine stands have become an important part of grizzly bear habitat management (Blanchard 1990; Mattson and Jonkel 1990). Data collected by the Interagency Grizzly Bear Study Team from 1977 to 1987 suggested that mixed species conifer stands at low to mid-elevations of whitebark pine's range were used most intensively by grizzly bears, primarily because of higher red squirrel (Tamiasciurus hudsonicus) densities (Reinhart and Mattson 1990), and that bears got almost all of their pine seeds (97 percent) by raiding squirrel caches (Mattson and Jonkel 1990). At higher elevation, purer whitebark pine received very little bear use and were relatively unimportant to the grizzly bear population. Grizzly bear use of large whitebark pine seed crops during 1986 and 1987 also suggested among-years (that is, annual) differences in habitats where bears fed on pine seeds (Mattson and Jonkel 1990).

Most tree species exhibit considerable annual variation in seed production (U.S. Department of Agriculture, Forest Service 1974). Where investigated, additional substantial variation in seed production among sites has also been found (e.g., Alexander, Edminster, and Watkins 1986; Franklin 1968; Grisez 1975). This variation among sites within a given year (that is, within-years variation) tends to dampen annual variation in seed production at the landscape level (Kozhevnikov 1963; Nesvetailo 1987) and, consequently, variation in food supply of wide-ranging seed consumers.

Whitebark pine seed production is also known to vary considerably among years (Blanchard 1990; Knight, Blanchard, and Mattson 1991); however, site and regional variation has not been well studied. Weaver and Forcella (1986) concluded that most variation in whitebark pine cone production was among trees within a given stand and that production did not vary significantly among stands within or between regions. Given the potential importance of pine seed production to grizzly bear habitat management and protection, additional study of among-site variation in cone seed production is needed to validate the conclusions of Weaver and Forcella (1986) and to determine the adequate duration of grizzly bear habitat studies - whether 10 years of data collection is long enough to document most variations in habitat use associated with bear feeding on pine seeds.

It is not clear from the literature how often whitebark pine seeds overwinter in cones on trees and whether wildlife use these overwintered seeds. For example, Hutchins and Lanner (1982), Arno and Hoff (1989), Hutchins (1990), and McCaughey and Schmidt (1990) state that few if any intact cones fall naturally to the ground and that seed consumers use virtually all seeds during the year that they mature. 
Lanner (1990) suggests that a number of undisturbed cones can overwinter on trees, but that they retain very little nutritional value. Conversely, circumstantial evidence from grizzly bear foraging activities suggests that many cones can overwinter on trees and in squirrel middens and that they provide enough nutrients to support heavy bear use (Kendall 1983; Mattson and Jonkel 1990; Mattson, Blanchard, and Knight 1991). Moreover, instances of bears scavenging fallen overwintered cones have been observed in the Yellowstone area and are quite common on seeds of other stone pines (subsection Cembrae) in Siberia (Mattson and Jonkel 1990). Resolution of this discrepancy is important to determining how much protection to offer foraging bears in whitebark pine stands during the spring and summer following good pine seed crops.

In this paper we present an analysis of grizzly bear feeding sites where bears fed on seeds of three successive large crops from 1985 to 1990. This analysis documents bear use of overwintered seeds and variation in habitat use and foraging strategies and, along with analysis of cone transect data, is the basis for hypotheses about site variation in cone production among successive large crops. We also elucidate the management implications of this site variation of crops and bear use of overwintered seeds.

\section{Study Area and Methods}

The 20,000-km² study area was centered on Yellowstone National Park and included portions of Wyoming, Montana, and Idaho. This area corresponded to the range of the Yellowstone grizzly bear population. Study area characteristics have been described by Knight and Eberhardt (1985), Blanchard and Knight (1991), and Mattson, Blanchard, and Knight (1991). Approximately 12 percent of Yellowstone Park consisted of habitat types in which whitebark pine was a major, long-persistent seral species and 2 percent of habitat types in which whitebark pine was climax (Despain 1990).

We collected cone production data annually from 1980 to 1990 , from 10 trees each on permanent transects. The number of transects increased from 9 to 21 during the study period as we increased the elevational and geographic range of our sample. Methods for this study are further described by Blanchard (1990).

Radio-collared grizzly bears were located from the air once to twice a week throughout the active season, March-October. A subsample of these locations was visited and sampled, stratified by bear and geographic area. We ascribed data to a radio-telemetry location only if there was a high probability of association with the sampled bear and time, determined by nearness of the sign to the telemetry location, age of sign, and correspondence of bear-specific sign such as tracks to the sampled animal. Other grizzly bear feeding activity encountered while en route to or from these locations was also sampled. Site data from these locations included physical measurements (e.g., slope, aspect, and elevation); results from a variable-radius timber overstory plot; ocular and frequency plot estimates of total plant and individual species cover; laboratory analysis of collected feces; and measurements of bear feeding activity. At whitebark pine seed feeding sites these measurements included estimated extent of feeding activity; percent of area excavated; percent deadfall cover; number of cones estimated to have been used by bears, either total or in $5 \times 5 \mathrm{~m}$ plots; and number of feces present. Fecal sampling and analysis methods are described by Mattson, Blanchard, and Knight (1991).

Data were also collected from a transect-based study conducted during 1990 and the fall of 1989 in the Cooke City area, immediately northeast of Yellowstone National Park. The study area was $108 \mathrm{~km}^{2}$ in size and spanned elevations from 2,265 to 3,140 m. During 1990, 137 bear activity sites were sampled along a total of $97 \mathrm{~km}$ of line transects spaced at regular intervals, perpendicular to major drainages. The 
same data were collected at these activity sites as at sites sampled in association with aerial telemetry locations. Approximately 30 percent of the total transect length intersected whitebark pine habitat types. Data from this study were attributable to both black (Ursus americanus) and grizzly bears because we could not consistently distinguish between sign of the two species.

We described the relationship between annual frequency of pine seeds in bear feces and mean number of cones per tree by nonlinear sigmoidal $\left(e^{-k}\right)$ regression (the NLIN procedure [SAS Institute, Inc. 1987]). Only the nine transects established in 1980 were used to estimate cone production for this analysis. Frequency of pine seeds in feces was calculated pooling September and October scats only for years when > 15 feces were collected during this period. Data for 1987 were not included because we suspected that cones matured early and had been heavily used by seed predators by the time cones were counted (Blanchard 1990).

We used unbalanced analysis of variance to test the hypothesis that cone production did not vary among years and sites and that variation among years was independent of variation among sites at whitebark pine cone transects (the GLM procedure [SAS Institute, Inc. 1987]). We also tested for equality of means and variances ( $t$-test and $f$-test, respectively) of cone production between transects in areas where there had been high and low levels of pine seed use by bears during 1989 and 1990. Bear-related data were analyzed by contingency tables using the log-likelihood ratio ( $G$ statistic). This approach was used because most variables were categorical or, in the case of basal area and percent stand composition, data distributions were highly nonnormal.

We also analyzed the frequency ( $G$ test) of cone production by individual trees $>$ the current-year mean, relative to whether cone production had been above average the previous two moderate-to-large cone crops $(\bar{X} \geq 15$ cones per tree). We hypothesized that production $>$ the contemporaneous mean during two previous crops would decrease the probability of cone production by an individual tree $>$ the current crop mean because of depleted carbohydrate reserves. We assumed that small crops (all with $\bar{X}<10$ cones per tree) would have little effect.

\section{Results}

\section{Bear Use}

Annual and Site Variation. The relationship between annual production of cones and frequency of pine seed use by bears, 1980 - 1989, was acutely sigmoidal (figure 1). Very little use occurred during years when mean number of cones per tree was $<21$ and peak use occurred at $>27$ cones per tree. This abrupt transition suggested a threshold.

Very few whitebark pine cones matured during 1986, 1988, and 1990, and we recorded only two instances of bear use of these crops (Knight, Blanchard, and Mattson 1991). However, grizzly bear use of the 1985, 1987, and 1989 crops was heavy ( $n=54,75$, and 90 feeding sites, respectively). Aspects and elevations of sites used by grizzly bears to feed on pine seeds differed among periods when they used the large 1985, 1987, and 1989 crops ( $G=74.85, d f=22, p<0.001$ ) (figure 2). Aspects and elevations differed between all individual time periods $(p \leq 0.005)$, with the greatest difference between $1987-88$ and $1989-90(G=55.48, d f=11, p<0.001)$. During $1985-86$ use was concentrated on east aspects at mid-elevations and on west aspects at high elevations of the whitebark pine zone. During 1987 use was concentrated on west and north aspects at low to mid-elevations, and during $1989-90$, on east and south aspects at high elevations. 


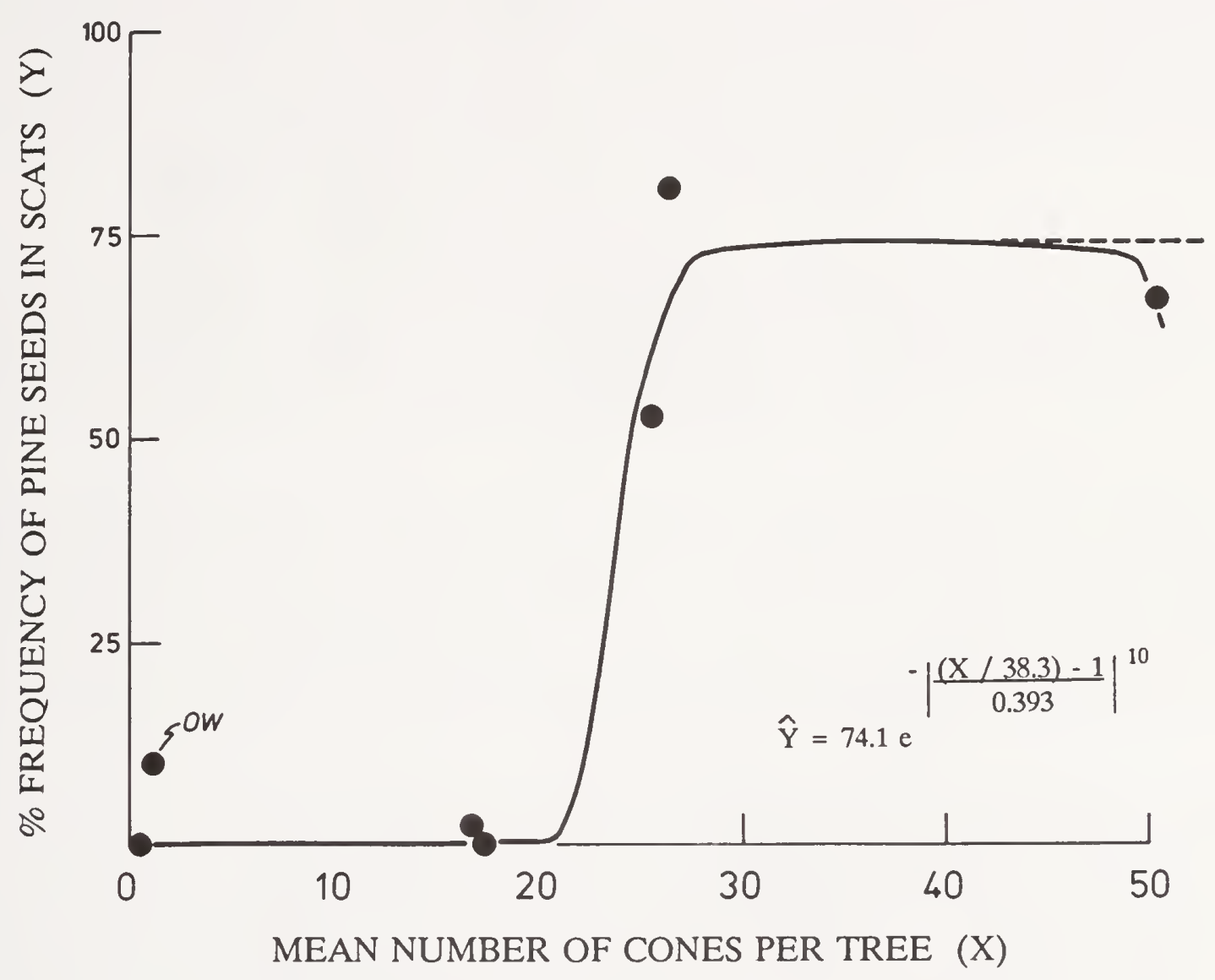

Figure 1. Relationship for the years 1980 through 1989 between percent frequency of pine seed remains in September and October grizzly bear feces and mean number of cones produced per tree on nine transects established in 1980. The data point labeled OW represents bear use of overwintered seeds rather than seeds that matured during the current year; frequency of current-year crop use was approximately zero. Data from 1987 were not used because of anomalous cone counts.

Other site characteristics varied with differences in aspect and elevation of intensive seed use by bears among the three periods. Distribution of feeding sites among landscape positions (ridge, upslope, midslope, and lowslope-bottom) differed among time periods ( $G=14.81, d f=6, p=0.023$ ). Most of this variation was caused by proportionally more feeding sites on ridges during 1989 - 90 (11 percent, versus 4 percent and 6 percent during 1985 - 86 and 1987, respectively) and on lowslopes and bottoms during 1987 (38 percent versus 17 percent and 23 percent during 1985 - 86 and 1989 - 90, respectively). These differences are in accord with those expected by differences in elevation of use.

Proportional use of habitat types $(G=24.50, d f=8, p=0.002)$ and cover types $(G=14.43, d f=8, p=$ 0.045 ) also differed as expected, primarily by differences in feeding sites between 1987 and other years. Feeding sites occurred in fewer high elevation dry habitat types (ABLA ARCO, ABLA/ARLA, and ABLA/RIMO; see Steele et al. 1983 for acronym definitions) during 1987 than in other years (5 percent versus 12 percent and 19 percent during 1989 - 90 and 1985 - 86, respectively). Feeding also occurred in more low elevation dry types ( $A B L A / S P B E, A B L A / B E R E$, and $A B L A / J U C O)$ (7 percent versus 0 percent 

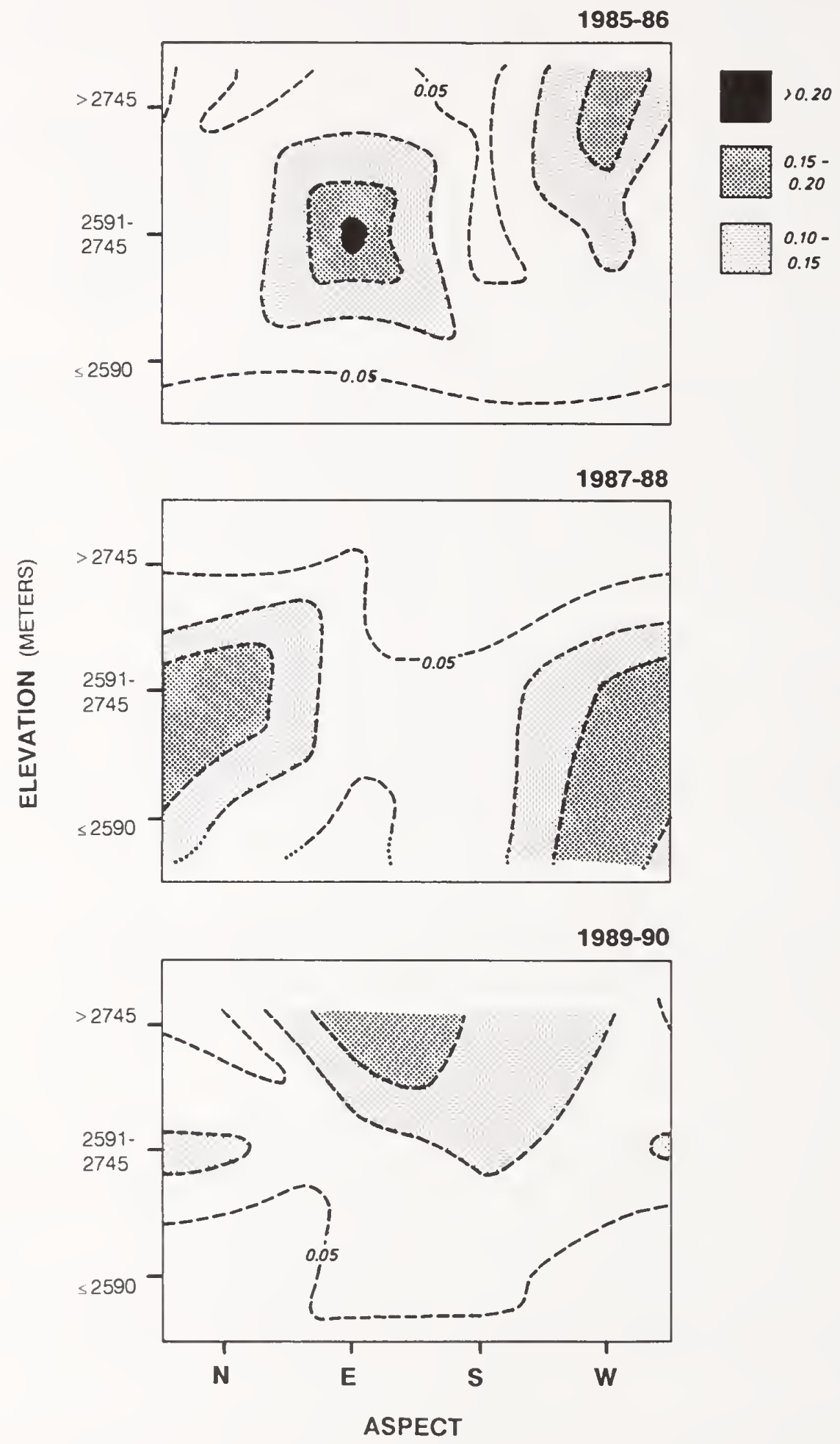

Figure 2. Proportional distribution of grizzly bear feeding on whitebard pine seeds, by four aspect and three elevation categories, for use of the 1985, 1987, and 1989 seed crops. Isolines were interpolated. 
in other years). Use during 1989 - 90 also differed from the other periods by more feeding sites in the whitebark pine climax series (12 percent versus 2 percent and 3 percent during $1985-86$ and 1987 , respectively). Cover type use differed only between 1987 and 1989 - 90 by greater use of Douglas-fir (Pseudotsuga menziesii) cover types during 1987 and by greater use of whitebark pine dominated cover types during 1989 - 90 (see Despain 1990 for cover type descriptions).

Major features of the forest overstory associated with pine seed use sites did not differ among time periods, including total basal area $(G=3.01, d f=6, p=0.80)$ and percent of total basal area in whitebark pine $(G=7.66, d f=8, p=0.47)$. Although no significant differences were evident, there was a tendency for more stands used during 1989 - 90 to have $>75$ percent and fewer stands to have $\leq 25$ percent whitebark pine basal area compared to both 1985 - 86 and 1987.

Variation in Use Strategies. Techniques by which grizzly bears acquired pine seeds at sampled radio-telemetry locations differed between 1989 - 90 and the other time periods $\left(G_{c}=16.28, d f=1, p\right.$ $<0.001$ ). Direct acquisition of seeds by scavenging fallen cones or, less often, by feeding directly off the tree canopy was more common during 1989 - 90 compared to 1985 -86 and 1987 (23 percent versus 4 percent for the other periods combined). Similarly 52 percent of 62 whitebark pine seed feeding sites found along transects in the Cooke City area during 1990 involved black and grizzly bears scavenging fallen cones or breaking tree limbs to obtain cones ( 8 percent of the total).

Cone remnants and intact cones were found on the ground at sites where bears scavenged fallen cones. In 18 of the 20 instances at telemetry sites during 1989 - 90, no squirrel middens or other squirrel activity were evident in the vicinity. At telemetry-related locations where bears had scavenged fallen cones, identifiable remnant and intact cones on the ground averaged $2.28 / \mathrm{m}^{2}(n=13$, standard deviation (SD) $=2.29$ ), and where the distinction had been made, density of intact cones retaining most of their seeds averaged $0.49 / \mathrm{m}^{2}(n=5, S D=0.52)$. In the Cooke City study area, consumed or disintegrated cones averaged $0.82 / \mathrm{m}^{2}(n=13, S D=0.93)$, and intact cones averaged $0.35 / \mathrm{m}^{2}(n=5, S D=0.42)$. Most of the consumed or disintegrated cones found at these sites had scales closely associated with the cone axis, suggesting that disintegration by wildlife feeding or other causes had occurred on the ground. Cone densities were measured throughout the summer and fall, with the probability that proportionally fewer intact cones were likely to be found as scavenging progressed.

Use of Overwintered Seeds. Telemetry-specific fecal and feeding site analyses show that grizzly bears made substantial use of overwintered whitebark pine seeds from May through September of 1986 and 1990 (figure 3). We noted bear use of a few current-year cones during September 1990, but most seeds used at that time were from the previous year's crop. Similarly heavy use of the overwintered 1978 seed crop by bears during 1979 was documented by Kendall (1983). Results specific to the Cooke City area corroborated the use of overwintered cones during 1990, declining from a June peak to a September low (figure 4).

Our telemetry-related data also show that advent and duration of heavy pine seed use by bears varied, especially between 1987 and 1989. In 1987 use was heavy by August and peaked in September, whereas in 1989 heavy pine seed use occurred only after August and peaked in October. Apparently the moderately large 1987 seed crop was close to fully exploited by October, and few seeds overwintered and were used during 1988 (figure 3) (Mattson and Jonkel 1990). 


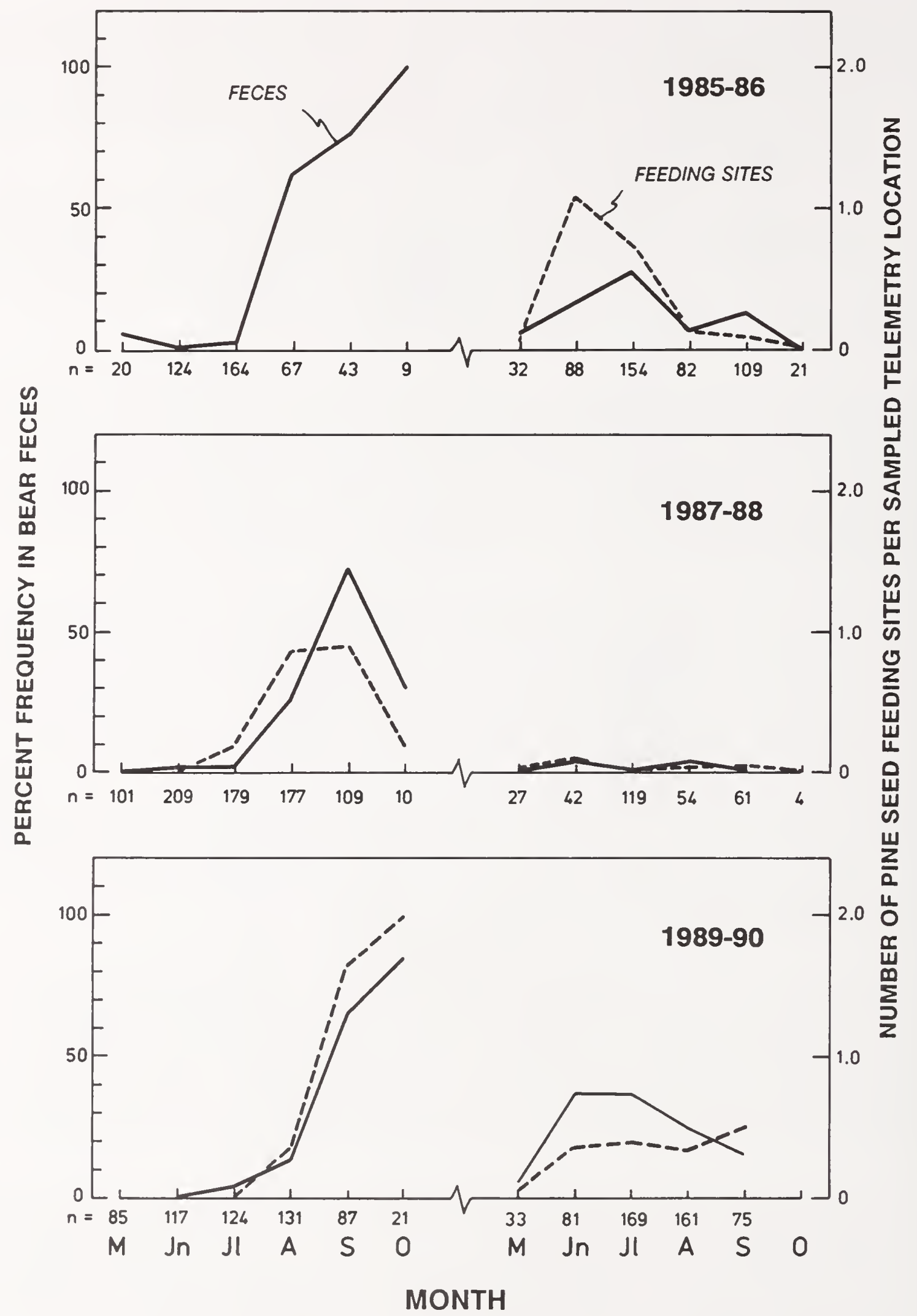

Figure 3. Percent frequency of whitebark pine seeds in Yellowstone grizzly bear feces and number of pine seed feeding sites per sampled telemetry location, by year and month. Criteria for sampling feeding sites were different during 1985, and so feeding site data are not shown. Monthly sample sizes are for feces. 


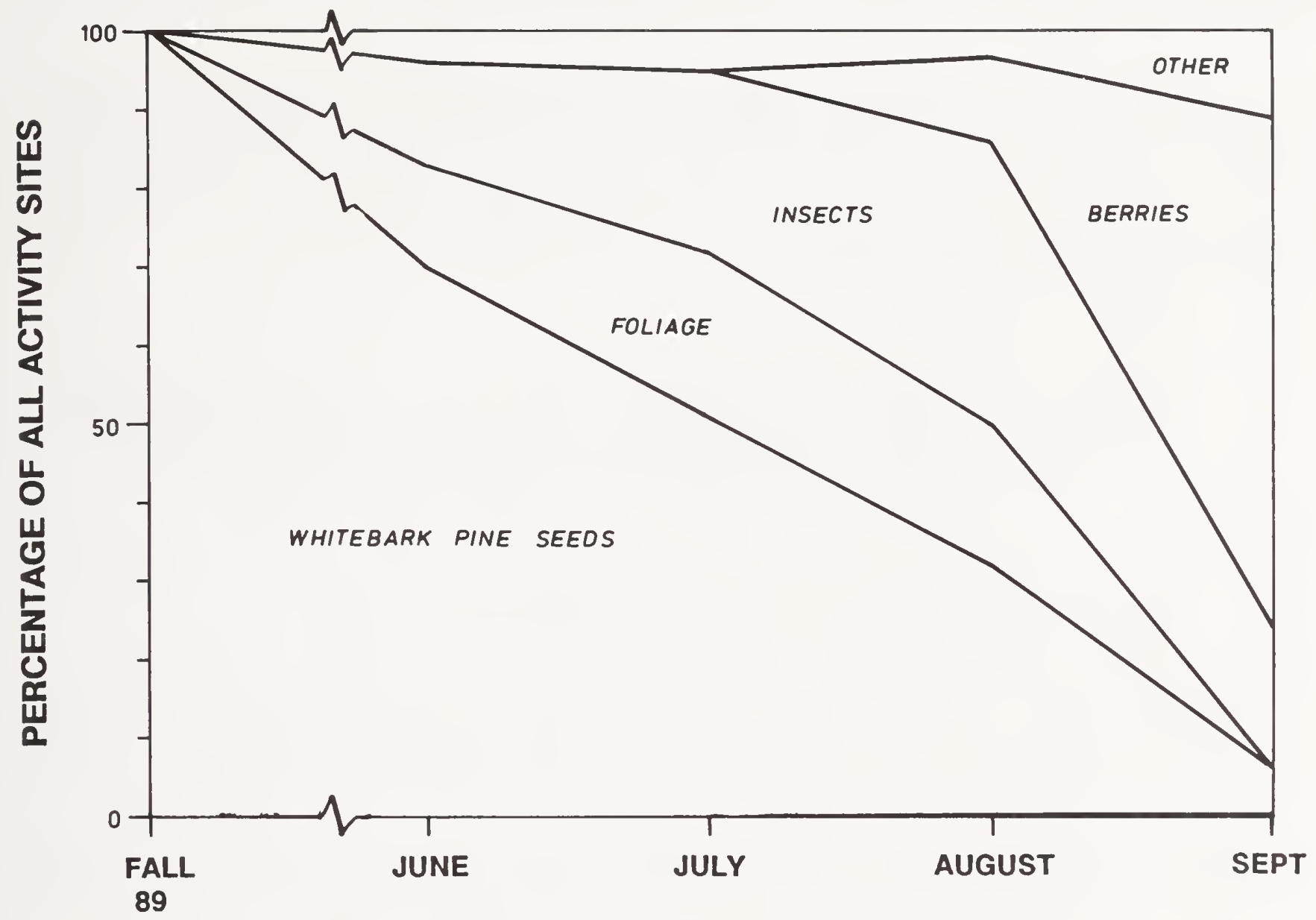

MONTH AND SEASON

Figure 4. Relative percentage of different feeding activities encountered on bear sign transects in the Cooke City area during 1989 and 1990, by month and pooled for fall of 1989. 


\section{Cone Transects}

Cone production varied among years $(F=53.13, d f=10, p<0.0001)$ and among sites $(F=9.64$, $d f=8, p<0.0001$ ) at the nine transects established in 1980, for which we had 11 years of data. Variation in production among these sites was not independent of variation among years $(F=8.20$, $d f=67, p<0.0001)$.

We did not find statistically significant differences in cone production among low, moderate, and high elevations during 1985, 1987, and 1989. Sample sizes were small, and among-site variation in cone production was high. However, elevational means did not contradict the hypothesis that cone production during these three crop years varied in accord with distribution of bear use. Production tended to be concentrated at low to mid-elevations during 1985, low elevations during 1987, and mid- to high elevations during 1989 (table 1).

Table 1. Mean number and standard deviation (SD) of whitebark pine cones produced per tree, averaged across transects and by year and elevational zone. Elevational zones were delimited differently than for grizzly bear use to equalize transect sample sizes among zones.

\begin{tabular}{|c|c|c|c|c|c|c|c|c|c|}
\hline \multirow[b]{3}{*}{ Year } & \multicolumn{9}{|c|}{ Elevation (m) } \\
\hline & \multicolumn{3}{|c|}{$2,561-2,683$} & \multicolumn{3}{|c|}{$2,684-2,805$} & \multicolumn{3}{|c|}{$2,805+$} \\
\hline & $\bar{x}$ & SD & $\mathbf{n}$ & $\overline{\mathbf{x}}$ & SD & $\mathrm{n}$ & $\overline{\mathbf{x}}$ & SD & $\mathrm{n}$ \\
\hline 1985 & 27.2 & - & 2 & 31.2 & 24.5 & 5 & 13.0 & - & 2 \\
\hline $1987^{\mathrm{a}}$ & 4.5 & - & 3 & 2.8 & 4.0 & 8 & 1.0 & 0.9 & 5 \\
\hline 1989 & 27.5 & 15.4 & 7 & 61.8 & 41.7 & 9 & 54.3 & 52.1 & 5 \\
\hline
\end{tabular}

aLow counts during 1987 probably resulted from early maturation and consumption of the seed crop prior to transect counts.

We stratified transects by aspects and elevations of high and low proportionate bear use during 1989 - 90 to test the hypothesis that mean and variance of cone production at transects did not vary between these areas of high and low bear use. We did not do a comparable analysis for the other periods because of insufficient transect sample sizes. Mean cone production did not differ between the two strata defined by bear use during 1989-90 (Cochran's $T=-1.52, d f=11.2, p=0.155$ ); however, variance among transects was higher in the stratum associated with lower use (SD $=50.06$ versus SD $\left.=16.07 ; F^{\prime}=9.70 ; d f=9,7 ; p=0.007\right)$.

We tabulated yearly intervals between the two largest cone crops observed on individual trees at the nine transects established in 1980. We observed no major difference in intervals depending on whether the largest or second largest crop had occurred first $(G=8.88, d f=4, p=0.068)$ and so we pooled the data ( $n=88$ intervals). Modal intervals occurred at four years (20 percent of the total) and nine years (19 percent). Only 24 percent of the intervals were $\leq 2$ years. 
Frequency of cone production by individual trees $>$ the current-year mean was inconclusively related to above-average production for the previous two moderate-to-large cone crops (table 2). No relationship was evident for the 1985 crop. Based on other results we could both accept (1987) or reject (1989) the null hypothesis, that above-average current-year cone production was independent of above-average cone production during the two previous crops.

Table 2. Proportion of whitebark pine trees producing above-average cone crops, considering production relative to the contemporaneous mean during the previous two moderate to large crops," and statistics for analysis of independence.

\begin{tabular}{|c|c|c|c|}
\hline \multirow[b]{2}{*}{ Previous Cone Crops } & \multicolumn{3}{|c|}{ Proportion of Trees $>\bar{X}$} \\
\hline & 1985 & 1987 & 1989 \\
\hline $\begin{array}{l}>\overline{\mathrm{X}} \text { Previous two crops } \\
>\overline{\bar{X}} \text { Most recent crop only } \\
>\overline{\mathrm{X}} \text { 2nd most recent crop only } \\
<\overline{\mathrm{X}} \text { Previous two crops }\end{array}$ & $\begin{array}{l}0.385 \\
0.294 \\
0.500 \\
0.231 \\
\end{array}$ & $\begin{array}{l}0.500 \\
0.562 \\
0.250 \\
0.154\end{array}$ & $\begin{array}{l}0.071 \\
0.182 \\
0.250 \\
0.421\end{array}$ \\
\hline \multicolumn{4}{|l|}{ Statistics } \\
\hline $\begin{array}{l}G \\
p \\
n\end{array}$ & $\begin{array}{r}3.73 \\
0.29 \\
83\end{array}$ & $\begin{array}{r}11.210 \\
0.011 \\
85\end{array}$ & $\begin{array}{r}7.910 \\
0.048 \\
75\end{array}$ \\
\hline
\end{tabular}

${ }^{a}$ Mean cone production of all trees $\geq 15$.

\section{Discussion}

Cone production at our permanent transects varied significantly among sites, trees, and years. Site variation was also associated with annual variation. These results suggest that even during years of heavy to average cone crops, nonrandom among-stand variation in production was substantial. Other studies of tree fruit and seed production have yielded similar results (e.g., Alexander, Edminster, and Watkins 1986; Franklin 1968; Grisez 1975; Kozhevnikov 1963). However, Weaver and Forcella (1986) found no significant among-stand or region variation in their study of whitebark pine cone production. Discrepancy between our results and those of Weaver and Forcella (1986) could be a consequence of their focus on higher elevation stands or differences in study years.

Bear use of pine seed crops also varied considerably. Widespread fall bear use was apparently contingent on substantial cone production, in excess of an average 21 cones per tree. This happened only three or four times (depending on actual production during 1987) in the 11 years from 1980 through 1990. However, during at least three years $(1981,1986$, and 1990), cone crops the previous year were large enough to sustain substantial bear use during the summer. Thus, pine seeds were not available to most bears during 7 of the 11 years. 
Sites used by bears to forage on large pine seed crops differed between successive crop years. Our analysis of how site variation in bear use related to cone production was compromised by inadequate transect sample sizes. However, our results do not contradict the plausible hypothesis that bears tended to more heavily use areas with more average cone production and less among-stand variation. During $1989-90$, when cone production tended to be concentrated at higher elevations, bears used more high elevation stands with whitebark pine cover types, of the whitebark pine habitat type series. During 1987, when cone production occurred at lower elevations, bears also used more low-elevation stands with Douglas-fir cover types, of drier subalpine fir (Abies lasiocarpa) habitat types.

Although intraspecific competition could mask selection for "optimal" foraging sites (Rosenzweig 1991), we suspect that large seed crops exceed demand and that observed bear use was sensitive to favorable site conditions. This supposition is partly based on other analyses showing that most grizzly bear mortality in the Yellowstone area, of which virtually all is human-caused, occurs during years of poor pine seed crops (Mattson, Blanchard, and Knight, 1992). Thus, we have hypothesized that availability and distribution of other foods used by bears during years of poor pine seed crops more directly limit the bear population than does availability of the episodic large pine seed crops (Mattson, Blanchard, and Knight 1991; Mattson, Blanchard, and Knight 1992).

If variation in bear habitat use does reflect availability of seeds, then bear use of the large 1985, 1987, and 1989 crops suggests interesting differences in whitebark pine cone production between successive large crop years. Specifically, distribution of bear feeding sites is a basis for hypothesizing that peak production does not occur at the same general elevation and aspect between successive large crops, especially, as during the period from 1985 through 1989, when crops occurred at two-year intervals.

As stated previously, results from our analysis of cone-count transects suggest synchronous variation of cone production among sites and years. Our analysis of cone production on individual trees also suggests that intervals between large crops were most commonly four and nine years. Both of these results lend further weight to the hypothesis suggested by bear use that peak production is nonrepetitive among sites between successive large crops. Because seed and fruit production by trees is known to be at least partly dependent on carbohydrate reserves (Fraser 1966; Kramer and Kozlowski 1960; Nesvetailo 1987; and others), availability of these reserves is the most likely proximal cause of this among-site variation in production. The frequent 4- to 9-year intervals between large crops on individual trees suggest that under most circumstances whitebark pine in our study area required this time to replenish the carbohydrate reserves needed to produce large crops. Under circumstances where large crops were produced in our study area at two- to three-year intervals, we expected that the same trees would not be contributing equally to successive large crops. However, our analysis of this specific question was inconclusive.

Variation in bear habitat use and presumably peak production of cones between successive large crops resulted in fundamental differences in how bears acquired pine seeds. The most striking difference occurred during 1989-90 when bears obtained far more seeds by scavenging on fallen cones compared to other years. Results from the Cooke City area corroborate a high frequency of scavenging on fallen overwintered cones, although the more frequent incidence of this behavior around Cooke City could be caused by the inclusion of black bear feeding in our sample. Nonetheless, these results reconcile what appeared to be major differences in how brown bears in Siberia and grizzly bears in the Yellowstone area acquired stone pine seeds (Mattson and Jonkel 1990).

The greater incidence of cone scavenging during 1989 - 90 appeared to derive from greater bear use of whitebark pine stands at elevations above the range of red squirrels (cf. Reinhart and Mattson 1990). 
Thus red squirrels were apparently not present to harvest and cache cones in many areas and were also not major competitors for seeds. Hutchins and Lanner (1982) observed that red squirrels were one of the major consumers of whitebark pine seeds, and so their absence probably translated into a greater number of cones overwintering on trees and being available for bears to scavenge when they fell the next year. We could not conclude from our observations to what extent cone fall was caused by natural dehiscence, wind-throw, or animals.

Bear use of pine seeds during 1989 - 90 also contradicted the conclusions of Mattson and Jonkel (1990) to the effect that Yellowstone grizzly bears made very little use of high elevation whitebark pine stands where red squirrels were scarce. During 1989 - 90 grizzly bears did use high elevation whitebark stands, and in two instances were observed for the first time during our study to use cones directly off the crowns of elfin trees at upper timberline. Use of cones directly from the crown by grizzly bears was also observed by Jonkel and Cowen (1971) in the Whitefish Range of northwestern Montana and by Mealey (1975) in the Yellowstone area.

\section{Management Implications}

Our results point to the pitfalls of short-term studies of bear habitat use. Mattson, Blanchard, and Knight (1991) arrived at the same conclusion based on large annual variation in grizzly bear food habits and suggested that five to seven years of study were needed to adequately document significant variation. It is clear from our analysis that strategies and habitat use associated with bear foraging on even a single food can be so varied that > six to nine years may be required to adequately document annual variation. A shorter duration, two- to three-year study of pine seed use by Yellowstone grizzly bears could have produced misleading or erroneous conclusions about specifically how and where bears acquired pine seeds. Some of the conclusions reached by Mattson and Jonkel (1990), based primarily on bear use of two seed crops, are an example of this risk. To date, no published study has given significant consideration to long-term annual variation in bear food habits (Mattson, Blanchard, and Knight 1991) or habitat use, much less habitat use associated with acquisition of a single important food.

From results presented here, we conclude that Yellowstone grizzly bears will potentially make intensive use of the entire elevational and site range of whitebark pine. No part of this range can be discounted as relatively unimportant to the grizzly bear population. However, bear use of pine seeds any given year will be highly varied and probably contingent on where and how much cone production has occurred. This conclusion is also a basis for hypothesizing that, as the duration of a bear habitat use study increases, fewer sites will be found to be unimportant to bears, at least during some year.

Our results also confirm that the substantial use of ovenwintered pine seeds by Yellowstone grizzly bears first recorded by Kendall (1983) is relatively frequent. Thus, habitats where bears use pine seeds need to be secure not only during the fall, but also potentially during the summer and late spring. Some bear use of overwintered pine seeds may persist into early fall and contradict use expected from the current year's seed crop. 


\section{Literature Cited}

Alexander, R.R., C.B. Edminster, and R.K. Watkins. 1986. Estimating potential Engelmann spruce seed production on the Fraser Experimental Forest, Colorado. Res. Paper RM-269. U.S. Department of Agriculture, Forest Service, 7pp.

Arno, S.F. and R.J. Hoff. 1989. Silvics of whitebark pine (Pinus albicaulis). Gen. Tech. Rep. INT-253. U.S. Department of Agriculture, Forest Service. 11pp.

Blanchard, B.M. 1990. Relationships between whitebark pine cone production and fall grizzly bear movements. Pages 362-363 in W.C. Schmidt and K.J. McDonald, compilers, Proceedings - Symposium on Whitebark Pine Ecosystems: Ecology and Management of a High-mountain Resource. Gen. Tech. Rep. INT-270. U.S. Department of Agriculture, Forest Service.

Blanchard, B.M. and R.R. Knight. 1991. Movements of Yellowstone grizzly bears. Biological Conservation 58:41-67.

Despain, D.G. 1990. Yellowstone vegetation: consequences of environment and history in a natural setting. Roberts Rinehart, Boulder, Colorado. 239pp.

Franklin, J.F. 1968. Cone production by upper-slope conifers. Res. Paper PNW-60. U.S. Department of Agriculture, Forest Service. 21pp.

Fraser, D.A. 1966. Vegetative and reproductive growth of black spruce (Picea mariana (Mill.) Bsp.) at Chalk River, Ontario, Canada. Canadian Journal of Botany 44:567-580.

Grisez, T.J. 1975. Flowering and seed production of seven hardwood species. Res. Paper NE-315. U.S. Department of Agriculture, Forest Service. 8pp.

Hutchins, H.E. 1990. Whitebark pine seed dispersal and establishment: who's responsible? Pages 245-255 in W.C. Schmidt and K.J. McDonald, compilers, Proceedings - Symposium on Whitebark Pine Ecosystems: Ecology and Management of a High-mountain Resource. Gen. Tech. Rep. INT-270. U.S. Department of Agriculture, Forest Service.

Hutchins, H.E. and R.M. Lanner. 1982. The central role of Clark's Nutcracker in the dispersal and establishment of whitebark pine. Oecologia (Berlin) 55:192-201.

Jonkel, C.J. and I.M. Cowan. 1971. The black bear in the spruce-fir forest of northwestern Montana. Wildlife Monograph 27. 55pp.

Kendall, K.C. 1983. Use of pine nuts by grizzly and black bears in the Yellowstone area. International Conference on Bear Research and Management 5:166-173.

Knight, R.R., B.M. Blanchard, and D.J. Mattson. 1991. Yellowstone grizzly bear investigations: annual report of the Interagency Study Team. U.S. Department of the Interior, National Park Service, Yellowstone National Park. 15pp. 
Knight, R.R. and L.L. Eberhardt. 1985. Population dynamics of Yellowstone grizzly bears. Ecology 66(2):323-334.

Kozhevnikov, A.M. 1963. [Fruit bearing of the Siberian stone pine in the western part of the Transbaikal]. Pages 80-97 in A.P. Shimanyuk, ed. [Fruiting of the Siberian Stone Pine in East Siberia]. Akademiya Nauk SSSR. Sibirskoe Otdelenie. Trudy Instituta Lesa I Drevesiny. Vol. 62. (Transl. from Russian, Israel Prog. for Sci. Transl., Jerusalem, 1966.)

Kramer, P.J., and T.T. Kozlowski. 1960. Physiology of Trees. McGraw-Hill, New York, New York.

Lanner, R. 1990. Biology, taxonomy, evolution, and geography of stone pines of the world. Pages 14-24 in W.C. Schmidt and K.J. McDonald, compilers, Proceedings - Symposium on Whitebark Pine Ecosystems: Ecology and Management of a High-mountain Resource. Gen. Tech. Rep. INT-270. U.S. Department of Agriculture, Forest Service.

Mattson, D.J., B.M. Blanchard, and R.R. Knight. 1991. Food habits of Yellowstone grizzly bears, 1977-1987. Canadian Journal of Zoology 69:1619-1629.

Mattson, D.J., B.M. Blanchard, and R.R. Knight. 1992. Yellowstone grizzly bear mortality, human-habituation, and whitebark pine seed crops. Journal of Wildlife Management 56(3):432-442.

Mattson, D.J. and C. Jonkel. 1990. Stone pines and bears. Pages 223-236 in W.C. Schmidt and K.J. McDonald, compilers, Proceedings - Symposium on Whitebark Pine Ecosystems: Ecology and Management of a High-mountain Resource. Gen. Tech. Rep. INT-270. U.S. Department of Agriculture, Forest Service.

McCaughey, W.W. and W.C. Schmidt. 1990. Autecology of whitebark pine. Pages 85-96 in W.C. Schmidt and K.J. McDonald, compilers, Proceedings - Symposium on Whitebark Pine Ecosystems: Ecology and Management of a High-mountain Resource. Gen. Tech. Rep. INT-270. U.S. Department of Agriculture, Forest Service.

Mealey, S.P. 1975. The natural food habits of free ranging grizzly bears in Yellowstone National Park, 1973-1974. M.S. thesis, Montana State University, Bozeman, Montana. 158pp.

Nesvetailo, V.D. 1987. [Long-term dynamics of cedar pine reproductive activity and radial growth in pine forests adjoining village in southern Taiga subzone]. Ekologiya 18(6):19-25. (Transl. from Russian, Consultants Bureau, New York, 1988.)

Reinhart, D.P. and D.J. Mattson. 1990. Red squirrels in the whitebark zone. Pages 256-263 in W.C. Schmidt and K.J. McDonald, compilers, Proceedings - Symposium on Whitebark Pine Ecosystems: Ecology and Management of a High-mountain Resource. Gen. Tech. Rep. INT-270. U.S. Department of Agriculture, Forest Service.

Rosenzweig, M.L. 1991. Habitat selection and population interactions: the search for mechanism. American Naturalist 137(Suppl.):S5-S28.

SAS Institute, Inc. 1987. SAS/STAT guide for personal computers. 6th ed. SAS Institute, Inc., Cary, North Carolina. 1028pp. 
Steele, R., S. Cooper, D. Ondov, D. Roberts, and R. Pfister. 1983. Forest habitat types of eastern Idaho-western Wyoming. Gen. Tech. Rep. INT-144. U.S. Department of Agriculture, Forest Service. 122pp.

U.S. Department of Agriculture, Forest Service. 1974. Seeds of woody plants in the United States. Agric. Handb. 450. U.S. Department of Agriculture, Forest Service. 883pp.

Weaver, T. and F. Forcella. 1986. Cone production in Pinus albicaulis forests. Pages 68-76 in R.C. Shearer, compiler, Proceedings - Conifer Tree Seed in the Inland Mountain West Symposium. Gen. Tech. Rep. INT-203. U.S. Department of Agriculture, Forest Service. 


\title{
Seasonal Maturation of Whitebark Pine Seed in the Greater Yellowstone Ecosystem
}

\author{
Ward W. McCaughey \\ U.S. Department of Agriculture, Forest Service \\ Intermountain Research Station \\ Montana State University \\ Bozeman, MT 59717-0278
}

\begin{abstract}
Whitebark pine is a critical component of the habitat needed for survival of grizzly in the Greater Yellowstone ecosystem. Management is relying more and more on planting whitebark pine for future cone production. As a result, large quantities of viable seed are needed for production of nursery stock in forest nurseries. In the past, collecting large amounts of whitebark pine seed has been a problem because seed consumers such as squirrels and the Clark's nutcracker compete for these important seeds within a limited time period. Therefore, timing of cone collection is critical - collect too soon and the seed is not ripe; collect too late and animals and birds have depleted the seed crop. This paper reports results from a pilot study on potential indices of whitebark pine seed maturation.
\end{abstract}

\section{Introduction}

Whitebark pine (Pinus albicaulis Engelm.) is considered a nontimber species and has recently been found to have significant wildlife, watershed, and aesthetic value. Whitebark pine seeds have long been known to be an important food source for birds, small mammals, and, more recently, grizzly bear (Ursus arctos horribilis) in the Greater Yellowstone ecosystem (Craighead, Scaggs, and Summer 1982; Kendall 1983; Knight, Blanchard, and Mattson 1987). Whitebark pine may well be used as a future monitor of global climate change because of the sensitivity of the high-elevation environments where it grows.

Fire suppression policies in the northern Rocky Mountains have increased intervals between natural fires. Under these conditions, shade-tolerant species such as subalpine fir (Abies lasiocarpa) and Engelmann spruce (Picea engelmannii) (Arno 1986; Tomback 1989) gradually replace the less shade-tolerant whitebark pine. When fires occur, cone-bearing stands of whitebark pine are eliminated because of the increase in shade-tolerant species producing higher fuel loading, which results in stand-replacement fires (Arno 1980).

Forest managers are using whitebark pine in operational plantings in an attempt to replace mature whitebark stands destroyed by fire and to establish cone production areas for wildlife in areas previously 
managed for timber production. These cone production areas naturally contain small amounts of whitebark pine with small crowns, apparently caused by interspecific competition. Cultural treatments are needed in cone production areas to eliminate interspecific competition and to promote wide crown development for better cone production. Since 1987 in the Gallatin National Forest more than 26,000 whitebark pine seedlings have been planted on nearly 300 acres for future cone production.

Cone crops of whitebark pine vary significantly between years and between stands for a variety of reasons (Weaver and Forcella 1990). When climatic and tree health conditions are conducive to cone initiation, a two-year cone and seed development process begins (Kozlowski 1971). During the two growing seasons prior to maturation, insects, disease, and climatic conditions combine to reduce cone crops (Edwards 1990). Timing of cone collections is critical for providing nurseries with an abundant supply of quality whitebark seed since cone crops are infrequent and reduced because of natural factors. Collecting large quantities of mature whitebark seed is a problem even when large crops are produced because of competing seed predators such as red squirrels (Tamiasciurus hudsonicus), chipmunks (Eutamias spp.), Clark's nutcrackers (Nucifraga columbiana), and a host of other small mammals and birds (Arno and Hoff 1989; McCaughey and Schmidt 1990), many of which begin collecting cones prior to seed maturity.

This pilot study evaluates seasonal maturation of whitebark pine seed and provides some preliminary indices for use by forest managers to better estimate when seed has matured sufficiently for collection. Hutchins and Lanner (1982) found that seed dry weight (oven dried) and seed coat thickness can be used as indicators of seed maturity. This study evaluated cone measurements such as length, width, and specific gravity, and seed measurements and ratios of embryo, endosperm, and total seed lengths, which may provide field measurable indices of whitebark pine seed maturity.

\section{Methods}

Cones were collected over a seven-week period in a nearly pure stand of whitebark pine on the west slope of Palmer Mountain on the Gardiner Ranger District of the Gallatin National Forest. The stand is 3.2 kilometers north of Yellowstone National Park at an elevation of 2,621 m. The vegetative cover is classified as a Pinus albicaulis/Abies lasiocarpa habitat type (Pfister et al. 1977) with an understory of Vaccinium scoparium.

Cones were collected seven times at seven-day intervals from July 27 to September 8 by climbing into whitebark pine crowns and detaching cones with a retractable 7.6-m pruning pole. Fifteen cones, three each from five randomly selected trees with large crowns, were collected weekly, placed in plastic bags to retain moisture, and transported to the Forestry Sciences Laboratory in Bozeman, Montana. The same five trees were used for each collection. Insect- and bird-damaged cones were discarded, and 10 sound cones from the remainder of each weekly collection (70 cones total) were used for further study. Immediately upon arrival in Bozeman sound cones were weighed and immersed in water in a graduate cylinder to determine the mean specific gravity for each week's collection.

The sound cones were air dried in burlap bags for 60 days following the last collection date (September 8). Cones were not after-ripened to reduce the effects of varying drying times from cone collection to seed extraction between the seven collections. Seeds extracted from each cone were stored as individual collections for further evaluation. Seeds were x-rayed to determine soundness, and empty seeds were discarded. Sound seeds were surface sterilized by soaking in 40 percent Clorox bleach for 
10 minutes, rinsed 10 times in distilled water with an additional 12-hour rinsing in running tap water to remove any residual Clorox (Wenny and Dumroese 1987), and then air dried. Dried seeds were placed on germination blotter paper in plastic germination boxes and left in dry-cold conditions $\left(2^{\circ} \mathrm{C}\right)$ for 85 days. Seeds were then imbibed and stratified at $2^{\circ} \mathrm{C}$ for 45 days. Seed boxes were then placed in a germination chamber with 12 hours of light at $25^{\circ} \mathrm{C}$ (day) and 12 hours of darkness at $15^{\circ} \mathrm{C}$ (night) temperature (Jacobs and Weaver 1990). When radicals emerged, germination was recorded. Based on the total number of sound seed, percent germination was calculated for each collection after 24 weeks in a germination chamber.

Cone and seed variables consisted of both measured and computed values. Cone lengths and widths were measured with calipers to the nearest centimeter. Seed measurements taken with calipers from $x$-rays included seed, endosperm, and embryo lengths to the nearest millimeter. Ratios of embryo to total seed length, endosperm to total seed length (percent of total seed filled), and embryo to endosperm length were computed from the seed measurements.

\section{Data Analysis}

The percentage of whitebark pine seeds germinating was used as a measure of seed maturity. Germination percentages were computed on a per cone basis as the number of seeds germinated from each collection date divided by the total number of sound seeds. Zero percent germination was weighted as a value of $[1 /(4 n)]$ to stabilize variance (Bartlett 1947) where $n$ is the total number of sound seeds for that cone. The arc sine transformation of the square root of percent germination was used to stabilize variance in all statistical analyses (Snedecor and Cochran 1980).

The Statistical Analysis System (SAS) was used to analyze whitebark pine maturity data. The $t$ test analysis procedure was used for significance ( 0.05 level) testing between collections for measured and computed variables.

\section{Results}

\section{Cone Indices}

Percent germination as a measure of seed maturity was evaluated in relation to cone length and width and specific gravity over the 7 collection periods. Mean specific gravity was erratic but generally decreased from 1.02 for cones collected on July 27 to 0.98 for cones collected on August 25 and then increased to 1.13 for cones collected on September 8 (table 1). Mean cone length and width values increased for the collection dates from July 27 through August 18, then slowly decreased between August 18 and September 8 (table 1).

\section{Seed Indices}

Percent germination was zero for seed collected in July, 3.4 percent for August 4, and 6.3 percent for August 10, and then significantly increased to almost 26 percent for seed collected on August 18 (table 1). Germination increased to almost 40 percent for seed collected on September 1 , but then dropped to below 23 percent for seed collected on September 8. 
Table 1. Mean cone length, width, specific gravity, and percent germination of whitebark pine by collection date

\begin{tabular}{|l|c|c|c|c|}
\hline \multirow{2}{*}{$\begin{array}{c}\text { Collection } \\
\text { date }\end{array}$} & $\begin{array}{c}|c| \\
\text { length } \\
(\mathrm{mm})\end{array}$ & $\begin{array}{c}\text { width } \\
(\mathrm{mm})\end{array}$ & \multirow{2}{*}{$\begin{array}{c}\text { Specific } \\
\text { gravity }\end{array}$} & $\begin{array}{c}\text { Percent } \\
\text { germination }\end{array}$ \\
\cline { 2 - 3 } & 2.11 & 1.48 & 1.02 & $0.00(\mathrm{a})^{1}$ \\
\hline July 27 & 2.66 & 1.75 & 1.01 & 3.40 (b) \\
\hline August 4 & 2.83 & 1.77 & 1.03 & 6.34 (b) \\
\hline August 10 & 3.00 & 1.89 & 1.00 & 25.78 (c) \\
\hline August 18 & 2.78 & 1.78 & 0.98 & 26.16 (c) \\
\hline August 25 & 2.65 & 1.68 & 1.06 & $39.46(\mathrm{c})$ \\
\hline September 1 & 2.50 & 1.67 & 1.13 & 22.54 (c) \\
\hline September 8 & & & & \\
\hline
\end{tabular}

${ }^{1}$ Similar and dissimilar letters in parentheses represent nonsignificant and significant differences, respectively.

Percent germination (seed maturity) was evaluated against several whitebark pine seed characteristics measured concomitantly with percent germination. Endosperm and total lengths of sampled seed increased significantly from July 27 to August 4 (figure 1). Embryos were not recognizable on $x$-rays and were considered to be zero until the August 4 collections. Embryo and endosperm lengths increased significantly from August 4 to August 10 and from August 10 to August 18 (figure 1). Means of total seed length for the cone collection periods increased gradually from August 4 to August 25 and from August 25 to September 1. Mean lengths of embryo, endosperm, and the entire seed decreased significantly for collections after September 1.

Ratios of embryo and endosperm (total cavity filled) to overall seed length and embryo to endosperm length (table 2) increased significantly from July 27 to August 4, from August 4 to August 10, and from August 10 to August 18. The embryo to endosperm ratio decreased significantly from August 25 to September 1.

The mean ratio of endosperm (total cavity filled) to total seed length increased from 0.63 to 0.76 from July 27 to August 10 and significantly increased to above 0.80 for collections after August 10 (table 2). Seed maturity, as measured by percent germination, increased significantly from 6 to more than 22 percent (table 1) during the same period. Percent germination and ratio of total seed filled were highest (39.5 and 0.83 , respectively) on September 1 . The embryo to total seed length ratio also increased significantly from August 10 to August 18, but was constant for the remaining collections (table 2). 


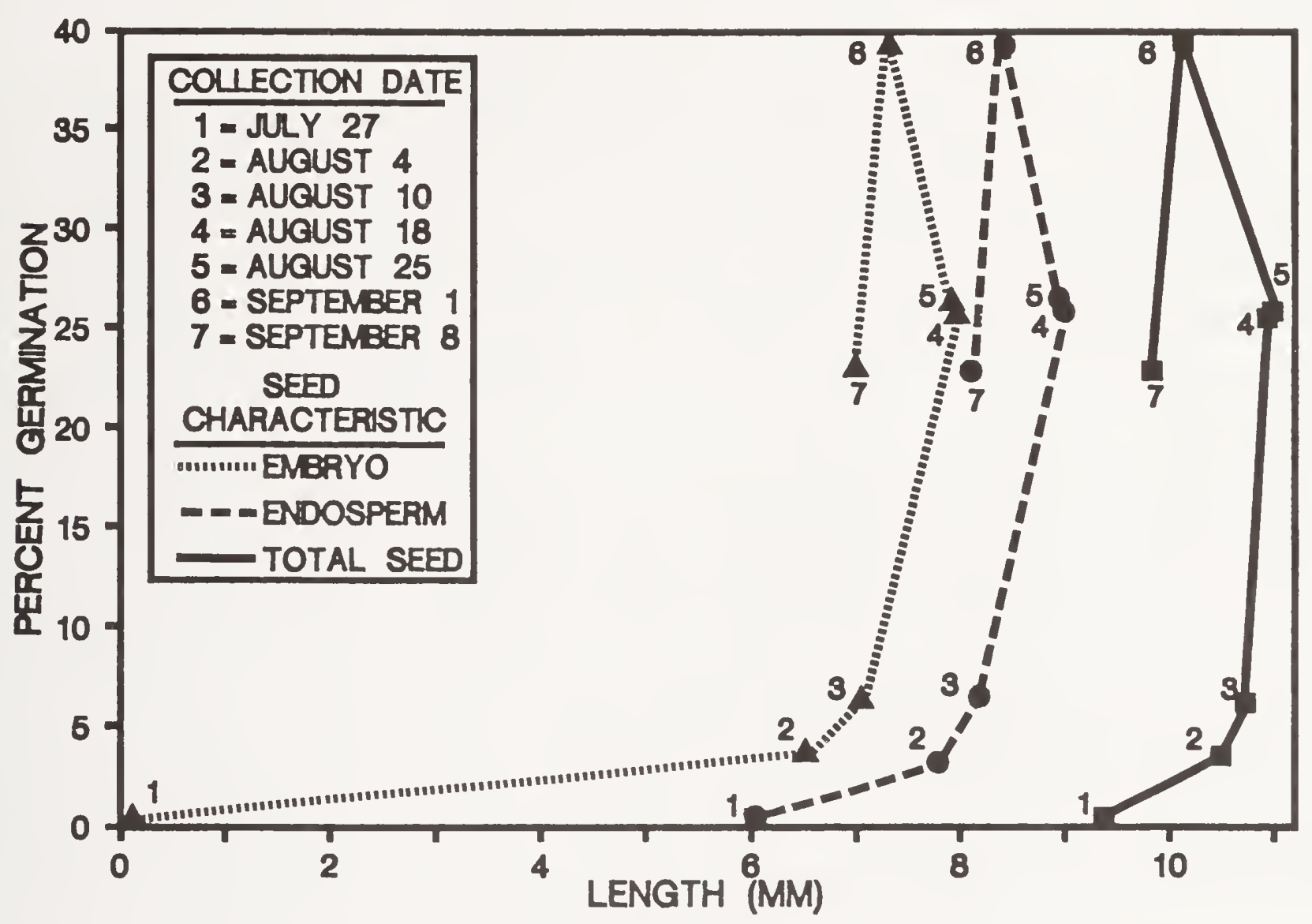

Figure 1. Percent germination of whitebark pine seed as related to lengths of embryo, endosperm, and total seed for seven collection dates. 
Table 2. Mean ratios for embryo and endosperm (total cavity filled) to total seed length, and embryo to endosperm length of whitebark pine by collection date

\begin{tabular}{|l|c|c|c|}
\hline \multirow{2}{*}{$\begin{array}{c}\text { Collection } \\
\text { date }\end{array}$} & Embryo & Endosperm & Embryo \\
\cline { 2 - 4 } & $\begin{array}{c}\text { Total seed } \\
\text { length }\end{array}$ & $\begin{array}{c}\text { Total seed } \\
\text { length }\end{array}$ & $\begin{array}{c}\text { Endosperm } \\
\text { length }\end{array}$ \\
\hline July 27 & 0.0000 (a) $)^{1}$ & 0.6342 (a) & 0.0000 (a) \\
\hline August 4 & 0.6234 (b) & 0.7459 (b) & 0.8355 (b) \\
\hline August 10 & 0.6537 (c) & 0.7566 (b) & 0.8637 (c) \\
\hline August 18 & 0.7303 (d) & 0.8276 (c) & 0.8824 (d) \\
\hline August 25 & 0.7193 (d) & 0.8167 (c) & 0.8807 (d) \\
\hline September 1 & 0.7215 (d) & 0.8327 (c) & 0.8665 (c) \\
\hline September 8 & 0.7067 (d) & 0.8219 (c) & 0.8599 (c) \\
\hline
\end{tabular}

${ }^{1}$ Within columns, similar and dissimilar letters in parentheses represent nonsignificant and significant differences, respectively.

\section{Discussion}

The demand for quality whitebark seed has increased in the past few years because of additional planned plantings by forest managers. Development of seed maturity indices that can be quickly obtained in the field is important because of infrequent and sometimes reduced cone crops, competition for seeds by a variety of animals such as the Clark's nutcracker and squirrels, and the inaccessibility of whitebark pine stands. There are several developed indices of seed maturity for other conifer species such as western larch (Larix occidentalis), grand fir (Abies grandis), and Douglas-fir (Pseudotsuga menziesii) (Pfister 1967; Rediske 1969; Shearer 1977). Germination of whitebark pine seeds was evaluated against indices of oven-dry seed weight, seed coat thickness, caloric content, and ash content by Hutchins and Lanner (1982). Seeds must be taken to a laboratory for evaluation of these indices. Indices evaluated in this study can be determined in the field by using a portable scale and a beaker of water to determine specific gravity and calipers and a knife to determine cone length and width, and embryo, endosperm, and total seed lengths.

Cone length, width, and specific gravity of cones on trees sampled at seasonal intervals did not indicate seed maturity (table 1). Cone lengths and widths gradually increased from July 27 to August 18 but decreased for later collections, making them unreliable indices of seed maturity. Decreased cone dimensions with season were caused either by shrinkage (unlikely), sampling error, or, more likely, by larger (more mature) cones being selectively removed from the trees. Nutcracker harvesting of whitebark seeds began around August 18 at this study area, and undisturbed cones were hard to find after that date. It appeared that nutcrackers and squirrels were selecting the more obvious (showy) cones. 
Because only intact cones were collected, sampling was skewed toward smaller, less showy cones on later collection dates. Few intact cones were found for the September 8 collection, and these were small and dense as evidenced by small cone length and width measurements and high specific gravities (1.13) (table 1).

The ratios of embryo and endosperm (total cavity filled) to total seed length appear to relate most closely to seed maturity. Ratios increased significantly from 0.65 to 0.73 and 0.76 to 0.82 , respectively, between August 10 and 18. This increase corresponded with percent germination of whitebark pine, which increased significantly from 6 to 26 percent for cones collected on August 10 and August 18, respectively, indicating a major change in seed maturity. Since ratios did not decrease thereafter, low and high ratios correspond to low and high germination, respectively. This information is similar to that found for other conifers. The ratio of embryo to seed length is also a good indicator of seed maturity in true firs (Oliver 1974), and the Gallatin National Forest is currently using the ratio value of 0.70 and above as an index of acceptable maturity of whitebark seed.

Germination of whitebark pine appears to be higher for later cone collection dates until about September 1. However, in this pilot study percent germination decreased from near 40 percent on September 1 to less than 23 percent on September 8. This decrease, although nonsignificant, was likely a function of sampling, as evidenced by the smaller cones with high specific gravities; however, this is considered to accurately reflect the cone and seed characteristics available at different collection times that operational collectors must deal with.

This preliminary study was conducted to evaluate field-measurable indices of seed maturation for whitebark pine. Because cones were not subjected to an after-ripening treatment, the effect of varying lengths of air drying for each collection was assumed minimal. At this time we have no information available to estimate how high germination would be if cones had been protected from seed consumers and allowed to mature. Cones in this study came from trees accessible to seed consumers since operationally harvested cones must come from natural, unprotected trees.

\section{Preliminary Management Recommendations}

Periodic monitoring of cones from whitebark pine stands is essential for obtaining quality seed. The following preliminary recommendations are made for collecting whitebark pine cones to obtain the highest germination of filled seeds.

Collect cones after embryo to total seed length ratios are above 0.65 .

Collect cones after endosperm to total seed length ratios (percent of the seed cavities filled) are above 0.75 .

Delay collecting if recommendations 1 and 2 are met, squirrel caching is minimal, and nutcrackers have not begun to collect seed from the stand.

This pilot study was located in one stand for one year and should be considered as a case study. It was conducted to provide preliminary information on potential indices of whitebark pine seed maturity and not to develop final maturation indices. Further studies from multiple areas using several potentially important indices such as seed dry weight, seed coat thickness, and seed measurement ratios are 
needed to develop the best indices of whitebark pine seed maturity. Temperature (degree-day) measures and their effects on seed maturity should be explored as well as changes in reducing sugar levels as reported for Douglas-fir (Rediske 1969). Cone storage variables should also be considered because of their known effects on other conifers such as noble fir (Abies procera) (Rediske 1965) and Douglas-fir (Rediske 1961). We also need to explore after-ripening techniques to allow earlier collections of cones and still obtain mature seed.

\section{Literature Cited}

Arno, S.F. 1980. Forest fire history in the Northern Rockies. Journal of Forestry 78(8):460-465.

Arno, S.F. 1986. Whitebark pine cone crops - a diminishing source of wildlife food? Western J. of Applied Forestry. 1(3):92-94.

Arno, S.F. and R.J. Hoff. 1989. Silvics of whitebark pine (Pinus albicaulis). Gen. Tech. Rep. INT-253. U.S. Department of Agriculture, Forest Service, Intermountain Research Station, Ogden, Utah. 11pp.

Craighead, J.J., G.B. Scaggs, and J.S. Sumner. 1982. A definitive system for analysis of grizzly bear habitat and other wilderness resources. Wildlands Institute Monograph 1. University of Montana, Missoula, Montana. 279pp.

Edwards, D.G.W. 1990. Cone prediction, collection and processing. Pages 78-102 in W.C. Schmidt and K.J. McDonald, compilers, Proceedings - Symposium on Whitebark Pine Ecosystems: Ecology and Management of a High-mountain Resource, 1989 March 29-31, Bozeman, Montana. Gen. Tech. Rep. INT-270. U.S. Department of Agriculture, Forest Service, Intermountain Research Station, Ogden, Utah.

Hutchins, H.E. and R.M. Lanner 1982. The central role of Clark's nutcracker in the dispersal and establishment of whitebark pine. Oecologia. 55:192-201.

Jacobs, J. and T. Weaver. 1990. Effects of temperature and temperature preconditioning on seedling performance of whitebark pine. Pages 134-139 in W.C. Schmidt and K.J. McDonald, compilers, Proceedings - Symposium on Whitebark Pine Ecosystems: Ecology and Management of a High-mountain Resource, 1989 March 29-31, Bozeman, Montana. Gen. Tech. Rep. INT-270. U.S. Department of Agriculture, Forest Service, Intermountain Research Station, Ogden, Utah.

Kendall, K.C. 1983. Use of pine nuts by grizzly and black bears in the Yellowstone area. International Conference on Bear Research and Management. International Bears Association, Madison, Wisconsin. 5:166-173.

Knight, R.R., B.M. Blanchard, and D.J. Mattson. 1987. Yellowstone grizzly bear investigations. Report of the interagency study team, 1987. U.S. Department of the Interior, National Park Service, Bozeman, Montana. 80pp.

Kozlowski, T.T. 1971. Growth and development of trees. Vol. I. Seed Germination, Ontogeny, and Shoot Growth. Academic Press, New York. 443pp. 
McCaughey, W.W. and W.C. Schmidt. 1990. Autecology of whitebark pine. Pages 85-96 in W.C. Schmidt and K.J. McDonald, compilers, Proceedings - Symposium on Whitebark Pine Ecosystems: Ecology and Management of a High-mountain Resource, 1989 March 29-31, Bozeman, Montana. Gen. Tech. Rep. INT-270. U.S. Department of Agriculture, Forest Service, Intermountain Research Station, Ogden, Utah.

Oliver, W.W. 1974. Seed maturity in white fir and red fir. Res. Pap. PSW-99. U.S. Department of Agriculture, Pacific Northwest Forest and Range Experiment Station, Berkeley, California. 10pp.

Pfister, R.D. 1967. Maturity indices for grand fir cones. Res. Note INT-58. U.S. Department of Agriculture, Forest Service, Intermountain Forest and Range Experiment Station, Ogden, Utah. 7pp.

Pfister, R.D., B.L. Kovalchik, S. Arno, and R. Presby. 1977. Forest habitat types of Montana. Gen. Tech. Rep. INT-34. U.S. Department of Agriculture, Forest Service, Intermountain Forest and Range Experiment Station, Ogden, Utah. 174pp.

Rediske, J.H. 1969. Effects of cone-picking date on Douglas-fir seed quality. Forest Science 15(4):404-410.

Rediske, J.H. and David C. Nicholson. 1965. Maturation of noble fir seed - a biochemical study. Weyerhaeuser Forest Paper 2, Weyerhaeuser Co. Forest Research Center, Centralia, Washington. $15 p p$.

Shearer, R.C. 1977. Maturation of western larch cones and seeds. Res. Pap. INT-189. U.S. Department of Agriculture, Forest Service, Intermountain Forest and Range Experiment Station, Ogden, Utah. 15pp.

Snedecor, G.W. and W.G. Cochran. 1980. Statistical Methods. 7th ed. lowa State University Press, Ames, lowa. 507pp.

Tomback, D.F. 1989. The broken circle: fire, birds and whitebark pine. Pages 14-17 in T. Walsh, compiler and editor, Wilderness and Wildfire. Misc. Publ. 50. University of Montana, School of Forestry, Montana Forest and Range Experiment Station, Missoula, Montana.

Weaver, T. and F. Forcella. 1990. Cone production in Pinus albicaulis forests. Pages 68-76 in W.C. Schmidt and K.J. McDonald, compilers, Proceedings - Symposium on Whitebark Pine Ecosystems: Ecology and Management of a High-mountain Resource, 1989 March 29-31, Bozeman, Montana. Gen. Tech. Rep. INT-270. U.S. Department of Agriculture, Forest Service, Intermountain Research Station, Ogden, Utah.

Wenny, D.L. and R.K. Dumroese. 1987. Germination of conifer seed surface sterilized with bleach. Tree Planters' Notes 38(3):18-21. 



\title{
Responses of Nematodes to Ungulate Herbivory on Bluebunch Wheatgrass and Idaho Fescue in Yellowstone National Park
}

\author{
Evelyn Merrill \\ Department of Zoology and Physiology, University of Wyoming \\ Laramie, WY 82071 \\ Jon Hak \\ Department of Zoology and Physiology, University of Wyoming \\ Laramie, WY 82071 \\ Nancy Stanton \\ Department of Zoology and Physiology, University of Wyoming \\ Laramie, WY 82071
}

\begin{abstract}
Above- and below-ground biomass of Idaho fescue (Festuca idahoensis) and bluebunch wheatgrass (Agropyron spicatum) plants and nematode densities under these species were sampled during the growing season inside and outside a two-year-old exclosure on Crystal Bench in Yellowstone National Park. Early in the growing season, grazed plants of both species had lower shoot and root biomass than ungrazed plants. Standing biomass of grazed plants was equal to ungrazed plants at the end of the growing season. Densities (no./g root biomass) of phytophagous and bacterial-feeding nematodes were higher under grazed than ungrazed plants of both plant species only early in the growing season. Foliar concentrations of $\mathrm{N}$ in grazed plants were higher than in ungrazed plants, but there was no difference in root $\mathrm{N}$ between grazed and ungrazed plants.
\end{abstract}

The effects of ungulate grazing on the northern winter range of Yellowstone National Park has recently received considerable attention (Coughenour 1991; Frank 1990; Singer 1992; Wallace, submitted). Early interest in this topic centered around the question to cull or not to cull elk in the park. However, as the concepts of "maintaining ecological processes" (Houston 1982) and "managing from an ecosystem perspective" (Keiter 1991) have gained acceptance in park management, understanding the dynamics and interactions of a broader array of herbivores inhabiting the park have become increasingly important. In this paper, we describe the results of a study that focused on the effects of above-ground herbivory on below-ground nematode density and trophic structure. 
Root-feeding nematodes are major herbivores in other grassland systems and may consume twice as much biomass as above-ground consumers (Ingham and Detling 1984; Stanton 1988). Houston (1982) reported that nothing is known about the effects of nematodes on the native grasses of the northern range, especially in combination with above-ground grazers. We hypothesized that if spring grazing is intense, grazed plants would initially show a decline in root growth and phytophagous nematodes. Cessation of root growth is a common response of plants to grazing and may occur within the first 2 - 24 hours (Hodgkinson and Baas Becking 1977). Evidence to date supports the idea that phytophagous nematode densities are highest under moderate levels of grazing and low under heavily grazed and ungrazed plants (Seastedt 1985; Seastedt, Ramundo, and Hayes 1988; Stanton 1983; Stanton, Morrison, and Laycock 1984). Because senescing roots subsequent to grazing provide increased substrates for decomposers, we also hypothesized that microbial activity and nitrogen mineralization should increase (Stanton, Morrison, and Laycock 1984). As a result, we expected to detect an increase in microbialfeeding nematodes.

As root regrowth occurred, we expected phytophagous nematodes to increase. However, we predicted that populations would not reach levels found under ungrazed plants because plants in grazed areas experience higher levels of nitrogen mineralization (Holland and Detling 1990) than ungrazed plants and may produce proportionally fewer numbers of root hairs (nutrient absorption organs), which serve as feeding sites for nematodes. Because of reduced densities of phytophagous nematodes and increased mineralization rates under grazed plants, we expected grazed plants to recoup their losses rapidly. The net result we predicted was that there would be no detectable differences in above-ground or belowground biomass during years of normal rainfall.

Thus, our study addressed three null hypotheses. First, root and shoot biomass of grazed and ungrazed plants will be similar at the end of the growing season. Second, density of phytophagous and microbialfeeding nematodes will not differ between grazed and ungrazed plants. Finally, nitrogen concentration of roots and above-ground foliage will not be higher in grazed than in ungrazed plants. We focused our attention on bluebunch wheatgrass (Agropyron spicatum) and Idaho fescue (Festuca idahoensis) because of their importance as winter range forages and because Mueggler (1975) reported that bluebunch wheatgrass was more sensitive and recovered more slowly from heavy clipping than Idaho fescue.

\section{Study Area}

Our study site is located in the upper portion of the northern winter range near Crystal Creek at an elevation of approximately $1,900 \mathrm{~m}$. The site is a flat bench created by glacial deposits. Soils at the site were described in an earlier study as sandy loam having a bulk density of $1.31 \mathrm{~g} / \mathrm{cc}, \mathrm{pH}$ of 6.30 , organic matter content of 5.4 percent, and nitrogen content of 0.2 percent (Frank 1990: table 2). Vegetation at the site is characterized as a xeric grassland dominated by bluebunch wheatgrass, Idaho fescue, junegrass (Koeleria cristata), needle and thread grass (Stipa comata), lupine (Lupinus sericeus), and horsebrush (Tetradymia canescens) (Wallace, submitted). This study occurred in the second growing season after the extreme drought and fires of 1988, but the site was not burned during the 1988 fires. Data from Mammoth, Wyoming indicate that precipitation was average during most of the 1989 growing season. The exceptions were higher than average precipitation in early May 1989 and below average precipitation in September (Frank 1990: figure 2). In 1990, January - March precipitation at Mammoth, Wyoming was lower than average, April and May precipitation was at or above normal, and June August precipitation was below normal. 
Although the site is grazed year-round by large ungulates, primarily elk (Cervus elaphus), bison (Bison bison), and pronghorn (Antilocapra americana), it receives its greatest use by all species in the winter and spring (Frank 1990; Wallace, submitted).

\section{Methods}

We collected 6 to 10 randomly selected plants of bluebunch wheatgrass and Idaho fescue from outside and inside a large exclosure $(15 \times 15 \mathrm{~m})$ that was established in August 1987 and had not received any ungulate grazing for more than two years (Frank 1990:17). Plants were collected with a soil corer (diameter $4.8 \mathrm{~cm}$, depth $10 \mathrm{~cm}$ ). Because of the rocky, shallow soil, sampling deeper than $10 \mathrm{~cm}$ was precluded. Smolik (1974) found that in the shortgrass prairie, the top $10 \mathrm{~cm}$ contains about 50 percent of the nematodes. Cores were kept cool in an ice chest while transported to the laboratory, where they were refrigerated until processing.

Above-ground biomass was clipped at $2 \mathrm{~cm}$, and standing dead and green biomass were separated, dried at $40^{\circ} \mathrm{C}$ for at least 48 hours, and weighed. The soil cores were suspended in cold water and the soil gently washed from the roots. The suspension was sieved first to remove plant tissue (sieve \#18) and then to remove nematodes (sieve \#325). Roots were hand-sorted while suspended in water, and crowns, including the above-ground biomass to $2 \mathrm{~cm}$, were cut from the roots. Roots and crowns were dried at $40^{\circ} \mathrm{C}$ for at least 48 hours and weighed. We made no attempt to distinguish between dead and live roots. We used dry weights in our analysis because dry-root weight and ash-free weight are highly correlated (Stanton 1983) $(r=0.94)$. Nitrogen content of roots, crowns, and above-ground green biomass was analyzed using standard macrokjeldahl techniques.

Four additional cores were collected, two within in the large exclosure and two in grazed areas to determine soil moisture. Soil moisture was determined as the percent difference in total core weight before and after drying at $60^{\circ} \mathrm{C}$ to a constant weight.

Nematodes were extracted on Baermann funnels for 48 hrs (Christie and Perry 1951). Nematode abundance and trophic category were determined by counting the number of individuals present in two $1-\mathrm{ml}$ subsamples of a $30-\mathrm{ml}$ suspension as described by Smolik (1974). Numbers of nematodes were corrected for extraction efficiencies, which averaged 92 percent for bacterial feeders and 93 percent for plant feeders. In the analysis, Monohysteridae were classified as bacterial feeders.

Normal distribution of our data sets was tested using a Lilliefors test (Lilliefors 1967). Only data on nitrogen concentration were normally distributed. Differences in biomass of plant parts from different grazing treatments were tested using a Mann-Whitney $U$ test. Logarithmic transformations of nematode counts provided normally distributed data. Differences in nitrogen concentration and nematode densities of grazed and ungrazed plants within approximately monthly sampling periods were tested using a t-test. We used a significance level of $a=0.05$ unless otherwise indicated. 


\section{Results}

\section{Plant Biomass}

Standing dead litter of ungrazed bluebunch wheatgrass was greater than grazed plants at the beginning of the growing season (table 1). This difference remained significant but narrowed during the growing season as dead plant material from previous years' growth fragmented, decomposed, or was eaten by small herbivores. Standing dead material within ungrazed Idaho fescue plants was also significantly greater than in grazed plants until the end of the growing season.

Table 1. Biomass (matter/plant core) of standing dead, green, and crown and root

biomass of Agropyron spicatum and Festuca idahoensis plants inside and outside a permanent exclosure on Crystal Bench winter range in Yellowstone National Park. Different letters indicate a significant difference between grazed and ungrazed plants at $p<0.05$.

\begin{tabular}{|c|c|c|c|c|c|c|c|c|}
\hline & \multicolumn{4}{|c|}{ Agropyron spicatum } & \multicolumn{4}{c|}{ Festuca idahoensis } \\
\cline { 2 - 9 } & May & June & July & Sept & May & June & July & Sept \\
\hline $\begin{array}{c}\text { Standing dead } \\
\text { Grazed } \\
\text { Ungrazed }\end{array}$ & $0.00^{\mathrm{a}}$ & $0.02^{\mathrm{a}}$ & $0.05^{\mathrm{a}}$ & $0.06^{\mathrm{a}}$ & $0.00^{\mathrm{a}}$ & $0.01^{\mathrm{a}}$ & $0.03^{\mathrm{a}}$ & 0.10 \\
\hline $\begin{array}{c}\text { Green biomass } \\
\text { Grazed }\end{array}$ & $0.26^{\mathrm{b}}$ & $0.19^{\mathrm{b}}$ & $0.45^{\mathrm{b}}$ & $0.17^{\mathrm{b}}$ & $0.04^{\mathrm{b}}$ & $0.06^{\mathrm{b}}$ & 0.24 \\
$\quad$ Ungrazed & $0.23^{\mathrm{a}}$ & $0.25^{\mathrm{a}}$ & 1.51 & 1.79 & $0.20^{\mathrm{a}}$ & 0.15 & 0.30 & 1.26 \\
\hline Crowns & $0.94^{\mathrm{b}}$ & $0.68^{\mathrm{b}}$ & 1.53 & 0.68 & $0.85^{\mathrm{b}}$ & 0.25 & 0.44 & 0.45 \\
$\quad$ Grazed & & & & & & & & \\
$\quad$ Ungrazed & 3.29 & 1.66 & 1.54 & 1.36 & 2.61 & 1.00 & 0.70 & 1.37 \\
\hline Roots & 3.14 & 1.37 & 1.26 & 1.28 & 3.02 & 1.11 & 0.94 & 1.03 \\
$\quad$ Grazed & & & & & & & & \\
Ungrazed & $0.98^{\mathrm{a}}$ & 1.05 & 0.92 & 1.90 & $1.02^{\mathrm{a}}$ & $0.89^{\mathrm{a}}$ & 0.68 & 1.62 \\
\hline
\end{tabular}

Above-ground green biomass of ungrazed plants was approximately three to four times greater than grazed plants in May (table 1). This difference disappeared in Idaho fescue by June and in bluebunch wheatgrass by July so that above-ground standing biomass of grazed plants of both species equaled that of ungrazed plants. In September, standing biomass of plants subjected to ungulate grazing was equal to plants that had been excluded from grazing in both species. Crown biomass was not different between grazed and ungrazed plants at any sampling date (table 1).

In May root biomass averaged 35 percent and 26 percent lower in grazed plants of bluebunch wheatgrass and Idaho fescue, respectively (table 1). These differences disappeared by early June in bluebunch wheatgrass but lingered into mid-July in Idaho fescue. By September root reserves were generally replenished. 


\section{Nitrogen Concentrations}

Nitrogen concentration of green above-ground biomass was significantly greater in plants outside the exclosure than inside the exclosure in both months sampled (table 2). However, $\mathrm{N}$ concentration of root biomass was similar in plants from inside and outside the exclosure.

Table 2. Nitrogen concentration of above-ground green biomass and roots of Agropyron spicatum and Festuca idahoensis plants inside and outside a permanent exclosure on Crystal Bench winter range in Yellowstone

National Park. Different letters indicate a significant difference between grazed and ungrazed plants at $p<0.05$.

\begin{tabular}{|l|c|c|c|c|}
\hline \multirow{2}{*}{} & \multicolumn{2}{|c|}{ Agropyron spicatum } & \multicolumn{2}{c|}{ Festuca idahoensis } \\
\cline { 2 - 5 } & May & June & May & June \\
\hline Above-ground growth & & & & \\
Ungrazed & $2.81^{+}$ & $1.65^{\mathrm{a}}$ & $1.72^{\mathrm{a}}$ & $1.33^{\mathrm{a}}$ \\
Grazed & 2.46 & $2.38^{\mathrm{b}}$ & $2.58^{\mathrm{b}}$ & $1.74^{\mathrm{b}}$ \\
\hline Roots & & & & \\
Ungrazed & 1.22 & 1.14 & 1.01 & 1.16 \\
Grazed & 0.93 & 1.39 & 1.06 & 1.16 \\
\hline
\end{tabular}

+ small sample size precluded statistical analyses

\section{Nematode Densities}

Abundance of nematodes followed a bimodal distribution with a peak in May when soil moisture was high (22 percent) and a nadir in July when soil moisture was at its lowest (2 percent) (table 3). In May densities of bacterial-feeding nematodes were significantly higher under plants of both species that were open to grazing than those not open to grazing. This difference persisted into June under Idaho fescue plants but not under bluebunch wheatgrass plants. Similarly, densities of phytophagous nematodes were higher under grazed plants than ungrazed plants and these differences persisted into June only under Idaho fescue plants.

\section{Discussion}

Both this study and others (Coughenour 1991, Singer 1992) have documented a 4 - 10-fold increase in plant standing dead material in areas on the northern range fenced from grazing and an increase in bare ground in grazed areas. Despite early seasonal differences in green biomass, by the end of the growing season green biomass of grazed plants of both plant species equaled that of plants in the ungrazed areas. Frank (1990) found that grazing stimulated above-ground primary production by 36 percent at the site in 1989, a year of average or above-average precipitation. Bluebunch wheatgrass appeared to take longer to replace above-ground biomass than Idaho fescue, but this was not true for root biomass. 
Table 3. Densities of nematodes (No./g dry roots $\times 1,000$ ) below Agropyron spicatum and Festuca idahoensis plants from inside and outside a permanent exclosure on Crystal Bench winter range in Yellowstone National Park. Different letters indicate a significant difference between grazed and ungrazed plants at $p<0.05$.

\begin{tabular}{|l|r|r|r|r|r|r|r|r|}
\hline & \multicolumn{4}{|c|}{ Agropyron spicatum } & \multicolumn{4}{c|}{ Festuca idahoensis } \\
\cline { 2 - 9 } & May & June & July & Sept & May & June & July & Sept \\
\hline Plant parasites & & & & & & & & \\
$\quad$ Grazed & $96^{\mathrm{a}}$ & 105 & 58 & 52 & $76^{\mathrm{a}}$ & $59^{\mathrm{a}}$ & 34 & 77 \\
Ungrazed & $202^{\mathrm{b}}$ & 100 & 42 & 56 & $346^{\mathrm{b}}$ & $167^{\mathrm{b}}$ & 37 & 59 \\
\hline Bacterial feeders & & & & & & & & \\
$\quad$ Grazed & $814^{\mathrm{a}}$ & 488 & 285 & 354 & $856^{\mathrm{a}}$ & $236^{\mathrm{a}}$ & 205 & 420 \\
$\quad$ Ungrazed & $991^{\mathrm{b}}$ & 285 & 249 & 281 & $1,319^{\mathrm{b}}$ & $539^{\mathrm{b}}$ & 286 & 782 \\
\hline
\end{tabular}

Our results indicate that above-ground grazing by ungulates facilitates feeding by some below-ground taxa. Plant-parasitic nematodes increased rather than decreased with grazing, as we had hypothesized. Seastedt, Ramundo, and Hayes (1988) hypothesized that below-ground herbivores may increase after moderate levels of above-ground grazing because root quality counteracts the absolute decline in root resources. We found no difference in root $\mathrm{N}$ between grazed and ungrazed plants but did not examine changes in other parameters such as soluble carbohydrates, secondary plant compounds, or fine root hairs. Damage to root tips also may stimulate lateral root growth, which may support high densities of nematodes (Hogger 1972; Rebois and Johnson 1973; Torrey 1976).

The high densities of microbial-feeding nematodes found under grazed plants in May (both species) and June (Idaho fescue only) may be related to root mortality. Dying roots provide a short-term source of carbon for microbes and a prey base for microbivorous nematodes. We suggest that increased microbial biomass and activity increased nitrogen mineralization. Subsequently grazing by nematodes and protozoa released nitrogen to plants that would otherwise have become inaccessible in the microbial biomass.

In summary, results of the study supported our first null hypothesis that root and shoot growth of grazed and ungrazed plants would be similar at the end of the growing season. We rejected the remaining two hypotheses that nematode densities and foliar nitrogen concentration were similar under grazed and ungrazed plants, at least early in the growing season when soil moisture was high. We suggest that above-ground grazing by ungulates influences nitrogen dynamics below-ground and that microbialfeeding nematodes play an important role in nitrogen turnover. However, the relationship between aboveand below-ground grazers remains unclear. 


\section{Acknowledgments}

We wish to thank Francis Singer, John Varley, and Rich Kluckas of Yellowstone National Park Service, and Mark Boyce and the late George Menkens from University of Wyoming - National Park Service Research Center for their administrative support. Jack Norland, Cathy Wilson, Renee Schenewerk, and Sarah Reitz provided assistance with field work and data collection. We thank Doug Frank for maintaining his exclosures. This study was funded through the University of Wyoming - National Park Service and the University of Wyoming Research Office.

\section{Literature Cited}

Christie, J.R. and V.G. Perry. 1951. Removing nematodes from soil. Proceedings of the Helmintholical Society, Washington 18:106-108.

Coughenour, M.B. 1991. Biomass and nitrogen responses to grazing of upland steppe on Yellowstone's northern winter range. Journal of Applied Ecology 28:71-82.

Frank, D.A. 1990. Interactive ecology of plants, large mammalian herbivores and drought in Yellowstone National Park. Doctoral Dissertation. Syracuse University, Syracuse, New York. 123pp.

Hodgkinson, K.C. and H.G. Baas Becking. 1977. Effect of defoliation on root growth of some arid zone perennial plants. Australian Journal of Agricultural Research 29:31-42.

Hogger, C. 1972. Effect of Tichodorus christiei inoculum density and growing temperature on growth of tomato roots. Journal of Nematology 4:66-67.

Holland, E.A. and Detling, J.K. 1990. Plant response to herbivory and below-ground nitrogen cycling. Ecology 71:1040-1049.

Houston, D.B. 1982. The Northern Yellowstone Elk. Macmillan, New York. 473pp.

Ingham, R.E. and J.K. Detling. 1984. Plant-herbivore interactions in a North American mixed-grass prairie. III. Soil nematode populations and root biomass on Cynomys ludovicianus colonies and adjacent uncolonized areas. Oecologia (Berlin) 63:307-313.

Keiter, R.B. 1991. An introduction to the ecosystem management debate. Pages 3-18 in R.B. Keiter and M.S. Boyce, editors, The Greater Yellowstone Ecosystem: Redefining America's Wilderness Heritage. Yale University Press, New Haven.

Lilliefors, H.W. 1967. On the Kolmogorov-Smirnov test for normality with mean and variance unknown. Journal of the American Statistical Association 64:399-402.

Mueggler, W.F. 1975. Rate and pattern of vigor recovery in Idaho fescue and bluebunch wheatgrass. Journal of Range Management 28:198-204. 
Rebois, R.V. and W.C. Johnson. 1973. Effect of Rotylenchulus reniformis on yield and nitrogen, potassium, phosphorus and amino acid content of seed of Glycene max. Journal of Nematology 5:1-6.

Seastedt, T.R. 1985. Maximization of primary and secondary productivity by grazers. American Naturalist 126:559-564.

Seastedt, T.R., R.A. Ramundo, and D.C. Hayes. 1988. Maximization of densities of soil animals by foliage herbivory: empirical evidence, graphical and conceptual models. Oikos 51:243-248.

Singer, F.J. 1992. Effects of elk and other ungulate grazing on the northern winter of Yellowstone National Park in F.J. Singer and J.D. Varley, editors, Effects of grazing by native ungulates on Yellowstone's northern range. National Park Service Report to Congress. Yellowstone National Park, Yellowstone Park, Wyoming.

Smolik, J.D. 1974. Nematode studies at the Cottonwood site. IBP. Grassland Biomedical Technology Rep. No. 251. National Resources Ecological Laboratory CSU, Ft. Collins, Colorado.

Stanton, N.L. 1983. The effect of clipping and phytophagous nematodes on net primary production of blue grama, Bouteloua gracilis. Oikos 40:249-257.

Stanton, N.L. 1988. The underground in grasslands. Annual Review of Ecology and Systematics 19: 573-589.

Stanton, N.L., D. Morrison, and W. Laycock. 1984. The role of plant parasitic nematodes in blue grama die-off. Journal of Range Management 37:447-450.

Torrey, J.G. 1976. Root hormones and plant growth. Annual Review of Physiology 27:435-459.

Wallace, L. submitted, Grazing and competition in montane grasslands. Ecology. 


\title{
The Genus Cortinarius (Agaricales) in the Greater Yellowstone Area; Mycorrhizal Host Associations and Taxonomic Considerations
}

\author{
Meinhard Moser \\ Institut fur Mikrobiologie (n. F.) \\ der Universität Innsbruck, A-6020 \\ Innsbruck, Austria \\ Kent $\mathrm{H}$. McKnight \\ Department of Botany and Range Science \\ Brigham Young University \\ Provo, Utah 84602 \\ Martin Sigl \\ Institut fur Mikrobiologie (n. F.) \\ der Universität Innsbruck, A-6020 \\ Innsbruck, Austria
}

\begin{abstract}
The genus Cortinarius is well represented in the Greater Yellowstone Area (GYA), where it has an important role in forest ecology as it has more species of ectomycorrhiza-forming fungi than any other genus. A total of 930 well-documented collections were made during 1983,1987, 1989, and 1991. Spruce associations have more Cortinarii than other plant communities. Cortinarius fruits less commonly in pine-dominated forests. There is a high degree of similarity between subalpine forests of the GYA and those of European mountains. Alpine Salix communities are also an interesting habitat for Cortinarius. In addition to the really dwarf willow communities, shrubby willow associations ascending well into the alpine zone offer interesting comparisons. Many new species of Cortinarius have been observed in our study areas. Some examples of taxonomic problems are discussed.
\end{abstract}

The genus Cortinarius Fr. is the largest genus of agaricaceous fungi. It is estimated to have over 2,000 species. In the GYA, it is represented by more species than any other genus of the Agaricaceae.

Most Cortinarii are regarded as obligate ectomycorrhizal symbionts. As yet we know of only one or two exceptions, and they are from the Southern Hemisphere. These conclusions come mainly from observations in nature, including mycosociological analyses and root excavations. However, there is 
experimental proof of mycorrhization for about 50 species (Moser 1960), most of which are in the subgenus Phlegmacium. This is the only subgenus of Cortinarius in which pure cultures starting with tissue isolates have succeeded in establishing mycorrhizae in a significant number of species. In the subgenera Leprocybe and Telamonia and in the closely related genus Dermocybe, pure cultures were established only with two or three species. Spore germination failed completely under laboratory conditions for the entire genus.

Just as Cortinarius is the largest genus of the Cortinariaceae, we think that in the GYA it is also the largest mycorrhizal genus. The great number of species and the wide ecological amplitude emphasize their important ecological role in forest ecosystems, particularly as symbionts of forest trees. They contribute also in an essential role to nutrient cycling, particularly by decomposing proteins and other nitrogen and phosphorous compounds. Both functions are essential for the life of a forest and also strongly influence the plant hormone gradient along the rootlets, stimulating the characteristic transformation of rootlets and influencing the carbohydrate flow from plant to fungus. On all poor soils, tree growth would be impossible for most forest trees without their mycorrhizal symbionts that enlarge their absorbing systems in the soil enormously and supply the trees with nitrogen, phosphorous, and mineral salts, as well as strongly influencing the plant hormone gradient along the rootlets. Thus ectomycorrhizal fungi are essential biotic factors for the higher plants, particularly forest trees. Conversely, the higher plants are essential for the fungi with respect to their carbohydrate and energy supply.

In 1983 we began a study concentrating on Cortinarius in this area, continuing in 1987, 1989, and 1991. Collecting covered a period from early July to early or mid-September, i.e., from the appearance of the last snowbank fungi until after the first killing frost of autumn. Collection areas were in the Yellowstone and Grand Teton National Parks, along the Rockefeller Memorial Highway between the parks, in the Beartooth Mountains, Teton and Shoshone National Forests, and the northern end of the Windriver range. The purpose of the study was primarily taxonomic and floristic, but some interesting ecological observations resulted from it also.

Over 900 collections are well documented with extensive descriptions, color slides, and herbarium specimens; for a considerable number of collections, colored paintings have also been prepared. The data are entered in a computer using modified Archivist software, which permits a quick comparison of the taxa involved. Spore measurements for statistical purposes were carried out with the help of a video camera and a video printer. Until now chemical studies were made with only a limited number of taxa. They concern thin layer chromatography comparisons of (1) anthraquinonic pigment patterns, which are often important in distinguishing species from the subgenera Phlegmacium, Dermocybe, Leprocybe, and in a few cases also in Telamonia, and (2) styrylpyrone pigments, which are helpful not only in defining generic limits but also in defining species. Determination of the fluorescence of fresh and dried specimens under ultraviolet (UV) light ( 354 and $255 \mathrm{~nm}$ ) gave us important data for differentiation of taxa otherwise often difficult to separate.

Thorough laboratory study of all collections has not yet been completed. Moreover, intensive type studies and comparison of material in herbaria both in the United States and Europe are necessary. Until these studies are completed, it is impossible to give the actual number of species encountered in different plant communities. However, we feel that a comparison of the number of collections in the different plant communities gives an indication of the relative frequency of Cortinarii in the area.

The 460 recorded collections of Telamonia are the highest number of any subgenus. The subgenus Phlegmacium is represented by 300 records. From the subgenera Cortinarius, Sericeocybe, Leprocybe, 
and Myxacium together we have only 160 records. These relative numbers correspond rather well with those found in European mountainous areas such as the Alps and Scandinavia. Myxacium, with only 15 records, is remarkably poorly represented in the GYA, whereas elsewhere in North America it is much more numerous than in Europe. Surprisingly, Dermocybe, a genus closely related to Cortinarius, is likewise rather poorly represented in the GYA. We have only nine records representing three to four species. The genus is rather abundant in comparable European subalpine forests and in other parts of America.

Cortinarii show a certain degree of host specificity that varies with the species. Some species are rather indifferent, some are very specific. The reasons for such specificity in mycorrhizae are still poorly understood. There may be biochemical ways for recognizing elicitor and receptor molecules similar to those found in plant pathogens, but as yet very few publications have dealt with this problem in mycorrhizae. (Lei, Wong, and Piche 1991)

A typical example of a rather specific relationship is Cortinarius fuscoperonatus Kühner, a representative of the subgenus Telamonia. This fungus is known from Europe and associated with Abies alba. In 1989 we made two collections of this fungus at Four-Mile Meadow in the Teton National Forest. These are the first collections known from North America. Unfortunately, at that time we did not note carefully enough the tree species present at the collecting sites. This year $C$. fuscoperonatus was found at a different location below Togwotee Lodge directly under Abies lasicarpa. A careful examination of the previous collecting sites where the fungus appeared again this year showed that Abies was there also. This confirmed the observations from Europe suggesting that this fungus is an obligate mycorrhizal associate of the genus Abies. Whether $C$. fuscoperonatus is associated with all species of Abies must be determined by future research.

Soil factors can greatly influence growth and fruiting of species of Cortinarius. The Picea engelmannii/Equisetum arvense community (Steele et al. 1983) offers an interesting example involving another host. We find this in patches, for example, in several places in the south of Turpin Meadow. In some of these stands Picea pungens may dominate. Similar observations were reported by Steele et al. (1983:36). Within the $P$. engelmannii/E. arvense community Cortinarii are relatively scarce, but in the marginal zone at the periphery of the stand Cortinarii are often very abundant. This summer 11 species of the subgenus Phlegmacium were observed in one such marginal zone of a small site over two successive days. One reason for this phenomenon may be that within the spruce/horsetail stand the soil moisture is too high and soil aeration is too low, whereas in the marginal area, these factors are at more nearly optimal equilibrium. Another factor may be that the $\mathrm{pH}$ range of $6.9-7.2$, as given for such sites by Steele et al. (1983), is known to be highly favorable for many Cortinarii, particularly species of the subgenus Phlegmacium. Our measurements range from 6.8 to 7.6 .

The plant communities richest in Cortinarius species in the GYA are those of the Picea englemanii series (Steele et al. 1983) or those in which Picea is a climax codominant. About 450 of our collections came from such habitats. Picea englemannii/Linnaea borealis, $P$. engelmannii/Vaccinium scoparium, and Picea engelmannii/Arnica cordifolia habitat types seem to offer the best sites for Cortinarii. Dominant Cortinarius species in such habitats are C. laniger Fr., C. allutus Fr., C. gentilis Fr., C. adalbertii Fav. ex Mos., and C. dilutus Fr. This certainly can be due to the fact that Picea engelmannii has a wide ecological amplitude and reaches its climax in more humid sites. Also, habitats derived from calcareous parent materials with $\mathrm{pH}$ values close to neutral are particularly favorable for any Cortinarii, especially members of the subgenus Phlegmacium. Some species, such as C. orichalceus, can be regarded as typical indicators for $\mathrm{pH}$ values near neutral. 
Pine forests are in general less rich in fruiting Cortinarii. This does not necessarily mean that fewer Cortinarii are there. It may be that the optimal combination of climatic and edaphic factors favoring fruiting occurs much more rarely.

A distinction must be made between two-needle and five-needle pine associations. In other fungal genera such as Suillus, for example, there are several species that have a strong specificity for either two-needle or five-needle pines. Our knowledge of Cortinarius in this respect is still rather limited. The only five-needle pine associations from which we have collections are Pinus albicaulis communities. Inasmuch as these communities are mostly mixed with Abies lasiocarpa, $P$. engelmannii, and/or $P$. contorta in their lower parts a definite connection of Cortinarii with this pine species is not yet firmly established. Some snowbank fungi are very frequently found in such communities, and at least one Cortinarius, Cortinarius flavoroseus ined., may be specifically associated with $P$. albicaulis. One Telamonia was collected in a pure Pinus albicaulis stand on the western slopes of Mt. Washburn. Comparable forests in Europe are Pinus cembra communities. A 12-year ecological study in the Tyrolean Alps included permanent plots in pure $P$. cembra stands, but the data are not yet published. When the analyses are complete similar Cortinarius-host relationships may be apparent. In Pinus albicaulis associations mixed with other conifers mentioned above, mainly of the Naccinium scoparium and /Arnica cordifolia habitat types, with moderate coverage we encountered about 15 species of Cortinarius.

Two-needle pine forests, $P$. contorta in this area and $P$. silvestris in Europe, are often rather dry habitats with few fruiting Cortinarii. Of course their mycelia may be present. We observed a heavy fruiting of Cortinarius in such habitats only once in the course of this study. This was during the second half of August 1983. During this period a relatively large number, about 20 species each, of Phlegmacium and Telamonia were recorded. Many of them have not been seen again. Unfortunately some of the study sites have been seriously altered or destroyed by the 1988 fires, precluding the possibility of further research.

By comparison, the more humid Pinus contorta communities with a mixture of Abies, Picea, or Pseudotsuga, particularly of the Naccinium scoparium, Naccinium globulare, and /Linnaea borealis community types, proved to be much richer in species of Cortinarius. No doubt this is due directly or indirectly to moisture conditions more nearly optimal for fruiting of such agariceous fungi.

A number of forest types in the GYA show a relatively high degree of similarity to certain Scandinavian forests with regard to their fungal populations. This applies to some Pinus contorta community types as well as spruce forests and mixed pine-spruce forests. For example, Cortinarius calopus Karsten (= Cortinarius fragrans Smith) is found typically in mixed pine-spruce forests of the Pinus Naccinium scoparium community type here and the Pinus Naccinium myrtillus community type in Scandinavia. Its occurrence in these pure pine forests seems to indicate that this fungus forms mycorrhizae with twoneedle pines. Although with all our collections of this fungus Pinus was present, we still cannot exclude the possibility that it also forms mycorrhizae with Picea both in America and in Europe. I have a single record of $C$. calopus from the northern Cascades where I did not note Pinus, but it may have been overlooked. A similar situation occurs with Cortinarius microspermus Lange. Perhaps it is not surprising that subalpine forests in Europe and the GYA show a high degree of similarity. (See table 1.)

Some species of Cortinarius are found only in association with Populus. We have 16 collections from Populus tremuloides communities, e.g., Cortinarius sertipes Kühner. In the GYA Cortinarius trivialis always occurs with Populus. 
Table 1. Cortinarius species common to Europe and the GYA
Subgenus Leprocybe
C. callisteus $\mathrm{Fr}$.:Fr.
C. gentilis Fr.:Fr.
C. venetus Fr. var. montanus Mos.
C. valgus Fr.
C. zinziberatus Fr.:Fr.

\section{Subgenus Myxacium}
C. absarokensis Mos. \& McKn.
C. trivialis J. E. Lge.
C. delibutus $\mathrm{Fr}$.
C. vibratillis Fr.:Fr.
C. favrei Mos. ex Henderson
Subgenus Sericeocybe
C. diosmus Kuehn.
C. anomalus $\mathrm{Fr}$.
C. ochrophyllus Fr.

C. calopus Karst. ( $=$ C. fragrans
A. H. Smith)

Subgenus Phlegmacium

C. infractus Pers.:Fr.

C. allutus Fr.

C. aureofulvus Mos.

C. aureopulverulentus Mos.

C. multiformis (Fr.) Fr. v. conferarum Mos.

C. calochrous Fr. v. caroli (Vel.)

C. olivellus R. Hry

Mos.

C. orichalcius Fr.

C. papulosus Fr.

C. fraudulosus Britz.

C. fulvoochrascens R. Hry.

C. parvus R. Hry.

C. glaucopus $\mathrm{Fr}$.

C. turmalis $\mathrm{Fr}$.

C. herpeticus Fr.

C. varius $\mathrm{Fr}$.

Subgenus Telamonia

C. adalbertii Fav. ex Mos.

C. albonigrellus Fav.

C. armenicus Fr.

C. chrysomallus Lam.

C. dilutus $\mathrm{Fr}$.

C. duracinus Fr. ss. lato

C. erythrinus Fr. fm.

C. flexipes $\mathrm{Fr}$.

C. fulvescens Fr. ss. Fav.

C. fuscoperonatus Kuehn.

C. hemitrichus Fr. fm. impocerus Fav.
C. laetus Mos.

C. laniger $\mathrm{Fr}$.

C. miniatopus J. E. Lge.

C. obtusus Fr.

C. paleaceus Fr. var. glaber ined.

C. pauperculus Fav.

C. renidens $\mathrm{Fr}$.

C. rigidipes Mos.

C. tenebricus Fav.

C. triformis Fr.

C. uraceaus Fr.

Willow associations in the alpine zone are a special habitat for Cortinarii and a diverse assortment of other fungus genera including Hebeloma, Inocybe, Lactarius, Russula, and Amanita. Here again, Cortinarius is represented with the highest number of species among the ectomycorrhizal fungi (table 2). Many of these have circumpolar distribution both in the arctic and alpine zones. Our investigations of 
such habitats in the GYA are restricted to Mt. Washburn, the Beartooth Pass area, Two Ocean Mountain near Togwotee Pass, and Union Peak in the Windriver Mountains.

\section{Table 2. New species of Cortinarius described from the GYA}
C. absarokensis Mos. \& McKn.
C. albobrunnoides ined.
C. fuscoflexipes Mos. \& McKn.
C. aurora ined.
C. mucronatus Mos. \& McKn.
C. cephalixoides ined.
C. pseudobovinus ined.
C. elotioides ined.
C. rufoannuliferus Mos. \& McKn.
C. flavaurora ined.
C. subfoetens ined.
C. vupicolor Mos. \& McKn.

In the alpine zone we must distinguish between the associations with truly dwarf willows (e.g., Salix nivalis, S. arctica, S. cascadensis) and the more shrubby willows of several dm height (Salix phylicifolia, S. glauca, S. brachycarpa, S. farriae, etc.), which are mainly subalpine but ascend in different places rather high up in the alpine zone. We have about 90 collections from these areas. Cortinarius albonigrellus, fuscoflexipes, pauperculus, mucronatus, pusillus, subtorvus, and favrei are examples of species associated with the really dwarf willows. We have found Cortinarius absarokensis only with shrubby willows. It can be very abundant in these habitats where it may even be an indicator species. In Europe we have only one record of this species.

Other Cortinarii may occur in both types of Salix communities, e.g. Cortinarius chrysomallus, C. vulpicolor, C. obscurissimus (ined.), although they reach their optimum fruiting in the dwarf willow associations. Corresponding to their habitat, fungi of the alpine zone have only a very short fruiting period, usually during the last two weeks of August. In rare mild autumn seasons, however, some have been seen to fruit into October in the Austrian Alps.

In the course of our studies many undescribed species were found (table 2). These will be published in other reports, but one example may be cited here. Cortinarius aurora ined. is particularly interesting as it belongs to a new section of the genus and also has unusual pigment types.

A number of taxonomic problems were encountered. Only two examples will be considered here: (1) Cortinarius renidens Fries versus Gymnopilus terrestris Hesler \& A. H. Smith, and (2) Cortinarius pseudoarquatus A. H. Smith versus Cortinarius fulvoochrascens Henry.

Cortinarius renidens is recognized by European mycologists as having an hygrophanous basidiocarp with orange-brown (moist) to apricot (dry) colored pileus, a rather strongly streaked stipe, and subglobose to broadly short-ellipsoid spores. This concept agrees well with the description and plates of Elias Fries with one exception: in Fries' illustrations and in all of his descriptions he mentions a yellow cortina. Such a fungus has not been seen since Fries' report, to the best of our knowledge, suggesting that the yellow cortina may have originated in the imagination of one of Fries' illustrators. Our first collections of this species during this study came from the Falls Campground below Brooks Lake. It is very common in the Greater Yellowstone Area, and we have many collections of it, giving us ample opportunity to study fresh material in all stages of development and conditions of growth and environmental stress. It was surprising to learn that American mycologists called it Gymnopilus terrestris Hesler. Hesler described it as a new species in the genus Gymnopilus because it lacks a cortina. Critical 
study of our many collections from the GYA, from Washington, and from Europe confirm the fact that it does not have a cortina, whereas the cortina is a key character for the genus Cortinarius. On the other hand all representatives of the genus Gymnopilus are characterized by the styrylopyron pigments hispidine and bis-noryangoninge. Cortinarius renidens (including the American collections called Gymnopilus terrestris) has none of these pigments, but it does have a pigment pattern similar to that of some Cortinarii. There is no significant difference between American and European material. In macroscopic characters American specimens are slightly more variable with regard to the striations on the stipe. In our study area we often find forms with nonstriate stipe surface together with others having a striate stipe arising from the same mycelium. There is a slight but insignificant difference in microscopic characters with regard to spore lengths among different collections, but it is only a few tenths of a micrometer. This difference does not justify placing them in a different species and certainly not in different genera.

Cortinarius fulvoochrascens is a very typical fungus associated with Picea abies in European mountain and subalpine spruce forests. In the GYA we found a fungus in subalpine spruce and mixed conifer forests that agrees very well in both micro- and macroscopic characters with European species. It was especially abundant in 1987. In American literature it keys out to Cortinarius pseudoarquatus A. H. Smith. A very careful statistical analysis of spore measurement data of many American and European collections revealed three clusters that could be regarded as taxonomic varieties but not species (table 3). Again, we have observed a greater range of variability in macroscopic characters in American collections than in European collections, but we conclude that they all belong to the same species.

Table 3. Spore measurements in $\mu \mathrm{m}$ for several American and European collections of C. fulvoochrascens $\mathbf{R}$. Henry respecting C. pseudo-arquatus A. H. Smith ( $n=31$ for each collection)

\begin{tabular}{|l|c|c|c|c|c|c|c|}
\hline & Length x Width & $\mathbf{x l}$ & $\mathbf{s}$ & $\mathbf{x w}$ & $\mathbf{s}$ & $\mathbf{Q}$ & $\mathbf{V}$ \\
\hline Washington: & & & & & & & \\
Stuntz 4276 & $12.0-15.3 \times 7.0-8.3$ & 13.7 & 0.80 & 7.8 & 0.33 & 1.8 & 436 \\
Smith 1714 & $12.6-14.7 \times 7.0-8.6$ & 13.9 & 0.57 & 7.7 & 0.35 & 1.8 & 430 \\
Stuntz 4205 & $12.7-14.7 \times 7.0-8.3$ & 13.3 & 0.46 & 7.8 & 0.28 & 1.7 & 412 \\
Ammirati 9568 & $11.7-16.0 \times 6.5-8.0$ & 13.0 & 0.90 & 7.3 & 0.40 & 1.8 & 366 \\
Ammirati 9556 & $11.7-16.7 \times 6.7-8.0$ & 13.4 & 1.14 & 7.1 & 0.41 & 1.9 & 353 \\
Stuntz 3332 & $11.0-14.0 \times 6.7-8.0$ & 12.7 & 0.85 & 7.1 & 0.42 & 1.8 & 337 \\
Wyoming: & & & & & & & \\
GYA 87/344 & $11.7-14.0 \times 7.3-8.1$ & 13.0 & 0.67 & 7.6 & 0.27 & 1.7 & 389 \\
GYA 87/218 & $11.3-14.0 \times 6.7-8.3$ & 12.5 & 0.84 & 7.6 & 0.42 & 1.6 & 383 \\
GYA 87/266 & $11.3-13.0 \times 7.0-8.0$ & 12.2 & 0.41 & 7.4 & 0.18 & 1.7 & 348 \\
Europe: & \multicolumn{1}{|l}{} & & & & & & \\
Tyrol 57/98 & $12.0-14.7 \times 6.7-8.0$ & 12.7 & 0.72 & 7.5 & 0.40 & 1.7 & 375 \\
\hline
\end{tabular}

${ }^{1}$ holotype of C. pseudo-arquatus

$\mathrm{xl}=$ mean length

$\mathrm{s}=$ standard deviation
$\mathrm{xW}=$ mean width

$Q=$ length/width ratio

$\mathrm{V}=$ volume 
The name C. fulvoochrascens has two years' priority over C. pseudoarquatus. There is also a much older name, $C$. riederi Weinmann, which is regarded by $\mathrm{J}$. Melot as belonging to this same species. However, the original diagnosis of Weinmann is rather short and ambiguous, shedding doubt on the correct interpretation of many characters. We will deal with these and numerous other taxonomic problems in greater detail in a later publication.

\section{Literature Cited}

Lei, J., K.K.Y. Wong, and Y. Piche. 1991. Extra cellular Concanavallin-A binding sites during early interactions between Pinus banksiana and two closely related genotypes of the ectomycorrhizal basidiomycete Laccaria bicolor. Mycological Research 95(3):357-363.

Moser, M. 1960. Die Gattung Phlegmacium. In Die Pilze Mitteleuropas Vol. V. Verlag Julius Klinkhardt, Bad Heilbrunn. 440pp. 34 col. pl.

Moser, M. and Kent H. McKnight. 1987. Fungi (Agaricales, Russulales) from the alpine zone of Yellowstone National Park and the Beartooth Mountains with special emphasis on Cortinarius. Pages 299-317 in Arctic and Alpine Mycology II. Plenum, New York.

Steele, R., St. V. Cooper, D.M. Ondov, C.W. Roberts, and R.D. Pfister. 1983. Forest habitat types of Eastern Idaho-Western Wyoming. Intermountain Forest and Range Experiment Station Gen. Tech. Rep. INT-144. U.S. Department of Agriculture, Forest Service, Ogden, Utah. 122pp. 


\title{
The Effects of the 1988 Wildfires on Diatom Assemblages in Streams of Yellowstone National Park
}

\author{
Christopher T. Robinson \\ Stream Ecology Center \\ Department of Biological Sciences, Idaho State University \\ Pocatello, ID 83209 \\ G. Wayne Minshall \\ Stream Ecology Center \\ Department of Biological Sciences, Idaho State University \\ Pocatello, ID 83209 \\ Samuel R. Rushforth \\ Department of Botany and Range Science \\ Brigham Young University \\ Provo, UT 84602
}

\begin{abstract}
The Yellowstone wildfires of 1988 provided the unique opportunity to examine recovery processes of aquatic systems following disturbance. A survey of 14 stream systems was conducted in late summer over the four years (1988 - 1991) following the wildfires. A number of physical measures were recorded in order to group sites by disturbance intensity using principal components analysis. Disturbed sites were associated with percent of catchment burned and amount of channel change over time. Streams of similar size were grouped by disturbance intensity (high or low); and the diatom assemblages were analyzed among years in terms of species richness, Simpson's Dominance Index, and Shannon's Diversity $\left(\mathrm{H}^{\prime}\right)$. Species richness decreased in small high-disturbance streams, diversity increased in small low-disturbance streams, and assemblages exhibited no change in large high-or low-disturbance streams for two years following the wildfires. The diversity of diatoms decreased in all streams in 1991. Principal components analysis based on the 20 most important diatom taxa was effective in showing temporal patterns in diatom assemblages and reflected the degree of disturbance at a site. These data suggest that the impact of wildfire on diatom assemblages was a function of stream size and channel morphology. Diatom assemblages of small streams (first and second order) were affected more by wildfire than assemblages of larger thirdand fourth-order streams.
\end{abstract}




\section{Introduction}

The wildfires of 1988 in Yellowstone National Park provided a unique opportunity to examine streamrecovery dynamics following a large-scale physical disturbance event. Fire influences stream structure and function by altering stream temperatures, flow regime, riparian vegetation, nutrient fluxes, sediment inputs, physical habitat, and canopy coverage (Minshall et al. 1989; Minshall, Brock, and Varley 1989; Minshall, Robinson, and Lawrence 1991; Spencer and Hauer 1991). Further, these effects should be dependent on stream size, morphology, and site characteristics (Minshall et al. 1989; Minshall and Brock 1992). Despite the dramatic changes that occur in streams following wildfire, little work has been completed to document these changes (Minshall, Brock, and Varley 1989), and no data exist to date on the effects of wildfire on lotic algal assemblages.

Diatoms are a ubiquitous component of lotic algal communities, have a diverse array of growth forms, and are sensitive to physical and chemical perturbations (Gregory 1983; Patrick 1977; Robinson and Rushforth 1987; Rushforth, Squires, and Cushing 1986; Stevenson and Lowe 1986). Consequently, diatoms are important study organisms for the examination of disturbance on streams. For example, various researchers have documented temporal changes in algal assemblages following the Mt. St. Helens eruption of 1980 (Rushforth, Squires, and Cushing 1986; Steinman and Lamberti 1988) and have noted variability in recovery sequences among streams caused by the disturbance intensity experienced. The wildfires of 1988 also affected streams to varying intensities. The present study examined diatom assemblages in streams that differ in respect to size and disturbance intensity. Our primary objective was to relate changes in diatom community structure to changes in stream physical characteristics resulting from the 1988 wildfires.

\section{Methods}

The 14 sites surveyed were located in the Blacktail Deer Creek, Cache Creek, Fairy Creek, Hellroaring Creek, Iron Springs Creek, Pebble Creek, and Rose Creek catchments (table 1). All stream sites are within Yellowstone National Park except for the Hellroaring Creek site, which is north of the park. Streams sampled ranged from first to fourth order in size and, based on park geographic information system (GIS) burn maps, from 0 percent to 92 percent of the catchment burned. Minshall, Robinson, and Lawrence (1991) provide exact location and physical and chemical descriptions for the streams sampled.

Physical characteristics used for the present analyses included stream order, catchment area, stream width, discharge, slope, percent catchment burned, and amount of channel change. Catchment area was determined from GIS maps (see Lawrence and Minshall, this volume, for details). The amount of channel change was determined from five permanent transects located at each site. Transects were placed about $50 \mathrm{~m}$ apart along the stream. Channel cross-sections (profiles) were measured each year at these transects and the amount of channel change (in square meters) averaged from the transects over the four years of study.

Diatom samples were collected from each stream site in early October 1988 and in August 1989, 1990, and 1991. The October 1988 samples were collected within two weeks to one month following the fires. Composite diatom samples were collected from stone substrates comprising riffle, run, and pool habitats at each site, preserved with 5 percent formalin, and returned to the laboratory. The composite sample was boiled in concentrated nitric acid, rinsed, mounted in Naphrax mountant, and examined under 1000X 
Table 1. List of physical measures to characterize study sites

\begin{tabular}{|l|c|c|c|c|c|c|c|}
\hline \multicolumn{1}{|c|}{ Stream } & Number & Order & $\begin{array}{c}\text { Catchment } \\
\text { Area }\left(\mathbf{h a}^{2}\right)\end{array}$ & $\begin{array}{c}\text { Dlscharge } \\
\left(\mathbf{m}^{\mathbf{3}} \mathbf{s}\right)\end{array}$ & $\begin{array}{c}\text { \% Catchment } \\
\text { Slope }\end{array}$ & $\begin{array}{c}\text { Channel } \\
\text { Change }\left(\mathbf{m}^{2}\right)\end{array}$ \\
\hline EF Blacktail & 1 & 1 & 1,281 & .031 & 2 & 92 & 2.11 \\
Cache & 2 & 1 & 138 & .001 & 13 & 64 & 1.03 \\
Twin & 3 & 1 & 1,020 & .076 & 11 & 68 & 1.68 \\
Cache & 4 & 2 & 377 & .004 & 10 & 71 & 2.60 \\
Fairy & 5 & 2 & 1,199 & .092 & 0 & 81 & 0.48 \\
Iron Springs & 6 & 2 & 615 & .065 & 14 & 5 & 0.76 \\
Blacktail & 7 & 2 & 3,297 & .098 & 4 & 88 & 2.43 \\
Cache & 8 & 3 & 12,052 & .184 & 2 & 68 & 10.30 \\
Iron Springs & 9 & 3 & 1,838 & .656 & 1 & 39 & 0.55 \\
SF Cache & 10 & 3 & 5,780 & .028 & 3 & 39 & 2.79 \\
Cache & 11 & 4 & 17,994 & .336 & 2 & 59 & 1.88 \\
Hellroaring & 12 & 4 & 6,639 & .067 & 2 & 46 & 0 \\
Rose & 13 & 2 & 2,390 & .009 & 8 & .92 & 0.60 \\
Pebble & 14 & 3 & 5,888 & .224 & 3 & 17 & 0.54 \\
\hline
\end{tabular}

oil immersion using a Zeis RA microscope with Nomarski optics (St. Clair and Rushforth 1976). Counts of 300 - 500 diatom frustules were made from each slide to determine relative density.

Principal components analysis (PCA) was used to indicate the intensity of disturbance experienced by each stream, based on the physical measures using the Statistica software package (Statsoft 1991). The scattergram generated from the PCA results provided information on the degree of temporal change and physical disturbance at each site. Based on the PCA scattergram, sites were grouped by size (first and second order, or third and fourth order) and by disturbance intensity (high or low) for diatom community analysis.

The diatom assemblages were analyzed in terms of species richness, Simpson's Index, and Shannon's Diversity $\left(H^{\prime}\right)$ using relative abundance data for each site and year. These indices were analyzed based on the groups designated above. Differences among years, within each group, were tested using analysis of variance on $\log (x+1)$ or arcsine (square-root) transformed data (Zar 1984). Data are expressed as nontransformed means.

In addition, year-to-year changes in diatom assemblages were examined for each site using PCA based on the 20 most abundant and frequent taxa. These taxa generally comprised at least 5 percent of the assemblage. Further, the range in maximum and minimum PCA factor scores from the four years of diatom data were used to determine the degree of temporal change experienced by each site. This value was regressed against the amount of channel change at a site in order to relate the degree of biotic change to physical change. 


\section{Results}

Principal components analysis using the physical measures explained 96 percent of the variation (two factors) among sites. Factor-1 was highly loaded with measures of stream size, and clearly separated sites by size (figure 1). Factor-2 was highly loaded with measures of percent catchment burned and amount of channel change. In addition, the amount of channel change was weakly associated with percent catchment burned, with outliers best explained by slope. For example, low-gradient streams (i.e., Fairy Creek and $3^{\circ}$ Iron Springs Creek) with a high percent of the catchment burned typically had low values for amount of channel change (table 1 and figure 1). In general, small streams tended to experience a higher degree of disturbance than the larger streams, as evidenced by the more negative loadings along Factor-2, except for $3^{\circ}$ Cache Creek (stream no. 8).

Sites were grouped according to size and disturbance intensity from the PCA scattergram and the relationship between percent catchment burned and amount of channel change. Groupings consisted of four first-and second-order high-disturbance streams (Twin, Cache $2^{\circ}$, EF Blacktail, and main Blacktail Creeks), four first- and second-order low-disturbance streams (Iron Springs, Cache $1^{\circ}$, Rose, and Fairy Creeks), three third- and fourth-order high-disturbance streams (SF Cache, Hellroaring, and Cache $3^{\circ}$ Creeks), and three third- and fourth-order low-disturbance streams (Iron Springs, Pebble, and Cache $4^{\circ}$ Creeks). These groupings allowed for a general among-group comparison of diatom species richness, Simpson's Index, and Shannon's Diversity Index.

Species richness decreased from 33 in 1988 to 24 taxa in the years following 1988 in small highdisturbance streams $(p=0.11$ ) (figure 2). The 1988 values should be expected to be close to prefire values. No significant changes occurred in species richness among years for the other stream groups analyzed. The relatively high variance found in small low-disturbance streams is a result of the extemely high richness of diatoms in Fairy Creek (c. 80 taxa identified), an open-canopy and thermally enriched stream. Diatom richness tended to decrease in 1991 in large low- or high-disturbance streams. In addition, there tended to be a greater number of taxa in low-disturbance streams (mean $=37$ taxa) than in high-disturbance streams (mean $=27$ taxa).

Simpson's Index increased from 17 to 27 in the years following the 1988 wildfires in small highdisturbance streams, although not statistically significant (figure 2). In contrast, this index decreased in 1989 and 1990 then returned to 1988 values in 1991 in small low-disturbance streams. Simpson's Index remained unchanged in large high- and low-disturbance streams. Shannon's Diversity $\left(\mathrm{H}^{\prime}\right)$ significantly decreased, as with species richness, following 1988 values in small high-disturbance streams $(p=0.04)$ (figure 2). Diversity decreased for all stream groups in 1991, a trend similarly exhibited in speciesrichness values for large streams.

Principal components analysis (PCA) was performed on the diatom assemblages based on the 20 most important taxa (figure 3). Taxa loadings and respective scores of Factor-1 consisted of Navicula cryptocephala var. veneta (NACV; -0.849), Nitzschia dissipata (NIDI; -0.755), Nitzschia hantzschiana (NIHA; -0.740), and Synedra ulna (SYUL; -0.672). Components of Factor-2 were composed of Nitzschia minutula (NIMI; 0.891), Navicula permitus (NAPR; 0.777), and Navicula arvensis (NAAR; 0.528). These two axes explained 51 percent of the variation observed. In general, the more disturbed sites had greater changes in the diatom assemblage among years than the less disturbed sites, according to the PCA results. Here, a change in species composition is related directly to a change in graph space. For example, a greater distance between data points in graph space indicates more change in species composition than a lesser distance between data points. These results reflect the PCA findings based 

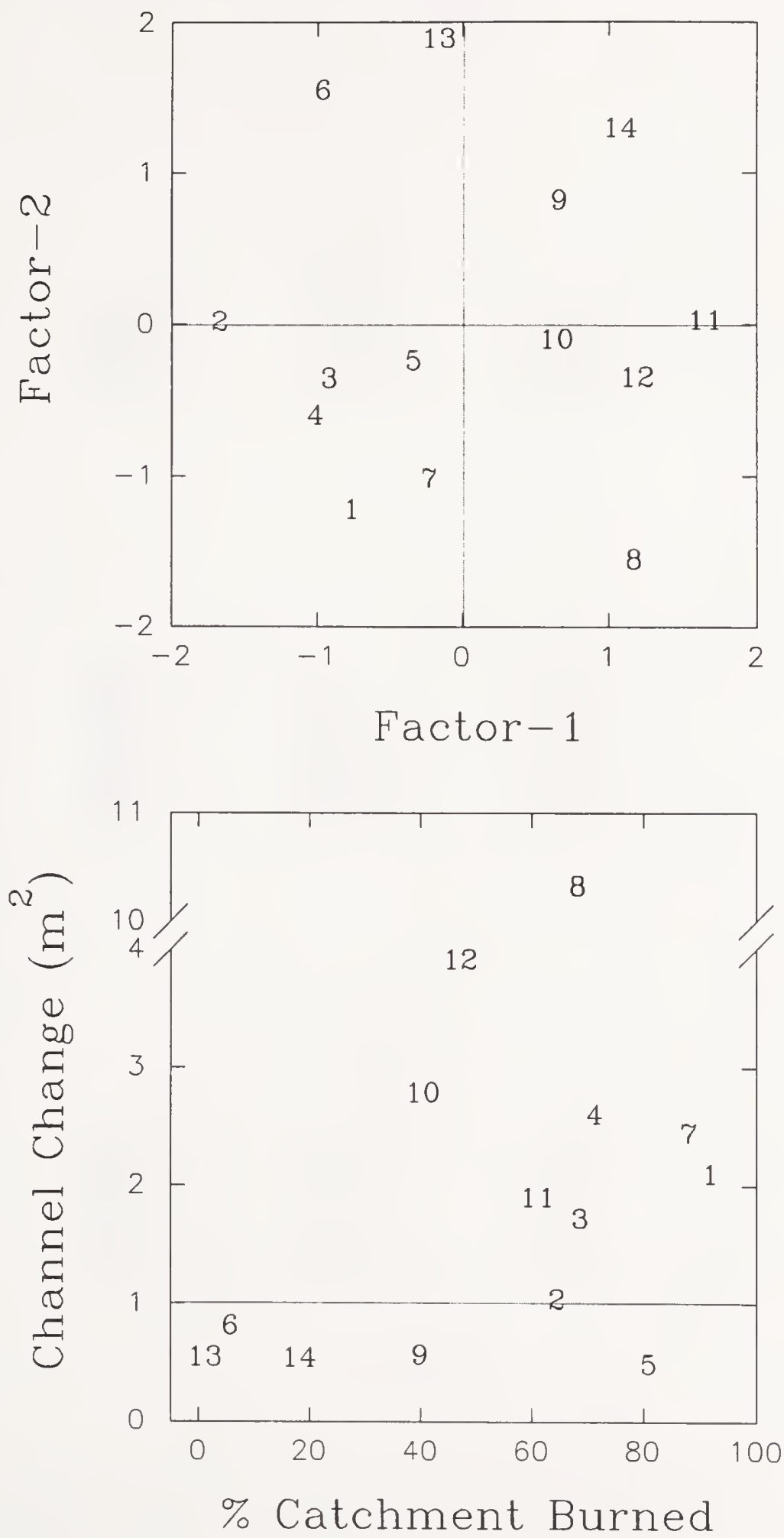

Figure 1. Principal components analysis scattergram for the 14 study streams, and scattergram of percent catchment burned against amount of channel change. Loadings for Factor-1 of the PCA included stream order (0.92), catchment area (0.89), stream width (0.95), discharge (0.87), and slope (-0.78); loadings for Factor-2 included percent of catchment burned $(-0.91)$ and amount of channel change $(-0.75)$. Numbers represent individual streams from table 1. 

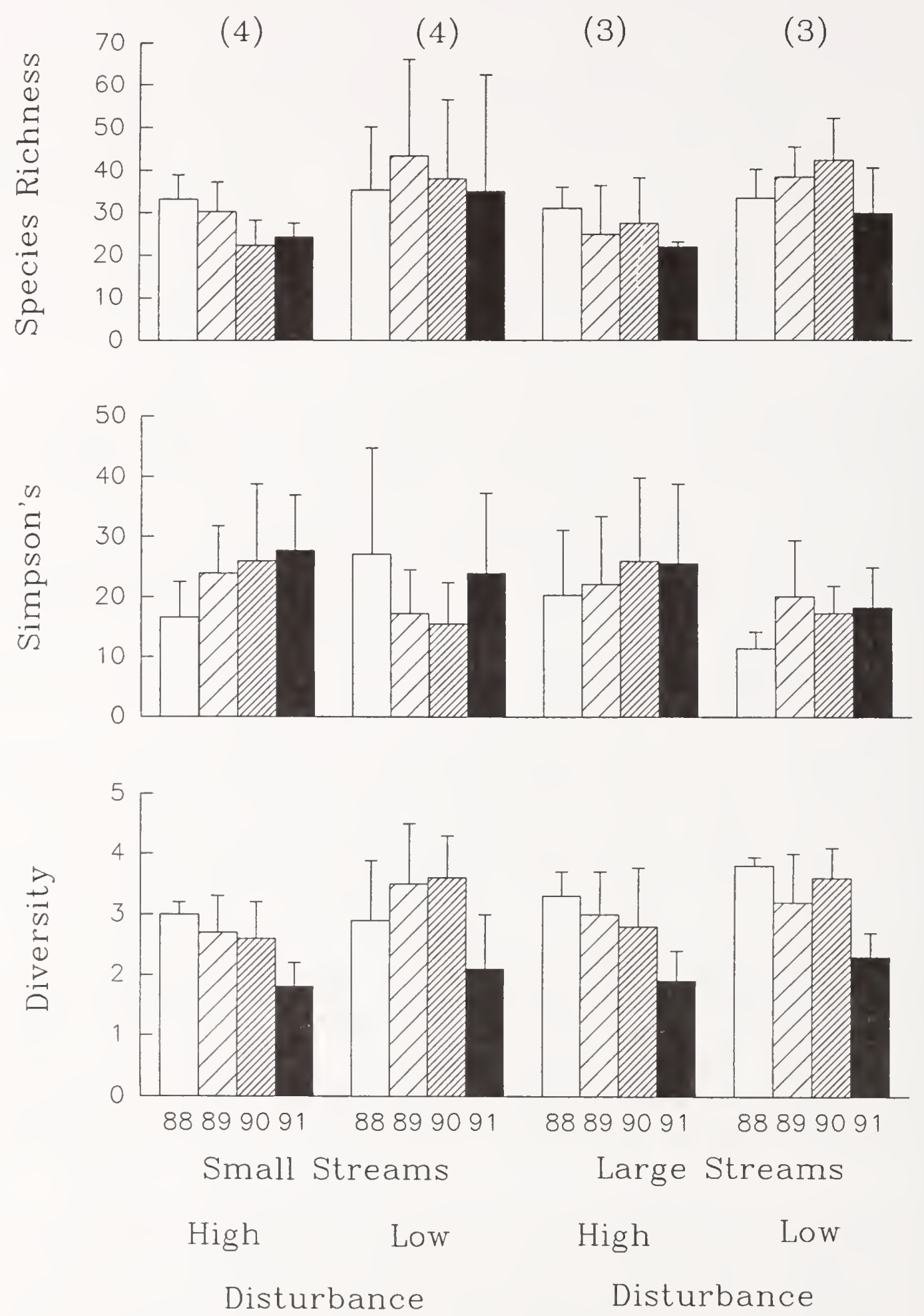

Figure 2. Bar graph summarizing temporal patterns in diatom species richness, Simpson's Index, and Shannon's Diversity for small and large streams and grouped as being either high- or low-disturbance systems. Bars represent +1 standard deviation, and numbers in parentheses equal number of streams in each group. 
1st Order

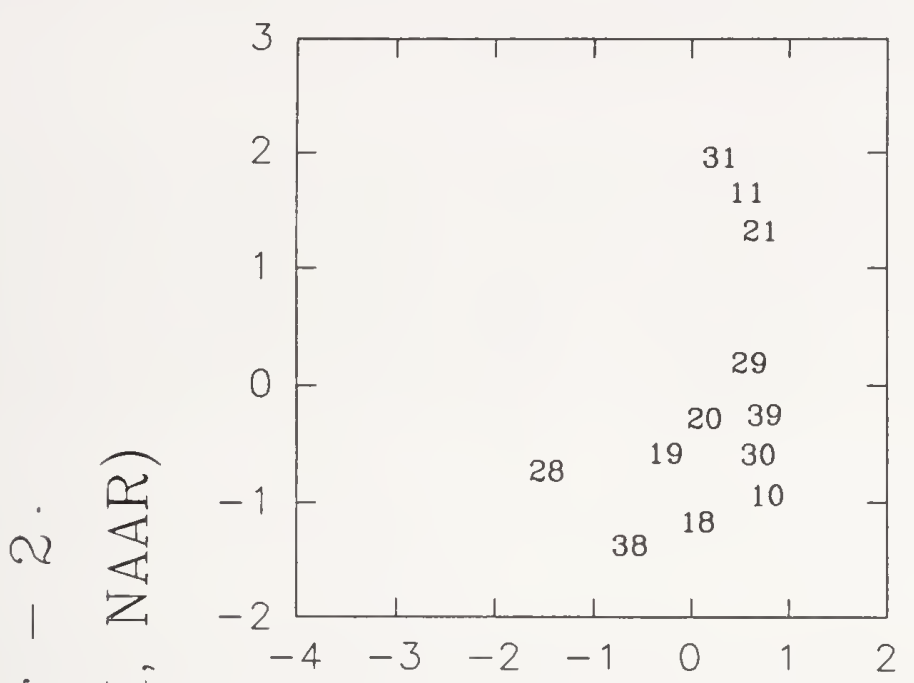

3rd Order

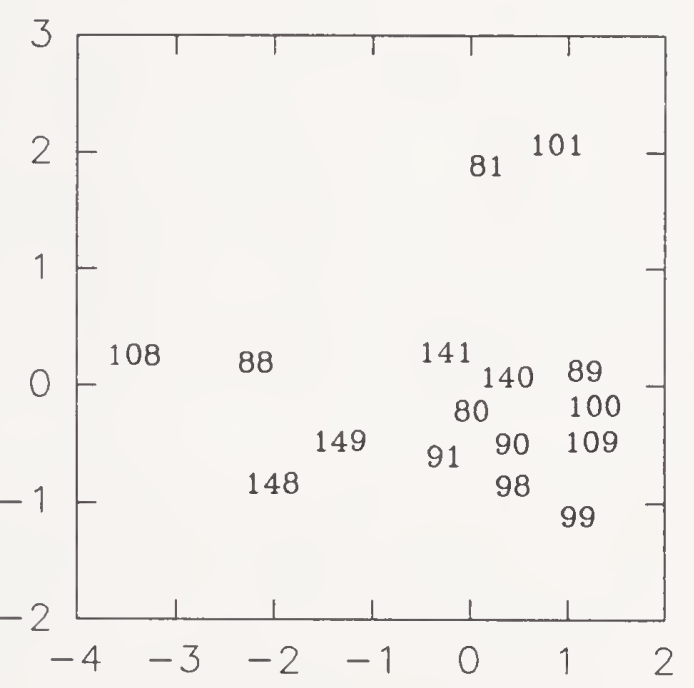

2nd Order

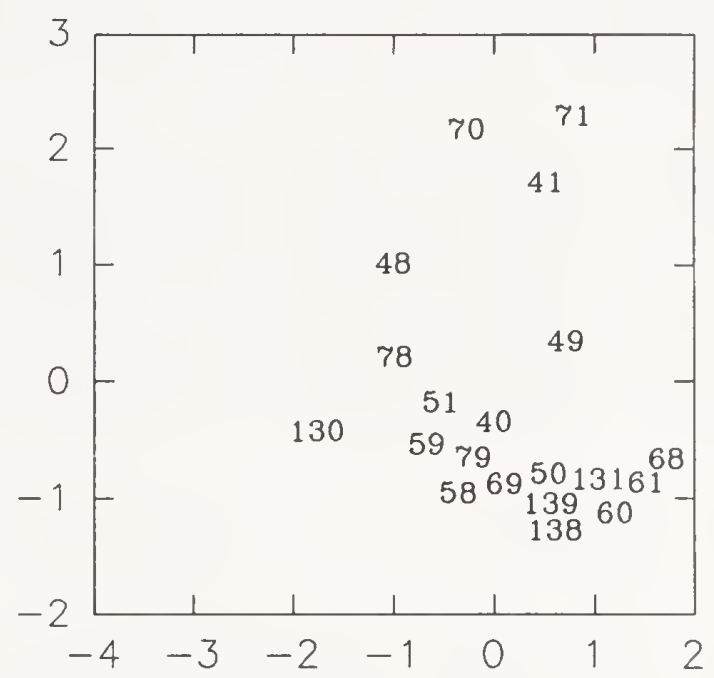

4th order

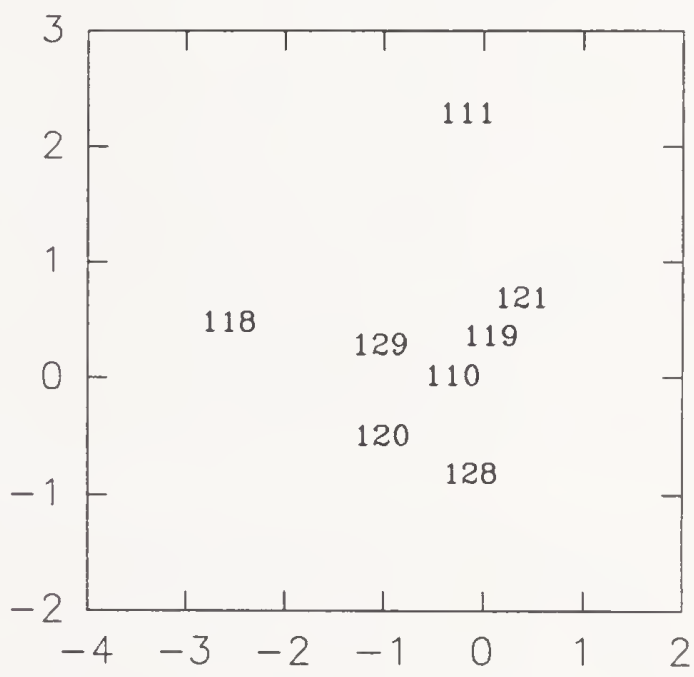

(NACV, NIDI, NIHA, SYUL)

Factor - 1

Figure 3. Principal components analysis scattergram for study streams using the top 20 diatom taxa. Streams separated by order for clarity of presentation. First number for each data point represents stream number from table 1; last number indicates year of study. For example, a 31 represents stream 3 (Twin Creek) for year 1991; 130 represents stream 13 (Rose Creek) for year 1990. Diatom notations and respective factor scores are found in the text. 
on the physical measures. For example, Cache Creek (stream 2) and main Blacktail Creek (stream 7) represent high-disturbance sites with substantial change occurring in species composition among years (figure 3), whereas Fairy Creek (stream 5) and Iron Springs Creek (stream 9) represent low-disturbance sites with little change occurring in species composition among years.

We regressed species composition change (i.e., the range in factor scores among years) against the amount of channel change measured at a site for small streams and large streams (figure 4). Small streams showed a significant positive regression of species composition change against channel change $\left(r^{2}=.46\right)$, suggesting more disturbed sites had greater changes in diatom assemblage structure than less disturbed sites. Large streams showed a nonsignificant positive relationship $\left(r^{2}=.14\right)$ for this analysis, suggesting that fire has less influence on larger stream systems than on small streams.

\section{Discussion}

Large-scale physical disturbances to aquatic systems range from volcanic eruptions (Rushforth, Squires, and Cushing 1986), and flood events (Fisher et al. 1982) to wildfire (Minshall et al. 1989; Minshall, Brock, and Varley 1989), with recovery dynamics varying temporally among streams. These studies all indicate that some streams are more prone to disturbance owing to size, catchment geomorphology, and general site characteristics than other streams. For example, Steinman and Lamberti (1988) attribute the differences observed among streams impacted by the Mt. St. Helens eruption to the intensity of disturbance experienced. Rushforth, Squires, and Cushing (1986) found spring sites to be less prone to disturbance than other lotic habitats. In the present study, resistance of algal assemblages in springlike habitats (e.g., Fairy Creek) was greater than in more disturbed sites (e.g., Cache Creek), from which much of the algae may have been removed. However, streams affected by wildfire may not be denuded of algae to the extent that they would be from a volcanic eruption, and thus recovery of algal assemblages may be more rapid in the former.

Our data suggest that some streams experienced a higher intensity of disturbance than other streams. The more disturbed systems experienced decreases in species richness and diversity and a predominance of few taxa. Further, PCA and regression analysis showed that these more disturbed systems displayed major changes in algal community structure over the period of study. In contrast, the less disturbed streams displayed little change in diatom community structure. In general, the more disturbed streams - e.g., Cache Creek sites - had greater channel slopes and were more prone to greater peak runoff events and thus to greater scouring. The Fairy Creek site, although extensively burned (81 percent), showed essentially no change and has a low gradient (table 1). Further, the Fairy Creek site is located in a meadow and is less prone to peak runoff events. This difference in response suggests that the frequency and intensity of small-scale disturbance events are enhanced in less resistant streams following a large-scale disturbance event. Consequently, less resistant systems take longer to recover than more resistant systems because of the interplay between large- and small-scale disturbance events.

It is interesting to note that the less disturbed first- and second-order streams displayed increases, although nonsignificant, in species richness and Shannon's diversity the first year following the fire. This fact suggests that other environmental factors, such as light conditions or nutrient levels, were enhanced or more optimal immediately following the fire. Both light and nutrient availability are important factors controlling algal assemblages in streams (Gregory 1983; Steinman et al. 1991; Towns 1981). In addition, Spencer and Hauer (1991) noted dramatic increases in phosphorus and nitrogen loadings in streams 


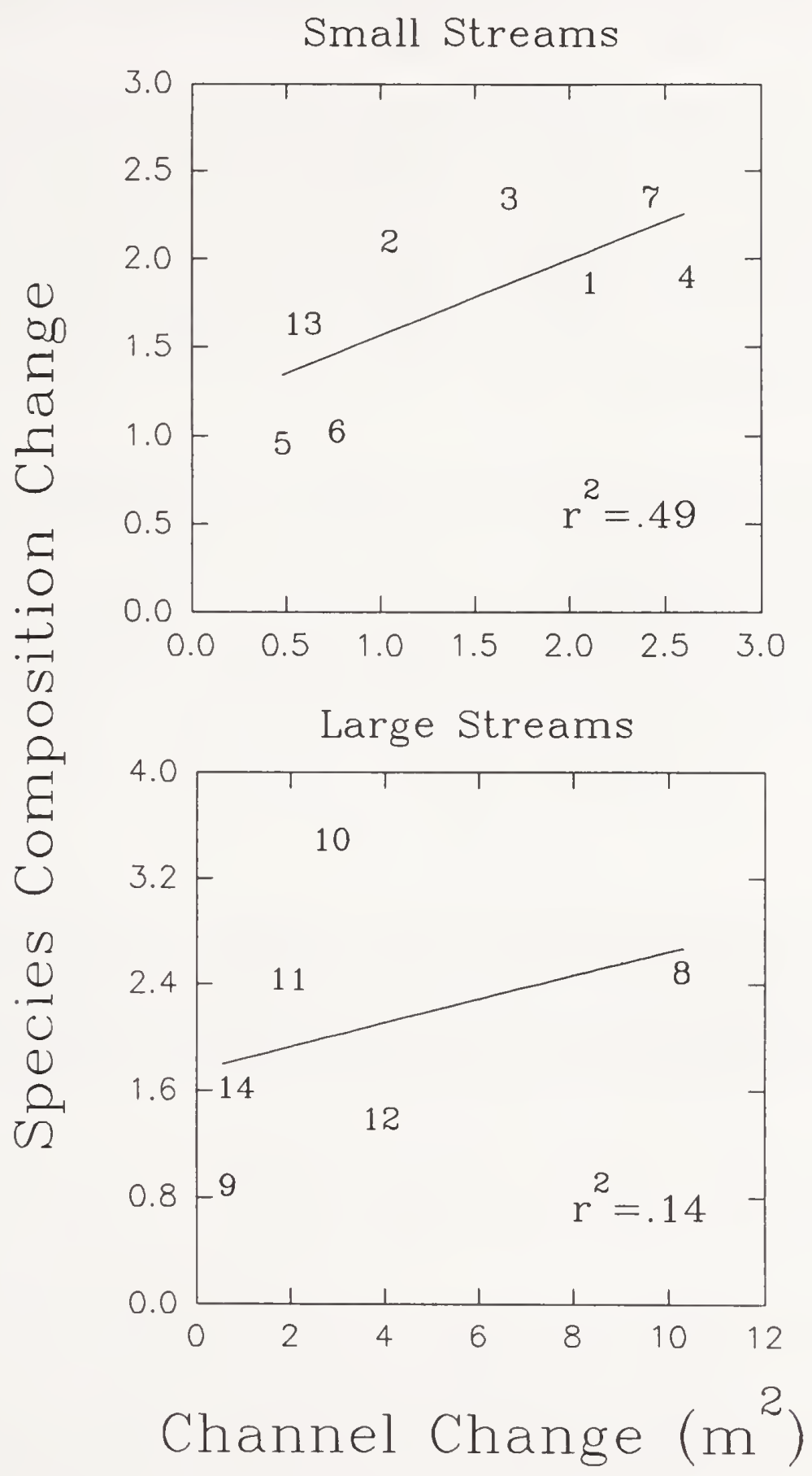

Figure 4. Separate regression scatterplots of amount of channel change against change in diatom species composition for small streams and large streams. Numbers represent individual streams from table 1. 
during a wildfire. Further, Minshall, Brock, and Varley (1989) suggest that nutrient levels are increased over prefire levels for about five years following wildfire.

Principal components analysis provided a useful tool for examining the temporal changes that occurred at each site. It also allowed for greater explanatory insight. For example, PCA indicated that fire effects differed among stream sizes and among streams of similar size. Although taxon-specific autecologies were not addressed in this paper, PCA indicated a reduction in loadings of Factor-1 (i.e., Navicula cryptocephala var. veneta, Nitzschia dissipata, Nitzschia hantzschiana, and Synedra ulna), with an increase in loadings of Factor-2 (i.e., Nitzschia minutula, Navicula arvensis, and Navicula permitus). N. permitus typically predominates systems that have been disturbed (Rushforth, Squires, and Cushing 1986; Rushforth, personal observation).

In summary, little work has been completed on the effects of major physical-disturbance events such as wildfire on streams and, specifically, on algal assemblages. The results of this study suggest that the effects of wildfire on lotic algal assemblages are variable but predictable. The resistance of streams to large-scale disturbance is a function of stream size and channel morphology. Algal assemblages in lowdisturbance streams may actually be enhanced through changes in light and nutrient levels following fire. In low-resistant streams, large-scale physical disturbance may increase the frequency and intensity of small-scale disturbance events and consequently prolong recovery processes.

\section{Acknowledgments}

This work could not have been completed without the cooperation of numerous individuals from the Stream Ecology Center of Idaho State University and the U.S. Fish and Wildife Service. Partial funding was provided through a National Park Service Grant, a Graduate Student Research Grant from Idaho State University, and the Department of Botany and Range Sciences, Brigham Young University. The manuscript was improved through comments from two anonymous reviewers.

\section{Literature Cited}

Fisher, S.G., L.J. Gray, N.B. Grimm, and D.B. Busch. 1982. Temporal succession in a desert stream ecosystem. Ecological Monographs 52:93-110.

Gregory, S.V. 1983. Plant-herbivore interactions in stream systems. Pages 157-190, in J.R. Barnes and G.W. Minshall, editors, Stream Ecology: Application and Testing of General Ecological Theory. Plenum Press, New York.

Minshall, G.W., D.A. Andrews, J.T. Brock, C.T. Robinson, and D.E. Lawrence. 1989. Changes in wild trout habitat following forest fire. Pages 111-119 in Proceedings: Wild Trout IV: Yellowstone National Park Symposium.

Minshall, G.W. and J.T. Brock. 1992. Observed and anticipated effects of forest fire on Yellowstone stream ecosystems. Pages 123-135, in R.B. Keiter and M.S. Boyce, editors, The Greater Yellowstone Ecosystem: redefining America's wilderness heritage. Yale University Press. 
Minshall, G.W., J.T. Brock, and J.D. Varley. 1989. Wildfires and Yellowstone's stream ecosystems. Bioscience 39:707-715.

Minshall, G.W., C.T. Robinson, and D.E. Lawrence. 1991. Effects of 1988 Fires on Aquatic Systems of Yellowstone National Park - 1990: Annual Report. National Park Service, Mammoth, Wyoming. 92pp.

Patrick, R. 1977. Ecology of freshwater diatoms - diatom communities. Pages 234-332, in D. Werner, editor, The Biology of Diatoms. Botanical Monographs 13, University of California Press, Davis.

Robinson, C.T. and S.R. Rushforth. 1987. Effects of physical disturbance and canopy cover on attached diatom community structure in an Idaho stream. Hydrobiologia 154:49-59.

Rushforth, S.R., L.E. Squires, and C.E. Cushing. 1986. Algal communities of springs and streams in the Mt. St. Helens region, Washington, U.S.A. following the May 1980 eruption. Journal of Phycology 22:129-137.

St. Clair, L.L. and S.R. Rushforth. 1976. The diatom flora of the Goshen Warm Spring Ponds and Wet Meadows, Goshen, Utah, U.S.A. Nova Hedwigia 28:353-425.

Spencer, C.N. and F.R. Hauer. 1991. Phosphorus and nitrogen dynamics in streams during a wildfire. Journal of the North American Benthological Society 10:24-30.

Statsoft. 1991. CSS: Statistica. Statsoft, Inc. Tulsa, Oklahoma.

Steinman, A.D. and G.A. Lamberti. 1988. Lotic algal communities in the Mt. St. Helens region six years following the eruption. Journal of Phycology 24:482-489.

Steinman, A.D., P.J. Mulholland, A.V. Palumbo, T.F. Flum, and D.L. DeAngelis. 1991. Resilience of lotic ecosystems to a light-elimination disturbance. Ecology 72:1299-1313.

Stevenson, R.J. and R.L. Lowe. 1986. Sampling and interpretation of algal patterns for water quality assessment. Pages 118-149 in B.G. Isom, editor, Rationale for sampling and interpretation of ecological data in the assessment of freshwater ecosystems. ASTM STP 894. American Society for Testing and Materials, Philadelphia.

Towns, D.R. 1981. Effects of artificial shading on periphyton and invertebrates in a New Zealand stream. New Zealand Journal of Marine and Freshwater Research 15:185-192.

Zar, J.H. 1984. Biostatistical Analysis, 2nd ed. Prentice-Hall, Englewood Cliffs, New Jersey. 718pp. 



\title{
Interactions Between Fire-injured Trees and Insects in the Greater Yellowstone Area
}

\author{
Kevin C. Ryan \\ Intermountain Research Station \\ U.S. Department of Agriculture, Forest Service \\ Intermountain Fire Sciences Laboratory \\ P.O. Box 8089 \\ Missoula, MT 59807 \\ Gene D. Amman \\ Intermountain Research Station \\ U.S. Department of Agriculture, Forest Service \\ Ogden Forestry Sciences Laboratory \\ 507 25th Street \\ Ogden, UT 84401
}

\begin{abstract}
After the 1988 Greater Yellowstone Area (GYA) fires, 24 permanent plots were established at 6 sites within 4 different burned areas. The purpose was to evaluate the effects of fire injury on susceptibility to insect attack and tree survival. Mensuration, fire injury, and insect attack data were collected on four species of burned conifers. By July 199176 percent of the 125 Douglas-fir had been infested by bark beetles (primarily by the Douglas-fir beetle) and wood borers; 58 percent of the 151 lodgepole pine were infested (primarily by the pine engraver); 82 percent of the 17 Engelmann spruce were infested (primarily by the spruce beetle); and 88 percent of the 17 subalpine fir were infested (primarily by wood borers). Fire injury combined with subsequent insect attack resulted in death to 55 percent of the Douglas-fir, 69 percent of the lodgepole pine, 82 percent of the Engelmann spruce, and all of the subalpine fir.
\end{abstract}

Mountain pine beetles have not been attracted to fire-injured lodgepole pine nor do such trees appear susceptible to a significant buildup of this insect. However, pine engraver beetles are attacking girdled and partially girdled lodgepole pine. Mortality of Douglas-fir is associated with a significant buildup of Douglas-fir bark beetles. The data, while not conclusive, suggest that insect populations are increasing in fire-injured trees and spreading to nearby uninjured trees, particularly in Douglas-fir.

These data were used as an independent test of a tree mortality model developed from data previously collected following prescribed fires. The model accurately predicted the death of Engelmann spruce and subalpine fir, but predicted mortality was too low for Douglas-fir and too high for lodgepole pine. Model failures can be partially explained by 
differences in the fire behavior experienced by trees in the two data sets, but interpretations are confounded by insect interactions.

\section{Introduction}

The type and degree of fire injury, tree vigor, and the postfire environment determine conifer survival after fire. Heat-caused injury to the canopy is the most common source of tree death (Peterson 1985; Peterson and Arbaugh 1986, 1989; Ryan 1990; Ryan, Peterson, and Reinhardt 1988), but injuries to bole cambium and roots may be more important in some cases (Ferguson, Gibbs, and Thatcher 1960; Ryan and Frandsen 1991; Ryan, Peterson, and Reinhardt 1988; Ryan and Reinhardt 1988; Swezy and Agee 1991). Mortality resulting from excessive crown injury normally occurs during the first two growing seasons following fire, while death resulting from bole and root injury often does not occur for two or more growing seasons (Ferguson, Gibbs, and Thatcher 1960; Ryan and Frandsen 1991; Ryan, Peterson, and Reinhardt 1988). Vigorous trees are more likely to survive moderate fire injuries than stressed, slow growing trees (Ryan 1990).

Based on data collected on 2,356 trees burned in 43 prescribed fires, Ryan and Reinhardt (1988) developed a logistic regression model to predict mortality of fire-injured conifers in the Northwestern United States. The model is contained in the BEHAVE fire behavior program (Andrews and Chase 1989) and is used by managers to predict and control mortality from prescribed fires. Following recent wildfires, managers also used the equation to predict mortality along travel corridors and in burned commercial forests. However, its use following wildfires has not been tested with independent data.

After publication the mortality model in Ryan and Reinhardt (1988) was reformulated by changing the functional form for including the effect of increasing bark thickness. The current equation fits the data as well and is more robust for management application. The model as it is currently formulated is

$$
P_{m}=1 /\left\{1+e^{[-1.941+(\text { bark factor }+ \text { crown factor })}\right\}
$$

where: $P_{m}=$ the probability of mortality $(0$ to 1.0$)$;

bark factor $=6.316\left[1-\mathrm{e}^{(-0.3937 \mathrm{BI})}\right], \mathrm{BT}$ is bark thickness $(\mathrm{cm})$;

crown factor $=-0.000535 \mathrm{CSC}^{2}, \mathrm{CSC}$ is crown volume scorched $(\%)$

Logistic models such as equation (1) can be used either to estimate the likelihood that an individual tree will die or to estimate the proportion of a similar population that can be expected to die (Ryan, Peterson, and Reinhardt 1988).

Insects are an important aspect of the postfire environment that affects tree survival. But because it is difficult to assess fire injuries to bole and roots adequately, it is often unclear whether insects are attacking mortally injured trees or are themselves a primary source of death. In the absence of significant bole or root injuries, the probability of attack by primary bark beetles, those that can infest and kill healthy trees, is initially low with light defoliation, increases with moderate to heavy defoliation, but often drops with complete defoliation (Furniss 1965; Miller and Keen 1960; Mitchell and Martin 1980; Wagener 1961). Bark beetles also attack trees with cambium injury but are thought to contribute little to mortality, except in conjunction with defoliation or when a large proportion of the circumference is killed (Ferguson, Gibbs, and Thatcher 1960; Ryan and Frandsen 1991; Wagener 1961). Secondary bark beetles (those commonly attracted to severely weakened or recently killed trees) and wood borers are often attracted 
to burned trees when suitable populations exist in the vicinity of the fires (Fellin 1980; Furniss and Carolin 1977). Their contribution to mortality, while thought to be minor (Mitchell and Martin 1980), is largely unknown. Host/insect species relationships and the degree to which fire-injured trees lead to a buildup of populations capable of attacking nearby unburned trees have not been determined for most species.

In 1988 canopy-consuming crown fires in the Greater Yellowstone Area (GYA) burned roughly 350,000 ha while surface fires burned an additional 200,000 ha (Greater Yellowstone Post-Fire Resource Assessment Committee, Burned Area Survey Team 1988). Crown fires badly charred and instantly killed most trees. Trees burned in surface fires received varying degrees of crown and bole injury. In 1989 we initiated a survey to improve our understanding of fire injury and insect interactions in the GYA. The objectives were to (1) examine short-term mortality of partially burned trees, (2) determine which insect species attacked fire-injured trees, (3) test the ability of equation (1) to predict mortality following uncontrolled fires in the Northern Rocky Mountains, and (4) make a preliminary assessment of the potential for build-up of bark beetle populations and their spread to adjacent unburned trees.

\section{Methods}

Canopy fires usually resulted in complete burning or severe scorching of the inner bark, especially in thin-barked trees. Because such trees are no longer suitable for bark beetle infestation, we focused our sampling on surface burned and adjacent unburned forests. We made observations on 24 variable radius plots (2.23 $\mathrm{m}^{2} \mathrm{ha}^{-1}$ basal area prism factor) within areas covered by four fires (table 1). Plots were located in lodgepole pine (Pinus contorta) and Douglas-fir (Pseudotsuga menziesii) forests at elevations between 2,000 and 2,500 m. In addition to lodgepole pine and Douglas-fir, we encountered a few Engelmann spruce (Picea engelmannii) and subalpine fir (Abies lasiocarpa). Individual trees were numbered with aluminum tags, except in the heavily used Madison River area, where successive observations were made by comparing tree diameter and location. Measurements were made of tree diameter at breast height, the percentage of the crown volume scorched, and the percentage of the circumference killed at the base. Crown scorch was ocularly assessed and expressed as the percentage of the prefire crown volume killed. We determined cambium injury by removing small sections of bark and visually inspecting tissues. Bark thickness was computed from tree diameter and species dependent equations (Ryan and Reinhardt 1988).

We classified insects attacking trees according to whether they were primary or secondary bark beetles, wood borers, or other insects (table 2). Observations of insects were restricted to the visible lower bole (c. $2 \mathrm{~m}$ ). We detected insect attack by inspecting for boring dust and for entrance and exit holes. Species were identified by removing a small portion of bark, exposing the phloem and cambium. Ovservations were made of insect attack and mortality from 1988 through 1991. Trees were classified as alive or dead based on the presence or absence of living foliage. We evaluated the performance of equation (1) by comparing the predicted status (alive or dead) with the observed tree status in 1991. The expected fate of an individual tree was determined by inspecting its probability of mortality. If the probability of mortality exceeded 0.5 , we predicted the tree would die. Otherwise, we predicted it would live. The expected number of dead trees in a stand was the product of the probability of mortalit!; and the number of trees.

Additional details on plot location, measurements, and preliminary observations based on the first two growing seasons are contained in Amman and Ryan (1991). 
Table 1. Location of plots and number of trees by species in the fire-injury and insect interaction survey of the 1988 Yellowstone fires

\begin{tabular}{|c|c|c|c|c|}
\hline Fire & Location & $\begin{array}{l}\text { No. } \\
\text { plots }\end{array}$ & Species & $\begin{array}{l}\text { No. } \\
\text { trees }\end{array}$ \\
\hline North Fork & $\begin{array}{l}\text { Bunsen Peak } \\
\text { Madison River }\end{array}$ & $\begin{array}{l}3 \\
4^{\mathrm{a}}\end{array}$ & $\begin{array}{l}\text { Douglas-fir } \\
\text { Douglas-fir } \\
\text { Lodgepole pine }\end{array}$ & $\begin{array}{r}52 \\
43 \\
6\end{array}$ \\
\hline Snake River & Grant Village & 1 & Lodgepole pine & 12 \\
\hline Huck & Rockefeller Parkway & 9 & $\begin{array}{l}\text { Douglas-fir } \\
\text { Engelmann spruce } \\
\text { Lodgepole pine } \\
\text { Subalpine fir }\end{array}$ & $\begin{array}{r}26 \\
2 \\
75 \\
9\end{array}$ \\
\hline Hunter & Ditch Creek & 7 & $\begin{array}{l}\text { Douglas-fir } \\
\text { Engelmann spruce } \\
\text { Lodgepole pine } \\
\text { Subalpine fir }\end{array}$ & $\begin{array}{r}4 \\
15 \\
58 \\
8\end{array}$ \\
\hline Total & & 24 & & 310 \\
\hline
\end{tabular}

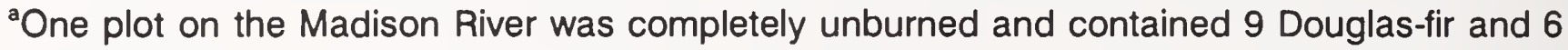
lodgepole pines.

${ }^{b}$ The Hunter fire occurred on the Bridger-Teton National Forest, about $50 \mathrm{~km}$ south of Yellowstone Park.

'Includes 19 lodgepole pines that were completely unburned.

\section{Results and Discussion}

\section{Douglas-fir}

Of the 125 Douglas-fir in the survey, 116 trees were burned to varying degrees. The remaining nine trees were in an unburned patch of forest and were not directly affected by fire. Mortality increased annually to 55 percent in late July 1991 (figure 1). We found no difference in tree diameter between living and dead Douglas-fir, but dead trees suffered greater crown scorch and basal girdling (table 3 ), indicating that they were exposed to more severe fires. Most trees that died in 1989 suffered both severe crown and bole injury. The majority of additional mortality between 1989 and 1991 occurred among trees that suffered little crown injury but had greater than 50 percent basal girdling. Mortality was substantially higher in trees with more than 50 percent crown scorch or more than 75 percent basal girdling (table 4).

Of the 116 Douglas-fir that burned, 26 percent were infested by insects in 1989, primarily the Douglas-fir beetle (DFB) (Dendroctonus pseudotsugae) and a few wood borer larvae of Buprestidae and Cerambycidae (Amman and Ryan 1991). Most infested Douglas-fir in 1989 had 50 percent or more stem girdling by fire. In 1990 infestation increased to 67 percent of the trees (Amman and Ryan 1991). By 1991 76 percent of the trees were infested (table 5). The Douglas-fir beetle was active at all survey locations 
(table 6). The data suggest DFB are not strongly attracted to trees with more than 75 percent crown scorch (table 4). In July 199142 of the 59 living Douglas-fir were infested with DFB. Most are more than half girdled by fire, and their vigor is deteriorating. Of the nine unburned Douglas-fir in the survey, six have been attacked by DFB and are dead or dying.

Table 2. Bark beetles and wood borers infesting trees in the Greater Yellowstone Area following the 1988 fires

\begin{tabular}{|c|c|c|c|c|}
\hline \multirow[b]{2}{*}{ Host } & \multicolumn{2}{|c|}{ Bark beetles } & \multirow[b]{2}{*}{ Borers } & \multirow[b]{2}{*}{ Other } \\
\hline & Primary & Secondary & & \\
\hline Lodgepole & Dendroctonus ponderosae & $\begin{array}{l}\text { Ips pini } \\
\text { Dendroctonus valens } \\
\text { Pityophthorous sp. } \\
\text { Pityogenes sp. }\end{array}$ & $\begin{array}{l}\text { Buprestidae } \\
\text { Cerambycidae }\end{array}$ & $\begin{array}{l}\text { Ambrosia } \\
\text { Hylurgops sp. } \\
\text { Hylastes sp. }\end{array}$ \\
\hline Douglas-fir & Dendroctonus pseudotsugae & Pseudohylesinus sp. & $\begin{array}{l}\text { Buprestidae } \\
\text { Cerambycidae }\end{array}$ & \\
\hline Engelmann spruce & Dendroctonus rufipennis & $\begin{array}{l}\text { Ips pilfrons } \\
\text { Scierus } \mathrm{sp} \text {. }\end{array}$ & $\begin{array}{l}\text { Buprestidae } \\
\text { Cerambycidae }\end{array}$ & $\begin{array}{l}\text { Siricidae } \\
\text { Ambrosia }\end{array}$ \\
\hline Subalpine fir & & & $\begin{array}{l}\text { Buprestidae } \\
\text { Cerambycidae }\end{array}$ & \\
\hline
\end{tabular}

\begin{tabular}{|c|c|c|c|c|c|c|c|}
\hline \multirow[t]{2}{*}{ SPECIES } & \multicolumn{6}{|c|}{ DEPTH (m) } & \multirow[b]{2}{*}{12} \\
\hline & 0 & 2 & 4 & 6 & 8 & 10 & \\
\hline \\
\hline \multicolumn{8}{|l|}{ Chara sp. } \\
\hline \multicolumn{8}{|l|}{ Elodea canadensis } \\
\hline \multicolumn{8}{|l|}{ Eleocharis acicularis } \\
\hline \multicolumn{8}{|l|}{ Hippuris vulgaris } \\
\hline \\
\hline \multicolumn{8}{|l|}{ Myriophyllum sibiricum } \\
\hline \multicolumn{8}{|l|}{ Nitella sp. } \\
\hline \multicolumn{8}{|l|}{ Polygonum amphibium } \\
\hline \multicolumn{8}{|l|}{ Potamogeton alpinus } \\
\hline \multicolumn{8}{|l|}{ Potamogeton gramineus } \\
\hline \multicolumn{8}{|l|}{ Potamogeton pectinatus } \\
\hline \multicolumn{8}{|l|}{ Potamogeton pusillus } \\
\hline \multicolumn{8}{|l|}{ Potamogeton richardsonï } \\
\hline \multicolumn{8}{|l|}{ Ranunculus aquatilis } \\
\hline \multicolumn{8}{|l|}{ Ranunculus flamula } \\
\hline \multicolumn{8}{|l|}{ Sagittaria cuneata } \\
\hline Sparganium sp. & & & & & & & \\
\hline
\end{tabular}

Figure 1. Percent mortality by species and year for trees burned in the 1988 Greater Yellowstone Area fires. SAF = subalpine fir, ES = Engelmann spruce, LPP = lodgepole pine, DF = Douglas-fir . 
There appears to be a pattern where DFB initially attacked severely injured trees, then attacked more lightly injured ones. Peterson and Arbaugh (1986) found that the level of insect attack was an important factor in the death of burned Douglas-fir in the northern Rocky Mountains. In later work they found insect attack was unimportant for predicting the fate of fire-injured Douglas-fir in the Cascade Mountains (Peterson and Arbaugh 1989), possibly because beetle populations were low. Our results confirm the co-occurrence of fire injury and insect attack. With our data it is not possible, however, to determine whether the spread of DFB to more lightly injured trees results from a gradual decline in those trees' resistance to attack or whether DFB populations increased and overwhelmed the trees' defensive capabilities. We suspect that DFB is a significant source of additional mortality.

Table 3. Average tree diameter, percentage crown scorch, and percentage basal girdling, and predicted probability of mortality $\left(P_{\text {mor. }}\right)$, by species and status

\begin{tabular}{|l|r|r|r|r|r|}
\hline \multicolumn{1}{|c|}{ Species/status } & $\begin{array}{c}\text { No. } \\
\text { trees }\end{array}$ & $\begin{array}{c}\text { Diameter } \\
(\mathbf{c m})\end{array}$ & $\begin{array}{c}\text { Crown } \\
\text { scorch } \\
(\%)\end{array}$ & $\begin{array}{c}\text { Basal } \\
\text { girdling } \\
(\%)\end{array}$ & P $_{\text {mort. }}$ \\
\hline $\begin{array}{l}\text { Douglas-fir } \\
\text { Alive } \\
\text { Dead }\end{array}$ & 52 & 38.9 & 25.6 & 68.3 & 0.27 \\
\hline $\begin{array}{l}\text { Engelmann spruce } \\
\text { Alive }\end{array}$ & 64 & 36.9 & 67.6 & 81.4 & 0.65 \\
$\quad$ Dead & 14 & 35.6 & 24.3 & 66.7 & 0.59 \\
\hline $\begin{array}{l}\text { Lodgepole pine } \\
\text { Alive }\end{array}$ & 35.7 & 55.0 & 100.0 & 0.80 \\
\hline Dead & 39 & 25.7 & 1.2 & 60.2 & 0.72 \\
\hline Subalpine fir & & 25.3 & 29.9 & 94.3 & 0.81 \\
$\quad$ Alive & 0 & - & & & \\
Dead & 17 & 25.7 & 67.2 & 96.5 & 0.92 \\
\hline$\quad$ Total & 276 & 31.3 & 37.3 & 81.7 & 0.66 \\
\hline
\end{tabular}

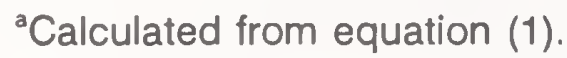

In addition to the unburned trees on our plots that are infested, we have observed DFB successfully attacking trees in unburned areas near our Madison River plots. Spread of DFB to unburned trees is contrary to observations by M. Furniss (1965), who found DFB established offspring in 88 percent of fire-injured Douglas-fir following a fire in Idaho, but found the number of offspring small because of pitch invasion of galleries and sour sap condition. He did not report any infestation after the first postfire year. However, R. Furniss (1941) observed DFB buildup in Douglas-fir in Oregon following the 1933 Tillamook fire. Beetles killed large numbers of uninjured trees in 1935 and 1936 . R. Furniss thought that frequent fires provided large numbers of injured trees for successive generations, thus allowing the DFB population to increase and overcome healthy trees' resistance. Our preliminary survey of fire and insect interactions was not designed to address questions of population buildup and beetle migration. However, the observed beetle activity prompted a more extensive survey of the GYA in 1991. Preliminary results 
indicate that extensive buildup of DFB is occurring in scorched trees (Amman unpublished data). It should also be noted that populations of DFB were increasing in the GYA at the time of the 1988 fires (Gibson and Oakes 1989; Knapp et al. 1988).

Table 4. Number of trees, percentage mortality, and number of trees infested by insects by species and fire injury

\begin{tabular}{|l|c|c|c|c|c|}
\hline \multirow{2}{*}{ Species } & \multirow{3}{*}{$\begin{array}{c}\text { Crown Scorch } \\
\text { (\%) }\end{array}$} & \multicolumn{4}{|c|}{ Basal Girdling (\%) } \\
\cline { 3 - 6 } & & $0-25$ & $26-50$ & $51-75$ & $76-100$ \\
\hline \multirow{2}{*}{ Douglas-fir } & $0-25$ & $2(100) 2$ & $12(42) 10$ & $14(21) 9$ & $18(22) 13$ \\
& $26-50$ & - & $6(17) 6$ & $4(50) 4$ & $5(40) 4$ \\
& $51-75$ & $1(100) 1$ & $3(0) 1$ & $4(25) 1$ & $12(60) 4$ \\
& $76-100$ & - & $8(88) 2$ & $1(0) 1$ & $26(100) 8$ \\
\hline \multirow{2}{*}{ Engelmann spruce } & $0-25$ & $1(0) 0$ & - & - & $4(75) 2$ \\
& $26-50$ & - & - & - & $3(100) 3$ \\
& $51-75$ & - & - & - & $5(80) 1$ \\
& $76-100$ & - & - & - & $4(100) 1$ \\
\hline \multirow{2}{*}{ Lodgepole pine } & $0-25$ & $5(40) 1$ & $16(19) 5$ & $14(7) 3$ & $59(83) 38$ \\
& $26-50$ & - & - & - & $8(100) 6$ \\
& $51-75$ & - & - & - & $6(100) 3$ \\
& $76-100$ & - & - & $1(100) 1$ & $17(100) 6$ \\
\hline \multirow{2}{*}{ Subalpine fir } & $0-25$ & - & $1(100) 1$ & - & $4(100) 3$ \\
& $26-50$ & - & - & - & $1(100) 0$ \\
& $51-75$ & - & - & - & $1(100) 1$ \\
& $76-100$ & - & - & - & $10(100) 6$ \\
\hline
\end{tabular}

aThe first number is the number of burned trees in the survey, the number in parentheses is the percentage of trees that died, and the third number is the number of trees infested by insects.

Equation (1) predicts that 48 percent of all Douglas-fir in the survey will die. This number is 7 percent less than observed through July 1991. On an individual tree basis, equation (1) accurately predicted the July 1991 status of three-fourths of the trees (table 7). The majority of trees missclassified are those expected to live but that are already dead. Equation (1) consistently underpredicted the death of trees with low crown injury and high basal girdling. Further, equation (1) cannot account for future deaths among current living but DFB-infested trees. The failure of equation (1) to predict the death of low crown-injury trees accurately may reflect a bias in the data used by Ryan and Reinhardt (1988) to build the model. Their data came predominantly from moderate-intensity surface fires where duff moisture was generally too high to support the sustained burning that leads to basal injury in thick-barked trees. Extended drought in 1988 dried the duff around the bases of most Douglas-fir. Heat from burning duff killed the cambium around much of the circumference of these trees. Equation (1) does not give adequate weight to predicting mortality resulting from such heating. The underprediction of mortality may also be associated with the high incidence of attack by DFB. 
Table 5. Cumulative distribution of insect infestation through 1991, by species

\begin{tabular}{|c|c|c|c|c|c|c|}
\hline \multirow[b]{2}{*}{ Species } & \multirow[b]{2}{*}{ Number } & \multicolumn{5}{|c|}{ Percent infested } \\
\hline & & Primary & Secondary & Other & Borers & Total $^{2}$ \\
\hline Douglas-fir & 125 & 62 & 0 & 0 & 20 & 76 \\
\hline Engelmann spruce & 17 & 24 & 6 & 18 & 65 & 82 \\
\hline Lodgepole pine & 151 & 5 & 41 & 13 & 13 & 58 \\
\hline Subalpine fir & 17 & 24 & 0 & 6 & 65 & 88 \\
\hline Total & 310 & & & & & \\
\hline
\end{tabular}

${ }^{\text {a }}$ Total percentage of trees attacked regardless of insect species. Many trees suffered attack from more than one species of insect.

\section{Lodgepole Pine}

Of the 151 lodgepole pine in the survey, 126 were burned. Death of fire-injured lodgepole pine was low in 1989 but increased substantially in 1990 (figure 1). Dead trees were similar in size to live trees but suffered greater fire injury (table 3). By late July 199169 percent of the burned lodgepole pine were dead even though most trees received less than 25 percent crown scorch (table 4). A total of 71 percent of the lodgepole pine were more than 75 percent girdled, and most of these died. All of the surviving trees received less than 25 percent crown scorch. Of the 25 unburned lodgepole pine in the survey, 2 trees died. Their death appears to be independent of the fires.

By 199158 percent of the 151 lodgepole pine were attacked by insects (table 5). This is a continuation of the trend for an annual increase in the cumulative number of attacked trees. We previously reported that 24 percent of these trees had been attacked in 1989 and 44 percent by 1990 (Amman and Ryan 1991). Mountain pine beetle (MPB), D. ponderosae, attacked eight trees. All MPB attacks occurred on the Hunter fire on the Bridger-Teton National Forest. In these trees MPB was mixed with the pine engraver (PE) (Ips pini) and the twig beetle (Pityophthorous confertus). Wood borers, both Buprestidae and Cerambycidae, were found occasionally in fire-injured lodgepole pine. Pine engravers accounted for the majority of insects attacking lodgepole pine. Most trees infested by PE had greater than 75 percent basal girdling but less than 50 percent crown scorch. Our sample size is small but suggests that $\mathrm{PE}$ is not strongly attracted to trees with high crown scorch, perhaps because high crown scorch in lodgepole pine is frequently accompanied by high bole injury, and dead cambium is not suitable PE habitat. The primary fire injury associated with insect infestation and subsequent death of these trees is basal girdling. As of July 19918 of the 64 living lodgepole pine were infested with PE. Pine engravers were active at all survey locations except Madison, which has a small sample size (table 6).

The lack of significant MPB activity is probably due to low population levels and habitat preference. Populations of MPB were low in the GYA in 1988 (Gibson and Oakes 1989; Knapp et al. 1988). Also, observations over the years suggest that MPB is not strongly attracted to fire-scorched trees. Mitchell and Sartwell (1974) report that mountain pine beetles seldom breed in fire-injured trees in numbers sufficient to cause an increase in the population. Hopkins (1905) found no MPB in fire-injured ponderosa 
pine in the Manitou Park area of Colorado. Blackman (1931), working on the Kaibab National Forest in northern Arizona, found MPB unattracted to fire-scorched trees because the scorched phloem did not offer favorable conditions for beetle offspring. Rust (1933) reported that fire-injured ponderosa pine were infested by MPB the first year following a fire in northern Idaho. However, the infestation declined the next year. Following fires in eastern Oregon, Geiszler et al. (1984) observed MPB mostly in larger diameter lodgepole pine that experienced some root injury or basal injury to less than one-third of the circumference. This behavior was in direct contrast to PE, which preferred smaller diameter lodgepole pine and those with more than one-third of the basal circumference killed.

Table 6. Cumulative insect infestation and observed mortality through July 1991 and expected mortality by location

\begin{tabular}{|c|c|c|c|c|c|}
\hline \multirow[b]{3}{*}{ Location } & \multirow[b]{3}{*}{ Species } & \multirow[b]{3}{*}{ No. trees } & & \multicolumn{2}{|c|}{ Kilied } \\
\hline & & & Infested & Observed & Expected $^{\mathrm{b}}$ \\
\hline & & & \multicolumn{3}{|c|}{ Percent } \\
\hline Bunsen Peak & Douglas-fir & 52 & 81 & 40 & 38 \\
\hline Madison River & $\begin{array}{l}\text { Douglas-fir } \\
\text { Lodgepole pine }\end{array}$ & $\begin{array}{l}43 \\
6^{c}\end{array}$ & $\begin{array}{r}63 \\
0\end{array}$ & $\begin{array}{l}58 \\
33\end{array}$ & $\begin{array}{r}35 \\
0\end{array}$ \\
\hline Grant Village & Lodgepole pine & 12 & 58 & 42 & 100 \\
\hline $\begin{array}{l}\text { Rockefeller } \\
\text { Parkway }\end{array}$ & $\begin{array}{l}\text { Douglas-fir } \\
\text { Engelmann spruce } \\
\text { Lodgepole pine } \\
\text { Subalpine fir }\end{array}$ & $\begin{array}{r}26 \\
2 \\
75 \\
9\end{array}$ & $\begin{array}{l}96 \\
50 \\
45 \\
89\end{array}$ & $\begin{array}{r}69 \\
100 \\
44 \\
100\end{array}$ & $\begin{array}{r}62 \\
100 \\
75 \\
100\end{array}$ \\
\hline Ditch Creek & $\begin{array}{l}\text { Douglas-fir } \\
\text { Engelmann spruce } \\
\text { Lodgepole pine }{ }^{\triangleleft} \\
\text { Subalpine fir }\end{array}$ & $\begin{array}{r}4 \\
15 \\
58 \\
8\end{array}$ & $\begin{array}{l}25 \\
87 \\
79 \\
88\end{array}$ & $\begin{array}{r}50 \\
80 \\
84 \\
100 \\
\end{array}$ & $\begin{array}{r}100 \\
80 \\
100 \\
100 \\
\end{array}$ \\
\hline Total & & 310 & & & \\
\hline
\end{tabular}

${ }^{a}$ Total percentage of trees infested regardless of insect species and including both burned and unburned trees.

'Expected mortality is based on the individual burned tree's expected status $\left(P_{m} \geq\right.$ $0.5=$ dead) as computed by equation (1).

'All 6 lodgepole pine were completely unburned.

Includes 19 lodgepole pines that were completely unburned.

Given the diameters and severity of basal girdling of our lodgepole pine (table 3), the high incidence of $\mathrm{PE}$ in this survey is consistent with the observations of Geiszler et al. (1984). Also, the large number of trees infested by pine engraver is not surprising because these beetles are able to reproduce in wind-broken material, including large branches, and in decadent trees (Sartwell et al. 1971). Such material is plentiful throughout the GYA. Consequently, although PE was not causing noticeable tree mortality in 1988, sufficient numbers were probably present to infest the fire-injured lodgepole pine in the spring of 1989. 
Table 7. Observed vs. expected mortality for four species

\begin{tabular}{|l|c|r|r|r|}
\hline \multirow{2}{*}{ Species } & & \multicolumn{3}{|c|}{ Predicted $^{\mathbf{2}}$} \\
\cline { 3 - 5 } & Observed & Alive & Dead & Total \\
\hline \multirow{2}{*}{ Douglas-fir } & Alive & 44 & 8 & 52 \\
& Dead & 21 & 43 & 64 \\
\hline \multirow{2}{*}{ Engelmann spruce } & Alive & 2 & 1 & 3 \\
& Dead & 1 & 13 & 14 \\
\hline \multirow{2}{*}{ Lodgepole pine } & Alive & 0 & 39 & 39 \\
& Dead & 0 & 87 & 87 \\
\hline Subalpine fir & Alive & 0 & 0 & 0 \\
& Dead & 0 & 17 & 17 \\
\hline \multirow{2}{*}{ Total } & & 68 & 208 & 276 \\
\hline
\end{tabular}

aPredicted mortality based on the number of trees with a calculated probability of mortality greater than 0.5 .

When equation (1) was used to predict the probability of mortality for all lodgepole pine in the survey, it predicted that 78 percent of the trees would die. This result compares to the observed 69 percent mortality. However, when applied on an individual tree basis, equation (1) completely failed to predict the survival of partially injured trees (table 7). Because lodgepole pine has thin bark, the calculated probability of mortality exceeded 0.5 , with the result that all trees were predicted to die. Equation (1) was developed from data collected on moderate-intensity surface fires that were relatively uniform in their spatial coverage. Because of its thin bark, lodgepole pine is relatively sensitive to fire. Any fire vigorous enough to bathe the bole in flames for more than a few seconds should cause extensive cambium injury. Because our survey was conducted along the margin between canopy-burned and unburned forests, many trees were lightly scorched only on a portion of their circumference, and survival was greater than predicted. This was particularly true on the plot near Grant Village, where equation (1) performed most poorly (table 6).

\section{Engelmann Spruce}

Because our survey focused on Douglas-fir and lodgepole pine forests, we encountered only 17 Engelmann spruce on our plots. By July 1991 spruce mortality was 82 percent (figure 1). As expected for a thin-barked species, mortality did not vary by tree diameter (table 3). Dead trees, however, received more crown and bole injury. The 14 trees that died were completely girdled. Two of the surviving trees are 90 percent girdled, infested with spruce beetle (SB) (D. rufipennis), and expected to die. This result compares favorably with equation (1), which predicts that two trees will live (table 7). Insects infested 65 percent of the trees in 1989, increasing to 82 percent in 1990 (Amman and Ryan 1991). No additional trees were attacked in 1991 (table 5). Dry duff around the base of the spruce resulted in slow-burning fires that often burned off the roots or so weakened them that the trees were easily toppled by wind. Windthrown spruce with unscorched trunks created an ideal habitat for the SB, which prefers windthrown trees (Schmid and Hinds 1974). The small additional SB infestation in 1990 probably occurred because 
the spruce beetle has a two-year cycle in the GYA. We expected a buildup of SB when beetles from trees infested in 1989 emerged in 1991. However, we found high winter-caused beetle mortality in our small sample. Partially burned spruce near our plots contain some SB, but there is little evidence of a major population buildup.

\section{Subalpine Fir}

Subalpine fir are noted for their lack of fire resistance, primarily because of their thin bark (Ryan 1990; Ryan and Reinhardt 1988). Virtually any fire vigorous enough to scorch the bark will cause cambium inujy, followed by sloughing of the dead bark. Wood borers (Buprestidae and Cerambycidae) infested 35 percent of our subalpine fir in 1989. This infestation increased to 71 percent in 1990 (Amman and Ryan 1991) and to 88 percent in 1991 (table 5). Sixteen of the fir suffered basal girdling in more than 75 percent of the circumference. Most of the bark on subalpine fir was badly burned and not conducive to bark beetle infestation. All 17 subalpine fir died following the fires. Equation (1) accurately predicted the fate of these trees (table 7).

\section{Conclusions}

The 1988 fires in the Greater Yellowstone Area killed many trees outright. Many more were partially injured but still provided suitable habitat for insects. Some trees escaped fire injury but were exposed to insect attack from nearby infested trees. It is difficult to assess all fire injuries adequately, so the extent to which insects contributed to tree death is uncertain. Additional research is needed to focus on the physiological responses of fire-injured trees and their relationships with insect ecology. Although our sample of trees is small compared with total for the GYA, these observations suggest a trend for continued bark beetle infestation of both fire-injured and uninjured trees for 1991. Whether or not infestations extend beyond 1991 will depend in part on the availablity of suitable host material, which in many areas has been exhausted.

Preliminary indications are that existing models for predicting fire-caused mortality of these species should be used with caution following wildfires, particularly in areas of uneven burning near the edges of more severely burned forests. Equation (1) may be applied to populations but should not be applied to individual trees when fuels and fire behavior result in a patchy burn or when duff around the base of trees is deep and dry enough to burn. The failure of the model to predict the survival of partially girdled trees illustrates the need to develop additional models that predict mortality directly from girdling rather than from bark thickness. Morphological factors related to potential resistance to cambium injury may be adequate for planning a prescribed burn, but are a weak substitute for actual measurement of injuries when making postfire predictions of individual tree mortality.

\section{Literature Cited}

Amman, G.D. and K.C. Ryan. 1991. Insect infestation of fire-injured trees in the Greater Yellowstone Area. Res. Note INT-398. U.S. Department of Agriculture, Forest Service. 
Andrews, P.L. and C.H. Chase. 1989. BEHAVE: Fire behavior prediction and fuel modeling system BURN subsystem, Part 2. Gen. Tech. Rep. INT-260. U.S. Department of Agriculture, Forest Service.

Blackman, M.W. 1931. The Black Hills beetle. Tech. Pub. 36. New York State College of Forestry, Syracuse University, Syracuse, New York, 77pp.

Fellin, D.G. 1980. A review of some interactions between harvesting, residue management, fire, and forest insects and diseases. Pages 335-414 in Environmental Consequences of Timber Harvesting in Rocky Mountain Coniferous Forests: Symposium Proceedings. Gen. Tech. Rep. INT-90. U.S. Department of Agriculture, Forest Service.

Ferguson, E.R., C. Gibbs, and R.C. Thatcher. 1960. "Cool" burns and pine mortality. Fire Control Notes 21(1):27-29. U.S. Department of Agriculture, Forest Service.

Furniss, M.M. 1965. Susceptibility of fire-injured Douglas-fir to bark beetle attack in southern Idaho. Journal of Forestry 63:8-11.

Furniss, R.L. 1941. Fire and insects in the Douglas-fir region. Fire Control Notes 5:211-213. U.S. Department of Agriculture, Forest Service.

Furniss, R.L. and V.M. Carolin. 1977. Western Forest Insects. Misc. Pub. 1339. U.S. Department of Agriculture, Forest Service.

Geiszler, D.R., R.I. Gara, and W.R. Littke. 1984. Bark beetle infestations of lodgepole pine following a fire in south central Oregon. Zeitschrift fur angewandte Entomologie 98:389-394.

Gibson, K.E. and R.D. Oakes. 1989. Bark beetle conditions, Northern Region, 1988. Forest Pest Mgmt. Rep. 89-7. U.S. Department of Agriculture, Forest Service, Northern Region, Missoula, Montana. 20pp., plus maps.

Greater Yellowstone Post-Fire Resource Assessment Committee, Burned Area Survey Team. 1988. Preliminary Burned Area Survey of Yellowstone National Park and Adjoining National Forests. Yellowstone National Park and Cooperating Agencies.

Hopkins, A.D. 1905. The Black Hills beetle. U.S. Department of Agriculture, Bureau of Entomology Bulletin 56. 24pp.

Knapp, A., J. Weatherby, J. Hoffman, V. Kalve, and L. LaMadeleine. 1988. Forest insect and disease conditions, Intermountain Region, 1988. U.S. Department of Agriculture, Forest Service, Intermountain Region, State and Private Forestry, Forest Pest Management. $31 \mathrm{pp}$.

Miller, J.M. and P. Keen. 1960. Biology and control of the western pine beetle. U.S. Department of Agriculture Misc. Pub. 800.

Mitchell, R.G. and R.E. Martin. 1980. Fire and insects in pine culture of the Pacific Northwest. Pages 182-190 in R.E. Martin et al., editors, Proceedings, 1980, Sixth Conference on Fire and Forest Meteorology. Society of American Foresters, Washington, D.C. 
Mitchell, R.G. and C. Sartwell. 1974. Insects and other arthropods. Pages R1-R22 in P.O. Cramer, editor, Environmental Effects of Forest Residues Management in the Pacific Northwest: A State-of-knowledge Compendium. Gen. Tech. Rep. PNW-24. U.S. Department of Agriculture, Forest Service.

Peterson, D.L. 1985. Crown scorch volume and scorch height: estimates of postfire tree condition. Canadian Journal of Forest Research 15:596-598.

Peterson, D.L. and M.J. Arbaugh. 1986. Postfire survival in Douglas-fir and lodgepole pine: comparing the effects of crown and bole damage. Canadian Journal of Forest Research 16:1175-1179.

Peterson, D.L. and M.J. Arbaugh. 1989. Estimating postfire survival of Douglas-fir in the Cascade Range. Canadian Journal of Forest Research 19:530-533.

Peterson, D.L. and K.C. Ryan. 1986. Modeling postfire conifer mortality for long-range planning. Environmental Management 10(6):797-808.

Rust, H.J. 1933. Final report on the study of the relation of fire injury to bark beetle attack in ponderosa pine (Tubb's Hill Burn). U.S. Department of Agriculture, Bureau of Entomology, Forest Insect Field Station. 22 pp.

Ryan, K.C. 1990. Predicting prescribed fire effects on trees in the Interior West. Pages 148-162 in M.E. Alexander and G.F. Bisgrove, technical coordinators, The Art and Science of Fire Management. Forestry Canada Information Report NOR-X-309.

Ryan, K.C. and W.H. Frandsen. 1991. Basal injury from smoldering fires in mature Pinus ponderosa Laws. International Journal of Wildland Fire 1(2):107-118.

Ryan, K.C., D.L. Peterson, and E.D. Reinhardt. 1988. Modeling long-term fire-caused mortality of Douglas-fir. Forest Science 34:190-199.

Ryan, K.C. and E.D. Reinhardt. 1988. Predicting postfire mortality of seven western conifers. Canadian Journal of Forest Research 18:1291-1297.

Sartwell, C., R.F. Schmitz, and W.J. Buckhorn. 1971. Pine engraver, Ips pini, in the Western States. Forest Pest Leaflet 122. U.S. Department of Agriculture, Forest Service. 5 pp.

Schmid, J.M. and T.E. Hinds. 1974. Development of spruce-fir stands following spruce beetle outbreaks. Res. Pap. RM-131. U.S. Department of Agriculture, Forest Service.

Swezy, D.M. and J.K. Agee. 1991. Prescribed-fire effects on fine-root and tree mortality in old-growth ponderosa pine. Canadian Journal of Forest Research 21:626-634.

Wagener, W.W. 1961. Guidelines for estimating the survival of fire-damaged trees in California. Misc. Pap. 60. U.S. Department of Agriculture, Forest Service. 



\title{
Landscapes of Northwestern Yellowstone National Park: Soils, Landforms, and Vegetation Characteristics with Interpretations for Erosion Potential and Productivity
}

\author{
Henry F. Shovic \\ Soil Scientist \\ Division of Research \\ Yellowstone National Park \\ Mammoth Hot Springs, WY
}

\section{Introduction}

The grasslands and shrublands north of Mammoth Hot Springs, Wyoming, are a critical part of the northern range. Though small in extent, the area provides important winter range for a variety of species. This paper interprets the results of a soils investigation in this area (Shovic et al. 1991) and provides information on soils and landscape relationships, soil interpretations for management activities, and spatial depiction of disturbed areas. This study is in support of the ongoing soil survey of Yellowstone National Park. Its objective is to report on grass and shrub site productivity and erosion parameters for landscapes in the study area and their relationships to inherent landform, soil, and vegetation characteristics.

The study area is about 4,065 hectares in northwestern Yellowstone National Park (figure 1). It includes the Stevens Creek area, McMinn Bench, the Rainbow Lakes area, part of northern Mount Everts, and Elk Plaza. The southern boundary is Mammoth Hot Springs, Wyoming; the northern boundary is Reese Creek and the Yellowstone River.

The area was purchased in the 1930 s by the National Park Service. A residence and related outbuildings are in the Stevens Creek area. Unused irrigation ditches are common in the area, with some large, eroded breaches at higher elevations. Plant communities in and near these ditches are commonly quite different than those on upland sites. Gravel pits, unused landfills, and building foundations occur in the area. There is a reservoir known as Ice Lake near Stevens Creek. An abandoned railroad grade transects the lower elevations. Unused roads lead to Rainbow Lakes and Ice Lake.

Elevations range from 1,585 m near the Yellowstone River to 2,075 $\mathrm{m}$ on the slopes above McMinn Bench. Landforms include earthflows and block glides, landslide scarps, stream-cut terraces and small valleys, glacial moraine, and steep stream breaks. Vegetation is commonly grasses and shrubs. Slopes are moderate ( 2 percent to 35 percent) with some steeper scarps. Topography includes rolling, chaotic 


\section{Study Area Location Map}

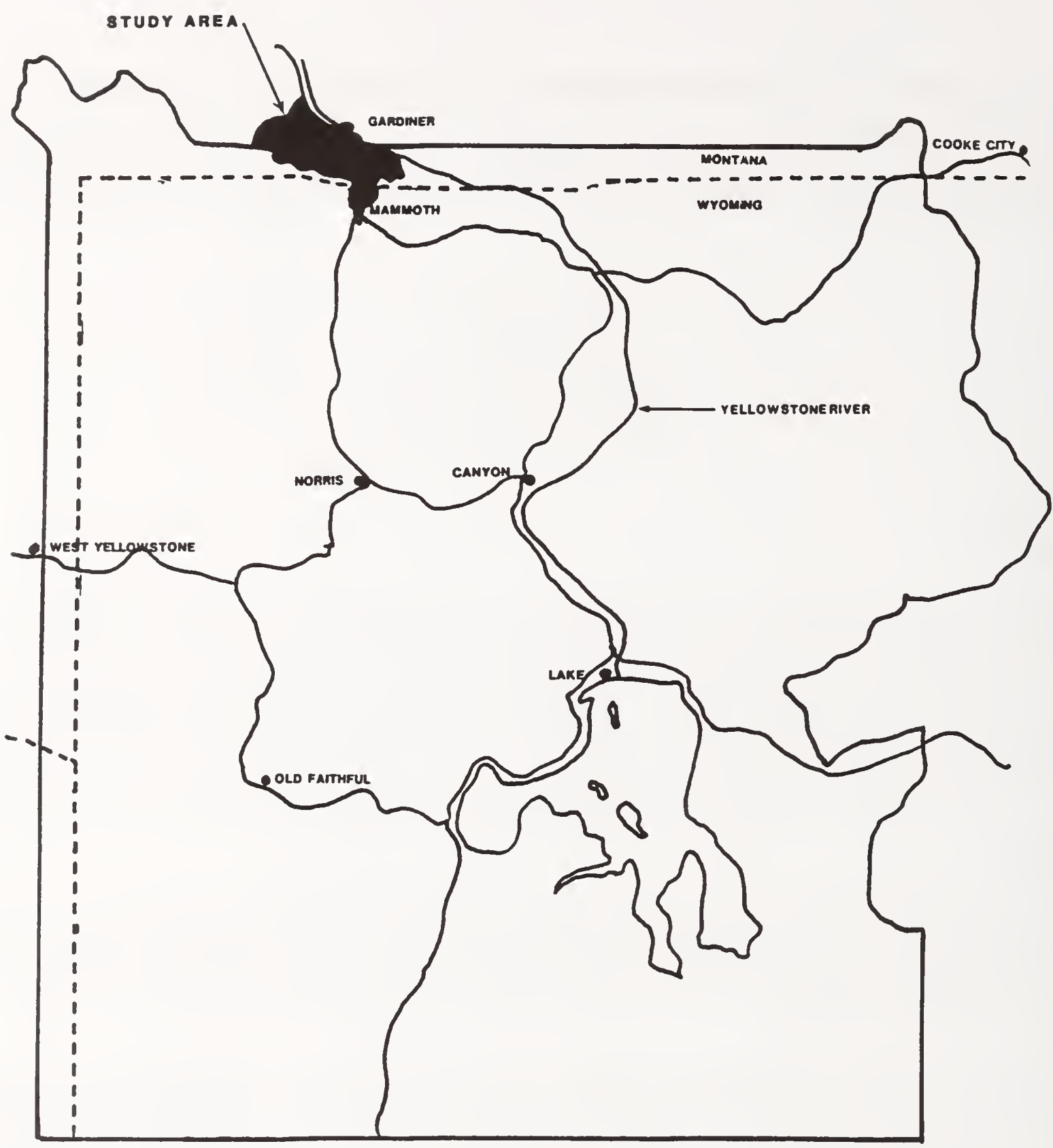

Figure 1. Location of the study area with respect to Yellowstone National Park. 
hills, nearly flat terraces, and gently undulating to moderately steep slopes (Fraser, Waldrop, and Hayden 1969; Morrison-Maierle, Inc. 1981; Pierce 1979; Waldrop and Hayden 1962). Most of the topography is relatively young (Pleistocene or Holocene).

Landslide vegetation is sparse, with sage, bitterbrush, greasewood, needlegrass, and other dry-environment species. Some flat terraces were farmed in the 1940s, and have a sparse cover of wheatgrass, mustards, and other annuals. Higher elevation vegetation on Mt. Everts is moist grassland. The Mammoth area has a mixture of scattered pine, sage, and grassland. Introduced or "exotic" species occur throughout the survey area.

The lithology of parent materials varies from Cretaceous sediments and Tertiary volcanics to gravelly or bouldery glacial till derived from a variety of rock types (Fraser, Waldrop, and Hayden 1969). The climate is relatively warm and dry (compared to the remainder of Yellowstone National Park), with 25 to $41 \mathrm{~cm}$ of precipitation. The area often is free of snow in the winter, and snowmelt occurs in May or early June. Mean temperatures range from $-1^{\circ} \mathrm{C}$ (minimum) to $13^{\circ} \mathrm{C}$ (maximum) with a mean annual temperature of $5.5^{\circ} \mathrm{C}$ (Yellowstone National Park, unpublished weather data).

Soils in the northern two-thirds of the survey area are unique to the region. They are formed in periglacial and preglacial landslide debris, stream alluvium, glacial outwash, and glacial till. High levels of sodium are common, affecting productivity, erosion potential, and plant communities. The soils compact and "seal" when wet partly because of high clay contents. Wind erosion occurs during dry periods. Soils in the southern one-third of the area have formed in a variety of materials, including weathered travertine, glacial till, landslide debris, and weathered shale and sandstone. These soils are nonsodic, with moderate to low fertility.

\section{Methods}

The soils investigation was completed using standard methods (Soil Survey Staff 1985 draft; Soil Survey Staff 1975). The information was compiled into a report for specialists and scientists. This report has a legend (a description of all the map units), detailed soil descriptions for representative sites, maps (scale $1: 24,000$ ), and interpretations (potential behavior of the soils). Habitat types follow Despain (1990) and Mueggler and Stuart (1980). Rangeland productivity by habitat type follows Shovic et al. (1991) and Mueggler and Stuart (1980).

\section{Results and Discussion}

Table 1 contains a list of map units, areal extent, and relative proportions in the survey area. These correlate to those mapped in figure 2. This map is a schematic representation of the soil maps in Shovic et al. (1991). Each map unit is a unique combination of soils, vegetation, topography, and geologic material, or a particular kind of disturbance.

Landscape interpretations are determined by analyzing particular combinations of soils, vegetation, and landform characteristics. One of the important characteristics is the sodium status in soils. Saline or sodic soils have unfavorable plant growth characteristics (Szabolcs 1989). These salts have been inherited 
Table 1. Areal extent of map units in the survey area

\begin{tabular}{|c|c|c|c|}
\hline Map Unit & Acres & Hectares & $\%$ of total \\
\hline FGT & 130 & 53 & 1.3 \\
\hline FLD & 291 & 118 & 2.9 \\
\hline FMC & 492 & 199 & 4.9 \\
\hline FME & 209 & 85 & 2.1 \\
\hline FMF & 526 & 213 & 5.2 \\
\hline FOW & 99 & 40 & 1 \\
\hline FST & 137 & 55 & 1.4 \\
\hline GTC & 883 & 357 & 8.8 \\
\hline GTF & 196 & 79 & 1.9 \\
\hline GTM & 2,126 & 860 & 21.1 \\
\hline LSI & 1,250 & 506 & 12.4 \\
\hline LSP & 1,132 & 458 & 11.2 \\
\hline LSV & 509 & 206 & 5.1 \\
\hline RSC & 712 & 288 & 7.1 \\
\hline RSF & 139 & 56 & 1.4 \\
\hline $\mathrm{SCH}$ & 631 & 255 & 6.3 \\
\hline SFL & 79 & 32 & 0.8 \\
\hline D01 & 86 & 35 & 0.9 \\
\hline D02 & 89 & 36 & 0.9 \\
\hline D03 & 10 & 4 & 0.1 \\
\hline D04 & 51 & 20 & 0.5 \\
\hline D05 & 7 & 3 & 0.1 \\
\hline D06 & 1 & 1 & 0.1 \\
\hline D07 & 12 & 5 & 0.1 \\
\hline D08 & 28 & 11 & 0.3 \\
\hline D09 & 1 & 1 & 0.1 \\
\hline
\end{tabular}


Table 1. Areal extent of map units in the survey area (cont.)

\begin{tabular}{|c|c|c|c|}
\hline Map Unit & Acres & Hectares & \% of total \\
\hline D10 & 35 & 14 & 0.3 \\
\hline D11 & 70 & 28 & 0.7 \\
\hline D12 & 3 & 1 & 0.1 \\
\hline D13 & 2 & 1 & 0.1 \\
\hline D14 & 3 & 1 & 0.1 \\
\hline D15 & 10 & 4 & 0.1 \\
\hline D16 & 99 & 40 & 1 \\
\hline Totals & $10,048.00$ & $4,065.00$ & 100.4 \\
\hline
\end{tabular}

from soil parent materials, and their accumulation in the soil profile is related to the relatively dry climate and high clay content in some areas. Map units affected by sodium are identified in table 2 (under comments).

Soil productivity, site productivity, and erosion status in table 2 are interpretations of soil and site characteristics described in the map legend (Shovic et al. 1991). These are made for the study area as a whole and are not meant to be site specific.

Soil productivity is a component of site productivity. Ratings are relative and based on soil texture, rock fragment content in the soil, rock fragments on the soil surface, fertility, and sodium status in the soil (table 3). In this area the presence of calcium carbonate in the solum (in the absence of high sodium levels) is related to soils having relatively high fertility (Shovic et al. 1991).

High soil productivity means there are no soil limitations to plant growth. Soils with high ratings generally have medium textures, few rock fragments, high fertility, and are on moderate slopes. Moderate soil productivity means there are no severe limitations to plant growth, but there are more rock fragments and lower water-holding capacity (less clay) than in soils rated high. Low soil productivity means there are significant limitations to plant growth, such as high sodium status or large numbers of rock fragments.

Following are some exceptions to the criteria used in table 3. Soils having moderate levels of salt (as evidenced by $\mathrm{pH}$ above 8.5 but without other physical indicators of high sodium status) are rated as moderate. Significant disturbance to the soils, such as high compaction levels, removal of surface soil, or covering with asphalt result in a low soil productivity rating. Irrigation in some disturbed fields may have raised salt levels above natural conditions. The low rainfall and slow soil permeability would contribute to its persistence after irrigation has ceased.

Site productivity is a measure of potential productivity expected on a site in terms of plant growth. Ratings are based on soil productivity, habitat types, erosion potential, and plant cover. 


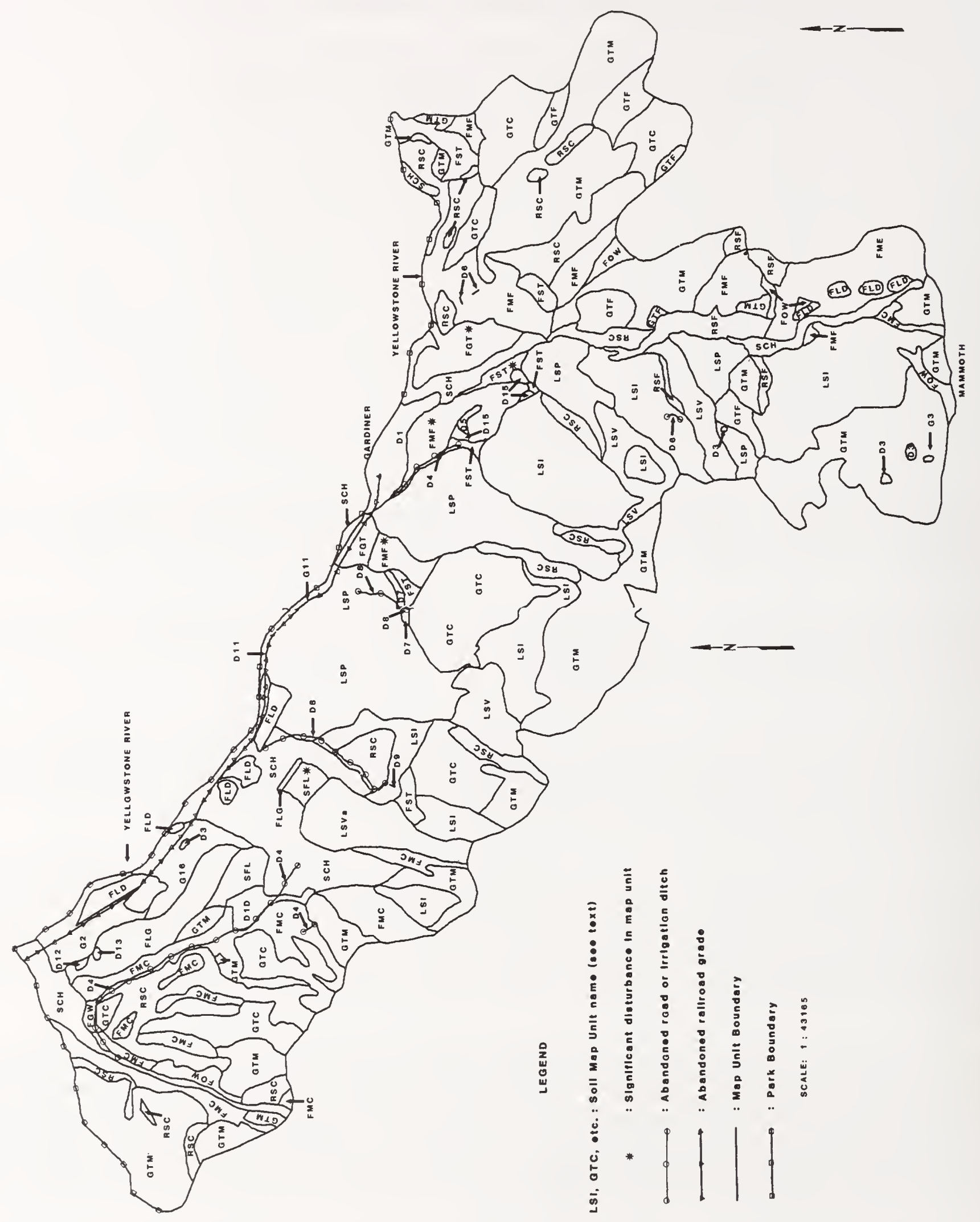

Figure 2. Schematic soil/landscape map of the study area. 
Table 2. Management interpretations and pertinent soil conditions for each map unit

\begin{tabular}{|c|c|c|c|c|}
\hline $\begin{array}{l}\text { Map } \\
\text { Unit }\end{array}$ & $\begin{array}{c}\text { Soil } \\
\text { Productivity }\end{array}$ & $\begin{array}{c}\text { Site } \\
\text { Productivity }\end{array}$ & $\begin{array}{l}\text { Erosion } \\
\text { Potentiai }\end{array}$ & Comments \\
\hline FGT & moderate & $\begin{array}{l}\text { low to } \\
\text { moderate }\end{array}$ & low & unit near Gardiner has compacted layers and "exotic" species \\
\hline FLD & low & low & low & large number of rock fragments \\
\hline FMC & moderate & moderate & low & \\
\hline FME & $\begin{array}{l}\text { low to } \\
\text { moderate }\end{array}$ & low & high & $\begin{array}{l}\text { salt and/or sodium can occur; entrenched erosive stream } \\
\text { channels }\end{array}$ \\
\hline FMF & $\begin{array}{l}\text { moderate to } \\
\text { high }\end{array}$ & $\begin{array}{l}\text { low to } \\
\text { moderate }\end{array}$ & low & $\begin{array}{l}\text { units near Gardiner have irrigation channels, some foundations, } \\
\text { and evidence of plowing }\end{array}$ \\
\hline FOW & $\begin{array}{l}\text { low to } \\
\text { moderate }\end{array}$ & low & low & large number of rock fragments can occur \\
\hline FST & $\begin{array}{l}\text { low to } \\
\text { moderate }\end{array}$ & low & moderate & $\begin{array}{l}\text { unit near Gardiner has some evidence of use as stockyard, with } \\
\text { many exotic species; salt can occur in root zone }\end{array}$ \\
\hline GTC & $\begin{array}{l}\text { low to } \\
\text { moderate }\end{array}$ & $\begin{array}{l}\text { low to } \\
\text { moderate }\end{array}$ & low & \\
\hline GTF & moderate & moderate & moderate & \\
\hline GTM & moderate & moderate & low & \\
\hline LSI & low & low & moderate & salt and/or sodium can occur in root zone \\
\hline LSP & low & low & high & salt and or sodium can occur in root zone \\
\hline LSV & $\begin{array}{l}\text { low to } \\
\text { moderate }\end{array}$ & $\begin{array}{l}\text { low to } \\
\text { moderate }\end{array}$ & $\begin{array}{l}\text { moderate } \\
\text { to high }\end{array}$ & $\begin{array}{l}\text { salt and/or sodium can cccur in root zone; LSVa has low } \\
\text { productivity }\end{array}$ \\
\hline RSC & low & low & moderate & many rock fragments \\
\hline RSF & low & low & $\begin{array}{l}\text { moderate } \\
\text { to high }\end{array}$ & many rock fragments \\
\hline $\mathrm{SCH}$ & moderate & moderate & $\begin{array}{l}\text { low to } \\
\text { high }\end{array}$ & $\begin{array}{l}\text { active stream and river channels; high erosion only near active } \\
\text { streams }\end{array}$ \\
\hline SFL & moderate & low & low & many exotics in part of unit; probably grazed or plowed \\
\hline D01 & low & & low & actively used site \\
\hline $\mathrm{D} 02$ & moderate & & low & highly disturbed \\
\hline $\mathrm{DO3}$ & low & & low & highly disturbed \\
\hline D04 & low & & $\begin{array}{l}\text { high to } \\
\text { moderate }\end{array}$ & highly disturbed \\
\hline D05 & low & & low & highly disturbed \\
\hline D06 & low & & low & highly disturbed \\
\hline D07 & low & & moderate & highly disturbed \\
\hline
\end{tabular}


Table 2. Management interpretations and pertinent soil conditions for each map unit (cont.)

\begin{tabular}{|c|c|c|c|l|}
\hline $\begin{array}{c}\text { Map } \\
\text { Untt }\end{array}$ & $\begin{array}{c}\text { Soll } \\
\text { Productivity }\end{array}$ & $\begin{array}{c}\text { Shte } \\
\text { Productlvity }\end{array}$ & $\begin{array}{c}\text { Eroslon } \\
\text { Potentlal }\end{array}$ & Comments \\
\hline D08 & $\begin{array}{c}\text { low to } \\
\text { moderate }\end{array}$ & & low & higly disturbed \\
\hline D09 & low & & low & highly disturbed \\
\hline D10 & moderate & & low & highly disturbed \\
\hline D11 & low & & low & highly disturbed \\
\hline D12 & low & & low to & highly disturbed \\
\hline D13 & low & & low & highly disturbed \\
\hline D14 & low & & low & highly disturbed \\
\hline D15 & low & & low & partially disturbed; soil productivity moderate in undisturbed parts \\
\hline D16 & moderate & & low & highly disturbed \\
\hline
\end{tabular}

Table 3. Criteria for rating soil productivity

\begin{tabular}{|c|c|c|c|c|c|}
\hline $\begin{array}{c}\text { Soll } \\
\text { Productlvity } \\
\text { Ratling }\end{array}$ & $\begin{array}{c}\text { Soll } \\
\text { Texture }\end{array}$ & $\begin{array}{c}\text { \% Rock Fragments } \\
\text { (surface/subsurface) }\end{array}$ & Soll Fertllity & $\begin{array}{c}\text { Sodlum or } \\
\text { Salt }\end{array}$ & Landform \\
\hline high & medium (silty) & $<20 /<20$ & high & low & swales \\
\hline moderate & $\begin{array}{c}\text { mod. coarse, } \\
\text { medium (loam) }\end{array}$ & $>20 /<50$ & moderate & low & rolling \\
\hline low & mod. fine, fine & $>50 />50$ & low to moderate & high & any \\
\hline
\end{tabular}

High site productivity means that average long term annual production is the highest in the survey area. Moderate and low site productivity indicate relative intermediate and low long-term production, respectively. See table 4 for rating criteria. A range of production is given for each rating, based on limited data from southwestern Montana (Shovic et al. 1991). These values are not meant to be site specific. Disturbed map units (D) are not rated for site productivity because production values are not known for the plant communities on those sites.

Erosion potential is a relative measure of the soil's tendency to erode under grazing pressure, wind, and water. Factors used in rating are slope steepness, plant cover, soil texture, sodium status, and number of rock fragments on the surface. An exception is map unit D11, which is rated low in spite of steep slopes. The soils in the railroad grade are very permeable and not likely to produce runoff.

High erosion potential is defined as having significant sediment produced from a major site in the short term (1- to 10-year frequency) either by snowmelt, significant summer events, or hydraulic action within or near streams. An example is the $\mathrm{SCH}$ map unit located next to active stream and river channels. High 
Table 4. Criteria for rating site productivity

\begin{tabular}{|c|c|c|c|c|}
\hline $\begin{array}{l}\text { Site Productlvity Rating } \\
\text { (kg/ha)* }\end{array}$ & Soll Productivity & $\begin{array}{c}\text { Common Habltat } \\
\text { Type }\end{array}$ & Erosion Potential & Average Cover (\%) \\
\hline high (1356-2182) & high & $\begin{array}{l}\text { ARTR/FEID or } \\
\text { FEID/AGSP }\end{array}$ & low & $>50$ \\
\hline moderate (493-1355) & moderate to low & $\begin{array}{l}\text { ARTR/FEID or } \\
\text { FEID/AGSP }\end{array}$ & low & $>50$ \\
\hline low $w^{\star}(211-492)$ & low & $\begin{array}{c}\text { AGSP/POSA or } \\
\text { SAVE/AGSM or } \\
\text { others }\end{array}$ & high to moderate & $<20$ \\
\hline
\end{tabular}

* range of values is in air dried annual production (from Shovic et al. 1991)

** ARTR/AGSP always rated as having low productivity

$\star \star \star$ ARTR/FEID $=$ Artemesia tridentata/Festuca idahoensis

FEID/AGSP = Festuca idahoensis/Agropyron spicatum

AGSP/POSA = Elymus spicatum/Poa sandbergii

SAVE/AGSM = Sarcobatus vermiculatus/Elymus smithii

ARTR/AGSP $=$ Artemesia tridentata/Elymus spicatum

sites have active rills, gullies, landslides, or evidence of sheet erosion. Vegetation is absent or sparse and is affected by erosion processes. The coarse fraction of soil is less than 20 percent of total soil volume. There is no significant erosion pavement nor other armoring by gravel or larger materials. Material commonly reaches perennial streams the same year it is eroded.

Moderate erosion potential refers to areas that have noticeable erosional features, but the proportion of the site actively eroding is low or erosion occurs only during extreme precipitation events. There may be no perennial stream impact under most conditions because of sediment trapping areas on the eroding slope. The eroded material eventually moves off-site, but not as quickly as in the high category.

Low erosion potential refers to cases where no evidence of active erosion is present. There may be relict forms of past erosional processes such as postglacial channels or scarps.

Rating criteria are given in table 5. The ratings are based on the factors given above and on map unit descriptions and are modified as necessary by field experience.

The above interpretations can be used to show inherent landscape properties and historical events that affect erosion potential, soil conditions, and vegetation. About 33 percent of the project area has clayey, salt-affected soils (tables 1 and 2 and Shovic et al. (1991)). These soils are poor plant growth media, with low water holding capacity, high root resistance, poor aeration, and possible sodium toxicity. They have many surficial rock fragments, which further reduce productivity.

All of the area has low or moderate long-term site productivity (table 5). Small areas (too small to separate at this scale of investigation) have high productivity, e.g., swales with silty soils in map unit GTM (Shovic et al. (1991)). Those areas make up only a small part of the entire survey area. Site productivity is also highly correlated to soil productivity and habitat type (tables 2 and 4 ). 
Table 5. Criteria for rating erosion potential

\begin{tabular}{|c|c|c|c|c|c|}
\hline Erosion Ratling & Slope $\left(\boldsymbol{x}_{)}\right.$ & Cover $(\boldsymbol{*})$ & Soll Texture & Sodlum or Salt & $\begin{array}{c}\boldsymbol{*} \text { Rock } \\
\text { Fragments }\end{array}$ \\
\hline high & $>45$ & $<15$ & mod. fine, fine & any & $<20$ \\
\hline moderate & $45>\ldots>10$ & $50>\ldots>15$ & any & yes & $50>\ldots>10$ \\
\hline low & $<10$ & any & any & any & $>50$ \\
\hline
\end{tabular}

"When parent material is glacial till, slope category is not used unless texture is moderately fine. In this case erosion rating is "moderate."

About 6 percent of the area has been highly disturbed in the past (table 1, figure 2). Most of this disturbance is in highly visible areas. Note the location of the $D$ (disturbed) map units and those marked with an "*" (figure 2). These areas look unnatural because of low vegetative cover, debris, foundations, or soil disturbance. This disturbance has significantly altered soil properties, which, in turn, affect vegetation composition and productivity. Apparently a large part of the area was heavily grazed by cattle in the early part of this century (Despain, D., Yellowstone National Park, personal communication). The effects of this widespread disturbance probably are still present.

Almost one-half of the survey area has moderate or high erosion potential, with 23 percent moderate, and 26 percent high (tables 1 and 2). A significant part of the area is unstable compared to surrounding landscapes. It is geologically young and still adjusting to current environmental conditions. Though causative factors were not separated in this study, it is probable that steep slopes, high clay content, salt concentration, and other inherent properties of the landscape are primarily responsible for the erosion potential.

There has been much discussion on the impacts of heavy wildlife use on the northern range (summarized in Coughenour and Singer 1991). Some suggested impacts are high erosion, low plant cover, and an increase in introduced or exotic species. The study area described here has been observed to have high winter use by ungulates and also appears to have these landscape characteristics. High wildlife use has undoubtedly contributed to average vegetative coverage, vegetative species dominance, and erosion status. However, its importance is confounded by inherent ecosystem properties and past disturbance described above. The ecosystems in the survey area are combinations of parameters: landforms (unstable landslides, steep slopes, erodible mudstones), soils (salt and clay concentration, large numbers of rock fragments), and vegetation (salt-tolerant or otherwise unproductive habitat types with inherently low cover; exotic or introduced species), all influenced by the relatively dry climate. These factors (and past disturbances) significantly influence soil productivity, site productivity, and erosion potential. The intensity of these environmental variables may confound any apparent effects of present wildlife use; therefore, assessments of the reasons for the area's appearance should be based on examination of all relevant ecological parameters as well as that use. 


\section{Literature Cited}

Coughenour, M.B. and F. Singer. 1991. The concept of overgrazing and its application to Yellowstone's northern range. In R.B. Keiter and M.S. Boyce, editors, The Greater Yellowstone Ecosystem, Redefining America's Wilderness Heritage. Yale University Press, New Haven, Connecticut, and London.

Despain, D. 1990. Yellowstone Vegetation. Robert Reinhart, Boulder, Colorado.

Fraser, G.D., H.A. Waldrop, and H. J. Hayden. 1969. Geology of the Gardiner Area, Park County, Montana. Geol. Surv. Bull. 1277. U. S. Government Printing Office, Washington, D.C. 118pp.

Morrison-Maierle, Inc. 1981. Geologic investigation, Gallatin National Forest. Project No. 916-081-01. Prepared for U.S. Department of Agriculture, Forest Service, Bozeman, Montana.

Mueggler, W.F. and W.L. Stewart. 1980. Grassland and shrubland habitat types of western Montana. Gen. Tch. Rpt. INT-66. U.S. Department of Agriculture, Forest Service, Intermountain Forest and Range Experiment Station, Ogden, Utah.

Pierce, K.L. 1979. History and dynamics of glaciation in the northern Yellowstone National Park area. U.S. Geological Survey. Prof. Paper 729-F. U.S. Government Printing Office, Washington, D.C. 90pp.

Shovic, H.F., A. Rodman, D. Neprud, and J. Lane. 1991. Soils Investigation of the Reese Creek - McMinn Bench - Mammoth Area, Northwestern Yellowstone National Park, Wyoming. Division of Research, Yellowstone National Park, Box 168, Mammoth Hot Springs, Wyoming.

Soil Survey Staff. 1975. Soil taxonomy. U.S. Department of Agriculture, Soil Conservation Service, U.S. Government Printing Office, Washington, D.C.

Soil Survey Staff. 1985 draft. Revised soil survey manual. USDA Handbook No. 18. U.S. Department of Agriculture, Soil Conservation Service, U.S. Government Printing Office, Washington, D.C.

Szabolcs, I. 1989. Salt affected soils. CRC Press, Boca Raton, Florida.

Waldrop, H.A. and H.J. Hayden. 1962. Landslides near Gardiner, Montana. U.S. Geological Survey Prof. Paper 450-E. U.S. Government Printing Office, Washington, D.C. 4pp. 



\title{
Vegetation Characteristics of Elk Summer Range in South-Central Montana
}

\author{
Fred G. Van Dyke ${ }^{1}$ \\ Montana Department of Fish, Wildlife, and Parks, \\ P.O. Box 1351, Red Lodge, MT 59068 \\ Brenda L. Probert ${ }^{2}$ \\ Montana Department of Fish, Wildlife, and Parks, \\ P.O. Box 1351, Red Lodge, MT 59068 \\ Jennifer J. Rozema ${ }^{3}$ \\ Montana Department of Fish, Wildlife, and Parks, \\ P.O. Box 1351, Red Lodge, MT 59068
}

\begin{abstract}
Species composition, coverage, production, diversity, nutritional quality, and community similarity were examined in wet and dry alpine plant communities on elk (Cervus elaphus) summer ranges on the Silver Run (SR) and Line Creek (LC) plateaus in south-central Montana from 1989 through 1991. Summer habitat and diet selection of elk were examined concurrently. Plant species diversity and community similarity did not change during the summer, but dry alpine sites generally had higher species diversity than wet alpine sites. Plants at wet alpine sites had higher protein and phosphorus $(P)$ levels. Forbs had higher levels of moisture, protein, digestibility, $\mathrm{Ca}$, and $\mathrm{P}$ than shrubs or graminoids. SR and LC elk maintained similar dietary protein levels (21.7 percent and 21.9 percent, respectively) despite differences in habitat use and diet. Elk appeared to optimize foraging by selecting individual plants of greater than average nutritional quality and by making functional responses to more abundant habitat and plant types.
\end{abstract}

'Present address: Department of Biology, Northwestern College, Orange City, IA 51041.

${ }^{2}$ Present address: Department of Wildlife Ecology, University of New Hampshire, Durham, NH 03824.

${ }^{3}$ Present address: 1781 168th Avenue, Spring Lake, MI 49456. 


\section{Introduction}

The quality of elk (Cervus elaphus) summer range is important to the long-term productivity and persistence of elk populations. Because winter ranges are rarely sufficient for maintenance energy requirements, elk must use energy acquired in other seasons, including summer, to offset deficits incurred in winter (Baker and Hobbs 1982). Studies of summer food habits studies of elk are common (Kufeld 1973), but nutritional assessments of summer forage are not (Baker and Hobbs 1982). Elk research and management have tended to focus on winter range (Scotter 1980), but recent investigations have demonstrated that quality and quantity of summer forage are among the most important variables determining annual variation in herd growth (Boyce and Merrill 1989). Johnston, Bezeau, and Smoliak (1968) and Baker and Hobbs (1982) demonstrated nutritional declines in forage over summer, but the latter found elk capable of maintaining diet quality despite declining nutritional quality of forage, probably by shifting to wetter areas with advancing season (Hayden-Wing 1980; Marcum and Scott 1985). Because feeding dominates elk activity budgets (Green and Bear 1990), understanding the characteristics of elk foraging areas and the mechanisms by which elk select such areas is important to effective elk management.

Numerous Montana elk studies have demonstrated the importance of moist areas on summer range (Lyon et al. 1985). Preliminary investigations of the Line Creek (LC) and Silver Run (SR) elk populations in south-central Montana indicated that the SR population had greater access to and made greater use of wet alpine habitats. We suspected that such sites might provide greater quantity and quality of forage and contribute to an historically higher productivity in the SR population. To investigate this hypothesis, we examined the quantity and quality of vegetation on these summer ranges in undisturbed wet and dry alpine environments. Our objectives were to determine (1) absolute and relative abundance of plant species, (2) differences in composition, quantity, and quality of vegetation on wet and dry alpine sites, and (3) concurrent elk response to site differences expressed in habitat and diet selection. Our goal was to relate such results to herd growth, home range use, animal movement patterns, and habitat selection in these herds.

\section{Study Area}

Both summer ranges occur in the Beartooth Mountains of south-central Montana. LC elk summer mainly on the Line Creek Plateau (LCP) between lat. $45^{\circ} 00^{\prime} \mathrm{N}$ and $45^{\circ} 04^{\prime} \mathrm{N}$ and long. $109^{\circ} 22^{\prime} \mathrm{W}$ and $109^{\circ} 19^{\prime} \mathrm{W}$. Summer range of the SR herd consists primarily of the Silver Run Plateau (SRP) between lat. $45^{\circ} 05^{\prime} \mathrm{N}$ and $45^{\circ} 10^{\prime} \mathrm{N}$ and long $109^{\circ} 30^{\prime} \mathrm{W}$ and $109^{\circ} 00^{\prime} \mathrm{W}$.

Plateau vegetation is characterized by treeless alpine environments. Dry alpine sites are dominated by forbs, including lupine (Lupinus sp.) and alpine avens (Geum rossii), and by graminoids, including sheep fescue (Festuca ovina) and elk sedge (Carex geyeri). Wet alpine site forbs include elkslip (Caltha leptosepala) and cinquefoil (Potentilla gracilis). Graminoids, which dominate wet alpine sites, include various aquatic sedges and cotton grass (Carex spp. and Eriophorum sp., respectively) and alpine bluegrass (Poa alpina). Shrubs are limited to various species of alpine willow (Salix spp.).

Elevations on the LCP range from 2,500 to $3,100 \mathrm{~m}$, and on the SRP from 2,800 to $3,800 \mathrm{~m}$. Average annual precipitation at the nearest National Climatic Data Center reporting station, Mystic Lake, Montana (approximately 28 and $35 \mathrm{~km}$ from the SRP and LCP respectively, at 2,339 m elevation) was $56.8 \mathrm{~cm}$, 
and annual snowfall averaged $386 \mathrm{~cm}$ (U.S. Department of Commerce 1992). Precipitation levels are slightly higher on the plateaus. Growing seasons are normally about 60 days, from mid-June through mid-August. Frosts and snowstorms can occur in any month on the plateaus, but July is normally frostand snow-free. Average daily maximum temperature at Mystic Lake in July has been $23.9^{\circ} \mathrm{C}$ from 1951 to 1992 (U.S. Department of Commerce 1992). Plateaus average 2 to $5^{\circ} \mathrm{C}$ cooler on a day-to-day basis.

Both plateaus and their adjoining drainages to the Montana state line are Forest Service lands administered by the Beartooth District of the Custer National Forest. The SRP is part of the Absaroka-Beartooth Wilderness Area. It is roadless, and livestock grazing is not permitted. The LCP, though not an officially designated wilderness area, is managed primarily for wildlife and is also roadless and ungrazed.

\section{Methods}

Relocations of radio-collared elk captured on both study areas were used to define elk summer ranges. Observed habitat use was determined from 228 relocations of radio-collared cow elk in July and August. June was excluded because some elk continued to use lower elevation areas during that month. Bulls were excluded because they tended to remain in forest habitats at lower elevations throughout the summer. Although bulls made some use of moist sites in forests, they did not appear to concentrate on these as heavily as cow-calf groups in alpine areas. This tendency may be related both to different foraging and different antipredator strategies used by bull and cow-calf groups (Geist 1982). Distribution and abundance of available habitat were determined from examination of 242 randomly selected sites on both plateaus.

One wet and one dry alpine site (plot) were selected on each plateau in areas known to receive heavy elk use or in vegetation types judged to be similar to heavily used areas. Selections were based on the presence or absence of previously defined indicator species. Plots were $20.1 \mathrm{~m} \times 20.1 \mathrm{~m}$. Corners on one side (baseline) of the plot were permanently marked with $0.6 \mathrm{~cm}$ metal rod stakes 1 to $1.2 \mathrm{~m}$ high.

Vegetation was initially sampled on June 28 and 29, 1989, on all sites. Sampling was repeated in July 1989; in June and July 1990; and in June, July, and August 1991. Sampling was not attempted earlier because in some years foraging areas were still under snow, especially on the SRP. Sampling was not continued after August because elk foraging normally declined on the plateaus after August and forage nutritional quality had declined below adequate levels by September. Six $20.1 \mathrm{~m} \times 66 \mathrm{~cm}$ belt transects were randomly surveyed in each plot at right angles to the baseline. Five $25.4 \mathrm{~cm} \times 50.8 \mathrm{~cm}$ microplots were sampled at $12 \mathrm{~m}$ intervals along each transect. In each of the 30 microplots, percent cover by species was determined by visual estimation using a calibrated microplot frame. New growth of shrubs, forbs, and grasses was clipped, sorted, and weighed. In each plant category, samples were combined by transect. If a transect did not produce sufficient material in a plant category for chemical analysis, transects were combined until sufficient material was collected. Starting points on the transects were changed in successive months to avoid reexamining and reclipping previously clipped microplots.

Species diversity and community similarity were calculated using the STRATA computer program (U.S. Forest Service ECODATA computer analysis package). Plant production was calculated from weights of clipped samples after adjustment for moisture and for number of belts included in the sample. Determination of total moisture, crude protein, ash, crude fiber, and crude fat was performed by staff of the Chemistry Station Analytical Laboratory, Montana State University, Bozeman, using analytical 
methods described by the Association of Official Analytical Chemists (AOAC) (1965). The last three variables were then used to determine nitrogen-free extract, which in turn was used to determine the percentage of total digestible nutrients (TDN) in plant samples.

Food habits and dietary protein were determined from pellet samples of both herds collected from June through August, 1989 through 1991. Analysis was conducted at the Wildlife Habitat Laboratory, Washington State University, Pullman, Washington. Plant categories and species were identified by microscopic examination of cross sections of pellets. Crude dietary protein (Kjeldahl $N \times 6.25$ ) was determined by procedures described by AOAC (1965).

Differences in nutritional values between months, site types, and plateaus were evaluated by multifactor analysis of variance (ANOVA). Differences within treatments were evaluated by confidence interval tests between means. Differences between habitat use and availability and between proportions of forbs, shrubs, and graminoids in herd diets were evaluated by contingency tables. Differences between dietary protein levels in herds were evaluated by a t-test. $P<0.05$ was considered significant in all cases.

\section{Results}

\section{Plant Coverage and Production}

Percent coverage of forbs and graminoids varied by month, site type, and plateau (figure 1). Wet alpine sites had greater coverage of graminoids than forbs in every month. Dry alpine sites had greater coverage of forbs than graminoids in each month except in August on the SRP. All sites increased in percent plant coverage from June to August. Overall plant coverage generally increased from June to July, and remained stable from July to August. This pattern was repeated in forb and graminoid categories. Both forb cover and graminoid cover peaked in July on the LC dry and SR wet sites, and in August on the LC wet and SR dry sites. Plant coverages on the LC dry and SR wet sites were similar to each other and significantly higher than percent plant coverages in the LC wet and SR dry sites $(p<0.01)$. The LC dry site had the highest forb coverage in every month, and the SR wet site had the highest graminoid and shrub cover in every month.

Total summer plant production and forb production were highest on the LC dry alpine site (table 1). Both forb and graminoid production were lowest on the SR dry alpine site. Graminoid production was highest on SR wet alpine site.

\section{Site Diversity and Similarity}

Species diversity varied little from June through August at each site (figure 2) Dry alpine sites had higher species diversity than wet alpine sites (1.09-1.23 and $0.80-1.08)$, respectively). The SR wet alpine site had the lowest diversity in every month.

Similarity between sites varied by community type, ranging from 31 percent (SR wet and LC dry) to 69 percent (SR dry and LC wet, table 2). Similarity of SR dry and LC wet sites increased from June to August, suggesting a rapid loss of moisture and s!.Jccession to dry site conditions on the LC wet site, with consequent changes in plant composition. All sites retained $>45$ percent internal similarity from June to August (figure 3). The most diverse community type, LC dry alpine, experienced the greatest 

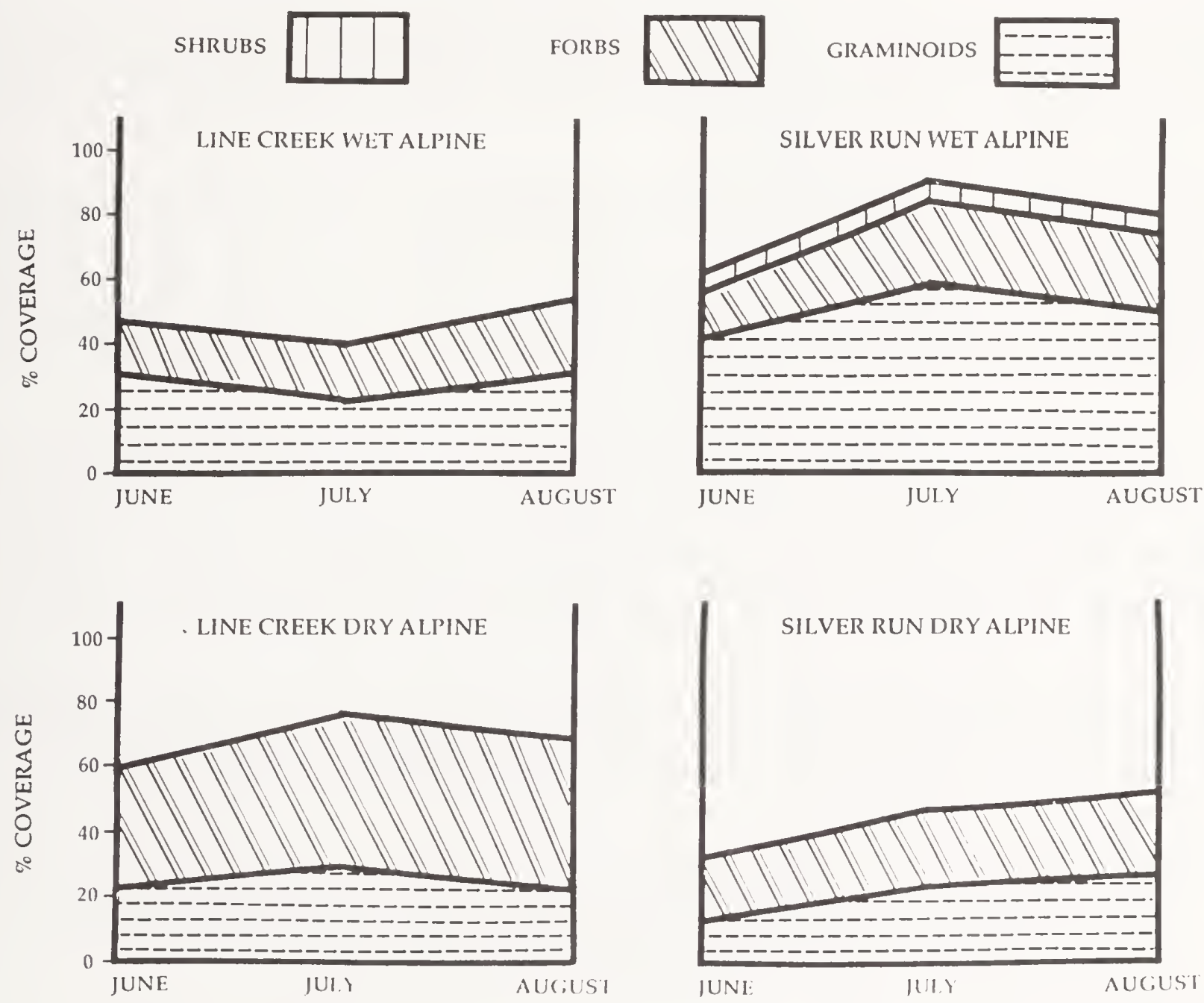

Figure 1. Plant coverage (percent) of shrubs, forbs, and graminoids on wet and dry alpine sites on the Line Creek and Silver Run study areas, south-central Montana, 1989-91. 
change in species composition. The least diverse community, SR wet alpine, experienced the least change.

\section{Plant Nutritional Quality}

Differences in plant nutritional values were not independent of study area, month, site type, or plant category $(p<0.02$, tables 3,4 , and 5$)$. SRP and LCP plants were similar in phosphorus (P) and TDN levels $(p>0.05)$ (table 3$)$. SRP plants had higher levels of moisture and lower levels of protein and calcium $(\mathrm{Ca})$ than LCP plants $(p<0.05)$.

Wet alpine vegetation had higher levels of protein on both plateaus $(p<0.01)$ (table 3$)$. Wet alpine sites also had higher $P$ levels. This difference was statistically significant only on the LCP $(p<0.01)$, but absolute differences were identical on both plateaus. Ca levels were higher on dry alpine areas $(p<0.01)$. Ca: $P$ ratios were within limits considered acceptable to ruminants, though higher ratios on dry alpine sites were approaching upper tolerance limits and may have partially offset advantages of increased Ca (Wise, Ordoveza, and Barrick 1963).

Plants on both plateaus showed declines in protein and P levels from June to July $(p<0.01)$ (table 4$)$. On the LCP, TDN also decreased from June to July, while moisture levels in plants increased $(p<0.05)$. The large increase in moisture content in shrubs was related to plant development, with shrubs usually not going into full leaf on the plateaus until mid-July. On both plateaus the greatest June to July nutritional declines occurred in forbs $(p<0.05)$. Ca:P ratios increased in all plant categories from June to July but remained within limits tolerable to ruminants (Wise, Ordoveza, and Barrick 1963).

Forbs were higher than graminoids in all nutrient categories on both plateaus $(p<0.05)$ (table 5). Shrubs also exceeded forbs in protein and $\mathrm{P}$ and, on the LCP, in TDN and $\mathrm{Ca}(p<0.05))$. Ca: $\mathrm{P}$ ratios in all plant categories were within limits acceptable to ruminants (Wise, Ordoveza, and Barrick 1963).

Table 1. Summer plant production ( $\mathrm{kg} / \mathrm{ha}$, dry weight) of graminoids and forbs on Line Creek (LC) and Silver Run (SR) study areas at wet and dry alpine sites, south-central Montana, 1989 - 1991

\begin{tabular}{|c|rl|rl|rr|rr|}
\hline & \multicolumn{2}{|c|}{ LC-WET } & \multicolumn{2}{c|}{ LC-DRY } & \multicolumn{2}{c|}{ SR-WET } & \multicolumn{2}{c|}{ SR-DRY } \\
\hline Forbs & 645.1 & $(218.0)^{\mathrm{a}}$ & 1094.6 & $(260.8)$ & 439.1 & $(65.4)$ & 357.7 & $(57.5)$ \\
Graminoids & 491.5 & $(157.3)$ & 536.4 & $(156.3)$ & 862.1 & $(106.4)$ & 282.4 & $(50.6)$ \\
\hline Total & 1136.6 & $(375.5)$ & 1659.8 & $(409.4)^{\mathrm{b}}$ & 1403.2 & $(160.5)^{\mathrm{b}}$ & 666.6 & $(114.0)^{\mathrm{b}}$ \\
\hline
\end{tabular}

${ }^{\text {a }}$ Standard error in parentheses.

${ }^{\text {b}}$ Total includes dry weight $(\mathrm{kg} / \mathrm{ha})$ of shrubs.

\section{Elk Habitat and Diet Selection}

Habitat use was not independent of population $(p<0.01)$ (figure 4$)$. Proportional use of different habitat types by elk in July and August was not different from availability in LC elk $(p=0.79)$ but was significantly different in SR elk $(p<0.01)$. SR elk made greater use of wet alpine areas and less use of dry alpine 


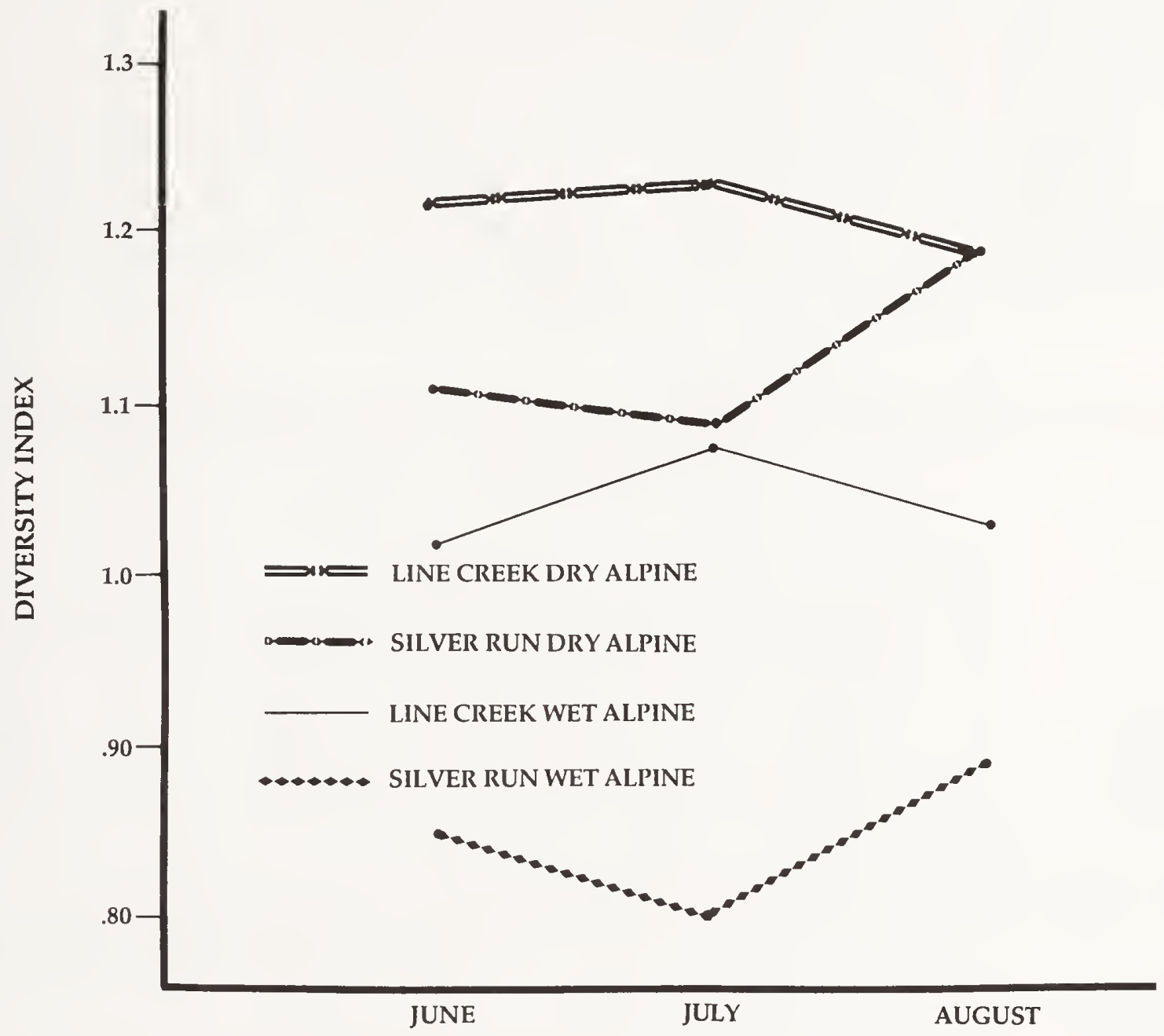

Figure 2. Species diversity (Shannon-Weiner) indices of wet and dry alpine sites from June - August on the Line Creek and Silver Run study areas, south-central Montana, 1989 - 91. 
areas than LC elk and appeared to select against dry alpine sites in favor of wet alpine and forested habitats. LC elk also tended to decrease use of plateau environments earlier than SR elk in any given year.

Graminoids formed the bulk of summer diets in both SR and LC elk (figure 5), but diet composition was not independent of herd $(p<0.05)$. SR elk made greater use of grasses, and LC elk made greater use of forbs. The most commonly consumed grasses were Poa spp. and Hesperochloa kingii (7.7 percent and 5.0 percent, respectively). Salix spp. were the most frequently used shrubs (6.6 percent). Geum rossii and Achillea millefolium were the most used forbs (3.0 percent and 1.4 percent, respectively). Graminoid composition remained nearly constant in both populations throughout the summer. Forb consumption increased in SR elk through early August but declined over the same period in LC elk. Average protein levels in elk diets did not vary between herds (SR 21.7 percent and LC 21.9 percent, $p=0.80$ ). However, LC elk showed a steady decline in protein levels from July through August. Protein levels of the SR herd remained constant until declining in mid-August.

Table 2. Average community similarity of wet and dry alpine sites on the Line Creek (LC) and on the Silver Run (SR) study areas in June - August, south-central Montana, $1989-1991$

\begin{tabular}{|l|c|c|c|c|}
\hline \multirow{2}{*}{ Site } & \multicolumn{4}{|c|}{ Site } \\
\cline { 2 - 5 } & LC-WET & LC-DRY & SR-WET & SR-DRY \\
\hline LC-WET & 100.0 & 45.3 & 51.8 & 68.8 \\
LC-DRY & 45.3 & 100.0 & 30.8 & 46.0 \\
SR-WET & 51.8 & 30.8 & 100.0 & 44.4 \\
SR-DRY & 68.8 & 46.0 & 44.4 & 100.0 \\
\hline
\end{tabular}

Note: Values range from 0 (no similarity) to 100 (identical species and proportions).

\section{Discussion}

\section{Plant Communities}

Species composition of wet and dry alpine plant communities on the SRP remained relatively stable throughout the summer. This was not the case on the LCP, particularly on the wet alpine site. From June through August increases of dry-site species and declines in some wet-site species suggested that the lower elevation LCP lost moisture more rapidly on wet sites than the higher elevation SRP. Consequently, the LCP had less persistence of species dependent on wet alpine areas. True wet alpine sites may not persist through the summer on the LCP, even in years of above-normal precipitation. In a drought year like 1988, it is possible that no wet alpine vegetation remained on the LCP after mid-July. Hayden-Wing (1980) found that 70 percent of all forage removed by elk in mountain meadows in the Idaho Primitive Area came from moist sites, though such sites contributed $<29$ percent of total forage production and only 36 percent of total area. Numerous studies in Montana have consistently identified moist areas, especially drainage heads, as receiving disproportionately heavy use by elk (Lyon et al. 1985), especially 


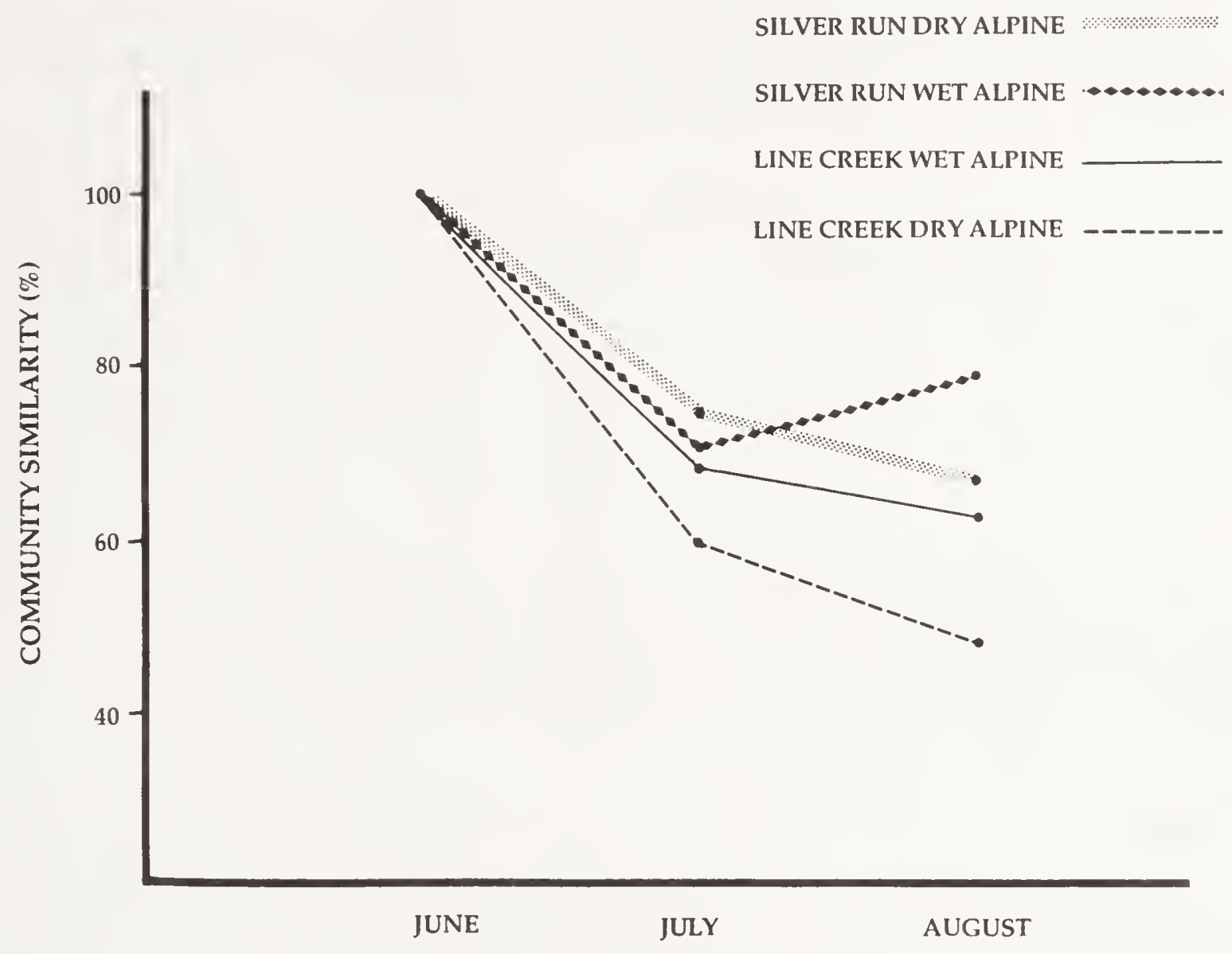

Figure 3. Succession of community similarity from Juen - August on the Line Creek and on the Silver Run study areas, south-central Montana, $1989-91$. 
during dry summers. A shortage of wet alpine sites on the LCP may constitute a detriment to elk summering on this plateau and may strongly influence habitat and diet selection in this population.

Table 3. Plant nutritional values (\%) of shrubs, forbs, and graminoids on wet and dry alpine sites on the Line Creek and Silver Run study areas in June and July, south-central Montana, 1989 - 1991

\begin{tabular}{|l|c|c|c|c|}
\hline \multirow{2}{*}{} & \multicolumn{2}{|c|}{ Line Creek } & \multicolumn{2}{c|}{ Silver Run } \\
\cline { 2 - 5 } & Wet alpine & Dry alpine & Wet alpine & Dry alpine \\
\hline Moisture & 58.50 & 57.50 & 62.90 & 60.00 \\
Protein & $13.40^{\mathrm{C}}$ & 12.10 & $11.90^{\mathrm{C}}$ & 10.80 \\
TDN & 63.50 & 63.50 & 62.00 & 62.00 \\
Ca & $0.73^{\mathrm{C}}$ & 0.93 & $0.59^{\mathrm{C}}$ & 0.84 \\
P & $0.17^{\mathrm{C}}$ & 0.14 & 0.17 & 0.14 \\
Ca:P & 4.29 & 6.64 & 3.47 & 6.60 \\
\hline
\end{tabular}

${ }^{a}$ Overall average different between plateaus. $p<0.05$. Multifactor ANOVA.

${ }^{b}$ Overall average different between plateaus. $p<0.01$. Multifactor ANOVA.

${ }^{C}$ Different from dry alpine, same plateau. $p<0.01$. Multifactor ANOVA.

Confidence interval test for differences between means.

\section{Plant Nutrition}

Nutritional differences between wet and dry alpine sites were relatively small, but higher protein and $\mathrm{P}$ levels at wet sites suggested that these conferred slight advantages to elk. Higher levels of $P$ would confer three advantages in particular. First, they would provide greater availability of an essential nutrient of particular importance to lactating females. Second, greater quantities of $P$ would lower the Ca:P ratio of ingested vegetation, thus increasing digestibility and weight gain/unit intake. Third, increased levels of $\mathrm{P}$ have been shown to cause a direct, linear increase in a ruminant animal's ability to absorb Ca into the bloodstream over a wide range of dietary Ca levels (Wise, Ordoveza, and Barrick 1963), thus increasing uptake of another nutrient that is also of particular importance in milk production and possibly offsetting the apparent disadvantage of lower levels of $\mathrm{Ca}$ associated with wet alpine sites.

\section{Summer Diets}

Both elk populations concentrated use on site types that had the highest plant production on their respective plateaus. Despite differences in habitat availability and in habitat and forage selection, the two common strategies demonstrated by both herds were to (1) use feeding sites in the most abundant habitat type, and (2) make a functional response to the most abundant plant category (forbs or grasses). Since dietary protein levels were well above plant averages, we can only conclude that elk elevated protein levels through selective foraging. Further, it appeared that elk found it more efficient to find forage of greater than average value in the more abundant plant categories, even if these had lower average 
Table 4. Plant nutritional values $(\%)$ of shrubs, forbs, and graminoids on the Line Creek and Silver Run study areas in June and July, south-central Montana, $1989-1991$

\begin{tabular}{|c|c|c|c|c|c|c|}
\hline & \multicolumn{3}{|c|}{ June } & \multicolumn{3}{|c|}{ July } \\
\hline & Shrubs & Forbs & Graminoids & Shrubs & Forbs & Graminoids \\
\hline \multicolumn{7}{|l|}{ Line Creek } \\
\hline Moisture ${ }^{a}$ & $20.50^{b}$ & 63.50 & $39.50^{b}$ & 73.30 & 67.90 & 53.60 \\
\hline Protein ${ }^{a}$ & $18.00^{b}$ & $17.00^{b}$ & 11.00 & 14.00 & 12.80 & 10.10 \\
\hline $\mathrm{TDN}^{\mathrm{a}}$ & - & $68.90^{b}$ & 60.40 & - & 65.00 & 58.70 \\
\hline $\mathrm{Ca}$ & 1.16 & 1.04 & 0.46 & 1.08 & 1.17 & 0.43 \\
\hline$P^{a}$ & 0.23 & $0.23^{b}$ & 0.12 & 0.17 & 0.15 & 0.09 \\
\hline $\mathrm{Ca}: \mathrm{P}$ & 5.04 & 4.52 & 3.83 & 6.35 & 7.80 & 4.78 \\
\hline \multicolumn{7}{|l|}{ Silver Run } \\
\hline Moisture & 59.8 & 69.80 & $45.40^{b}$ & 66.20 & 69.90 & 53.90 \\
\hline Protein $^{a}$ & 11.4 & $16.50^{b}$ & 9.40 & 12.20 & 11.80 & 8.70 \\
\hline $\mathrm{TDN}^{\mathrm{a}}$ & - & $69.30^{b}$ & $54.50^{b}$ & - & 65.10 & 59.20 \\
\hline $\mathrm{Ca}$ & - & $0.95^{b}$ & 0.35 & - & 1.15 & 0.38 \\
\hline $\mathrm{P}^{\mathrm{a}}$ & - & $0.24^{b}$ & 0.10 & - & 0.15 & 0.09 \\
\hline Ca:P & - & 3.95 & 3.50 & - & 7.67 & 4.22 \\
\hline
\end{tabular}

${ }^{a} X$ plant levels different by month on this plateau. $p<0.05$.

'Different from July, same plant category. $p<0.05$.

nutritional quality, than to invest time searching for plants of higher average nutritional levels in less abundant categories.

Elk favored graminoids on both the LCP and SRP despite the fact that forbs and shrubs on these ranges had higher moisture, protein, TDN, $\mathrm{Ca}$, and $\mathrm{P}$ levels. This finding may be consistent with the prediction of Spalinger and Robbins (1986) that ruminants such as elk should base forage selections more on structural characteristics of vegetation - especially plant cell wall thickness, which affect handling (rumination) time - rather than simply on dry matter digestibility.

\section{Predictions and Management Implications}

Geist (1982) noted that, to fatten adequately for winter, elk should seek out summer ranges with the following characteristics: (1) concentrated food supply, (2) minimal fiber content in forage, and (3) a large pulse (annual production cycle) in a short time. The alpine environment provides all three by (1) concentrating all forage in one photosynthetic layer (a mat of low forbs and graminoids with no trees and minimal shrub growth), (2) providing lower fiber content in forage than similar species at lower 
elevations (Baker and Hobbs 1982; Johnston, Bizeau, and Smoliak 1968), and (3) providing forage adapted to a short growing season during which almost all plant energy is diverted to new growth rather than maintenance of persistent plant structures. Hence, with the additional advantages of reduced stress from heat, insects, and humans, the well-documented patterns of elevational migrations to alpine summer range in Rocky Mountain elk in general (Craighead, Atwell, and O'Gara 1972) and in this study in particular appear to be a highly adaptive behavioral strategy that can be expected to continue.

Table 5. Plant nutritional values (\%) of shrubs, forbs, and graminoids on the Line Creek and Silver Run elk summer ranges in June and July, south-central Montana, 1989 - 1991

\begin{tabular}{|l|c|c|c|c|c|c|}
\hline & \multicolumn{3}{|c|}{ Line Creek } & \multicolumn{3}{c|}{ Silver Run } \\
\cline { 2 - 7 } & Shrubs & Forbs & Graminoids & Shrubs & Forbs & Graminoids \\
\hline Moisture & 58.20 & 66.20 & $48.80^{\mathrm{a}}$ & 65.20 & 69.90 & $51.40^{\mathrm{b}}$ \\
Protein & 15.10 & 14.50 & $10.40^{\mathrm{b}}$ & 12.10 & $13.50^{\mathrm{c}}$ & $8.90^{\mathrm{b}}$ \\
TDN & 66.90 & 66.70 & $59.30^{\mathrm{b}}$ & - & 66.90 & $57.20^{\mathrm{a}}$ \\
Ca & 1.10 & 1.10 & $0.45^{\mathrm{b}}$ & $0.57^{\mathrm{a}}$ & 1.01 & $0.36^{\mathrm{a}}$ \\
P & 0.19 & 0.19 & $0.10^{\mathrm{b}}$ & 0.19 & 0.21 & $0.09^{\mathrm{b}}$ \\
Ca:P & 5.79 & 5.79 & 4.50 & 3.00 & 4.80 & 4.00 \\
\hline
\end{tabular}

${ }^{a}$ Different from forbs. $p<0.05$. Multifactor ANOVA. Confidence interval test for differences between means.

${ }^{b}$ Different from forbs and shrubs. $p<0.05$. Multifactor ANOVA. Confidence interval test for differences between means.

'Different from shrubs. $p<0.05$. Multifactor ANOVA. Confidence interval test for differences between means.

Moist sites have been shown to be important forage reservoirs of high nutritional value during mid-and late summer (Marcum and Scott 1985). This importance appeared to be reflected in habitat selection characteristics of SR elk. Plant production and digestibility were similar in dry and wet alpine areas, and LC elk demonstrated that utilization of dry alpine sites can be an effective summer foraging strategy. However, the more rapid declines in summer dietary protein levels in this population, coupled with its chronically lower productivity, suggest that greater access to wet alpine areas could confer important nutritional benefits over dry alpine areas. Moist sites may be particularly important in drier years as forage reservoirs of high nutritional value (Marcum and Scott 1985).

Lyon and Ward $(1982,474)$ note that "The first consideration in a management plan for elk should be the protection of critical areas in order to ensure adequate and sustaining forage and cover supplies." Managers should ensure that high-elevation summer ranges remain accessible to adjacent elk populations and free from disturbances that reduce forage production or discourage elk use of the area. Because wet alpine areas appear to be less abundant on the LCP, creation of additional wet areas through water development projects may improve both quality of forage and long-term productivity of this population. 


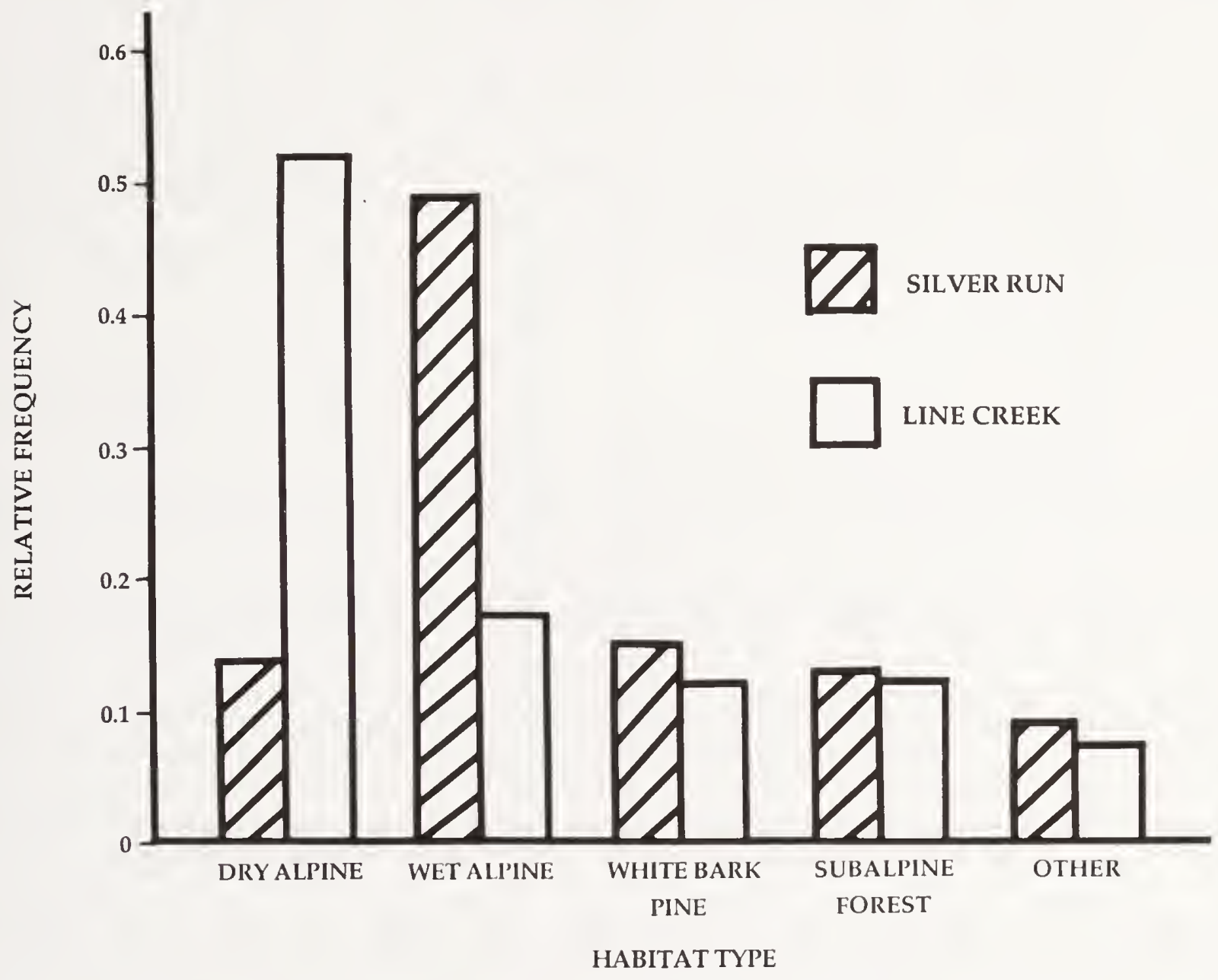

Figure 4. Use of habitat types in July and August by elk on the Line Creek and Silver Run study areas, south-central Montana, 1988 - 91. 


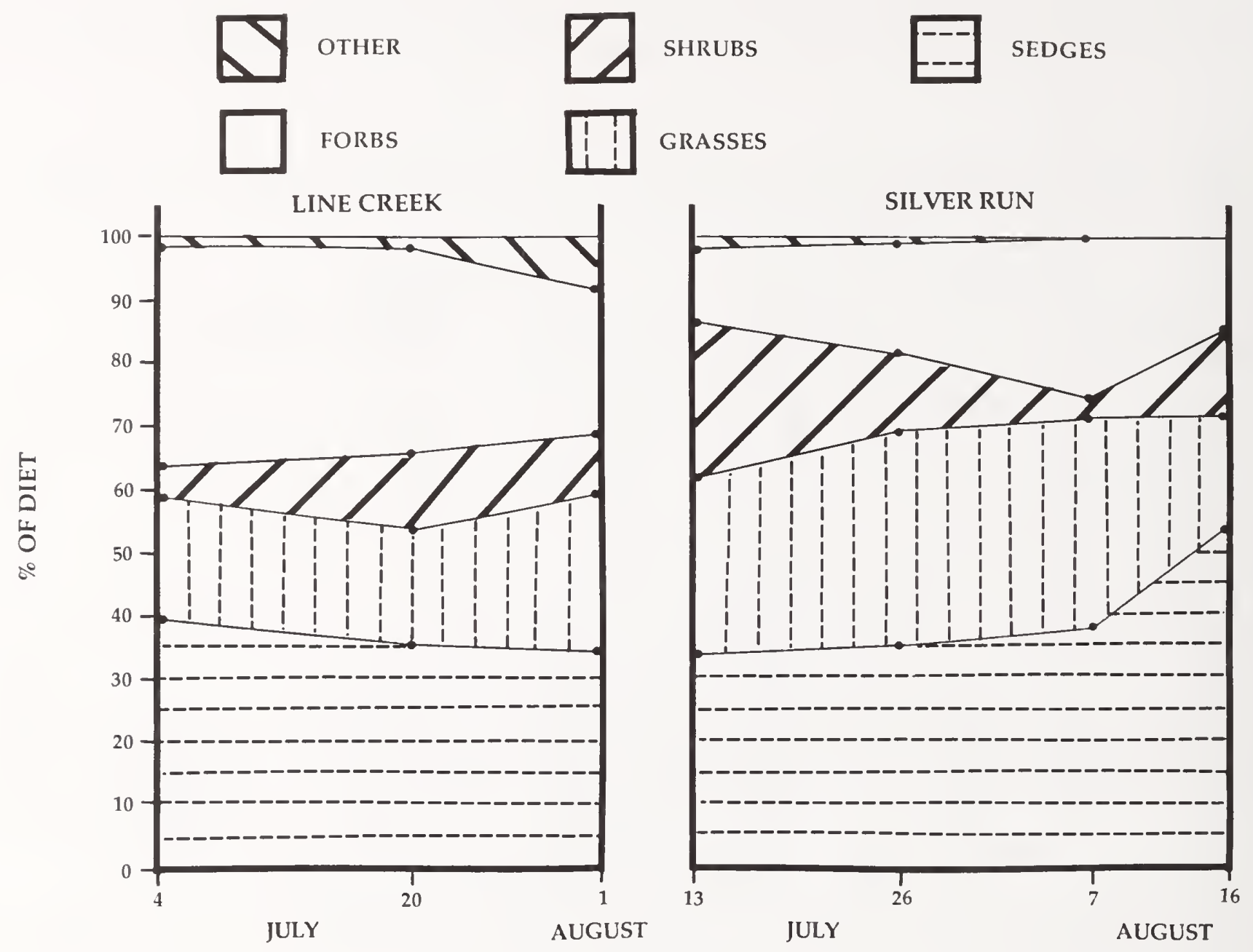

Figure 5. Grass, sedge, shrub, and forb proportions in July and August diets of elk on the Line Creek and Silver Run study areas, south-central Montana, 1988 - 89. 


\section{Acknowledgments}

This study was administered by the Montana Department of Fish, Wildlife, and Parks (MDFWP) through a cooperative agreement with the U. S. Forest Service (USFS), Custer National Forest, Beartooth District. Major funding was provided by the USFS, the Rocky Mountain Elk Foundation, and the Montana Chapter of Safari Club International. C.H. Goodall (Gordon College, MA), J.P. Skubinna (Bethel College, MN), and J.P. DiBenedetto (USFS), assisted with plot selection and plant identification and collection. L. Torma and the staff of the Chemistry Station Analytical Laboratory, Montana State University (MSU), Bozeman, conducted chemical nutritional analyses of plant samples. R.C. Brownson (Montana Agricultural Extension Service, MSU), determined values of total digestible nutrients (TDN) in samples. B.B. Davitt and the staff of the Wildlife Habitat Laboratory, Washington State University, Pullman, determined food habits and dietary protein levels in elk from pellet samples. Reviews by D.T. Patten, Arizona State University, Tempe, and two anonymous referees greatly improved an earlier draft of the manuscript.

\section{Literature Cited}

Association of Official Analytical Chemists. 1965. Official methods of analysis. 10th ed. Assoc. Official Analytical Chemists, Washington, D.C. 957pp.

Baker, D.L. and N.T. Hobbs, 1982. Composition and quality of elk summer diets in Colorado. Journal of Wildlife Management 46:694-703.

Boyce, M.S. and E.H. Merrill. 1989. Effects of the 1988 fires on ungulates in Yellowstone National Park. Tall Timbers Fire Ecology Conference. 18 May 1989. Tallahassee, Florida.

Craighead, J.J., G. Atwell, and B.W. O'Gara. 1972. Elk migrations in and near Yellowstone National Park. Wildlife Monographs 29. 48pp.

Geist, V. 1982. Adaptive Behavioral Strategies. Pages 219-277 in J.W. Thomas and D. E. Toweill, editors, Elk of North America: Ecology and Management. Stackpole Books. Harrisburg, Pennsylvania. 698pp.

Green, R.A. and G.D. Bear. 1990. Seasonal cycles and daily activity patterns of Rocky Mountain elk. Journal of Wildlife Management 54:272-279.

Hayden-Wing, L.D. 1980. Elk use of mountain meadows in the Idaho Primitive Area. Pages 40-46 in M.S. Boyce and L.D. Hayden-Wing, editors. North American elk: Ecology, Behavior, and Management. University of Wyoming. Laramie, Wyoming. 294pp.

Johnston, A., L.M. Bezeau, and S. Smoliak. 1968. Chemical composition and in vitro digestibility of alpine tundra plants. Journal of Wildlife Management 32:773-777.

Kufeld, R.D. 1973. Foods eaten by the Rocky Mountain Elk. Journal of Range Management 26:106-113.

Lyon, L.J., T.N. Lonner, J.P. Weigand, C.L. Marcum, W.D. Edge, J.D. Jones, D.W. McCleerey, and L.L. Hicks. 1985. Coordinating elk and timber management: final report of the Montana Cooperative Elk-Logging Study. Montana Department of Fish, Wildlife and Parks. Helena, Montana. 53pp. 
Lyon, L.J. and A.L. Ward. 1982. Elk and land management. Pages 443-447 in J.W. Thomas and D.E. Toweill, editors, Elk of North America: Ecology and Management. Stackpole Books. Harrisburg, Pennsylvania. 698pp.

Marcum, C.L. and M.D. Scott. 1985. Influences of weather on elk spring-summer habitat. Journal of Wildlife Management 49:73-76

Scotter, G.W. 1980. Management of wild ungulate habitat in the United States and Canada: a review. Journal of Range Management 33:16-27.

Spalinger, D.E. and C.T. Robbins. 1986. The assessment of handling time in ruminants: the effect of plant chemical and physical structure on the rate of breakdown of plant particles in the rumen of deer and elk. Canadian Journal of Zoology 64:312-321.

U.S. Department of Commerce. 1992. Annual climatological summary. U.S. Department of Commerce. Asheville, North Carolina.

Wise, M.B., A.L. Ordoveza, and E.R. Barrick. 1963. Influence of variations in dietary calcium:phosphorous ratio on performance and blood constituents of calves. Journal of Nutrition 79:79-84. 


\title{
Long-term Vegetational Response to Climatic Change and Edaphic Conditions in Yellowstone National Park
}

\author{
Cathy Whitlock \\ Department of Geography \\ University of Oregon \\ Eugene, OR 97403
}

The distribution of vegetation in Yellowstone National Park represents the response of plants to a hierarchical set of environmental controls that operate on different temporal and spatial scales. On time scales of several millennia and at hemispheric spatial scales, slowly varying components of the climate system (e.g., ice-sheet size and ocean-surface temperature) influence continental and regional patterns of temperature and moisture. Spatial distributions of vegetation on a finer landscape scale are further influenced by local variations in environment, including substrate, microclimate, and biological interactions. An understanding of vegetational history provides a means to assess the relative importance of these controls. This information is available from radiocarbon-dated pollen records obtained from sediment cores collected in lakes and wetlands.

In the last 15,000 years, three large-scale controls have dominated the climate system of the western U.S. (see Barnosky, Anderson, and Bartlein 1987; COHMAP Members 1988; Thompson et al. in press). The first was the direct effect of the Laurentide ice sheet on northern hemisphere temperatures. The ice sheet at its maximum size depressed temperatures by $4^{\circ} \mathrm{C}-10^{\circ} \mathrm{C}$ in the northern middle latitudes (Broccoli and Manabe 1987; Kutzbach and Guetter 1986). The second control was the latitude of the jet stream, which was governed by the size of the Laurentide ice sheet. The third control was the amplitude of the seasonal cycle of radiation. Between 12,000 and 6,000 years before the present (yr B.P.) the seasonal cycle of radiation was amplified relative to the present as a result of the greater tilt of the earth's axis then and the occurrence of perihelion in summer (Kutzbach and Guetter 1986). Maximum amplification occurred between 10,000 and 9,000 yr B.P., when summer radiation in the northern hemisphere was greater than today by c. 8 percent (Kutzbach 1987).

Paleoclimatic simulations with general circulation models suggest how climatic patterns in the western United States may have responded to these controls (Barnosky, Anderson, and Bartlein 1987; COHMAP Members 1988; Thompson et al. in press). In model simulations of 12,000 yr B.P., winter precipitation was higher than before in the Yellowstone region as a result of the northward shift of the jet stream from its full-glacial position. Annual temperatures were also higher as a result of a smaller Laurentide ice sheet and greater solar radiation in summer. Model simulations place the jet stream in its present position at 9,000 yr B.P. Greater summer radiation at 9,000 yr B.P. directly increased temperatures and decreased effective moisture in the northwestern United States. Indirectly, increased summer radiation caused an 
expansion of the eastern Pacific subtropical high pressure system off the Northwest (Heusser, Heusser, and Peteet 1985).

The direct and indirect effects together brought intense summer drought and warming to the northwestern United States. In the Rocky Mountain region, increased summer radiation indirectly strengthened onshore flow of air into the southwest, causing an increase in summer precipitation (Thompson et al. in press). In the model simulations for 6,000 yr B.P., the subtropical high is weaker than at 9,000 yr B.P. but still stronger than at present, while the onshore flow diminished and shifted eastward toward the Great Plains. Thus the northwestern United States became gradually wetter and cooler, while the southwest and Rocky Mountain region became drier and cooler.

In general, the fossil pollen record from the Yellowstone region corroborates this climatic scenario and illustrates the importance of the large-scale controls. During the early part $(15,000-10,000 \mathrm{yr}$ B.P.) of the postglacial period, the patterns of vegetational change were broadly similar throughout the region (Baker 1976, 1983; Barnosky, Anderson, and Bartlein 1987; Gennett and Baker 1986; Waddington and Wright 1974; Whitlock 1993). Tundra vegetation colonized the denuded terrain as early as 15,000 yr B.P. As the climate warmed, Engelmann spruce invaded the region and grew in an open parkland between 12,000 and 11,000 yr B.P. Subalpine fir and pine were present by 11,000 yr B.P. and formed a subalpine forest like the present-day spruce, fir, and whitebark pine forest of the region. At 10,000 yr B.P. lodgepole pine became the dominant conifer at most of the study sites.

The vegetation history of the Central Plateau represents an exception to the general sequence (Whitlock 1993). Pollen data indicate that the plateau was largely treeless before $10,000 \mathrm{yr}$ B.P. The region today is characterized by infertile rhyolitic soils that support lodgepole pine forest (Despain 1983). The absence of spruce, fir, and whitebark pine in the early postglacial period suggests that these species have always grown poorly on rhyolitic substrates, even when lodgepole pine was not a competitor. In this case edaphic controls were as important as climate in shaping the early character of the vegetation.

In the last 10,000 years the vegetational history of the Yellowstone region has been spatially more heterogeneous (Whitlock and Bartlein 1993). The major contrasts have occurred between regions that today experience a summer-dry climate and those that are summer-wet. The summer-dry area includes central and southern Yellowstone National Park and northern Grand Teton National Park. In this region lodgepole pine, Douglas-fir, and in some cases aspen were more abundant in the forest between 9,500 and 5,000 yr B.P. These taxa imply that summers were warmer and drier during this interval than at present. After 5,000 yr B.P. a closed spruce-fir-pine forest developed as conditions became cooler and more humid.

The northern range lies in the summer-wet region. Pollen records suggest that the northern range was occupied by a forest of limber pine, possibly whitebark pine, lodgepole pine, and juniper between 9,500 and 7,000 yr B.P. The apparent absence of Douglas-fir parkland indicates that summer then was wetter than today. Beginning at 7,000 yr B.P. and more markedly after 3,000 yr B.P., the introduction of dry parkland conditions is inferred from the increase in Douglas-fir and grass pollen.

The contrast in the vegetational history between 9,500 and 5,000 yr B.P. suggests that different parts of the Yellowstone region were responding to different climatic controls created by the amplification of the seasonal cycle of solar radiation. The southern summer-dry region experienced greater summer drought, probably as a result of the strengthened subtropical high. Concurrently the northern range received greater summer precipitation as a result of enhanced monsoonal circulation. The overall effect was that 
the increase in summer radiation served to intensify the summer-wet/summer-dry contrast in climate that exists between these two regions today (Whitlock and Bartlein 1993).

The paleoecologic record therefore provides evidence that the vegetation of the Yellowstone region is a product of changes in large-scale hemispheric controls, continental changes in atmospheric circulation, and regional and local environmental variations. Seasonal changes in solar radiation, which affected the entire hemisphere, were manifest in Yellowstone as an intensification of sharply delimited climatic regimes and vegetational patterns. The fact that disparate vegetational changes on a local scale occur in response to changes in large-scale controls has important implications in considering the vegetational patterns that may develop in Yellowstone with future global climatic changes.

\section{Literature Cited}

Baker, R.G. 1976. Late Quaternary vegetation history of the Yellowstone Lake basin, Wyoming. U.S. Geological Survey Prof. Paper 729-E:E1-E48.

Baker, R.G. 1983. Holocene vegetational history of the western United States. Pages 109-127 in H.E. Wright, Jr., ed., Late-Quaternary Environments of the United States. University of Minnesota Press, Minneapolis, Minnesota.

Barnosky, C.W., P.M. Anderson, and P.J. Bartlein. 1987. The northwestern U.S. during deglaciation: vegetational history and paleoclimatic implications. Pages 289-321 in W.F. Ruddiman and H.E. Wright, Jr., editors, North America and Adjacent Oceans During the Last Deglaciation. The Geology of North America. Vol. K-3. Geological Society of America, Boulder, Colorado.

Broccoli, A.J. and S. Manabe. 1987. The influence of continental ice, atmospheric $\mathrm{CO}_{2}$, and land albedo on the climate of the last glacial maximum. Climate Dynamics 1:87-99.

COHMAP Members. 1988. Climatic changes of the last 18,000 years: observations and model simulations. Science 241:1043-1052.

Despain, D.G. 1983. Nonpyrogenous climax lodgepole pine communities in Yellowstone National Park. Ecology 64:231-234.

Gennett, J.A. and R.G. Baker. 1986. A late-Quaternary pollen sequence from Blacktail Pond, Yellowstone National Park, Wyoming, U.S.A. Palynology 10:61-71.

Heusser, C.J., L.E. Heusser, and D.M. Peteet. 1985. Late-Quaternary temperatures and precipitation for the northwest coast of North America. Nature 315:485-487.

Kutzbach, J.E. 1987. Model simulations of climatic patterns during the deglaciation of North America. Pages 425-446 in W.F. Ruddiman and H.E. Wright, Jr., editors, North America and Adjacent Oceans During the Last Deglaciation. The Geology of North America. Vol. K-3. Geological Society of America, Boulder, Colorado. 
Kutzbach, J.E. and P.J. Guetter. 1986. The influence of changing orbital patterns and surface boundary conditions on climate simulations for the past 18,000 years. Journal of Atmospheric Sciences 43:1726-1759.

Thompson, R.S., C. Whitlock, P.J. Bartlein, S.P. Harrison, and W.G. Spaulding, in press. Climatic changes in the western United States since 18,000 yr B.P. In H.E. Wright, Jr., J.E. Kutzbach, T. Webb III, W.F. Ruddiman, F.A. Street-Perrott, and P.J. Bartlein, editors, Global Climates Since the Last Glacial Maximum. University of Minnesota Press, Minneapolis, Minnesota.

Waddington, J.C.B. and H.E. Wright, Jr. 1974. Late Quaternary vegetational changes on the east side of Yellowstone Park, Wyoming. Quaternary Research 4:175-184.

Whitlock, C. 1993. Postglacial vegetation and climate of Grand Teton and southern Yellowstone National Parks. Ecology. In press.

Whitlock, C. and P.J. Bartlein. 1993. Spatial variations of Holocene climatic change in the Yellowstone region. Quaternary Research 39. In press. 


\title{
Yellowstone Plants and Their Environments: A Conference Review
}

\author{
Dennis H. Knight \\ Department of Botany, University of Wyoming \\ Laramie, WY 82071
}

If Yellowstone National Park (YNP) is an indicator, more scientists are working in national parks than ever before. This is fortunate because the challenge of maintaining parks in their "natural" state, in perpetuity, is formidable and requires pertinent ecological information of the highest quality. Progress is being made in Yellowstone. Two hundred scientists and managers from seventeen colleges and universities, five state and federal agencies, and five other organizations were attracted to the First Biennial Scientific Conference on the Greater Yellowstone Ecosystem (GYE). With "Plants and Their Environments" as the conference theme, most of the 60 presentations focused on paleoecology, plant-fire interactions, plantfire-insect interactions, and plant-large mammal interactions. Nearly all of the papers pertained to research in YNP. In general, the results presented at the conference were impressive. About two-thirds of the papers were quantitative and analytical or experimental. This is encouraging, as debates pertaining to park management can only be resolved with the application of good science. More than anecdotal observations are needed.

The conference provided an opportunity for exchange of information among scientists and managers representing plant ecology and many other disciplines. Among other topics, the proceedings include papers on the effects of the 1988 fires on stream chemistry and microorganisms, the effects of fuel moisture on fire spread, the effect of large herbivores on riparian bird species diversity, natural area selection and design, the production of secondary metabolites, genetic analyses of plant populations, grizzly bear food, models of ungulate behavior, packhorse impacts, fire behavior, and the challenges of fire management. The broad range of topics can be appreciated more fully by scanning the table of contents. This review focuses on the papers that pertained most directly to Yellowstone plants and their environment.

\section{Paleoecology and Climate Change}

Because national parks are part of our natural heritage, many would prefer that they not change. Human instinct encourages preservation or restoration. But ecosystems are continually changing, a fact that was made clear by the paleoecologists participating in the conference. Based on fossil pollen records from lake sediments, Whitlock determined that tundra was prevalent in Yellowstone at the time of glacier 
retreat $\sim 14,000$ years before present (B.P.). About 11,500 years B.P., Engelmann spruce formed a spruce parkland on the comparatively more fertile, nonrhyolitic substrates. Whitebark pine and subalpine fir joined the spruce several centuries later (11,000 - 9,500 years B.P.), but the rhyolitic soils of the Central Plateau remained unforested during this period. The climate gradually became warmer, although it was cooler and more humid than today. Continued warming since 9,500 years B.P. led to the expansion of lodgepole pine throughout the GYE. Limber pine was present at low elevations, and Douglas-fir expanded to higher elevations between 9,500 and 4,500 years B.P. In the last 4,500 years the climate has become cooler and wetter at high elevations and, as a result, spruce and fir are more common there. Concurrently, Douglas-fir woodlands are now found only at lower elevations.

Two other presentations illustrated more recent vegetation change. Barnosky studied packrat middens in caves. By identifying the species of small mammal bones found at different depths, she concluded that the grasslands of the Lamar River valley were taller and more mesic about 1,500 years B.P. The climate subsequently became drier, however, and within 500 years, a shorter grassland had developed. Fires also caused change. Millspaugh studied layers of charcoal sediments in lakes on the Central Plateau, with the objective of documenting fires over a longer time span than is possible from traditional tree ring - fire scar studies. Seven periods of extensive fires were dated from the present back to 1520.

Although paleoecologists typically examine changes on the scale of millenia, it seems clear that fires and climatic change occur at the scale of centuries - the same time scale at which forest succession occurs. This observation makes it difficult to know with confidence whether future changes in YNP vegetation will be the result of management decisions, climatic change, or other processes. Dwight Billings, in his keynote address, discussed the kinds of changes that could occur with global warming. Among other predictions, he suggested that alpine species might not be able to tolerate their mountaintop habitats if warming occurs too rapidly.

Overall, the paleoecological presentations were detailed and convincing. Acknowledging the changes documented by paleoecologists has promoted process-oriented management rather than the object- or scene-oriented management mandated by the 1916 Organic Act for the National Park Service - 75 years ago - and reinforced 28 years ago by the Leopold Report. Norman Christensen, in the first A. Starker Leopold Lecture, discussed the importance of understanding ecological processes in changing environments, but he also cautioned that process-oriented management should not ignore the sociopolitical importance of preserving species or specific landscape mosaics when that is possible and prudent.

\section{Plant-Fire Interactions}

Many ecologists predicted the effects of the 1988 fires. Some of the predictions were correct, but results presented at the conference indicate that views are changing on certain aspects of fire ecology in the Greater Yellowstone Ecosystem. In particular, new information is now available on seed banks, regrowth of herbaceous vegetation, lodgepole pine seedling establishment, insect-fire interactions, fire behavior, and the effects of fire on aquatic ecosystems. Fortunately, the 1988 fires were carefully documented with maps that show the time and rate of burning, and with aerial photographs that sometimes enable the determination of burn intensity (Chase, Hartford, and Rothermel). Some excellent studies have been initiated. 
A common prediction during and after the 1988 fires was that the perennial understory vegetation would expand rapidly by vegetative reproduction. This process might be comparatively slow where understory vegetation was sparse prior to the fire, such as in some old-growth forests or on comparatively dry or infertile soils. Still, herbaceous recovery was expected to be quite rapid. In fact, a wide range of understory responses was observed, with dense "flower gardens" developing in some areas and hardly any herbaceous cover developing elsewhere even after three years. In most forests, vegetative regrowth was quite slow in the first year but increased rapidly in the second year (1989-90). Whether originating from sprouting or seedling establishment, the new plants grew and reproduced vigorously in the absence of competition from trees. Many of the plants were annuals in the second and third years (Turner, Romme, and Gardner).

In general, stands subjected to hot crown fires have less vegetative cover (sometimes $<5$ percent) after three years than those that burned less intensively. Older stands with sparse herbaceous vegetation might have burned more intensively than younger stands, but two papers suggested that hot crown fires in 1988 were governed more by climatic conditions than by stand age or fuel availability (Renkin and Despain; Turner et al.). Renkin and Despain reported that flammability increased greatly when the moisture content of dead and down wood $(>7.6 \mathrm{~cm})$ was 13 percent or below, and that seral stage was not an important factor determining burn intensity in late summer when the fuels had less than 10 percent moisture. They also found that stand-replacing fires were less common in Douglas-fir forests than in more dense lodgepole pine forests.

Riparian vegetation and grassland or meadow vegetation recovered more rapidly than the coniferous forests because of a greater prefire abundance of plants capable of sprouting. Both annual net primary productivity (NPP) and grazing were found to be higher on burned winter range in 1989 and 1990 than on comparable unburned sites (Wallace, Turner, Romme, Despain, O'Hara, and Wu). Keigley presented a conceptual framework for evaluating the effects of fire and subsequent flooding on riparian vegetation. Lawrence and Minshall observed recovery of riparian vegetation within a year after the 1988 fires, but floods during the second year uprooted much of the vegetation.

Plant ecologists have given great emphasis recently to the importance of dormant seed in determining the trajectory and rate of succession following disturbances. Clark, Weaver, and Despain compared seed banks in different habitats that had burned at varying intensities to areas that had not burned. Surface soil samples were cultured in a greenhouse under conditions favorable for seed germination. New seedling density ranged from 13 to $7,000 / \mathrm{m}^{2}$ in unburned forests and savannas, and from 500 to $15,000 / \mathrm{m}^{2}$ in unburned meadows and grasslands. Clark et al. found that hot fires could kill many of the seeds in the soil. Seeds that did survive, however, germinated and grew rapidly in the second and third years, greatly enlarging the seed bank and, subsequently, plant density. On unburned sites, the surface soil increased in estimated seed density from warm-dry to cool-wet sites, and decreased in seed density with stand age. In some areas, the seed bank of unburned forest soils was surprisingly sparse, with many expected species not being found.

In a laboratory study, Clark et al. measured the temperature tolerances of seeds. While some species were intolerant of $50^{\circ} \mathrm{C}$ (e.g., lodgepole pine), the germination of most species was stimulated by that same temperature. Only a few species survived $150^{\circ} \mathrm{C}$.

The adaptations of lodgepole pine were discussed frequently in 1988, primarily in terms of the serotinous cones that were thought to characterize most trees. Serotinous cones store seed for many years before heat breaks the resin bonds on the cone scales. The seed is then dispersed by wind, often following fire and at a time when conditions for the establishment of this pioneer species are ideal. Thus, the "seed 
bank" for lodgepole pine is mostly in the cones rather than the soil. Two observations presented at the conference suggest a somewhat different interpretation. First, the proportion of lodgepole pine trees in Yellowstone that are serotinous may be lower than many believed (from 0 percent to 48 percent of the trees in different stands; Ellis, von Dohlen, Anderson, and Romme), and second, the 1988 crown fires often burned the cones along with the enclosed seeds. To be sure, many lodgepole pine seedlings have become established since 1988, sometimes at "doghair" densities of up to $180 / \mathrm{m}^{2}$, but most of the seed apparently is coming from adjacent unburned forest or from trees that were burned only partially or at moderate temperatures (Ellis et al.). Light or moderately burned stands had seedling densities that were 4 to 24 times greater than hotter burns. Lodgepole seed dispersal from serotinous cones can be $50 \mathrm{~m}$ or more, but seedling density was highest near the edge of stand-replacing crown fires. Contrary to popular belief, seedling density was not correlated only with the percentage of serotinous trees. Distance from unburned or lightly to moderately burned forest is also important. In other words, seedling density seems to be a function of seed mortality during fire.

This modified view of serotiny as an adaptation to fire is one of the more important observations to emerge thus far from fire research in Yellowstone. It is important to note, however, that seedling density now exceeds prefire tree density in many of the forests that have been studied, and surely this fact is partially due to the seed storage capacity of those trees with serotinous cones that, by chance, were burned less severely. It is also noteworthy that the centers of areas burned with hot crown fires had very few tree seedlings in 1991.

Aspen also is reproducing well after the 1988 fires (Renkin, Despain, and Clark). Most botanists had believed that aspen seedling establishment is a rare event, but seedlings of this species were abundant in 1989 - probably because the fire created ideal seed-bed conditions (Renkin et al.). The establishment of aspen seedlings is known to require an extended period of moist conditions, such as occurs with much-reduced water uptake from the soil following the death of so many nonsprouting conifers. As a result of the fires, aspen probably will become more abundant (though it may still occupy less than about 8 percent of the park).

\section{Plant-Fire-Insect Interactions}

Many have speculated about the interactions between fire and insects (especially bark beetles in the genera Dendroctonus and Ips). For example, insect-caused tree mortality is sometimes suggested as a mechanism for increasing forest flammability. Turner, Romme, and Gardner observed that light or moderate insect infestations can actually reduce the occurrence of crown fires, primarily by reducing fuel continuity. Mistletoe is thought to have a similar effect. However, forests with severe infestations of insects or mistletoe were burned by hot crown fires in 1988 more often than would have been expected by chance (Turner et al.).

Trees that are injured by fire but not killed, such as those on the edge of a crown-fire burn, are thought to be more susceptible to invasion by bark beetles. Ryan and Amman found this to be true for Douglasfir following the 1988 fires, with injured trees being the source of Douglas-fir bark beetles (Dendroctonus pseudotsugae) that now are spreading to some unburned trees. Thus, postfire mortality can be caused secondarily by the insects. Apparently, the burning of bark at the base of Douglas-fir trees, where litter accumulates, facilitates bark beetle invasion. Healthy trees also can be invaded successfully when the beetle population is large. Ryan and Amman observed the same interaction between Engelmann spruce 
and spruce beetle ( $D$. rufipennis), though cold winters have greatly reduced spruce beetle population sizes.

It is interesting that mountain pine beetles ( $D$. ponderosae) have not yet reacted in the same way to firedamaged lodgepole pine. Ryan and Amman found that fire-damaged lodgepole pine often had high populations of the Ips bark beetle, but not the mountain pine beetle. They doubted that the spread of mountain pine beetles would be hastened by the 1988 fires.

\section{Plant - Large Mammal Interactions}

Perhaps the most controversial topic in Yellowstone plant ecology is the effect of elk and bison on winter range, particularly the northern range where 60 and 28 percent of the YNP elk and bison herds, respectively, winter. Elk and bison populations on the northern range were quite high in 1988 (about 20,000 elk and 900 bison). Such high numbers have been attributed to a series of mild winters that allowed more of the animals to overwinter in the park, thereby avoiding predation by hunters (569 of the 900 bison were killed by hunters outside YNP during the harsher winter of 1989 - 90; S. Coleman, personal communication). Also, a comparatively small proportion of the herd has been lost due to insufficient winter food. Some are convinced that the winter range is overgrazed, a view that is supported by evidence of heavy browsing on aspen, willow, and even juniper.

Several studies are nearing completion on the effects of elk and bison on winter range. With regard to grasslands, no evidence was presented at the conference that suggests excessive grazing. S.J. McNaughton, in his keynote address, put this research in perspective by pointing out similarities between Yellowstone and the Serengeti of Africa. In both places, large ungulates can stimulate annual NPP, probably through the removal of apical dominance and the enrichment of soil fertility by urination and defecation. Despite the consumption by elk of 45 percent of the biomass, Frank and McNaughton found that NPP on the Northern Range was 36 to 85 percent higher than in exclosures. Moreover, Singer and Harter observed higher protein content in grasses on grazed plots. Wallace found no correlations between grazing intensity and plant species diversity, and two studies concluded that variations in climatic conditions were more important than grazing intensity in causing the biomass fluctuations that were observed (Coughenour, Singer, and Reardon; Wallace). Lane and Montagne observed that soil bulk density was somewhat higher outside of long-term grazing exclosures, but they did not conclude that grazing had a deleterious effect.

The reason that high levels of grazing are not having an adverse impact on herbaceous vegetation is, perhaps, that much of the foraging occurs when the plants are dormant during the fall or winter. In the spring, elk and bison disperse to higher elevations as new plant biomass is produced. By moving up the mountain, the herbivores extend the period that nutritious forage is available to them and minimize the length of grazing time in a particular area (Coughenour). Grazing intensity on the winter range is thereby comparatively low during the summer when plants are storing energy in root systems for the following year. As McNaughton pointed out in comparing YNP to the Serengeti, the seasonal migrations of large herbivores must be considered when evaluating carrying capacity. Models are now being developed that simulate elk foraging behavior in relation to forage availability, snow depth, metabolic requirements, and other factors. It was encouraging to see the incorporation of physiological information on plants and animals in these models (Coughenour; Van Dyke), just as it was encouraging to learn about the importance of nematode herbivory in a session that focused largely on ungulates (Merrill, Stanton, and Hak). Future research on carrying capacity should take a holistic view of the ecosystem. 
In contrast to their impact on herbaceous plants of grasslands, large ungulates are having a significant impact on aspen and willows. Photographs shown during the conference illustrate heavy browsing. Often the aspen trees appear restricted to exclosures, though small root sprouts (not apparent in the photographs) may persist elsewhere despite heavy browsing (Despain). Aspen bark is eaten by elk during the winter, leading to the formation of conspicuous scar tissue. Despain suggests that scar formation, root sprouting, and the production of chemicals that minimize herbivory are important mechanisms that enable aspen to tolerate browsing. Apparently unprotected plants remain small until, for some reason, there is a period of several years when browsing is less intensive. The same may be true for willows (Singer and Mack), though Kay and Wagner showed photographs suggesting that willows have been eliminated from some riparian zones during the past century. It is possible that both aspen and willows could have been eliminated from some areas by heavy browsing pressure, but no maps or data were presented at the conference to indicate whether such losses are rare or widespread.

Kay and Wagner concluded that the cause of heavy or excessive browsing on woody plants is the large number of elk that now winter in YNP. Comparing historic photos with modern photos, they note an abundance of willow and the lack of scar tissue on aspen bark in the 1800s. Such comparisons, they argue, falsify the assumption that the current level of elk influences on winter range is natural. They believe that the winter concentrations of elk on the northern range have been caused by human pressures in the past century on prehistoric winter ranges outside of the park. If adverse effects on winter range plants can be documented, they would advocate either herd reduction or the acquisition of more winter range. To evaluate their argument, it is necessary to determine the extent of aspen and willow deterioration in relation to succession, fire, and climatic trends as well as the current level of herbivory. Photographs suggest some interesting hypotheses, but they can only be tested with spatial and temporal analyses.

Less controversial is the interaction between whitebark pine and grizzly bears. The large seeds of this pine are an important food for the bears, and four presentations at the conference described some of the details (McCaughey; Mattson; Mattson and Reinhart; Morgan and Bunting). For example, abundant seed is produced by individual trees at intervals of three to seven years, depending on environmental conditions and age. Frost and insects can reduce the quantity of seed produced, and seed-caching birds such as the Clark's Nutcracker are competitors for this food source. In subalpine forests, the availability of seed to bears is sometimes enhanced by squirrels that cut cone-bearing branches. Bears then eat the seed on the ground or raid squirrel seed caches.

\section{Habitat Restoration}

Many are concerned about the environmental and aesthetic damage caused by the 30 miles of fire lines constructed in 1988. The Park Service responded to this problem with a massive effort that involved the planting of native species and the replacement of logs and other detritus. This work was done by hand and the results were very impressive, as illustrated with photographs at the conference Williams and Smith). It was encouraging to learn that erosion from these firelines was minimal and that thus far there is no evidence suggesting that the firelines will serve as corridors for the invasion of exotic plants. YNP staff and others working on restoration in the GYE (Chambers, Brown, and MacMahon) have learned a great deal about seed biology and the establishment requirements of native plants. 


\section{Summary}

Knowledge pertaining to the ecology of plants in Yellowstone National Park was advanced to a new level of sophistication by the participants in this first conference on science in the Greater Yellowstone Ecosystem. New results were presented on prehistoric vegetation dynamics, successional patterns following the 1988 fires, interactions between insects and fire-damaged trees, habitat restoration, the effects of fires on riparian ecosystems, and the effects of large mammals on northern range grasslands.

Some topics were conspicuous by their absence. For example, there was only one paper on plants of the geyser basins of Yellowstone. Similarly, there was only one paper on the vascular plants of the region's rivers and lakes. Moreoever, despite the availability of digitized vegetation maps for the park, they were not used except for one or two studies of the northern winter range. There were no reports on exotic plants, nor on the plants of unusual habitats such as the Pitchstone Plateau. With the exception of one nematode report and one mycological study, the interactions of vascular plants and microorganisms were not addressed; and little was presented on the responses of plants to environmental gradients (except for studies done on the northern range). A few studies addressed interactions between terrestrial and aquatic ecosystems, but this topic alone could be the theme of a future conference.

Several clear messages emerged from the conference: (1) ecosystem change is a long-term process that may preclude the development of an equilibrium; (2) succession following the 1988 fires is highly variable and depends on fire intensity, prefire seed density in the soil, and the prefire abundance of sprouting plants; (3) lodgepole pine seedling density following fire is determined as much by burn intensity as by the abundance of serotinous cones; (4) herbaceous plants are not adversely affected by current numbers of elk and bison in the park, though heavy browsing on willows and aspen is obvious; and (5) climate is the dominant factor determining flammability, insect population dynamics, and the productivity of winter ranges.

Yellowstone National Park and the Greater Yellowstone Ecosystem offer many research opportunities in landscapes relatively free from human influences. There is great environmental variability, and whole networks of watersheds, not just isolated forests or meadows, have been subjected to essentially natural influences for millenia. Fire suppression probably has had a minor effect in most areas, and air quality is comparatively good. Like other large parks and natural areas, Yellowstone provides opportunities for long-term experiments on such topics as natural regulation, the interactions of factors affecting plant and animal populations, and the effects of terrestrial vegetation patterns on aquatic ecosystems. Given the opportunity, scientists can help managers achieve the important but difficult goal of natural area preservation.

\section{Acknowledgments}

Gene Amman, Bill Romme, Linda Wallace, Tad Weaver, and Cathy Whitlock provided helpful comments on an early draft of this review. 

Section II

\section{Conference Abstracts}





\title{
GIS Documentation of the 1988 Greater Yellowstone Area Fire Growth
}

\author{
C.H. Chase \\ Intermountain Research Station \\ USDA Forest Service \\ P.O. Box 8089 \\ Missoula, MT 59807 \\ R.A. Hartford \\ Intermountain Research Station \\ USDA Forest Service \\ P.O. Box 8089 \\ Missoula, MT 59807 \\ R.C. Rothermel \\ Intermountain Research Station \\ USDA Forest Service \\ P.O. Box 8089 \\ Missoula, MT 59807
}

The 1988 fire season in the Greater Yellowstone Area (GYA) provided an unprecedented opportunity to study the behavior of large wildland fires. The fires generated considerable interest, and much technology was applied to monitoring their progress. Vegetation and topography have been extensively described for much of the GYA. A geographic information system (GIS) was used to store, organize, and present the broad range of data assembled for documenting and analyzing the growth of major fires and fire complexes in the GYA.

Geographical Resources Analysis Support System, or GRASS, implemented on a SUN SPARCstation1, was chosen to digitize and analyze the daily position of the GYA fires of 1988 in a cooperative study between the Intermountain Research Station's Fire Behavior Research Work Unit and the National Park Service. The fire record incorporates data from a variety of sources including daily infrared photography flights, satellite imagery, ground reconnaissance, aerial reconnaissance, command center intelligence, and recollections of fire behavior observers. Fire position was digitized from topographic maps to construct a file of daily fire location in vector format. The vector file was converted to raster format for further analysis. The data base will be available in electronic form. Additional plans involving the fire growth data include (1) evaluation of fire growth using reconstructed weather parameters; (2) construction and validation of a large-fire growth simulation model; and (3) further analysis of fire 
behavior and modeling of extreme fire behavior using severity, vegetation, topography, and weather layers. 


\title{
Seedbanks under Climax Rocky Mountain Vegetation and the Effects of Fire on Them
}

\author{
D.L. Clark \\ Department of Biology \\ Montana State University \\ Bozeman, MT 59717 \\ and \\ Research Division \\ Yellowstone National Park, WY 82190 \\ T.W. Weaver \\ Department of Biology \\ Montana State University \\ Bozeman, MT 59717 \\ and \\ Research Division \\ Yellowstone National Park, WY 82190 \\ D.G. Despain \\ Department of Biology \\ Montana State University \\ Bozeman, MT 59717 \\ and \\ Research Division \\ Yellowstone National Park, WY 82190
}

The objectives of this project were (1) to compare seed banks from communities ranging from low grasslands (Bouteloua gracilis, Agropyron spicatum, and Festuca idahoensis), through deciduous broadleaf vegetation (Artemisia tridentata and Populus tremuloides), coniferous forests (Pseudotsuga menziesii and Abies lasiocarpa), to high grasslands (Festuca idahoensis, Deschampsia caespitosa, and alpine tundra); (2) to estimate the effects of fire on the seed banks of each of these communities; and (3) to estimate temperature $\mathrm{LD}_{50} \mathrm{~s}$ for the seeds of common species.

To compare seed banks of climax communities, we analyzed composite soil samples ( 25 cores) from three sites in each of the 14 environmental types listed above. To determine the effect of fire on seed banks, we compared samples from undisturbed portions of each community with portions which were burned in the 1988 Yellowstone area fires. To estimate temperature $L_{50}$ for seeds, unburned samples 
were subjected to oven heating at temperatures of 50,100 , and $150^{\circ} \mathrm{C}$. Thus, our factorial design included 14 environmental types, 5 fire/heat treatments, and 3 replications.

Seed bank density and diversity were compared across environmental types (habitat types) by comparing seedling populations germinated from unburned soils during three simulated seasons. Seed density averaged about 4,000 seeds $/ \mathrm{m}^{2}$, with fewer $\left(1,000 \mathrm{seeds} / \mathrm{m}^{2}\right)$ germinating in dry grasslands (Bouteloua and Agropyron) and Abies forests, and more appearing in Populus groves $\left(7,000 \mathrm{seeds} / \mathrm{m}^{2}\right)$ and Deschampsia meadows $\left(14,000\right.$ seeds $\left./ \mathrm{m}^{2}\right)$. The bank contained few tree or shrub seeds and roughly equivalent numbers of graminoid-perennial forb-annual forb seeds. Seed bank species richness averaged about 40 species, with lower numbers (10 - 15) in dry grasslands and dense subalpine fir forests; only about 25 percent of seed bank species had densities greater than $100 \mathrm{seeds} / \mathrm{m}^{2}$. While vegetation richness and seed bank richness were similar for all types, roughly 30 percent of the plants present in the vegetation were absent from the seed bank, and reciprocally, about 30 percent of seed bank species were absent from the vegetation. Relevee tables showing the distribution of individual species along the altitudinal gradient are available. Recognizing that seed bank dynamics involve both inputs and losses (e.g., predation and germination), we suggest that both density and diversity are low where resources are limited by climate (dry grasslands) or competition (subalpine fir forests).

Seed bank density was approximately halved by fire in grasslands and shrublands and reduced by over 90 percent under forests. Fire reduced seed bank richness to 30 percent to 50 percent of unburned values, whether one considered total presence or only species occurring in densities greater than 100 seeds $/ \mathrm{m}^{2}$. While fire did not affect lifeform guilds differentially, it did affect species differently. The $L_{50}$ for most seeds was $70-85^{\circ} \mathrm{C}$, although for intolerant seeds (e.g., Pinus contorta, Taraxacum officinale, and Poa alpina), it was less than $65^{\circ} \mathrm{C}$, and it exceeded $120^{\circ} \mathrm{C}$ for tolerant seeds (e.g., Astragalus alpinus, Geranium bicknellii, Oxytropis deflexa, Iliamna rivularis, and Trifolium hybridum). We conclude that fire increases the importance of resistant species in the vegetation by stimulating emergence, and while it may decrease the importance of intolerant species by reducing seed bank numbers or diversity, this effect is diminished by the survival and resprouting of burned plants, which exhibit rapid vegetative growth and produce large numbers of seeds during the first few postfire years. 


\title{
Plant - Ungulate Ecology of Grasslands on the Northern Range of Yellowstone National Park
}

\author{
Douglas A. Frank \\ Biological Research Labs \\ 130 College Place, Syracuse University \\ Syracuse, NY 13244 \\ Samuel J. McNaughton \\ Biological Research Labs \\ 130 College Place, Syracuse University \\ Syracuse, NY 13244
}

Although Yellowstone's northern range grasslands and their large herds of native ungulates have been a favorite topic of study for botanists, zoologists, and wildlife biologists alike, no study has investigated how Yellowstone's herbivores influence energy and nutrient flows on the northern range. The objectives of this study were (1) to determine what effect ungulates have on above-ground production of northern range grasslands, and (2) to measure plant production and herbivore consumption at diverse sites on winter, transitional, and summer ranges.

The effect of ungulates, primarily elk and bison in this study, on above-ground primary production was determined by comparing productivity of grazed vegetation with that of ungrazed, permanently fenced vegetation at four sites. Temporary exclosures $(1.5 \times 1.5 \mathrm{~m}, \mathrm{n}=5-7$ per site) moved every four weeks from snowmelt to snowfall were used to measure production under grazing, and productivity of ungrazed vegetation was taken as peak biomass in permanent exclosures $(10 \times 10 \mathrm{~m}$ or $15 \times 15 \mathrm{~m}, 3$ per site). Above-ground productivity of grazed vegetation was higher than that of ungrazed vegetation by 11 percent to 85 percent.

Above-ground production of grazed vegetation and ungulate consumption were measured at 13 sites. An average of 45 percent of the above-ground productivity was consumed among grazed sites. Aboveground production was positively and linearly related with the amount consumed by herbivores. This indicated that across the northern range landscape, as patch productivity increased, so too did consumption at a constant rate per unit productivity. In addition, an analysis of when the sites were grazed indicated that consumption occurred while plants were growing. Young vegetation had higher nitrogen content than phenologically older tissue; therefore, ungulates increased the duration of a high quality diet by tracking young vegetation across the landscape. We suggest that the temporal coupling of grazing and plant growth may be an important factor underpinning large herbivore stimulation of grassland productivity in Yellowstone. 



\title{
Grassland Change Over 2000 Years in Northern Yellowstone Park
}

\author{
Elizabeth A. Hadley-Barnosky \\ Department of Integrative Biology \\ University of California \\ Berkeley, CA 94707
}

Plant communities of the northern range in Yellowstone Park are composed of a patchwork of microhabitats locally governed by a variety of environmental factors including slope, aspect, substrate, effective moisture, and soil type, to name a few. Along the Lamar River, upstream of its confluence with the Yellowstone River, microhabitat ecotones are especially pronounced along moisture gradients. The majority of the large till-covered surface above the river is sparsely vegetated with grassy patches and sagebrush (Artemisia). Mesic sites with denser grass are found in small swales and drainages. Northfacing slopes are covered with Douglas fir (Pseudotsuga menziesii) forest.

Evidence from a paleontological site, Lamar Cave, suggests that the spatial coverage of these and other microhabitats has changed during the past 1,700 years. At least 1,500 years ago the prairie vole (Pitymys ochrogaster) occupied the study area, as did the western jumping mouse (Zapus princeps). Neither now occupies the study area, and both are tall-grass inhabitants today. Also at 1,500 years ago, relative percentages of small mammals [voles (Microtus) that dwell in mesic microhabitats today were prevalent over those that favor open, xeric grasslands [ground squirrels (Spermophilus)]. By 1,000 years ago, this condition was reversed, with ground squirrels dominating the faunal assemblage at the cave and the prairie vole and jumping mouse absent from the record. Slightly more mesic conditions have returned since 1,000 years ago, as evidenced by a slight rise in vole percentages relative to ground squirrels: however, the present is still drier than the mesic conditions of 1,500 years ago.

This evidence from the small mammal fossils of Lamar Cave indicates that grass density has changed over 2,000 years and suggests that microhabitats expand and contract with changing environmental conditions, in this case probably effective moisture. 



\title{
Packhorse Grazing Impacts in a Wilderness Area
}

\author{
Katherine Hansen \\ Department of Earth Sciences \\ Montana State University \\ Bozeman, MT 59717 \\ Kathrin Olson-Rutz \\ Department of Animal and Range Sciences \\ Montana State University \\ Bozeman, MT 59717 \\ Clayton Marlow \\ Department of Animal and Range Sciences \\ Montana State University \\ Bozeman, MT 59717 \\ Leonard Gagnon \\ Department of Animal and Range Sciences \\ Montana State University \\ Bozeman, MT 59717
}

One management goal of wilderness areas is to perpetuate natural processes and to minimize humaninduced changes. Although little is known about the specific changes induced by the grazing of pack stock in wilderness areas, many managers consider it a problem. Grazing pressures may be concentrated because meadows suitable for grazing may be scarce in high-elevation wilderness areas.

We used an experimental approach to evaluate changes in soil compaction, plant height and stem counts, and ground cover in response to horse grazing on a dry, upper timberline $(2,660 \mathrm{~m})$ meadow in the Lee Metcalf Wilderness of the Greater Yellowstone Area. Horses were picketed on 15-m diameter circles for 4, 8, and 18 hour durations once during July, August, or September, 1988 through 1991. Each year, both new circles were grazed and old circles were regrazed (to accumulate impact) within the same study area. Four replicates of each treatment (grazing duration) were used, and four control circles (not grazed) were measured for each grazing month. This design allowed us to measure the change induced by grazing at different phenological periods of plant growth and for different grazing durations. Horses were also repeatedly picketed on a set of circles for a 4- and 8-hour period in July, August, and September to evaluate the effect of repeated grazing during one growing season. 
Plant and soil measurements were collected prior to grazing, immediately after, and one year later. Soil surface compaction (measured by penetrability of a pocket penetrometer) increased or decreased immediately after grazing, depending on weather-induced surface soil moisture changes. Grazing tended to increase soil compaction caused by horse hoof impact when the soil was moist, but decreased compaction when the soil was dry or very wet. The immediate change in soil compaction after grazing was greater after 8 and 18 hours of grazing than after the 4 hours. Despite immediate changes (measured immediately after horses were removed), the soils appeared to recover in one year, with compaction values equaling those of ungrazed circles. Similarly repeated grazing induced immediate changes, but over the course of the summer soil compaction showed no significant effect of the grazing. Therefore, one summer of grazing produced little or no change in soil surface compaction. However, soil recovery ability may alter if plant cover changes in response to several seasons of grazing.

Picket duration did not significantly alter the relationship between plant cover, litter, and bare soil the year following grazing. However, there were patterns of change. Eighteen hours of grazing in August 1988 and 4, 8, and 18 hours of grazing in August 1989 appeared to reduce vegetal cover the following year. Conversely, bare soil increased on the same treatments. Bare soil also appeared to increase with 8 and 18 hours of grazing in September 1989 with a concomitant reduction in litter rather than vegetal cover. After two years of grazing on the same circles, vegetal cover appeared to be similar to the controls, but the grazed circles had more bare ground and less litter than the ungrazed circles.

The horses grazed a greater proportion of grasses than forbs and grazed the grasses to a lower height. The preferential grazing of grasses was reflected in stem counts the following year. On the meadow grazed in 1988, circles grazed in July tended to have more forb stems than the ungrazed circles the following year. In contrast, grazing for 18 hours in August tended to reduce grass and forb stem counts the following year. September 1988 pregrazing data were missing; therefore we could not calculate that month's grazing-induced change, if any, over the year.

The 1989 meadow response supported these trends. Eight and 18 hours of grazing in July increased the number of forb stems, but forbs were not affected by grazing in August and September. Grazing for 18 hours in July, and any grazing in August and September, reduced grass stem counts in 1990. Changes in stem counts from 1988 to 1989 and 1989 to 1990 were not significantly influenced by soil moisture, soil penetration resistance, or ground cover. Stem counts after two years of grazing followed the same pattern.

Although height class distributions were different between grasses and forbs, they were not significantly affected by duration or month grazed one year. This could be for several reasons. Culm length may underestimate the impact of defoliation on plants. We probably did not measure maximum heights of all species, because we measured all plants at only one time during summer. Also, our height class categories were rather broad. Plant height changes following defoliation in other studies would not have resulted in placing the plants in lower height classes. After two years of grazing there appeared to be a reduction in grasses greater than $4 \mathrm{~cm}$ with grazing for 8 or 18 hours after July. The forbs were less affected and appeared most sensitive to September grazing.

The single grazing treatments did not influence elk grazing the following summer, as measured by grazed plant frequency before horse grazing.

To evaluate whether horse grazing one summer influenced elk grazing the following year, we measured grazed plant frequency on all the circles the year after horse grazing. Grazing by elk was not influenced by the amount of horse use the previous summer. 


\section{Acknowledgments}

This research was supported in part by funds provided by the Intermountain Research Station, Forest Service, U.S. Department of Agriculture, the Montana Agricultural Experiment Station, and Montana State University. 



\title{
Relationships among Breeding Songbirds, Willows, and Browsing by Elk and Moose in and Around Northern Yellowstone National Park
}

\author{
Sally Graves Jackson \\ Department of Fisheries and Wildlife \\ Utah State University \\ Logan, UT 84322 \\ John A. Kadlec \\ Department of Fisheries and Wildlife \\ Utah State University \\ Logan, UT 84322
}

Although the impacts of domestic livestock on riparian vegetation have been well documented in the western United States, little is known about the impacts that browsing by large native ungulates may have. In the northern Yellowstone area, some willow stands experience intense browsing by elk and moose, whereas others experience medium or very low amounts of browsing. Given the high use of riparian zones by wildlife in general, it is important to understand the effect of browsing-induced habitat alteration on birds breeding in the park's riparian areas. The objectives of this study were (1) to compare the numbers and densities of birds among willow stands that have experienced different intensities of browsing by elk and moose, (2) to measure the relationship between five focal species of songbirds and aspects of habitat structure, and (3) to develop and evaluate predictive models that relate presence or absence of the five species to habitat characteristics. In eight large willow stands during two breeding seasons (1989 and 1990), we conducted censuses of breeding birds and measured habitat and shrub characteristics. The densities of five focal birds (Common Yellowthroat, Lincoln's Sparrow, Warbling Vireo, Wilson's Warbler, and Yellow Warbler) varied considerably among sites. The frequency of severely browsed willows in the sites ranged from 3.5 percent to 100 percent. Total bird densities and total numbers of species were lowest in sites in which 70 percent or more of the willows were severely browsed, suggesting that birds have a threshold of tolerance for browsing-induced changes to the vegetation. Only two sites had all five species and only one species - the Lincoln's Sparrow occupied all eight sites. To determine the habitat associations of the five focal species, aspects of habitat structure were measured in both random and bird-centered 0.04-ha circular plots. Plots of principal component scores were used to compare available and selected habitat. Within the eight sites sampled, Common Yellowthroats and Lincoln's Sparrows occupied the widest arrays of available habitat, whereas Warbling Vireos, Wilson's Warblers, and Yellow Warblers were associated with willows of specific heights, foliage at certain height intervals, and certain willow spacing. We believe that intense browsing does affect the assemblages of breeding birds in willows, but we also speculate that factors such as food 
abundance, type and gradient of adjacent plant community, and soil-water relationships are important. Preliminary tests of the predictive models indicate that such site- and landscape-level factors should be incorporated into future models, since it is these factors that determine the potential floristics and physiognomy of each willow stand.

\section{Acknowledgments}

Funding for this research was provided by the Welder Wildlife Foundation (Sinton, Texas), with additional support from the Utah State University Ecology Center. 


\title{
Short-Term (Five-Year) Effects of Air Pollution on Lodgepole Pine
}

\author{
J. Jacobs \\ Biology Department, Montana State University \\ Bozeman, MT 59717 \\ T. Weaver \\ Biology Department, Montana State University \\ Bozeman, MT 59717 \\ M. Cole \\ Forestry Sciences Lab, USDA Forest Service \\ Bozeman, MT 59717
}

\section{Introduction}

We used lodgepole pine as a model for estimating the potential effects of cross-boundary air pollution on wilderness or managed forests (1) because it is a dominant tree in the area, (2) because it probably represents other conifers well, and (3) because, as a conifer, it is relatively sensitive to air pollution thus any decline should give advance warning of air pollution damage to other plants.

To estimate the direct impacts of air pollution, we compared the growth of untreated lodgepole pine trees with the growth of paired trees given either mild or harsh treatments with four pollutants generated by the coal-burning and smelting industries - sulfuric acid (at $\mathrm{pH} 3$ or 1), nitric acid (at pH 3 or 1), copper chloride (at 0.001 or 0.01 molar) or zinc chloride (at 0.001 or 0.01 molar). The solutions were applied to 25 -year-old trees in the field at either annual or fortnightly intervals.

\section{Acid Effects}

Five annual applications of either $\mathrm{HNO}_{3}$ or $\mathrm{H}_{2} \mathrm{SO}_{4}$, whether at $\mathrm{pH} 3$ or 1 , had no effect on either height or diameter growth of lodgepole pine. Fortnightly applications - 15 at pH 3 - over three summers were also without effect. Fortnightly applications at $\mathrm{pH} 1$ reduced diameter growth without effect on height growth. 


\section{Metal Effects}

Metal treatments that killed greenhouse seedlings $(0.001$ and $0.01 \mathrm{M})$ had no effect on the growth of trees sprayed annually in the field.

\section{Length of Term}

In wilderness or in actively managed areas, it is probably more important to consider pollution impacts in a long-term, rather than in a short-term context. If pollution occurs for a short period only, we expect no negative effects from the highest concentrations expected in natural rainfall - $\mathrm{pH} 3$ acid or $0.01 \mathrm{M}$ metals. However, if pollution at these levels occurs over extended periods we expect soil-mediated cumulative effects that will be extremely difficult to remedy. Acid rain will modify soils by releasing toxic aluminum and leaching nutrient elements in proportion to the acid delivered. Simultaneously, metal pollutants will inexorably accumulate in soils until toxic levels are reached. 


\title{
Comparison of Soils Inside and Outside of Grazing Exclosures on Yellowstone National Park's Northern Winter Range
}

\author{
John R. Lane \\ Buchanan Consultants, Ltd. \\ Farmington, NM 87401 \\ Cliff Montagne \\ Montana State University \\ Bozeman, MT 59717
}

Eight 25-year-old exclosures from five sites in Yellowstone National Park's northern winter range were studied in 1986 and 1987 to determine soil chemical and physical properties inside and outside of exclosures. Nutrient analysis sampling, soil surface-bulk density, and double-ring infiltration were conducted inside and outside of all exclosures. A simulated rainfall study was conducted inside and outside five exclosures. The rain was applied under three separate treatments: vegetation undisturbed, vegetation clipped, and vegetation and litter removed. There were significant differences $(p \leq 0.10)$ for some soil chemical properties. However, these soil chemical property differences were not consistent inside and outside exclosures, or at depth within an exclosure. Soil surface $(0-5 \mathrm{~cm})$ fine earth $(\leq 2 \mathrm{~mm})$ bulk density was significantly higher outside (grazed) four exclosures $(p \leq 0.10)$. One exclosure had significantly higher infiltration inside. With simulated rainfall, no significant differences were detected in runoff or sediment yield inside or outside of exclosures for the vegetation undisturbed treatment. Three exclosures had significantly more runoff outside the exclosures for the vegetation clipped treatment. For the vegetation and litter removed treatment, two exclosures had significantly more runoff outside and two exclosures had significantly higher sediment yield outside. There appears to be no detectable overall difference between soils inside and outside of exclosures. No conclusions can be made concerning soil changes over time due to grazing or protection from grazing, because there were no preexclosure baseline soils data.

${ }^{1}$ Formerly of Yellowstone National Park. 



\title{
Records of Fire Preserved in Lake Sediments from the Central Plateau of Yellowstone National Park
}

\author{
Sarah H. Millspaugh \\ Department of Geography \\ University of Oregon \\ Eugene, OR 97403
}

Fire is a significant form of vegetation disturbance in the Yellowstone ecosystem, and thus knowledge of local fire history is an important element of studies that involve vegetation history. A primary method for studying fire history is to analyze fire-related proxy inputs preserved in lake sediments. Charcoal is deposited in lake sediments by aerial processes during a fire and by erosional processes in the lake catchment. Increased erosion following a fire introduces magnetically enhanced minerals into a lake, which can be a fire indicator. The influx of these minerals results in high magnetic susceptibility measurements in the sediments. Pollen can also be analyzed to identify disturbance caused by fire. Fire events may be associated with increases in herbaceous pollen from taxa that rapidly colonize a burned area following a fire.

The objective of this study is to analyze the stratigraphic occurrence of charcoal, magnetic susceptibility, and pollen composition in lake sediments in order to obtain information about past fires in Yellowstone National Park. The Yellowstone fires in 1988 created an opportunity to study the abundance and distribution of modern charcoal in the surface sediments of small lakes. Charcoal, pollen, and paleomagnetic minerals in cores were analyzed to reconstruct a local fire history for the past 500 years.

The study sites are primarily small lakes (c. 15 ha) chosen for their simple bathymetry and limited catchment size. Four lakes are in burned catchments; three additional lakes in nonburned catchments serve as control sites. All of the lakes in nonburned catchments are within a 7-km distance of a burned area. To monitor changes in the abundance and distribution of charcoal within these lakes following the 1988 fires, surface sediment $(0-2 \mathrm{~cm})$ was collected biannually at one- to two-meter intervals of water depth parallel to the direction of the fire. Sediment was wet-sieved and charcoal pieces in each size class were counted under a binocular scope. Charcoal pieces $<0.125 \mathrm{~mm}$ in size were difficult to identify and quantify; thus the analysis focused on the $0.125-0.250 \mathrm{~mm}$ size range, which contained the same information.

The data collected between March 1989 and August 1990 indicate that an important source of charcoal to lakes was from aerial fallout during the fire. During the 1988 fires some charcoal was deposited in deep water immediately; however, much stayed suspended in the water column and was carried to 
shore by wind and wave activity. Cross-lake transects in burned and unburned lakes showed significantly higher quantities of charcoal on the downwind shore than the upwind shore. Another significant source of charcoal to lakes in burned catchments is introduced by slope wash processes, especially in lakes that lie in catchments with steep upland slopes adjacent to the lake.

The distribution of charcoal in water depths $>1 \mathrm{~m}$ is different for each lake and appears to be dependent on specific bathymetry. Charcoal abundance in water depths $>1 \mathrm{~m}$ increased between 1989 and 1990 in all of the burned sites and in two unburned sites. This increase is apparently a result of charcoal input from upland slopes in the burned sites and from resuspension and redeposition of charcoal from the shore zone in all sites. Charcoal quantities and distribution will probably continue to change as more charcoal is added through slopewash processes, and charcoal from the shore region ( $<1 \mathrm{~m}$ water depth) is redeposited and resuspended.

The airshed surrounding a lake is larger than the hydrologic catchment, especially in the case of the Yellowstone fires in 1988. This assumption is based on the following results. The average amount of charcoal in each lake does not correspond directly to the percentage of burn in the immediate catchment. One lake in an unburned area contains an average amount of charcoal that is higher than that of other lakes in burned catchments. Based on present data, average charcoal abundance is not a good indicator of whether a lake lies in a burned catchment or an unburned catchment within $7 \mathrm{~km}$ of a fire. As charcoal from the 1988 fires continues to be secondarily added to lakes in burned areas, the ability to discriminate a catchment fire may improve.

Short cores $(60-80 \mathrm{~cm})$ were taken from three lakes in the Central Plateau to reconstruct a fire history for the past 500 years. Of particular interest was whether local catchment fires could be distinguished from regional fires by use of various proxy data in the sedimentary record. The cores were dated by the $210 \mathrm{~Pb}$ method and examined at $1-\mathrm{cm}$ intervals for charcoal and magnetic susceptibility. For one lake, pollen was examined at $1-\mathrm{cm}$ intervals above and below depths with abundant charcoal. The fire record established from sediment cores was compared to a record of fires for the past 300 years determined by dendrochronological data (Romme 1982). These results indicate that the combination of charcoal, magnetic susceptibility, and pollen in lake sediment cores is a sensitive tool for reconstructing past fire events.

Charcoal was present throughout each core, although distinct peaks were identifiable. The stratigraphic occurrence of a charcoal peak (as defined by a threshold value) and a magnetic susceptibility peak at the same level matched well with times of catchment fires inferred from the dendrochronological record. For example, fires burned in the catchment of Duck Lake in 1632 and 1703 (Romme personal communication, 1990) and charcoal peaks date to $1636-1651$ and $1704-1725$. Neither charcoal abundance nor magnetic susceptibility values are sufficiently high to identify the 1988 fires as yet, which suggests that not enough time has elapsed for fire inputs to reach deep water. These results are consistent with the observation based on modern sampling that charcoal abundance will continue to increase in deep-water sediments as charcoal is introduced from upland slopes and redeposited from the shore zone of lakes.

Several charcoal peaks are present in all three study sites and probably represent times when large areas of the Central Plateau burned. The charcoal record suggests that regional fires burned in c. 1520 1570, $1620-1650,1690-1720$, and $1740-1780$. From mid-1700 to 1988, a small fire occurred c. 1891 , but overall there were few fires in the Central Plateau study area. By comparison, the charcoal data suggest that fires were more numerous from c. 1500 to mid-1700, occurring on a frequency of c. 40- to 50-year intervals. 
Pollen percentages associated with historic fire events at Duck Lake show noticeable variations in the abundance of conifer pollen and total herb pollen. Pine pollen percentages decrease below each charcoal level and probably reflect the local burning of the lodgepole pine forest. Increases in total herb pollen are also associated with charcoal peaks and probably reflect an increase in herbaceous taxa that rapidly colonize a burned area.

\section{Literature Cited}

Romme, W. H. 1982. Fire and landscape diversity in subalpine forests of Yellowstone National Park. Ecological Monographs 52:199-221. 



\title{
Aspen Seedlings Following the 1988 Yellowstone Fires
}

\author{
Roy Renkin \\ Management Biologist \\ Branch of Natural Resources \\ Yellowstone National Park, WW 82190 \\ Don Despain \\ Research Ecologist \\ National Biological Survey \\ Yellowstone National Park, WY 82190 \\ Dave Clark \\ Reclamation Specialist \\ Montana Department of State Lands \\ Billings, MT 59101
}

Aspen seedling establishment in western North America under natural conditions has been described as nonexistent, rare, or occasional. Aspen seedling establishment through sexual reproduction has never been observed in Yellowstone National Park. Aspen is a clonal species, and asexual propagation of above-ground stems is by vegetative root suckering.

Aspen seeds complete development in early spring and are dispersed by wind during May and June. Abnormal germination and early seedling mortality are common when optimal temperature, moisture, and substrate conditions are not present. Continued seedling survival beyond the early germination phase depends on three critical factors: (1) bare mineral soil; (2) freedom from plant competition; and (3) sufficient moisture throughout the growing season.

Rarely are these exacting field conditions encountered in the West. Natural events such as earthquakes or mudslides or human-caused events such as damming or highway construction could create suitable establishment sites. Some authors hypothesize that fire in western states may create suitable establishment sites, while another makes anecdotal reference to aspen seedlings predominantly in recently burned areas of northern Idaho.

Here we report ubiquitous aspen seedlings exclusively within burned areas of Yellowstone National Park, describe morphological characters for distinguishing between recent seedlings and root suckers, and use permanent transects and field exclosures to describe early trends in survival and growth of aspen. Similar trends are also compared with lodgepole pine seedlings on plots where both occurred. 
Thousands of aspen seedlings were observed over a very broad area in many different burned vegetation types. Potential seedling locations include forests that experienced high-intensity crown fire and wet nonforest types that burned to mineral soil. Sites were typically represented by occasional to few incidental seedlings scattered over a wide area or concentrated locally in favorable wet microsites. Establishment sites usually had deep ash deposits with abundant moss, indicating ample moisture availability. We hypothesize that ash generated from the fires enhanced soil moisture holding capacity and retention on site, thereby contributing to successful establishment.

Aspen seedlings/saplings, apparently germinating from seed the first few years following fire, were also found in two older forest burns from 1979. About 30 seedlings/saplings were widely distributed throughout each burn, had attained heights ranging from 30 to $45 \mathrm{~cm}$, and all had been browsed many times.

Aspen seedlings have only a slight resemblance to the mature form. Seedling leaves are much narrower and pointed, almost lanceolate, 1.5 to 2 times longer than wide, rather than the familiar orbicular shape of mature aspen. Seedling leaf petioles are not obviously vertically flattened as in mature aspen, but are rounded. During the second growing season seedlings do somewhat resemble the juvenile growth phase of vegetative root shoots, but the first two to six leaves remain narrower than those of root shoots. Root shoots are recognizable because they arise from specialized lateral roots of the parent clone and do not typically possess the vertical taproot and fibrous branching rootlets of seedlings.

Paired cotyledons or cotyledon scars and buds at or a few millimeters above the soil surface, and the first pair of nearly opposite true leaves at right angles to and directly above the cotyledons, were visual identifiers useful in distinguishing between seedlings and root shoots without excavation of the root. In contrast, the entire leaf pattern is strongly alternate on root shoots. Axillary leaf buds demonstrated this pattern long after leaf fall and through the second growing season.

Nine permanent transects (three forested, six nonforested) and two fenced exclosures (one forested, one nonforested, with paired inside and outside subplots) were established in the fall of 1989. At each transect and exclosure site, either a $10-\mathrm{m}^{2}$ or $20-\mathrm{m}^{2}$ plot was sampled depending on seedling density. An additional $1-\mathrm{m}^{2}$ subplot was placed on the pond margin inside the nonforested exclosure. Overall, five forested plots (four unfenced, one fenced) and nine nonforested plots (seven unfenced, two fenced) were measured.

Aspen seedling density ranged from 0.6 to $1014 / \mathrm{m}^{2}$ in 1989 at all 14 plots. Average tallest height ranged from 5.7 to $27.8 \mathrm{~cm}$ (mean = 12.8). On the five forested plots, lodgepole pine seedlings ranged from 0.4 to $8.3 / \mathrm{m}^{2}$ and from 1.9 to $3.6 \mathrm{~cm}$ (mean =3.0) in height. Where aspen and lodgepole pine seedlings coexist, aspen were two to four times taller than lodgepole pine.

All 14 of the plots had persistent aspen seedlings when revisited in 1990. In some cases the original seedling stem had died back and suckers were observed off the year-old root system. The density of surviving seedlings ranged from 0.05 to $332 / \mathrm{m}^{2}$. Average tallest heights increased and ranged from 9.0 to $39 \mathrm{~cm}$ (mean $=19.4$ ). Aspen seedlings on unfenced plots $(n=11)$ averaged $13.4 \mathrm{~cm}$ in height, whereas on fenced plots $(n=3)$ they averaged $30 \mathrm{~cm}$ in height. The density of lodgepole pine seedlings was slightly reduced on two plots, remained the same on two plots, and was reduced to zero on another.

Survival of aspen seedlings was significantly greater on forested ( $n=4$ ) than nonforested $(n=7)$ unfenced plots $(p=0.004)$. On all forested plots $(n=5)$, aspen seedling survival was not significantly 
different from survival of lodgepole pine seedlings $(p=0.62)$, even though no lodgepole seedlings survived on one plot. Another site demonstrated equal densities and survival of both lodgepole pine and aspen seedlings.

Six (4 nonforested, 2 forested) of the 14 plots supported a total of 91 new aspen seedlings-of-the-year in 1990. Three forested plots also supported a total of 20 new lodgepole pine seedlings. Willow seedlings were also recorded on seven of the plots (five nonforested, two forested) over the two years.

Aspen seedling survival was influenced by the presence of ungulates, spring flooding, disease, and intraspecific competition. Assuming that the proportion of browsed, surviving seedlings reflected local ungulate density and utilization, ungulate presence (BR) negatively influenced seedling survival (SURV) on the 11 unfenced plots: [SURV $=77.592-0.726 \mathrm{BR}, r=0.79, p=0.004$ ]. The hoof action of ungulates, rather than browsing per se, may have contributed more to mortality since both browsed and unbrowsed aspen seedlings were commonly observed to be uprooted and displaced. Portions of plots submerged during spring runoff showed a high degree of aspen seedling mortality. Similarly, the terminal portion of many seedlings had died back late into the 1989 season, and laboratory analysis showed that these seedlings had succumbed to the leaf and shoot blight commonly known as shepard's crook (Venturia tremulae). Areas with an unusually high density of aspen seedlings in 1989 showed corresponding high levels of mortality in 1990.

Ungulate presence did not influence lodgepole pine seedling survival $(p=.209)$ on the four unfenced forested plots. Spring flooding, however, was responsible for the die-off of lodgepole pine seedlings on one site.

These sites will be monitored over time as the successional process continues. 



\title{
Forest Type, Fuel Moisture, and Lightning-Caused Fires
}

\author{
Roy Renkin \\ Management Biologist \\ Branch of Natural Resources \\ Yellowstone National Park, WY 82190 \\ Don Despain \\ Research Ecologist \\ National Biological Survey \\ Yellowstone National Park, WY 82190
}

Forest type and fuel moisture have been shown to influence the occurrence and activity of lightningcaused fires in Yellowstone National Park. Significantly more lightning-caused fires occur in climax Engelmann spruce/subalpine fir forests and in old-growth, mixed-canopy lodgepole pine forests - more than expected, based on the proportion of those forest types in the park. Early- and mid-successional lodgepole pine forests, on the other hand, experience significantly fewer lightning-caused fires than expected. These trends are evident across a broad spectrum of moisture conditions. Lightning-caused fire ignitions increase when fuel moisture estimates for large ( $>3$ inch diameter) dead and downed fuels approach 13 percent. Continued activity of fires is constrained by forest type. The climax spruce/fir and old-growth, mixed canopy lodgepole pine forests burn readily and show a positive association with stand-replacing crown fire, whereas the early- and mid-successional lodgepole pine forests do not. These trends were evident during the first 16 years of the prescribed natural fire program and during the early portion of the 1988 fire season. During the later stages of 1988 these relationships continued but became weaker, probably because of drought conditions, continued high winds associated with frontal passage, and the broad expanse of active fire perimeter. 



\title{
Suckering in Burned Aspen as Related to Above-Ground and Below-Ground Biomass
}

\author{
Roy Renkin \\ Management Biologist \\ Branch of Natural Resources \\ Yellowstone National Park, WY 82190 \\ Don Despain \\ Research Ecologist \\ National Biological Survey \\ Yellowstone National Park, WY 82190
}

Vegetative root suckering has long been recognized as a means of long-term propagation in clonal species such as trembling aspen (Populus tremuloides Michx.). This suckering is regulated by auxins produced in the aerial portions of the tree and translocated to the roots. When movement of these chemicals is halted by burning, cutting, or defoliation, suppressed buds on the roots are released and new suckers (i.e., ramets) are produced.

From 30,000 to 150,000 ramets per hectare have been reported in aspen stands following burning. While hormonal, environmental, and root carbohydrate reserves play a role in ramet initiation and growth, such variance in suckering has been attributed to "varying degrees" of fire intensity. A surface fire of low intensity that leaves some living trees may not effectively eliminate the chemical pathway, thus maintaining some level of sucker suppression. On the other hand, a high-intensity fire may also kill some of the surficial roots from which ramets arise, again contributing to a lowered suckering response. The general thought is that optimal suckering is produced when a fire is of the proper intensity to remove the overstory and sufficiently disrupt the auxin flow but not kill surficial roots.

Our observations in Yellowstone suggest that even a low-intensity fire will stimulate prolific suckering and that perhaps other factors contribute more to the suckering response than fire intensity. We investigated the relationship of root biomass to preburn above-ground standing crop and the subsequent production of new ramets in the first year following fire.

We used a planar intercept technique, developed to estimate the volume of dead and downed woody fuels, to measure root biomass. This involved digging a $4 \times 0.5 \mathrm{~m}$ trench down to parent material, tallying root intersections by size class ( $<1 / 4$ inch, $1 / 4-1$ inch, $1-3$ inches, and $>3$ inches in diameter) along the side of the trench, and applying an appropriate mathematical formula for each root size class (for roots $<3$ inches in diameter: $\mathrm{RB}=\mathrm{K}^{\star} \mathrm{A}^{\star} \mathrm{Di}^{\star} \mathrm{Si}{ }^{\star} \mathrm{Ni} / \mathrm{L}$, where $\mathrm{RB}=$ root biomass in tons/acre; $\mathrm{K}=11.64$, 
a constant; $A=1.13$, a nonhorizontal angle factor; $\mathrm{Di}=$ the average diameter squared of roots in size class $\mathrm{i}$; $\mathrm{Si}=$ the specific gravity of root size class $\mathrm{i}$, to be measured for each size class; $\mathrm{Ni}=$ the number of intersections of root size class $i$; and $L=$ the length of the sampling line in feet. The equation is similar for roots greater than 3 inches except Di is replaced by the sum of the squared diameter for each root encountered. All measurements were converted to metric units presented here.) The data reported here were collected from 18 different aspen clones in the northern portion of the park.

We also employed a series of standing crop measurements including tree density, spacing, diameter at breast height, basal area, and tree height to correlate with each root trench.

Five of the eighteen clones were experimentally burned in 1986 - 87 to observe ramet production and growth following fire. Three sites were enclosed within a $25 \times 25 \mathrm{~m}$ fence. Two additional sites were similarly fenced after the 1988 fires. All five enclosure sites were revisited between growing seasons to determine production for the previous season. Aspen ramets were clipped within an $8 \times 25 \mathrm{~m}$ subplot to determine the biomass of ramets produced and the average ramet height.

Total root biomass ranged from 1.3 to 43.7 metric tons/ha, and basal area ranged from 4.6 to $50.5 \mathrm{~m}^{2} / \mathrm{ha}$ at all 18 sites. The oven-dried biomass of ramets produced at the five enclosure sites ranged from 0.02 to .49 metric tons/ha. The average height of ramets ranged from 23.3 to $75.3 \mathrm{~cm}$ at seven (five fenced, two unfenced) burn sites.

Total root biomass was positively correlated, and showed the best correlation, with basal area for each root trench' (metric tons/ha of root biomass $=-18.57+22.22$ [square meters of basal area/ha] 7.791 [square meters of basal area/ha] ${ }^{2}+0.91$ [square meters of basal area/ha] $; r^{2}=0.88, p=0.00$ ). Areas with less than 6 square meters of basal area had a root biomass of less than 7 metric tons/ha. Basal area ranging from 6 - 16 square meters/ha generally produced about 12 metric tons/ha of root biomass. Basal areas greater than 16 square meters/ha showed a corresponding incremental increase in root biomass.

Ramet biomass produced the first year after fire was positively correlated with both preburn basal area and root biomass (metric tons/ha of ramets produced $=-5.68+1.275$ [square meters of basal area/ha], $r^{2}=0.90, p=0.013$; and $-4.209+0.887$ [metric tons/ha of root biomass], $r^{2}=0.94, p=0.006$ ). On the average, 15.4 meters/ha of basal area and/or 11.5 metric tons/ha of root biomass were required to produce 0.1 metric ton/ha of ramets.

Average ramet height was also positively correlated with basal area and root biomass (average ramet length $=2.52+0.43$ [square meters of basal area/ha], $r^{2}=0.85, p=0.004$; and $2.941+0.33$ [metric tons/ha of root biomass], $r^{2}=0.81, p=0.006$, respectively). On the average, 25 square meters/ha of basal area and/or 19 metric tons/ha of root biomass were required to produce 0.5 meter of ramet growth.

Root biomass at a point beneath the aspen canopy can be determined from basal area at that point, and both can be used to predict the local response of aspen to burning. Other factors such as root carbohydrate levels and site conditions undoubtedly influence the fire response, but were not measured here. It is apparent that some sites are more favorable for aspen than others - the more favorable sites

${ }^{1}$ Because of heteroscedasticity, the natural logarithms of both the independent and dependent variable were used in data analysis and equations presented here. 
supported a greater root biomass/basal area and subsequently produced more ramet biomass that grew taller. These considerations are being further investigated to define the optimal aspen environment. 



\title{
Relationships Between Spatial Heterogeneity and Large-Scale Fires on Subalpine Plateaus in Yellowstone National Park
}

\author{
Monica G. Turner \\ Environmental Sciences Division \\ Oak Ridge National Laboratory \\ Oak Ridge, TN 37831 \\ William H. Romme \\ Biology Department \\ Fort Lewis College \\ Durango, CO 81301 \\ Robert H. Gardner \\ Environmental Sciences Division \\ Oak Ridge National Laboratory \\ Oak Ridge, TN 37831
}

Spatial variation in the behavior and severity of the 1988 fires in Yellowstone National Park created an extremely heterogeneous landscape. We initiated studies in 1989 to address three general questions. First, how does prefire heterogeneity of the landscape affect fire spread and severity? Prefire heterogeneity in our study includes the spatial variability in abiotic factors, such as slope and aspect, as well as in biotic factors, such as the mosaic of stand-age classes and the effects of prior disturbances like mountain pine beetle (Dendroctonus ponderosae Hopk.) or mistletoe (Arceuthobium americanum Nutt. ex Engelm.) infestations. Second, how do the effects of prefire heterogeneity on fire spread and severity change under moderate and severe burning conditions? Third, how do the postfire patterns of burn severities influence plant reestablishment? Two hypotheses are examined: (1) the percent cover of herbaceous vegetation, which was composed primarily of individuals that had resprouted from surviving rhizomes, does not differ with distance from the edge of the burned area, and (2) the presence of seedlings of lodgepole pine (Pinus contorta var. latifolia Engelm.) is independent of the spatial pattern of burn severity.

Field studies were conducted on three $1-\mathrm{km}^{2}$ sites on areas of the subalpine plateau in which a mosaic of fire severity was observed aerially and from the ground. All three sites were located on glacial till composed primarily of rhyolite at elevations of 2,300 to $2,400 \mathrm{~m}$. The two most important environmental gradients controlling vegetation on the plateau are related to elevation and geological substrate, with moisture generally increasing with elevation and soil fertility lower on rhyolite than on andesite substrate. 
Our study areas represent the dry and infertile end of the major gradients. The broad-scale analyses were conducted on the park geographic information system (GIS) and encompassed a 1,300-km² section of the Yellowstone Plateau, the same study area in which long-term fire history studies have been conducted by Romme and Despain. More than 75 percent of this landscape contained stands that exceeded 100 years in age. Elevation in the area ranged from 2,120 to $3,040 \mathrm{~m}$, with 90 percent of the area between 2,270 and $2,730 \mathrm{~m}$.

At each of the three field sites, we sampled 100 points distributed regularly in a $1-\mathrm{km} \times 1-\mathrm{km}$ grid, recording information on fire severity (severity class, depth of ash, depth to which soil was charred, and percent mineral soil exposed), prefire forest structure (forest successional stage; tree density; tree species; and tree size, measured by diameter at breast height), first- and second-year plant responses (percent cover of graminoids, forbs, and low shrubs; dominant species; and number of seedlings of Pinus contorta var. latifolia), and general site characteristics (slope and aspect).

Fire severity was not influenced by slope, aspect, tree density, or tree size. Fire severity was affected by stand age, with older successional stages more likely to have burned, and by prefire effects of mountain pine beetle and mistletoe infestations. Increasing severity of mistletoe infestation was associated with increasing probability of crown fire. Severe prefire beetle damage increased the probability of crown fire, whereas light or moderate beetle damage decreased this probability. Also, fires that occurred early in the 1988 season (under more typical drought conditions) appeared more responsive to the prefire spatial mosaic of successional stages than did fires that burned later in the season (under extremely low fuel moisture and high winds). Plant reestablishment was affected by postfire heterogeneity in the landscape due to overall burning patterns and the variable fire severity within burned areas. The depth to which soil was charred increased with fire severity, ranging from an average of $5.8 \mathrm{~mm}$ in lightly burned sites to $13.6 \mathrm{~mm}$ in sites that experienced crown fires. In 1989 unburned sites had the highest vegetative cover in forbs (12 percent), graminoids (18 percent), and low shrubs (20 percent). Total vegetative cover declined somewhat in lightly burned sites but was extremely low in moderately burned (< 10 percent) and crown fire sites ( $<4$ percent). The percent cover of exposed mineral soil was greatest in crown fire sites (82 percent) and lowest in unburned sites (5 percent). By 1990 vegetative cover had generally doubled, and the density of lodgepole pine seedlings increased by fivefold.

Despite generally low densities, there were significant differences in the abundance of lodgepole seedlings among burn severity classes and between years. Sites affected by crown fire burns had a lower seedling density than the other three burn severity classes, and there was a fivefold increase in seedling abundance between 1989 and 1990 (Tukey's studentized range test, $p<0.05$ ). However, because densities were so low, a Chi-square analysis was used to examine the expected and observed number of sampling points at which one or more seedlings were present within each burn severity class. The presence of seedlings differed among burn severity classes in both 1989 ( $c 2=8.338$, df $=3, p<$ $0.04)$ and $1990(\mathrm{c} 2=30.16, \mathrm{df}=3, p<0.0001)$. During both years seedlings were present more often than expected on lightly burned sites and less often than expected on sites that experienced crown fires. The spatial pattern of burning also appeared to influence lodgepole seedling density. During 1989 lodgepole seedlings were found more often on edge sites than on interior sites $(p=0.005)$, with 39 percent of edge sites but only 7 percent of interior sites containing seedlings. During 1990, however, no difference was observed in the presence of lodgepole seedlings on edge and interior points $(p=0.37)$.

In general the floristic composition of the burned areas was very similar to that of adjacent unburned areas. Most of the individual plants present in 1989 and 1990 appeared to be either adult forms whose above-ground structures had survived the fire or vegetative sprouts from surviving rhizomes or root stocks. We observed seedlings of the annual species, Collinsia parviflora Lindl. and Gayophytum diffusum 
T. \& G., and of six perennial species, Cirsium arvense (L.) Scop., Epilobium angustifolium L., Lupinus argenteus Pursh, Pinus contorta Dougl., Populus tremuloides Michx., and Carex sp. (C. geyeri Boott or C. rossii Boott, or both). However, seedlings of the perennial species were much less numerous than sprouts in all study sites and over all burn classes. Resprouting perennial plants bore few flowers in 1989 , but flowered abundantly in 1990. Consequently, we expect to find increasing numbers of seedlings in the burned areas over the next several years.

Our studies on the 1988 Yellowstone fires support suggestions that the spatial mosaic of burn severities is important. Extensive areas that experienced fires of high severity contained low densities of seedlings, probably because much of the seedbank in the canopy and the soil was destroyed. Remnant unburned or lightly burned patches within a severely burned area may provide a seed source that will considerably increase the rate of plant reestablishment. Thus, we hypothesize that the spatial geometry of the burn mosaic will differentially influence plants that exhibit the modes of reproduction. The rate of reestablishment of plants that depend on the dispersal of propagules should be influenced by the size of the burned patch, the distance to the nearest unburned forest patch, and the amount and spatial distribution of burn severities within the patch. In contrast, the rate of reestablishment of resprouting species should be controlled primarily by burn severity, regardless of the size of the burned patch or the distance to an unburned forest patch. We have initiated new, long-term studies to test these hypotheses in Yellowstone National Park. 


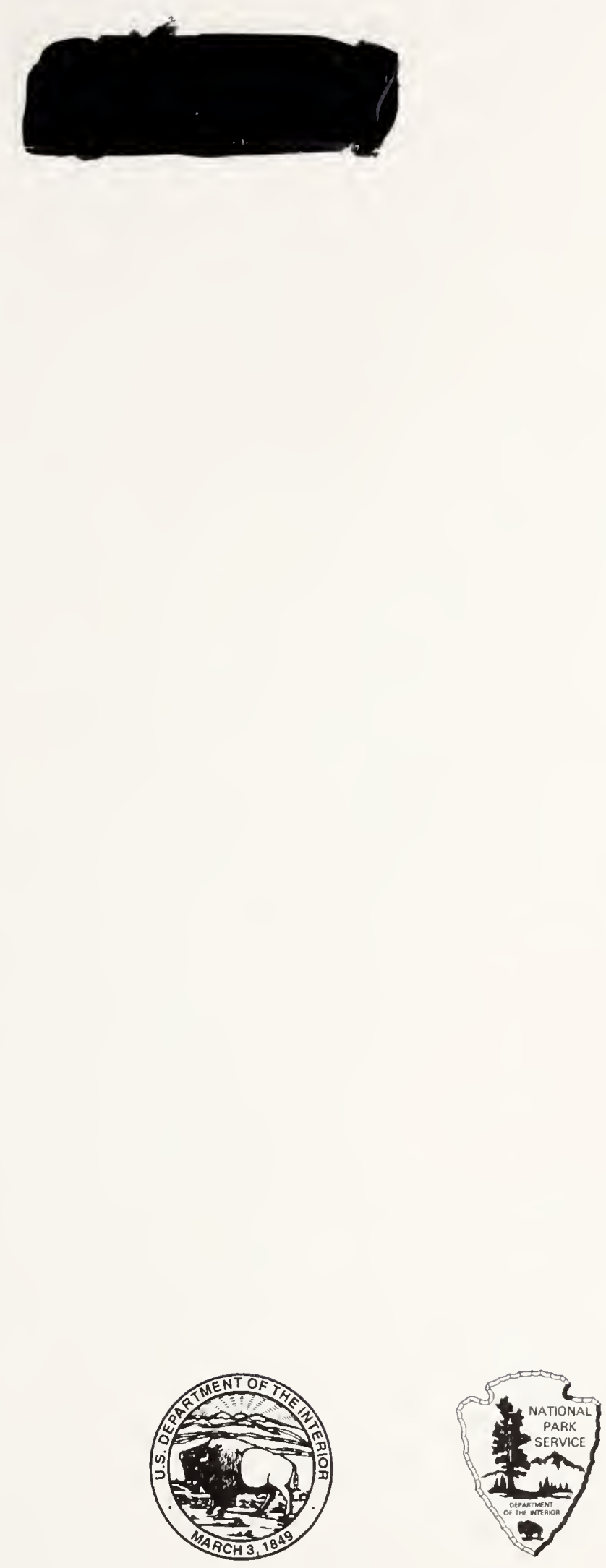

As the nation's principal conservation agency, the Department of the Interior has responsibility for most of our nationally owned public lands and natural resources. This includes fostering sound use of our land and water resources; protecting our fish, wildlife, and biological diversity; preserving the environmental and cultural values of our national parks and historical places; and providing for the enjoyment of life through outdoor recreation. The department assesses our energy and mineral resources and works to ensure that their development is in the best interests of all our people by encouraging stewardship and citizen participation in their care. The department also has a major responsibility for American Indian reservation communities and for people who live in island territories under U.S. administration. 
